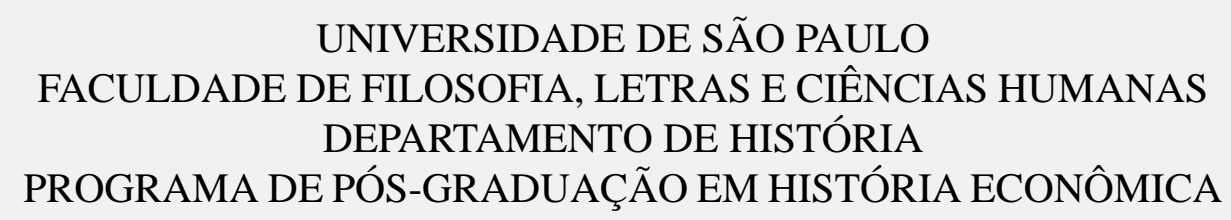

\title{
PODER POLÍTICO E DISTRIBUIÇÃO ORÇAMENTÁRIA EM SÃO PAULO NA PRIMEIRA REPÚBLICA - 1890-1920
}

Cesar Mucio Silva

Tese apresentada ao Programa de Pós-Graduação em História Econômica, do Departamento de História, da Faculdade de Filosofia, Letras e Ciências Humanas da Universidade de São Paulo, para obtenção do título de Doutor em Ciências (História).

Orientador: Prof. Dr. José Jobson de Andrade Arruda 


\section{DEDICATÓRIA}

Dedico esse trabalho à Rogéria Cristina Raniero Silva, minha esposa,

e para Eduardo Raniero Silva, meu filho. 


\section{AGRADECIMENTOS}

Ao Prof. Dr. José Jobson de Andrade Arruda pela honrosa acolhida e tolerância. À Professora Vera Ferlini pelo inesquecível apoio no decorrer de sua disciplina e pelas valiosas sugestões no texto de qualificação. À Professora Raquel Glezer pela recepção e atenção naquele primeiro e importante momento em que eu pisava em solo uspiano. Ao Professor José Leonardo do Nascimento (IA/UNESP) pelas indicações bibliográficas preciosas feitas a mim, e por sua sensibilidade refinada demonstrada em nossos diálogos quando do exame de qualificação. Ao Professor Paulo Alves (UEL/ UNESP) que desde os anos 90 não tem faltado com qualquer tipo de apoio para com seu ex-aluno. À esse grupo fabuloso, incorporo, por fim, a amiga Iveti Cavinatti (ALESP), elo corajoso e indispensável entre mim e o Dr. Jobson.

Aos amigos Marcos Castro (Fundação Prefeito Faria Lima - CEPAM) e Marcos Corrêa Campos (Controladoria da Prefeitura Municipal de Piracicaba) pela verdadeira aula-show e acompanhamento constante no dificílimo universo dos orçamentos públicos e legislação correspondente, além das minuciosas correções do que por mim era feito no campo das emendas ao orçamento. Maria Luiza Simões (Jornal da UNESP), mais uma vez, nos últimos sete anos, revisou com competência e profissionalismo outro texto de minha autoria. Saulo Silva, apesar da pouca idade, mostrou experiência de "gente grande" na tarefa de diagramação completa do trabalho, onde não escapara das armadilhas dos mapas, tabelas, gráficos e assemelhados. Juliana Castro e Marlene A. de Paula (CEPAM) também têm parte nesse verdadeiro desiderato.

Por fim gostaria de estender esses sinceros agradecimentos aos amigos Deputado Federal Renato Amary, Edson “Nino” Marcusso, Bira, Fernando Chaves Neto, Eric Romero, Luciano Viana, Carlos Laíno, Sônia Monzani, e Cecília Ruiz Calixto, companheiros de trabalho, luta e política que não me negaram apoio nessa difícil fase de conclusão da pesquisa, onde os dias de férias acabaram sendo insuficientes para tanto trabalho. Ditinha Pereira Leite, Elsinha Sinbo, Luana e Ana Czsnack, Meg Christoffani, Noeli Castro, Fátima Zanelato e Mara Marcato torceram de perto por mim - foi muito bom. À Dra. Márcia Coelho, devo quase tudo. 


\title{
RESUMO
}

O estudo das relações e práticas políticas no Legislativo Paulista, no período de 1890 a 1920, sobretudo no que se refere aos acordos e disputas entre os parlamentares das diferentes zonas econômicas e distritos eleitorais pelos recursos orçamentários, durante o processo anual de elaboração do orçamento estadual.

\section{Palavras-Chave}

\author{
Representação parlamentar \\ Relações de poder \\ Zonas econômicas \\ Distritos eleitorais \\ Orçamento estadual \\ São Paulo \\ Primeira República
}

\begin{abstract}
This research is about the study of political relationships and practices in the Paulista Legislative, in between 1890 to 1920, specially on what it refers to the agreements and dispute among parliamentarians from different economic zones and election stations by the budget resources, during the annual process about the State budget planning.
\end{abstract}

\section{Key Words}

Parliamentary representation

Power relationship

Economical zones

Election stations

State budget

São Paulo

First Republic 


\section{SUMÁRIO}

Introdução 7

Capítulo I - A Formação do Poder no Brasil e em São Paulo. Do Império à República.

1. A formação do Poder no Brasil. 12

2. A formação do Poder em São Paulo.................................................................. 15

3. A política e Doutrina Paulista............................................................................... 19

4. O Poder Local e a República............................................................................................. 24

Capítulo II - Aspectos Econômicos e Sociais que Caracterizam São Paulo na Primeira República (1890-1920).

1. O Café, Sua Importância e Expansão ................................................................. 28

2. Ferrovias ...................................................................................................................................333

3. A Indústria e a Penetração Econômica Estrangeira ........................................... 38

4. São Paulo Dividido em Zonas e em Distritos Eleitorais

Caracterização e Cronologia

Capítulo III - Grupos Políticos Hegemônicos e suas Relações Econômicas e de Poder no Estado de São Paulo.

1. O Coronelismo e suas Práticas .74

2. Os coronéis e a Questão da terra: Legalização,

Especulação Fundiária e a Violência 78

3. Coronelismo e Oligarquias no Interior Paulista . .84

Capítulo IV - A Política e o Processo Eleitoral

1. Política e Processo Eleitoral 95

2. O Partido Republicano Paulista e os Esquemas de Poder 100

Capítulo V - A Questão do Orçamento.

1. Debates Parlamentares que Explicitam o Problema do Orçamento 107

2. As Forças Políticas e a Distribuição dos Recursos Orçamentários

Conclusão 
MAPAS (FIGURAS) e TABELAS

\section{Mapas}

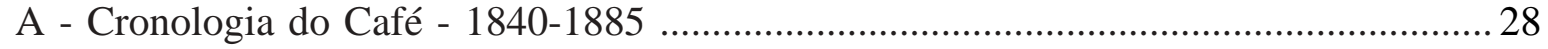

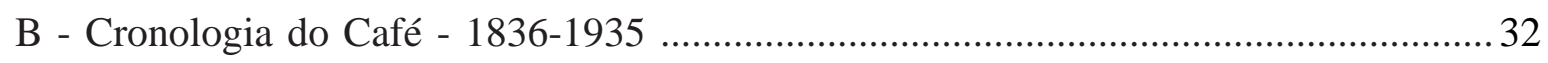

C - Expansão da Malha Ferroviária - 1900-1940 .............................................................. 37

D - Estado de São Paulo - Expansão Ferroviária e Regionalização ................................... 47

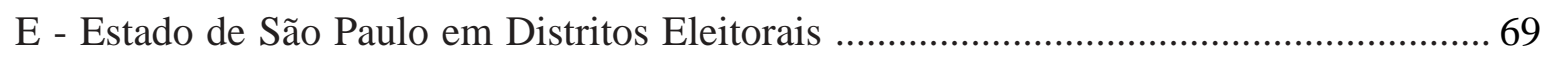

\section{Tabelas}

2.1 - Relação Entre Habitantes - Ferrovias - Cafeeiros - 1860-1930 ................................ 36

2.2 - A Indústria na Primeira República - Número de Estabelecimentos - 1889-1930 ........ 39

2.3 - Distribuição da População de São Paulo por Zonas - 1886-1920 .............................66

2.4 - População Economicamente Ativa, por Setor, São Paulo e Brasil - 1920-1940 .........67

2.5 - Distribuição da Produção de Café em São Paulo por Região/Zonas (\%peso)

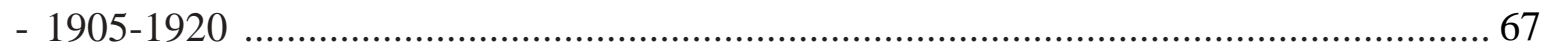

2.6 - Classificação dos (12 primeiros) Municípios Paulistas por Renda - 1885-1920.......... 68

5.0 - Tabelas Dirigentes da Comissão de Fazenda e Contas - 1890-1920 ..........................112

5.1 - Quantidade de Emendas Apresntadas, por Zona - 1891-1906 .................................. 125

5.2 - Valor Total das Emendas Apresntadas, por Zona - 1891-1906 ................................ 126

5.3 - Quantidade de Emendas Apresentadas, por Distritos Eleitorais - 1907-1920 ............127

5.4 - Valor Total das Emendas Apresentadas, por Distritos Eleitorais - 1907-1920 ...........128

5.5 - Quantidade de Emendas Substutivas Aprovadas pela Comissão

de Fazenda e Contas, por Distritos Eleitorais - 1907-1920 ...........................................129

5.6 - Valor Total das Emendas Substutivas Aprovadas pela Comissão

de Fazenda e Contas, por Distritos Eleitorais - 1907-1920 


\section{INTRODUÇÃO}

Quais teriam sido as linhas de força que estavam sendo operacionalizadas no plano estadual, no seu todo ou em parte, e que foram capazes de, ao mesmo tempo, manter um consenso político regional e permitir ao Estado Nacional Republicano o desempenho de suas funções de poder moderno para uma sociedade que se desenhava como emergente? É preciso examinar a atuação dos políticos republicanos na Câmara dos Deputados do Estado de São Paulo, do ponto de vista de um poder dos mais importantes na construção da ordem política regional, com a proclamação da República em 1889.

O estudo das relações e práticas políticas no Legislativo Estadual paulista na Primeira República, no período 1890-1920, sobretudo no que diz respeito aos acordos e disputas que se davam durante todo o processo de elaboração e conclusão do orçamento estadual, anualmente, foi o tema central escolhido para esta pesquisa. Sem dúvida reconhecido como um dos momentos mais importantes das legislaturas, do exercício parlamentar, o debate em torno do orçamento estadual tem se mostrado ao longo da história revelador de pontos de vista da ação de seus agentes e dos interesses local e regional aos quais representam, fazendo funcionar, simultaneamente, todas as peças de uma engrenagem poderosa, capaz de alcançar a administração do Estado nacional, e é costumeiramente denominada política oligárquica.

Aqui, por que não fazer o registro de uma primeira indagação, ou seja: como os parlamentares representantes de regiões definidas como frágeis economicamente, em diferentes momentos do período em questão (1890-1920), como por exemplo o Vale do Ribeira, o Vale do Paranapanema, a Alta Paulista e a Baixa Sorocabana entre outras, se comportavam perante uma realidade econômica estadual, traduzida em poder proporcional, que tinha, por outro lado, sobretudo na zona Central, com o município de Campinas à frente, seguido por Piracicaba, na Mogiana, com a força do 
café de cidades como Ribeirão Preto, na Capital ou a na Baixa Paulista, com municípios fortes na produção cafeeira como São Carlos e Rio Claro, suas principais forças? O que ao final desse embate coube a cada parte e a que custo?

O período delimitado para essa pesquisa, ou seja de 1890 a 1920, justifica-se sobretudo por se tratar, primeiro, de um momento importante e bastante intenso do processo de criação de governos locais, agora com maior autonomia, principalmente até a primeira década do século XX. Com isto, viu-se a ampliação das atribuições e atividades das Assembléias Legislativas estaduais, fosse em suas relações com o Poder Executivo e Legislativo dos municípios, fosse em seu relacionamento com outros poderes das esferas estadual e federal. Segundo, porque nesse processo de criação de governos locais com maior autonomia constata-se uma relação diretamente proporcional com períodos de grande prosperidade na produção e comércio do café, induzindo a um incremento da economia paulista e a uma verdadeira ebulição no cotidiano político.

A impressão que se tem ao se trabalhar com a bibliografia da Primeira República, é que temas como coronelismo, mandonismo, oligarquias e também hegemonia e federalismo dominaram, até há pouco, o debate historiográfico. A lista é bastante ampla e a qualidade e a originalidade de tais estudos, sem dúvida, alargaram horizontes para novas pesquisas*.

Com tal situação, optei por essa proposta de estudo, a qual considero relevante, sobretudo na medida em que proponho, ao distanciar-me de tais temas, buscar analisar as relações políticas entre as regiões paulistas, por meio de seus representantes no interior do parlamento estadual, e que espaços foram capazes de conquistar na distribuição orçamentária. Nesse sentido posso, uma vez mais, perguntar: que papel realmente teriam no jogo político as regiões e municípios de pouca expressão econômica? O que se discutia e se acordava nas relações políticas entre os representantes de regiões e municípios "fortes" em relação aos "não-fortes" dentro do parlamento paulista, que acabou por alimentar durante muito tempo um certo consenso estadual que pormenorizadamente

\footnotetext{
* Para citar apenas alguns trabalhos publicados: FAORO, Raimundo. Os donos do poder; FAUSTO, Boris. Pequenos ensaios de História da República, 1889-1945 e História Geral da Civilização Brasileira, tomo III; TELAROLLI, R. Eleições e fraudes eleitorais na República Velha; PERISCINOTTO, R. M. Classes dominantes, Estado e os conflitos políticos na Primeira República em São Paulo; CARONE, E. A República Velha; HOLANDA, S. B. História Geral da Civilização Brasileira - Do Império à República; DIAS, Maria Odila L. S. Cotidiano e poder em São Paulo no século XIX; DINIZ, Eli. Voto e máquina política. Patronagem e clientelismo no Rio de Janeiro; LEAL, V. N. O coronelismo e o coronelismo de cada um, DADOS/1980; NOGUEIRA, M. A. As desventuras do liberalismo: Joaquim Nabuco, a Monarquia e a República; WITTER, José Sebastião. Partido político, federalismo e República e República, política e partido: o PRF e a política dos governadores; VEZENTINI, P. G. F. Liberais e a crise da República Velha; SILVA, Hélio. República Velha: instituições e classes sociais; VILLAÇA, M. V. e ALBUQUERQUE, R. C. Coronel, coronéis; GOMES, A. M. C. Burguesia e Trabalho - política e legislação social no Brasil, 1917-1937; BASBAUM, L. História sincera da República: das origens até 1889; CASALECCHI, J. E. Proclamação da República e O Partido Republicano Paulista; CARVALHO, J. M. de. Pontos e Bordados. Escritos de História e Política.
} 
ainda não se discutiu e também não veio à luz do discurso historiográfico?

Com todo esse controle em suas mãos, as oligarquias estaduais, muitas vezes, viam-se na obrigação de decidir não apenas sobre questões e interesses próprios, mas também sobre projetos e questões nacionais da República. É importante analisar essa perspectiva, esses momentos em que se discutiam e se decidiam os chamados “problemas nacionais”. Portanto, é necessário analisar a história política e econômica da Primeira República considerando a composição das forças oligárquicas estaduais em suas próprias relações e entre elas e os acontecimentos no âmbito do poder nacional.

A presente pesquisa ficou estruturada da seguinte forma: $O$ primeiro capítulo, intitulado $A$ formação do poder no Brasil e em São Paulo, traz em suas páginas alguns aspectos da evolução histórica da formação do poder no Brasil e em São Paulo, num espaço de tempo que parte do Império e chega à Primeira República. Nele, não ficaram de fora questões e discussões sobre a existência de uma "doutrina paulista", perseguida e colocada em prática como norte às pretensões e estratégias para conquista e manutenção do poder pela elite paulista, tanto no cenário político estadual como no nacional.

Em Aspectos econômicos e sociais que caracterizaram São Paulo na Primeira República (1890-1920), segundo capítulo deste texto, procurei esboçar um quadro que contivesse alguns dados e informações básicos sobre questões fundamentais como a produção cafeeira, sua importância como principal produto de exportação da pauta brasileira durante décadas, além de alguns números de sua expansão. As ferrovias, a indústria nascente e o capital estrangeiro também receberam rápidas pinceladas e melhoraram a formação e o entendimento desse quadro econômico e social de fins do século XIX e início do século XX. Destaco, nesse capítulo, a caracterização das chamadas zonas paulistas, demarcadas segundo o traçado das ferrovias e pontos de referência para esse estudo, sobretudo no período de 1891 a 1906, como regiões de origem e projeção política de seus representantes para o Legislativo Paulista.

No terceiro capítulo - Grupos políticos hegemônicos e suas relações econômicas e de poder no Estado de São Paulo - busco dar "vida" e uma certa concretude aos atores principais dessa trama, aos seus atos e às suas relações, à disputa pela posse da terra, à coerção e violência, enfim, desses artífices do coronelismo e oligarquias no interior paulista.

Intitulado A política e o processo eleitoral, no quarto capítulo desta tese quis trazer à luz registros de como se ordenava legalmente o processo político na Primeira República, algumas de suas alterações e reformas, e principalmente o embate eleitoral propriamente dito, em arenas ainda local e regional, tendo como agremiação principal o Partido Republicano Paulista, suas práticas, motivações e movimentação por todo território paulista. Daqui veremos emergir muitas personali- 
dades políticas que, no desenrolar dos últimos itens desta pesquisa, aparecerão como velhos conhecidos, dado sobretudo à ferrenha militância e engajamento nas lutas pelos recursos públicos do orçamento estadual.

Não poderia ser outro nosso quinto e último capítulo senão aquele que discorrerá sobre o diaa-dia das onze legislaturas estudadas neste trabalho, perfazendo significativos trinta anos de trabalho parlamentar, discursos e proposituras de praticamente mil e trezentos políticos e seus milhares de emendas ao orçamento público. Com isto espero, modestamente, ter, ainda que em pequena escala, avançado nos estudos e na compreensão de um dos períodos mais fascinantes da história política e econômica do Brasil - a Primeira República. A questão do Orçamento é o nome do último capítulo. 
CAPÍTULO I - A FORMAÇÃO DO PODER NO BRASIL E EM SÃO PAULO. DO IMPÉRIO À REPÚBLICA 


\section{A formação do Poder no Brasil}

A história política do Brasil compreende dois momentos: o primeiro refere-se à instalação da burocracia colonial portuguesa desde o surgimento das capitanias hereditárias (1534) e, depois, com a instituição do Governo Geral, em 1549. Esse período corresponde à história administrativa do Brasil sob o domínio português com o início da colonização, prolongando-se até 1822/1824 com a emancipação política, a formação da monarquia brasileira e o coroamento de Dom Pedro I, então herdeiro do trono deixado pelo seu pai, Dom João VI.

A instituição da monarquia em 1824, mediante o estabelecimento do estatuto jurídicopolítico viabilizou formalmente a estrutura de um estado centralizado em que o imperador governava com um Conselho de Ministros, sob o comando de um chefe de Gabinete, e o Conselho de Estado, formado por conselheiros indicados pelo imperador ${ }^{1}$.

Em linhas gerais, a estrutura da monarquia é constituída do Poder Legislativo, formado pela Câmara dos Deputados e a Câmara do Senado, ambas reunidas no modelo bicameral e que deu origem ao Congresso Nacional. Havia, ainda, os Conselhos Gerais das províncias, com poderes legislativos locais. Mas o Estado, de caráter centralizador, se ocupava de uma outra instância de poder em mãos do imperador. É o chamado Poder Moderador, sob o controle do Executivo, articulado ao Conselho de Ministros e ao Conselho de Estado. O terceiro nível da estrutura do Estado era sustentado pelo Poder Judiciário, organizado com base nos Tribunais de Justiça².

Enfim, a Constituição de 1824 apresenta características marcadamente centralizadoras, por meio do Poder Moderador do imperador, o qual tinha poderes de intervenção nas esferas do Legislativo e do Judiciário, podendo intervir também nos Conselhos das províncias ${ }^{3}$.

Os Poderes Legislativo e Judiciário estavam subordinados ao Executivo, particularmente em relação ao Poder Moderador. Os ministros de confiança do imperador, por exemplo, poderiam ainda ocupar cargos específicos tanto na Câmara do Senado como na Câmara dos Deputados. O Legislativo poderia sofrer veto por parte do Executivo, sobretudo nos projetos por ele elaborados, o que acabava se configurando em algo do tipo "a última palavra era a do imperador".

\footnotetext{
${ }^{1}$ Constituição do Império, 1824. CF. PIERANGELLI, José Henrique. (Org.). Códigos Penais do Brasil. Evolução histórica. São Paulo: Jalovi, 1980.

${ }^{2}$ Idem.

${ }^{3}$ Para detalhes sobre o Poder Moderador, ver: ARINOS, Afonso de Melo Franco - "Idéias Políticas do Constitucionalismo Imperial". In: O pensamento constitucional brasileiro. Brasília: Câmara dos Deputados, 1978. p. 23-47.
} 
O sistema eleitoral era socialmente discriminatório e utilizava critério econômico para a escolha dos candidatos e também dos eleitores. Os candidatos ao Poder Legislativo eram eleitos de forma indireta. À Câmara dos Deputados competia fiscalizar os atos do Conselho de Estado e do Conselho de Ministros, mas não os atos do imperador. A Câmara do Senado, por sua vez, era eleita com base numa lista tríplice apresentada pelas províncias, e ao imperador cabia, ainda, indicar pessoalmente um terço dos senadores da lista. É preciso lembrar que a Câmara dos Deputados e a Câmara do Senado não podiam promulgar leis e decretos. Somente ao imperador cabia legislar sobre matéria econômica e administrativa do Império ${ }^{4}$.

O imperador exercia, de fato, o poder por meio do Poder Moderador. Assim, os Poderes Legislativo e Judiciário estavam subordinados ao Executivo, podendo o imperador dissolver a Assembléia Geral ou convocá-la para tratar dos interesses e das conveniências pessoais em matérias do Poder Executivo - o que revela a ausência de atos democráticos do imperador.

Com a proclamação da República, o Estado passa por alterações em sua estrutura jurídica e política. Por exemplo, as atribuições do Congresso Nacional foram ampliadas e as do Executivo reduzidas, se comparadas com o Estado monárquico. Ao Congresso cabia deliberar sobre matéria econômica, administrativa e de segurança nacional (área militar). Ao Congresso republicano competia, ainda, legislar sobre a organização do Exército e da Marinha. No Império, essa atribuição cabia ao Poder Executivo. A partir da República, o próprio Congresso Nacional passa não só a elaborar leis como também a sancioná-las sem a aprovação do Executivo.

O sistema eleitoral republicano foi um avanço em relação ao sistema do Império. A República ampliou o direito a todos os cidadãos com 21 anos para votarem e serem votados, desde que alfabetizados e do sexo masculino. No que diz respeito à presença às eleições, o voto não era obrigatório.

A constituição republicana, de fato, atribuiu amplos poderes ao Congresso Nacional, particularmente quanto ao papel fiscalizador dos atos do Poder Executivo, além de cobrar prestação de contas dos ministros e das demais autoridades.

A República das Oligarquias (1894-1930) recebeu essa denominação porque baseou toda sua ação político-administrativa na existência das oligarquias estaduais. Estas eram definidas, como já vimos, como grupos bastante fechados, constituídos por elementos das classes dominantes (latifundiários) e que exerciam o monopólio da política em seus Estados. Naturalmente, as oligarquias

\footnotetext{
${ }^{4}$ Para outros detalhes, consultar: PRADO JR., Caio. Evolução política do Brasil e outros estudos. São Paulo: Brasiliense, 1969; FAORO, Raymundo. Os donos do poder. Formação do patronato político brasileiro. Porto Alegre: Globo, 1976. v. 1.
} 
mais poderosas (paulistas e mineiras) tinham uma influência decisiva no cenário político nacional. Não obstante, cada unidade da Federação se encontrava sob o férreo controle de sua própria oligarquia. Assim sendo, o período que vai da posse de Prudente de Morais (1894) à Revolução de 1930 caracterizou-se pela defesa dos interesses desses grupos minoritários, com predomínio da oligarquia cafeeira, instituindo-se para isso um verdadeiro esquema oligárquico do qual faziam parte a Política dos Governadores, o Coronelismo e a Política do Café com Leite, entre outros. Mesmo com choques e cisões dentro do bloco, como durante o governo Hermes da Fonseca ou na sucessão de Epitácio Pessoa, em nenhum momento, porém, os setores médios e urbanos - e muito menos as camadas inferiores da população - tiveram qualquer participação no processo político-administrativo desse esquema de minorias, apesar da existência do sufrágio universal masculino e a descoberto.

Lembremos que, delineada por Prudente de Morais e oficializada por Campos Sales, em 1900, a Política dos Governadores era um compromisso firmado entre o governo federal e os governos estaduais, representados por grupos oligárquicos regionais. Esses grupos passavam a gozar de ampla autonomia, contando com todo o apoio do presidente da República, sendo reconhecidos como parceiros preferenciais. Em troca, dariam total apoio ao governo federal. Assim, os deputados federais e senadores, eleitos pelas oligarquias estaduais, não opunham nenhum embaraço à política presidencial no plano nacional.

Com isso, somente seriam empossados os parlamentares eleitos pelo grupo situacionista de cada Estado. Os candidatos das oposições que se elegessem seriam sistematicamente cortados das listas de votação, pela própria Comissão Verificadora dos Poderes do Congresso Nacional. Na época, dizia-se que eles eram degolados, pois não chegavam a assumir seus mandatos. Essa política garantiu a supremacia do Executivo Federal sobre o Legislativo, e consolidou o poder local das oligarquias estaduais.

A proclamação da República não alterou a organização da economia e da sociedade brasileiras. De acordo com alguns políticos da época, o Brasil continuava seguindo a sua "vocação essencialmente agrária”. Daí o predomínio da grande propriedade, especializada na produção de gêneros agrícolas para o mercado externo. Com isso, mantinham-se os privilégios políticos e sociais das elites agrárias, o que mantinha à margem a maior parte da população brasileira.

No decorrer do período, contudo, a expansão da atividade industrial e a urbanização que dela resultou propiciaram o aparecimento de uma incipiente burguesia industrial, a expansão do setor de serviços e o crescimento do operariado, dando origem às primeiras greves. Nesse mesmo processo, deu-se a ascensão das camadas média e urbana, formadas entre outros por profissionais liberais, funcionários públicos e pequenos comerciantes. 


\section{A formação do Poder em São Paulo.}

A compreensão das peculiaridades do poder local no Estado de São Paulo no período estudado insere-se num quadro muito mais amplo da vida política brasileira, alicerçada no que se convencionou chamar de República das Oligarquias. É certo que, no caso específico de São Paulo, o desenvolvimento material que se processou desde as últimas décadas da monarquia teve como elemento nuclear a lavoura cafeeira, eixo de um complexo econômico ao qual se atrelaram a expansão territorial, uma grande malha ferroviária, o crescente movimento imigratório e a expansão urbano-industrial. Com a proclamação da República em 1889 e, depois, com a Constituição de 1891, as antigas províncias são transformadas em Estados com plena autonomia política, administrativa e econômica 5 . Viu-se, com isso, a consolidação dos poderes regionais no Brasil enquanto configuração de um projeto político gestado nos anos finais do Império, num contexto histórico de governo centralizado, marcado por contradições e conflitos sociais e políticos.

Em São Paulo, uma junta provisória formada por Prudente de Morais, Rangel Pestana e Joaquim Mursa vai governar o Estado até a escolha constitucional do presidente, isto é, no período de 16/11/1889 a 14/12/18896. Em 30 de abril de 1891, é convocada uma Assembléia Constituinte Estadual, sob a presidência de Luiz Pereira Barreto, para a discussão e a elaboração da primeira Constituição paulista sob a República, que acabaria promulgada em 14 de julho 1891.

Com a Constituição Estadual de 1891 é estabelecido o estatuto legislativo bicameral, constituído pela Câmara dos Deputados e a Câmara dos Senadores, sendo seus representantes eleitos pelo voto direto. Segundo o texto constitucional, a Câmara dos Deputados seria formada por quarenta deputados eleitos para um mandato de três anos, numa representação de um deputado para quarenta mil habitantes. Já o Senado paulista estaria composto por vinte senadores, maiores de trinta e cinco anos de idade, eleitos para um mandato de seis anos, com uma renovação, a cada três anos, de pelo menos cinqüenta por cento de seus membros ${ }^{7}$.

\footnotetext{
${ }^{5}$ A Constituição Federal de 1891 garantiu autonomia e soberania aos Estados, mas estes não delegaram esses mesmos direitos aos municípios. Toda e qualquer decisão comum entre os municípios deveria ter a aprovação do governo estadual, isto é, do Congresso do Estado, conforme estabelecia o artigo 56 da Constituição do Estado de São Paulo em 1891. A Constituição remetia o direito de autonomia dos municípios à lei ordinária a ser ainda estabelecida, seja política, eleitoral ou econômica, como estabelecia o artigo 53. Embora a autonomia e a soberania fossem garantidas em âmbito estadual, a União manteve os vínculos com todos os Estados com base no princípio federativo, designado por "Estados Unidos do Brasil". CF. Constituição do Estado de São Paulo (sala das sessões do Congresso Constituinte em 14 de julho de 1891).

${ }^{6} \mathrm{O}$ próprio Prudente de Morais, membro da referida junta, acaba escolhido governador, tomando posse em 14 de julho de 1889. CF. CARONE, Edgard. A Primeira República, 1889-1930. 2. ed., São Paulo, 1973.

7 “[...] as duas Câmaras (dos deputados e dos senadores) funcionavam separadamente, com regimentos e atribuições próprias, porém existem as sessões de fusão. Pelos dispositivos constitucionais, o Congresso Legislativo deve se reunir, ordinariamente, no dia 7 de abril de cada ano, durante três meses em sessões diárias (menos sábados, domingos e feriados) com início às 12 horas e término às 16 horas [...] O período legislativo pode ser adiado ou prorrogado, a partir do consenso das duas casas [...]". In: Assembléia Legislativa de São Paulo. Um exercício de democracia. São Paulo: ALESP, 1984.
} 
É preciso lembrar que, no plano federal, o Estado republicano, no período que se seguiu à instalação do governo provisório, toma importantes medidas administrativas e políticas em relação à organização das antigas províncias e municípios. Pelas determinações do governo, os Estados são comandados por interventores federais, nomeados pelo presidente da República, e os municípios são administrados por um Conselho de Intendentes.

Assim, a natureza do poder regional nos Estados muda de sentido com a República, pois implicará não só em autonomia local (municipal, que já existia, parcialmente), como também em poder autônomo no plano estadual, principalmente tendo o poder de legislar sobre questões da propriedade e do trabalho, particularmente sobre a imigração para a grande lavoura paulista.

A Constituição republicana permitiu aos Estados o poder de elaborar leis e aplicá-las em todas as áreas da economia, da política e da sociedade. Com tais poderes, o governo paulista desencadeará uma série de leis para organizar a estrutura política e administrativa no Estado. Por exemplo, em 1898, pela Lei Estadual no 374, o governo vai dar um ordenamento mais adequado às questões administrativas dos municípios paulistas. Assim, ressurge o cargo de prefeito como expressão do Poder Executivo municipal, sendo este cargo exercido por um vereador eleito por seus pares.

No tocante aos partidos políticos, a Constituição de 1891 nem fez referência, pois se admitiam os partidos republicanos como herdeiros do processo histórico que resultou na proclamação da República. Mas a inexistência de outros partidos raramente era reclamada pelos políticos da República, mesmo pelos ex-monarquistas agora integrados à ordem republicana. Na realidade, os partidos republicanos eram instrumentos da organização política que expressavam a vontade de seus dirigentes e dos grupos aos quais pertenciam. Os demais grupos estavam excluídos das benesses que o partido poderia proporcionar em termos de posição de mando e de cargos na administração pública. Isso ocorria em todos os níveis das estruturas administrativas federais, estaduais e municipais. Mesmo os cargos importantes, da alçada partidária e eleitoral, só eram ocupados pelos membros do grupo que controlava o partido, como eram os casos do seu comitê executivo, da presidência da mesa apuradora nas eleições, da liderança da maioria nas Câmaras Estaduais e no Senado e das presidências, também nas Câmaras e no Senado ${ }^{8}$. Para ocupar o cargo de presidente da Comissão Executiva ou mesmo ser apenas membro titular, a fidelidade pessoal era condição básica, podendose permanecer por mais uma legislatura na Executiva.

\footnotetext{
${ }^{8}$ CF. LOVE, Joseph. A Locomotiva: São Paulo na Federação brasileira, 1889-1937. Rio de Janeiro: Paz e Terra,
} 1982. p. 385-407. 
Os partidos foram criados nos Estados, à maneira republicana, e passaram por mudanças internas, em seus procedimentos partidários, conforme os jogos de interesse de suas lideranças, pelo menos até 1930, quando da emergência da Revolução de Outubro e da instalação do governo Vargas no Rio de Janeiro. Em seguida (1931), Vargas decreta a ilegalidade dos partidos republicanos. Estes só retornam à legalidade em 1933. O PR durou apenas mais alguns anos, tendo se cindido em $1937^{9}$.

A República veio a conhecer um novo partido somente em 1926 (o Partido Democrático), justamente um partido de oposição ao perrepismo, que foi uma espécie de partido único com identidade nos chamados republicanos históricos. O PD viveu até 1934, quando então foi criado o Partido Constitucionalista, de origem paulista, mas que foi fechado também por Vargas em 1937.

Campos Salles, em 1900, propõe um acordo entre os governadores, no sentido de se buscar uma política de maioria republicana para tornar o país governável. O seu nome não era associado ao Partido Republicano, mas as lideranças estaduais propuseram uma aliança eleitoral com base na mudança da Comissão de Verificação de Poderes, que até então (1900) era composta por cinco membros, sendo a presidência exercida pelo mais velho. A proposta de Campos Sales determinava que a presidência da comissão deveria ser ocupada pelo presidente da Câmara Federal com o término de seu mandato. Assim, o grupo hegemônico do Partido Republicano poderia controlar a lista dos eleitos para a Câmara e o Senado, conforme os interesses e os acordos políticos e eleitorais dos Estados e de seus respectivos grupos aliados.

Com isto, acabou-se por criar uma oposição fraca nos Estados, onde seus líderes foram excluídos do jogo eleitoral e partidário imaginado e colocado em prática por Campos Salles, quando então é restaurada a antiga prática de verificação de poderes - o que permitiu o ressurgimento de uma oposição dentro dos Partidos Republicanos estaduais. Na verdade, o modelo eleitoral pela hegemonia de um grupo aliado a outros para o exercício da política, excluindo-se os partidos estaduais de pouca expressão e com pouca densidade eleitoral, era uma estratégia para eliminar a violência, que era muito frequiente por ocasião das eleições municipais, estaduais e, principalmente, nos pleitos para a escolha do presidente da República.

Campos Salles anotou em sua correspondência pessoal a ausência de partidos no processo político-eleitoral brasileiro, pois entendia que a República não criara mecanismos para o surgimento de partidos diferenciados, colocando inclusive o partido dos monarquistas na ilegalidade ${ }^{10}$.

\footnotetext{
${ }^{9}$ Idem, p. 407.

${ }^{10}$ SALLES, Campos. Da Propaganda à Presidência. São Paulo: s.c.p. 1908. CARONE, Edgard. A Primeira

República (1889-1930): Texto e contexto. 2. ed. São Paulo, 1973. p. 102-103 e 109.
} 
Portanto, a possibilidade de supressão de uma prática política que engendrava violência entre os grupos e lideranças nos momentos dos processos eleitorais foi uma decisão que Campos Salles desejou como presidente, apelando para o apoio dos governadores e das bancadas no Senado e na Câmara Federal que formavam a maioria.

A violência eleitoral, no momento da apuração dos votos enviados pelas juntas ao Congresso Nacional, refletia a luta entre os grupos nos Estados e dificultava a diplomação, pois eram freqüentes as listas em duplicata e ambas reivindicavam a legalidade dos seus eleitos. Para Campos Salles era:

"[...] sombria a perspectiva que apresentavam os trabalhos de verificação de poderes. O regimento estatuía que ao mais velho dos diplomados cabia a presidência interina da Câmara, incumbindo a ela a lista dos diplomas presumivelmente legítimos. Ao mais velho, pois, caberia, em última análise, a formação da sua Câmara. A questão estava assim entregue a um certificado de idade. Não é preciso muita argúcia para figurar as inúmeras hipóteses de fraudes que poderiam ser sugeridas $[\ldots]^{11} . "$

A política de Campos Salles visava, em última instância, construir uma maioria no Congresso Nacional que apoiasse seus atos como presidente da República. Defendia que os Poderes Executivo e Legislativo, com o apoio dos Estados, deveriam formar a base de um governo partilhado, respeitando-se as peculiaridades de ambos os Poderes:

“[...] O poder, que, pela sua natureza de suas prerrogativas, se acha em condição de esclarecer e dirigir, é o Executivo. É daqui que se origina a necessidade de uma maioria que, pela comunhão de vistas e pela íntima afinidade das aspirações, constitua um sólido laço de união entre os dois poderes, e os conduza com segurança em uma ação conjunta, evitando rivalidade e conflitos que são absolutamente incompatíveis com o funcionamento harmônico e salutar de um governo bem constituído. Os sufrágios que elegerem o primeiro magistrado são os mesmos que devem formar a maioria no Congresso, e aí está o vínculo de íntima e vigorosa aliança entre os dois poderes $[\ldots]^{12} . ”$

\footnotetext{
${ }^{11}$ Ibid. p. 104. Ainda sobre vida e governo de Campos Salles, passaria adiante indicação de um trabalho admirável e inovador na pesquisa da História do Brasil, onde se constata "a difícil combinação correta entre rigor historiográfico e literatura de ficção" em Ayrton Marcondes, Campos Salles. Uma investigação na República Velha, da Editora da Universidade Sagrado Coração, Bauru, 2001, prefácio do professor José Leonardo do Nascimento (IA/UNESP).

${ }^{12}$ Ibid. p. 100-101.
} 
Essa política de composição de uma maioria deu origem à chamada "Política dos Governadores", que Campos Salles preferia, porém, chamar de "Política dos Estados". No pleito de sua sucessão, Salles não teve dificuldades em obter apoio dos Estados que representavam também a maioria no Congresso Nacional. O nome indicado foi o de Rodrigues Alves, antigo monarquista, mas que aderiu à República por pragmatismo e pela irreversibilidade da ordem política republicana ${ }^{13}$.

A organização de novos partidos após a proclamação da República decorreu da dificuldade de articulação do Partido Republicano para torná-lo nacional. O Partido Republicano Federal, fundado em 1893, se propôs a ocupar o espaço político nacional com a intenção de reunir os republicanos de 15 de novembro de $1889^{14}$. Entendiam seus proponentes que o antigo Partido Republicano tinha cumprido sua tarefa histórica. Era preciso, agora, um partido que fosse prático, que estivesse organizado para consolidar a República. Não se tratava de um partido para fazer oposição ao governo republicano, mas para ser alternativa política para recompor as instituições da República comprometidas com o governo dos militares e, principalmente, com o governo Floriano Peixoto, que naquele momento enfrentava conflitos e resistências armadas no Rio de Janeiro e no sul do País. A vida do PRF não foi longa e, já em 1897, ocorrem as cisões desencadeadas a partir do próprio líder do partido na Câmara Federal, o senhor Francisco Glicério, também seu fundador ${ }^{15}$. Ainda, ao longo da Primeira República vão surgir outros partidos regionais, de relativa expressão eleitoral e representativa, como foram os casos do Partido Libertador, no Rio Grande do Sul, do Partido Republicano Constitucionalista e do Partido Democrático em São Paulo, em 1926, que foi oposição ao PRP.

\section{A Política e Doutrina Paulista}

O modo de fazer a política republicana em São Paulo está relacionado à conquista do poder central (o Executivo federal) por parte dos cafeicultores do interior paulista, logo após a derrocada do domínio dos militares, que se encerra com Floriano Peixoto. Nas eleições realizadas em $1^{\circ}$ de março de 1894, foi eleito Prudente de Morais para a Presidência da República, dando início, então, ao ciclo de governos civis da Primeira República.

\footnotetext{
${ }^{13}$ Os Estados de Minas Gerais, Rio de Janeiro, Ceará, Bahia, Paraná, Santa Catarina, Goiás e Rio Grande do Norte, apoiaram unanimemente a candidatura de Rodrigues Alves, resultado de uma costura política de Campos Salles.

${ }^{14}$ Para outros detalhes, ver: WITTER, José Sebastião. República, Política e Partido. Bauru/São Paulo: Editora da Universidade Sagrado Coração, 1999. p. 23-55.

${ }^{15}$ WITTER, José Sebastião. Op. cit. p. 120-121. Sobre as relações do Partido Republicano Federal e os governos de Floriano Peixoto e Prudente de Morais, consultar SOUZA, Maria do Carmo Campello de. O processo político partidário na Primeira República. In: MOTA, Carlos Guilherme (Org.). Brasil em Perspectiva. 3a ed. São Paulo: Difel, 1973. p.178-182.
} 
Com o fim do Florianismo ${ }^{16}$ o Partido Republicano Paulista ascende eleitoralmente e assume a política republicana no plano nacional, implantando um projeto político para o Brasil sustentado na economia cafeeira.

É preciso investigar quais os motivos que levaram os políticos republicanos de São Paulo a assumirem o controle da hegemonia política no plano nacional, acabando por desenvolver todo um projeto de construção do poder republicano em bases civis, divorciando-se, assim, da tutela militar, a qual deixou profundas marcas, impregnadas nas práticas políticas republicanas desde a proclamação em $1889^{17}$. E nem poderia ter sido diferente, pois os militares estiveram à frente do processo inicial de construção da República.

A tese fundamental que explica a forte presença dos republicanos paulistas no controle do Estado nacional, após a era dos militares, diz respeito ao modo como foi possível construir o poder regional no Estado de São Paulo. Aliás, por poder regional entende-se a construção das alianças políticas e econômicas entre os políticos do Interior, ligados ao Partido Republicano Paulista, com base na estrutura política coronelística. Tratava-se de uma bem montada máquina eleitoral, que vinha acompanhada de uma estratégia de apadrinhamento de "famílias" e de "parentelas" que estavam voltadas para as "causas republicanas".

É certo, porém, que se atribua ao poder econômico do café capacidade de provocar alteração radical na estrutura de poder. De fato, o café representava um poder enorme dos produtores paulistas $^{18}$.

Mas é preciso examinar a atuação dos políticos republicanos na Câmara dos Deputados do Estado de São Paulo, enquanto um poder dos mais importantes na construção da ordem política regional, com a proclamação da República em 1889.

Assim, como dissemos, a natureza do poder regional nos Estados passa por mudança profunda de sentido com a República, implicando não só numa autonomia local, como sobretudo em poder autônomo no plano estadual. Com tais poderes, um pouco mais adiante, em 1898, a Lei

\footnotetext{
${ }^{16} \mathrm{O}$ "Florianismo" foi um movimento liderado pelos adeptos de Floriano Peixoto, também denominados de "jacobinos", elementos que usavam da violência para protestar contra o governo republicano constituído. Cf. QUEIROZ, Suely R.R. de. Os radicais da República. Jacobismo: ideologia e ação (1893-1897). São Paulo: Brasiliense, 1986. ${ }^{17}$ Vide tese de KUGELMAS, Eduardo. Difícil hegemonia. Um estudo sobre São Paulo na Primeira República. Tese de Doutoramento, USP, 1988.

${ }^{18}$ FAUSTO, Boris. Pequenos ensaios de história da República, 1889-1945. São Paulo: CEBRAP, 1972. Ver ainda DEAM, W. A Industrialização de São Paulo. São Paulo: Difel, 1971.
} 
Estadual no 374 acabará por dar um ordenamento mais adequado às questões administrativas também dos municípios. O dirigente local será necessariamente um vereador, eleito pelos seus pares. Mantêm-se quatro intendências, sendo os intendentes indicados pelo prefeito ${ }^{19}$.

Recordemos que, ainda antes da República, o Império concentrava os poderes na Coroa, cabendo ao parlamento legislar e atuar apenas na esfera suplementar das instituições monárquicas. Da mesma forma, as Assembléias Legislativas Provinciais, criadas em 1834 com o Ato Adicional, também se ocupavam com questões secundárias ou de pouca importância. Tais assembléias continuaram, ao longo de toda a segunda metade do século XIX, praticamente inoperantes e pouco representativas em termos políticos. Mas é a partir de 1872, com a fundação do Partido Republicano em São Paulo, que terá início o movimento de oposição partidária à Monarquia de D. Pedro II.

O papel que São Paulo desempenhou na condução da política republicana no Brasil, sobretudo no período de 1894 a 1898, no governo Prudente de Morais, é importante que registremos, derivou não somente de sua importância econômica com o café como pauta principal da exportação do País, mas também da densidade demográfica e eleitoral. Convém lembrar que São Paulo e também Minas Gerais, no início da República, já possuíam os maiores colégios eleitorais do Brasil, ainda que apenas $8 \%$ da população possuísse o direito garantido de votar. Ao longo dos últimos anos do século XIX e início do século XX, esses Estados exerceram hegemonia política sobre os demais ${ }^{20}$.

Mas não apenas questões como a densidade demográfica e eleitoral faziam de São Paulo uma força política hegemônica. Outros fatores também indicaram a superioridade política do Estado, como, por exemplo, o fato de o Partido Republicano Paulista demonstrar uma certa organicidade em território paulista, com dirigentes políticos respaldados em grupos bastante fortes e coesos, além de profissionais técnicos e intelectuais na condução das políticas públicas do Estado.

Tratava-se de uma oligarquia bem estruturada, tendo cada grupo sua área de atuação e influência, com o reconhecimento do poder estadual, que acabava por legitimar os papéis políticos exercidos pelos oligarcas e seus prepostos. Acresce, ainda, o poder de repressão que emanava do Estado Paulista, com sua polícia organizada, treinada e equipada. São Paulo apresentava a polícia mais capacitada para a tarefa de combater qualquer movimento de inversão da ordem proveniente dos “inimigos” da República, fossem quem fossem.

\footnotetext{
${ }^{19}$ LAPA, J.R.A. (Org.). História Política da República. Campinas: Papirus, 1990, p. 107-22.

20 " [...] o número de eleitores em cada Estado era essencial ao processo político, visto que o presidente se elegia pelo voto popular direto e, em muitos sentidos, o poder executivo controlava os outros dois poderes [...]" In: CARDOSO, Fernando Henrique. O modelo político brasileiro. São Paulo: Difel, 1972.
} 
As eleições municipais eram momentos em que os políticos podiam medir suas forças e demonstrar prestígio junto às elites locais. $\mathrm{O}$ apoio de deputados e do governador geralmente determinava qual grupo iria dominar ou já dominava o poder municipal. Maria Isaura Pereira de Queiroz, em O mandonismo local na vida política brasileira, demonstrou exaustivamente como na Primeira República "[...] as lutas municipais continuaram de primordial importância para a política brasilei$r a[\ldots]^{21}$ ". Tais políticos informalmente exerciam várias atividades ou funções, geralmente eram proprietários de fazendas, comerciantes com diferentes negócios, empregando muitos trabalhadores como agregados ou camaradas, controlando, portanto, o mercado de força de trabalho regional.

Com essa posição de poder, o político tinha condições de exercer forte influência sobre os eleitores. Segundo Vítor Nunes Leal, ${ }^{22}$ muitos desses políticos eram também advogados, médicos, sacerdotes e até escritores, prestando pessoalmente serviços aos seus eleitores, inúmeras vezes sem receber qualquer remuneração. Em suma, tratava-se de uma estratégia da "prática de favores" que marcou profundamente o modo de fazer política no final do Império e início da República no Brasil. A caracterização dessa prática é lapidar na análise clássica de Maria Isaura Pereira de Queiroz:

“[...] para quem não tinha eleitorado, era situação bastante difícil; os mandões locais continuavam nos municípios, dominando a administração, poder judiciário, polícia, câmara municipal; a oposição nem sequer podia votar, porque o processo eleitoral estando nas mãos da câmara ou do judiciário, era o mesmo que estar nas mãos do 'coronel' [... $]^{23}$."

Como se vê, o centro da política é o município e, por isso mesmo, o governo estadual mantinha com os políticos locais uma relação de cordialidade e parceria para assegurar estabilidade e continuidade do poder, evitando-se confrontos entre essas esferas de mando. Não é por outra razão que se

“[...] exigia do chefe da política estadual muito trabalho na coordenação e harmonização dos 'coronéis' das diferentes zonas, tendo em vista não só a eleição de seu candidato, como sua própria permanência no cargo, sem ameaças de ser derrubado por adversários $[\ldots]^{24}$.”

\footnotetext{
${ }^{21}$ QUEIROZ, Maria Isaura Pereira de. O mandonismo local na vida política brasileira e outros ensaios. São Paulo: Alfa-Omega, 1976, p. 20. Destaque também para o importante trabalho de SALLUN JR., Brasílio. Capitalismo e Cafeicultura. Oeste Paulista: 1888-1930. São Paulo: Duas Cidades, 1982.21

${ }^{22}$ LEAL, Vitor Nunes. Coronelismo, enxada e voto. São Paulo: Alfa-Omega, 1978.

${ }^{23}$ QUEIROZ, M.I.P. Op. cit., p. 116

${ }^{24}$ Idem, p. 117.
} 
Quando chegava a haver disputas pela hegemonia política numa dada região, entre as principais lideranças, o governador aguardava o desfecho dessas lutas para depois se manifestar, geralmente assegurando apoio ao vencedor ${ }^{25}$.

Por fim, dos políticos republicanos no Senado e na Câmara paulista que entraram em cena depois da proclamação, Prudente de Morais, Campos Salles e Júlio Prestes foram os principais artífices que, com um discurso civil, buscaram eleger o desenvolvimento da economia cafeeira e a autonomia municipal enquanto um projeto político bem articulado ${ }^{26}$. Eles são chamados pela historiografia de "republicanos históricos", pois militaram nos congressos do partido e participaram da propaganda republicana, desde 1870 . Cerca de 200 republicanos estiveram envolvidos nesses congressos, sendo 80 deles de São Paulo. Dos paulistas, os mais atuantes foram Américo Brasiliense, Américo de Campos, Antonio Francisco de Araújo Cintra, Antonio Francisco de Paula Souza, Antonio Muniz de Souza, Bernardino de Campos, Cesário Mota Júnior, Francisco Glicério, Francisco de Paula Cruz, Francisco Rangel Pestana, João Tobias de Aguiar, José Alves de Cerqueira Cesar, Luiz Antonio de Oliveira Cruz, Luiz Pereira Barreto, Manoel Ferreira de Campos Salles, Martinho da Silva Prado Júnior, Prudente de Morais, Rafael de A. Paes de Barros, entre outros ${ }^{27}$.

O governo civil de Prudente de Morais não significou a consolidação da República e o fim da hegemonia dos militares no poder, mas o prenúncio de um conjunto de valores institucionais assentados na lógica do federalismo, que assegurava a estabilidade do regime republicano.

Quando Campos Salles assume o governo republicano, o projeto nacional do PRP vai ser executado e se consolidar com base nas estruturas regionais de poder (os Estados se articulam seguindo a política desenvolvida em São Paulo através das alianças que foram sendo costuradas entre os coronéis e os "novos políticos"28.

O fato relevante nesse processo político é que os grupos cafeeiros de São Paulo, agora organizados em blocos regionais, acabaram também incorporando os interesses dos "industriais emergentes" na política do governo, o que deu origem à tese segundo a qual o Estado republicano defendia os interesses da burguesia industrial ${ }^{29}$.

\footnotetext{
${ }^{25}$ Idem, p. 121. Sobre esta mesma questão ver também JANOTTI, Maria de Lourdes Mônaco. O coronelismo, uma política de compromissos. São Paulo:Brasiliense, 1981.

26 Para uma reflexão sobre os governos de Prudente de Morais e Campos Salles, ver CARDOSO, Fernando Henrique. Dos governos militares a Prudente/Campos Salles. In: FAUSTO, Boris. (Org.). História Geral da Civilização Brasileira. São Paulo: Difel, v. 8, 1978.

27 LANG, Alice de B. da Silva Gordo. A propaganda republicana paulista na Província de São Paulo - 1984.

${ }_{28}$ Os "novos políticos" eram provenientes de setores econômicos e sociais não ligados diretamente à economia cafeeira como, por exemplo, alguns industriais e comerciantes e também militares que atuavam na política no começo da República.

29 DEAN, W. Op. Cit., pp. 30/40; FAUSTO, Boris. Op. Cit.
} 
É possível também levantar a hipótese de que no governo Campos Salles foi elaborada uma doutrina política e uma prática política para garantir uma estrutura de sustentação das diferentes formas de dominação local e regional por parte das oligarquias que se articulam sob as instituições republicanas, enquanto o Executivo federal cuidava da política nacional e internacional com o apoio dessas mesmas oligarquias. Assim, a República implantava o seu sistema oligárquico a partir de um "pacto" assegurado institucionalmente, e com a continuidade de uma prática política que marcaria, até os anos 30 do século XX, o modo de funcionamento do Estado republicano no Brasil ${ }^{30}$. Era a chamada "Política dos Governadores”, pela qual Minas e São Paulo dividiam as áreas de interesse e também se revezavam no controle da política do governo, além de desenvolverem ações no campo da economia e das finanças.

\section{O Poder local e a República}

O papel que São Paulo desempenhou na condução da política republicana no Brasil, no período 1894-1898, no governo de Prudente de Morais, deriva não somente de sua importância econômica com o café enquanto pauta principal da exportação do País, mas também da densidade demográfica e eleitoral de São Paulo.

São Paulo e Minas Gerais eram Estados politicamente organizados nos moldes oligárquicos e que, ao longo dos anos 1894 a 1905, exerceram uma hegemonia política sobre os demais Estados. De São Paulo saíram seis presidentes eleitos para um período de doze anos, e de Minas três, mas em compensação cumpriram dez anos e meio de governo republicano ${ }^{31}$.

Convém lembrar que São Paulo e Minas, no início da República, já possuíam os maiores colégios eleitorais do País, embora apenas $8 \%$ da população votasse.

Tudo indica que a superioridade política de São Paulo decorria de vários fatores: o PRP estava organizado em todo o Estado de São Paulo, os dirigentes políticos estavam respaldados em grupos coesos e fortes, com profissionais técnicos e intelectuais na condução das políticas públicas do Estado; a oligarquia paulista estava bem estruturada, tendo cada grupo sua área de atuação e influência, com o reconhecimento do poder estadual que legitimava os papéis políticos exercidos pelos oligarcas e seus prepostos. Simultaneamente, o PRP reinava praticamente sozinho no cenário da política brasileira, pois não havia partidos ou grupos expressivos de oposição, pelo menos até 1926, quando é organizado o Partido Democrático.

\footnotetext{
${ }^{30}$ Ver os "cinco pontos" desse pacto em CARONE, Edgard. Op. Cit. p.104.

${ }^{31}$ Veja-se abordagem de LOVE, Joseph. Op. Cit., p. 385-90.
} 
Durante o governo Floriano Peixoto, São Paulo e Minas garantiram apoio majoritário ao presidente, principalmente nas questões econômicas e políticas, mas também sustentaram militarmente o Estado do Rio Grande do Sul contra os federalistas. Ou seja:

“[...] A burguesia dos dois mais importantes Estados da união compreendia, por sua vez, ser importante a aliança com a ditadura militar, a fim de garantir sua futura direção do governo federal [...] $]^{32}$."

Havia o projeto de São Paulo de ocupar todo o espaço possível, particularmente em aliança com Floriano Peixoto. Os teóricos políticos paulistas, como Prudente de Morais e Campos Sales, sabiam como conduzir uma estratégia a longo prazo para garantir a tomada de poder pelas vias democráticas e eleitorais.

A importância que as Assembléias Legislativas dos Estados passaram a ter foi delegada pela Constituição republicana de 1891, a qual retirou do poder central - da monarquia deposta - o seu papel legislador. É o princípio da federação que foi assegurado pela República, implantando a autonomia como um instrumento do poder democrático no conjunto das instituições públicas no Brasil:

“[...] A República substitui o poder central que a Coroa exercia pelo Estado federal, que expressa a União ou o conjunto dos estados federados. Ou seja, a federação, na qual os seus componentes gozavam de uma determinada autonomia da faculdade para organizar-se e constituir-se, para elaborar legislação própria em matéria atribuída à sua competência e para gerir os seus negócios [... $]^{33}$.”

O federalismo, na realidade, era um arranjo político, ainda que constitucional, com o objetivo de tornar formal e ideológico um conjunto de práticas que passavam ao largo dos princípios teóricos do liberalismo clássico.

Quando havia disputas pela hegemonia política numa dada região, entre os principais coronéis, o presidente do Estado aguardava o desfecho dessas lutas para depois se manifestar, geralmente assegurando apoio ao vencedor ${ }^{34}$.

\footnotetext{
${ }^{32}$ JANOTTI, Maria de Lourdes Mônaco. “A República: oposições e consolidação.” In: LAPA, José Roberto do Amaral. Op. cit., p. 55.

${ }^{33}$ GUILHERME, Glicério de Freitas. "Glicério: República e Federação". In: LAPA, José Roberto do Amaral. Op. cit., p. 90.

${ }^{34}$ JANOTTI, Maria de Lourdes Mônaco. Op. Cit., 1981 QUEIROZ, Maria Isaura Pereira de. Op. cit., p. 121.
} 
Os fundadores do PRP, Campos Sales, Bernardino de Campos, Américo de Campos, Quirino dos Santos, J. V. de Almeida Prado, etc. se empenharam em organizar depois os congressos do partido para a definição de sua doutrina e programa de ação política ${ }^{35}$.

A representação de São Paulo, junto ao governo central da monarquia, em 1870, não era certamente expressiva e, portanto, destoava da sua importância econômica, principalmente com o café que nesse momento se encontrava em fase de grande expansão pelo Oeste da Província.

Os políticos das Regiões Norte e Nordeste, cuja economia estava em decadência (particularmente a produção açucareira), ainda detinham o poder, controlando os aparelhos legislativos e judiciários da monarquia, além de ocuparem os altos cargos públicos e administrativos do Estado. Segundo Zimmermann,

“[...] é no aparelho do Estado que se concretizam os mecanismos de solidificação dos interesses de classe, expressos na lei. Mas esse aparelho estava controlado pelos políticos da região do nordeste do país, principalmente Bahia ${ }^{36}$.”

É importante destacar o modo de fazer a política na Assembléia Provincial de São Paulo, ressaltando, em particular, a atuação dos políticos do Partido Republicano Paulista.

O PRP era um partido pequeno na Assembléia Provincial, mas o seu desempenho político, de seus deputados, revelava-se atuante e com uma postura moderada de oposição à monarquia; propunha apenas reformas políticas e mudanças sociais de certa forma conservadoras:

“[...] Os republicanos levavam para a Assembléia Provincial dois tipos de discussão: uma sobre política geral e outra sobre questões provinciais. Quanto a política geral procuravam abordar problemas do governo central (sua forma e atuação), da centralização do regime e do papel dos partidos monárquicos [... $]^{37}$.”

Em suma, os republicanos paulistas estiveram frente a frente com a organização de um partido que, embora ligado à política regional, tinha um projeto nacional centrado numa doutrina coerente e numa prática cotidiana de se fazer da política um instrumento de controle com base na "estratégia do favor", do "filhotismo", do apadrinhamento e, particularmente, da prática de fidelidade das relações pessoais.

${ }^{35}$ DEBES, Célio. A propaganda republicana em São Paulo, 1872 - 1889, In: LAPA, José Roberto do Amaral. Op. Cit., p. 109-10.

${ }^{36}$ ZIMMERMANN, M.E.M. Da propaganda à República (A organização do Partido Republicano Paulista, 18701889. In: LAPA, José Roberto do Amaral. Op. cit., p. 127.

${ }^{37}$ Ibid, p. 135. 
CAPÍTULO II - ASPECTOS ECONÔMICOS E SOCIAIS QUE CARACTERIZAM SÃO PAULO NA PRIMEIRA REPÚBLICA (1890 - 1920) 


\section{O Café, sua Importância e Expansão}

O café possui um papel relevante no passado recente do Brasil e, sobretudo, para o Estado de São Paulo, apresentando-se como a principal riqueza da região por mais de um século. Introduzido no País no início do século XVIII, destinou-se em grande parte a suprir as necessidades do consumo interno. Todavia, foi no século XIX que o mesmo passou a ter uma importância crescente na economia nacional. Ademais, o café contribuiu para a ordenação territorial, na medida em que sua expansão pelo interior do Estado fez surgir várias cidades, estabelecendo redes de comunicação, principalmente as ferrovias, movimentando portos, contribuindo mais tarde para a constituição do parque industrial, para o incremento da imigração e, ainda, para a expansão da população.

A cultura cafeeira encontra-se intimamente vinculada aos aspectos econômicos e sociais da sociedade brasileira, principalmente a paulista, tendo sido várias as regiões que se beneficiaram do café para se afirmarem como áreas desenvolvidas. A importância do café é não apenas econômica, mas também política, tendo em vista que ele consolidou a hegemonia política e o predomínio econômico do Centro-Sul, transformando-o na região brasileira na qual o desenvolvimento capitalista foi pioneiro e mais acentuado.

\section{Figura - A - Cronologia do Café - 1840 a 1885}

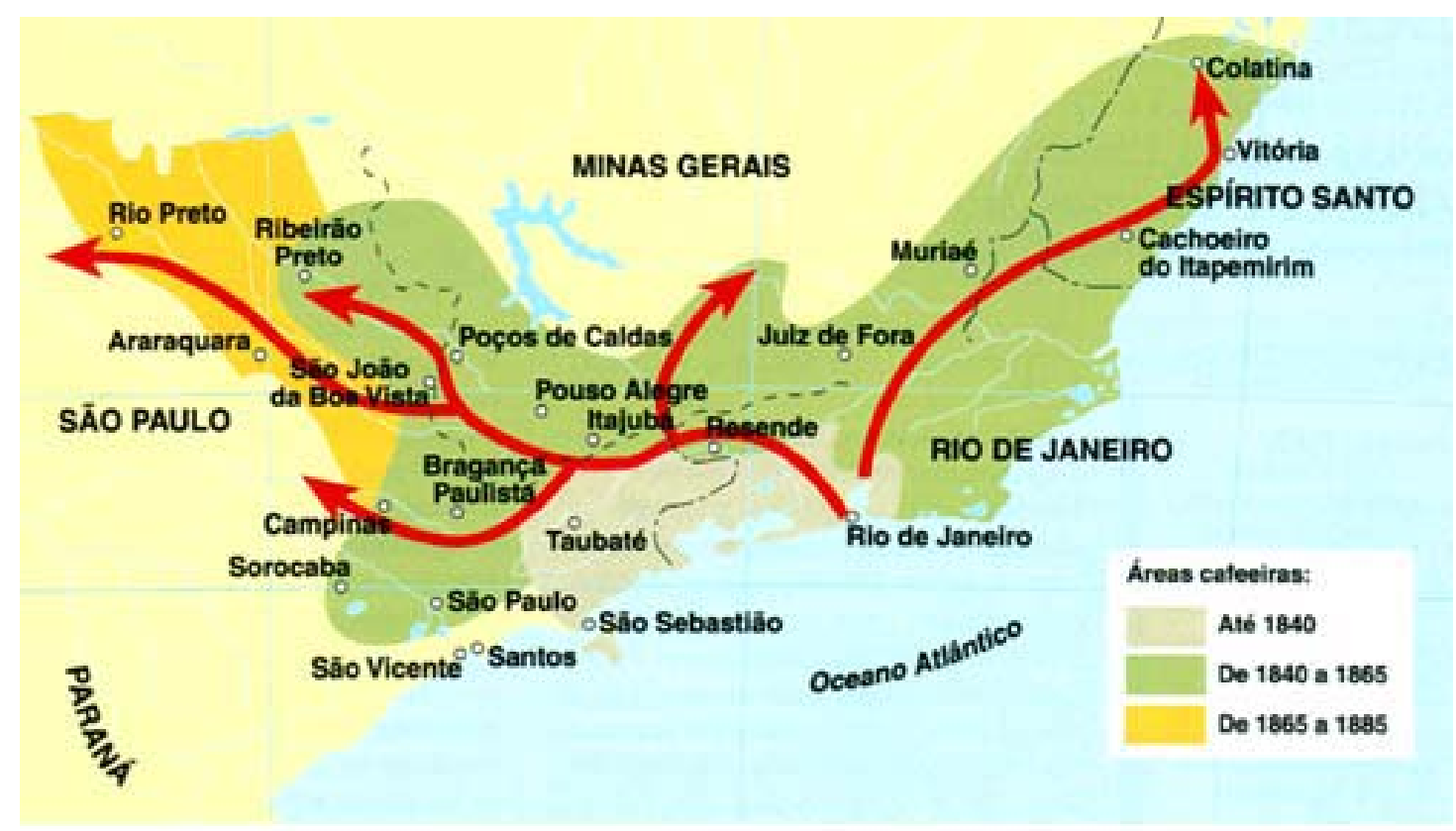

Fonte: www.multirio.rj.gov.br/.../oeste_paulista.html

Em 1850, as chamadas terras devolutas representavam dois terços do território do Estado de São Paulo. Nos anos seguintes há uma verdadeira corrida por essas terras, mobilizando milhares de famílias de vários Estados do Brasil, principalmente de Minas Gerais, para o Vale do Paraíba e também para o Oeste Paulista e a região Central de São Paulo. 
O Oeste Paulista, principalmente a região de Campinas, ingressa no ciclo do café, já que o Vale do Paraíba estava diminuindo a cultura do produto, uma vez que suas terras perderam as propriedades orgânicas, tornando-se impróprias para o plantio dos cafezais. Já as terras roxas do Oeste eram de boa qualidade e adaptadas ao café. As plantações no interior de São Paulo contavam com melhor infra-estrutura em estradas e ferrovias para atender à demanda da economia cafeeira.

“[...] Gradativamente a produção no Vale do Paraíba entrou em decadência. Antes da Proclamação da República, o chamado oeste paulista supera a região do Vale como grande produtor. Para este deslocamento concorreram alguns fatores básicos. Eles dizem respeito às condições geográficas (superioridade de clima e do solo do Oeste Paulista), facilidade de crédito, disponibilidade de força de trabalho, desenvolvimento de adequado sistema de transporte. É provável também que o regime de trabalho adotado em São Paulo, dando preferência ao colonato e não a parceria como em Minas Gerais, tenha possibilitado lucros mais elevados no período de ascenso ${ }^{l}$.

O certo é que o café no Oeste Paulista era mais capitalizado por estar baseado no trabalho livre do colonato, onde o trabalhador imigrante era contratado para cuidar de um determinado número de pés de café, desde a carpa à colheita e ao transporte do produto para os terreiros e, depois, para os barracões. Conforme o contrato entre o fazendeiro e o trabalhador imigrante, uma cláusula importante era aquela que dava direito de plantar milho e feijão nos corredores dos cafeeiros - o que proporcionava uma relativa vantagem para o imigrante-colono.

“[...] o pagamento pelo trato de mil pés de café era, em 1895, de 90 mil réis e de 600 réis pela colheita de cinqüenta litros de frutos. Numa pesquisa agrícola feita em 1907 [...] o relator dá como cifras médias de 60 a 100 mil réis por mil pés de café e de 500 a 600 réis por cinqüenta litros colhidos."

A expansão da economia cafeeira voltava-se em grande medida às necessidades do mercado internacional. Nos últimos anos do século XIX o Brasil já era o primeiro grande produtor mundial de café. Tal expansão fora incentivada, no âmbito internacional, pela generalização do consumo do produto na Europa e, sobretudo, nos Estados Unidos da América. No curso dos anos de 1850 a 1900, os Estados Unidos passariam a consumir maior quantidade de café brasileiro do que toda a

\footnotetext{
${ }^{1}$ FAUSTO, Boris. Pequenos ensaios de História da República (1889-1945). SP:CEBRAP, 1972, p.1. Do mesmo autor Expansão do Café e política cafeeira. In: História Geral da Civilização Brasileira. Tomo III, $1^{\circ}$. vol., p. 199200. Ver ainda HOLlOHAY, T. Imigrantes para o café. Café e sociedade em São Paulo (1886-1934). Rio de Janeiro: Paz e Terra, 1984.

${ }^{2}$ MARTINS, J. de S. O cativeiro da terra. São Paulo: LECH, 1978, p. 87.
} 
Europa em conjunto, em especial a partir do qüinqüênio 1870-1874. Segundo números apresentados pelo professor Antônio Delfim Netto, as exportações de café do Brasil, "na média de cinco anos, se destinaram percentualmente em 58,2\% aos Estados Unidos e 41,8\% à Europa ${ }^{3} . "$

No plano interno, ainda antes da proclamação da República, segundo o professor Roberto C. Simonsem, São Paulo já assumira a primeira colocação na produção brasileira de café, superando a província mineira no ano de 1881 e a fluminense ainda em $1889^{4}$.

O café apresenta a sua grande expansão entre 1888 e 1898, abrangendo uma vasta área territorial do interior de São Paulo. As regiões como a Mogiana, a Baixa Paulista, onde estavam situados os municípios de São Carlos, Pirassununga, Descalvado etc., a região Central, sobretudo as cidades de Campinas, Itatiba, Serra Negra, Itapira, Espírito Santo do Pinhal e São João da Boa Vista, e parte da Alta Sorocabana, formada por Botucatu e Piraju, receberam milhares de imigrantes e migrantes para o trabalho nas plantações de café.

Esse período de expansão do café corresponde ao surgimento de muitos municípios. O período de 1898 a 1910, no entanto, ficará marcado pelo crescimento mais lento dos cafezais, devido, entre outros motivos, à redução do consumo por importantes países da Europa, importadores do produto. Apesar dessa redução do plantio, a economia paulista manteve-se em crescimento e os investimentos em ferrovias e armazéns também tiveram continuidade.

Entre 1910 e 1920, os cafezais voltaram a crescer mais rapidamente, principalmente durante a Primeira Guerra Mundial (1914-1918). Essa mudança se explica pela elevação dos preços no mercado mundial, e também pela política de Campos Salles, sobretudo por meio do chamado Convênio de Taubaté , em 1907, que valorizava a produção cafeeira, política essa que durou até 1929, quando veio a grande crise da produção capitalista no mundo. Lígia Osório dá a seguinte informação sobre o ano de 1929:

"De 710 milhões de pés de café [...] houve uma ampliação para 828 milhões em 1918, e para mais de 1 bilhão em 1927, isto sem contar as novas plantações feitas para substituir os cafezais velhos das zonas antigas ${ }^{6}$.

\footnotetext{
${ }^{3}$ DELFIM NETTO, Antônio. O problema do café no Brasil. São Paulo, USP-FEA, 1959, p. 39-41.

${ }^{4}$ SIMONSEM, Roberto C. Aspectos da história econômica do café. In: Evolução industrial do Brasil e outros estudos. São Paulo, Companhia Editora Nacional, 1973, p. 190-2.

${ }^{5}$ Os dois principais objetivos do Convênio de Taubaté consistiam, de um lado, na retirada do mercado de parte da safra, com os recursos do empréstimo, restringindo a oferta e conseqüente elevação do preço internacional do produto; a seguir, buscou-se a estabilização da taxa cambial em nível mais baixo do que aquela então em vigor. In: FAUSTO, Boris. Op. cit, p. 215.

${ }^{6}$ SILVA, Lígia M. Osório. A apropriação territorial na Primeira República In: SILVA, S., SZMRECSANYI, T. (Orgs). História Econômica da Primeira República. São Paulo: EDUSP, 2002 p. 165.
} 
Entre 1918 e 1924 os cafezais tomam novas direções, agora pelos trilhos da Estrada de Ferro Noroeste, que partia de Bauru para o Mato Grosso. Foi nesse período que surgiram pelo menos uma dezena de novas cidades que cresceram rapidamente: Marília, Araçatuba, Salto Grande, Ourinhos, Lins, Jaboticabal, São José do Rio Preto, Agudos, Indiana, etc. ${ }^{7}$.

Na medida em que os solos tornavam-se cansados, o café seguia em direção ao interior, sendo que por onde passava fomentava o deslocamento populacional, a fundação de novas cidades, a abertura de estradas e ainda possibilitava elevadas rendas para seus produtores, sobretudo, nesses tempos, no Estado de São Paulo.

As denominadas zonas novas passaram a ser abrangidas pela expansão do café, de modo mais acentuado, na medida em que as chamadas zonas velhas passavam por períodos de declínio na produção, em função da diminuição da fertilidade do solo, do aumento no custo de produção, com aplicação de insumos, e dos momentos de crise de superprodução ou de queda de preços dentro e fora do Brasil. Outrossim, o valor da terra, inferior àquele praticado nas regiões mais tradicionais, também contribuiu de maneira favorável para o incremento da cafeicultura nas bocas de sertão.

Do ponto de vista estritamente econômico-político, em texto escrito para a renomada coleção História Geral da Civilização Brasileira, em seu tomo III, $1^{\circ}$. volume, tratando da Estrutura de poder e Economia no Brasil Republicano (1889-1930), novamente o professor Boris Fausto afirma que a análise da economia cafeeira no Brasil e da política do café durante a Primeira República ganha sentido sobretudo a partir de dois marcos histórico estruturais, ou seja: o “[...] predomínio e hegemonia da burguesia do café no plano interno e sua dependência do capitalismo internacional no plano externo"; e a transformação da hegemonia política interna em subordinação no plano internacional, condicionando a própria forma que assume esta hegemonia dentro do País. Assim, tanto o primeiro como o segundo marco estabeleceriam os limites das opções políticas possíveis, fosse para as forças sociais que representam o grupo hegemônico, fosse para aqueles que correspondem aos setores a ele subordinados ${ }^{8}$.

Insiste em frisar, ainda, que o exercício da hegemonia não se realiza sem atritos e confrontos, já que ela pressupõe "a compatibilidade mas não a identidade de interesses entre diferentes forças sociais”. Por fim, constata o autor que, nas últimas décadas do Império, a burguesia

\footnotetext{
${ }^{7}$ Idem, p. 168.

${ }^{8}$ O autor lança mão dos conceitos de "predomínio" e "hegemonia" no sentido e definição que lhes dá o pensador italiano Antônio Gramsci. O "Predomínio" correspondendo à dominação de uma classe, ou fração de, no campo da economia, como decorrência da relação de classes estreitamente ligadas à estrutura social objetiva e independente da vontade dos homens. Por sua vez, "Hegemonia" corresponderia à dominação no nível da política, onde intervêm a consciência e a vontade dos atores sociais, para decidir questões em conflito não só em um plano corporativo, como em um plano universal. FAUSTO, Boris. Op. cit., p. 195.
} 
cafeeira já assumira o controle da máquina estatal da província de São Paulo9 . Com a Proclamação da República, a hegemonia da burguesia do café alcançará o nível nacional, em meio a lutas em que os opositores se concentravam principalmente na esfera militar. Assim, os principais Estados da Federação acabariam por impor na Carta Constitucional de 1891 “os princípios que assegurariam esta hegemonia", ou seja, o estabelecimento de ampla autonomia para os Estados, principalmente levando-se em conta a possibilidade destes contraírem empréstimos externos, a formação de forças militares públicas próprias e, no âmbito da distribuição das rendas do País, acabou por “atribuir os impostos de exportação aos Estados-membros". Por certo São Paulo levaria ampla vantagem.

\section{Figura - B}

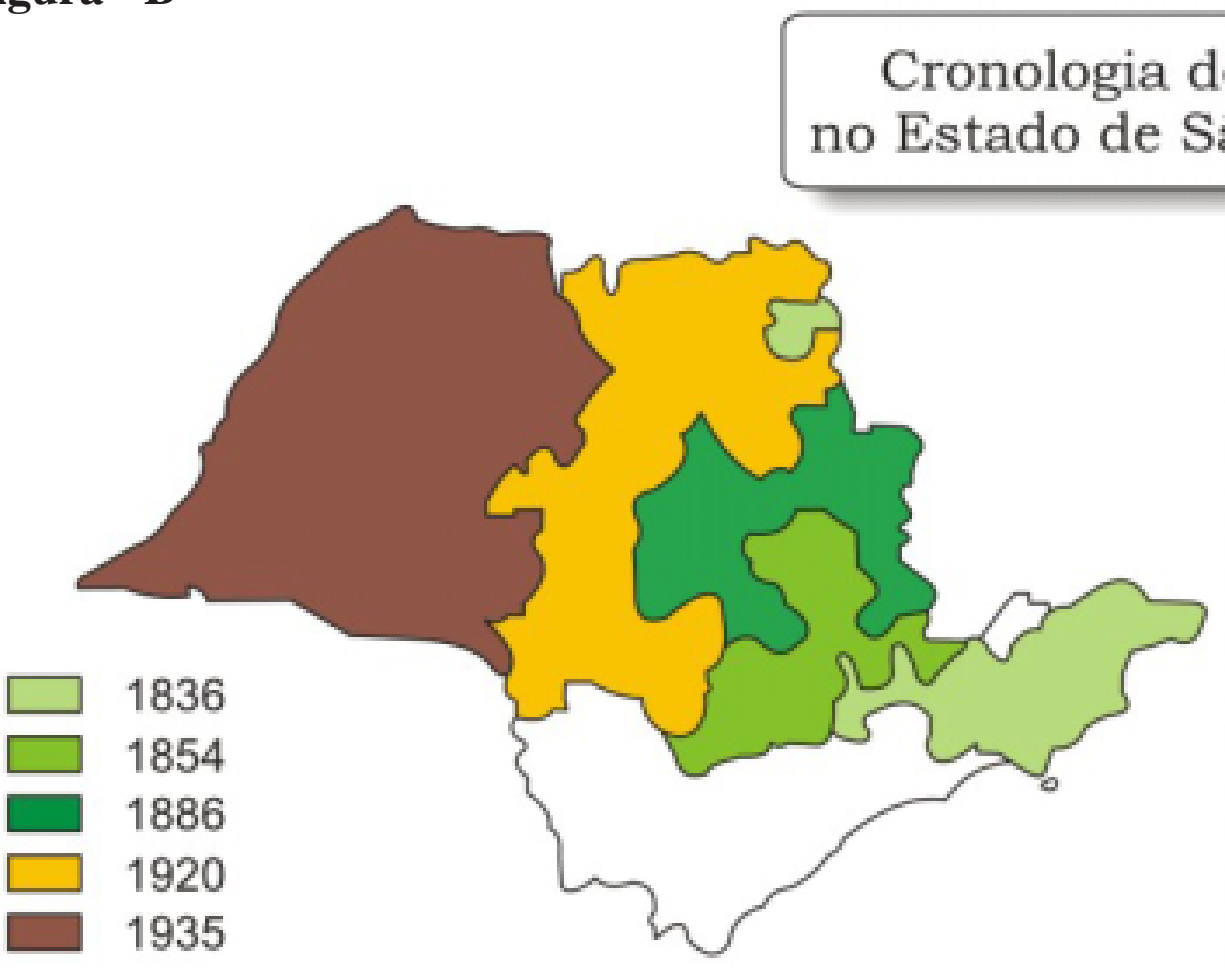

Figura criada a partir de MILLIET, S. 1982, p. 19-28.

\footnotetext{
${ }^{9}$ Em artigo intitulado Estado, capital cafeeiro e política tributária na economia paulista exportadora, 1889-1930, o professor Renato M. Perissinotto mostra, em situação mais complexa acerca das relações de agentes estatais e parte da classe economicamente dominante da economia cafeeira paulista, que tais agentes, ao promoverem uma política tributária essencialmente baseada no imposto de exportação, serviam-se de parte significativa do excedente produzido pelo capital cafeeiro para financiar as atividades ordinárias do aparelho estatal paulista, como educação, polícia, etc. E que isto muito desagradou aos membros daquela fração de classe. O artigo é encontrado em Latin American Research Review. University of Texas, v. 36, n. 1 (2001), p. 151-169.
} 


\section{Ferrovias}

A Província de São Paulo foi pioneira na implantação da malha ferroviária, que avançava pelo interior, desbravando a vegetação e transpondo rios e elevações montanhosas até proporcionar o surgimento de centenas de vilas e distritos que depois, rapidamente, seriam transformadas em municípios e comarcas.

A primeira estrada de ferro foi a Santos-Jundiaí, chamada São Paulo Railway, construída para transportar o café do interior paulista para o porto de Santos, responsável por sua remessa aos países europeus. Foi em 1867 que teve início sua construção ${ }^{10}$. Outras ferrovias foram criadas no Estado de São Paulo, como a Estrada de Ferro Paulista, em 1872, a Estrada de Ferro Ituana, em 1873, a Mogiana, em 1875, e a Sorocabana, também em 1875. Anos mais tarde, em 1905, é construída a Estrada de Ferro Noroeste do Brasil. Esse boom das ferrovias está diretamente ligado à expansão do café pelo interior paulista, em várias regiões.

“[...] Os custos dos empreendimentos acabou forçando uma associação que deu origem, em 1892, à Estrada de Ferro União Sorocabana; e mesmo assim surgiram problemas. Em 1904 foi arrendada pelo governo federal e, no ano seguinte, a província assumiu seu controle, para depois transferi-lo por arrendamento a um consórcio franco-canadense. Desse modo, a União Sorocabana passou a ser chamada Sorocabana Railway Company, até 1919, quando voltou à administração do governo de São Paulo ${ }^{11}$.”

A implementação das ferrovias, em sua grande maioria oriunda de investimentos privados, trouxe uma dupla vantagem para os cafeicultores:

"Se de um lado, as ferrovias transferiram sensíveis economias externas e diminuíam os custos aos cafeicultores, por outro lado, esses mesmos cafeicultores cuidaram para que ela fosse também lucrativa. Desta forma, a ferrovia passa a cumprir mais dois importantes papéis. Um, por se tornar uma nova e rentável oportu-

\footnotetext{
${ }^{10}$ Sobre as ferrovias paulistas destaco, entre outros bastante importantes: MATOS, O. N. Café e ferrovias: a evolução ferroviária de São Paulo e o desenvolvimento da cultura cafeeira. São Paulo: Arquivo do Estado de São Paulo, 1981; SAES, F. A. As ferrovias de São Paulo - 1870-1940. São Paulo: Hucitec, INL/MEC, 1981; SEGNINI, L. P. Ferrovia e ferroviários. São Paulo: Cortez, 1982; POSSAS, L. M. V. Mulheres, trens e trilhos. Modernidade no sertão paulista. São Paulo: EDUSC, 2001; CASTRO, M. I. M. O preço do progresso. A construção da Estrada de Ferro Noroeste do Brasil, 1905-1914. Campinas: UNICAMP. Dissertação de Mestrado, 1993. 14 SILVA, L.M.O. A apropriação territorial na Primeira República. In: SILVA, S.; SZMRECSANYI, T. (Orgs.). História Econômica da Primeira República. São Paulo: EDUSP, 2002. p. 157-186.

${ }^{11}$ DEL RIOS, Jéferson. Ourinhos. Memórias de uma cidade paulista. São Paulo, Ourinhos, Prefeitura Municipal/ IMESP, 1992, p. 21-22.
} 
nidade de inversão a parcelas do excedente gerado pelo complexo cafeeiro, tornando-se destino de parte desses capitais; outro, refere-se a sua lucratividade relativamente alta, que lhe confere o caráter de origem de novos capitais que permitem uma nova ampliação dos excedentes do complexo ${ }^{12}$ ".

A ferrovia assume, desta forma, um papel de agente disciplinador, responsável por mudanças que aconteceram nos mais diversos níveis da atividade humana. Ao longo dos trilhos das ferrovias vão se formando os núcleos urbanos entrelaçados com as fazendas de café. A maioria das cidades do interior de São Paulo, das chamadas regiões da Alta Sorocabana, Alta Araraquarense, Alta Paulista e Média Sorocabana, originou-se de acordo com o traçado e a implantação das ferrovias.

"[...] o que se desejava destacar e imprimir na mente de todos era o aspecto multiplicador das ferrovias, capazes de desencadear um processo de desenvolvimento nunca visto no Brasil. O movimento e a velocidade, intrínsecos aos trens, deveriam fazer mais do que conduzir celeremente mercadorias e pessoas: sua influência se espraiaria por todas as atividades dos homens. ${ }^{13}$ ",

Porém, antes mesmo da chegada dessas ferrovias já existiam algumas cidades com histórias próprias de sua fundação, como Bauru, Jaú, Rio Claro, Ribeirão Preto, Sorocaba, Jundiaí, Campinas, Itapetininga, Botucatu, Santa Cruz do Rio Pardo, Piraju, Campos Novos Paulista, etc.

A instalação dessas estradas foi baseada em investimentos dos fazendeiros paulistas, que não só se preocupavam com o transporte do café, como também previam a certa valorização de suas terras e o surgimento de núcleos urbanos. As ferrovias receberam também investimentos estrangeiros, principalmente de capitais ingleses, franceses e belgas em algumas dessas estradas.

A Sorocabana e a Paulista não eram exclusivamente para o transporte do café para o porto de Santos; elas se prepararam, além disso, para o transporte de passageiros entre as cidades interligadas e com a capital paulista. Essas duas estradas eram troncos e delas saíam ramais para atendimento às fazendas e aos núcleos urbanos - o que acabou por proporcionar um retorno financeiro complementar, valorizando ainda, como dissemos, a propriedade rural e a propriedade urbana. A manutenção desses ramais ficava por conta dos municípios e dos fazendeiros locais.

\footnotetext{
${ }^{12}$ CANO, Wilson. Raízes da concentração industrial de São Paulo. São Paulo: HUCITEC, 1990, p. 52-3.

${ }^{13}$ CASTRO, M. I. M. Op. cit., p. 74. Um estudo detalhado da formação das cidades às margens da Estrada de Ferro Noroeste é encontrado em GHIRARDELLO, Nilson. À beira da linha. Formações urbanas da Noroeste Paulista. São Paulo: EDUNESP, 2002.
} 
As regiões abrangidas pelas ferrovias aos poucos vão sendo reconhecidas por sua cultura cafeeira e o seu potencial para outras culturas, como o algodão e o milho, produtos de forte comercialização tanto no mercado interno como no externo, particularmente o algodão.

É sabido que o Centro-Oeste, na região de Botucatu, era a porta de contato e entrada para o sertão (boca do sertão). Botucatu é elevada à condição de município no ano de 1855 , passando à condição de comarca em 1866. Em 1885, outra cidade, Campos Novos, já em plena área do sertão, próximo ao Rio Paranapanema, passou a receber produtos de subsistência de sua região e seus produtores providenciavam o transporte em lombos de burros para Botucatu, então centro distribuidor e de comercialização dos produtos do sertão.

Bauru foi também uma cidade criada antes da implantação da Ferrovia Noroeste, em 1896. Nessas regiões "boca de sertão" as famílias foram se instalando em terras devolutas, dedicando-se, então, à produção de culturas de subsistência: cultivavam milho, batata, mandioca, feijão e alfafa e criavam gado, suínos e cabras, os quais destinavam-se ao consumo próprio e às praças de Botucatu, Sorocaba, Lençóis Paulista, etc ${ }^{14}$.

A região Noroeste e o Vale do Paranapanema tiveram seus territórios e seus recursos naturais mapeados pela Comissão Geográfica e Geológica do Estado de São Paulo, entre 1902 e 1906, com vista ao desenvolvimento econômico dessas regiões. A ocupação dessas regiões deu-se lentamente por famílias que se deslocaram de Minas Gerais, de regiões onde o café estava em decadência, pelo menos no período de 1860 a 1900. No período seguinte, já ocorrerá forte expansão do café com a chegada de imigrantes estrangeiros para a frente de expansão do interior paulista.

Em Bauru, por exemplo, depois de 1880 começam a chegar grandes fazendeiros paulistas da região de Jaú, Batatais e Capivari, visando a aquisição de grandes áreas de terras para o plantio de café. É justamente nesse momento que se instalam em Bauru fazendeiros como Joaquim de Toledo Piza, Araújo Leite, Azarias Leite, José Ferreira de Figueiredo e outros ${ }^{15}$.

Registra-se, assim, a presença de coronéis sintonizados com a política estadual, sobretudo depois da Proclamação da República. Quando da expansão das Estradas de Ferro Sorocabana e Noroeste, é importante notar, Jorge Tibiriçá ocupava a Presidência do Estado. Em 1908, com Afonso Pena à frente da Presidência da República, viu-se, a "era de ouro" do coronelismo, momento em que o acesso às terras devolutas fazia fortunas em pouco tempo. Por exemplo, a família Rodrigues

\footnotetext{
${ }^{14}$ Conforme GHIRARDELlO, Nilson, Op. cit., p. 72-73; MOMBEIG, Pierre. Pioneiros e fazendeiros em São Paulo. São Paulo: HUCITEC, 1984, p. 134-36.

${ }^{15}$ GHIRARDELLO, Nilson. Op. cit., p. 78-9.
} 
Alves, por volta de 1898, ocupou uma grande área de terras, legalizando-a formalmente. Então com mais de 10 mil alqueires, somente uma pequena parcela acabou destinada à formação de um povoado, a Vila de Piratininga.

Virgílio Rodrigues Alves, irmão do presidente Rodrigues Alves, foi também coronel e chefe político local. Em suas terras contavam-se dois milhões de pés de café. Com facilidades para a legitimação das propriedades, precisavam apenas apresentar documentos comprovando a posse, quase sempre por meio de recibos falsos fornecidos pelos grileiros. A fazenda Flores, em Cafelândia e Lins, de propriedade de Albuquerque Lins, e a fazenda Itacolony, de Hector Legru, em Promissão, também resultaram dessa ocupação e legalização das terras devolutas.

Em 1908, a partir também de terras devolutas, foram formadas as fazendas no município de Lins, em nome dos seguintes fazendeiros: Manoel Francisco Ribeiro, Frederico M. Costa, Amâncio Nogueira, José do Rego, Francisco Veloso Martins, João Pedro Carvalho, Joaquim de Godoy, etc. É interessante registrar ainda o destacado coronel Manoel Bento Cruz que, junto com outros investidores, tendo entre esses Hector Legru, com capital estrangeiro, colocaram à venda uma área de terra que ia de Promissão, passando por Araçatuba e chegando a Lins, dividida em centenas de partes ${ }^{16}$. Para isso, foi formada a The San Paulo Land Lumber e Colonization Company, empresa que cuidou da reabilitação dessas terras e vendeu-as como um empreendimento empresarial. Ao longo de 1920 as terras do interior estavam sendo direcionadas para a produção cafeeira. Agora, porém, eram divididas em propriedades menores e logo destinadas à venda, estimulando sobremaneira o lucro por meio da especulação ${ }^{17}$.

\section{1 - RELAÇÃO ENTRE HABITANTES-FERROVIAS-CAFEEIROS}

\begin{tabular}{|c|c|c|c|}
\hline Ano & Habitantes & Ferrovias (Km) & Cafeeiros \\
\hline 1860 & 695000 & 0 & 26800000 \\
\hline 1870 & 830000 & 139 & 60462000 \\
\hline 1880 & 1107000 & 1212 & 106300000 \\
\hline 1890 & 2279000 & 3373 & 220000000 \\
\hline 1910 & 2800000 & 4825 & 696701545 \\
\hline 1920 & 4592188 & 6616 & 826644755 \\
\hline 1930 & 7160705 & 7099 & 1188058354 \\
\hline
\end{tabular}

Fonte: ARAÚJO FILHO, 1956

\footnotetext{
${ }^{16}$ Muitos dos personagens aqui citados serão reencontrados quando do estudo das práticas de deputados e senadores no Parlamento paulista.22 Muitos dos personagens aqui citados serão reencontrados quando do estudo das práticas de Deputados e Senadores no Parlamento Paulista.

${ }^{17}$ GHIRARDELLO, N. Op. cit., p. 99.
} 


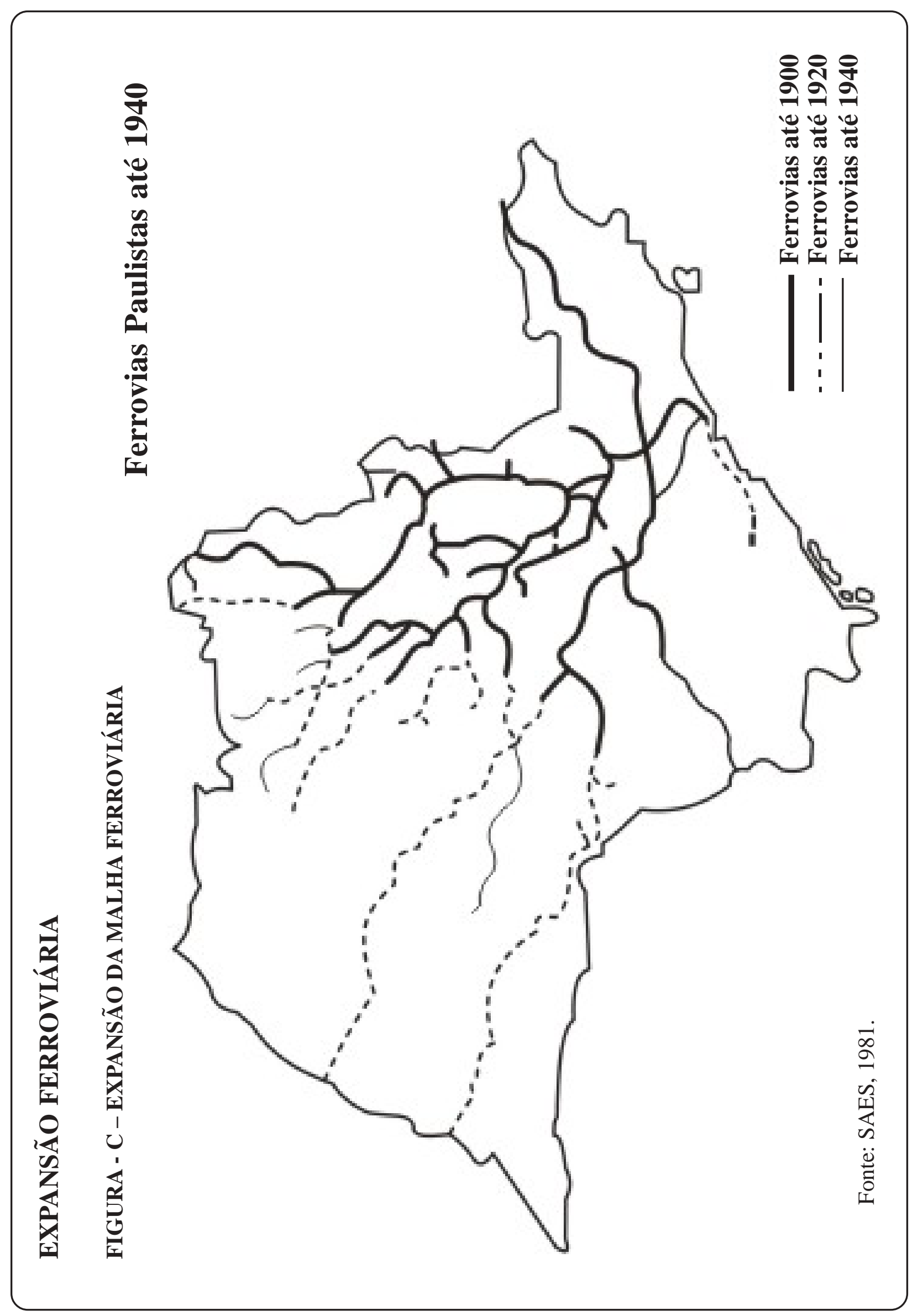




\section{A indústria e a Penetração Econômica Estrangeira}

Embora não se possa falar em "industrialização", a Primeira República foi marcada pela expansão das atividades industriais; uma tendência em curso desde as iniciativas que marcaram a Era Mauá, no século XIX, passando pelas tentativas "industrializantes" que marcaram o início da República (época do "encilhamento"), quando surgiram várias indústrias, boa parte delas aniquilada pela crise econômico-financeira que se seguiu ${ }^{18}$.

$\mathrm{Na}$ verdade, o processo de expansão industrial no período está diretamente relacionado aos primeiros indícios de crise do sistema de base agrário-exportadora. Seu desenvolvimento, por outro lado, não ocorreu de forma integrada, caracterizando-se mais como um processo espontâneo, devendo-se menos à ação de um forte grupo social

e coeso ligado a um programa de industrialização e menos ainda a uma política governamental deliberada. Ele resultou mais das condições propícias encontradas pela indústria: o País carecia de recursos para importar tudo que necessitava, existindo então uma área de consumo não satisfeita que crescia e se diversificava, à disposição do setor ${ }^{19}$.

Sob os aspectos econômico e social, os empresários industriais estavam ligados à produção cafeeira, quer pelo fato de que as atividades industriais nasceram vinculadas aos negócios cafeeiros, quer pelo aproveitamento de um mercado consumidor originado desse setor, ou ainda pelos laços de parentesco. De um modo geral, as indústrias na Primeira República formaram, dentro da classe dominante, um grupo com interesses próprios, mas que acabaria por aceitar a hegemonia do setor cafeeiro, beneficiando-se inclusive, de forma indireta, dos mecanismos que os governos desenvolviam para proteger a cafeicultura, como a desvalorização da moeda, a baixa cambial e outras medidas que enca-

\footnotetext{
${ }^{18}$ Ainda que em contraste com o tamanho e consistência do texto acima, segue relação de trabalhos indispensáveis para o estudo da história da industrialização no Brasil e, em especial, em São Paulo. CANO, W. Raízes da concentração industrial em São Paulo. Rio de Janeiro/São Paulo: DIFEL, 1977. CARDOSO, F. H. Condições sociais da industrialização: o caso de São Paulo. Revista Brasiliense, (28), março/abril, 1960. DEAN, W. A industrialização de São Paulo. São Paulo: DIFEL/EDUSP, 1971. FURTADO, C. Formação econômica do Brasil. 8. ed., São Paulo: Companhia Editora Nacional, 1968. LUZ, N. V. A luta pela industrialização do Brasil. 2. ed., São Paulo: Alfa-Ormega, 1975. MARTINS, J. S. Conde Matarazzo, o empresário e a empresa.. 2. ed., São Paulo: Hucitec, 1973. MELLO, J. M. C. O capitalismo tardio. 4. ed., São Paulo, Brasiliense, 1986. PELÁEZ, C. M. História da industrialização brasileira. Rio de Janeiro: Apec, 1972. PRADO JR., C. História econômica do Brasil. 12. ed., São Paulo: Brasiliense, 1970. SILVA, S. Expansão cafeeira e origens da industrialização no Brasil. São Paulo: Alfa-Omega, 1976. SIMONSEN, R. C. Evolução industrial do Brasil e outros estudos. São Paulo: Companhia Editora Nacional/EDUSP, 1973. SODRÉ, N. W. Formação histórica do Brasil.. 4. ed., São Paulo: Brasiliense, 1967. VERSIANI, F. R. e VERSIANI, M.T.R.O. A industrialização brasileira antes de 1930: uma contribuição. In: VERSIANI, F. R. e BARROS, J. R. M. (Orgs.). Formação econômica do Brasil. São Paulo, 1973. VILLELA, A. V. e SUZ1GAN, W. Política do governo e crescimento da economia brasileira, 1889-1945. Rio de Janeiro: IPEA/INPES, 1973. SUZIGAN, W. Indústria brasileira: origem e desenvolvimento. Nova edição. São Paulo: HUCITEC/EDUNICAMP, 2000.

${ }^{19}$ SAES, Flávio Azevedo Marques de. A controvérsia sobre a industrialização brasileira. In: Estudos avançados. v. 3, n.7. São Paulo: IEA/USP (set./dez.), 1989. Versão menos especializada ver em MAIA COSTA, H. Cadernos de História. São Paulo: UNIP, 1998.
} 
reciam as importações. Por outro lado, ao se considerar a ação governamental, verifica-se que o Estado não tomou uma atitude industrializante, mas também não foi antiindustrializante.

Durante a Primeira República, além dos inúmeros obstáculos que cerceavam o seu desenvolvimento, a indústria era freqüentemente acusada pelos setores agrários e pelas populações urbanas de ser "artificial” e "provisória”, "de viver de favores oficiais" e de ser a principal causadora da alta do custo de vida. Durante o governo Campos Salles, por exemplo, Joaquim Murtinho, o seu ministro da Fazenda, afirmava que as nossas indústrias eram "artificiais", produziam artigos de qualidade inferior e preço superior em comparação com os similares estrangeiros e, portanto, não mereciam nenhuma ajuda do governo federal.

Quanto ao seu caráter "provisório", é preciso levar em conta o papel de alguns fatores externos, que de certo modo contribuíam para o aumento da produção industrial. Nesse caso, avultaram em importância, segundo um entendimento corrente (para muitos estudiosos, ainda discutível), os estímulos gerados pela Primeira Guerra Mundial.

\begin{tabular}{|c|c|c|}
\hline \multirow{7}{*}{ Tabela 2.2} & \multicolumn{2}{|c|}{ A Industrialização na Primeira República } \\
\hline & Ano & $\begin{array}{c}\mathrm{N}^{0} \text { de } \\
\text { Estabelecimentos }\end{array}$ \\
\hline & 1889 & 626 \\
\hline & 1907 & 3.250 \\
\hline & 1914 & 7.430 \\
\hline & 1920 & 13.336 \\
\hline & 1930 & 18.023 \\
\hline
\end{tabular}

Figura adaptada a partir de SILVA, Sergio - 1976, p. 80-89

De fato, a grande "explosão" das indústrias ocorreu entre 1914 e 1920, ou seja, nos anos que envolveram também a Grande Guerra, quando o Brasil conheceu um surto industrial. Esta interrompeu ainda a importação de vários produtos industrializados, o que, aliado à queda do câmbio, teria ensejado a oportunidade para a fundação de muitas novas indústrias e, principalmente, para a reorganização das existentes.

No decorrer dessa última fase, o setor predominante era a indústria têxtil (60\%), com a de produção de alimentos ocupando o segundo lugar (15\%). Em 1920, a produção industrial paulista representava 31,5\% do total nacional, seguida pela do Rio de Janeiro, com 20,85\%. Por volta de 1930, a indústria já contribuía com 10\% da produção do País. Nesse momento, além dos setores têxtil e alimentício, destacavam-se também as indústrias de calçados, de móveis e de produtos intermediários, como o cimento e o ferro-guza. 
No século XIX, a industrialização ocorrida no Brasil, como em outros países subdesenvolvidos - segundo uma corrente de pensamento histórico-econômico determinada, - foi provocada por uma expansão do setor exportador, sobretudo do café, principal produto comercializado pelo País desde a década de 1830. A expansão do mercado consumidor externo de café e a sua valorização foram as bases do capital acumulado pela elite, especialmente em São Paulo - maior produtor no período de estudo, 1880-1920.

Na sua tese "Indústria brasileira: origem e desenvolvimento", Wilson Suzigan avalia quanto do investimento industrial foi influenciado pelo desempenho das exportações de produtos agrícolas. $\mathrm{O}$ autor realiza uma série de estudos de casos detalhados de indústrias nas quais os investimentos foram induzidos pela expansão da economia baseada na exportação de produtos agrícolas. Ainda, por meio desses estudos, ele verifica a diversificação do desenvolvimento industrial e a transição para o Capitalismo Industrial.

A ligação entre os dois setores econômicos, já enfraquecida pela diversificação das atividades industriais e pelos incentivos governamentais ao setor, sofreu uma ruptura definitiva na década 1930, após a crise no setor exportador e a Grande Depressão (1929) - que paralisou o fluxo internacional de mercadorias e capitais. Sob essas condições inicia-se o processo de industrialização para substituição dos importados.

Durante a Primeira República, a força do capital estrangeiro foi encarada como um fenômeno natural num país em expansão, necessitando dele e de suas técnicas superiores. O capitalismo inglês foi o grande privilegiado por esta política: o London \& River Plate Bank, do grupo Rotschild, foi o intermediário entre o governo brasileiro e a Inglaterra nos empréstimos negociados durante o período. Além dos benefícios financeiros, a indústria inglesa vai ser beneficiada com as possibilidades abertas pela crise industrial de 1901, cujo resultado foi o aumento da exportação industrial britânica para o Brasil.

Rodrigues Alves consolidou ainda mais esta ligação, com sua política de prosperidade e estabilidade cambial, uma vez que a moeda estável acabaria por propiciar a entrada de capitais e braços estrangeiros. Com isso, instalaram-se no Brasil inúmeras empresas estrangeiras: das 201 empresas fundadas entre 1889 e 1910, 160 eram estrangeiras.

Os fatos se repetiram durante todo o período, numa concordância entre as classes dirigentes brasileiras e o capital internacional: em 1915, representantes do grupo Rotschild telegrafaram diretamente a Wenceslau Brás para saber se haveria intervenção no Rio de Janeiro, pois tinham interesses naquele Estado. Durante a Grande Guerra verificou-se uma natural retração do capital 
estrangeiro. Contudo, a necessidade de abastecer os países em conflito possibilitou a instalação de um grande número de frigoríficos estrangeiros no Brasil, como o Armour e o Swift.

Com o fim da Primeira Guerra, os países europeus e os Estados Unidos voltaram a investir maciçamente no Brasil. Um ramo também marcado pela penetração de capitais americanos e ingleses foi o da eletricidade. Desde o começo do século, a Light and Power, empresa anglo-canadense, dominou sua produção e distribuição em São Paulo e Rio de Janeiro. Entre 1928 e1929 a Electric Bond \& Share adquiriu as pequenas companhias de eletricidade de todo o Brasil.

De 1889 a 1930, a dependência econômica brasileira perante as potências estrangeiras cresceu, com empréstimos que se constituíam em formas de controle das receitas do País: alfândegas e ferrovias ficaram por muito tempo sob o controle do capital estrangeiro, como garantia dos juros e prestações devidas. 


\section{São Paulo Dividido em Zonas e em Distritos Eleitorais. Caracterização e Cronologia}

Retomando parte da questão central desse trabalho, ou seja, vendo necessidade em delinear as regiões e localidades em todo território paulista, demarcando-as econômica, social e politicamente chegaria à existência de um espaço que ambientara a origem e cotidiano da representação política paulista, exercício bastante necessário para a pesquisa histórica. Assim estive, por um bom tempo, certo de que essa dinâmica teria sido obrigatoriamente encenada partindo mesmo de regiões ou zonas cujas forças representativas no interior do parlamento estariam deitadas em seu poder econômico, resultante da produção cafeeira do conjunto de municípios de cada uma, padrão de propriedade além de capacidade tributária e cômputo geral de suas riquezas.

Acreditava haver essa necessidade, já que partira da hipótese de que representantes dessas zonas (consagradas por diferentes autores como antigas, pobres e/ou decadentes, em oposição às novas e ricas ou ainda às novas porém pobres) teriam o grau de sucesso na luta anual pelos recursos oriundos do orçamento estadual diretamente relacionado à força econômica das zonas que representavam. E cristalizada tal hipótese, estariam então as zonas "pobres" e "decadentes", com seus respectivos parlamentares, fadadas a que papel nesse tabuleiro político, onde o que poderia estar em jogo era, muitas vezes, a sobrevivência de ambos? Teriam conseguido tais zonas, por meio de seus representantes, em algum momento nesse período (1890-1920), encontrado espaços e brechas que as teriam transformado em força hegemônica no quadro político estadual e, conseqüentemente, perante os parlamentares das zonas ricas, amealhando assim maior parte do bolo orçamentário, causando uma divisão entre grupos de uma mesma elite? Se não conseguiam, como se dava então essa partilha no âmbito do parlamento paulista.

Uma questão ainda se faz necessário levar a considerações: seria o delineamento desse cenário realmente importante para se contextualizar um jogo político cujo processo eleitoral, relembremos, pelo menos até 1905/6, dava-se de forma a que todos os candidatos ao Parlamento eram obrigatoriamente forçados a buscar votos por todo território paulista, ainda que tivessem em suas bases eleitorais (região de origem e depois distritos) o grosso de suas votações? Teria sentido, ou não, enfim, acreditar que o Estado de São Paulo, no período em questão (1890-1920), teria vivido dois momentos distintos em sua história político-eleitoral, ambos caracterizados e influenciados pela natureza da divisão do território paulista - sendo um primeiro no início da República até a reforma constitucional de 1905, quando os votos ainda são disputados em todo Estado, e um segundo quando esse passa a ser dividido por distritos eleitorais? 
Bem, com ou sem sentido, foi ficando claro que com tais indagações a resolver e estudando apenas informações biográficas dos parlamentares, arrolando cidade de origem, ramificações familiares ou fortuna pessoal não completaria um quebra-cabeça com força e segurança histórica necessária para que chegasse a bom termo esse trabalho. Foi preciso, então, decifrar detalhadamente discursos, proposituras e demais práticas no âmbito do legislativo paulista em torno do orçamento, e, definitivamente, incorporar, sim, a caracterização econômica e social dessas zonas, entendendo que só assim daria forma e cores mais consistentes a esse pano de fundo que ambientara nossas questões e os atores desse interessante drama.

Já que partia, então, de tais indagações, por que não realizar um esforço a mais de confrontação entre diferentes documentos, todos assinalando, ao longo dessa história, espaços, agentes e medidas legais que engendraram a totalidade do nosso drama? As iniciativas principais adotadas, acreditando, assim, serem as mais eficazes, foram, primeiro, a criação de ilustrações (em forma de mapas) ressaltando divisões do território paulista por zonas e por distritos eleitorais; segundo, trazendo no mesmo corpo do texto frações de documentos que informam o conjunto de municípios que compuseram tanto uma como outra ilustração-situação.

Com tais informações visuais, obviamente baseadas em bibliografia e fontes documentais tornadas clássicas pela historiografia, imagino agregar consistência a inúmeros dados e resultados que serão apresentados ao longo deste trabalho e facilitar a compreensão de situações chaves também aqui discutidas. E se, com isto, estiver ainda sendo capaz de criar um clima mais envolvente e realista aos leitores, acreditem, vou sentir-me absolutamente recompensado.

Como bem entenderam e trataram Love, Monbeig, Camargo, Oliveira entre outros ${ }^{20}$ (para cristãos novos, questão teórico-metodológica de complexo entendimento), a regionalização é um processo que se define sobretudo pelo problema que se quer analisar e consideram válido um amplo leque de critérios alternativos para as divisões regionais. Entre esses poderíamos citar o período de colonização, os tipos de organização econômica, redes de comunicação e sistemas ferroviários. Não deixaram de fora também regiões "sociais" que foram definidas de diferentes modos, das quais destacam caracterização de "zonas não contíguas”, identificadas em função de aspectos similares provenientes de informações e dados coletados no âmbito dos municípios. Porém, pode-se ressaltar que a maior parte dos critérios de regionalização que foram baseados na população, referem-se aos

\footnotetext{
${ }^{20}$ LOVE, J. Op. cit., pp. 41-3. MONBEIG, P. Os problemas da divisão regional de São Paulo. Instituto Brasileiro de Geografia e Estatística, 1954, pp. 181-9. CAMARGO, José Francisco de. Crescimento da população do Estado de São Paulo e seus aspectos econômicos. Ensaios Econômicos. 14, v.2, FIPE/USP, 1981, pp. 10-5. GONÇALVES OLIVEIRA, Éden. Áreas homogêneas no território de São Paulo sob o ponto de vista da organização agrária. Revista Brasileira de Economia. 27, 1, 1973, pp. 115-30.
} 
“padrões históricos de ocupação do território" e, entre esses, é nítida a relevância da questão da penetração das estradas de ferro pelo interior do território paulista.

Em fragmento de texto importante dentro de sua discussão acerca do tema, Love faz o seguinte registro segundo o ponto de vista daquele que ele definiu como seu problema a analisar:

"Em nosso caso, a principal preocupação é com a evolução do comportamento político [...] infelizmente não existe nenhuma maneira totalmente satisfatória para se definir as regiões políticas em São Paulo [...] Os distritos legislativos e eleitorais tinham diferentes sedes, muitas vezes, as divisões oficiais não correspondiam à distribuição efetiva do poder. O território paulista, exceto pelas quatro zonas 'antigas' - área que circunda a capital, o vale do Rio Paraíba, o sul subdesenvolvido (Baixa Sorocabana) e o litoral sul - foi ocupado em função dos cafezais e das ferrovias que avançaram pelo interior adentro [...] [e]Entre os vários esquemas desse tipo, escolhi o proposto por José Francisco de Camargo, que reconhece dez regiões [também chamaria por zonas]" ${ }^{21}$.

Para o meu caso, no entanto, ainda que não negligenciando a importância de tal debate, fato parcialmente solucionado com uma boa leitura desses trabalhos, não perdi a clareza de que era desnecessária uma total submersão nas águas profundas dessa discussão. Precisava sim, e tão-somente, procurar entender os caminhos percorridos pelos diferentes autores, suas técnicas e métodos utilizados, resultados alcançados, teses e distinções que os diferenciavam. A partir daí, partiria para "minha" opção de caracterização, totalmente baseada num conjunto de opiniões e fundamentações de alguns desses autores. Isso porque, relembremos, o foco de investigação deste trabalho passa ao largo desse debate e emerge de uma situação em que as zonas já estão divididas, sob os padrões históricos de ocupação do território e conseqüente expansão cafeeira, além do traçado das ferrovias. É esta minha opção. Mais adiante, serão os distritos eleitorais os marcos dessa divisão territorial paulista e ponto de partida dos principais atores dessa remontagem de alguns importantes aspectos da história política e econômica dessa locomotiva chamada São Paulo.

Para isto, apoiei-me principalmente em quatro trabalhos costumeiramente utilizados, dada sua relevância, por inúmeros cientistas sociais. São eles: Crescimento da população no Estado de São Paulo e seus aspectos econômicos, de José Francisco de Camargo, numa reimpressão da FIPE/ USP de 1981; A locomotiva. São Paulo na Federação Brasileira (1889-1937,) de Joseph Love (1981); Imigrantes para o café. Café e sociedade em São Paulo, 1886-1934, de Thomas H. Hollo-

\footnotetext{
${ }^{21}$ LOVE, J. Op. Cit., p.41.
} 
way (1984), e, por fim, Roteiro do Café e outros ensaios. Contribuição para o estudo da História Econômica e Social do Brasil, de Sérgio Milliet (1982).

Começo, porém, nesse momento de caracterização das zonas, insistindo em algumas rápidas advertências e explicações dos autores em questão, acerca dos limites e da complexidade dos critérios por eles adotados para a regionalização do território paulista (o que não seria muito diferente com outras unidades federativas) e que, como reproduzimos, devem ser definidos mediante o problema que se quer analisar.

Sérgio Milliet estabeleceu unidades territoriais estatísticas, formadas por blocos de municípios de modo que conservassem, com razoável grau de aproximação, as mesmas áreas em diferentes épocas em que se comparavam os dados demográficos e econômicos. No entanto, teve apontados pontos fracos na diretriz de que laçou mão, entre eles o problema principal residiria sobretudo na precariedade de importantes pontos e dados de todos os censos federais utilizados, anteriores ao de 1940, este tido como "muito mais idôneo", porém não utilizado por Milliet, uma vez que o período de suas pesquisas antecedera em alguns anos o censo de 1940.

Já José Francisco de Camargo traz como diferencial em seu trabalho exatamente a preocupação com a qualidade das informações nos censos anteriores ao de 1940. Atentando para seus pontos fortes e fracos, passa a considerar a ocupação do território e ampliação dos domínios dos cafezais (chegada e expansão), e também a evolução do traçado das estradas de ferro no Estado de São Paulo. Outro ponto a favor de seu método teria sido a sua preocupação em incorporar em suas pesquisas as chamadas "zonas antigas" - a área que circundava a capital paulista, o litoral sul, o vale do Paraíba e o sul subdesenvolvido -, o que também não ocorrera com Milliet.

Thomaz Holloway, enfatizando a necessidade de se lançar mão de um esquema "mais formal", sobretudo com vistas ao melhor aproveitamento de dados quantitativos da história socioeconômica de São Paulo então existentes, dá forma ao seu esquema de regionalização tendo como base os critérios de Milliet e Camargo, em especial aqueles que refletiam o desenvolvimento histórico do Estado de São Paulo, uma divisão que mantivesse as regiões constantes no decorrer do tempo, permitindo, assim, comparações entre diferentes tipos de dados, sem negligenciar o acompanhamento cronológico. Insistiu ainda na necessidade de as regiões serem pequenas o suficiente para manutenção de um determinado nível de coesão e diferenciação de outras regiões. Incorpora, por fim, o que chamou de "considerações mais específicas, como o desenvolvimento da rede de estradas de ferro, aspectos físicos e atividades econômicas predominantes, alcançando, assim, o número de 11 zonas.

Por fim, para Joseph Love (cuja opção citei com algum detalhe na página 36), atribuindo a José Francisco de Camargo a construção de um esquema mais completo, por aí seguiu sua análise, 
fazendo seu percurso baseado na existência de dez zonas. À primeira vista, num registro sem aprofundamento de estudo, vê-se a diferença entre os diferentes números de zonas adotados pelos autores no fato de Love e Camargo terem acabado por ampliar o número de municípios e territórios na região central do Estado, mais tarde denominada $3^{\text {a }}$. zona (Central). 


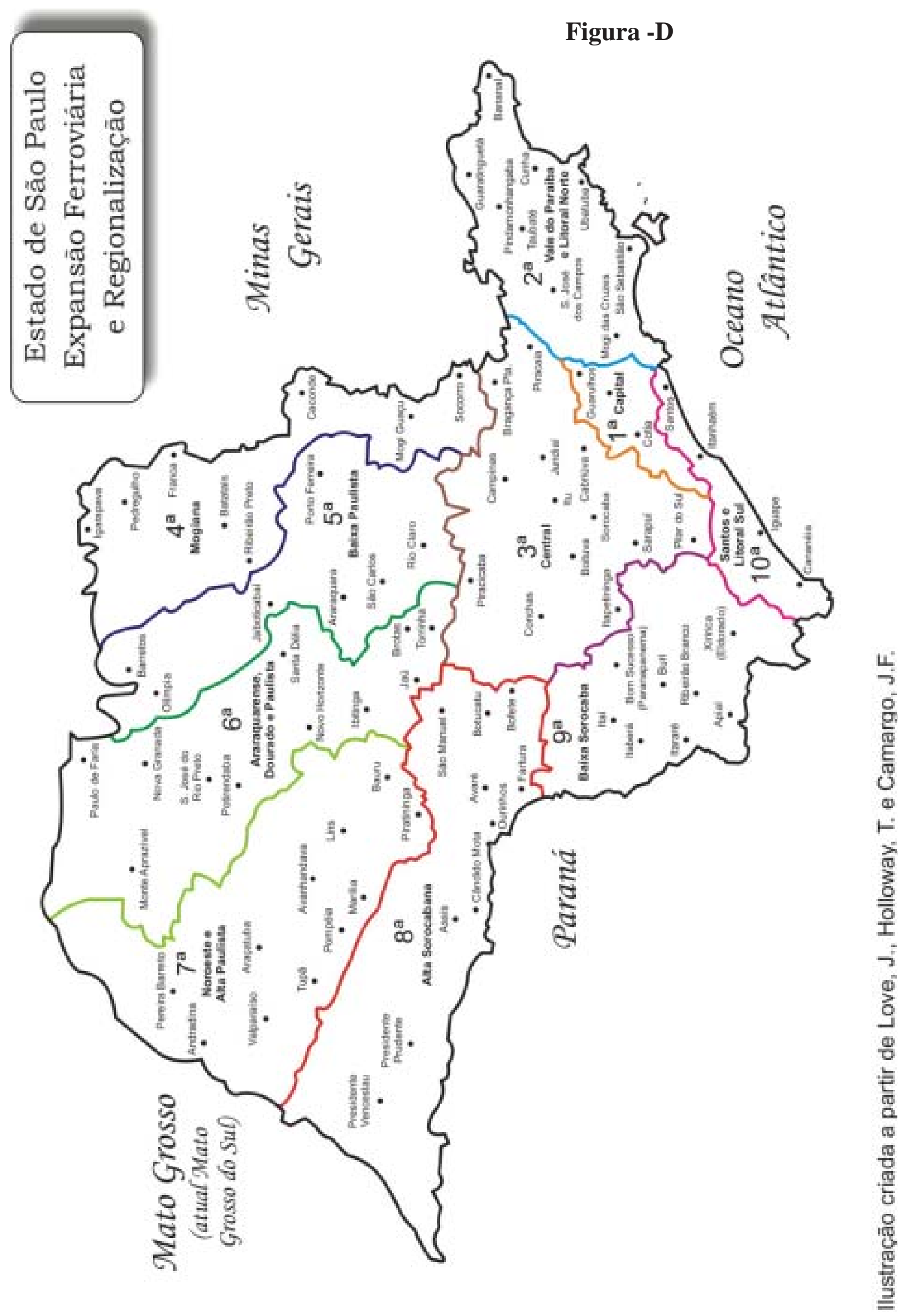




\section{1' zona: CAPITAL}

\begin{tabular}{|c|c|}
\hline Municípios & Data de criação \\
\hline Capital & $5-9-1558$ \\
\hline Guarulhos & $24-3-1880$ \\
\hline Cotia & $2-4-1856$ \\
\hline Itapecerica & $8-5-1877$ \\
\hline Juquerí & $27-3-1889$ \\
\hline Santo André & $30-11-1938$ \\
\hline Santo Amaro & $10-7-1832$ \\
\hline São Bernardo & $12-3-1889$ \\
\hline
\end{tabular}

A primeira zona ${ }^{22}$ era então constituída pela área da Capital e cidades circunvizinhas, englobando oito municípios, sendo que sete desses criados até o ano de 1889 e um em 1938 (Santo André). Para essa pesquisa, não vi necessidade premente em excluir esse último município, por sua existência concreta não abarcar o período em estudo (1890-1920). Sendo a menor territorialmente entre as dez zonas em estudo, sua participação na população total do Estado sai dos $5 \%$ no ano de 1886 para atingir mais de $20 \%$ em 1940.

Aí estavam também as menores propriedades agrícolas, então constituídas por fazendas localizadas ao redor da capital e com sua produção cafeeira praticamente extinta. Geraram-se, com isso, espaços para o cultivo de diferentes produtos.

Para o ano de 1907, assinalam Camargo e Love que a capital paulista registrava um número aproximado de 15 mil operários industriais, para uma população que já alcançara os 230 mil habitantes. Esse número, que representa um momento da história econômica paulista, torna-se tímido quando o comparamos com os 75 mil já em 1940, sem dúvida resultado da expansão do número de empregos sobretudo no setor industrial. Para Villela e Suzigan²3, não apenas esses números se expandiam na capital, como também nos municípios de seu entorno, que também compunham a $1^{\text {a }}$. zona, e se transformavam em subúrbios industriais.

\footnotetext{
${ }^{22}$ Daqui pra frente, todo o material que arrola o conjunto de municípios das dez zonas foi extraído de CAMARGO, J.F. Op. Cit., notas 24 a 33.

${ }^{23}$ VILLELA, Aníbal Villanova e SUZIGAN, Wilson. Política de governo e crescimento da economia brasileira, 1889-1945. Série Monográfica, 10. RJ:IPEA/INPES, 1973. Ainda sobre formação econômica e crescimento industrial ver publicações de VERSIANI, Flávio R., em especial, para esse capítulo, Formação econômica do Brasil: a experiência da industrialização. São Paulo: Saraiva, 1977, escrita com BARROS, J.R.M.de.
} 
Para os anos escolhidos de 1885-6, 1896 e 1920 (Love segue análise e classificação até 1938), a classificação dos municípios paulistas quanto a suas respectivas rendas mostra que a capital paulista manteve-se à frente de outros importantes municípios do Estado de São Paulo durante esses anos, e que, muito provavelmente, fico tentado a afirmar, sobretudo quando se acompanha uma linha ascendente constante nesse período, isso pode ter acontecido também durante todo intervalo que constitui o conjunto desses anos. Apresentava, então, uma renda (em contos, valor corrente e arredondado) de 338 para os anos de 1885-6, 3.864 para 1896 e 25.563 para o ano de 1920.

E mais. Convergiam para a capital paulista todas as estradas de ferro que ligavam as diversas zonas do interior do Estado de São Paulo. Assim, por tais dados e informações, ainda que fragmentados, a $1^{\mathrm{a}}$. zona constituiu-se no maior centro de concentração demográfica e econômica de todo Estado. 


\section{2a zona: VALE DO PARAÍBA e LITORAL NORTE}

\begin{tabular}{|c|c|}
\hline Municípios & Data de criação \\
\hline Areias & 28-11-1816 \\
\hline Queluz & $4-3-1842$ \\
\hline Barreiro & $9-3-1859$ \\
\hline Pinheiros & 27-6-1881 \\
\hline Bananal & $10-7-1832$ \\
\hline Cunha & $15-9-1785$ \\
\hline Guaratinguetá & $13-2-1651$ \\
\hline Aparecida & $7-12-1928$ \\
\hline Pindamonhangaba & $10-7-1705$ \\
\hline São Bento do Sapucaí & $16-4-1858$ \\
\hline Campos do Jordão & 19-6-1934 \\
\hline São Luiz do Paraitinga & $9-1-1773$ \\
\hline Lagoinha & 31-1-1881 \\
\hline São Sebastião & $16-3-1636$ \\
\hline Caraguatatuba & $20-4-1857$ \\
\hline São José dos Campos & $27-7-1767$ \\
\hline Formosa & $3-9-1805$ \\
\hline Jacareí & 1653 \\
\hline Santa Branca & $5-3-1856$ \\
\hline
\end{tabular}

\begin{tabular}{|c|c|}
\hline Lorena & $16-9-1788$ \\
\hline Silveiras & $28-2-1842$ \\
\hline Jataí & 22-2-1889 \\
\hline Cruzeiro & $6-3-1871$ \\
\hline Cachoeira & $9-3-1880$ \\
\hline Piquete & $7-5-1891$ \\
\hline Mogi das Cruzes & $17-8-1611$ \\
\hline Salesópolis & 24-3-1857 \\
\hline Guararema & 3-6-1898 \\
\hline Santa Isabel & $10-7-1832$ \\
\hline Igaratá & $3-6-1874$ \\
\hline Paraibuna & $10-7-1832$ \\
\hline Natividade & 18-4-1863 \\
\hline Taubaté & 5-12-1645 \\
\hline Caçapava & $14-4-1855$ \\
\hline Jambeiro & $30-3-1876$ \\
\hline Buquira & $26-4-1880$ \\
\hline Tremembé & 26-11-1896 \\
\hline Redenção & $8-5-1877$ \\
\hline Ubatuba & $28-10-1637$ \\
\hline
\end{tabular}

Descrita historicamente como a mais antiga zona de colonização do Estado e a que possuiu as primeiras e maiores fazendas, a zona do Vale do Paraíba ${ }^{24}$ alternou a produção de algodão, de açúcar e atingiu seu apogeu como região produtora de café, no período que abrange os anos 50 a 70 do século XIX.

As áreas dos municípios da segunda zona foram as primeiras a ser ocupadas, de forma extensiva e permanente, no Estado de São Paulo, segundo registram os trabalhos que nos apóiam neste capítulo. Do ponto de vista econômico, distinguiu-se das demais zonas por sua ligação com o

\footnotetext{
${ }^{24}$ Municípios extintos: Jataí / 21-5-1934, Igaratá / 21-5-1934, Lagoinha / 21-5-1934, Buquira / 21-5-1934. Salesópolis, antiga São José do Paraitinga; Igaratá, antiga Patrocínio de Santa Isabel; Cachoeira, antiga Bocaina; Formosa, antiga Vila Bela da Princeza; Barreiro, antiga São José do Barreiro; Piquete, antiga Vila Vieira do Piquete; Pinheiros, antiga São Francisco de Paula dos Pinheiros. Este último, reduzido à condição de distrito de paz em 21-51934, ficou pertencendo ao município de Queluz. Novamente elevado a município em 4-9-1937.
} 
porto do Rio de Janeiro, por meio do escoamento de sua produção cafeeira via ferrovia federal Central do Brasil, em direção à capital federal, enquanto costumeiramente a ligação das outras áreas era feita com o porto de Santos.

O cultivo nas grandes fazendas utilizava em larga escala o trabalho escravo, e reunia, até metade do século XIX, o maior número deles. Em 1886, sua população escrava alcançara o número de 28.500 almas, o que lhe conferia o segundo lugar em número em toda província.

Contudo, o café, devido à própria natureza da planta, vinha, com o decorrer do tempo e de suas vultosas safras, "cansando o solo", acabando por diminuir significativamente sua produtividade. A busca pela terra roxa no oeste do Estado e a abertura de novos cafezais mais produtivos, junto com a abolição da escravatura, levaram a região a uma relativa estagnação econômica e, segundo vários autores, a um posterior declínio e decadência ${ }^{25}$. Aglomerados populacionais que partiram em busca de novas regiões com terras férteis diminuíram a participação dessas cidades no cômputo regional. Em 1886, o número de habitantes da região representava 27,5\% do total da província, enquanto que, em 1920, essa taxa passou a 10,6\%. Porém, nunca é demais lembrarmos que, para alguns especialistas no assunto, deve-se levar em conta uma não correlação estreita entre as rendas municipais e os movimentos da população.

Por fim, do ponto de vista da classificação dos municípios paulistas por Renda, a zona do Vale do Paraíba e Litoral Norte classificou importantes municípios de seu bloco, alternando entre os anos de 1885-6, 1896 e 1920 três de suas unidades. Taubaté e Pindamonhangaba (1885-6), que ocuparam, respectivamente, o quarto e oitavo lugares, com rendas de 34 e 23 contos/ano. Para o ano de 1896, Taubaté se mantém na quarta melhor colocação, agora com 442 contos/ano e Pindamonhangaba desaparece desse grupo de municípios para aparecer Guaratinguetá, então em décimo lugar e com renda de 174 contos/ano. Em 1920 só permanecerá o município de Taubaté, então ocupando a nona colocação, apesar de sua significativa renda de 576 contos/ano. Se levássemos a análise até o ano de 1938 (também pinçado e analisado por Joseph Love, e com base em relatórios da "Commissão Central" para os anos citados), o Vale do Paraíba paulista não apareceria com nenhum de seus municípios entre os doze mais bem colocados nessa escala de riqueza.

\footnotetext{
25 Em sua tese de doutoramento intitulada O triângulo das barreiras do Vale do Paraíba Paulista (1835-1860), USP/ 2001, Hernani Maia Costa estuda pormenorizadamente a dinâmica das barreiras nessa região e acaba trazendo para o centro das discussões afirmações que contrariam essas constantes afirmações sobre a decantada "decadência" do Vale do Paraíba, no Estado de São Paulo. Relembremos que se entendia por barreiras (e ainda hoje) espécies de postos fiscais localizados principalmente nos acessos de povoações de cidades, para controle de tráfego e/ou cobrança de taxas de entrada de mercadorias, gêneros etc. E por tal volume da movimentação no período estudado, entre outros argumentos, não acredita o autor numa possível decadência.
} 


\section{$3^{\text {a }}$ zona: CENTRAL}

\begin{tabular}{|c|c|}
\hline Municípios & Data de criação \\
\hline Itapetininga & $8-10-1770$ \\
\hline Angatuba & $10-3-1885$ \\
\hline Guareí & $16-3-1880$ \\
\hline Sarapuí & $13-3-1872$ \\
\hline Pilar & $12-5-1891$ \\
\hline Tatuí & $13-2-1844$ \\
\hline Porangaba & $26-12-1927$ \\
\hline Pereiras & $5-5-1889$ \\
\hline Parnaíba & $14-11-1625$ \\
\hline Araçariguama & $7-5-1874$ \\
\hline São Roque & $10-7-1832$ \\
\hline Uma & $24-3-1857$ \\
\hline Atibaia & $27-6-1769$ \\
\hline Nazaré & $10-6-1850$ \\
\hline Piracaia & $24-3-1859$ \\
\hline Joanópolis & 17-8-1895 \\
\hline Capivari & $10-7-1832$ \\
\hline Jundiaí & $14-12-1655$ \\
\hline Itatiba & $20-2-1857$ \\
\hline
\end{tabular}

\begin{tabular}{|c|c|}
\hline Porto Feliz & $13-10-1797$ \\
\hline Boituva & $6-9-1937$ \\
\hline Tieté & $8-3-1842$ \\
\hline Conchas & $4-12-1916$ \\
\hline Laranjal & $8-10-1917$ \\
\hline Bragança & $17-10-1797$ \\
\hline Itu & $18-4-1654$ \\
\hline Indaiatuba & $24-3-1859$ \\
\hline Monte Mor & $24-3-1871$ \\
\hline Cabreuva & $24-3-1859$ \\
\hline Salto & $27-3-1889$ \\
\hline Campinas & $16-11-1797$ \\
\hline Americana & $12-11-1924$ \\
\hline Sorocaba & $3-3-1661$ \\
\hline Campo Largo & $7-3-1857$ \\
\hline Piedade & $24-3-1857$ \\
\hline Piracicaba & $31-10-1821$ \\
\hline Santa Barbara & $15-6-1869$ \\
\hline São Pedro & $22-2-1881$ \\
\hline Rio das Pedras & $10-7-1894$ \\
\hline
\end{tabular}

A terceira zona apresenta uma maior heterogeneidade geográfica ${ }^{26}$, se comparada às demais. Servida pelas estradas de ferro Paulista, Sorocabana (compreendendo a antiga Ituana) e Bragantina, foi a primeira região a ser formada por estas vias férreas. Na escala cronológica do cultivo do café, a zona Central sucedeu o Vale do Paraíba. Com a descoberta de sua terra roxa - a boa qualidade desta para a produção cafeeira - e o transporte barateado pela malha ferroviária, já em 1886 ela comercializava o dobro das sacas de café do Vale. A cidade de Campinas, centro da zona, ocupava lugar de destaque, sendo uma das mais prósperas de todo o Estado, sobretudo nos últimos anos desse século.

\footnotetext{
${ }^{26}$ Araçariguama, município extinto em 21-5-1934. Angatuba, antiga Espírito Santo da Boa Vista; Campinas, antiga São Carlos; Itatiba, antiga Belem de Jundiaí; Piracicaba, antiga Constituição; Piracaia, antiga Santo Antonio da Cachoeira; Americana, antiga Vila Americana; Monte Mor, antiga Capivari de Cima; Joanópolis, antiga São João do Curralinho; Tietê, antiga Pirapora de Curuçá. Sarapuí, incorporado ao município de Itapetininga em 21-5-1934 e ao de Sarapuí em 7-10-1937. Pilar, incorporado ao município de Piedade em 21-5-1934 e ao do mesmo nome em 5-111936; Campo Largo, reduzido à condição de distrito de paz em 3-7-1934, sendo incorporado ao município de Sorocaba e elevado novamente a município em 5-11-1936.
} 
Para o período de 1874 e 1881, ainda sob o Império, Campinas só rivalizava com o Vale do Paraíba como expressivo centro escravocrata de São Paulo. Entretanto, foram seus fazendeiros os pioneiros na introdução da mão-de-obra livre imigrante em terras paulistas, como substituição do trabalho escravo.

A cidade de Sorocaba e seu entorno, por muito tempo, manteve uma atividade pecuária de muares extensa, fornecendo burros de carga para outras zonas e até para outras províncias, como Minas Gerais.

Ao contrário da segunda zona, a queda da fertilidade de seu solo não foi seguida por uma decadência econômica. Campinas, Jundiaí e Sorocaba acabaram por ser beneficiadas por investimentos de capital que culminam com a industrialização dessas áreas.

Entre os anos de 1900 e 1920, a população da região teve um acréscimo de 82,3\%. Contudo, apesar do crescimento populacional, sua importância na formação da população estadual caiu com a expansão para o Oeste e a busca de novas terras para o café (de 25\%, em 1886, a 16,4\%, em 1920).

Nos anos de 1885, 1886 e 1896, a zona Central manteve três de suas unidades bem colocadas na classificação por Renda no quadro dos principais municípios paulistas para esse critério. Campinas, para os anos de 1885-6, ocupava a terceira colocação e um montante de renda de 82 contos/ano; Itu, para o mesmo período, 20 contos/ano e o décimo lugar; e Capivari, então na décima primeira posição, 18 contos/ano. Para o ano de 1896, mantém o número de três municípios, continuando Campinas a ocupar a terceira melhor posição, com renda que alcançara os 1.049 contos/ ano. No entanto, foram os municípios de Piracicaba e Sorocaba que melhoraram significativamente suas posições, pois até então não constando das doze principais unidades, Piracicaba atingiu a sétima posição, com renda de 252 contos/ano, e Sorocaba chegou, à nona colocação, com expressiva renda de 236 contos/ano.

Vê-se, assim, que a performance da terceira zona, nesses primeiros anos escolhidos, melhora não apenas na questão do aumento de suas rendas, mas também nas significativas colocações alcançadas. Porém no ano de 1920 oscila para baixo, perdendo uma vaga para as demais zonas. Mantém, ainda, Campinas, em terceirolugar, com renda de 2.040 contos/ano, e Sorocaba no décimo segundo lugar e renda de 497 contos/ano. 
$4^{a}$ zona: MOGIANA

\begin{tabular}{|c|c|c|c|}
\hline Municípios & Data de criação & Santo Antonio da Alegria & $10-3-1885$ \\
\hline Amparo & $14-3-1857$ & \begin{tabular}{|l|} 
Ribeirão Preto \\
\end{tabular} & $\frac{10-3-188 J}{12-4-1871}$ \\
\hline Pedreira & $31-10-1896$ & \multirow{2}{*}{ Cravinhos } & $22-7-1897$ \\
\hline Socorro & 24-3-1871 & & \multirow{2}{*}{$5-12-1896$} \\
\hline Mogi Mirim & $27-6-1769$ & Sertãozinho & \\
\hline Itapira & $2-3-1858$ & Pontal & 23-1-1935 \\
\hline Pinhal & 9-4-1877 & Batatais & 14-3-1839 \\
\hline & $9-4-18 / 1$ & Altinópolis & 3-12-1918 \\
\hline \begin{tabular}{|c|} 
Mogi Guassú \\
\end{tabular} & $9-4-1877$ & Brodosqui & $22-8-1913$ \\
\hline São João da Boa Vista & 24-3-1859 & Jardinópolis & $27-7-1898$ \\
\hline Vargem Grande & $1-12-1921$ & Franca & $3-10-1821$ \\
\hline Águas da Prata & $3-7-1935$ & Patrocínio do Sapucaí & 10-3-1885 \\
\hline Casa Branca & $25-2-1841$ & Ituverava & 10-3-1885 \\
\hline \begin{tabular}{|c|} 
Tambaú \\
\end{tabular} & 20-8-1898 & Guará & $19-12-1925$ \\
\hline São José do Rio Pardo & $20-3-1885$ & Igarapava & $14-4-1873$ \\
\hline Grama & 4-11-1925 & Pedregulho & 21-12-1921 \\
\hline Caconde & $5-4-1864$ & Nuporanga & $10-3-1885$ \\
\hline Tapiratiba & 27-12-1928 & Orlandia & $25-11-1909$ \\
\hline Mococa & $24-3-1871$ & São Joaquim & 26-12-1917 \\
\hline São Simão & $22-4-1865$ & Morro Agudo & $31-8-1924$ \\
\hline Santa Rosa & $21-12-1910$ & Serra Negra & $24-3-1859$ \\
\hline Serra Azul & $14-11-1927$ & Lindóia & $16-11-1838$ \\
\hline Cajurú & $18-3-1865$ & & \\
\hline
\end{tabular}

A quarta região foi ${ }^{27}$, por sua vez, a primeira "boca do sertão" do Estado, e se constituiu como prolongamento da região de Campinas, ocorrido por meio da construção da Estrada de Ferro Mogiana, que em 1875 ligava Campinas a Mogi-Mirim e, a partir de 1883, alcança Ribeirão Preto. No início do século XX, a Mogiana é a mais importante região do cultivo de café em São Paulo. Registra-se a existência expressiva de 115.149 alqueires de áreas cultivadas, com uma produção de 12.145.312 arrobas, em 1905.

27 Itapira, antiga Nossa Senhora da Penha do Rio do Peixe; Mococa, antiga São Sebastião da Boa Vista; Ituverava, antiga Carmo da Franca; Igarapava, antiga Santa Rita do Paraíso; Pinhal, antiga Espírito Santo do Pinhal; Nuporanga, antiga Espírito Santo de Batatais. Esta última passou, em 25-9-1909 a ser distrito de paz do município de Orlândia, sendo elevado novamente a município em 28-12-1926. 
Por ser fruto da expansão cafeeira, a zona tem um crescimento populacional a uma taxa de $159,6 \%$ no período de 1886 a 1900. Já no período seguinte, de 1900 a 1920, essa porcentagem é de $75 \%$, ainda um aumento muito significativo.

O declínio da produção cafeeira nessa região foi bem mais lento que nas demais, o que possibilitou a manutenção de um maior número de propriedades agrícolas de grande porte. Um outro fator importante teria sido a substituição da produção cafeeira pela pecuária bovina em suas terras e pastos. Em 1940, a região já era a maior criadora de gado do Estado de São Paulo.

Para os anos de 1885-6, a Mogiana classifica dois de seus municípios entre os doze primeiros. São eles Mogi-Mirim e Amparo. O primeiro, no quinto lugar, soma suas rendas em 29 contos/ ano. O segundo, vindo na posição logo abaixo (sexto lugar), apresentava para o período a renda de 26 contos/ano. Em 1896, soma mais um município nessa relação. Passam, então, a compor a lista: o município de Ribeirão Preto, quinto lugar e 428 contos de renda/ano; Amparo, oitavo lugar e 248 contos de renda/ano; e, no décimo segundo lugar, Itapira e seus 165 contos/ano. Enfim, para o ano de 1920, vê-se a elevação de Ribeirão Preto para a quarta posição, com expressivos 1.256 contos de renda/ano. É seguido, ainda, pelo município de Amparo, que se mantém em sexto, com 836 contos/ ano. Finalmente, no mesmo ano, aparece Sertãozinho, na décima colocação e com 561 contos/ano.

Vê-se assim que para esses anos escolhidos, a Mogiana (4⿳a . zona) chega a alternar número significativo de seus municípios entre os mais importantes, mantendo-se sempre bem representada no quadro geral. 
5 zona: Baixa Paulista

\begin{tabular}{|c|c|}
\hline Municípios & Data de criação \\
\hline Rio Claro & $7-3-1845$ \\
\hline Anápolis & $21-6-1897$ \\
\hline Itirapina & $25-3-1935$ \\
\hline Araras & $24-3-1832$ \\
\hline Araraquara & $10-7-1832$ \\
\hline Barreto & $10-3-1885$ \\
\hline Cajobi & $30-12-1926$ \\
\hline Olímpia & $7-12-1917$ \\
\hline Colina & $24-12-1925$ \\
\hline Guaíra & $18-3-1928$ \\
\hline São Carlos & $18-3-1865$ \\
\hline Santa Rita & $10-3-1885$ \\
\hline
\end{tabular}

\begin{tabular}{|c|c|}
\hline Descalvado & $22-4-1865$ \\
\hline Porto Ferreira & $29-7-1896$ \\
\hline Piraçununga & $22-4-1895$ \\
\hline Leme & $29-8-1895$ \\
\hline Sta. Cruz da Conceição & $4-7-1898$ \\
\hline Limeira & $8-3-1842$ \\
\hline Palmeiras & $20-3-1885$ \\
\hline Jaboticabal & $5-7-1867$ \\
\hline Bebedouro & $19-7-1894$ \\
\hline Monte Azul & $22-12-1914$ \\
\hline Pitangueiras & $6-3-1893$ \\
\hline Guariba & $6-11-1917$ \\
\hline Viradouro & $26-12-1916$ \\
\hline
\end{tabular}

A quinta zona ${ }^{28}$, localizada na parte "baixa" da Estrada de Ferro Paulista, corresponde à porção do Estado servida pela mesma estrada de ferro e também pela Estrada de Ferro São PauloGoiás. Ambas avançaram gradualmente em direção ao norte, alcançando os já prósperos municípios de Rio Claro, primeiramente, depois São Carlos e, em 1885, Araraquara. Fora a última zona a ser ocupada no século XIX, reduto final de dependência da mão-de-obra escrava para a lavoura cafeeira.

Considerada no final do século XIX e início do XX como das zonas agrícolas mais desenvolvidas do Estado de São Paulo, chegou a possuir, nesse período, o número impressionante de 150 milhões de pés de café, responsáveis por uma produção de 7,5 milhões de arrobas/ano. Para o ano de 1920 , experimentou significativa redução na produção do produto (50\%), mesmo vendo que o número de cafeeiros continuava a aumentar.

A sua população cresceu vertiginosamente, sobretudo no período que vai de 1836 a 1900 , chegando a somar, no ano de 1886, mais de 133 mil habitantes. No período de 1900 a 1920 esse número acabou praticamente por dobrar. Exemplo que ilustra bem essa rápida expansão populacional pela qual passara a zona da Baixa Paulista é o aumento demográfico de municípios como Barretos, Cajobi, Olímpia, Colina e Guairá. Juntas somavam, no ano de 1900, aproximadamente 9,6 mil

28 Santa Cruz da Conceição, município extinto em 21-5-1934. Santa Rita, antiga Santa Rita do Passa Quatro; Descalvado, antiga Belem do Descalvado; Palmeiras, antiga São Carlos do Pinhal; Rio Claro, antiga São João do rio Claro 
habitantes e, em 1940, contavam com mais de 130 mil, ou seja, um acréscimo da taxa, segundo registra Camargo, de $1.227 \%$.

Entre os doze primeiros municípios paulistas classificados por sua renda/ano, a Baixa Paulista fez-se representar nos anos 1885-6 pelos municípios de Rio Claro ( $7^{\circ}$. lugar e renda de 25 contos), São Carlos ( $9^{\circ}$. lugar e 21 contos de renda/ano) e Limeira (12 ${ }^{\mathrm{a}}$. posição e 18 contos de renda/ano). No ano de 1896 São Carlos manteve-se, agora ocupando a sétima posição e com 297 contos/ano de renda, aparecendo Jaboticabal no décimo primeiro lugar com 174 contos de renda. Finalmente, em 1920, novamente São Carlos permanece em privilegiada posição ( $7^{\mathrm{a}}$. e 754 contos), mantendo-se, assim, em destaque em todos os anos selecionados, seguida por

Araraquara, então ocupando o oitavo lugar e defendendo uma renda de 718 contos/ano. 


\section{6 zona: Araraquense, Douradense e Paulista}

\begin{tabular}{|c|c|}
\hline Municípios & Data de criação \\
\hline Monte Alto & $31-8-1895$ \\
\hline Pirangi & $7-3-1935$ \\
\hline Ariranha & 20-12-1918 \\
\hline Tabapuan & 27-11-1919 \\
\hline Jaú & $23-4-1866$ \\
\hline Barra Bonita & $14-12-1912$ \\
\hline Itapuí & $11-9-1913$ \\
\hline Bariri & $16-6-1890$ \\
\hline Boa Esperança & $21-7-1898$ \\
\hline Brotas & $14-2-1859$ \\
\hline Torrinha & $30-11-1922$ \\
\hline Rio Preto & $19-7-1894$ \\
\hline Cedral & 27-12-1929 \\
\hline Mirassol & 23-12-1924 \\
\hline Monte Aprazível & 23-12-1924 \\
\hline Tanabi & 23-12-1924 \\
\hline Nova Granada & $19-12-1925$ \\
\hline Potirendaba & $20-12-1935$ \\
\hline Uchoa & $30-12-1925$ \\
\hline José Bonifácio & 28-12-1926 \\
\hline Ibirá & $12-12-1921$ \\
\hline
\end{tabular}

\begin{tabular}{|c|c|}
\hline Palestina & $23-12-1936$ \\
\hline Paulo de Faria & $30-11-1938$ \\
\hline Doutorado & $19-5-1897$ \\
\hline Dois Córregos & $16-4-1874$ \\
\hline Mineiros & $29-8-1898$ \\
\hline Pederneiras & $2-5-1891$ \\
\hline Ibitinga & $4-7-1890$ \\
\hline Tabatinga & $18-12-1925$ \\
\hline Matão & $27-8-1898$ \\
\hline Santa Adélia & $22-3-1916$ \\
\hline Pindorama & $31-12-1935$ \\
\hline Ribeirão Bonito & $5-3-1890$ \\
\hline Catanduva & $14-11-1917$ \\
\hline Bocaina & $23-5-1891$ \\
\hline Taquaritinga & $16-8-1892$ \\
\hline Fernando Prestes & $5-7-1935$ \\
\hline Itápolis & $24-4-1891$ \\
\hline Borborema & $19-12-1925$ \\
\hline Novo Horizonte & $28-12-1916$ \\
\hline Itajobi & $25-10-1918$ \\
\hline Mundo Novo & $24-9-1928$ \\
\hline
\end{tabular}

$\mathrm{Na}$ cronologia do avanço do café em território paulista, a sexta zona ${ }^{29}$ tornou-se marco intermediário entre as chamadas "velhas" áreas de fronteira da Mogiana e Paulista e as zonas mais novas, a oeste do Estado. Ainda no ano de 1886, constituía-se por apenas três municípios (Jaú, Brotas e Dois Córregos).

Foi a partir do desenvolvimento desta zona que a relação cronológica equivalente à chegada do café e posterior aparecimento da ferrovia começou a mudar - diferente dentão com as demais zonas. Aqui as duas atividades aconteceram se não ao mesmo tempo, quase que simultaneamente.

\footnotetext{
${ }_{29}$ Bocaina, antiga São João da Bocaina; Itapuí, antiga Bica de Pedra; Taquaritinga, antiga Ribeirãozinho; Itápolis, antiga Boa Vista das Pedras.
} 
Como fica explicitado em sua própria denominação, a sexta zona formara-se por três importantes estradas de ferro: Paulista, Douradense (economicamente tida como prolongamento da Paulista) e Araraquarense. Em 1905 tinha nos municípios de Jaú, Dois Córregos, Brotas, Bariri, Ribeirão Bonito e Taquaritinga prósperos municípios cafeicultores, com destaque para Jaú, que sozinho contava com perto de 23 milhões de cafeeiros, cuja produção aproximava-se de 1,5 milhão de arrobas.

Em 1920, a população total da região chegara a mais de 580 mil pessoas, contra as pouco mais de 30 mil ainda em 1886. Só Rio Preto (atual São José do Rio Preto) já possuía 127 mil almas. Para os estudiosos, tornou-se zona de particular interesse na medida em que exemplificou a "marcha do café dentro de uma mesma unidade, acompanhada da marcha da população", fenômeno denominado como "penetração pioneira".

Talvez até mesmo pela cronologia da criação do conjunto de seus municípios, de datas mais recentes, é em 1920 que eleva seu primeiro município ao rol de classificação dos doze primeiros municípios paulistas pela importância de sua renda/ano. Tratou-se de Jaú, que naquele momento atingia o décimo primeiro lugar, com 553 contos de renda/ano. 


\section{$7^{\mathrm{a}}$ zona: Noroeste e Alta Paulista}

\begin{tabular}{|c|c|}
\hline Municípios & Data de criação \\
\hline Lins & $27-12-1919$ \\
\hline Getulina & $25-3-1935$ \\
\hline Iacanga & $27-12-1924$ \\
\hline Garça & $27-12-1928$ \\
\hline Marília & $24-12-1928$ \\
\hline Vera Cruz & $10-12-1934$ \\
\hline Pompeia & $30-11-1938$ \\
\hline Piratininga & $17-12-1913$ \\
\hline Duartina & $11-12-1926$ \\
\hline Gália & $20-12-1927$ \\
\hline Pirajuí & $3-12-1914$ \\
\hline Cafelandia & $30-12-1925$ \\
\hline Baurú & $2-4-1887$ \\
\hline
\end{tabular}

\begin{tabular}{|c|c|}
\hline Avaí & $2-12-1919$ \\
\hline Presidente Alves & $2-12-1927$ \\
\hline Penápolis & $22-12-1913$ \\
\hline Avanhandava & $29-12-1925$ \\
\hline Birigui & $8-12-1921$ \\
\hline Glicério & $30-12-1925$ \\
\hline Tupã & $30-11-1938$ \\
\hline Promissão & $29-11-1923$ \\
\hline Coroados & $26-12-1928$ \\
\hline Araçatuba & $8-12-1921$ \\
\hline Guararapes & $5-1-1937$ \\
\hline Valparaíso & $8-1-1937$ \\
\hline Andradina & $30-11-1938$ \\
\hline Pereira Barreto & $30-11-1938$ \\
\hline
\end{tabular}

Com exceção de Bauru ${ }^{30}$, todos os municípios desta zona foram criados a partir de 1913. Assim, a nossa sétima zona constituiu-se em "pioneira" por excelência, pois suas terras para o cultivo de café foram tomadas com a derrubada de florestas virgens, e sua população intensificou-se com a construção da Estrada de Ferro Noroeste do Brasil, em 1905. No ano de 1900, Bauru era o único município da região, com 7.815 habitantes. Duas décadas depois, a região alcança mais de 136 mil habitantes e vê o nascimento de mais seis municípios.

Neste primeiro vintênio, temos a penetração da Noroeste, que tem em Bauru seu ponto de partida, alcançando, alguns anos mais tarde, o município de Penápolis. É nesse período, contudo, que se intensifica a expansão desta zona - um aumento populacional da ordem de mais de $350 \%$ (618.990 habitantes), mais precisamente, em quatorze anos. De 1920 a 1934 surgem cidades importantes, como Marília (1928), Araçatuba (1921), Garça (1928). A inauguração da estação da Companhia Paulista de Estradas de Ferro em Marília, no ano de fundação da cidade, marca uma continuação da marcha por novas terras rumo ao novo-oeste.

Como afirma o professor José Francisco de Camargo, “(...) população e estradas de ferro [caminharam] pari passu na penetração pelas terras do oeste paulista, notando-se, então, a concor-

30 Bauru, antiga Espírito Santo da Fortaleza. 
dância entre o adensamento demográfico e a expansão da produção agrícola". Para Holloway, os trilhos claramente teriam precedido o café. Com áreas consideradas modestas se comparadas ao padrão médio das de outras regiões, em 1905, ainda constituída apenas por Bauru, cultivava mais de 1.300 alqueires, ao mesmo tempo em que gerava uma produção que ultrapassava as 90 mil arrobas de café. Para o ano de 1934, esse número já alcançara mais de 13 milhões de arrobas. Com pouco mais de uma década e meia de existência, no ano de 1920 o município de Bauru já era destaque entre os doze primeiros municípios paulistas na classificação de renda gerada por ano. Ocupando o quinto lugar nessa tabela de classificação, contava com a significativa quantia de 921 contos.

Assim, as características da região são definidas, como vimos, pela condição inicial de "zona pioneira", apresentando um rápido povoamento, junto à expansão das linhas férreas e, pouco mais adiante, um alto grau de presença de imigrantes. 
$8^{a}$ zona: Alta Sorocaba

\begin{tabular}{|c|c|c|c|}
\hline \multicolumn{2}{|c|}{ Data de criação } & Bocaiuva & $1-10-1924$ \\
\hline Presidente Pudente & 28-11-191 & Botucatú & $14-4-1855$ \\
\hline Santo Anastácio & $19-11-1925$ & Bofete & 21-4-1880 \\
\hline Presidente Wencesláu & $2-9-1926$ & Piramboia & $15-4-1891$ \\
\hline Regente Feijó & $23-6-1935$ & Conceição do Monte Alegre & 22-6-1896 \\
\hline Martinópolis & 30-11-1938 & Maracaí & $19-12-1924$ \\
\hline Presidente Bernardes & 23-1-1935 & Paraguaçú & $30-12-1924$ \\
\hline São Manoel & $10-3-1885$ & Quatá & $4-11-1925$ \\
\hline Agudos & $27-7-1898$ & Sapezal & $22-6-1896$ \\
\hline Bela Vista & $10-3-1898$ & Rancharia & $5-7-1935$ \\
\hline Assis & $29-12-1917$ & Fartura & 31-3-1891 \\
\hline Candido Mota & $28-12-1923$ & Ipaussú & $20-9-1915$ \\
\hline Avaré & $7-7-1875$ & Óleo & 14-12-1917 \\
\hline Itatinga & $24-7-1896$ & Ourinhos & $13-12-1918$ \\
\hline Cerqueira Cesar & $10-10-1917$ & Palmital & $18-12-1919$ \\
\hline Santa Cruz do Rio Pardo & $24-2-1876$ & Platina & 24-11-1915 \\
\hline Espírito Santo do Turvo & $15-5-1886$ & Pirajú & $25-4-1886$ \\
\hline Bernadino do Campos & 9-10-1923 & Salto Grande & 27-12-1911 \\
\hline Chavantes & $4-12-1922$ & Santa Barbara do Rio Pardo & $3-4-1876$ \\
\hline Lençóes & $25-4-1865$ & S. Pedro do Turvo & $29-5-1891$ \\
\hline
\end{tabular}

Também esta uma zona pioneira ${ }^{31}$, formou-se por municípios servidos pela extensão mais afastada e, por isso, mais recente da Estrada de Ferro Sorocabana. Seus trilhos chegaram a Botucatu em 1889 e, entre os anos de 1900 e 1910, até Ourinhos. Entre 1911 e 1920, atingem Santo Anastácio e, nos anos trinta, Presidente Epitácio, no rio Paraná - numa assustadora distância de nada mais nada menos que 891 quilômetros da capital paulista.

Botucatu, São Manoel, Piraju, Bela Vista, Lençóis, Avaré, Santa Cruz do Rio Pardo formam um grupo de cidades mais antigas da região e, no período em questão, sempre tiveram sua

\footnotetext{
${ }^{31}$ Espírito Santo do Turvo, município extinto; Platina, município extinto em 25-5-1934; Anhembi, município extinto em 12-6-1934. Bela Vista, antiga Campos Novos; Avaré, antiga Rio Novo; Bofete, antiga Rio Bonito; Piraju, antiga São Sebastião do Tijuco Preto; Agudos, antiga São Paulo dos Agudos; Conceição do Monte Alegre, município criado em 1896; incorporado ao município de Sapezal em 1934. Sapezal, município extinto em 1938, incorporado ao município de Paraguaçu. Piramboia, distinto de paz anexado ao município de Anhembi em 21-5-1934, passando o município de Anhembi a denominar-se Piramboia em 12-6-1934.
} 
economia baseada na produção cafeeira. Em 1886, elas continham uma população de mais de 70 mil pessoas. Após a virada de século, a região assiste a uma expansão demográfica, chegando a ter, em 1920, 300 mil habitantes, além do aparecimento de mais oito municípios, como por exemplo Assis e Ourinhos. Fora, pois, uma zona formada por municípios criados alguns na segunda metade do século XIX e outros no século XX.

Em 1905, a zona produzia mais de 3 milhões de arrobas de café, produto de exatos 48.679.539 cafeeiros. Contudo, 15 anos mais tarde, ela sofreria uma queda em sua produção - para algo em torno de 1 milhão e meio de arrobas. A recuperação viria nos idos de 1934, com números que chegarão a mais de 7 milhões de arrobas. E não só do café enriquecia a agricultura da região, ela era uma das maiores produtoras de algodão do Estado de São Paulo nos anos de 1940, com destaque para o município de Presidente Prudente.

Percorrendo uma área em que o café ainda não havia penetrado de forma intensa, a constituição da oitava zona fora, em larga medida, uma "empreitada especulativa" que visava a abertura de novas áreas para a exploração agrícola de caráter comercial.

Quanto à lista dos doze primeiros municípios paulistas destacados por suas rendas/ano, nenhuma de suas unidades chegou a ocupar lugar de relevância nesse quadro, mesmo se esticarmos nossa investigação ao ano escolhido de 1938. 
9a zona: Baixa Sorocaba

\begin{tabular}{|c|c|}
\hline Municípios & Data de criação \\
\hline Itapeva & $27-7-1769$ \\
\hline Buri & $1-12-1921$ \\
\hline Itaberá & $8-4-1891$ \\
\hline Itararé & $28-8-1893$ \\
\hline Itai & $1-8-1891$ \\
\hline Bom Sucesso & $2-5-1886$ \\
\hline Ribeirão Branco & $25-2-1893$ \\
\hline Capão Bonito & $2-4-1857$ \\
\hline São Miguel Arcanjo & $1-4-1889$ \\
\hline Itaporanga & $6-3-1871$ \\
\hline Taquari & $24-12-1925$ \\
\hline Ribeirão Vermelho & $12-11-1924$ \\
\hline Xiririca & $10-3-1842$ \\
\hline Iporanga & $3-4-1873$ \\
\hline Apiá & $14-8-1871$ \\
\hline Ribeira & $20-10-1910$ \\
\hline Copeiras & $30-12-1924$ \\
\hline
\end{tabular}

A nona zona ${ }^{32}$ é a mais pobre entre as regiões do Estado. Apenas três municípios são servidos por estrada de ferro - Buri, Itapeva e Itararé, todos no traçado inferior da Estrada de Ferro Sorocabana. As demais cidades acabariam cortadas por estradas de rodagem abertas quando se dava a exploração de minérios em cidades como Xiririca (atual Eldorado), Iporanga e Apiaí. Caracterizou-se também por ter sido uma zona de fraca densidade demográfica, com crescimento lento, porém contínuo. A exceção era Itapeva, cuja população alcançava pouco mais de 19 mil habitantes, em 1886. Para o ano de 1920 chega a mais de 28 mil almas.

Economicamente fraca, na cronologia do avanço do café a Baixa Sorocabana participou timidamente, com uma produção, em 1905, de pouco mais de 117 mil arrobas e em constante processo de queda. Entre outros produtos agrícolas, apresentava o cultivo de cereais e uma pequena pecuária. Não chegou, por fim, a levar nenhum de seus municípios sequer a uma razoável colocação na classificação entre os 12 primeiros por volume de renda/ano.

\footnotetext{
32 Bom Sucesso, Município extinto em 3-7-1934; Ribeirão Branco, município extinto em 1-5-1934; Ribeirão Vermelho, município extinto em 21-5-1934; Capoeiras, município extinto em 21-5-1934. Itaí, antiga Santo Antonio da Boa Vista; Itaporanga, antiga São João Batista do Rio Verde; Capão Bonito, antiga Parapanema; Itaberá,antiga Lavrinhas. Iporanga, reduzida à condição de distrito de paz em 21-5-1934, ficou pertencendo ao município de Apiaí, elevado novamente a município em 23-12-1936; Ribeira, reduzida à condição de distrito de paz em 21-5-1934, ficou pertencendo ao município de Apiaí; elevado novamente a município em 3-1-1936.
} 


\section{$10^{\text {a }}$ zona: Santos e Litoral Sul}

\begin{tabular}{|c|c|}
\hline $\begin{array}{c}\text { Municípios } \\
\text { Santos }\end{array}$ & $19-1-1545$ \\
\hline Guarujá & $30-6-1934$ \\
\hline São Vicente & $22-1-1532$ \\
\hline Itanhaem & $4-1561$ \\
\hline Iguape & 1659 \\
\hline Prainha & $30-11-1938$ \\
\hline Jacupiranga & $20-12-1927$ \\
\hline Cananea & $13-7-1600$ \\
\hline
\end{tabular}

Segundo registrou o professor José Francisco de Camargo, compreende esta zona ${ }^{33}$ os municípios do litoral sul, alguns dos quais favorecidos pelo ramal Santos-Juquiá da Estrada de Ferro Sorocabana e agrupados a Santos nessa mesma faixa litorânea. Estiveram, durante muito tempo, com sua vida econômica dependentes do porto de Santos.

Destacava-se o município de Santos entre o conjunto de sua zona, sobretudo por suas claras peculiaridades e principais números de seu desenvolvimento econômico e demográfico, principalmente se confrontados com os das demais unidades. Para o ano de 1836, a população da décima zona representava apenas 6,6\% do total da Província, fato interessante quando se leva em conta tratar-se das mais antigas vilas criadas no País. Em 1886, interessante notar, Iguape ainda possuía a maior população da área, só sendo ultrapassado por Santos na virada do século XIX para o século XX, quando este atinge o número de 50 mil almas. Importante ressaltar que apesar da relativa importância do município e porto de Iguape para o conjunto da zona, fora apenas Santos a cidade a aparecer e se manter presente na classificação dos municípios paulistas, por renda, em todos os anos escolhidos para a pesquisa de Joseph Love, por mim também adotados: 1885-6, no segundo lugar e com renda de 209 contos/ano; 1896 também na segunda posição e com expressivos 1.997 contos. Por fim, 1920, novamente na segunda colocação e com seus 7.085 contos de renda para aquele ano.

Com o histórico e constante incremento da exportação de café, Santos entra num processo bastante agudo de desenvolvimento, desaguando num igualmente importante aumento de sua população. Transformara-se também em porta de entrada da massa de imigrantes europeus, que foram rumo aos milhões de cafezais do interior paulista.

\footnotetext{
33 Itanhaem, antiga Conceição de Itanhaem.
} 
Na já bastante citada tabela dos doze primeiros municípios paulistas classificados por renda, Joseph Love não deixa de fazer ressalvas quanto à insuficiência de dados para vários municípios, em vários anos, o que resultará em informações totais da renda incompletas. Ainda assim lancei mão de mais esse importante conjunto de dados para a realização deste trabalho, por considerá-los referências importantes para a caracterização das dez zonas aqui adotadas. Elas melhoram significativamente na medida em que se agregam outros conjuntos de dados, como por exemplo os que tratam dos aspectos demográficos e da produção cafeeira.

Junto a esta tabela, outras referências deste e dos demais autores citados foram úteis nessa brevíssima exposição e delimitação das regiões de onde sairão eleitos os futuros representantes para o Legislativo Paulista - foco importante desta pesquisa. Ciente e atento para com os limites metodológicos constantemente frisados, chego a não ter dúvidas de que a somatória dos dados aqui resgatados será eficaz para uma necessária e suficiente visualização do que se procurou, com bastante afinco, demonstrar neste terceiro item do segundo capítulo: a caracterização das dez zonas paulistas, tomada pelo critério de regionalização imposto pelo traçado das linhas ferroviárias.

\section{Tabela 2.3}

Distribuição da População de São Paulo por Zonas, 1886-1940 (porcentagem)

(Excluídos do original os dados de 1940)

\begin{tabular}{|c|c|c|c|}
\hline Zona & $\mathbf{1 8 8 6}$ & $\mathbf{1 9 0 0}$ & $\mathbf{1 9 2 0}$ \\
\hline Capital $*$ & $6,1 \%$ & $12,3 \%$ & $20,6 \%$ \\
\hline Vale do Paraíba & $27,5 \%$ & $17,8 \%$ & $6,6 \%$ \\
\hline Central & $24,3 \%$ & $18,2 \%$ & $11,8 \%$ \\
\hline Mogiana & $14,6 \%$ & $20,4 \%$ & $11,7 \%$ \\
\hline Baixa Paulista & $10,9 \%$ & $12,1 \%$ & $8,1 \%$ \\
\hline Araraquense & $2,7 \%$ & $6,5 \%$ & $13,2 \%$ \\
\hline Alta Paulista & - & $0,3 \%$ & $11,9 \%$ \\
\hline Alta Sorocabana & $5,9 \%$ & $5,2 \%$ & $10,1 \%$ \\
\hline Baixa Sorocabana & $4,5 \%$ & $3,5 \%$ & $2,4 \%$ \\
\hline Litoral Sul & $3,5 \%$ & $3,7 \%$ & $3,6 \%$ \\
\hline
\end{tabular}

“Fonte: Camargo, Crescimento da população, 1: 104.

* A proporção relativa do município da capital foi 3,9\% em 1886; 10,5\% em 1900; 12,6 em 1920 e 18,5\% em 1940."

In: LOVE, J. Op. cit. p. 51. 
Tabela 2.4

População Economicamente Ativa, por Setor, em São Paulo e no Brasil, 1920 e 1940 (porcentagem)

\begin{tabular}{|c|c|c|c|c|}
\hline \multirow{2}{*}{ Setor } & \multicolumn{2}{|c|}{ São Paulo } & \multicolumn{2}{c|}{ Brasil } \\
\cline { 2 - 5 } & $\mathbf{1 9 2 0}$ & $\mathbf{1 9 4 0}$ & $\mathbf{1 9 2 0}$ & $\mathbf{1 9 4 0}$ \\
\hline Agricultura & $63 \%$ & $56 \%$ & $70 \%$ & $66 \%$ \\
\hline Indústria & $18 \%$ & $16 \%$ & $14 \%$ & $10 \%$ \\
\hline Prestação de serviços & $19 \%$ & $28 \%$ & $17 \%$ & $23 \%$ \\
\hline
\end{tabular}

Fonte: VILLELA, A.V. e SUZIGAN, Política do governo e Crescimento da Economia Brasileira, 1889-1945. 1973, p. 291.

Tabela 2.5

Distribuição da Produção de Café em São Paulo, por Região [Zonas]

1905 e 1920 (\% / Peso)

\begin{tabular}{|c|c|c|}
\hline Região / Zona & $\mathbf{1 9 0 5}$ & $\mathbf{1 9 2 0}$ \\
\hline Capital & $0 \%$ & $0 \%$ \\
\hline Vale do Paraíba & $5 \%$ & $4 \%$ \\
\hline Central & $13 \%$ & $11 \%$ \\
\hline Mogiana & $34 \%$ & $44 \%$ \\
\hline Baixa Paulista & $21 \%$ & $16 \%$ \\
\hline Araraquarense & $16 \%$ & $15 \%$ \\
\hline Alta Paulista & $0 \%$ & $3 \%$ \\
\hline Alta Sorocabana & $11 \%$ & $8 \%$ \\
\hline Baixa Sorocabana & $0 \%$ & $0 \%$ \\
\hline Litoral Sul & $0 \%$ & $0 \%$ \\
\hline
\end{tabular}

Adaptado de CAMARGO, J.F. Op. cit., p. 107-8 e LOVE, Op. cit., p. 66. 
Tabela 2.6
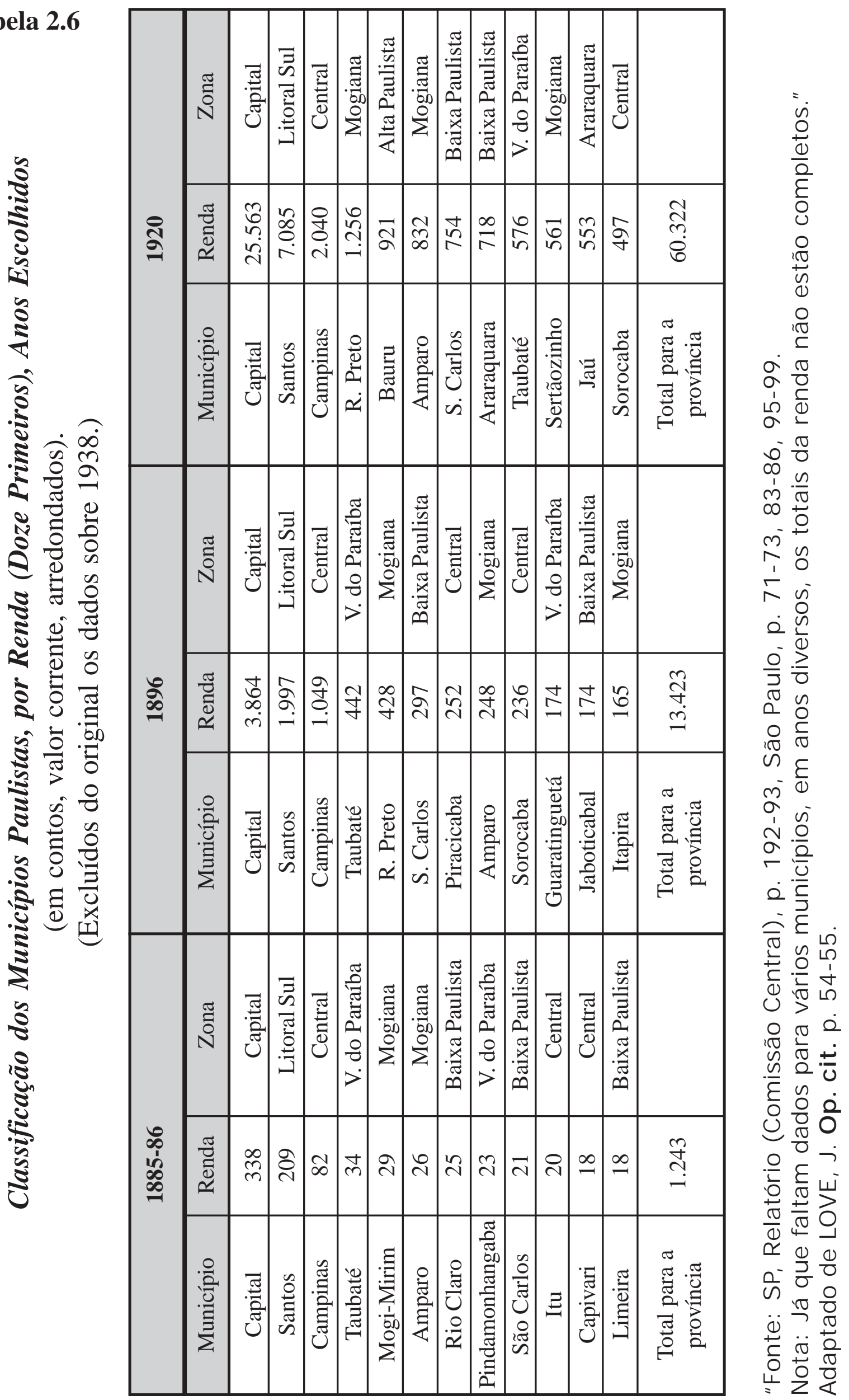
A reforma constitucional de 1905 restabeleceu o sistema distrital para as eleições de deputados. Com isso, os políticos voltaram a disputar votos em distritos delineados e não mais em todo território. Abaixo arrolo algumas informações visuais, justamente para que tenhamos idéia em que proporção tal mudança pode ou não ter afetado o trabalho parlamentar em defesa de seus redutos.

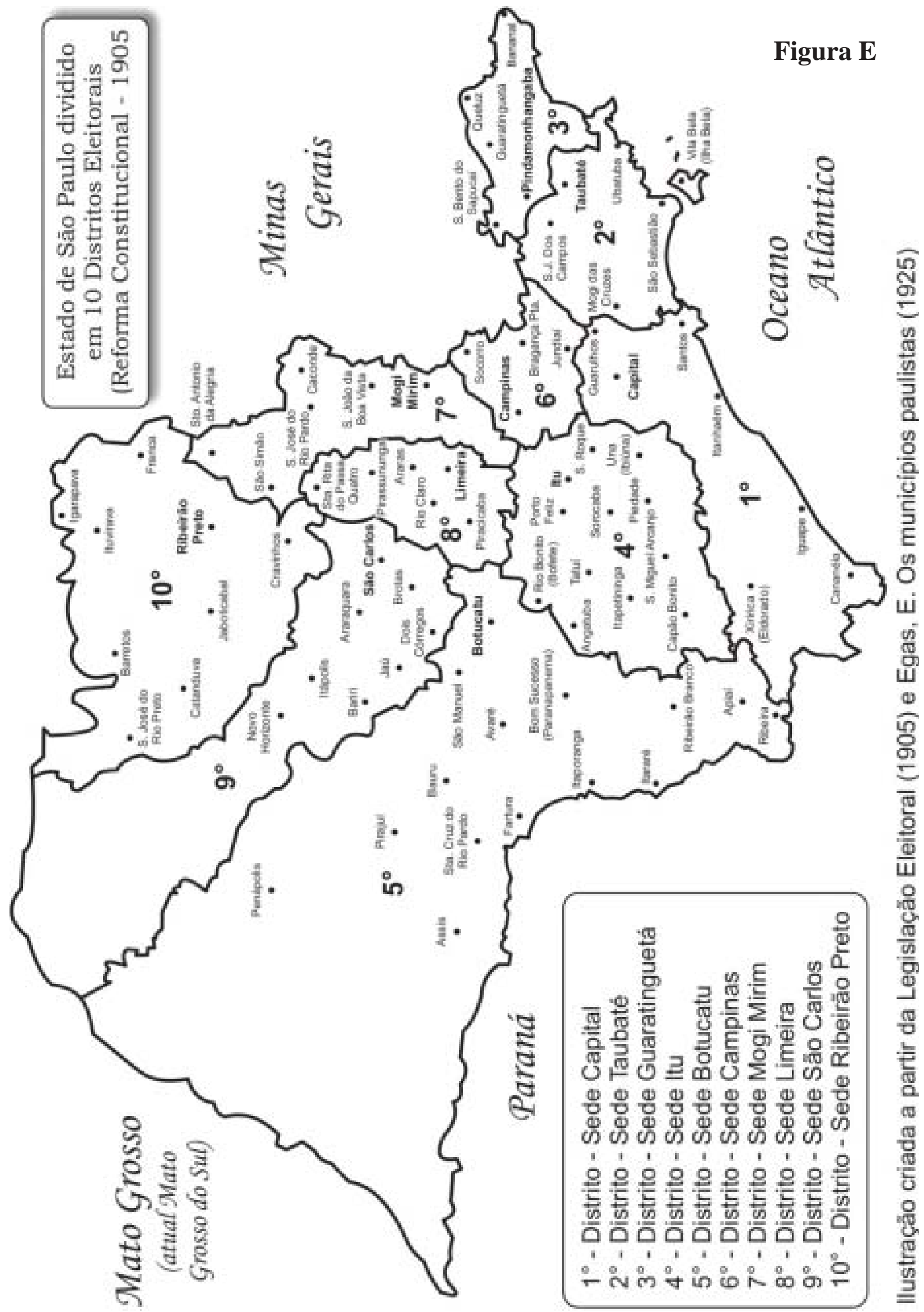




\begin{tabular}{|c|}
\hline 1o Distrito \\
\hline CAPITAL - SÃO PAULO \\
\hline CANANEA \\
\hline CUTIA \\
\hline GUARULHOS \\
\hline IGUAPE \\
\hline IPORANGA \\
\hline ITANHAEM \\
\hline ITAPECERICA \\
\hline JUQUERY \\
\hline PARNAIBA \\
\hline SANTO AMARO \\
\hline SANTOS \\
\hline SÃO BERNARDO \\
\hline SÃO VICENTE \\
\hline XIRIRICA \\
\hline
\end{tabular}

\begin{tabular}{|c|}
\hline 3o Distrito \\
\hline AREIAS \\
\hline BANANAL \\
\hline CACHOEIRA \\
\hline CRUZEIRO \\
\hline CUNHA \\
\hline GUARATINGUETÁ \\
\hline JATAI \\
\hline LORENA \\
\hline PINDAMONHANGABA \\
\hline PINHEIROS \\
\hline PIQUETE \\
\hline QUELUZ \\
\hline SÃO BENTO DO SAPUCAI \\
\hline SÃO JOSÉ DO BARREIRO \\
\hline SILVEIRAS \\
\hline
\end{tabular}

\begin{tabular}{|c|}
\hline 20 Distrito \\
\hline BUQUIRA \\
\hline CAÇAPAVA \\
\hline CARAGUATATUBA \\
\hline GUARAREMA \\
\hline IGARATÁ \\
\hline JACAREI \\
\hline JAMBEIRO \\
\hline LAGOINHA \\
\hline MOGI DAS CRUZES \\
\hline NATIVIDADE \\
\hline PARAIBUNA \\
\hline REDENÇÃO \\
\hline SALESÓPOLIS \\
\hline SANTA BRANCA \\
\hline SANTA ISABEL \\
\hline SÃO JOSÉ DOS CAMPOS \\
\hline SÃO LUIZ DO PARAITINGA \\
\hline SÃO SEBASTIÃO \\
\hline TAUBATÉ \\
\hline TREMEMBÉ \\
\hline UBATUBA \\
\hline VILA BELA \\
\hline
\end{tabular}

\begin{tabular}{|c|}
\hline 4음 Distrito \\
\hline ANGATUBA \\
\hline ARAÇARIGUAMA \\
\hline CABREUVA \\
\hline CAMPO LARGO DE \\
\hline SOROCABA \\
\hline CAPÃO BONITO \\
\hline CAPIVARI \\
\hline CONCHAS \\
\hline GUAREI \\
\hline INDAIATUBA \\
\hline ITAPETININGA \\
\hline ITÚ \\
\hline LARANJAL \\
\hline MONTE MOR \\
\hline PEREIRAS \\
\hline PIEDADE \\
\hline PILAR \\
\hline PORTO FELIZ \\
\hline RIO BONITO \\
\hline SALTO DE ITU \\
\hline SÃO MIGUEL ARCANJO \\
\hline SÃO ROQUE \\
\hline SARAPUI \\
\hline SOROCABA \\
\hline TATUI \\
\hline TIETE \\
\hline UNA \\
\hline
\end{tabular}




\begin{tabular}{|c|}
\hline 5음istrito \\
\hline AGUDOS \\
\hline ANHEMBI \\
\hline APIAI \\
\hline ASSIS \\
\hline AVARE \\
\hline BAURU \\
\hline BOM SUCESSO \\
\hline BOTUCATU \\
\hline CAMPOS NOVOS DE \\
\hline PARANAPANEMA \\
\hline CERQUEIRA CESAR \\
\hline CONCEIÇÃO DE MONTE ALEGRE \\
\hline ESPIRITO SANTO DO TURVO \\
\hline FARTURA \\
\hline FAXINA \\
\hline IPAUSSU \\
\hline ITABERA \\
\hline ITAPORANGA \\
\hline ITARARE \\
\hline ITATINGA \\
\hline LENÇOIS \\
\hline PENAPOLIS \\
\hline PIRAJU \\
\hline PIRAJUI \\
\hline PIRATININGA \\
\hline PLATINA \\
\hline RIBEIRA \\
\hline RIBEIRÃO BRANCO \\
\hline SALTO GRANDE \\
\hline SANTA BARBARA DO RIO PARDO \\
\hline SANTA CRUZ DO RIO PARDO \\
\hline SANTO ANTONIO DA BOA VISTA \\
\hline SÃO MANOEL \\
\hline SÃO PEDRO DO TURVO \\
\hline
\end{tabular}

\begin{tabular}{|c|}
\hline 60 \\
\hline Distrito \\
\hline AMPARO \\
\hline ATIBAIA \\
\hline BRAGANCLA \\
\hline CAMPINAS \\
\hline CURRALINHO \\
\hline ITATIBA \\
\hline JUNDIAI \\
\hline NAZARETH \\
\hline PEDREIRAS \\
\hline PIRACAIA \\
\hline SERRA NEGRA \\
\hline SOCORRO \\
\hline
\end{tabular}

\begin{tabular}{|c|}
\hline 7으 Distrito \\
\hline CACONDE \\
\hline CAJURU \\
\hline CASA BRANCA \\
\hline ESPIRITO SANTO DO PINHAL \\
\hline ITAPIRA \\
\hline MOCOCA \\
\hline MOGI GUASSU \\
\hline MOGI MIRIM \\
\hline SANTA ROSA \\
\hline SANTO ANTONIO DA ALEGRIA \\
\hline SÃO JOÃO DA BOA VISTA \\
\hline SÃO JOSÉ DO RIO PARDO \\
\hline SÃO SIMÃO \\
\hline TAMBAU \\
\hline
\end{tabular}

\begin{tabular}{|c|}
\hline 8 Distrito \\
\hline ANAPOLIS \\
\hline ARARAS \\
\hline DESCALVADO \\
\hline LEME \\
\hline LIMEIRA \\
\hline PALMEIRAS \\
\hline PIRACICABA \\
\hline PIRASSUNUNGA \\
\hline PORTO FERREIRA \\
\hline RIO CLARO \\
\hline RIO DAS PEDRAS \\
\hline SANTA BARBARA \\
\hline SANTA CRUZ DA CONCEIÇÃO \\
\hline SANTA RITA DO PASSA QUATRO \\
\hline SÃO PEDRO \\
\hline
\end{tabular}




\begin{tabular}{|c|}
\hline 9 o Distrito \\
\hline ARARAQUARA \\
\hline BARIRI \\
\hline BARRA BONITA \\
\hline BICA DE PEDRA \\
\hline BOA ESPERANÇA \\
\hline BROTAS \\
\hline DOIS CORREGOS \\
\hline DOURADO \\
\hline IBITINGA \\
\hline ITAPOLIS \\
\hline JAU \\
\hline MATÃO \\
\hline MINEIROS \\
\hline NOVO HORIZONTE \\
\hline PEDERNEIRAS \\
\hline RIBEIRÃO BONITO \\
\hline SÃO CARLOS \\
\hline SÃO JOÃO DA BOCAINA \\
\hline
\end{tabular}

\begin{tabular}{|c|}
\hline 10 Distrito \\
\hline BARRETOS \\
\hline BATATAIS \\
\hline BEBEDOURO \\
\hline BRODOWSKI \\
\hline CATANDUVA \\
\hline CRAVINHOS \\
\hline FRANCA \\
\hline GUARIBA \\
\hline IGARAPAVA \\
\hline ITUVERAVA \\
\hline JABOTICABAL \\
\hline JARDINOPOLIS \\
\hline MONTE ALTO \\
\hline MONTE AZUL \\
\hline ORLANDIA \\
\hline PATROCINIO DO SAPUCAI \\
\hline PITANGUEIRAS \\
\hline RIBEIRÃO PRETO \\
\hline RIO PRETO \\
\hline SANTA ADELIA \\
\hline SÃO JOAQUIM \\
\hline SERTÃOZINHO \\
\hline TAQUARITINGA \\
\hline VILA OLIMPIA \\
\hline VIRADOURO \\
\hline
\end{tabular}

À primeira vista o que se percebe nessa mudança, de zonas para distritos como espaços de disputa de votos, sobretudo geograficamente, é que que não fora assim de grande monta. Será necessário então buscar nas atidudes dos parlamentares, nesses momentos distintos, algum gesto capaz de identificar, ou não, alternância explícita de condutas. 
CAPÍTULO III - GRUPOS POLÍTICOS HEGEMÔNICOS E SUAS RELAÇÕES ECONÔMICAS E DE PODER NO ESTADO DE SÃO PAULO 


\section{O Coronelismo e suas Práticas}

O fenômeno do coronelismo como é estudado pela historiografia brasileira tem implicações teóricas que não foram devidamente dimensionadas e nem mesmo suscitaram reflexões mais pontuais em torno da sua eficácia conceitual ${ }^{1}$. É preciso relacionar o coronelismo como uma forma de poder pessoal configurada em exemplos de poder constituído por grupos políticos (os chefes políticos locais) que controlavam o eleitorado e sobre ele exerciam toda sorte de poder, decidindo sobre a escolha de candidatos.

Os coronéis de São Paulo podem ser caracterizados como típicos representantes de uma oligarquia agrária voltada para o capital agrícola-mercantil, e não de uma oligarquia absenteísta da atividade mercantil, como era o caso da oligarquia do Nordeste, que também não deixava de ser dependente de muitos favores do governo federal e estadual. A oligarquia agrária mercantil de São Paulo detinha um controle mais efetivo no âmbito do poder privado. Tinha ramificações nos aparelhos e órgãos do Poder Público como estratégia para fazer valer suas demandas e interesses junto ao governo, relacionando-se, portanto, direta ou indiretamente, com os três poderes estaduais em aliança com o poder central.

Todo esse espaço disponível de trânsito no poder permitia a construção de um elenco de favores, caminhos de mão-dupla para o atendimento de grupos atuantes, com seus privilégios na estrutura de clientela que funcionava nos diferentes níveis de governo. Maria Isaura Pereira de Queiroz faz, entre outros, o seguinte registro acerca do coronelismo:

“O coronelismo é [...] uma forma tomada por essa proteção. Assim, o poder político é medido através da quantidade de votos de que dispõe um chefe local ou regional no momento das eleições. Procurando manter ou expandir a força dos coronéis, os cabos eleitorais são elementos de ligação indispensáveis entre o coronel e a massa de votantes. A estrutura, grosso modo, se apresenta hierarquizada em três níveis: os coronéis; abaixo deles os cabos eleitorais; e na base da estratificação política, os eleitores. Além do papel do proselitismo, tem o cabo eleitoral a função de organizar a massa, mantendo-a 'em forma' para os pleitos ${ }^{2} . "$

\footnotetext{
${ }^{1}$ Essa questão é tratada por ALVES, P. Coronelismo, mandonismo local e oligarquias: críticas e proposições aos modelos de interpretação da História Política da Primeira República. In: DE NIPOTTI, C.; JOANILHO, A . (Orgs.). Leituras em História. Curitiba: Aos Quatro Ventos, 2003. p. 175-91.

${ }^{2}$ QUEIROZ, M.I.P. de. O coronelismo numa interpretação sociológica. In: FAUSTO, B. (Org.). O Brasil Republicano - Estrutura de Poder e Economia, 1889-1930. História Geral da Civilização Brasileira. v. 8, tomo III, São Paulo: Difel, 1975. p.157.
} 
Foi na Primeira República que as práticas coronelísticas se disseminaram por toda a sociedade, ampliando os poderes pessoais dos fazendeiros de café que controlavam a administração pública estadual e municipal. O grau de autonomia dos Estados teve importância na origem do coronelismo, na formação das práticas políticas nos municípios que, por sua vez, dependiam dos Estados. A própria Constituição de 1891 deu plena autonomia aos Estados, e cabia a estes o papel de organização e arranjo administrativo e político dos municípios. O princípio de federação e de centralização era conferido em estatutos dos municípios e dos Estados, mas nem sempre refletia a realidade, na qual relações de poder tomavam sentido diferente, revelando então suas contradições, o que acabava por negar a origem do pacto republicano.

No caso do município, por exemplo, sujeito à vontade das administrações estaduais, nem sempre as verbas chegavam como repasses próprios e por direitos previstos em orçamento estadual. Na realidade, o presidente do Estado tinha um poder grande de manobra sobre os recursos públicos, que eram manipulados conforme acordos e acertos feitos com os prefeitos. Predominavam nessas relações as discussões pessoais e de grupos, ficando as comunidades ausentes nesses pactos políticos.

“A própria estrutura do regime republicano impunha a submissão do município à Constituição Federal e à Estadual. Como a divisão em estado é arbitrária, a realidade concreta é o município, mas, paradoxalmente, este tem que ceder suas pretensões ante a própria necessidade de aglutinação dos múltiplos interesses intermunicipais, coordenados pelo Estado ${ }^{3}$."

O papel do coronel era o de intermediar as relações entre municípios e Estados, lembrando que nem sempre essa convivência era fácil, principalmente quando as partes se apresentavam como sendo situação versus oposição. Porém, o que realmente contava era a interdependência de poder que havia entre municípios e Estados. Ou seja, o eleitorado majoritário estava localizado no interior do Estado, nas pequenas vilas, distritos e cidades encravadas nas imensas áreas de terras onde predominava a cultura do café. As capitais dos Estados, num período significativo na Primeira República, tinham uma população bem menor que as zonas rurais. “(...)Por volta de 1890, a população rural correspondia a $75 \%$ da população total. Em 1930 essa porcentagem se reduzia a $70 \%{ }^{4}$

A população rural em Estados como Rio de Janeiro, São Paulo, Paraná, Minas Gerais e Rio Grande do Sul sempre foi maior do que a população urbana. Em 1920, a população rural paulista

\footnotetext{
${ }^{3}$ ver JANOTTI, M. L. M. Coronelismo: uma política de compromissos. São Paulo: Brasiliense, 1981. p. 62.

${ }^{4}$ BASBAUM, L. História Sincera da República - 1889 a 1930. São Paulo: Alfa-Omega, 1976. p.141. Dados e informações semelhantes estão também em LOVE, J. A Locomotiva. São Paulo na Federação Brasileira 18891937. Rio de Janeiro: Paz e Terra, 1982. p. 44 - 52.
} 
representava $63 \%$ do total e a do Rio de Janeiro, $68 \%$. No caso paulista observa-se um expressivo aumento da população por causa da migração interna e também da imigração européia. A população da capital, em 1920, passa a ser de aproximadamente 580.000 habitantes, contra os $64.930 \mathrm{em}$ 1890. No Rio de Janeiro, enquanto em 1890 a capital registrava praticamente 523.000, em 1920 tinha mais de 1.150 .000 habitantes $^{5}$.

Certas retribuições e papéis exercidos pelo coronel junto à população local asseguram-lhe micropoderes no âmbito da sociabilidade estabelecida entre o fazendeiro e seus agregados, compadres e amigos de confiança de longa data. O coronel se valia de sua postura pública como se fosse um servidor público do Estado para obter recursos dos cofres do governo que, em seguida, acabavam aplicados em serviços ou em obras que geralmente beneficiavam pessoas, grupos, parentes e amigos que circulavam à sua volta.

Raymundo Faoro faz a seguinte observação a respeito dessas relações:

"O coronelismo se manifesta num compromisso, em troca de proveitos entre o chefe político e o governo estadual, com atendimento por parte daquele, dos interesses e reivindicações do eleitorado rural [...]."."

O coronelismo como uma certa prática política marcou profundamente os anos vinte, tanto no meio rural quanto no meio urbano. A longevidade dessa prática está relacionada à ausência de um poder público bem organizado, com instâncias e aparelhamentos estatais eficazes no trato da administração pública. O próprio município padecia da falta de recursos próprios, dependendo sempre das esferas estaduais e federal para cuidar dos problemas e das carências mais imediatas da comunidade, a qual funcionava precariamente, sem as mínimas condições de atender os cidadãos nas suas necessidades de sobrevivência.

Podemos dizer que nas cidades do interior paulista, e mesmo na capital, manteve-se um padrão de poder face a uma sociedade rarefeita e pouco diferenciada socialmente, no campo e na cidade. A relação entre sociedade civil e Estado era feita por poder intermediário do coronel, caracterizando-se, portanto, por um distanciamento alienador. A alteração dessa estrutura, possibilitando uma redefinição das relações políticas e sociais, dependia de uma evolução do sistema capitalista e, conseqüentemente, de transformações radicais e de mudanças nos papéis das cidades. Ou seja, as cidades tornar-se-iam unidades de produção e de trabalho, relativamente autônomas, incorporando então toda uma massa de trabalhadores, e não mais apenas de moradores. Essa revolução só iria ocorrer depois dos anos de 1930.

\footnotetext{
${ }^{5}$ Idem.
}

${ }^{6}$ FAORO, R. Os donos do poder. Formação do patronato político brasileiro. Porto Alegre: Globo, 1979. v. II, p. 631. 
Quando o coronel, por falta de prestígio, enfrentava dificuldades de obtenção de recursos para seu município, geralmente ele atribuía isso à falta de um deputado de seu grupo na Assembléia Legislativa que pudesse ter acesso ao presidente da província - mais tarde presidente do Estado. Nota-se que a política da "troca de favores", comum ao coronelismo, nem sempre funcionava a contento - o que irritava o coronel à frente de seus correligionários locais. De modo geral, os políticos locais, mesmo os mais esclarecidos e com formação intelectual, não percebiam ou não tinham a consciência de que a autonomia de suas ações era apenas uma concessão do poder outorgante do Estado. Enfim, o que se percebe é que:

"Na base do coronelismo havia, de um lado, um poder público real que se fortalecia e um poder privado que entrava em decadência; de outro lado, havia uma situação crítica do município, que vivia entre a falta de autonomia legal e a autonomia extralegal implícita no compromisso coronelista. ${ }^{7}$ "

O coronel estava desobrigado de representar o papel da autoridade na República, ainda que ocupasse cargo na administração pública. O que lhe dava legitimidade era o compromisso assumido junto ao poder local e junto à sua comunidade e conforme as demandas pessoais que tinha de atender, cujo retorno se materializava na forma de votos por ocasião das eleições.

O eleitorado dependia do coronel, pois este era a "fonte" de onde se buscava o atendimento pessoal de alguma vantagem econômica ou de prestação de serviço. Mesmo quando a reivindicação fosse feita para atender demandas da comunidade por serviço público, era o coronel a via para se chegar aos recursos públicos do Estado. Por outro lado, por ocasião das eleições para presidente, deputado estadual ou senador do Estado, é o coronel que possui o esquema eleitoral de voto de cabresto. Quanto maior o eleitorado sob controle, mais prestígio e poder tem o coronel. Assim, os recursos obtidos por um coronel de uma região urbana populosa, com milhares de eleitores, revelavam seu poder e influência política junto às autoridades republicanas.

${ }^{7}$ KERBAUY, M.T.M. A morte dos coronéis: Política interiorana e poder local. Araraquara: UNESP, 2000. p. 30. 


\section{Os Coronéis e a Questão da terra : Legalização, Especulação Fundiária e a Violência.}

Na Primeira República, os coronéis tinham poderes quase ilimitados. O fato de viverem suas relações políticas praticamente sem oposição e sem adversários não os livrava de, vez por outra, verem-se envolvidos em situações de conflito com outras lideranças locais, ainda que todos pertencessem ao mesmo partido - o PRP.

Joseph Love cita um caso clássico de oposição isolada de uma família poderosa de Ribeirão Preto (sede do $10^{\circ}$ distrito), em 1910, que enfrentou a máquina política estadual quase imbatível nos arranjos das forças políticas que controlavam os esquemas de poder do PRP na região. O coronel Joaquim Cunha Junqueira era homem forte em Ribeirão Preto e atuava por fora do esquema político do PRP e das demais autoridades regionais perrepistas. Mas, para isso, contava com o apoio do governo federal ${ }^{8}$.

Como já afirmado em capítulos anteriores, a regra política passava por alianças e acordos pessoais entre os coronéis locais e de distritos eleitorais do Estado de São Paulo. As autoridades regionais do PRP não admitiam que os coronéis locais mantivessem contatos diretos com o governador e seus secretários - exatamente o que passou a fazer Junqueira entre os anos de 1909 e 1910. Lembremos, sempre, que o papel dos coronéis locais era reconhecido e aceito pelas autoridades republicanas como parte da engrenagem da máquina partidária do PRP.

Quanto às áreas de terra do Estado, o mais comum nas regiões do interior era a prática da legalização de títulos de propriedade intermediada ou feita diretamente pelo coronel em benefício da pessoa "protegida" do mandão. Somente o coronel do PRP tinha poder para induzir o juiz a acatar suas sugestões quando se tratava de benefício jurídico. A ligação dos cartórios com os coronéis não era simples coincidência. Na verdade, tratava-se de estreita ligação, por vezes até traduzida por laços de parentesco, que visava favorecer ambas as partes. Forjavam-se documentos, em troca de favores pessoais e monetários.

Como se vê, o Poder Judiciário era uma instância comprometida com os interesses pessoais ou de grupos que dominavam a política regional no interior paulista. Somente após 1921 é que esse mesmo Poder foi desatrelado de suas relações que resultavam em acordos e pressões dos coronéis em benefício de pessoas de seus grupos de interesse. Nesse esquema de interesses em torno da propriedade da terra, o papel dos advogados e engenheiros agrimensores era determinante. Para

\footnotetext{
${ }^{8}$ LOVE, Joseph. Op. cit., p. 180.
} 
legalizar uma área de terra, exigia-se um arsenal de documentos legais como prova documental feita pelo advogado, com planta baixa elaborada pelo engenheiro com as medidas corretas e as definições dos limites da propriedade objeto da legalização.

A história da legalização de terras no interior paulista é marcada também pela violência, principalmente em relação às terras devolutas, que formalmente pertenciam ao governo do Estado, mas na prática eram objetos de disputas. Cada coronel alegava que a área em disputa lhe pertencia por posse e, por essa razão, estava empenhado em legalizá-la. Na verdade, os coronéis buscavam ampliar as suas áreas sobretudo para o plantio do café. A imprensa da época, na capital, costumava registrar esses casos de disputas de terra pela violência, denunciando os crimes praticados pelos capangas. Essa violência, na maioria das vezes, nem era julgada, fosse por "falta de provas" ou por "inexistência de testemunhas" ". Joseph Love aponta para vários casos de violência por disputas de terras e assassinatos praticados a mando de coronéis.

A violência durante os processos eleitorais predominava no interior paulista, se comparada com a que acontecia na capital. Tal fato se explica principalmente porque o colégio eleitoral no interior correspondia a $80 \%$ do total de eleitores do Estado. Essa situação só vai se alterar por volta de 1940, quando a capital passa a ter um colégio eleitoral mais amplo, alcançando números na ordem de $50 \%$ do total de eleitores.

Não há como negar que tais crimes políticos estavam associados a uma ausência de cultura e de cidadania, embora já vivendo com base e princípios democráticos da república brasileira. A sociedade rústica do sertão, sob o tacão dos coronéis, não tinha como se organizar autonomamente, até por falta de condições legais e de sustentação de classes.

A Lei de Terras de 1850 definiu juridicamente o modo como a propriedade da terra deveria ser tratada, considerando que o capitalismo no Brasil exigia mudanças em face do desenvolvimento da sociedade. $\mathrm{O}$ acesso à terra deveria ser permitido pela lei e dentro da lógica do modelo de estrutura capitalista, a fim de impor o reino da mercadoria a toda forma de propriedade. Essa era também uma estratégia de intervenção nas relações sociais. Essa lei regulamenta em definitivo a forma própria de compra e venda de terras públicas. A execução da lei de 1850 estabelecera que toda posse deveria ser regularizada com o devido registro, em cartório previamente designado para esse fim. Essa obrigatoriedade estava definida como prazo a ser cumprido em dois anos, no máximo, desde que o interessado comprovasse estar nas terras há mais de cinco anos.

\footnotetext{
${ }^{9}$ idem, p. 180-81.
} 
Ocorre, porém, que a maioria dos posseiros ou ocupantes de terras, analfabetos e sem acesso à informação, acabavam não tomando conhecimento da lei e, portanto, não fazendo o devido registro das terras que ocupavam. Somente no final do século XIX é que se percebe um índice maior de legalização da propriedade da terra. Portanto, apesar de a lei ser de domínio público, a regulamentação da propriedade da terra não se fez, no geral, de forma adequada. Nem sempre a descrição e a definição da área pelo posseiro ou ocupante era correta nos registros do cartório. Tais imprecisões, no futuro, vieram causar uma série de transtornos legais quando da transmissão da propriedade para terceiros, adquirentes ou herdeiros em situações de partilha. Segundo Flávia A. M. de Oliveira,

"Sem o preciso conhecimento das áreas das propriedades, deu-se continuidade ao processo de compra e venda, doações, heranças, hipotecas que foi tornando a situação da propriedade fundiária cada vez mais caótica. Criou-se um emaranhado legal de difícil solução. Muitas vezes, uma mesma área passava a ter mais de um título. As partilhas por herança na maioria dos casos estipulavam o valor da propriedade e dividiam entre os herdeiros os valores a eles correspondentes, sem fazer-se menção à área. Com freqüência o mesmo ocorria em escrituras de compra e venda. ${ }^{10}$,

A Lei de Terras também proporcionou o aumento da violência no campo, principalmente quando grandes proprietários passavam a requerer registros de terras que delegavam títulos ocupados com informações e documentos forjados. De posse legal de grandes extensões de terras, geralmente devolutas, a etapa seguinte era tratar da "limpeza do território", isto é, a expulsão de índios ocupantes ou antigos posseiros. Nem sempre essa questão era resolvida por negociação ou acordos entre as partes. Muitas vezes, a solução adotada era a violência por meio de capangas contratados pelo especulador de terras e beneficiado com o título da área de terras legalizadas. Essa é a história de como se processava a concentração das terras paulistas no final do século XIX. Porém, a partir de 1890 , o que se viu foi quase todas as áreas de terras devolutas serem regularizadas como propriedade privada, nas mãos de poucos proprietários e especuladores fundiários do Estado de São Paulo e, em larga medida, figuras importantes da engrenagem política de suas regiões.

É a partir dessa realidade que se perceberá a expansão das fazendas de café em quase todas as regiões do interior paulista. Certamente que o crescimento do consumo do café no mundo estimulou a expansão em ritmo acelerado da produção e o avanço do café nos anos finais do século

\footnotetext{
${ }^{10}$ OLIVEIRA, Flávia A. M. de. Faces da dominação da terra. (Jaú, 1890 - 1910). São Paulo: Edunesp/Fapesp, 1999, p.7.
} 
XIX, com a criação de muitas fazendas agora organizadas sob a forma de companhias agrícolas, com a participação de grupos de investidores e, entre estes, muitos do exterior. Viu-se que somente por meio de companhias era possível a produção de café em larga escala e com condições para receber a introdução de processos de mecanização dessa cultura.

O modelo de propriedade nas zonas cafeeiras não se apresentava de forma homogênea de organização e funcionamento enquanto unidade produtiva no interior paulista. Entre 1890 e 1920 , as fazendas com grandes extensões de terras para o café concentravam-se nas regiões de Campinas e Ribeirão Preto, com cerca de 120 mil hectares, enquanto em outras áreas cafeeiras as fazendas eram relativamente menores, com cerca de 25 mil hectares. Cidades como Rio Claro, Jaú, Bauru, Piraju, Botucatu, Rio Preto, Itu, Piracicaba, etc. possuíam pequenas e médias propriedades entre $50 \%$ e $80 \%$ do total das propriedades ${ }^{11}$.

O acesso dos fazendeiros aos cartórios, à Justiça, enfim, às máquinas burocráticas, facilitava o projeto de incorporação de novas terras (terras devolutas) com baixo custo financeiro. É aqui que o partido tinha papel determinante no encaminhamento das demandas de seus líderes. O PRP apoiava fortemente os coronéis em suas demandas e interesses através do vínculo que tinha com as autoridades governamentais da República. Os Poderes Executivo e Legislativo estadual eram acionados para elaborar projetos e leis que atendessem diretamente aos interesses do produtor paulista ${ }^{12}$.

Por lei ou decreto, o Estado poderia declarar a legitimidade da posse da terra, desde que o interessado provasse por documento legal ser o primeiro posseiro ou ocupante da área em processo de legalização. Na ausência de documentação, o interessado poderia ainda requerer a posse provando que nela vinha cultivando produtos de subsistência, possuindo casa no imóvel em questão, objeto de legalização.

Essas decisões eram tomadas pelo governo paulista por meio de seus órgãos públicos, controlados pelo PRP, o que evidenciava uma série de práticas irregulares por parte das autoridades públicas do Estado de São Paulo. Eram comuns as pressões de advogados junto à Justiça em razão da vontade de seu cliente, por ser pessoa e autoridade de renome no cenário político e pelas posses e poder econômico que tinha. Nos processos de divisão judicial de terras, dificilmente os coronéis perdiam seus pleitos. No período entre 1890 e 1920, o governo paulista, por meio de suas autoridades, concedeu muitos títulos de propriedade aos correligionários do PRP naqueles processos por

\footnotetext{
${ }^{11}$ HOLLOWAY, Thomas H. Imigrantes para o café. Café e sociedade em São Paulo, 1886-1934. Rio de Janeiro: Paz e Terra, 1984, p. 23-8.

12 Evidentemente, são inúmeros os casos em todo o período estudado. Ver seção de discursos e proposituras no conjunto dos A.C.D.E.S.P. 1890-1920.
} 
eles requeridos, ao mesmo tempo em que decretava a invalidação dos títulos antigos em mãos da outra parte em litígio.

A lei que facilitava esse tipo de demanda judicial para a legalização da propriedade da terra foi elaborada em 1890. Com isso, houve um aumento expressivo de processos por disputas de terras e sua conseqüente legalização, com a concessão dos títulos ao vencedor da demanda judicial.

A Justiça não estava preparada e não possuía pessoal técnico para proceder a levantamentos topográficos, medições e elaboração de plantas com delimitações precisas das áreas e ajuizar procedimentos processuais cabíveis a cada caso. Por isso, os agrimensores, advogados e testemunhas eram facilmente obtidos pelos coronéis demandantes e de prestígio político e influência junto às pessoas e funcionários desses órgãos públicos. Assim, ganhavam, como dissemos, facilmente demandas judiciais ${ }^{13}$.

A especulação fundiária no interior paulista teve início, como foi dito, com a Lei de Terras de 1850. Ela estabelecia um prazo bastante curto, de apenas quatro anos (1850 a 1854), para a legalização da propriedade. Ocorre que os posseiros foram os últimos a tomar conhecimento da lei e, assim, ficaram impedidos de legalizar suas posses, facilitando então o trânsito de especuladores e grileiros que falsificaram documentos (títulos de propriedade), além de arrumarem falsas testemunhas para completarem o processo de apropriação das terras devolutas do Estado.

Esse processo engendrou uma forte elevação do preço da terra. Isto é, os particulares legalizavam as terras devolutas e, depois, as vendiam por valores muito mais elevados. Como muito bem diz Lígia Osório:

"[..] não foi a venda das terras devolutas que provocou a valorização, mas a grilagem - isto é, a venda das terras devolutas por parte de particulares que delas se apropriavam. ${ }^{14}$ "

A corrida pela especulação fundiária só se encerra após a edição da Lei 545, de 2 de agosto de 1898, quando então as posses passaram a ser reconhecidas nos títulos de domínio com data

\footnotetext{
${ }^{13}$ Flávia Arlanch M. Oliveira estuda vários casos de demanda judicial ocorridos na Comarca de Jaú, no período de 1890 a 1920. Ver também COBRA, N. A. Em um recanto do sertão paulista. São Paulo: Hennies, 1923. E ainda cf. Love, J. op. cit.

${ }^{14}$ SILVA, Lígia M. Osório. Terras Devolutas e Latifúndio (efeitos da Lei de 1850). 1 $^{\text {a }}$ ed. Campinas: EDUNICAMP, 1996. Importante que se veja também da mesma autora A Apropriação Territorial na $1^{a}$. República. Op cit., p. 15769. Apoiei-me ainda em LIMA, Ruy Cirne. Pequena História Territorial do Brasil. Sesmarias e Terras Devolutas. Arquivo do Estado de São Paulo. 1991, pp. 15-33
} 
anterior a 1878, ou quando o ocupante da terra possuísse moradia edificada e cultivo de cultura na área territorial sob sua posse desde o ano de 1868 e conforme provas testemunhais ou documentais. Em suma, o governo reconhecia a legitimidade das posses e das ocupações ${ }^{15}$. Tais critérios foram estabelecidos nos dispositivos da lei de 1898.

O Registro Público das Terras, de 5 de janeiro de 1900, estabelecia a obrigatoriedade de se cadastrar as terras nas Comarcas (terras devolutas do governo estadual, excluídas aquelas que haviam sido cedidas aos municípios). Obrigava também que os posseiros com títulos de propriedade legalizados ou as terras vendidas (antes devolutas) também fossem cadastrados ${ }^{16}$.

É interessante notar que, quando a lei de 1898 estendeu a data inicial, então 1854, para 1878, acabou por estimular fortemente os grileiros a falsificar títulos de propriedade para vendê-las rapidamente. Por outro lado, acabou obrigando os posseiros também à legalização de suas posses, até porque corriam o risco de perdê-las para os grileiros. A maioria dos posseiros correu para os cartórios para a devida legalização.

Embora a legislação de terras tivesse cumprido parte de suas funções para criar uma rede fundiária normalizada, em moldes do princípio da propriedade privada, toda terra pública continuou sendo cobiçada por especuladores, que conseguiam burlar as leis e a Justiça estadual para, assim, continuar praticando toda a sorte de ilegalidades contra as terras dos posseiros e dos ocupantes, enquanto pequenos lavradores.

Foi preciso que o Estado, em 1921, mais uma vez, tomasse medidas na questão das terras devolutas em benefício dos posseiros. Estes receberam uma espécie de intimação para regularizarem suas posses, agora de forma mais simples e rápida. O que explica tal iniciativa foi, sobretudo, o avanço do capitalismo no campo e nas relações de trabalho. Era preciso definir quem teria a terra e quem nela trabalharia.

\footnotetext{
${ }^{15}$ SILVA, Lígia M. Osório. Op. cit., p. 166-67.
}

${ }^{16}$ Idem, p. 167. 


\section{Coronelismo e Oligarquias no Interior Paulista}

É importante mapear quais as figuras representativas do PRP durante a Primeira República nas diferentes regiões e cidades do interior paulista no período entre 1890-1920. Vamos destacar os principais grupos políticos e as cidades que estavam organizadas a partir do modelo político oligárquico, além de analisar a divisão e a hierarquia de poder e como configuravam suas relações de poder.

Em Jaú os grandes proprietários de terras viviam em constante disputa pelo poder local - o que marca uma luta permanente entre as famílias ao longo do final do século XIX e até a década de 1920, do século seguinte.

A família Almeida Prado é uma das mais antigas que fincaram raiz na cidade e na região e dominou a política local, vinculando seus interesses ao governo do Estado e à Assembléia Legislativa em diferentes momentos da história política da Primeira República ${ }^{17}$. Segundo Flávia Oliveira,

“[...] essa família aportou em Jaú depois da fundação da cidade [...] Os Almeida Prado de Jaú faziam parte de uma extensa parentela que há várias gerações atuava na política da capitania e depois Província de São Paulo, o que certamente lhes garantia amplos contatos políticos a nível provincial, fundamentais no momento da conquista do poder. Em decorrência disso, quando foi eleita a segunda Câmara Municipal em 1868, o Partido Conservador, articulado por representantes da família Almeida Prado, foi o grande vencedor. Membros dessa família passaram a ocupar vários cargos na administração local ${ }^{18}$ ",

O que se observa é que havia uma tradição de atuação política dos Almeida Prado que vinha desde o século XVIII e foi por meio de um partido - o Conservador, então oposição ao Partido Liberal em Jaú - que o chefe do clã, Lourenço de Almeida Prado, entrou para a administração da cidade.

Anos mais tarde, o Partido Republicano em Jaú se organizou de uma dissidência do Partido Liberal, já que o Partido Conservador dos Almeida Prado estivera por longos anos na administração local:

"Foi através desse partido que as antigas lideranças conseguiram galgar novamente o poder. Quando da eleição da nova Câmara Municipal em 1882, Jaú teve uma Câmara dominada pelos republicanos, em pleno império ${ }^{19}[. .$.$] "$

\footnotetext{
${ }^{17}$ OLIVEIRA, Flávia Arlanch Martins de. Faces da Dominação da terra (Jaú, 1890-1910). São Paulo: EDUNESP/ FAPESP, 1999, p.85-102.

${ }^{18}$ Idem, p. 86

${ }^{19}$ OLIVEIRA, Flávia A. M. de. Op. cit. p. 87.
} 
Mas os Almeida Prado voltam ao cenário do poder em 1895, quando então é eleito Constantino Gonçalves Fraga, genro de Francisco de Almeida Prado. O seu partido, agora, em plena República, era o minúsculo Partido Monarquista. Porém, em 1902 o PRP local, depois de uma série de lutas internas, retoma o poder municipal na figura de seu líder Luiz Ferraz do Amaral, irmão do deputado estadual coronel Edgard Ferraz do AmaraL ${ }^{20}$.

O que se observa é a formação de dois blocos políticos disputando cargos de representação local, mas articulados à política do governo estadual e à Assembléia Legislativa na figura dos deputados estaduais.

De um lado estavam os remanescentes do Partido Monarquista, ainda com relativa força em Jaú, com os Almeida Prado, e, de outro, o grupo do chefe local do PRP, o coronel Edgard Ferraz e seu irmão Luiz Ferraz do Amaral. Mas havia uma dissidência no PRP que eventualmente recebia apoios dos Almeida Prado, justamente do Partido Monarquista. Nessa disputa entre os blocos, tinha papel determinante o apoio que o governo estadual pudesse dar a um dos lados:

"Venceria aquele que conseguisse mostrar superioridade cooptando apoios a nível local e estadual. Foi Vicente de Almeida Prado, representante do tronco familiar número $V$, que se mostrou mais perspicaz para articular a derrota do grupo oposto e para tanto teve apoio de uma extensa parentela que dispunha de muitos membros poderosos para influenciar no andamento da política local ${ }^{21}$."

Em Jaú as duas famílias rivais se opunham por uma questão de espaço político local e não por razões ideológicas ou de classe. Até porque ambas pertenciam à mesma classe social. Formavam a elite local e estavam enquadradas na estrutura oligárquica de poder. Não é por outra razão que faz a seguinte afirmação a professora Maria de Lourdes Janotti:

“[...] o café fizera brotar a elite política republicana, a autoridade coronelística e oligárquica foi exercida pelos troncos familiares mais importantes [...] Isso fez com que na direção do Partido Republicano Paulista coexistissem diversos grupos oligárquicos do interior do Estado. As diversas oposições estaduais eram absorvidas ,em regra, por nova composição de forças na direção do Partido. Essa situação não eliminava a violência da dominação, apenas se apresenta com outras formas de coerção ${ }^{22}$."

\footnotetext{
${ }^{20}$ Idem, p. 87.

${ }^{21}$ Idem, p. 91.

${ }^{22}$ JANOTTI, Maria de Lordes Mônaco. Op. cit., p.40.
} 
Fora no governo Jorge Tibiriçá que a família Prado conseguira dar uma “virada” na política em Jaú, deslocando o coronel Edgard Ferraz das esferas de influência do palácio do governo de São Paulo. Foi, assim, decisivo o apoio de Tibiriçá à candidatura de Vicente de Almeida Prado ao governo local. Possibilidade essa existente não por uma questão de partido apenas, mas devido ao parentesco de Jorge Tibiriçá com a família Prado.

Nessas eleições de 1906, Vicente de Almeida Prado foi eleito deputado estadual, além de outros correligionários da região, como Cincinato Braga e Álvaro de Carvalho, então todos líderes políticos locais e regionais do PRP dissidente. O grande perdedor foi o coronel e deputado Edgard Ferraz que saiu do PRP bastante desgastado. No ano seguinte o PRP elege uma nova Direção, composta por Vicente de Almeida Prado (presidente) e Amaral Carvalho (secretário).

A trajetória de Vicente de Almeida Prado foi longa, com vários mandatos de deputado estadual, além do cargo de senador do Estado de São Paulo. A hegemonia política dos Almeida Prado, em Jaú, estendeu-se ao longo da Primeira República.

Jorge Tibiriçáa ${ }^{23}$ pode ser considerado o típico político da capital, aristocrata e intelectual com formação européia, além de empresário e fazendeiro. Como político republicano ocupou o governo paulista por duas vezes, em 1890-1891 e 1904-1908. Foi também membro da comissão executiva do PRP por quase vinte anos. Sua família morava em Paris quando do seu nascimento, no ano de 1855, e sua mãe era francesa. Seu pai, João de Almeida Prado, veio de uma família dos tempos do Brasil colônia e foi um dos fundadores do PRP em Itu no ano de 1873, onde residia nessa época, em uma grande fazenda de café.

A vida política de Tibiriçá esteve associada ao PRP desde o começo da República, tendo sido indicado para ser diretor da Estrada de Ferro Mogiana em 1889, por seu sogro, um dos fundadores da estrada de ferro e governador da Província de São Paulo durante o Império, como dissemos, em 1886. Tibiriçá foi também o segundo governador de São Paulo sob a República, nomeado por Deodoro da Fonseca. Mais tarde ocupou o cargo de secretário da Agricultura, entre 1892 e 1895. No final dos anos vinte do século XX, elegeu-se senador pelo Estado de São Paulo, com passagem pela presidência da Assembléia Legislativa por um mandato. Na Comissão Executiva do PRP foi responsável pela indicação de nomes para deputado estadual, senador do Estado e do governador que o sucedeu. Essas indicações, porém, dependiam de acordos regionais e acertos entre os políticos do PRP e de seu diretório central.

\footnotetext{
${ }^{23}$ Os dados biográficos e várias das questões aqui tratadas foram condensados por LOVE, Joseph, Op. cit., p.234-5. Dados biográficos foram também extraídos de ABRANCHES, Dunshee de. Governos e Congressos da República dos Estados Unidos do Brazil. Apontamentos biographicos sobre todos os Prezidentes e Vice-Presidentes da República, Ministros de Estado, e Senadores e Deputados ao Congresso Nacional (1889 a 1917). 2. v. São Paulo, 1918.
} 
Manoel Bento da Cruz, grande proprietário de fazendas de café na Noroeste, residiu, inicialmente, em Penápolis. Grande parte de suas terras fora obtida por compra e outras tantas, mediante legalização de posses. Estendiam-se do quilômetro 178 da estação de Hector Legru até à estação de Lins. As terras situadas ao longo dos trilhos estavam divididas em lotes padrão para serem vendidas como fazendas.

Bento da Cruz, juntamente com outros sócios, direciona seus negócios sob a forma empresarial, por meio de uma companhia de terras e colonização. Nascido no Rio de Janeiro no ano de 1875, era de origem portuguesa, de uma família rica ligada ao comércio atacadista. Estudou nas melhores escolas do Rio (Colégio Pedro II e Faculdade Nacional de Direito). Casou-se muito jovem, com uma moça de família aristocrática de São Paulo, sobrinha do barão de Serra Negra. Transferiu-se para São Paulo, tendo morado em diferentes cidades do interior e trabalhado como advogado na legalização de terras. Interessante notar que ocupou a função de titular do Cartório de Registro de Imóveis e depois a de promotor público. Quando se estabeleceu em Penápolis, advogou para clientes que eram grileiros e posseiros, requerendo para eles imensas glebas de terras devolutas. Seus honorários eram pagos com terras legalizadas e, geralmente, essas representavam a metade da área obtida juridicamente como posse.

Bento não era apenas um coronel fazendeiro rico; era também um interlocutor junto aos investidores e engenheiros responsáveis pela construção da Ferrovia Noroeste. Foi "mestre" em alterar os planos originais do traçado da ferrovia, propondo que os trilhos passassem onde ele e seus clientes e amigos possuíssem terras, ou em glebas que estavam sendo vendidas por sua empresa de colonização.

A The San Paulo Land Lumber e colonization company, criada em 1912, tinha, como sócios de Manoel Bento da Cruz, Presciliano Pinto de Oliveira, o inglês James Mellor e o escocês Robert Clarck. O capital da empresa era composto de 8 mil ações no valor de 800 milhões de contos de réis. A companhia tinha em sua carteira de imóveis uma área de 6.500 alqueires, além de mais de 60 mil alqueires de terras virgens, situadas entre os rios Tietê, Aguapeí e Feio.

Na zona noroeste havia ainda, por volta de 1920, outras vinte empresas loteadoras de fazendas, como a Brazilian Plantation Company, proprietária de algo em torno de 15 mil alqueires, e a Companhia de Terras, Madeiras e Colonização de São Paulo, com 64 mil alqueires em terras. Essa última explorava a venda de pequenos sítios com 10 ou mais alqueires.

Manoel Bento da Cruz não era um coronel como qualquer outro. Seu perfil aponta para a figura de um homem empreendedor, moderno e bastante educado. A sua desenvoltura e trânsito fácil nos escalões do governo lhe asseguravam vantagens nos seus negócios e de seus parentes e amigos. 
Sua cultura e conhecimento nas letras e no Direito davam-lhe destaque nas esferas políticas e sociais e entre as elites. Para quem era versado em cinco idiomas, realmente isso não era pouco. Bento era visto como o "homem que fez a Noroeste" e também como "plantador de cidades". Não era um coronel de origem na propriedade da terra. Era, antes, um republicano urbano, ligado ao comércio, aos negócios, e não à grande propriedade da terra. Seu vínculo com o governo ocorre por volta de 1905, quando de seu estabelecimento em Penápolis. Ao se envolver com os negócios da terra, procurando legalizá-las, teve contato direto com os políticos do Estado. Assim, foi criando laços políticos com essas autoridades, tendo participação ativamente no PRP, sobretudo a partir de 1911. Seu grupo político era formado pelo deputado federal Raul Renato de Melo Cardoso, o deputado estadual Luiz de Toledo Piza Sobrinho, o coronel Virgílio Rodrigues Alves, além do secretário do interior Oscar Rodrigues Alves. Todos tinham interesses e projetos em comum, como grandes proprietários de terras na Região Noroeste, na cidade de Bauru, Penápolis, Piratininga e Lins.

As características e posturas do homem bom ficavam de lado em situações de crise, dando lugar ao coronel bastante violento, que recorria aos capangas armados para expulsar ocupantes das terras que havia legalizado para si ou seus clientes. Usava da força também para intimidar eleitores indecisos, forçando-os a votar naqueles candidatos por ele indicados, por ocasião das eleições. Às vezes, por desentendimentos políticos na região, mandava expulsar seus desafetos mediante tiros e espancamentos.

Carregava no seu dia-a-dia uma legião de inimigos, principalmente os coronéis de Bauru e São José do Rio Preto. Em certa ocasião, quando da solicitação de elevação de Penápolis à condição de município, os políticos de Bauru criaram toda sorte de empecilhos, entrando em choque frontal com Bento. A tramitação do projeto de criação do município de Penápolis estava barrada na Assembléia Legislativa de São Paulo, sobretudo pelo deputados representantes de forte grupo situacionista de Bauru. Diante dessa demora, Manoel Bento se associa à oposição contra esse grupo, então liderado por Vergueiro Lorena, para pressionar o governo do Estado a interferir na decisão do parlamento para a aprovação da criação do município de Penápolis.

A emancipação política da cidade de Penápolis ocorre em 1913, ano em que se reelege vereador em Bauru e é indicado pelos colegas edis ao cargo de Prefeito. Vergueiro Lorena, seu opositor e promotor público, é transferido por pressão de Bento da Cruz para outra Comarca, prova clara da ligação do prefeito com o governo do Estado. Por sua vez, Vergueiro, como funcionário público, não tinha outra alternativa senão cumprir a ordem de remoção expedida pelo presidente do Estado.

Entre 1914 e 1920, Bento Cruz ocupou sucessivamente os cargos de vereador, presidente da Câmara e prefeito de Bauru, tornando-se o político mais reconhecido e líder em toda zona da 
Noroeste. Nesse mesmo período, controlava também a política em sua terra, Penápolis, onde conseguiu eleger a maioria dos vereadores e o prefeito por ele indicados.

O grupo político do coronel Bento da Cruz foi responsável pelo domínio das maiores áreas rurais dos municípios de Bauru e Penápolis, recorrendo aos cofres públicos para efetuar melhorias e infra-estrutura nas terras pertencentes à empresa de colonização de sua propriedade. Ao mesmo tempo, desenvolvia uma política de atração de migrantes e imigrantes para a ocupação e criação de cidades na zona noroeste.

Como prefeito de Bauru e tendo o domínio político de Penápolis, sua administração foi conduzida a partir de grandes modificações na malha urbana e melhorias na zona rural. Entre as primeiras medidas tomadas estava aquela que estabeleceu o cadastramento dos imóveis urbanos, alargamento e alinhamento de ruas, elaboração de mapas e plantas da cidade, principalmente para permitir a confecção de escrituras, dando validade às aquisições e às transmissões do direito de propriedade. Obviamente, tratava-se de uma forma de regularizar os terrenos para que fossem depois ofertados ao mercado de terras urbanas, embora tivessem, nesses tempos, baixo valor econômico.

Acabava, assim, atraindo moradores de fora para a cidade, pois uma vez tais terrenos ocupados e com casa de moradia, certamente haveria mão-de-obra disponível e ocasional para as fazendas em formação em sua região de influência. Essas mudanças ocorridas em Bauru e Penápolis vão também acontecer em outras cidades próximas, como Lins, Avanhandava, Promissão, Araçatuba e Birigüi - claro que sob o comando de Bento da Cruz. Certamente que esses loteamentos e áreas urbanas ficavam isentos de impostos. Vale dizer, por fim, que os núcleos urbanos, com sua expansão e crescimento demográfico, é que trouxeram, de fato, valorização econômica aos imóveis rurais da região. Daí, então, o papel das modernas empresas de colonização que atuavam na formação de glebas rurais e urbanas e também na estruturação dos núcleos urbanos, formando um só processo na lógica do capital imobiliário e agrário no interior paulista.

Arnolfo Azevedo ${ }^{24}$ foi um político de formação bastante aristocrática. Filho de uma família antiga do Vale do Paraíba, proprietária de fazendas de café desde a fase áurea da economia cafeeira nessa região. Seu pai transformara-se em barão no final do Império, chefe político local que controlava o Partido Conservador na década de 1880. Advogado formado pela Faculdade de Direito de São Paulo, como político foi deputado estadual (1895-1900) e federal, chegando a presidir a Câmara Federal entre 1921-1926.

\footnotetext{
${ }^{24}$ Ver LOVE, Joseph. Op. cit. p.235-6.
} 
Suas ligações políticas tiveram início quando de sua atuação como vereador e prefeito de Lorena. Logo depois da Proclamação da República, em meio a uma conspiração para depor o Marechal Deodoro da Fonseca, Arnolfo articulou-se com outros políticos do PRP, conseguindo evitar a evolução e execução do golpe - o que lhe assegurou a direção do partido em Lorena. Teve apoio praticamente incondicional de Rodrigues Alves, então principal chefe político regional em todo Vale do Paraíba. Aliado político e amigo de Washington Luis, ligou sua carreira à desse líder político paulista, até 1930, quando se torna senador da República.

Dentre outros chefes políticos do interior paulista, destacando-se por sua personalidade forte e comportamento imprevisível, vê-se a ascensão de Rodolfo Miranda. Militante partidário pouco convencional, tomava atitudes que muitas vezes contrariavam a lógica do partido e se indispunha com outros líderes políticos e chefes locais. Esteve, em várias oportunidades, ao lado ora de determinados líderes do PRP ora ao lado de grupos distintos, sobretudo de olho em seus próprios interesses. No ano de 1891, por exemplo, apoiou ostensivamente Deodoro da Fonseca contra os dissidentes civis republicanos e Américo Brasiliense, presidente de São Paulo.

Em 1897, em pleno conflito com o Partido Republicano Federal, acaba apoiando Francisco Glicério contra Prudente de Morais. Depois, em 1907, com a candidatura de Albuquerque Lins à presidência do Estado, indicado pelo PRP, resolve aliar-se a Campos Salles, que acaba derrotado. Como dissemos, tratava-se de um político de posições freqüentemente destoantes das políticas convencionais, chegando por várias vezes a romper com a política estadual dominante. Contudo, conseguiu manter-se na política da Primeira República, tendo sido deputado federal entre 1897 e 1909 , além de membro permanente da Comissão Executiva do PRP no período de 1917 a 1930. Foi fazendeiro na Alta Paulista, numa região que mais tarde daria origem à cidade de Marília, industrial em Piracicaba e banqueiro em Santos.

Esses três políticos tinham muita coisa em comum nas suas histórias de vida - a formação política, a forma de atuação e as relações de poder que vivenciavam. Enfim, Tibiriçá, Azevedo e Miranda não foram coronéis "típicos", como aqueles analisados pela historiografia da Primeira República ${ }^{25}$.

Um coronel típico de atuação no interior paulista foi Ataliba Leonel, particularmente nos anos vinte do século XX. Segundo Love ${ }^{26}$, sua influência na Alta e Média Sorocabana deu-se no governo de Washington Luis, no início dos anos de 1920 e se estende até 1930. Ataliba Leonel era

\footnotetext{
${ }^{25}$ Em JANOTTI, M. L. M. Op. cit.; CARONE, Edgard. A República Velha (Evolução Política). São Paulo: Difel, 1974.; FAORO, R. Op. cit.; QUEIROZ, Maria Isaura P. Op. cit.; TELLAROLLI, Rodolfo. O poder local na República Velha. São Paulo: Cia. Editora Nacional, 1977.

${ }^{26}$ LOVE, Joseph. Op. cit. p.237.
} 
natural de Itapetininga (zona central) e desde 1893 vinha atuando politicamente junto aos domínios eleitorais de Fernando Prestes.

Fernando Prestes, por sua vez, era um coronel com muitas fazendas na Sorocabana e Mogiana. Dedicava-se à criação de gado e â fazenda de café. Fora também banqueiro e por alguns anos diretor da Estrada de Ferro Mogiana.

A família de Ataliba Leonel não era considerada de origem aristocrática como as de outros políticos da Primeira República. Seu pai era natural da província paulista e foi oficial da Guarda Nacional no período do Império. Estudou em São Paulo, obtendo o título de bacharel em Direito, na Faculdade de Direito no ano de 1895. Estabeleceu seu escritório de advocacia na capital paulista, logo se transferindo para o município de Piraju, na Alta Paulista, região onde prosperava a cultura do café. Love ${ }^{27}$ diz que "após 1904 [Ataliba Leonel] serviu ou como deputado ou como senador estadual" a maior parte do tempo mas, mesmo assim, preocupava-se em manipular o voto dos eleitores da Alta Sorocabana em benefício do Partido Republicano Paulista”. Segundo o autor, Leonel era temido e respeitado, tendo conseguido firmar sua influência política até a fronteira com Mato Grosso, a quase 320 quilômetros de Piraju.

Nessa região, cidades como Santa Cruz do Rio Pardo, Cerqueira César, Sarutaiá, Avaré, Ourinhos, Palmital, São Pedro do Turvo, Salto Grande, Ipauçu e Chavantes eram controladas por Ataliba Leonel por meio dos coronéis locais, que lhe asseguravam obediência política na hierarquia dos poderes local e regional. Em Ourinhos, por exemplo, o coronel Jacinto Ferreira de Sá, quando reivindicava obras para a localidade, recorria a Leonel - o que significava posteriormente a retribuição desse favor na forma de votos para os candidatos indicados por Ataliba, fosse para a eleição à presidência do Estado, fosse para os cargos de deputado estadual, federal ou senador de São Paulo. Faziam parte de seu forte grupo políticos de expressão como Jorge Tibiriçá, Carlos de Campos e Fernando Prestes.

Aqueles coronéis e chefes políticos locais não se destacavam no cenário político estadual como se destacara Leonel. Todos viviam à sua sombra. Acima de Leonel estavam políticos como Washington Luis, Júlio Prestes, Fernando Prestes e outros. Já os coronéis mais conhecidos da região e fiéis a Ataliba Leonel eram: Albino Garcia, de Bernardino de Campos; Henrique Cunha Bueno, de Ipaussu; José Machado e Cândido Dias de Melo, de Palmital; Antônio Evangelista da Silva e Leônidas Vieira, de Santa Cruz do Rio Pardo; além do já citado Jacinto Ferreira de Sá, de Ourinhos.

\footnotetext{
${ }^{27}$ Idem, p.238.
} 
Em Araraquara, desde 1890, a política coronelística girava em torno de algumas famílias que formavam a elite local. O coronel Bento de Abreu fora considerado um "político moderno" por sua atuação política e administrativa na cidade que simbolizava, então, a própria modernidade. Foi reconhecido como precursor das reformas urbanas e um agente modernizador ${ }^{28}$.

Bento de Abreu era natural de Campinas, mas muito cedo mudou-se para São Carlos, por volta de 1890, dedicando-se inicialmente ao comércio, ligando-se depois à atividade bancária, em uma agência de propriedade de sua família. Acaba deixando tal atividade após a falência da agência, então denominada Banco União de São Carlos. Nesses dias corriam boatos de que o fechamento da instituição fora fraudulento e em benefício de seus proprietários ${ }^{29}$.

As ligações de parentesco de Bento de Abreu com outras famílias locais eram visíveis, particularmente com as famílias Pinto Arruda e Arruda Botelho. Tratava-se de famílias que deram origem a uma parentela que vinha se formando desde a segunda metade do século XIX. Os Botelhos, por exemplo, vieram de Piracicaba e se instalaram em São Carlos, onde adquiriram várias fazendas de café. As grandes fortunas da época eram também constituídas por "casamentos arrumados", que ocorriam inclusive entre pessoas de uma mesma família. Era uma forma de "proteger" as fortunas nas mãos da elite e de garantir as posições sociais de destaque. Garantiam ainda as posições políticas nas esferas municipal, estadual e federal. Essa perspectiva é apontada por Cláudia Regina Vargas:

"Bento de Abreu foi casado com Maria Isabel Botelho de Abreu Sampaio Vidal, filha de Bento Carlos de Arruda Botelho e de Maria Isabel de Oliveira Botelho e neta dos Barões de Dourado e bisneta dos Viscondes de Rio Claro [...] Por outro lado, predominava a mentalidade na qual o fator econômico era denominador comum nas relações ${ }^{30}$."

Entre os anos de 1911 e 1929, ocupou vários cargos em Araraquara, onde iniciou sua vida pública. Foi vereador, prefeito e presidente da Câmara em várias gestões. Comprou fazendas em toda região, tendo sido o fundador da cidade de Marília ${ }^{31}$.

Bento de Abreu Sampaio Vidal obtivera uma área de terras por meio de legitimação de posses e da compra de outras. O objetivo era atrair interessados na cultura do café e, evidentemente,

\footnotetext{
${ }^{28}$ VARGAS, Claudia Regina. As várias faces da cidade. Bento de Abreu e a modernização de Araraquara (19081916). Dissertação de Mestrado em História, UNESP, Franca, 2000.

${ }^{29}$ VARGAS, C. R. Op. cit. p. 71.

${ }^{30}$ Idem, p. 61.

${ }^{31}$ CORRÊA, Anna Maria Martinez. História social de Araraquara, 1817-1930. Dissertação de Mestrado em História, USP, São Paulo, 1967, p. 363.
} 
vender tais terras, posteriormente, na forma de médias propriedades e a preços acessíveis, criando assim condições para a ocupação da região.

Politicamente, não era tão fácil a criação de um município. Geralmente, os moradores do local estavam entre os principais beneficiados. Porém, quando se tratava de áreas da zona rural, o problema tornava-se ainda mais complexo. Isso porque ao se criar um município tais ações implicavam sempre na divisão e redistribuição dessas terras e daqueles moradores - eleitores ali estabelecidos. De modo que os "municípios cedentes" julgavam-se prejudicados por perdas de receitas advindas de impostos e taxas, e também desprestigiados no cenário político estadual..

Esse processo é descrito pela professora Anna Maria Martinez Corrêa da seguinte forma:

"A criação de um município passava por uma discussão na Câmara dos Deputados. O projeto era apresentado por um deputado à Comissão destinada a estudálo. O pedido era acompanhado de uma série de informações a respeito do local, como população, produção, número de eleitores etc. Depois de realizar os estudos necessários, a comissão elaborava um parecer, que era discutido em plenário. Tais discussões geralmente eram tranqüilas, uma vez que os articuladores da proposta procuravam manter entendimentos com os interessados, estabelecendose formas de compensação aos perdedores, quando em condições de reclamar ou fazer reivindicações, por disporem de porta-vozes na Câmara. Na maioria das vezes, tais reclamações não passavam dos limites municipais ${ }^{32}$.”

Bento de Abreu ficou conhecido por sua atuação obstinada na formação de vilas, distritos e municípios. Era uma estratégia política acertada para quem estava voltado para a comercialização de terras e possuía prestígio político de outros chefes locais e autoridades do governo. Enfim, a criação de um município era sempre um momento privilegiado de demonstração de força política de um coronel na região onde seu nome era devidamente reconhecido e respeitado.

\footnotetext{
${ }^{32}$ CORRÊA, Ana Maria Martinez. Poder local e representatividade político-partidária no Vale do Paranapanema, 1920-1930. Tese de Livre-Docência em História, UNESP, Assis, 1988, p.107-7.
} 
CAPÍTULO IV - A POLÍTICA E O PROCESSO ELEITORAL 


\section{Política e Processo Eleitoral}

O sistema político republicano, embora se baseasse no princípio da representação eleitoral dos Estados, não possuía mecanismos e nem regras que expressassem a construção de um modelo político de poder equilibrado. Esse equilíbrio da representação no Brasil sempre foi destorcido pelas práticas desde o final do Império. A representação paulista na Assembléia Imperial, por exemplo, era insignificante, contanto apenas com 9 deputados de um total de 125 membros, e no Senado a situação não era melhor: contava apenas com 4 senadores de um total de 60 parlamentares.

Com a República, a baixa representação política de São Paulo pouco se alterou. Em 1890, São Paulo teve a garantia de que sua representação parlamentar no Congresso Nacional seria ampliada conforme a Constituição de 1891 determinava. Passou a ter 22 deputados de um total de 212 e 3 senadores independentes do número da população do Estado. Era uma representação satisfatória mas não ideal. Havia ainda um certo desequilíbrio.

O desequilíbrio era bastante evidente no caso de Minas Gerais e Bahia. Em 1890, Minas tinha $22 \%$ do total da população do Brasil, mas tinha apenas 37 deputados, que representavam 17\% da Câmara Federal, enquanto a Bahia, com 13\% da população, tinha 22 deputados, uma representação igual à de São Paulo, que tinha $10 \%$ da população brasileira. Por essa razão, o jogo político no plano federal dependia de alianças que eram formadas pelos Estados. Qualquer projeto de lei que implicasse em interesse dos Estados, a sua comprovação dependia de apoio da maioria no Congresso Nacional. Nenhum Estado conseguia aprovar qualquer medida sem apoio de outros Estados. Em qualquer situação, o Congresso só dava continuidade em seus processos mediante acordos entre as bancadas dos Estados. Como se vê, a vida política brasileira estava atrelada às estruturas de dominação política conforme a vontade dos Estados, passando, portanto, pela política estadual ${ }^{1}$.

O processo eleitoral no Brasil era restritivo, votavam apenas os alfabetizados. No sistema censitário do Império, por exemplo, em 1886 havia apenas mil eleitores, menos de $1 \%$ da população brasileira, que era de 13 milhões de habitantes. Na República, em 1898, havia 462 mil eleitores, cerca de $2,7 \%$ da população, que não ultrapassava a casa das 17 milhões de almas. Em suma, a população votante no país, até 1930, não passou de 3\% da população do Brasil. No começo do século, o eleitorado do Estado de São Paulo não passava de 1\% do total da população, mas essa baixa porcentagem de eleitores não diminuía o poder dos coronéis.

\footnotetext{
${ }^{1}$ Para outros detalhes sobre essa questão, ver: DORIA, Carlos Alberto. Coronelismo e oligarquia. In MENDES JR., Antonio e MARANHÃO, Ricardo (Orgs.). Brasil História. Texto e consulta República Velha. São Paulo: Civilização Brasileira, 1979, v. 3, p. 189; cf. KUGELMAS, Eduardo. A Primeira República, no período de 1891 a 1909. In: Berguelman, Paula, Pequenos Estudos e Ciência Política. São Paulo: Pioneira, 1973. p. 189.
} 
Em 1898, a região do Vale do Paranapanema, dominada pelo clã de Rodrigues Alves, era a mais importante econômica e politicamente sob o PRP embora historicamente o PRP fosse dominante na região do Estado, desde o final do século até 1930, não representa o foco do poder político dos coronéis republicanos ${ }^{2}$.

O Estado de São Paulo na Primeira República estava dividido, como dissemos, em dez regiões, onde o poder republicano estava distribuído através das várias seções do PRP no estado. O equilíbrio de forças entre os grupos políticos geralmente era alterado por vários motivos: primeiramente, aquele que determinava maior ou menor força de uma região sobre a outra, era a dimensão da produção cafeeira. Por exemplo, de 1880 a 1907, o Vale do Paraíba teve o predomínio na produção cafeeira. É quando o café da região Central do interior paulista assume uma posição de destaque e a produção do Vale começa a declinar. Por outro lado, os grupos fortes politicamente também eram mais numerosos, e o PRP, por sua vez, era mais organizado e dinâmico. Segundo Joseph Love, o poder maior de uma dada região pode ser medido pela arrecadação de recursos pelo PRP e identifica sua hegemonia política. Coincidentemente, essa maior arrecadação correspondia à maior produção cafeeira da referida região.

As regiões mais importantes econômica e politicamente eram: Vale do Paraíba, Mogiana, as regiões Centrais, o Oeste e a Baixa Paulista. Segundo Joseph Love, a porcentagem da renda do PRP, por região, é a seguinte: Capital, 6\%; Vale do Paraíba, 19\%; região Central, 19\%; Mogiana, 21\%; Baixa Paulista, 12\%; Araraquarense 7\%; Alta Paulista, 0\%; Alta Sorocabana, 8\%; Baixa Sorocabana, 4\%; Litoral Sul, 4\%. É preciso lembrar que em 1896 as zonas Central, Mogiana e Baixa Paulista eram responsáveis por $78 \%$ da produção paulista. Em 1905, a produção cafeeira nessas regiões era de $68 \%$ do total da produção cafeeira do Estado 3 .

O processo eleitoral na República Velha descreve de maneira precisa como deve funcionar a vida política no país. Há uma hierarquização de competências que o voto popular vai estabelecer como uma prática a seguir, findo o processo das eleições. O organograma é mais ou menos o seguinte: o presidente eleito ocupa o alto do organograma, em seguida vem o Partido Republicano, responsável por todo o ritual das eleições, e como se trata de partido único, ele está "eleito naturalmente" em todos os Estados, depois vêm os coronéis não eleitos e os que não foram sequer candidatos, continuam em seus partidos locais, mas muito bem articulados aos que foram eleitos e com seus cargos assegurados em um dos níveis de governo. Por fim, os prefeitos que foram eleitos serão os mediadores do poder local nos níveis acima do seu - ou seja, os níveis estadual e federal. Eis

\footnotetext{
${ }^{2}$ LOVE, Joseph. Op. cit. p. 192.

${ }^{3}$ CAMARGO, José Francisco de. Crescimento da população no estado de São Paulo e seus aspectos econômicos; LOVE, Joseph. Op. cit. p. 213.
} 
então como as oligarquias se formam e centralizam nas suas mãos todo o poder da República, carregando também seus familiares, parentes, afilhados e padrinhos e os eleitores, que são os agregados mais importantes no processo eleitoral.

Leôncio Basbaum descreve muito bem como os agregados eleitores se relacionavam no mundo da fantasia criado pelo coronel:

"Para servir aos coronéis, os sertanejos de qualquer categoria social, trabalhador, parceiro ou pequeno proprietário, e a fim de dar uma aparência legal ao predomínio dos mesmos, tinham que votar com ele." Os analfabetos aprendiam às vezes a assinar o nome para lançar na urna um voto cujo nome não podiam ler. E se o perdessem seria a mesma coisa. Em vésperas de eleição eram conduzidos em lotes, de qualquer modo, aos locais próximos dos postos eleitorais onde eram guardados às vezes com sentinelas nos chamados quartéis ou currais, nos quais se fazia a concentração dos eleitores. $O$ chefe político lhes dava além da condução, roupa, cachaça e um papelete de voto, [...] seu voto é um serviço que presta ao coronel não ao Estado4."

No dia da votação os mesários do PRP estavam a postos para a recepção do voto. Não havia nenhuma dificuldade de votar diante dos mesários, pois como zelosos cidadãos da República tinham por dever auxiliar diretamente os eleitores. A experiência desses mesários do PRP certamente influenciava na obtenção de um número maior de votos para os candidatos inscritos aos cargos eletivos.

Maria de Lourdes Mônaco Janotti assinala como eram esses procedimentos no dia das eleições:

"[...] a mesa receptora dos votos intervinha em todos os sentidos sobre o eleitorado. Quando um analfabeto se apresentava para votar, os próprios componentes da mesa preenchiam as cédulas e assinavam a lista de presença. Aos indesejáveis , sob qualquer alegação - a mais comum era o desacato -, mandavam prender. A interferência policial era notória e os amedrontados eleitores faziam muitas vezes questão de mostrar claramente a quem se destinava seu voto para evitar futuras complicações. Dessa forma, nada havia de livre ou secreto no ato de votar, porquanto sempre existiu a coerção, inclusive com presença no local de votação, de capangas do coronel. No momento da apuração, ao menor pretexto, anulavam-se cédulas ou acrescentavam-se votos, sem fiscalização da oposição, impedida de entrar no recinto ${ }^{5} . "$

\footnotetext{
${ }^{4}$ BASBAUM, Leôncio. História sincera da República, 1889-1930. São Paulo: Alfa Omega, 1975, 2. v. p. 191.
}

${ }^{5}$ JANOTTI, Maria de Lourdes Mônaco. Sociedade e política na Primeira República. São Paulo: Atual, 1999. p. 41. 
O voto era essencial para o funcionamento do PRP, das Diretorias municipais e do Diretório Central, na capital. Porém, a Constituição de 1891 consagrou o direito de voto apenas aos cidadãos alfabetizados. E aí está o problema, o gargalo da política na Primeira República. O país era praticamente marcado por uma maioria analfabeta. A República foi um modo político de assegurar o elitismo que nasceu com o Império. Por essa razão, a política não era um direito de todos, mas apenas da minoria, pois geralmente quem sabia ler reunia alguma forma de posse e de propriedade, exceto alguns pobres alfabetizados. Entre 1895 e 1902 :

“[...] Menos de 6\% da população nacional participavam das eleições [...] a política nessa época resumia-se, claramente, numa disputa entre setores da elite política nacional. Não obstante, verdadeiras clivagens registraram entre grupos regionalmente diferenciados. Com exigências conflitantes com grandes contingentes de eleitores e organizações disciplinadas sabiam traduzir as suas aspirações em exigências no início da República, São Paulo e Minas já estavam à frente dos outros Estados em número de eleitores [... $]^{6 ”}$.

Enfim, o número de eleitores de cada Estado dava o perfil político para que tal unidade administrativa ditasse, de certo modo, quais seriam os pontos básicos de sua prática política no conjunto dos demais Estados. Enfim, um colégio eleitoral majoritário marcava efetivamente o processo político.

“[...] visto que o presidente se elegia pelo voto popular direto e, em muitos sentidos, o Poder Executivo controlava os outros dois poderes do governo, podendo até intervir militarmente nos Estados mais fracos ${ }^{7} . "$

O papel dos cabos eleitorais nos processos eleitorais não deve ter mudado muito, a exemplo de como se cabalavam votos na República Velha. O cabo eleitoral nessa época decidia a eleição para o candidato, pois o voto tinha que ser buscado pessoalmente e não só no dia da eleição. Voto era compromisso de compadre, de amigo, de parente. A conquista dos votos começava bem antes das eleições: visitas periódicas aos eleitores com atenção e agrados, mediante presentes simbólicos sem muito valor monetário; cumprimentos em datas de aniversário, participação freqüente em festas religiosas ou em épocas de São João e São Pedro, etc. Tudo era necessário para cativar simpatia, amizade, mantendo freqüentes contatos. Sobre os cabos eleitorais, diz Maria de Lourdes Janotti:

${ }^{6}$ CARDOSO, F. H. - Dos governos militares a Prudente e Campos Salles. In FAUSTO, Bons. (Org.). História de civilização brasileira. O Brasil Republicano. Estrutura de poder e economia; (1889-1930). São Paulo: Difel, 1975, tomo 3, v. 1. p. 55.

${ }^{7}$ Idem. p. 56. 
"Esses cabos eleitorais profissionais eram geralmente mestiços semi-analfabetos de boa fala, populares nos respectivos bairros e que graças às suas altas relações atendiam a pequenos e grandes pedidos que variavam de um par de sapatos a um cargo publico à altura do requerente, e alistavam eleitores cujos títulos nas mãos negociavam com o candidato o tanto de voto. Mas, como dissemos, receber maior número de votos não significava ser eleito. Era preciso atravessar a barreira do reconhecimento de poderes, feito em conjunto pela Câmara e Senado, para apurar a legalidade da eleição, analisar as atas eleitorais e examinar tudo de novo, pois não havia naquela época Tribunais Eleitorais ${ }^{8}[\ldots]$ "

O preenchimento das atas era uma prática que considerava apenas a vontade da mesa feita para computar o número de cédulas preenchidas com o nome do candidato que deveria ganhar as eleições. O papel era uma formalidade necessária para criar a ilusão de que a lei eleitoral estava sendo cumprida. Depois, a Comissão Executiva do partido (o PRP) reconhecia apenas os nomes dos candidatos que deveriam ser considerados eleitos. Ou seja, os nomes previamente escolhidos pelos coronéis.

Os resultados também eram divulgados pela imprensa e pelos Boletins de Comissão Executiva do PRP. Nem sempre os resultados da Comissão Executiva e dos jornais eram os mesmos. É que às vezes, após as eleições, os candidatos preferem se retirar do cenário das apurações oficiais e se concentrar em suas casas com as urnas e as atas para poder elaborar os resultados a seu favor. Leôncio Basbaum lembra que:

“[...] em certa ocasião a Paraíba mandou duas turmas de candidatos a deputados eleitos: uma, a do governador com 500 votos e a outra a favorita do Ministério Público da Justiça (Epitácio Pessoa) com cerca de 1000 votos. É que no dia da apuração os oposicionistas não puderam entrar nas Repartições onde funcionavam as juntas. Em certo distrito haviam votado os vivos, presentes, os mortos e ausentes. Isso pelo menos foi demonstrado para dar vitória aos candidatos do ministro da Justiça. Na presidência Rodrigues Alves, entre outros casos, o Senado reconheceu o Barão Ladário que obteve 270 votos, enquanto eleito e não empossado, Antonio Bittencourt obtivera 7.334 votos. A isso chama-se degola. E quem defendeu o reconhecimento dos menos votados foi ninguém menos que Rui Barbosa. A publicação do quadro dos votantes refere-se aos que votaram a favor da degola dos eleitos nos revela surpresas terríveis. É que na Velha República ninguém escapa, absolutamente ninguém, ao crime de ter atentado contra a "verdade eleitoral"."

${ }^{8}$ BASBAUM, Leôncio. Op. cit. p. 191.

${ }^{9}$ Idem, p. 192-193. 


\section{O Partido Republicano Paulista e os Esquemas de Poder}

Os partidos republicanos foram criados à luz de uma realidade política que pressupunha uma federação partidária apenas formalmente, ou seja, os partidos seriam regidos por um único estatuto que modificava tão-somente os nomes das pessoas e dos Estados. Desses partidos, o Partido Republicano Paulista era o mais atualizado e atuante. Não é por outra razão que os filiados do PRP representavam o grupo político mais influente na política nacional e os mais antigos da história do republicanismo. Basta lembrar, por exemplo, que o líder do PRP no começo da República foi Américo Brasiliense, um dos fundadores do partido signatário do Manifesto Republicano de 1870.

O segundo partido em importância foi o Partido Republicano Mineiro, cujo líder e primeiro governador republicano foi Cesário Alvim.

Tudo indica que no caso do Estado de São Paulo as relações políticas foram muito tensas nos primeiros anos da República. Américo Brasiliense tinha sido deposto por seus antigos companheiros de partido, em dezembro de 1891, para dar lugar ao seu vice, Cerqueira César. Também, o presidente da Comissão Executiva do PRP - o positivista Luis Pereira Barreto - foi afastado do cargo.

Essas mudanças estavam associadas à deposição de Deodoro da presidência e à posse de Floriano Peixoto. Ao mesmo tempo, a Câmara Estadual Paulista pára também por sua radical mudança com a deposição de todos os deputados e a consequiente reorganização do PRP. O novo presidente de Comissão Executiva passou a ser Prudente de Morais e os novos membros escolhidos foram republicanos históricos como Bernardino de Campos, Julio de Mesquita, Cesário Mota, Francisco Glicério, Camilo e Francisco Rodrigues Alves ${ }^{10}$. Esses eram os políticos que apoiavam Floriano Peixoto e representavam a República pós-1891, depois do expurgo dos republicanos de última hora aliados de Deodoro. Refiro-me aos ex-monarquistas, como também tinha sido o Marechal Deodoro.

O esquema de poder dos republicanos históricos passava por acertos e acordos internos no PRP e com o poder nacional. De certo modo, o PRP conseguiu exercer o monopólio do poder no nível federal, ocupando a maioria dos cargos na República, além dos cargos no Estado de São Paulo. Essa "hegemonia" dos históricos se explica pelo segundo dado: ao longo da Primeira República, os republicanos históricos ocuparam 36 anos de poder em nove mandatos no governo paulista ${ }^{11}$.

Os demais partidos da República, exceto os de Minas Gerais e Rio de Janeiro, ficavam praticamente ausentes da estrutura do poder nacional. Esse processo monolítico de poucos partidos no controle do País gerou algumas oposições estaduais, como no Rio Grande do Sul.

\footnotetext{
${ }^{10}$ LOVE, Joseph. A Locomotiva: São Paulo na Federação Brasileira, 1889-1937. Rio de Janeiro: Paz e Terra, 1982. p. 159.

${ }^{11}$ Idem, p. 160.
} 
Ainda que as dissidências ocorressem por razões políticas e motivações regionais, o problema, na verdade, estava ligado à dificuldade de acesso aos recursos financeiros da União para obras públicas pelos Estados e municípios e também à disputa dos cargos públicos e de outros interesses econômicos localizados regionalmente. A questão dos interesses econômicos é relevante para os diferentes grupos políticos da República.

Não foi por outra razão que a República procurou atender aos interesses financeiros dos bancos.

Os principais chefes políticos dos partidos republicanos estavam diretamente ligados a instituições bancárias, como Bernardino de Campos, Rodrigues Alves, Campos Salles, Cerqueira César e Prudente de Morais.

Detalhando melhor essa questão, Joseph Love escreveu da Primeira República:

"[...] os quatro membros da comissão executiva [estavam] ligados a esses chefes. Antonio de Pádua Sales e Rubião Junior faziam parte do Banco de Comércio e Indústria, Lacerda Franco e Bernardino, ao Banco União, Frederico de Abranches, ao Banco de São Paulo, e Campos Sales, ao Banco de Crédito Real. Todos ocupavam, ou vieram a ocupar posições de chefia em seus respectivos bancos ${ }^{12}$."

Como se vê, os republicanos estavam ligados à economia cafeeira, mas também se amaseiavam ao capital financeiro. O sucesso da política de valorização do café, em 1907, na Convenção de Taubaté indica a força do Estado de São Paulo e a defesa intransigente, pela República, dos interesses dos fazendeiros de café ${ }^{13}$.

A boa performance econômica dos fazendeiros refletia-se no caráter diversificado dos investimentos que implementavam em outras atividades: "os grandes proprietários preferiam residir na capital, para ficar mais próximos da atividade bancária e da exportadora. Muitos diversificaram seus interesses em diferentes atividades econômicas, introduzindo-se na prática capitalista ${ }^{14}$ ”.

O papel da Comissão Executiva do PRP era estratégico na forma de se fazer a política republicana, pois intermediava os interesses diferenciados do partido, ocupando-se ainda da interlocução do governador com os coronéis. O presidente da Executiva exercia a chefia do poder do partido, mas também representava os interesses das diferentes regiões do interior paulista. Cabia ao

\footnotetext{
${ }^{12}$ LOVE, Joseph. Op. cit. p. 161.

${ }^{13}$ Sobre esse Convênio, ver: HOLLOWAY, T. Vida e morte do Convênio de Taubaté. Rio de Janeiro: Paz e Terra, 1978.

${ }^{14}$ JANOTTI, Maria de Lourdes Mônaco. Op. cit. p. 40.
} 
presidente da Comissão cuidar das demandas por recursos financeiros para obras, fazendo gestões junto ao governador e à Assembléia Legislativa para o caso de obras públicas e de concessão de cargos públicos do Estado nas cidades e regiões controladas pelos coronéis, principalmente os coronéis que eram responsáveis pelos distritos eleitorais do Estado.

Muitas vezes, a Comissão Executiva do PRP cuidava de gerenciar demandas por leis e decretos específicos junto à Assembléia estadual que atenderiam aos interesses de regiões e dos coronéis locais. O caso mais comum da ação da Comissão Executiva do partido era em relação aos pedidos de coronéis que pleiteavam transformação da condição de "sua" vila à de distrito, ou então de distrito à de município, ou, ainda, a elevação do município à condição de Comarca. Esses pedidos eram freqüentes, particularmente depois de 1910, quando se observa um forte fluxo de imigrantes para o Brasil, além das migrações internas que se intensificavam em todo Estado de São Paulo.

"Pelo menos durante os primeiros anos da República [a comissão] podia também interceder junto à Câmara Estadual em defesa de políticas específicas, além de, em comum acordo com o governador, proceder à indicação de nomes para o preenchimento de cargos estaduais e federais. Na década de 1890, embora de modo informal, influiu muito no governo do Estado ${ }^{15}$."

Os grupos oligárquicos formados por Campos Salles, Rodrigues Alves, Bernardino de Campos, Fernando Prestes, Altino Arantes, Washington Luis, Jorge Tibiriçá, Rubião Junior e Francisco Glicério, dominaram por longos anos os principais cargos na administração estadual e dentro do Partido Republicano Paulista. Esses políticos ocupam cargos presidenciais e os postos chaves do Legislativo estadual e federal, dominando todo o regime republicano. Os grupos têm bases em zonas do interior e a representação na Comissão Diretora do partido. São seus membros que em reuniões específicas discutem na Comissão seus pontos de vista, para depois decidir quais as medidas a serem tomadas pelo partido. A maioria dos grupos se mantinha ou se revezava na Comissão Executiva.

Em 1896 estavam na Executiva Francisco Glicério, João Batista Melo Oliveira, Bernardino de Campos, Rubião Junior e Julio de Mesquita. Já em 1901 há uma certa renovação da Comissão Executiva, então formada por Bernardino de Campos, Cerqueira César, Melo Oliveira, Rubião Junior e Ferraz de Sales $^{16}$. No ano seguinte, há nova alteração da diretoria, mas não são mais os tradicionais nomes da oligarquia paulista. São seus representantes, uma espécie de "laranjas", que vão comandar a Comissão Executiva do PRP. Representando Rodrigues Alves estava Frederico Abranches; Prudente de Morais, José Alves Guimarães Junior; Cerqueira César, Alfredo Guedes; Campos

\footnotetext{
${ }^{15}$ LOVE, Joseph. Op. cit. p. 163.

${ }^{16}$ CARONE, Edgard. A República Velha. (Instituições e Classes Sociais). São Paulo: Difel, 1972. p. 271-272.
} 
Salles, Pádua Sales; e Bernardo de Campos, Antonio Lacerda Franco. Já em 1909, a Comissão Executiva era formada por: Bernardino de Campos, Rubião Junior, Pádua Sales, Siqueira Campos, Dino Bueno, Jorge Tibiriçá, Cesário Bastos, Francisco Glicério e Adolfo Gordo ${ }^{17}$.

Vimos que a Executiva do PRP era o coração do partido, de um partido mais pragmático do que teórico, sem uma definição ideológica e identificado como uma organização partidária da elite paulistana. O Partido Republicano não tinha uma estrutura do tipo formal e moderna, apenas se limitava a uma secretaria com um secretário e um auxiliar, geralmente em sede própria, onde ocorriam as reuniões dos filiados e membros da Executiva e dos grupos políticos com cargos municipais, estaduais e federais. Era na sede que a Comissão Executiva do partido se reunia para analisar as demandas e pedidos recebidos, e decidir sobre os meios de encaminhamento dos mesmos e a solução para cada caso.

A documentação do partido era gerenciada pelo secretário, que mantinha contato direto com o presidente da Executiva. Toda a atividade da vida partidária era escriturada e todo acervo era mantido em pastas com os nomes dos chefes políticos, endereços de cada um, região de abrangência de cada chefe político e sua importância eleitoral, além de outras informações sobre cidades, distritos, vilas e sedes das Comarcas. Enfim, a documentação constituída pelo partido seguia o princípio fundamental da política na época, que era formar o clientelismo para se exercitar um modo bem pessoal de prática política. Enfim, a estrutura e funcionamento do partido tinha suas próprias regras, que se refletiam em sua história ${ }^{18}$.

Normalmente, a Executiva era constituída a partir dos diretórios municipais, que tinham força e poder para a escolha dos candidatos aos cargos eletivos nas eleições municipais, estaduais e até nas eleições para presidente da República, Câmara dos Deputados Federais e Senadores. Cabia também à Comissão Executiva a declaração dos eleitos pela comissão verificadora, que ficavam na lista dos chamados "degolados".

O mandato da Comissão era de um ano, mas os seus membros podiam ser reconduzidos por vários mandatos. O deputado estadual de Piraju, Ataliba Leonel, por exemplo, foi eleito e reeleito por uma dezena de mandatos na presidência da Comissão Executiva do PRP em Piraju. Além de ser deputado estadual, Ataliba foi vereador em mandatos concomitantes (vereador e deputado ao mesmo tempo). Houve momento em que ele era deputado estadual, vereador e presidente da Câmara Municipal. Também presidiu o $5^{\circ}$ Distrito Eleitoral de Botucatu por cinco anos ${ }^{19}$. Enfim, essa

\footnotetext{
${ }^{17}$ CARONE, Edgard. Op. cit. p. 271-272.

${ }^{18}$ Para uma perspectiva mais ampla do Partido Republicano na Primeira República, ver: MELO FRANCO, Afonso Arinos de. História e Teoria dos partidos políticos no Brasil. São Paulo: Alfa-Omega, 1974.

${ }^{19}$ Para outros detalhes sobre Ataliba Leonel, ver: CACERES, Miguel. Piraju - Memórias políticas e outras memórias. Piraju, 1998; LOVE, Joseph. Op. cit. p. 236-238.
} 
prática era comum na época e acatada sem muita oposição, embora houvesse resistência informal por parte dos críticos ao PRP. Mas a longevidade nos cargos políticos, para o PRP, era considerada legitima e prova cabal da competência de seu ocupante.

Enfim, as Comissões Executivas tendiam a permanecer por anos e quando alguém era substituído, o processo não era por eleição, mas por indicação de seus próprios membros. Ou seja, a rotatividade dos cargos e a forma de composição da Executiva não ocorriam por escolha democrática, embora o partido defendesse o liberalismo político clássico. O poder da Comissão Executiva do PRP foi mantido até 1928, quando se operam algumas mudanças internas, transferindo algumas das competências para o âmbito do Poder Executivo Estadual - o que aumentou o poder do governador. Na realidade, a Comissão Executiva já vinha perdendo algumas de suas prerrogativas, como por exemplo a de indicar candidatosa governador.

Joseph Love ${ }^{20}$ lembra que, em 1915, Rodrigues Alves indicou Altino Arantes como seu sucessor; em 1919 Altino Arantes escolheu Washington Luis para sucedê-lo. Em 1923, Washington Luis impôs Carlos de Campos para candidato ao governo, à revelia da Comissão Executiva, que então havia proposto outro nome. Em outros Estados, esse processo que não era nada democrático foi muito semelhante ao caso de São Paulo.

Os governos paulistas buscaram reduzir as tensões dentro do PRP nos diretórios do interior, onde as lutas caracterizavam-se por disputas em torno de cargos na administração republicana, federal, estadual e municipal.

O fato de o PRP ser um partido único e não possibilitar muitas combinações e arranjos políticos locais estaduais (nem sempre isso era possível) dificultava a acomodação das diferenças, de indivíduos e de grupos. Por essa razão surgem as dissidências, que pouca chance tinham de criar um espaço dentro do partido.

A solução, então, seria ocupar espaço no controle da Câmara Municipal ou cargos na administração estadual. O partido, por si próprio, não representava todas as tendências ou grupos dentro do perrepismo paulista, que era diferente de outros PRs nos demais Estados.

O Partido Republicano Paulista buscava construir um sistema de alianças considerando todas as regiões, mas com uma sintonia fina nos problemas locais e nas figuras dos coronéis de cada região, que polarizava problemas diferentes e particulares. Esta é na verdade uma situação reconhecida pelos próprios grupos divergentes em cada região do interior. Na verdade, nota-se a ausência

${ }^{20}$ LOVE, Joseph. Op. cit. p. 164. 
de um projeto político estadual de longo alcance, pelo menos até 1920, com o início do governo Washington Luis, com suas medidas de moralização política no sentido de imprimir uma nova prática política mais civilizada e sem a violência que até então campeava por todos os Diretórios Políticos do PRP, particularmente no interior do Estado.

De certo modo, as alianças costuradas nem sempre funcionam dentro e fora do PRP, quer seja no âmbito das relações locais, regionais, quer seja no plano nacional. O que explicaria essa situação, essa realidade, seria a existência de partido único?

"A ausência de partidos nacionais tornava o sistema de alianças extremamente instável, modificando-se de quatriênio para quatriênio e mesmo de ano para ano. Dentro desse panorama cambiante e por vezes caleidoscópio, devemos levar em conta três planos: as relações entra o Centro e os Estados, as alianças entre os Estados, e as disputas faccionais dentro de cada Estado, com suas repercussões nos dois outros planos. Nesse jogo político preponderavam os três grandes Estados: Minas, São Paulo, Rio Grande, conforme já foi dito tantas vezes ${ }^{21}[\ldots]$ ”

As alianças tinham por base a descentralização do poder republicano, tendo os governos municipais, estaduais e federal plena autonomia para implementar políticas próprias e específicas em cada esfera de governo. Para efetivar esse projeto, esse modelo de funcionamento dos poderes nesse três níveis, os coronéis, os banqueiros, os comerciantes e depois até os industriais tiveram que entrar em acordo através do PRP - o que demonstrava que esse partido em São Paulo tinha capacidade de articulação política, com a costura de seus interesses diferenciados em torno de um projeto em comum. Esse era o estilo oligárquico do governo republicano específico e flexível do Estado de São Paulo.

\footnotetext{
${ }^{21}$ KUGELMAS, Eduardo. Difícil hegemonia. Um estudo sobre São Paulo na Primeira República. Tese de Doutorado em Ciência Política, USP, 1986. p. 63-64
} 
CAPÍTULO V - A QUESTÃO DO ORÇAMENTO 


\section{Debates Parlamentares que Explicitam o Problema do Orçamento}

É importante ressaltar que os debates, discursos e demais proposituras legislativas em torno do processo de construção e votação do orçamento paulista, em todo seu percurso regimental, no espaço de tempo aqui pesquisado (1890-1920), davam-se, em geral, sem muita interferência explícita e contínua, no seu dia-a-dia, por parte do Congresso Nacional. Excetuaria, é claro, aqueles momentos muito graves da vida nacional, onde o que estava em jogo eram sobretudo aspectos da estrutura política dominante - leia-se fundamentos da política econômica (financeiros e monetários), interesses políticos divergentes com outras unidades da Federação ou ainda questões de ordem internacional.

Por meio de uma autonomia calculada, davam de ombros às questões alheias aos interesses da indústria do café, permanecendo os parlamentares paulistas seguros, no seu cotidiano, de que não lhes faltaria o silêncio amigo e cúmplice do Legislativo e Executivo federal, em tempos em que ambos já haviam sido tomados pelo manto hegemônico da burguesia cafeeira ${ }^{1}$.

Lançando olhos atentos ao cotidiano parlamentar e principalmente a todos os feitos que culminavam na construção das peças orçamentárias, em cada ano legislativo pesquisado (trinta anos), em número de onze legislaturas, configurava-se um conjunto de práticas das quais, posso afirmar, confortavelmente, constituir-se num jogo que se desenrolava por meio de duas frentes diferentes, porém desencadeadas de forma simultânea: movimentações não raras vezes espetaculares, que chegavam a monopolizar quase a totalidade dos trabalhos e de tempo demandado no Legislativo estadual com vistas aos interesses locais. É dessa, digamos, categoria de movimentação a origem e preocupação com as infinitas solicitações de auxílios diversos e que abrangiam as diferentes áreas e funções da administração estadual (recursos para Santas Casas, escolas, pontes, cadeias, prolongamento de ramais ferroviários, melhoria nos vencimentos de funcionários públicos, etc.), voltados à municipalidade e seu cotidiano precário. São movimentos e práticas pensados, calculados na realidade dessas localidades, e de repercussão e publicidade vitais para o controle e apaziguamento de seus currais eleitorais.

\footnotetext{
${ }^{1}$ Diz o professor Fausto: "Nas últimas décadas do Império, a burguesia do café já assumira o controle da máquina estatal da província de São Paulo [...] Com o advento da República, a hegemonia da burguesia do café se estende do nível estadual ao nível nacional, através de um breve processo de lutas onde os opositores se concentram sobretudo no estrato militar [...] os grandes Estados impuseram na Constituição de 1891 os princípios que assegurariam esta hegemonia [...] ampla autonomia estadual, com a possibilidade de os Estados contraírem empréstimos externos e contarem com forças militares próprias. Na distribuição de rendas, atribuiu os impostos de exportação aos Estadosmembros. Garantindo [...] a receita das unidades maiores e em especial de São Paulo".FAUSTO, Boris. Estrutura de Poder e Economia. "Expansão do café e política cafeeira". In : História Geral da Civilização Brasileira. Livro segundo, 4ª. Edição, Rio de Janeiro: Bertrand Brasil, 1990, p. 195-248.
} 
Um outro tipo de movimentação de parlamentares, de forma alguma menos importante que a primeira, caracterizava-se na busca constante de uma sintonia mais fina com o Executivo paulista, atento ao quadro econômico vivido, como com a necessidade do equilíbrio das contas públicas, e que acabava por gerar evidentemente um clima bem mais amistoso entre as duas esferas de poder e capaz de facilitar aos diferentes presidentes do Estado uma maior mobilidade no remanejamento de recursos, preservando, assim, melhores condições de governabilidade e, por vias mais que diretas, a estrutura hegemônica de poder.

Tais situações permeavam, como disse, os debates parlamentares acumulados nos registros dos Anais da Câmara dos Deputados de São Paulo, sobretudo naqueles momentos em que se deliberava sobre questões orçamentárias e, em especial, nas justificativas de recusas de emendas para companheiros de parlamento. Dizia o deputado Rubião Júnior, homem habilidoso em questões de contas e, nesse momento, investido do cargo de presidente da Comissão de Fazenda e Orçamento, ao então presidente da Câmara paulista, o deputado Luiz de Toledo Piza e Almeida:

“[...] senhor presidente [...] a quantidade e a importância das modificações propostas bem demonstram o empenho e o cuidado com que foi estudado o trabalho da comissão [Fazenda e orçamento] de forma a poder satisfazer a todas as necessidades que a ele se pretendem [...]. As emendas oferecidas foram em número de sessenta e sete, das quais cinqüenta e sete se referem ao capítulo da despesa, uma à receita, uma simultaneamente à receita e à despesa, sete às disposições permanentes e uma simultaneamente à receita e às disposições permanentes [...] Vou considerar essas modificações, analisando-as quanto baste para tornar bem conhecido o pensamento da comissão. Quanto às [não todas] emendas supressivas entende a comissão que não podem ser adotadas, umas, porque visam trazer embaraços à administração, prejudicando o serviço público [...] que não pode estar na mente do Congresso criar ao poder executivo, outras, por estarem em franco desacordo com as leis que organizaram as repartições públicas, e que temos obrigação de respeitar até que sejam revogadas pelos trâmites constitucionais ${ }^{2}[. .$.$] "$

\footnotetext{
${ }^{2}$ Manifestação do Deputado Rubião Júnior na 72a . Sessão ordinária em 1 de agosto de 1898, ACDESP, p.620-33. Referia-se o deputado às seguintes emendas, descritas aqui de forma resumida: "[...] no. 18 que suprimia verba para publicação da revista do Museu de São Paulo e entregando ao Diário Oficial que não está preparado para fazê-lo; no. 22, que reduz a verba marcada para os grupos escolares e escolas providas, para pagamento de professores substitutos presumíveis; no. 25, reduzindo a dotação do Diário Oficial; no. 27, sobre expediente da Secretaria de Justiça, diligências policiais e socorros públicos [...]; no. 30, que reduz a verba para núcleos coloniais já existentes [...]; no. 31, sobre saneamento do Estado já de si enfraquecida, com relação à importância desse serviço; e as de números $\mathbf{3 2} \mathbf{e} \mathbf{3 3}$, sobre verbas eventuais das secretarias de Agricultura e Fazenda. Para cada peça orçamentária debatida e organizada nesses trinta anos pesquisados, outras demonstrações de semelhante importância foram registradas.
} 
E assim prosseguiam as explicações do deputado Rubião Júnior, não poucas vezes interrompido por manifestações de "apoiado", "muito bem, muito bem". Alinhavando suas justificativas apoiado em pontos importantes que davam cor e forma ao quadro de limitações econômicas por que passavam o Estado e o País, acabava, simultaneamente, por jogar luz às constantes disputas entre parlamentares por recursos públicos.

O consenso possível era alcançado na seqüência desses rumorosos embates, onde, naquele momento, o que de mais importante poderia haver não era outra coisa se não a defesa e atenção aos municípios e regiões que compunham sua base eleitoral. Quando o contrário acontecia e o impasse tomava corpo, era comum aos parlamentares membros da Comissão de Fazenda e Orçamento lançarem mão de artifícios que acreditavam se imporem à "inconsistência" de tais justificativas, sempre alegadas pelos deputados contrariados. Entre esses, e comum às várias legislaturas, estava o de reproduzir dos últimos orçamentos aprovados, de anos diretamente anteriores, os "corretos" motivos e valores decididos, conseguindo, assim, o encerramento forçado dos debates para o exercício em questão.

Nesse sentido, reputo lapidar outra manifestação do deputado Rubião Júnior:

"Completando o pensamento manifestado pela quase unanimidade da Câmara [...] a comissão de fazenda apresenta uma emenda aditiva contemplando as casas de misericórdia e estabelecimentos de ensino que figuram no orçamento passado e cuja exclusão não se justificaria no momento [...] Atendendo às reduções feitas na despesa, a comissão aceita com prazer as emendas aditivas [...] e que têm sido atendidas nos orçamentos anteriores ${ }^{3}[\ldots] ”$.

Para o ano de 1899 as coisas não caminharam de forma diferente, assim como nos demais anos. Registravam a $68^{\mathrm{a}}$. e $71^{\mathrm{a}}$. Sessões Ordinárias do mesmo ano o seguinte:

“[...] o coletor de Pindamonhangaba e outros pedem aumento da porcentagem que percebem [...] Aberto o precedente, seria impossivel pôr um dique às pretensões do funcionalismo [...] A comissão, não querendo tomar a responsabilidade pelo aumento de despesas com o funcionalismo, é de parecer que seja o pedido arquivado"”. E também "[...] as outras emendas apresentadas devem ser rejeitadas [...] por que criam isenções de impostos ou aumentam as despesas concorrendo para depressão da receita, que em suas bases principais está exposta a constantes oscilações, as quais acompanham o valor do produto por assim dizer exclusivo da exportação do Estado, que é o cafés [...]".

\footnotetext{
${ }^{3}$ Tratava o nobre deputado de diversas emendas. Para detalhes ver p. 621, 72a . Sessão Ordinária de 1898. 3 Tratava o nobre deputado de diversas emendas. Para detalhes ver página 621, 72ª . Sessão Ordinária de 1898.

${ }^{4}$ Parecer no. 165 da Comissão de Fazenda, lido durante a 68 ${ }^{a}$. Sessão Ordinária em 28/7/1899, p.740.4 Parecer no. 165 da Comissão de Fazenda, lido durante a 68ª . Sessão Ordinária em 28/7/1899, p.740.

${ }^{5}$ Despacho da Comissão de Fazenda, lido na 71a . Sessão Ordinária em 1/8/1899, p. 763.
} 
Ponto alto de cada ano legislativo, os debates sobre o orçamento estadual... (para abrir a discussão sobre atribuição de poderes págs. 794 a 801/1899. Pretendo ler e "traduzir" sem muitas citações, ou seja, compreender o que se passava e inserir, de forma alinhavada, com o conteúdo do texto e do item. Próximo passo ver orçamento não como ficção mas como uma lógica de intenções do papel rascunho.

\section{As Forças Políticas e a Distribuição dos Recursos Orçamentários}

Em seu Capítulo II, que tratava da eleição da mesa e outras atribuições, o regimento interno da Câmara dos Deputados de São Paulo indicava, em seus artigos $18^{\circ}$ e $19^{\circ}$, que a primeira sessão depois da abertura do Congresso era o momento de se proceder à eleição da mesa, que teria que servir durante a sessão legislativa e seria composta de um presidente, um primeiro e um segundo secretário6. Nos artigos seguintes afirmava que os referidos membros seriam eleitos por escrutínio secreto, em cédulas separadas e por maioria absoluta de votos dos deputados presentes.

No período de 1890 a 1920, presidiram a Câmara os parlamentares: Augusto Cesar de Miranda Azevedo, no período de 1891 a 1892, que deu início à sua vida política na Capital Paulista, sede da primeira zona; Antonio Francisco de Paula Sousa, filho de tradicional família do município de Itu e com forte atuação em toda a zona Central do Estado, presidiu no ano de 1892; natural de Capivari, então importante município da zona Central do Estado ( $3^{\mathrm{a}}$ zona), Luiz de Toledo Piza e Almeida comandou a Câmara no período de 1892 a 1899, perfazendo assim sete anos e alguns meses. A seguir, elege-se o senhor Carlos Augusto Pereira Guimarães, natural do Vale do Paraíba (2a zona), onde também atuava como liderança política importante. O quinto e o sexto presidentes foram, respectivamente, Antônio de Pádua Sales (1901 a 1903) e João Alvarez Rubião Júnior (1903 a 1906). Por fim, o sétimo e o oitavo presidentes no comando da Câmara, os dois últimos ainda dentro do período aqui estudado, foram Carlos de Campos (1907 a 1915), político natural da capital paulista, onde também possuía sua força eleitoral, nesse momento já como sede do primeiro distrito eleitoral no Estado de São Paulo, e Antonio Alvarez Lobo, presidente da Câmara dos Deputados de São Paulo por longos onze anos (1915 a 1926) e participação política expressiva e freqüente nas regiões de Itu e Campinas, agora sedes do quarto e quinto Distritos Eleitorais, ou se preferíssemos voltar a poucos anos antes, municípios que estavam circunscritos à zona Central do Estado ( $3^{\mathrm{a}}$ zona).

\footnotetext{
${ }^{6}$ Cada legislatura tinha a duração de três anos e cada sessão quatro meses de funcionamento (num mesmo ano), podendo ser prorrgada ou adiada
} 
Assim, ainda que ocasionalmente ficassem de fora os mandatos dos senhores Pádua Sales e Rubião Júnior, que somados presidiram a Câmara por seis anos, apenas para efeito de uma simples conta de somar e por nos faltarem dados, constata-se a forte presença de representação dos municípios da zona Central do Estado ( $3^{\mathrm{a}}$ zona), e mais tarde quarto e sexto Distritos Eleitorais, em primeiro lugar com 19 anos no comando da casa (computado 1926). Em seguida teríamos a Capital (sede da primeira zona até 1906 e do primeiro distrito a partir de 1907), cujos representantes comandaram durante 11 anos. Por sua vez, a então zona do Vale do Paraíba ( $2^{\mathrm{a}}$ zona), unicamente com base nos dados incompletos de que dispúnhamos até o momento, teve sob seu comando a presidência da Câmara durante três anos. Com a análise do destino das emendas destes e dos demais parlamentares como veremos mais adiante, fomos capazes de sugerir situações mais completas no que diz respeito às informações que nos foram chegando.

Ainda sob a ordenação do Regimento Interno da Câmara, outra questão fora particularmente importante para esse estudo: as regras de composição e funcionamento das Comissões Permanentes da casa. Entre as oito existentes, dedicamos especial atenção à Comissão de Fazenda e Contas. No Capítulo III, artigo $31^{\circ}$ do Regimento fora regulamentado que à segunda Comissão Permanente, denominada Fazenda e Contas, caberia a organização do projeto do orçamento estadual e o estudo de tudo que significasse possibilidade de aumento ou redução da despesa ou receita do Estado, bem como de todas as questões que dissessem respeito, direta ou indiretamente, ao crédito do Estado. Rivalizando em importância, e irmã gêmea da Comissão de Justiça, Constituição e Poderes, a Comissão de Fazenda e Contas, com o decorrer das legislaturas, foi acumulando prerrogativas e demonstrando desenvoltura tal em suas atribuições, que nos leva a compreender nessa situação o exercício do Poder compartilhado entre seus pares e sobretudo por parte dos dirigentes da Mesa da Câmara. Obviamente que enxergávamos aí também a mão forte do chefe do Executivo Paulista. Assim, com tanta desenvoltura no exercício de suas incumbências, claro que não ficara imune às manifestações de protesto de grupos oposicionistas e mesmo de membros da situação. 


\begin{tabular}{|c|c|c|c|c|c|}
\hline \multicolumn{6}{|c|}{ Eleição - Presidente da Comissão de Fazenda e Contas } \\
\hline Legislatura & Ano Legislativo & Total de Cédulas & Parlamentar & Votaçäo & Distrito \\
\hline \multirow{6}{*}{$1^{\text {a }}$ Legislatura } & \multirow{3}{*}{1.891} & \multirow{3}{*}{23} & Cesário Bastos & 23 votos & \\
\hline & & & Paulo Egydio & 22 votos & \\
\hline & & & Ferreira Braga & 21 votos & \\
\hline & \multirow{3}{*}{1.892} & \multirow{3}{*}{29} & Ávaro Carvalho & 28 votos & \\
\hline & & & Ridavia Corrêa & 28 votos & \\
\hline & & & Luiz Piza & 27 votos & \\
\hline \multirow{6}{*}{$2^{\mathrm{a}}$ Legislatura } & \multirow{3}{*}{1.893} & \multirow{3}{*}{21} & Ávaro Carvalho & 20 votos & \\
\hline & & & Ridavia Corrêa & 20 votos & \\
\hline & & & Silva Vergueiro & 19 votos & \\
\hline & \multirow{3}{*}{1.894} & \multirow{3}{*}{21} & Silva Vergueiro & 14 votos & \\
\hline & & & Ridavia Corrêa & 14 votos & \\
\hline & & & Ávaro Carvalho & 12 votos & \\
\hline \multirow{11}{*}{$3^{a}$ Legislatura } & \multirow{3}{*}{1.895} & \multirow{3}{*}{34} & Ávaro Carvalho & 24 votos & \\
\hline & & & Melo Peixoto & 23 votos & \\
\hline & & & Francisco Malta & 8votos & \\
\hline & \multirow{5}{*}{1.896} & \multirow{5}{*}{25} & Ávaro Carvalho & 18 votos & \\
\hline & & & Rodrigues Guiẫo & 17 votos & \\
\hline & & & Francisco Malta & 16 votos & \\
\hline & & & Pereira de Queiroz * & 20 votos & \\
\hline & & & Arnolpho Azevedo * & 18 votos & \\
\hline & \multirow{3}{*}{1.897} & \multirow{3}{*}{24} & Rubiẫo Júnior & 14 votos & \\
\hline & & & Eugeino Egas & 13 votos & \\
\hline & & & Francisco Malta & 13 votos & \\
\hline \multirow{10}{*}{$4^{\mathrm{a}}$ Legislatura } & \multirow{3}{*}{1.898} & \multirow{3}{*}{27} & Rubiẫo Júnior & 21 votos & \\
\hline & & & Francisco Malta & 17 votos & \\
\hline & & & Pádua Salles & 16 votos & \\
\hline & \multirow{3}{*}{1.899} & \multirow{3}{*}{28} & Rubiẫo Júnior & 22 votos & \\
\hline & & & Pádua Salles & 18 votos & \\
\hline & & & Francisco Malta & 14 votos & \\
\hline & \multirow{4}{*}{1.900} & & Rubiẫo Júnior & 21 votos & \\
\hline & & 31 & Pádua Salles & 20 votos & \\
\hline & & 31 & Francisco Malta & 20 votos & \\
\hline & & & Eugenio Egas * & 22 votos & \\
\hline & & & Rúbiẫo Júnior & 24 votos & \\
\hline & 1.901 & 32 & Pádua Salles & 20 votos & \\
\hline & & & Eugeino Egas & 19 votos & \\
\hline & & & Rúbiẫo Júnior & 20 votos & \\
\hline $5^{\mathrm{a}}$ Legislatura & 1.902 & 32 & Veiga Filho & 18 votos & \\
\hline & & & Eugenio Egas & 10 votos & \\
\hline & & & Herculano de Freitas & & \\
\hline & 1.903 & & Veiga Filho & & \\
\hline & & & Antonio Mercado & & \\
\hline
\end{tabular}

* Eleitos para preenchimento de vagas abertas

Tabela 5.0 


\begin{tabular}{|c|c|c|c|c|c|}
\hline \multicolumn{6}{|c|}{ Eleição - Presidente da Comissão de Fazenda e Contas } \\
\hline Legislatura & Ano Legislativo & Total de Cédulas & Parlamentar & Votaçäo & Distrito \\
\hline \multirow{9}{*}{$6^{\mathrm{a}}$ Legislatura } & \multirow{3}{*}{1.904} & \multirow{3}{*}{33} & Herculano de Freitas & 23 votos & \\
\hline & & & Veiga Filho & 20 votos & \\
\hline & & & Aureliano de Gusmão & 20 votos & \\
\hline & \multirow{3}{*}{1.905} & \multirow{3}{*}{24} & Herculano de Freitas & 17 votos & \\
\hline & & & Veiga Filho & 15 votos & \\
\hline & & & Aureliano de Gusmão & 15 votos & \\
\hline & \multirow{3}{*}{1.906} & \multirow{3}{*}{29} & Herculano de Freitas & 20 votos & \\
\hline & & & Aureliano de Gusmẫo & 19 votos & \\
\hline & & & Veiga Filho & 18 votos & \\
\hline \multirow{15}{*}{$7^{\mathrm{a}}$ Legislatura } & \multirow{5}{*}{1.907} & \multirow{5}{*}{39} & Carlos Guimarẫes & 32 votos & $2^{\circ}$ \\
\hline & & & Pereira de Queiroz & 31 votos & $6^{\circ}$ \\
\hline & & & Veiga Filho & 31 votos & $8^{\circ}$ \\
\hline & & & Fontes Júnior & 30 votos & $3^{\circ}$ \\
\hline & & & Dario Ribeiro & 30 votos & $7^{\circ}$ \\
\hline & \multirow{5}{*}{1.908} & \multirow{5}{*}{29} & Pereira de Queiroz & 24 votos & $6^{\circ}$ \\
\hline & & & Fontes Júnior & 23 votos & $3^{\circ}$ \\
\hline & & & Antonio Lobo & 22 votos & $6^{\circ}$ \\
\hline & & & Veiga Filho & 22 votos & $8^{\circ}$ \\
\hline & & & Dario Ribeiro & 22 votos & $7^{\circ}$ \\
\hline & \multirow{5}{*}{1.909} & \multirow{5}{*}{27} & Pereira de Queiroz & 23 votos & $6^{\circ}$ \\
\hline & & & Fontes Júnior & 22 votos & $6^{\circ}$ \\
\hline & & & Antonio Lobo & 21 votos & $8^{\circ}$ \\
\hline & & & Veiga Filho & 21 votos & $3^{\circ}$ \\
\hline & & & Dario Ribeiro & 21 votos & $7^{\circ}$ \\
\hline \multirow{15}{*}{$8^{a}$ Legislatura } & \multirow{5}{*}{1.910} & \multirow{5}{*}{28} & Pereira de Queiroz & 21 votos & $6^{\circ}$ \\
\hline & & & Veiga Filho & 19 votos & $3^{\circ}$ \\
\hline & & & Antonio Lobo & 19 votos & $6^{\circ}$ \\
\hline & & & Fontes Júnior & 18 votos & $7^{\circ}$ \\
\hline & & & Sampaio Vidal * & 24 votos & $8^{\circ}$ \\
\hline & \multirow{5}{*}{1.911} & \multirow{5}{*}{26} & Pereira de Queiroz & 24 votos & $6^{\circ}$ \\
\hline & & & Fontes Júnior & 22 votos & $3^{\circ}$ \\
\hline & & & Aureliano de Gusmẫo & 20 votos & $10^{\circ}$ \\
\hline & & & Antonio Lobo & 19 votos & $6^{\circ}$ \\
\hline & & & Sampaio Vidal & 19 votos & $7^{\circ}$ \\
\hline & \multirow{5}{*}{1.912} & \multirow{5}{*}{30} & Pereira de Queiroz & 25 votos & $6^{\circ}$ \\
\hline & & & Fontes Júnior & 23 votos & $3^{\circ}$ \\
\hline & & & Aureliano de Gusmẫo & 22 votos & $10^{\circ}$ \\
\hline & & & Antonio Lobo & 22 votos & $6^{\circ}$ \\
\hline & & & Nogueira Martins & 21 votos & $4^{\circ}$ \\
\hline
\end{tabular}

*Eleitos para preenchimento de vagas abertas 


\begin{tabular}{|c|c|c|c|c|c|}
\hline \multicolumn{6}{|c|}{ Eleição - Presidente da Comissão de Fazenda e Contas } \\
\hline Legislatura & Ano Legislativo & Total de Cédulas & Parlamentar & Votaçäo & Distrito \\
\hline \multirow{17}{*}{$9^{a}$ Legislatura } & \multirow{7}{*}{1.913} & \multirow{7}{*}{26} & Pereira de Queiroz & 23 votos & $6^{\circ}$ \\
\hline & & & Fontes Júnior & 18 votos & $3^{\circ}$ \\
\hline & & & Nogueira Martins & 18 votos & $4^{\circ}$ \\
\hline & & & Francisco Sodré & 18 votos & $2^{\circ}$ \\
\hline & & & Paes de Barros & 16 votos & $6^{\circ}$ \\
\hline & & & Antonio Lobo * & 26 votos & $6^{\circ}$ \\
\hline & & & Aureliano de Gusmẫo * & 25 votos & $10^{\circ}$ \\
\hline & \multirow{5}{*}{1.914} & \multirow{5}{*}{29} & Pereira de Queiroz & 23 votos & $6^{\circ}$ \\
\hline & & & Nogueira Martins & 22 votos & $4^{\circ}$ \\
\hline & & & Antonio Lobo & 21 votos & $6^{\circ}$ \\
\hline & & & Aureliano de Gusmẫo & 21 votos & $10^{\circ}$ \\
\hline & & & Fontes Júnior & 20 votos & $3^{\circ}$ \\
\hline & \multirow{5}{*}{1.915} & \multirow{5}{*}{27} & Aureliano de Gusmẫo & 23 votos & $10^{\circ}$ \\
\hline & & & Fontes Júnior & 19 votos & $3^{\circ}$ \\
\hline & & & Dario Ribeiro & 19 votos & $7^{\circ}$ \\
\hline & & & Abelardo Cesar & 19 votos & $7^{\circ}$ \\
\hline & & & Mario Tavarez & 19 votos & $8^{\circ}$ \\
\hline \multirow{15}{*}{$10^{\mathrm{a}}$ Legislatura } & \multirow{5}{*}{1.916} & \multirow{5}{*}{29} & Mario Tavarez & 27 votos & $8^{\circ}$ \\
\hline & & & Pedro Costa & 22 votos & $2^{\circ}$ \\
\hline & & & Abelardo Cesar & 21 votos & $7^{\circ}$ \\
\hline & & & Erasmo de Assumpçẫo & 21 votos & $4^{\circ}$ \\
\hline & & & Vicente Prado & 21 votos & $9^{\circ}$ \\
\hline & \multirow{5}{*}{1.917} & \multirow{5}{*}{29} & Mario Tavarez & 24 votos & $6^{\circ}$ \\
\hline & & & Erasmo de Assumpçã̃o & 21 votos & $4^{\circ}$ \\
\hline & & & Pedro Costa & 20 votos & $6^{\circ}$ \\
\hline & & & Abelardo Cesar & 20 votos & $10^{\circ}$ \\
\hline & & & Dario Ribeiro & 18 votos & $3^{\circ}$ \\
\hline & \multirow{5}{*}{1.918} & \multirow{5}{*}{26} & Mario Tavarez & 22 votos & $10^{\circ}$ \\
\hline & & & Abelardo Cesar & 20 votos & $3^{\circ}$ \\
\hline & & & Erasmo de Assumpçẫo & 19 votos & $7^{\circ}$ \\
\hline & & & Dario Ribeiro & 18 votos & $7^{\circ}$ \\
\hline & & & José Roberto & 18 votos & $8^{\circ}$ \\
\hline \multirow{10}{*}{$11^{\mathrm{a}}$ Legislatura } & \multirow{5}{*}{1.919} & \multirow{5}{*}{31} & Mario Tavarez & 27 votos & $6^{\circ}$ \\
\hline & & & Erasmo de Assumpçẫo & 23 votos & $7^{\circ}$ \\
\hline & & & Azevedo Júnior & 23 votos & $1^{\circ}$ \\
\hline & & & Júlio Prestes & 23 votos & $4^{\circ}$ \\
\hline & & & Abelardo Cesar & 23 votos & $7^{\circ}$ \\
\hline & \multirow{5}{*}{1.920} & \multirow{5}{*}{26} & Mario Tavarez & 23 votos & $8^{\circ}$ \\
\hline & & & Erasmo de Assumpçẫo & 19 votos & $4^{\circ}$ \\
\hline & & & Azevedo Júnior & 18 votos & $1^{\circ}$ \\
\hline & & & Júlio Prestes & 17 votos & $4^{\circ}$ \\
\hline & & & Abelardo Cesar & 17 votos & $7^{\circ}$ \\
\hline
\end{tabular}

*Eleitos para preenchimento de vagas abertas 
A cada sessão legislativa (anualmente), votava-se para a formação de uma nova Comissão. Do início da República até às eleições de 1906, ainda sem o efeito da Reforma Constitucional de 1905, a Comissão de Fazenda era composta por três parlamentares de um total de 40 deputados. Já a partir da sessão legislativa de 1907, agora sob efeito da nova lei, cinco membros comporiam a Comissão, numa casa com 50 deputados eleitos. Essa situação vai se repetir até os anos 20 do século XX.

Tomemos então a 1ª Legislatura (1891-1892) como objeto de análise, exemplificando, com isto, a forma e o método que serão adotados para o trato e informações das que seguiram.

Comandaram a Comissão de Fazenda e Contas no ano de 1891 os deputados Cesário Bastos, de Santos, Paulo Egydio, da capital, e Ferreira Braga, do município de Sorocaba ${ }^{7}$. Num parlamento onde estavam aptos a votar 40 deputados, pouco mais de 50\% (23) depositaram suas cédulas para a escolha dos membros da Comissão. Como a escolha dava-se por escrutínio secreto, em listas que variavam de três a cinco nomes, conforme o período, ficava claro que acordos entre um grupo significativo de deputados acabassem por eleger parlamentares previamente escolhidos. O confronto do número de cédulas depositadas com o número de votos recebidos pelos vencedores escancara tal afirmação, ao mesmo tempo expõe, para um olhar atento, algumas estratégias que talvez buscassem confundir os tratados legislativos, desejando deixar para a posteridade registros de um exercício democrático naturalmente sem vício ou artimanha alguma. Cesário Bastos recebeu 23 votos das 23 cédulas depositadas, enquanto Paulo Egydio recebeu 22 votos e Ferreira Braga, 21. Ao final da apuração raramente não despontava um quarto candidato, nunca com mais de 1 voto recebido, numa sensação enganosa de rebeldia política ou interesse de demonstrar algum grau legítimo de competição.

No que diz respeito ao período de 1891 a 1906, compreendendo o conjunto que vai da $1^{\text {a }}$. à $6^{\text {a }}$. Legislaturas, tal situação não sofrera transformação. Digno de nota, porém, com o decorrer das outras cinco legislaturas (2a, 3a, 4a, 5a, e 6a), a diferença entre o número de cédulas depositadas em relação aos votos recebidos pelos eleitos passara a ser maior, mais cédulas depositadas contra um número menor de votos recebidos. A estratégia, no entanto, continuava a mesma, ou seja, a diferença entre os candidatos eleitos era sempre diminuta e também lá aparecia um último pretendente a receber o mesmo 1 voto.

\footnotetext{
7 Obtivemos informações acerca da origem dos parlamentares apenas para $1^{\text {a }}$ legislatura, que vai de 1891 até 1892. Depois, até 1906, encontramos dificuldades
} 
Da $7^{\text {a }}$ Legislatura até a 11 , compreendendo o período de 1907 a 1921, agora sob as luzes de seus distritos de origem, as estratégias foram exatamente as mesmas, com a diferença de que agora se elegiam cinco deputados para a referida Comissão. Não descartando, porém, que durante as 11 legislaturas estudadas, e dados sobretudo a dissidência e rompimentos entre os parlamentares do Partido Republicano Paulista, em uma outra ocasião a oposição realmente conseguiu emplacar alguns de seus quadros. É difícil fazer tal afirmação ainda que com ressalvas. Acredito que só mesmo agregando um número bem maior de fontes e informações a esse quadro chegaríamos a uma precisão maior acerca dessas conjecturas.

Para o período de 1907 a 1920, com os Distritos Eleitorais funcionando com circunscrições de eleitores, foi possível traçar um perfil da origem dos parlamentares que compuseram a Comissão de Fazenda e Contas. Salta aos olhos a hegemonia dos deputados do 6o Distrito Eleitoral, cuja sede era Campinas e contava ainda com municípios da importância de Jundiaí e Bragança Paulista. Nesses quatorze anos das cinco últimas legislaturas escolhidas, presidiram nada mais nada menos do que nove vezes, sendo sete delas consecutivas (1908 a 1914). Na maioria destas, emplacaram não apenas o presidente, mas pelo menos mais um parlamentar do mesmo distrito. As demais Comissões de Fazenda tiveram à frente de sua direção parlamentares do 2o distrito (1907), com sede em Taubaté, no Vale do Paraíba, do 10o distrito, duas vezes (1915-1918), cuja sede era o município de Ribeirão Preto, do $4^{\circ}$, também por duas vezes (916-1920), com sede em Limeira e ladeado pela força de Piracicaba. Importância significativa teve a representação do 7o, 3o e 4o distritos, com sedes em Mogi Mirim, Pindamonhangaba e Itu, respectivamente, estando o 7o representado em dez Comissões (1907, 1908, 1909, 1910, 1911, 1915, 1916, 1918, 1919 e 1920). Em alguns anos com mais de um representante, o $3^{\circ}$ distrito também esteve representado em 11 Comissões $\left(1907,1908,1909,1810,1911,1912\right.$, 1913, 1914, 1915, 1917 e 1918) e, por fim, o $4^{\circ}$ distrito, que em sete oportunidades elegeu representantes (1912, 1913, 1914, 1916, 1917, 1919 e 1920). A lista se encerra com o registro de duas participações do 1o distrito (Capital), nos anos de 1919 e 1920, e com o $9^{\circ}$ distrito, com sede em São Carlos apenas na Comissão eleita em 1916. Lembremos que tais dados referem-se ao período escolhido, de 1907 a 1920.

Faltaram-nos dados biográficos sobre os parlamentares que ocuparam a Comissão de Fazenda e Contas no período de 1891 a 1906, o que nos impossibilitou uma análise mais completa e precisa acerca da origem desses políticos. Nossa intenção era, com esses dados biográficos, somados aos dados e informações para os anos de 1907-1920, tentar fechar um quadro mais completo sobre esse jogo de poder pela disputa de tão importante Comissão.

No entanto, ao dirigirmos maior atenção às práticas parlamentares no encaminhamento das emendas aos orçamentos, em cada sessão legislativa, no período de 1890 a 1920, ou seja, perfazen- 
do um número importante de 30 orçamentos, outras situações interessantes vão sendo desveladas.

Ainda com nossa atenção no funcionamento da Comissão de Fazenda e Contas, podemos aceitar a idéia de que aos acordos quando da eleição de seus dirigentes atrelava-se também o modo de agir desses parlamentares no encaminhamento e destino dos recursos orçamentários, num primeiro momento, e a mesma prática quando era chegado o momento de se apresentar emendas.

Entre a $1^{\text {a }}$ e a $2^{\text {a }}$ Legislaturas (1891 a 1904), por exemplo, praticamente $100 \%$ das emendas ao orçamento foram destinadas a todas as zonas simultaneamente. No ano de 1891, a prática adotada não apenas fora esta, como todos os três parlamentares da Comissão assinaram as mesmas 20 emendas apresentadas, encaminhando-as para o mesmo destino, ou seja, a um conjunto de zonas sem a especificação ${ }^{8}$.

Para os anos de 1892, 1893 e 1894, apenas meia dúzia de emendas entre o número total apresentado, tiveram destinos próprios, como foi o caso de três emendas para a $1^{\mathrm{a}}$ zona (Capital), respectivamente, uma em 1892 e duas em 1894; duas emendas para a $3^{\text {a }}$ zona (Central), ambas em 1893; e uma emenda para a $10^{\text {a }}$ zona (Litoral Sul), também no ano de 1893. Dessas seis emendas com destino identificado, todas foram aprovadas. Tomando-se as catorze emendas restantes, ainda apresentadas pelos membros da Comissão de Fazenda, e outras trinta e cinco do conjunto dos demais parlamentares em atividade, o ano 1891 encerrou seu exercício como um total de 49 emendas (6 para destinos identificados e 43 para conjunto de zonas sem especificação).

Esse estudo, como se vê, preocupou-se também em distinguir do conjunto total de emendas apresentadas, não apenas para o ano de 1891 como para todo o período escolhido (1890-1920), número e percentual de emendas aprovadas e volume de recursos que coube em cada situação. Em comentários finais para o ano de 1891 tivemos 41 emendas, ou seja, 83,7\%, efetivamente aprovadas, arrebatando expressivos 98,2\% do total do montante inicial dos recursos destinados ao orçamento. Daqui, coube ao conjunto das zonas não especificadas $90,9 \%$ do total de recursos, e outros 9,1\% para a zona da Capital. As outras duas zonas contempladas foram a Central e o Litoral Sul, que receberam emendas de caráter administrativo, que não envolveriam recursos em moeda.

No intervalo que vai do ano de 1895 a 1906, quando a disputa eleitoral ainda se dava pelos candidatos buscando votos em todo o território paulista, as ações dos deputados da Comissão de

\footnotetext{
${ }^{8}$ É importante ressaltar que optamos por "criar" tanto uma zona número 11 para 1891 a 1906, como também um $11^{\circ}$ distrito para 1907 a 1920 cujo objetivo fora dar "destino" às emendas todas as vezes em que um determinado número delas era encaminhado para um conjunto de zonas e distritos sem a especificação ou identificação de cada um(a). Também digno de destaque foi a opção em considerar nos casos quando uma mesma emenda era assinada por vários deputados e também para diferentes destinos, consideramos cada deputado como autor dessa mesma emenda o que faz 1 ser considerado 10 caso fosse essa a quantia de deputados assinantes-autores.
} 
Fazenda alternavam-se conforme decorriam sessões legislativas. A sessão legislativa de 1895 ficaria marcada pela apresentação de 20 outras emendas, desta vez capitaneadas unicamente pelo presidente da Comissão deputado Álvaro de Carvalho, que destinou 5 emendas para municípios da 1a. zona, 4 para os da $2^{\text {a }}$. zona, 5 para os da $3^{\text {a }}$. zona, 1 para os da $4^{\text {a }}$ zona, 3 para os da $10^{\text {a }}$ zona e 2 para os da "zona11" (conjunto de zonas não especificadas). Isso significa que os demais parlamentares investidos da função de dirigentes da mesma Comissão não apresentaram emenda alguma. Até o ano de 1898 situações como esta contribuíram para uma reduzida participação da Comissão no total de emendas apresentadas pelo conjunto da casa numa distribuição que não mais favorecia ao conjunto de zonas não especificadas e sim uma divisão bem mais equilibrada com as demais regiões.

A prática de destinar grande volume de emendas, de forma simultânea, para o conjunto das zonas não especificadas (zona11) retorna com bastante força no ano de 1899 e assim permanece até o final da $6^{\text {a }}$. Legislatura, no ano de 1906. Os números apurados para todo o período de 1891 a 1906 (1a a 6a Legislaturas) confirmam essa seqüência de afirmações, no que diz respeito unicamente ao trabalho dos parlamentares dirigentes da Comissão de Fazenda, já que são os seguintes: do total de 655 emendas apresentadas (100\%), 488 (74,5\%) seguiram para o conjunto de zonas não especificadas (a qual denominamos zona 11) e 167 emendas (25,5\%) para conjuntos de municípios incorporados às zonas identificadas no corpo do orçamento. Desses 25,5\% a 1ª zona (Capital Paulista e seu entorno) ficou com 5,8\%, a 2a zona (Vale do Paraíba e Litoral Norte) com exatos 5\%, e à 3ª zona (Central) couberam 6\% das emendas. Já a 4a zona (Mogiana) obteve 3,1\% do total, a 5a (Baixa Paulista) ficou com 0,6\%, a $6^{\mathrm{a}}$ zona (Araraquarense) com 0,9\%, a 8 a zona (Alta Sorocabana) com $0,2 \%$ e a 10a zona (Santos e Litoral Sul) com 4\%. Nenhuma emenda fora destinada às zonas 7a e 9a, a saber a Noroeste/Alta Paulista e a Baixa Sorocabana, esta última com problemas de crescimento econômico até os dias de hoje.

Se computarmos o restante das emendas apresentadas, agora pelo conjunto de todos os parlamentares, para o mesmo período de 1891 a 1906, para esta mesma zona um índice incrivelmente baixo de $0,3 \%$ do total fora destinado à zona da Baixa Sorocabana. A menos que estivesse contemplada em meio às emendas destinadas às zonas sem especificação, fato difícil de crer, tais informações já davam forma a alguns aspectos da histórica pobreza dessa região.

Rastreado o trabalho da Comissão de Fazenda e Contas também para o período de 1907 a 1920, alcançando da 7 ${ }^{\text {a }}$ à $11^{\text {a }}$. Legislaturas, com o território paulista então dividido em dez distritos eleitorais e com 50 deputados eleitos, os números carregam algumas informações, fechando todo o período dessa pesquisa. Primeiramente, é possível afirmar que a prática de destinar o maior volume de emendas ao grupo de distritos sem especificação (não mais considerando as regiões sob o ponto de vista das zonas), foi igualmente mantida, sobretudo se considerarmos os anos de 1907 a 1912, ou 
seja, $7^{\text {a }}$. e $8^{\text {a }}$. Legislaturas, com $59 \%$ e $37 \%$, respectivamente. Alguns fatos, contudo, modificam sensivelmente as demais situações.

É muito provável que uma vez identificados, de maneira mais acentuada, com seus redutos de origem (os distritos eleitorais) e vendo-se claramente atrelados aos mesmos, membros da Comissão de Fazenda e Contas passaram a destinar grande número de emendas a um mesmo distrito eleitoral, obviamente predominando suas áreas de representação. Exemplos claros aconteceram seguidamente, num movimento que alternava ora como os maiores beneficiados o $1^{\circ}$, o $2^{\circ}$ e o $3^{\circ}$ distritos eleitorais, ora do $4^{\circ}$ ao $10^{\circ}$, em períodos distintos.

Três outros aspectos devem ser notados em toda essa movimentação. O primeiro, eu diria serem as emendas destinadas ao primeiro distrito eleitoral, com sede na capital paulista. Foi um distrito que durante longas treze sessões legislativas, o que equivale às discussões do mesmo número de orçamentos somente em duas ocasiões (1919 e 1920), teve representantes na Comissão de Fazenda e Contas. Isto, no entanto, não impediu de estar entre os maiores beneficiados pela mesma Comissão. O fato é que interessados ou não na representação de seu distrito eleitoral em comissão de tal relevância, pairava no ar (discussões, proposituras, dados, etc.) que seus líderes estavam seguros quanto ao atendimento de suas demandas, muito provavelmente resultado de acordos firmados entre seus pares.

Um segundo aspecto a ressaltar é precisamente o que acontecia com aqueles membros da Comissão de Fazenda e Contas, representantes dos $2^{\circ}$ e $3^{\circ}$ distritos eleitorais, herdeiros das áreas e municípios da antiga zona do Vale do Paraíba e Litoral Norte. Esses parlamentares representavam um ou outro desses distritos, mas acabavam por destinar emendas para ambos, dando a impressão de ainda visualizarem o grande Vale como uma única zona, uma única região. A divisão distrital, assim, não surgiu como obstáculo ou sério empecilho a ponto de dificultar ou mesmo inviabilizar relações e acordos históricos entre seus líderes locais e destes com seus representantes no parlamento. Os dados referentes à aprovação dessas emendas (apêndices) reforçam essas afirmações.

Por fim, a partir de 1907 e reforçada em 1913, por uma reorganização nas práticas para elaboração do orçamento, o período de 1907 a 1920 e os deputados do parlamento paulista testemunharão a ampliação dos poderes da Comissão de Fazenda, traduzida sobretudo na liberdade de manter, prejudicar ou substituir emendas dos demais parlamentares, com a constante justificativa de se adequar o volume de despesas com o de receitas, mantendo o equilíbrio das contas públicas. Como toda ação resultante de uma situação de poder, a Comissão de Fazenda não ficou livre da pressão de seus pares, sempre na direção de uma argumentação legal que considerava que uma vez orçada a receita e fixada a despesa, por lei, para o corrente exercício, nada poderia obstaculizar as verbas destinadas a obras já consignadas. 
Antes de darmos continuidade ao trabalho com alguns outros dados acerca do comportamento dos parlamentares paulistas em relação à luta pelos recursos públicos do orçamento estadual e de suas manifestações em defesa de suas zonas/distritos de origem, uma pausa para rápidas considerações sobre o gráfico que segue.

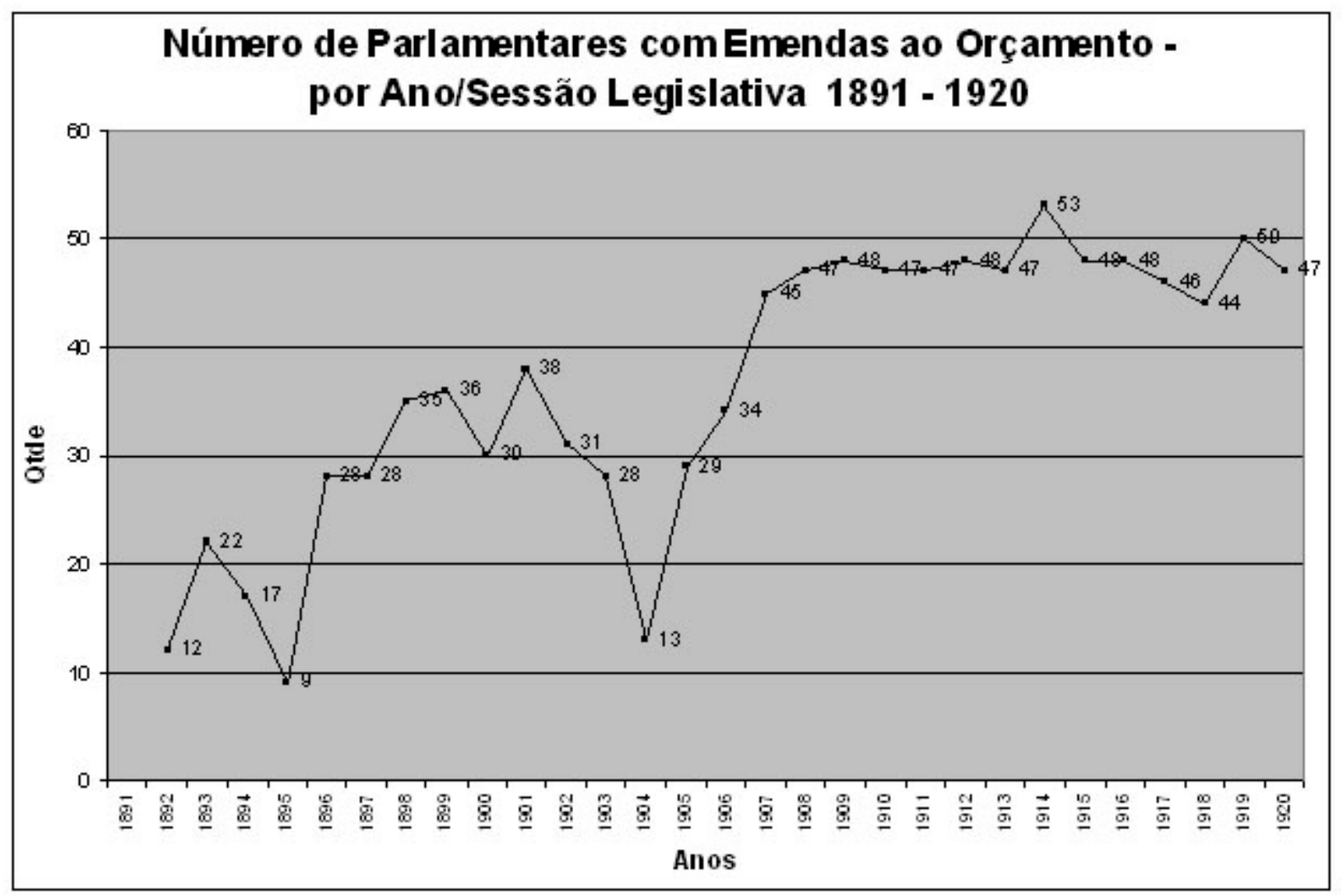

Como se vê, trata-se de ferramenta que facilita a visualização das informações aí contidas. Entre essas informações ressalto uma considerável discrepância no número de deputados que apresentaram emendas ao orçamento estadual, independentemente de elas terem sido ou não aprovadas, entre os períodos de 1891 a 1906 e 1907 a 1920. Pesou mais o engajamento direto do parlamentar, num trabalho que os debates parlamentares desvelaram como um corpo a corpo firme e freqüente nesses agitados períodos. De 1891 a 1906, 40 deputados eram eleitos para o parlamento paulista. Já de 1907 a 1920, esse número subiu para 50, como já dissemos, devido à reforma constitucional de 1905. No primeiro período constatamos uma média de atuação que girou em torno de $65 \%$ do total dos deputados. Desse número, chamam a atenção anos como os de 1892, 1895 e 1904, com números bastante pequenos de participações, ou seja, 12 parlamentares (30\%) para o ano de 1892, 9 parlamentares $(22,5 \%)$ no ano de 1895 e 13 deputados no ano de 1904 . Nos demais anos dessa primeira etapa os índices subiram significativamente, chegando a expressivos 95\% para o ano de 1901, 90\% para 1898 e 87,5\% para 1899.

Para o $2^{\circ}$ período escolhido (1907-1920) a média passou para aproximadamente $95 \%$. Somente no ano de 1918 o índice não alcançara a faixa dos $90 \%$ ou mais, ficando porém muito perto, com $88 \%$. 
Tais informações reforçam a constatação de que quando entrava na pauta da mesa do Congresso a questão orçamentária, das primeiras discussões, ainda como projeto de lei, até sua aprovação final, transformava-se em questão da maior relevância para todos os parlamentares, e de grande ebulição para o Congresso em geral. No que diz respeito aos ausentes desse processo, principalmente no período de 1891-1906, indicaria as constantes faltas e afastamentos desses parlamentares, comumente registrados nos Anais da Câmara dos Deputados de São Paulo, tendo como uma das justificativas a hegemonia de grupos internos que obstaculizavam a participação de facções em conflito, e não descartaria totalmente, apesar das incertezas, a dificuldade desses políticos de se identificarem como representantes de longínquas zonas por todo o território paulista, onde buscavam votos, inibindo contrapartidas que compensassem tal esforço dentro do parlamento.

Para os anos de 1907 a 1920, quando praticamente todos os deputados participaram desse verdadeiro embate, questões como possíveis períodos de rápida melhoria da economia do país e conseqüentemente das finanças do Estado de São Paulo podem ter aguçado o apetite dos parlamentares por recursos do orçamento. Não descartaria ainda que o conjunto de parlamentares tenha vislumbrado no poder e prerrogativas acumuladas pela Comissão de Fazenda e Contas, principalmente quando lançava mão de Emendas Substitutivas, prejudicando as originais dos demais políticos, um alerta para a necessidade de estar permanentemente vigilante, criando e reforçando estratégias para que se mantivessem "vivos" nesse processo.

Por fim, para que compreendamos ainda um pouco mais de como se davam as relações e práticas parlamentares no decorrer dessas sessões legislativas, como foco para a disputa pelos recursos do orçamento público, e que refletiram em ganhos e perdas para as zonas ou distritos eleitorais, uma série de outros dados foram trabalhados e alguns desses escolhidos.

Para isso confrontaremos números acerca da quantidade de emendas apresentadas e destinadas aos diferentes municípios que constituíam as dez zonas do Estado de São Paulo, demarcadas, lembremos, segundo o traçado das ferrovias. À quantidade de emendas retratadas nas tabelas abaixo estará atrelado o montante dos recursos a elas destinados e, no conjunto dessas duas variáveis, quantas acabavam aprovadas, com quais valores definidos e em benefício, ou prejuízo, de quais zonas, para os anos de 1891 a 1906, e de quais distritos eleitorais, para o período de 1907 a 1920.

\section{Examinados os trinta volumes dos Anais da Câmara dos Deputados do Estado de São} Paulo, não encontrei registros que definam ou dêem pistas dos mecanismos que faziam funcionar a prática de se agrupar emendas ao orçamento estadual e ao mesmo tempo destiná-las a um conjunto de municípios ou vilas que constituíam as diferentes zonas demarcadas em terras paulistas, e fartamente citadas neste trabalho. A existência desse fenômeno nos levou, como dissemos, a criar uma virtual zona 11 (e não $11^{\mathrm{a}}$ zona) com vistas a organizar esse amontoado de números e informações, 
transformando-a em item que aglutinaria esses dados.

Porém, no meu entender, o maior prejuízo que possa ter resultado desse entrave fora exatamente o surgimento de um problema teórico a ser discutido e buscada uma chance para sua solução. Infelizmente, não alcancei esse último objetivo. Com isto, algumas indagações permanecerão na reta final deste trabalho, quem sabe à espera de pesquisadores mais tarimbados.

Como disse, o exame atento das fontes não revelou o fato de se destinar emendas para diversas zonas e regiões sem especificação significaria que todas as dez zonas seriam contempladas naquele momento, ou apenas algumas delas. Também não ficou claro quando tais ações aconteceram juntamente com o envio de outras emendas destinadas às zonas determinadas, se estas zonas estariam atendidas tanto em uma como noutra situação, ou tratava-se de medidas excludentes. Se optássemos por uma ou por outra situação, discrepância na conclusão de idéias e no fechamento adequado de números, certamente aconteceria.

Sendo assim, achei por mais correto, do ponto de vista da qualificação e quantificação das medidas, optar pela distinção entre as duas situações. Nossa base para tal decisão está centrada em textos que reforçaram e distinguem a realidade econômica das zonas paulistas, considerando o período escolhido para este trabalho.

Voltemos, então, a mais alguns números e situações. Para os anos de 1891 a 1906, fecharam-se os números da seguinte forma: a denominada zona 11, no final desse período acabou arrebatando $43 \%$ do total das emendas aprovadas e 59\% dos recursos, colocando-se numa virtual primeira colocação entre as demais zonas ${ }^{9}$. A seguir tivemos a $2^{\mathrm{a}}$ zona (Vale do Paraíba e Litoral Norte). A esta couberam 19,5\% das emendas aprovadas e 19,4\% do total de recursos. Seguiram-se a esta a $3^{\text {a }}$ zona (Central), a $1^{\mathrm{a}}$ zona (Capital) e a $4^{\mathrm{a}}$ zona (Mogiana), com 10,3\% das emendas aprovadas e $8,4 \%$ dos recursos, $9,8 \%$ das emendas com $9,5 \%$ dos recursos e $6,7 \%$ das emendas e $4,7 \%$ dos recursos, respectivamente. No time intermediário vieram a $5^{\text {a }}$ zona (Baixa Paulista), com 3,4\% do total das emendas aprovadas para o período de 1891 a 1906 e 2,8\% dos recursos, a $10^{\mathrm{a}}$ zona (Santos e Litoral Sul) com 3,7\% das emendas e 2,6\% dos recursos, a $8^{a}$ zona (Alta Sorocabana), com seus $2,75 \%$ das emendas aprovadas e 2,2\% dos recursos. Nas três últimas porções estão postas a $6^{\mathrm{a}}$ zona (Araraquarense), com 22\% das emendas aprovadas e 2\% dos recursos, a 9a zona (Baixa Sorocabana), com 1,3\% das emendas efetivamente aprovadas e 1,4\% dos recursos. Por último, para a $7^{\mathrm{a}}$ zona nem emendas nem quaisquer recursos foram destinados. Em princípio julgo que tal situação fora

\footnotetext{
9 Provavelmente a soma das porcentagens não atingiu os $100 \%$, sobretudo devido a inúmeros cálculos e fórmulas empregados quando da passagem de dados da fonte consultada (Anais do Congresso Paulista) para as dezenas de tabelas que compõem este trabalho. No entanto, o caráter da proporcionalidade e equivalência foi preservado. A opção pelo arredondamento das cifras e porcentagens, com certeza, terá contribuído para essas inofensivas imprecisões
} 
assim resolvida por se tratar, nesse período (1891-1906), de uma zona que ainda dava seus primeiros passos rumo à constituição de vilas e municípios, e reconhecida pela bibliografia como pioneira, com imensas áreas a desbravar.

Enquanto o plenário votava os projetos de lei e posteriormente as peças orçamentárias, dando-lhes um determinado conjunto de números e valores, ao final da sessão legislativa a Comissão de Fazenda e Contas tecia suas próprias propostas, que acabavam por prevalecer, inclusive com os votos daqueles mesmos parlamentares que pouco antes ainda defendiam com afinco seus pleitos junto à mesma Comissão.

Entre uma situação e outra, as coisas mudavam bastante. Observando os números finais para o período de 1907 a 1920, a situação ficou da seguinte forma, ainda sem as emendas substitutivas: para o 1o distrito eleitoral, com sede na capital do Estado, 12,8\% das emendas apresentadas e expressivos $30,1 \%$ do total dos recursos destinados ao orçamento colocavam-no num honroso primeiro lugar. Uma vez votada a proposta da Comissão de Fazenda, esses números passaram para $16,7 \%$ e $21,8 \%$, respectivamente. Ou seja, se do lado da quantidade de emendas houve um ganho da ordem de $4 \%$, no que dizia respeito ao volume de recursos efetivamente aprovados, houve uma queda de exatos $8,3 \%$.

E assim continuou funcionando a Câmara dos Deputados de São Paulo, ou melhor, todo o Congresso paulista, até os anos 20, quando finda o período escolhido para esta pesquisa. Para os demais distritos eleitorais, a situação se desenhara da seguinte forma: o $2^{\circ}$ distrito, com sede em Taubaté, no Vale do Paraíba, partiu dos $13 \%$ do número total de emendas apresentadas e 7,3\% dos recursos destinados para $9,4 \%$ do total de emendas e reduzidos $4,1 \%$ dos recursos. $\mathrm{O} 3^{\circ}$ distrito eleitoral, também na região do Vale, com sede no município de Pindamonhangaba, passou exatamente pela mesma situação, ou seja, encerrou o período de 1890 a 1920 primeiramente com $11 \%$ das emendas apresentadas e 7,6\% dos recursos disponíveis, para chegar, por meio das emendas substitutivas, a 11,3\% do número de emendas e 3,8\% dos recursos destinados ao orçamento.

A mesma situação se repetiu com o $4^{\circ}$ distrito, com sede em Itu, que teve porcentagem dos recursos reduzida de $8 \%$ para 2,5\%; com o $5^{\circ}$ distrito, com sede em Botucatu, de 9,5\% para 3,5\%; com o $6^{\circ}$ distrito, com sede em Campinas, com uma redução mínima de 0,2\% - tinha 3,6\% e ficou com 3,4\%; com o $7^{\circ}$ distrito, sede em Mogi Mirim; com o $8^{\circ}$, sede em Limeira; com o $9^{\circ}$, com sede em São Carlos; e também o $10^{\circ}$, que tinha o município de Ribeirão Preto como sede. Entre o maior ou o menor grau de perda, digno de nota, ganhou o $6^{\circ}$ distrito eleitoral, que viu o montante de seus recursos reduzir-se a ínfimos 0,2\%. Lembremos que, páginas acima, quando estudávamos o domínio da Comissão de Fazenda e Contas por parlamentares e suas zonas ou distritos de origem, a hegemonia dos deputados do $6^{\circ}$ distrito eleitoral em extenso período e grande número de sessões 
legislativas despontara claramente.

Por fim, quero lembrar que também para a análise do período de 1907 a 1890 a Comissão de Fazenda e Contas manteve a prática de destinar vultosas fatias dos recursos orçamentários para conjuntos de distritos agrupados, porém não especificados.

Com o volume de material e dados levantados para este trabalho, observa-se que inúmeras são ainda as variáveis a serem exploradas, sobretudo para o estudo de aspectos da história econômica num período tão fértil da História do Brasil. Bastará a algum interessado uma passada rápida de olhos no conjunto de dados e informações que constam nos apêndices, resumidamente em página de rosto, para tais considerações acabarem por confirmadas. 
Tabela 5.1

ழூ

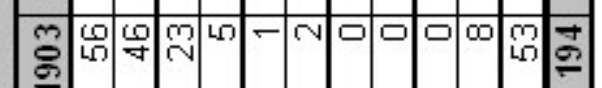

๘

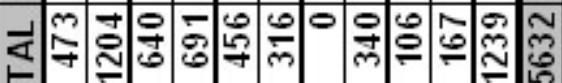

요

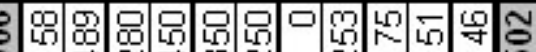

귀ำ

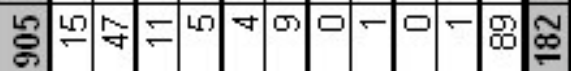

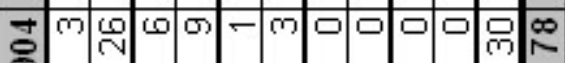

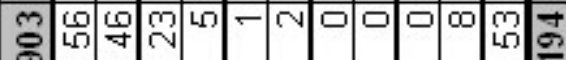

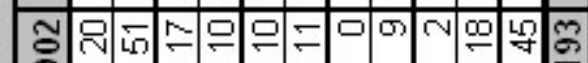

-

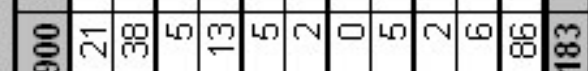

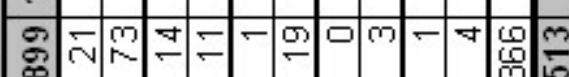

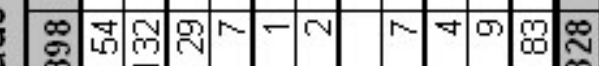

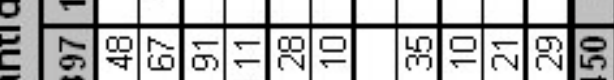

ชั

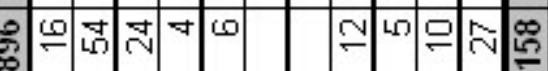

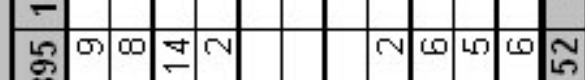

ஓ

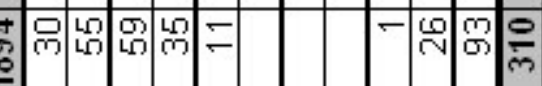

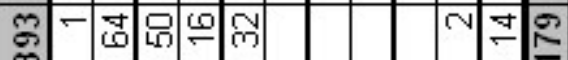

里

त्रेल-

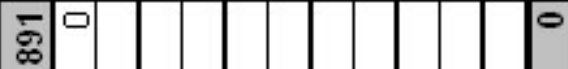

政

ब 0

总 砳

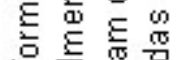

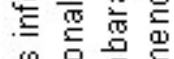

(i) 응

范

$\stackrel{a}{2}$ 듬

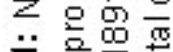

क क

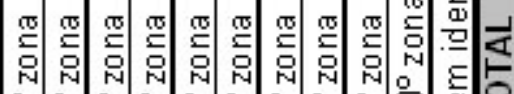

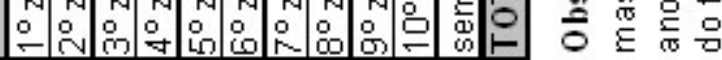




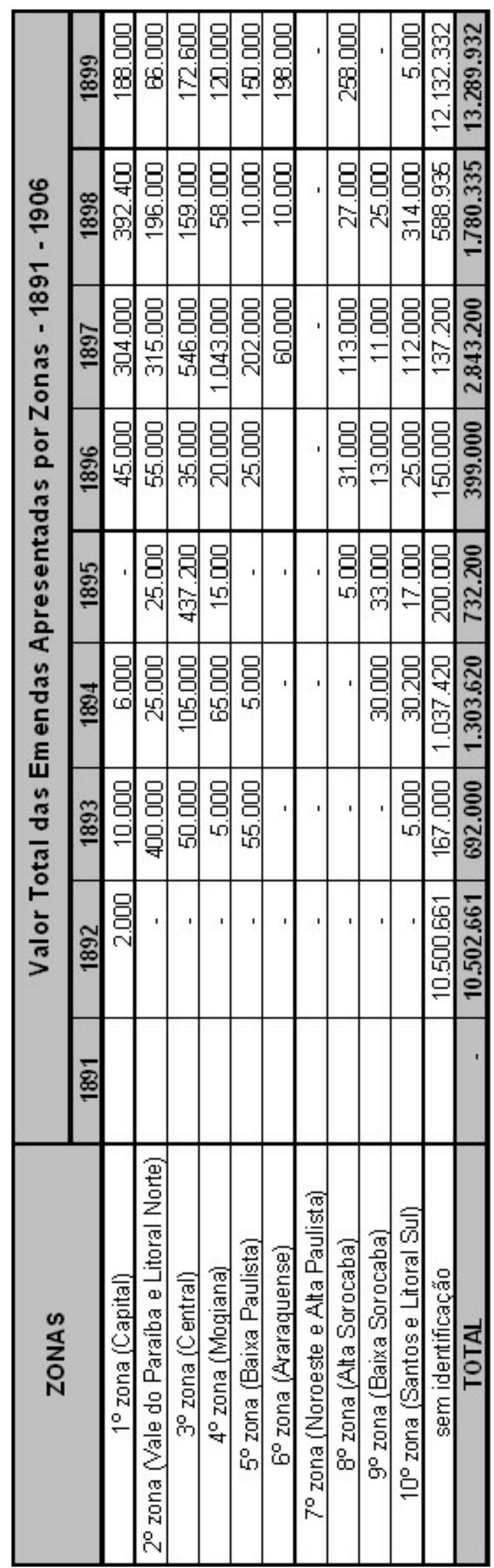

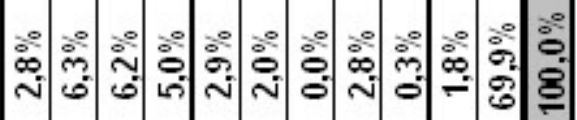

Tabela 5.2

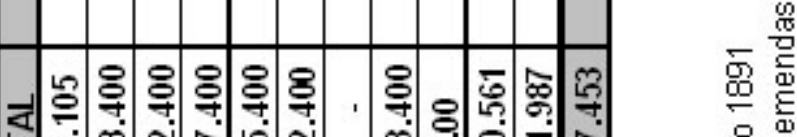

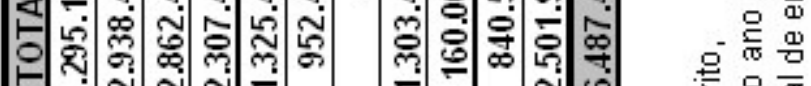

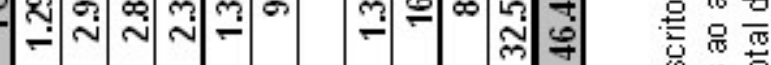

के क⿺

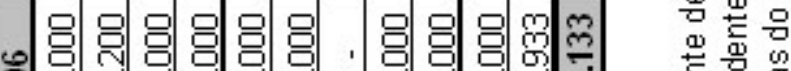

क्ञ

总 $\frac{\mathrm{O}}{\mathrm{g}}$

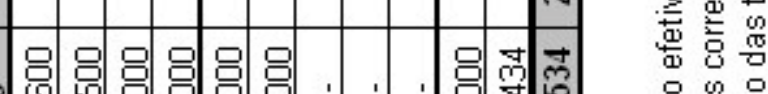

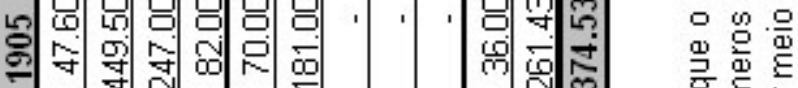

高完

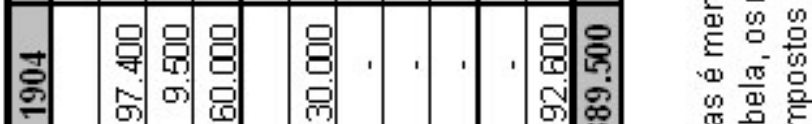

娄 要

要通

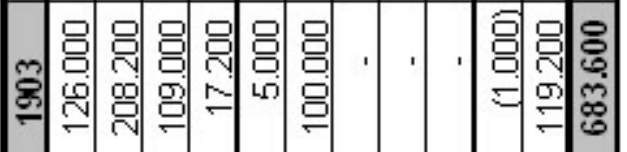

哯

㟧恕

范

톤 음

은 음

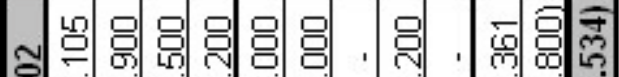

$\stackrel{\mathbb{T}}{二}$

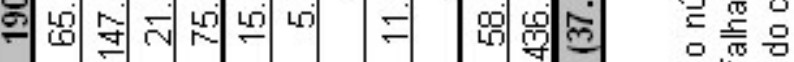

을 윰

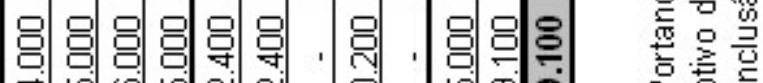

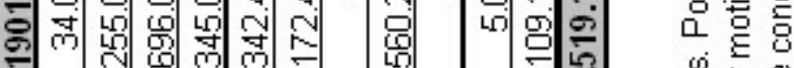

क

产哭

产

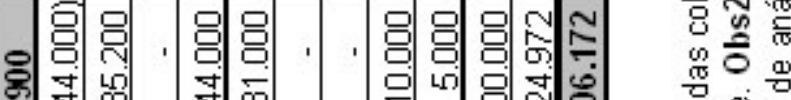

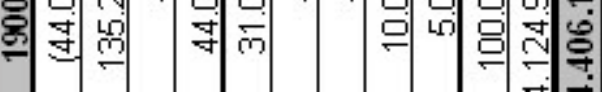

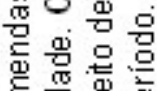

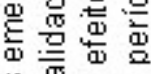

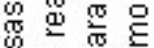

制

骂号 压

言寻

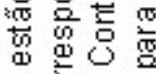

号总要

总高总

究 兽 离

它结离䎡

空言

要递妿

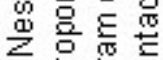

는

商要焉产 
Tabela 5.3

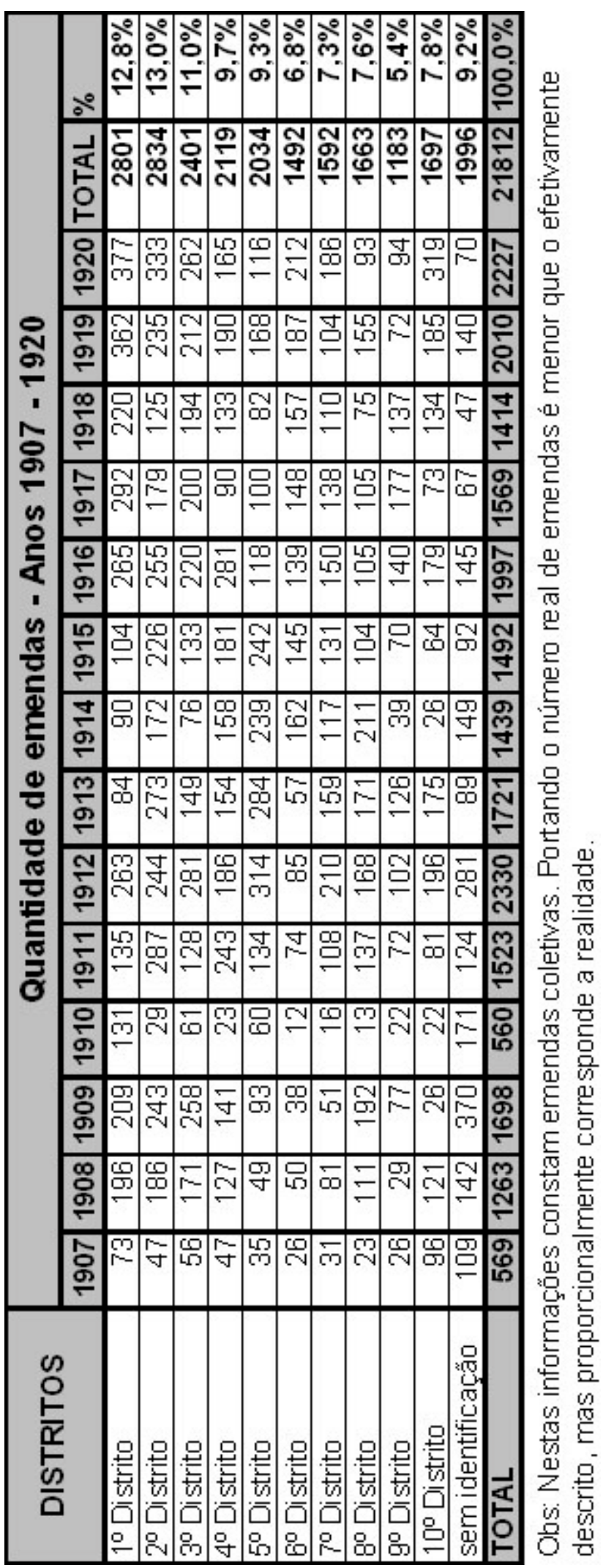


Tabela 5.4

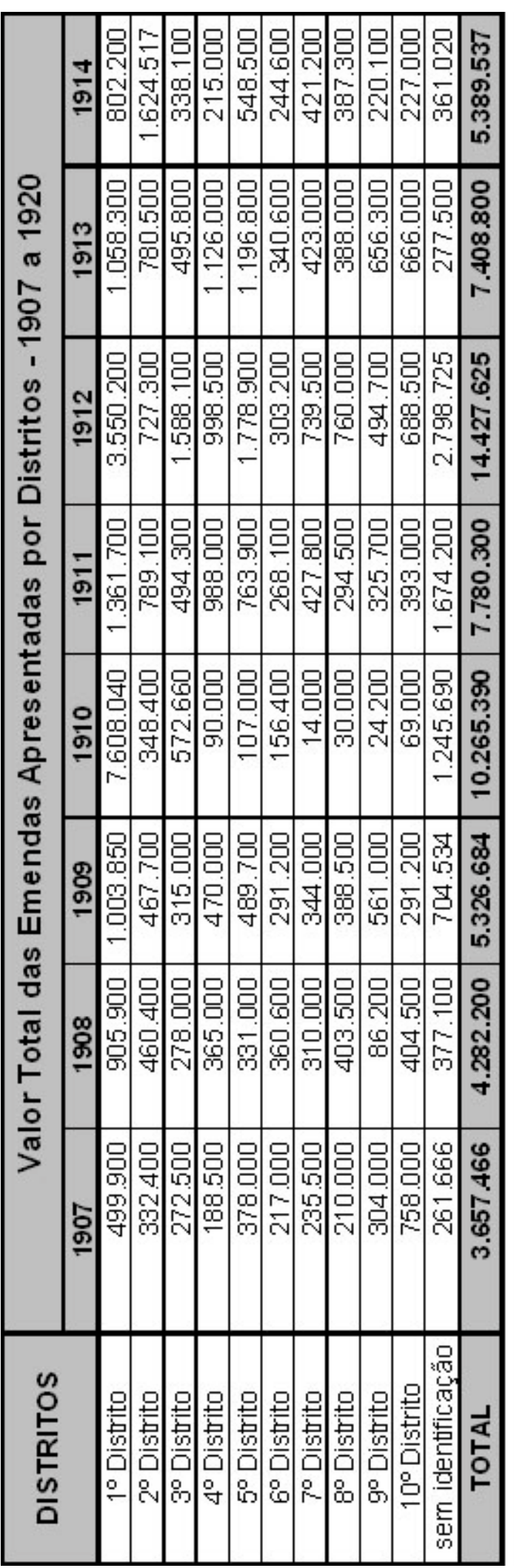

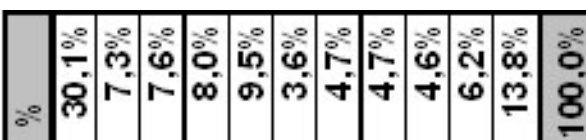

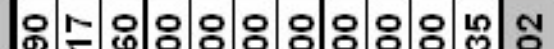
-

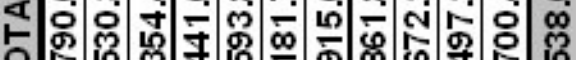
○狩 -

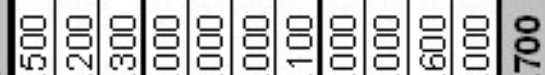
이 \% - 00 N

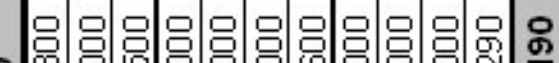
क

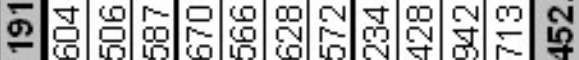
क्ष

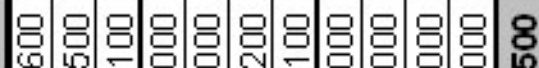
$\infty \infty 0$

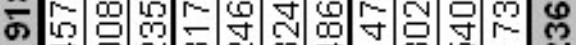

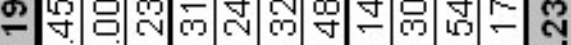

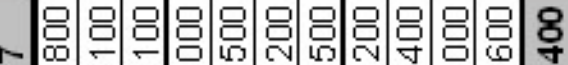
क - $\omega$ in $N$ 寸 10

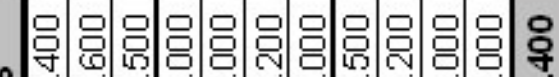

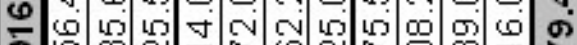

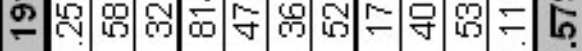
ci

隐号号号号号号号号号号号용 ю 는

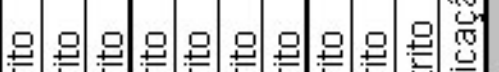

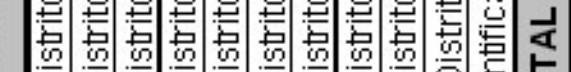

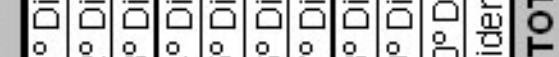

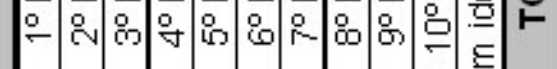


Tabela 5.5

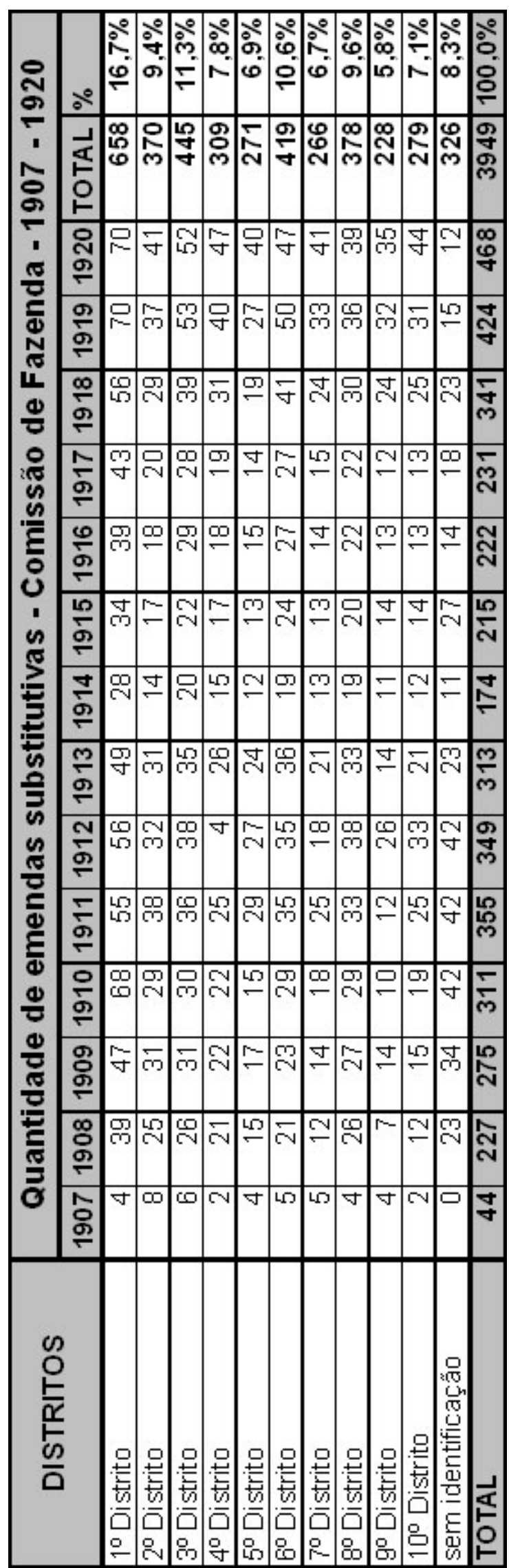




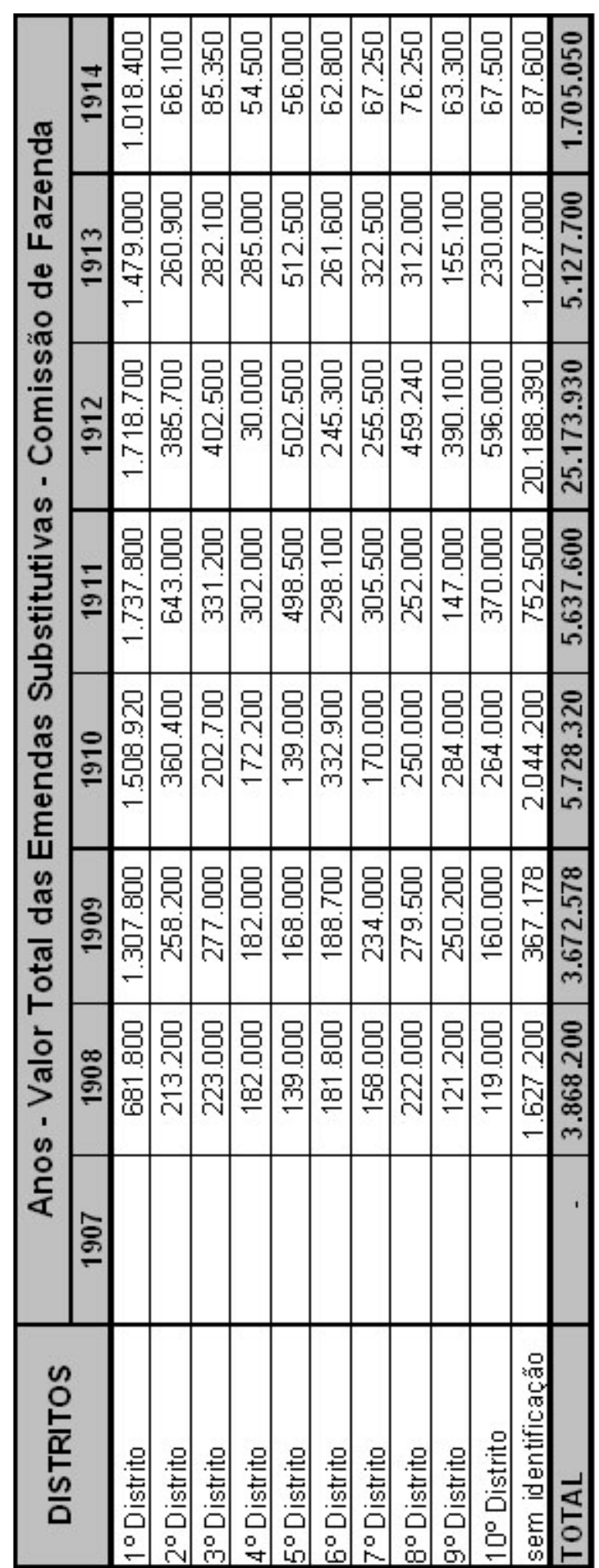

సं

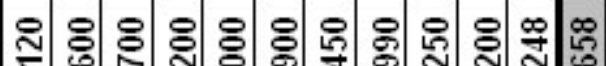

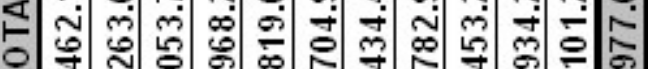

ஸ் mं- N N N N N N

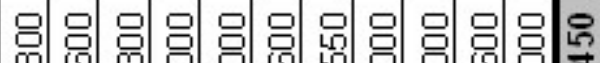

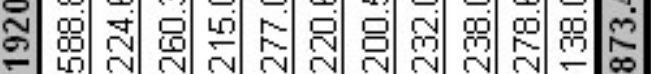

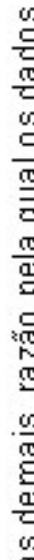

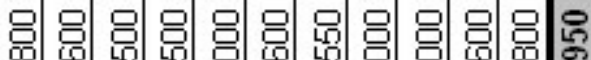

क

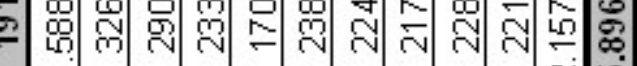

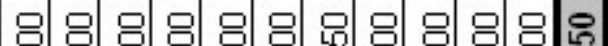

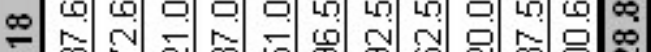

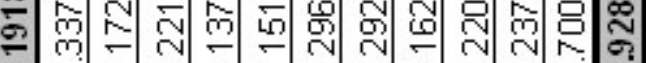

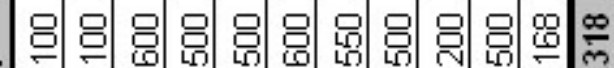

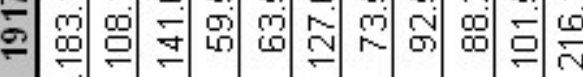

100

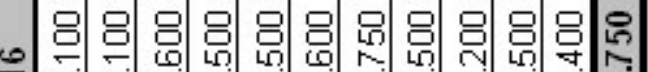

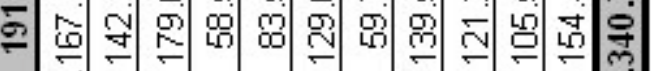

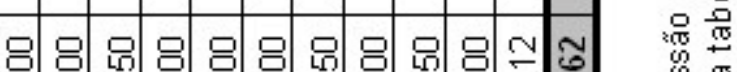

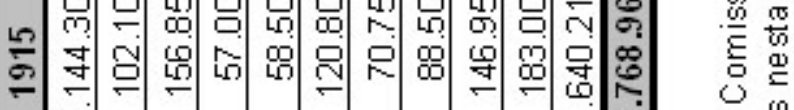

(

总密

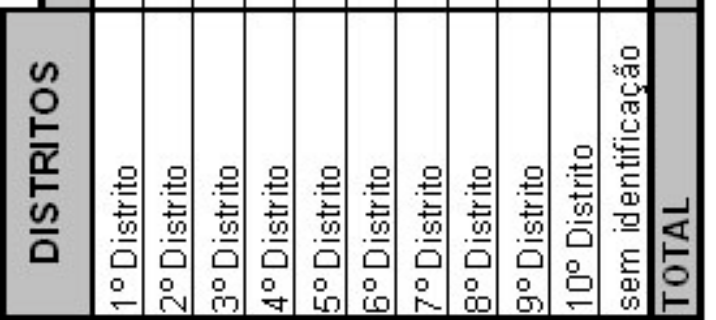

a

용

क

要

is

Tabela 5.6 


\section{Conclusão}

Chego ao final deste texto com um pouco mais de dúvidas do que de esclarecimentos em torno do tema a que me propus trabalhar. Ainda assim, alegro-me ter sido possível identificar aspectos importantes de como se deram as relações dentro do parlamento paulista, do ponto de vista da representatividade das zonas e distritos eleitorais do Estado de São Paulo no período de 1890 a 1920, durante o processo de construção do orçamento estadual.

Abríamos este texto, ainda na introdução, com certas incertezas acerca de como as regiões consideradas pobres, por meio de seus representantes, conseguiriam, ou não, romper cercos e buscar espaços suficientes para o atendimento de suas zonas e distritos de origem, com volumes significativos de recursos públicos. O embate, como se viu, dar-se ia no âmbito da Câmara dos Deputados de São Paulo e a temática central, como dissemos, era o orçamento estadual.

A análise das centenas de discursos, proposituras e o estudo detalhado dos projetos de lei do orçamento, além das milhares de emendas a eles apresentadas, levaram-me a algumas conclusões que, apesar do grande volume desses dados trabalhados, precisarei para esta conclusão de rápidos registros que me levaram a entender certas situações, quase nunca suficientemente claras e transparentes aos olhares mais desatentos.

Não me restaram dúvidas de que os esperados espaços “conquistados” pelos representantes das zonas e distritos que somavam menor poder econômico, foram unicamente aqueles permitidos pelo conjunto de deputados em postos-chave e de real mando dentro do legislativo. E não era coincidência que praticamente a totalidade desses parlamentares tivessem sua representação em regiões forte econômicamente. Seguindo a classificação do Professor José Francisco de Camargo, que não foram refutadas por pesquisadores como Joseph Love e Thomaz Holloway, para citar apenas esses casos que também levaram para seus estudos preocupações com critérios para regionalização do território paulista, ficaram claramente definidas como regiões ricas sobretudo as zonas da Capital e entorno, a zona Central, a Mogiana e Baixa Paulista. Do outro lado, estariam as zonas da Baixa e Alta Sorocabana, além da Noroeste (ainda em processo de criação de municípios e expansão territorial), Litoral Sul (zona da qual os autores excluíam o município de Santos) e a tradicional zona do Vale do Rio Paraíba, na minha opinião menos decadente do que afirmam muitos pesquisadores, porém muito distante da tradição e riqueza que marcara seu apogeu em tempos de café.

Assim, vimos que os municípios e regiões mais fortes praticamente decidiam, tanto no plano político como no econômico, os rumos e os eixos da ação governamental. E mais, no parlamento paulista as relações entre os deputados apontaramm para a formação deste "consenso estadual" também sobre a política regional do governo em relação ao interior e sobre acordos e acertos 
com o poder federal. Com isto, tal "consenso" garantiu, de certo modo, uma unidade de comando da política estadual, por conta dos acordos estabelecidos nas bases dos grandes fazendeiros do interior e de homens de poder da capital. Enfim, a voz da "Casa de Leis" era resultado, sim, de uma prática fundada em acordos e troca de favores. Coube-me assim a vontade de esmiuçá-la.

Assim, o sistema de alianças políticas, integrando os interesses diferenciados dos grandes fazendeiros do interior paulista, fartamente apontados nos capítulos II e III deste trabalho, e atrelados a um conjunto bastante expressivo de dados e informações oriundas da dinâmica do parlamento paulista na disputa por recursos públicos, não me deixaram mais dúvidas: fora definitivamente as práticas que permitiram a formação desse consenso e que também foi capaz de equilibrar as diferenças regionais, obviamente numa relação de poder favorável a alguns, e construir, inclusive, elos políticos e de favores entre todas as lideranças do Estado de São Paulo.

As oligarquias estaduais estavam, assim, sedimentadas em práticas de dominação em suas regiões, áreas e municípios, onde atuavam no âmbito econômico e político, partindo da esfera privada e com apoio dos instrumentos públicos dos Poderes Executivos dos municípios, dos Estados, das Câmaras locais, das Assembléias Legislativas e do Congresso Nacional. 


\section{APÊNDICES}

\section{Apêndice A}

Série-evolução, por Zona, da Quantidade de Emendas Apresentadas - 1891-1906

\section{Apêndice B}

Série-evolução, por Zona, de Valor de Emendas Apresentadas - 1891-1906

\section{Apêndice C}

Série-evolução, por Distrito Eleitoral, da Quantidade de Emendas Apresentadas - 1907-1920

\section{Apêndice D}

Série-evolução, por Distrito Eleitoral, do Valor de Emendas Apresentadas - 1907-1920

\section{Apêndice E}

Série-evolução, por Distrito Eleitoral, da Quantidade de Emendas Aprovadas - 1907-1920

\section{Apêndice F}

Série-evolução, por Distrito Eleitoral, do Valor Total das Emendas Substutivas - 1907-1920

\section{Apêndice G}

Comparativo entre Emendas Apresentadas e Aprovadas, por Zonas, 1891-1906

(Quantidade e Valor)

\section{Apêndice H}

Comparativo entre Emendas Apresentadas, Rejeitadas e Prejudicadas, por Distrito Eleitoral, 1907-1920

(Quantidade e Valor)

\section{Apêndice I}

Série de Planilhas indicando Destino das Emendas, de cada Deputado, da $1^{\text {a }}$ à $11^{\mathrm{a}}$ Legislaturas 1891-1920 
Apêndice A

Série-evolução, por Zona, da Quantidade de Emendas Apresentadas - 1891-1906 

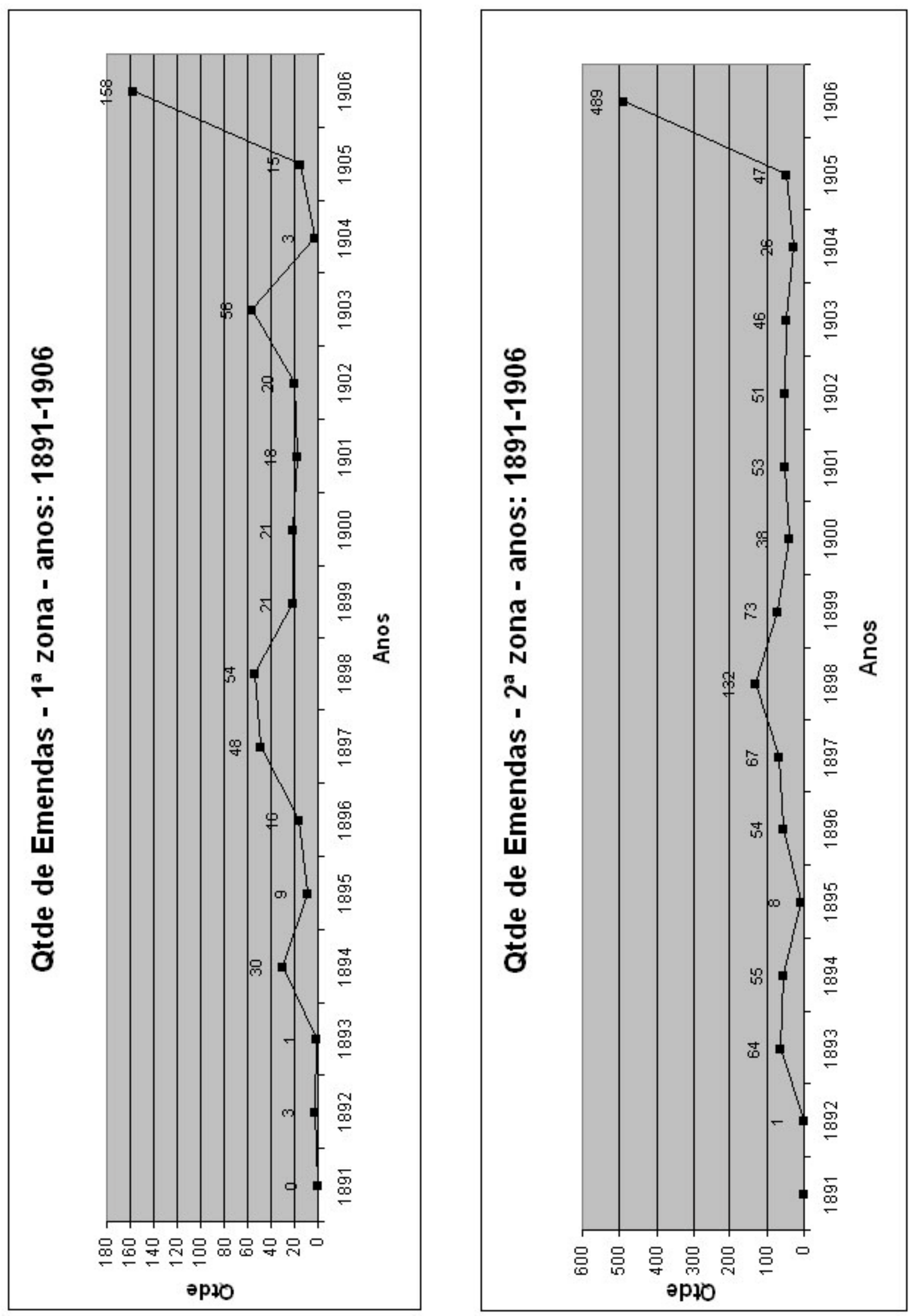

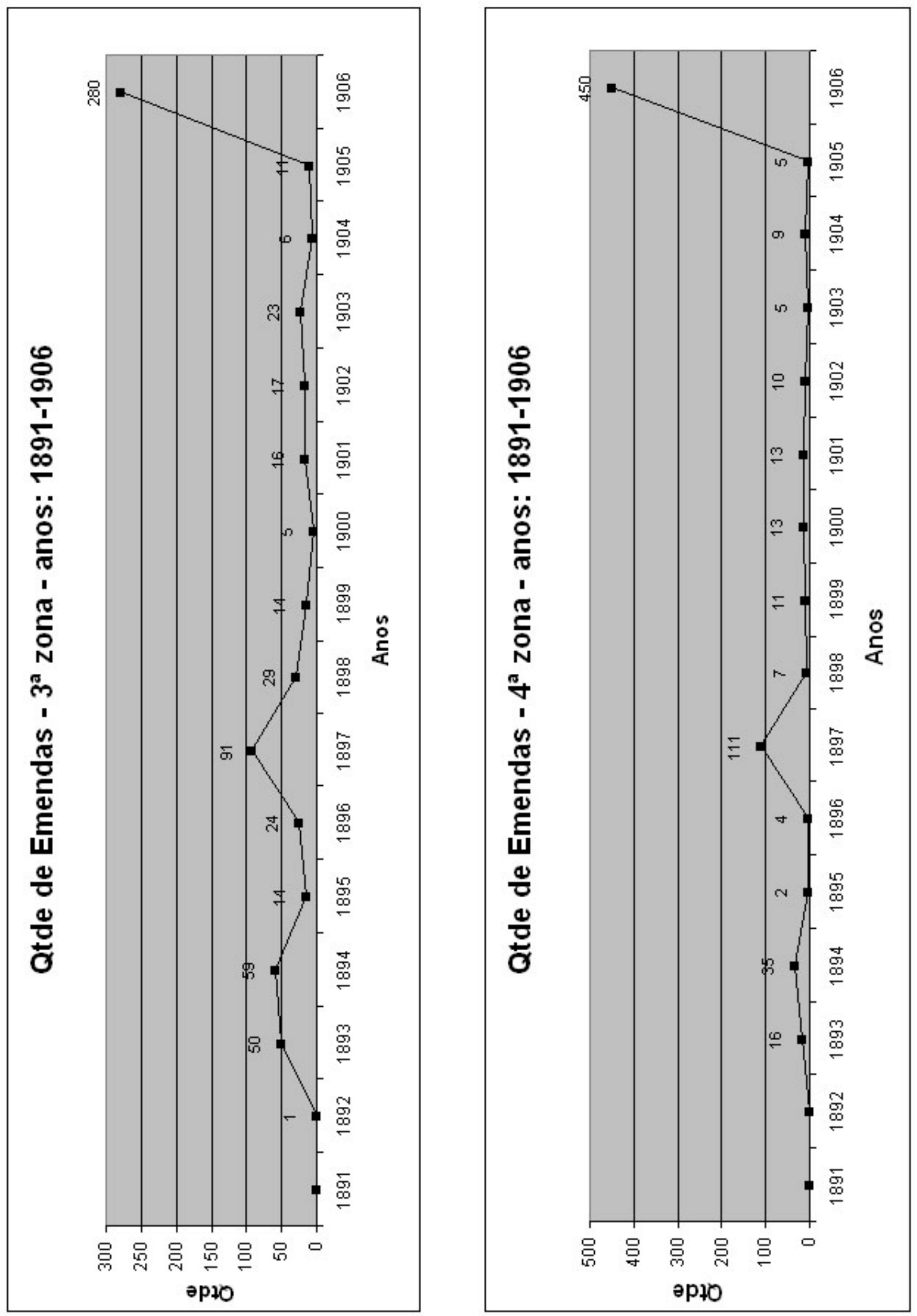

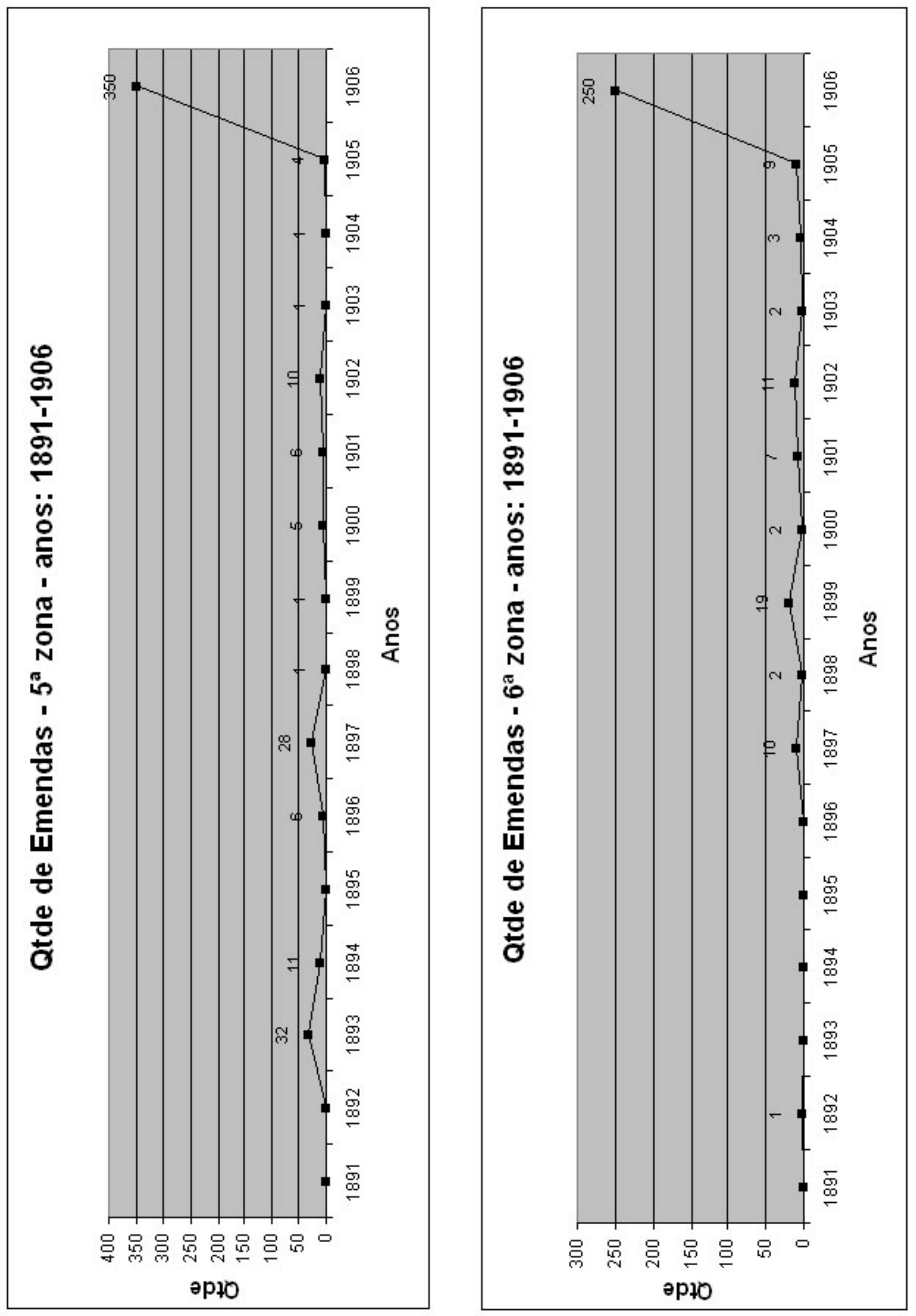

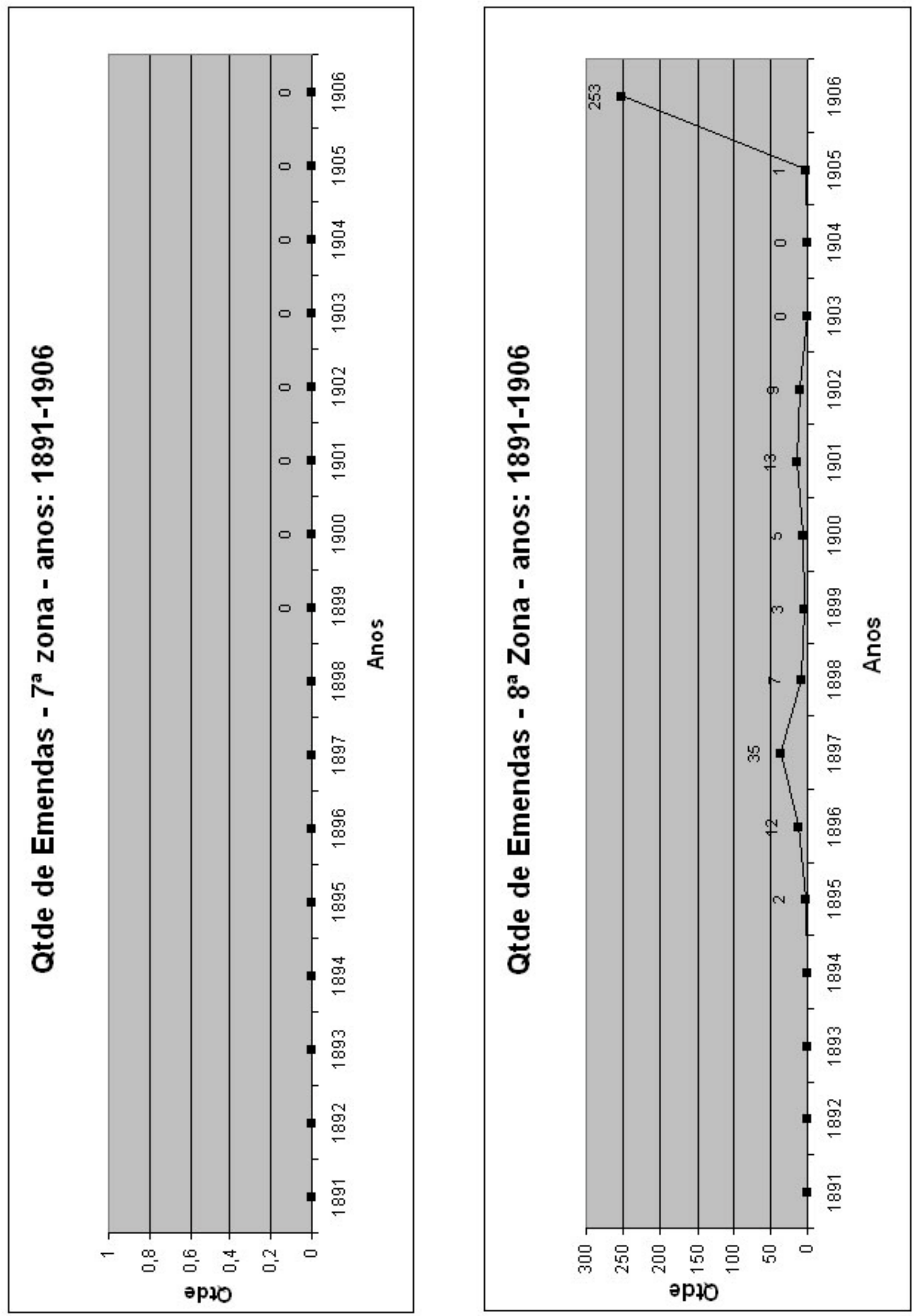

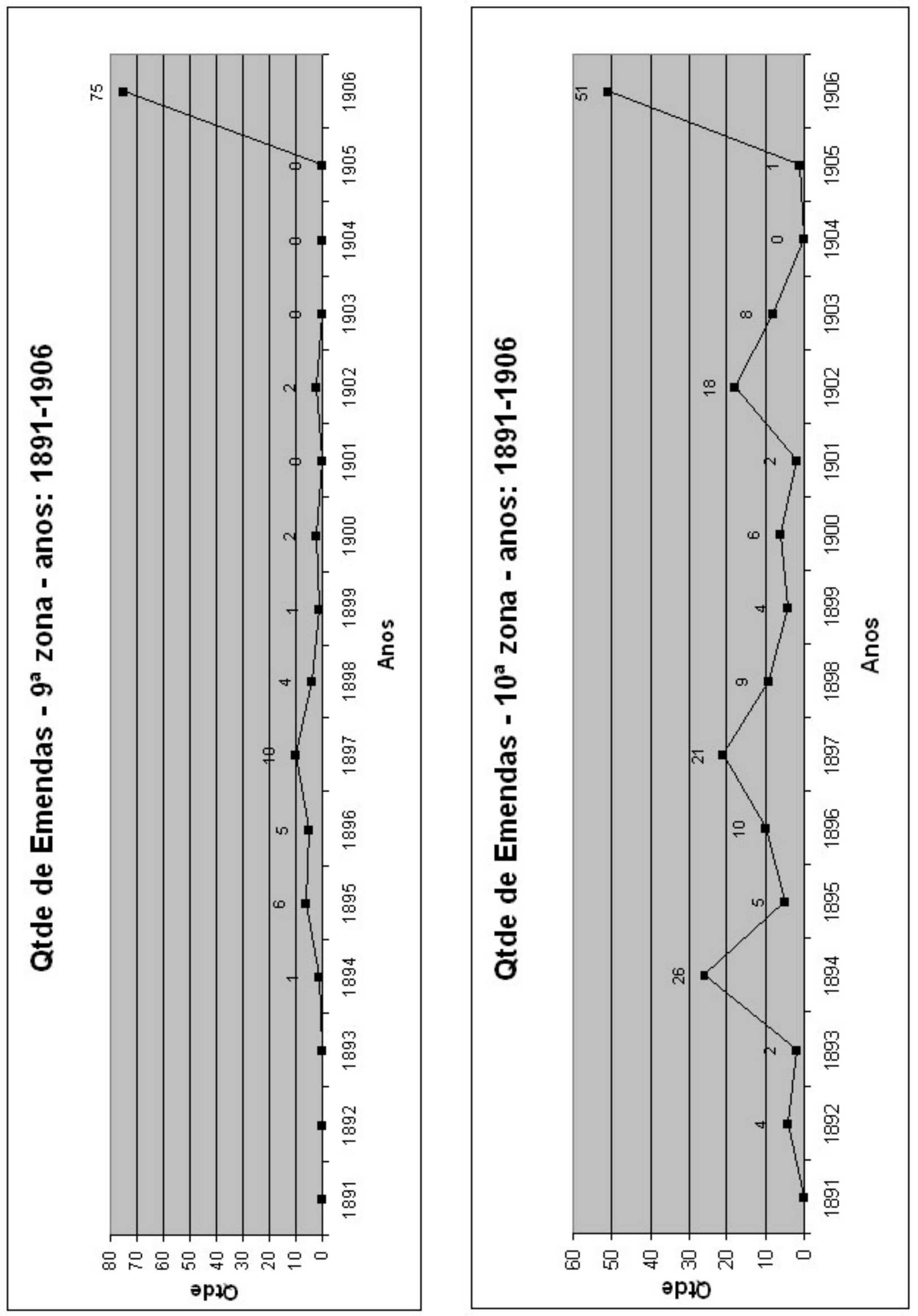


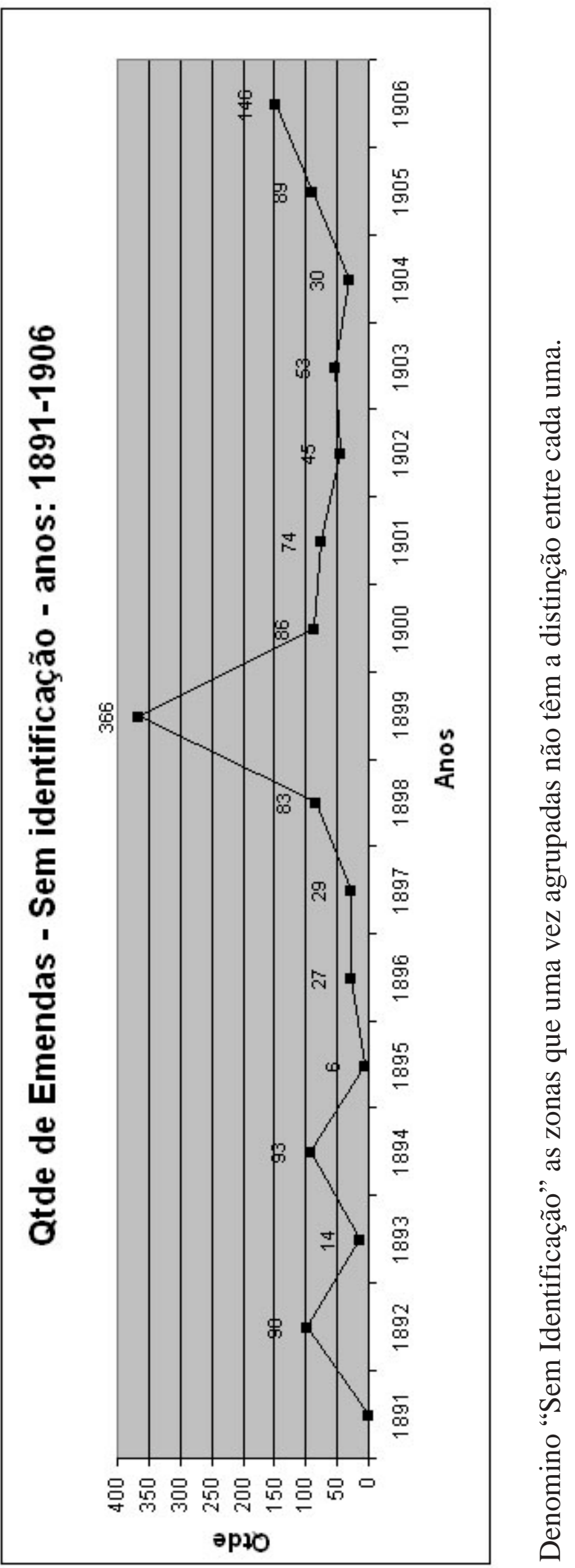


Apêndice - B

Série-evolução, por Zona, de Valor de Emendas Apresentadas - 1891-1906 

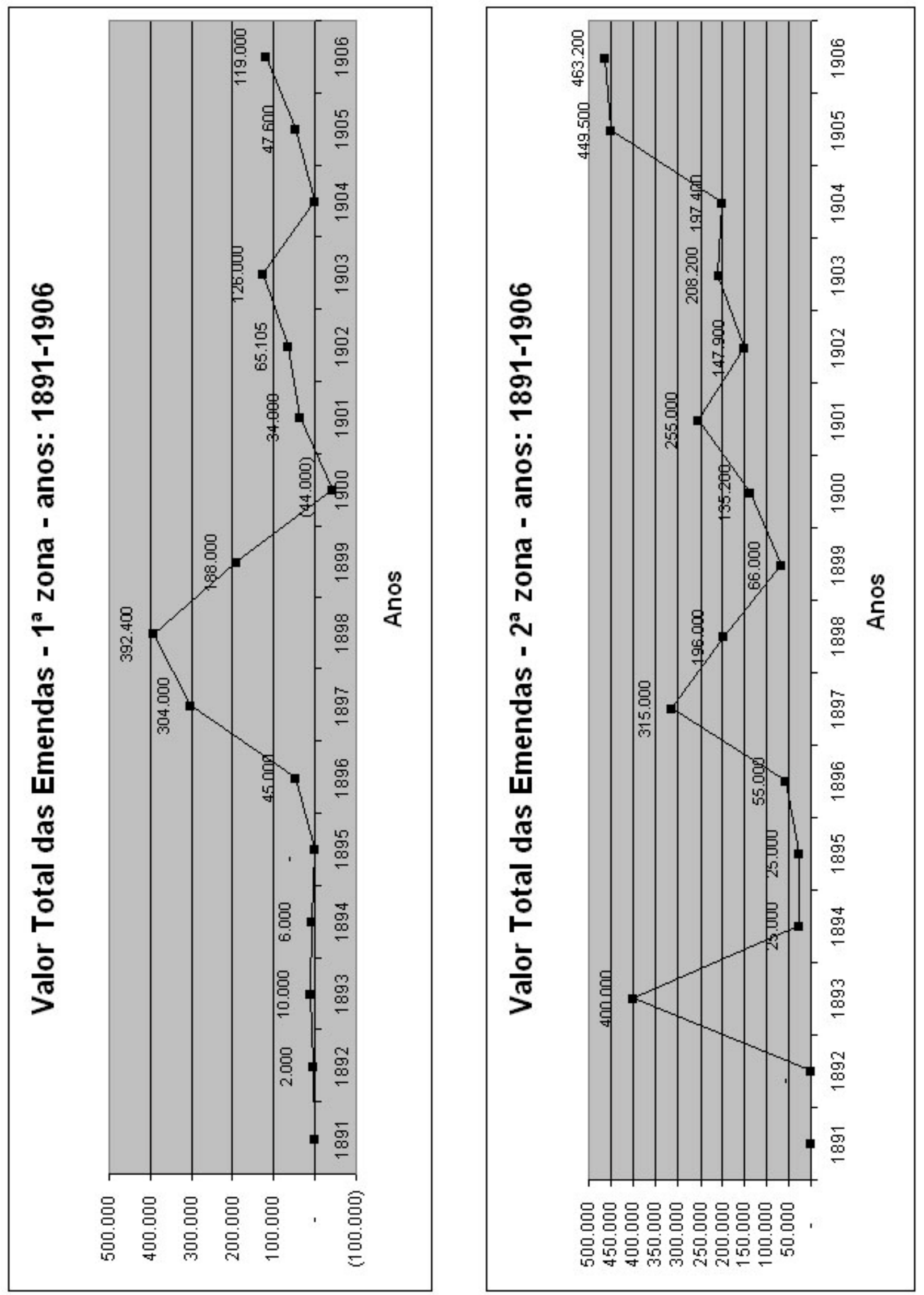

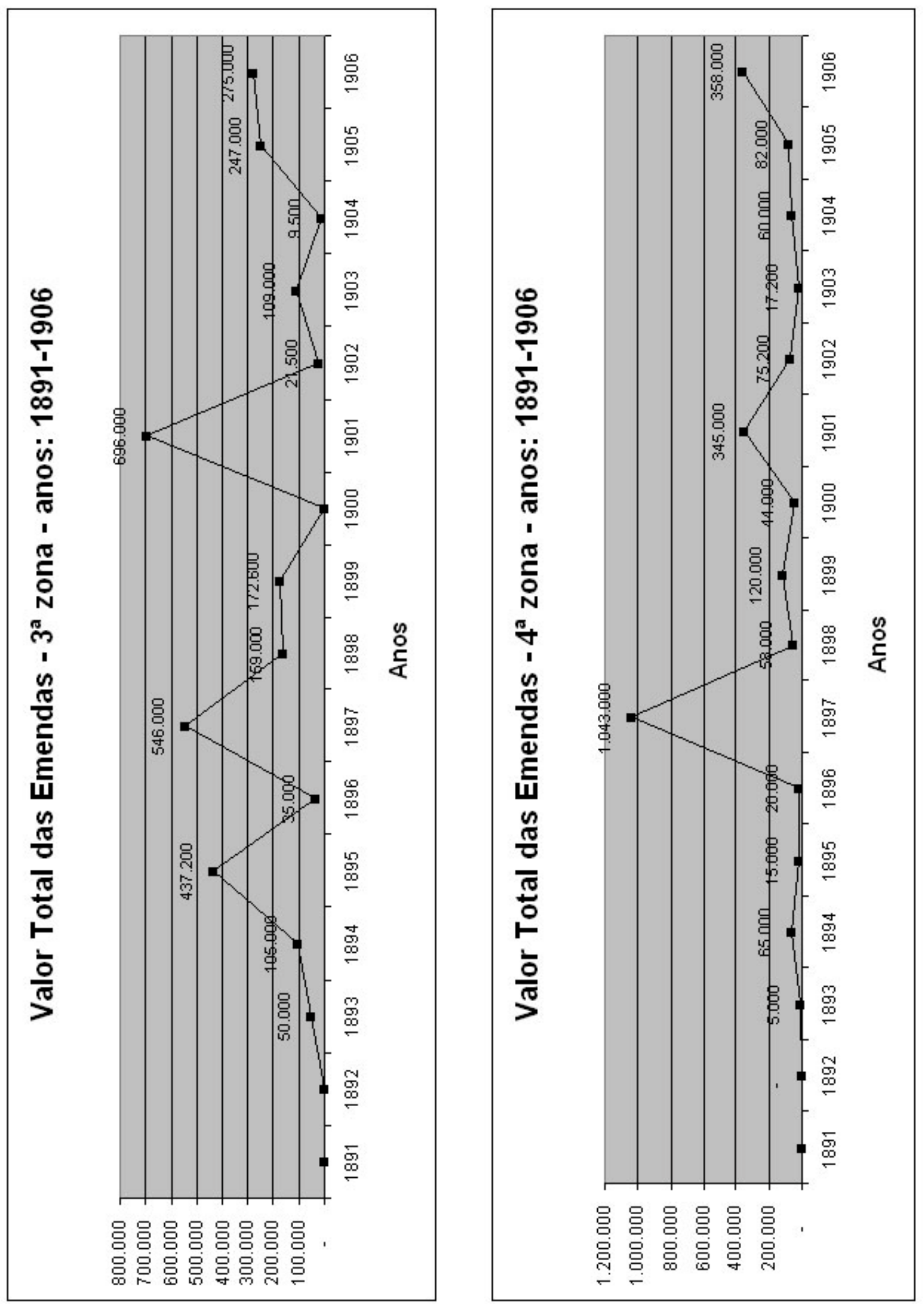

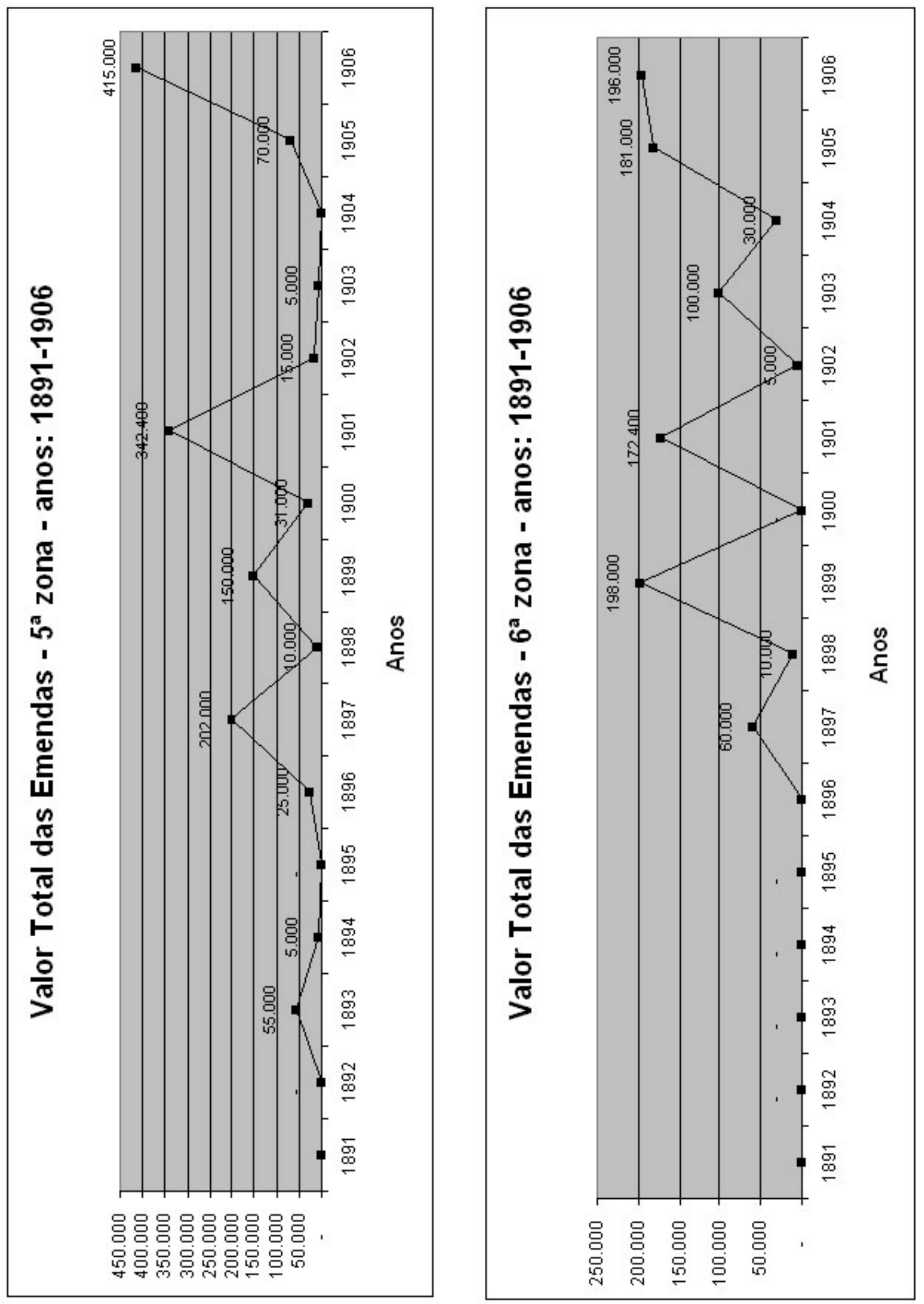

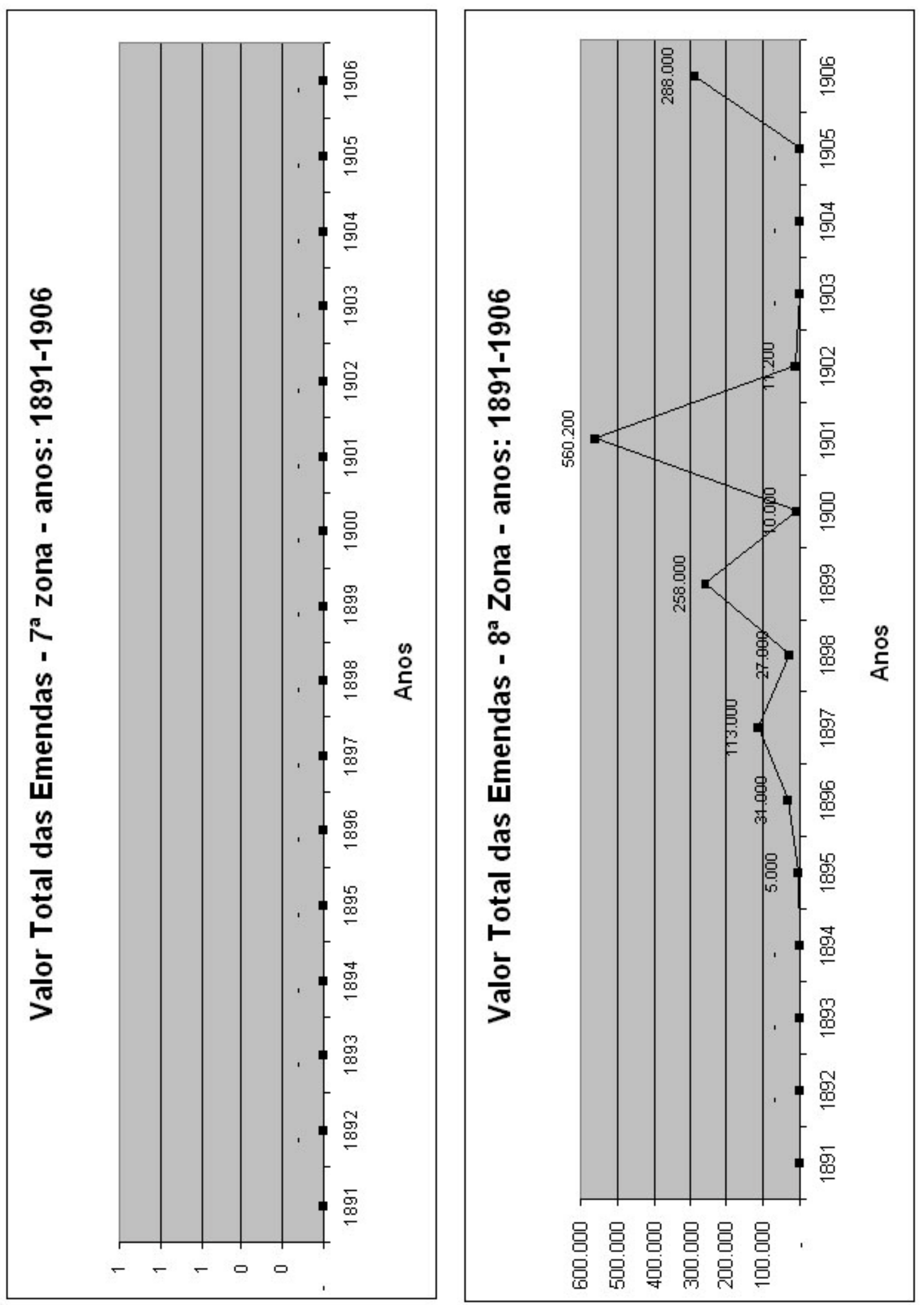

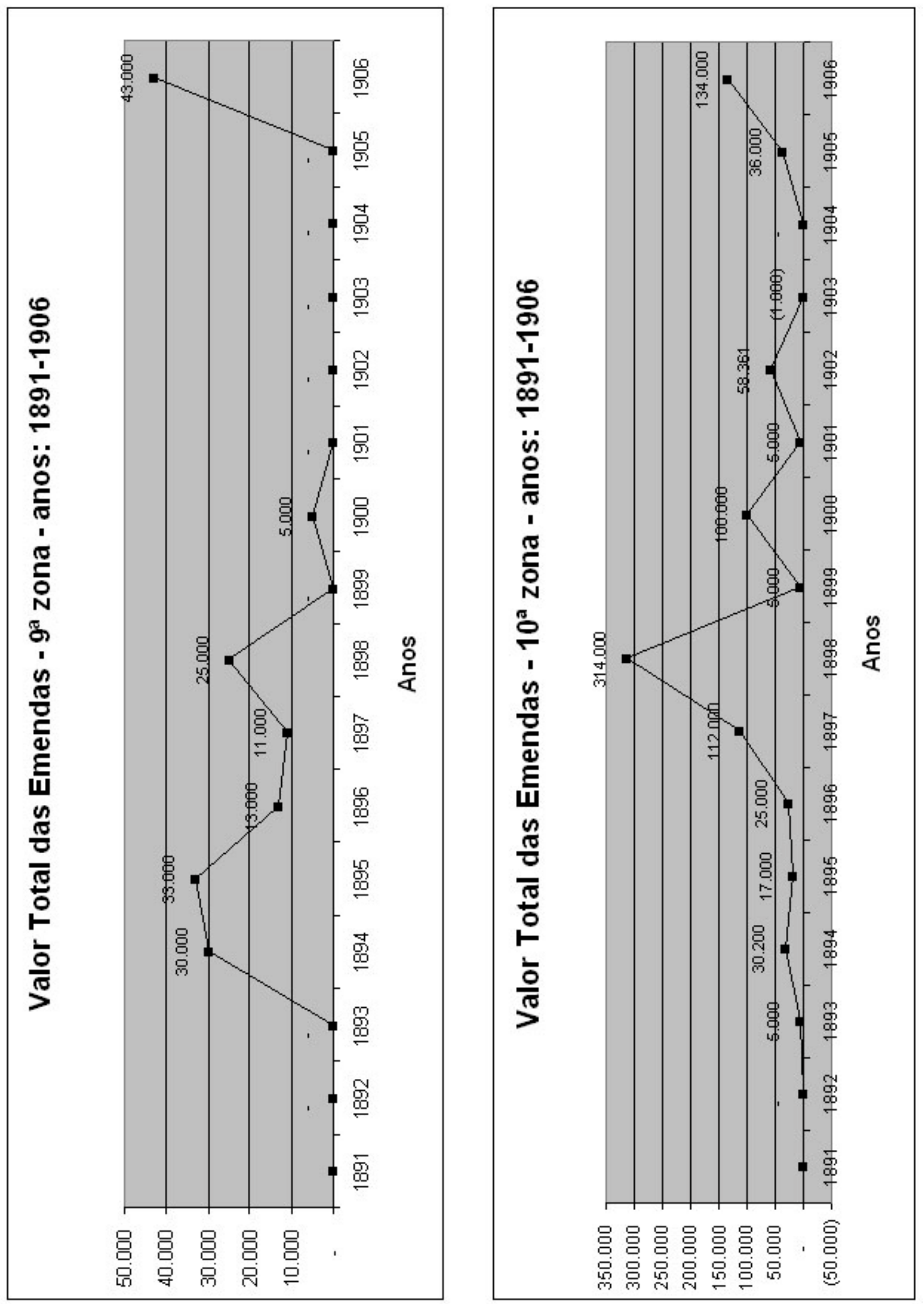


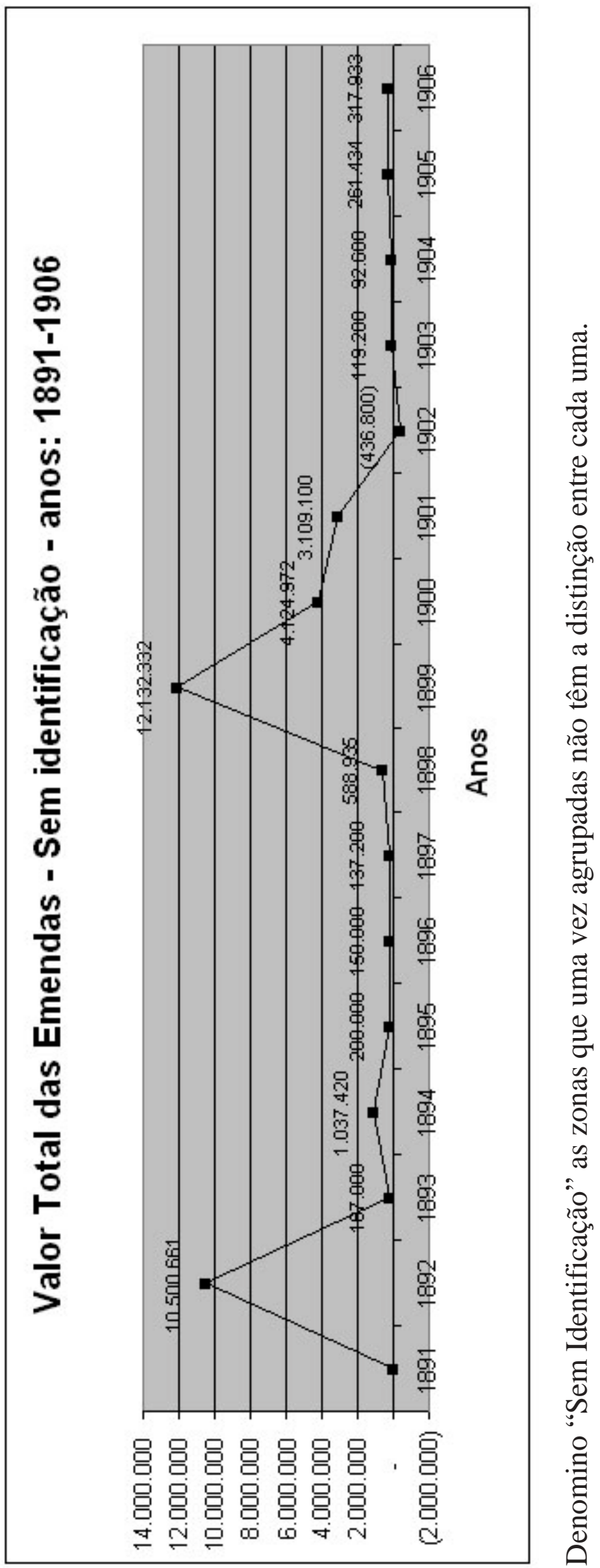


Apêndice C

Série-evolução, por Distrito Eleitoral, da Quantidade de Emendas Apresentadas - 1907-1920 

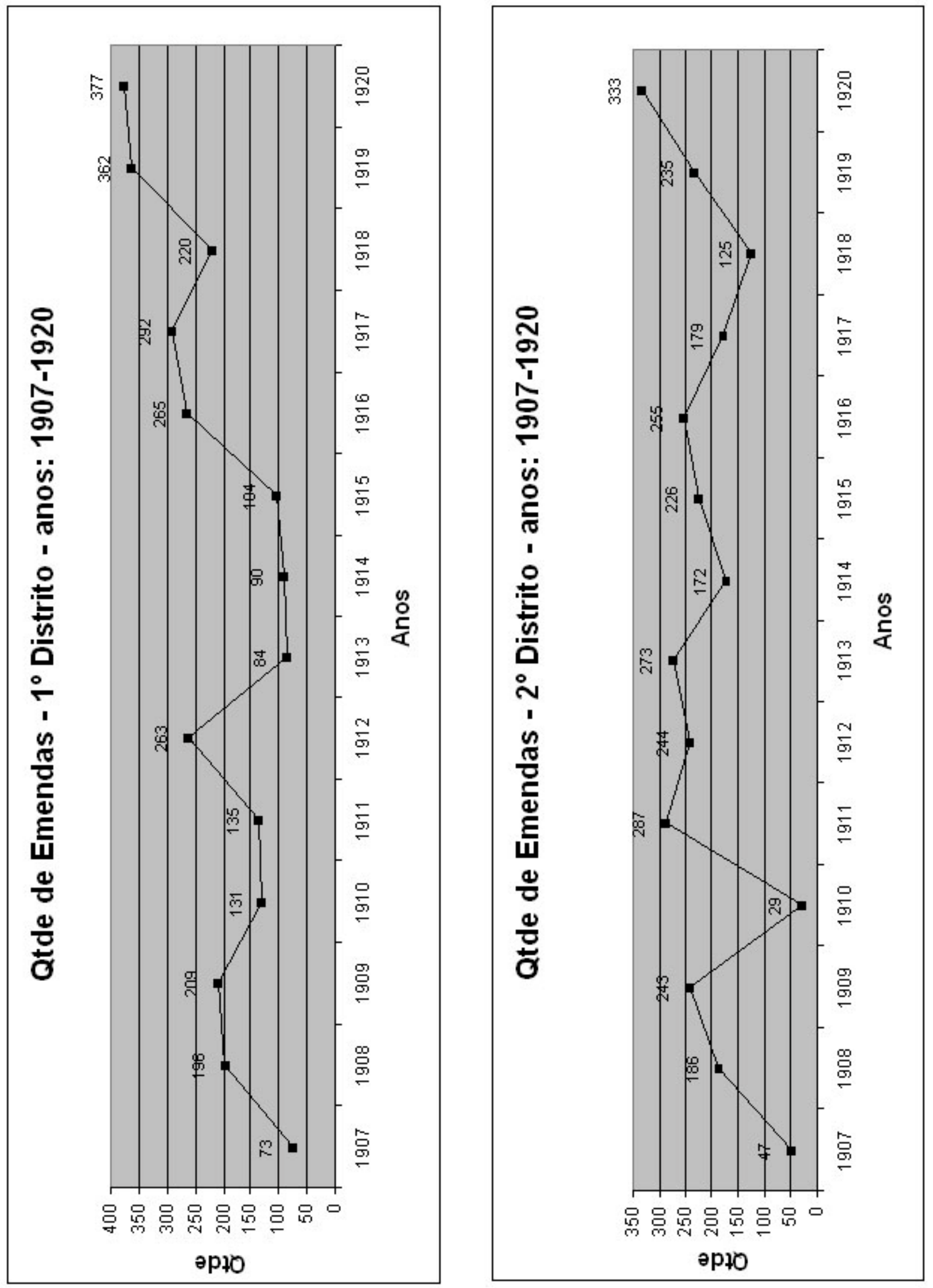

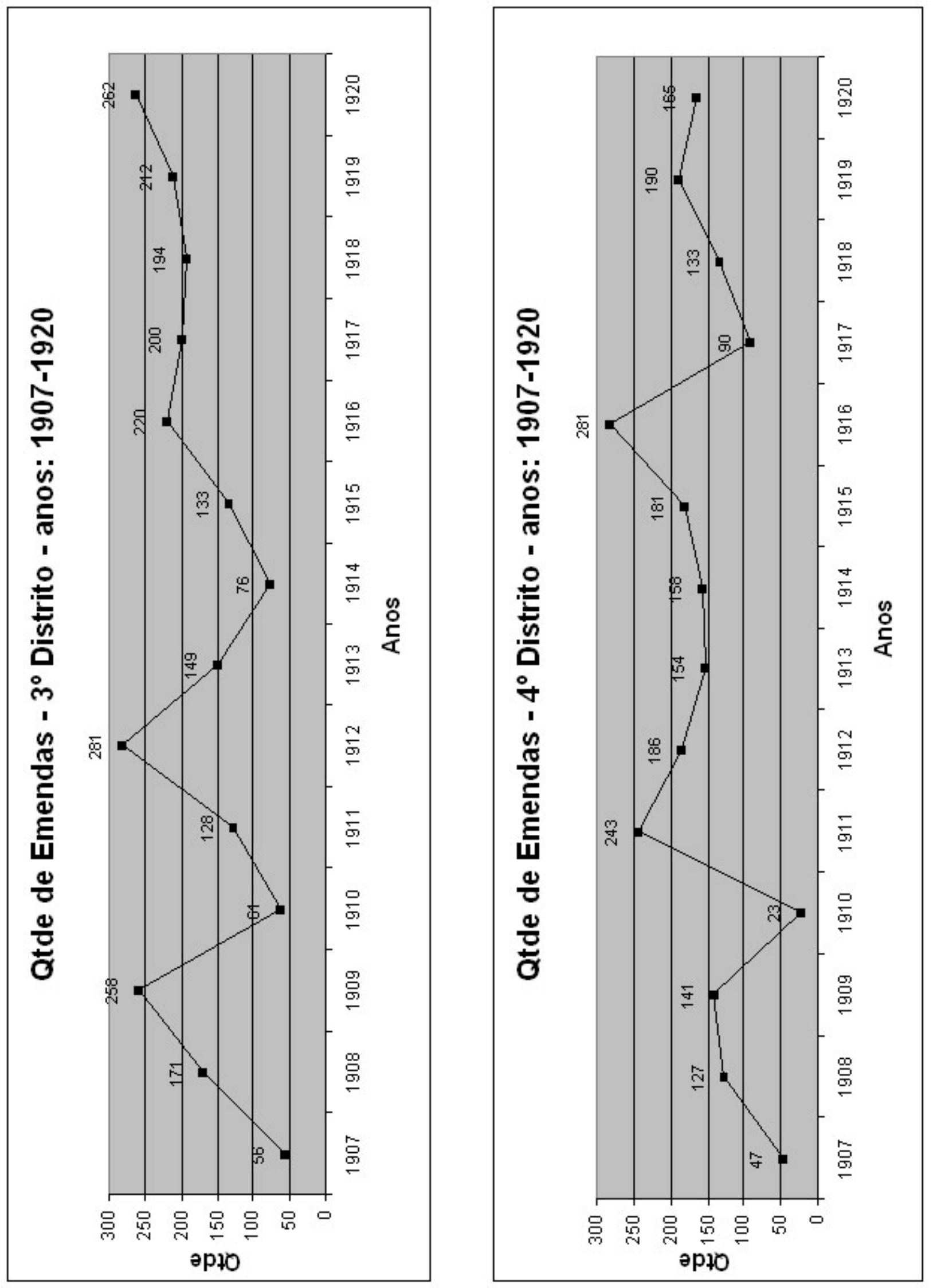

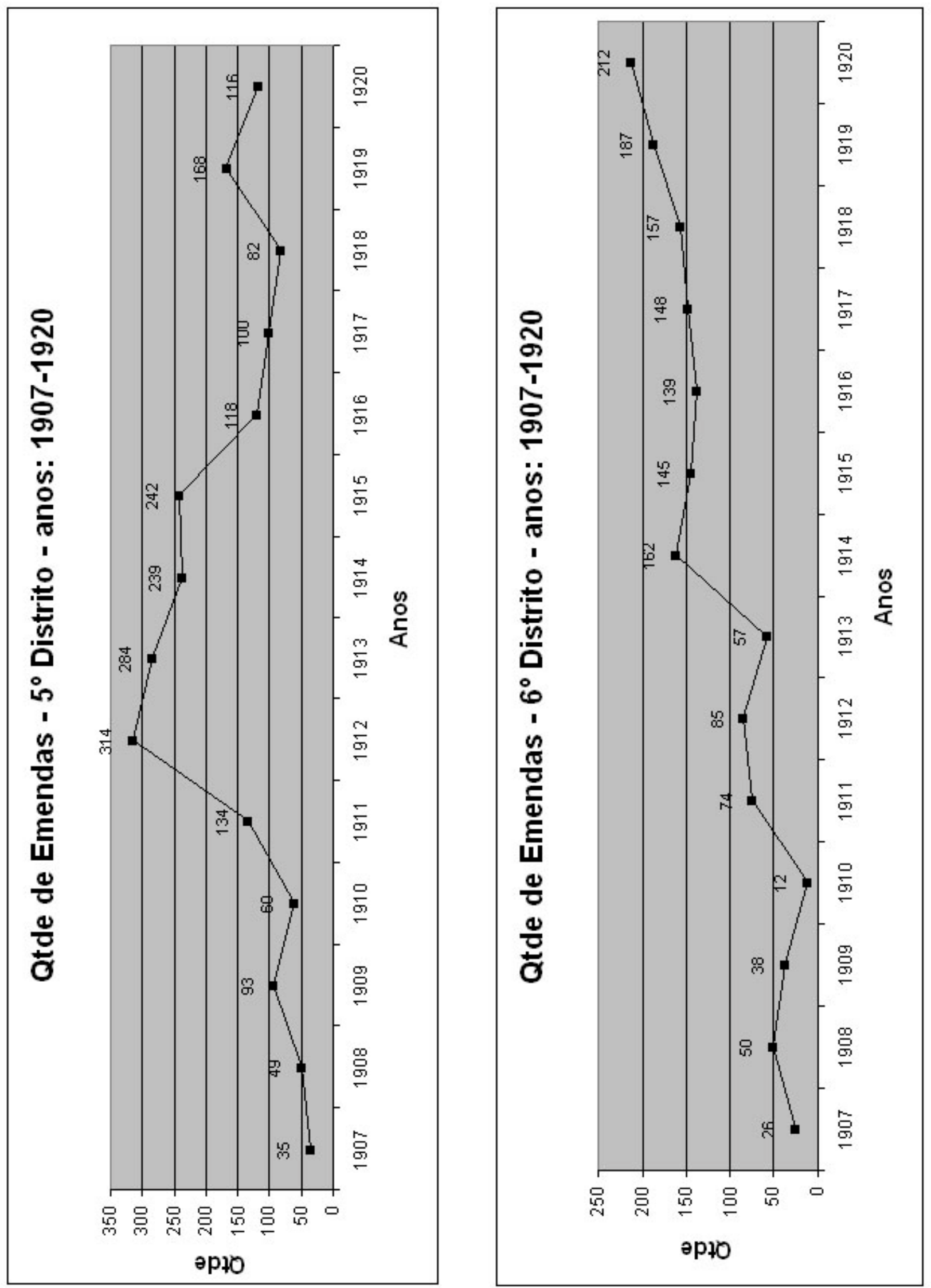

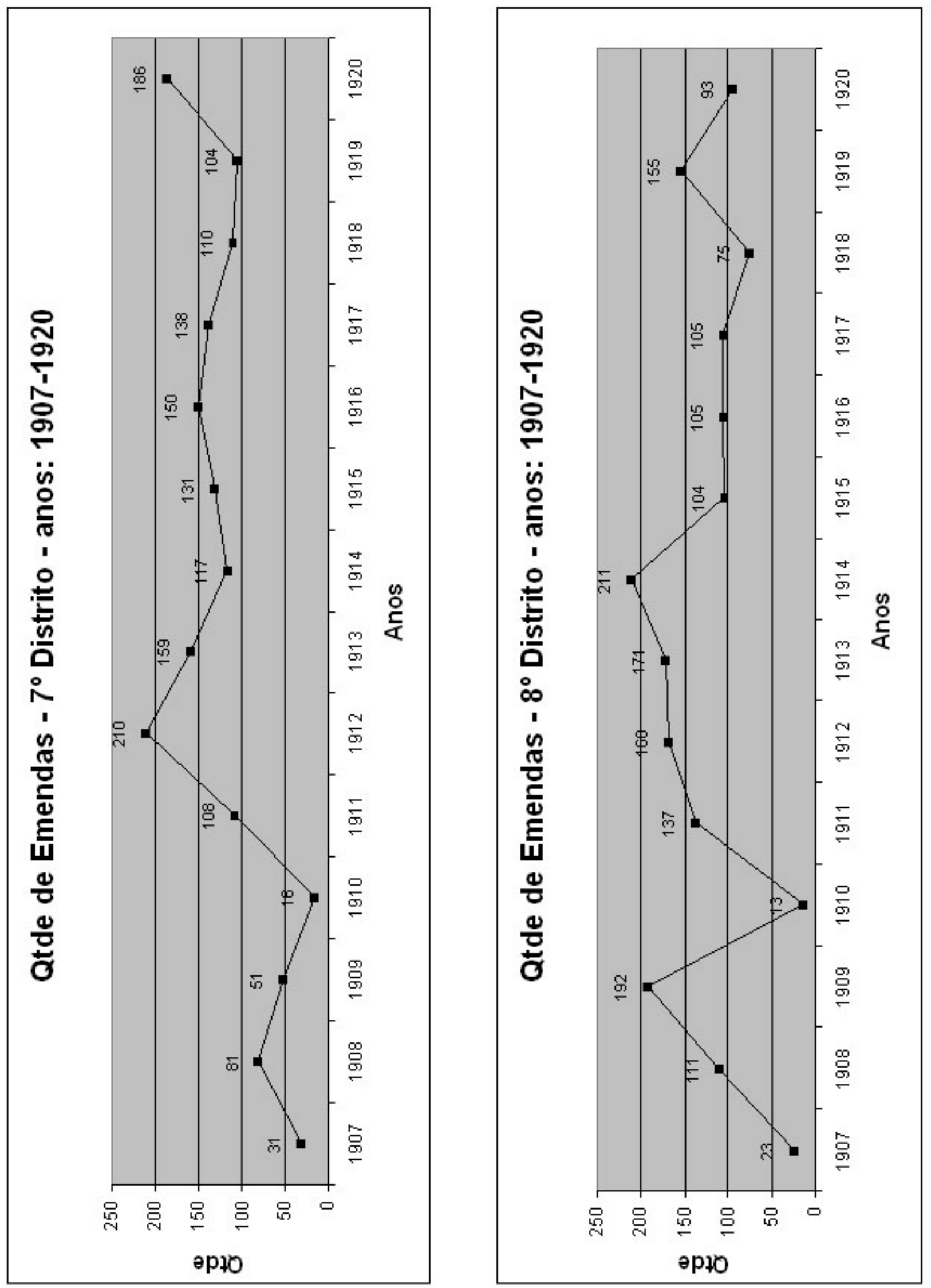

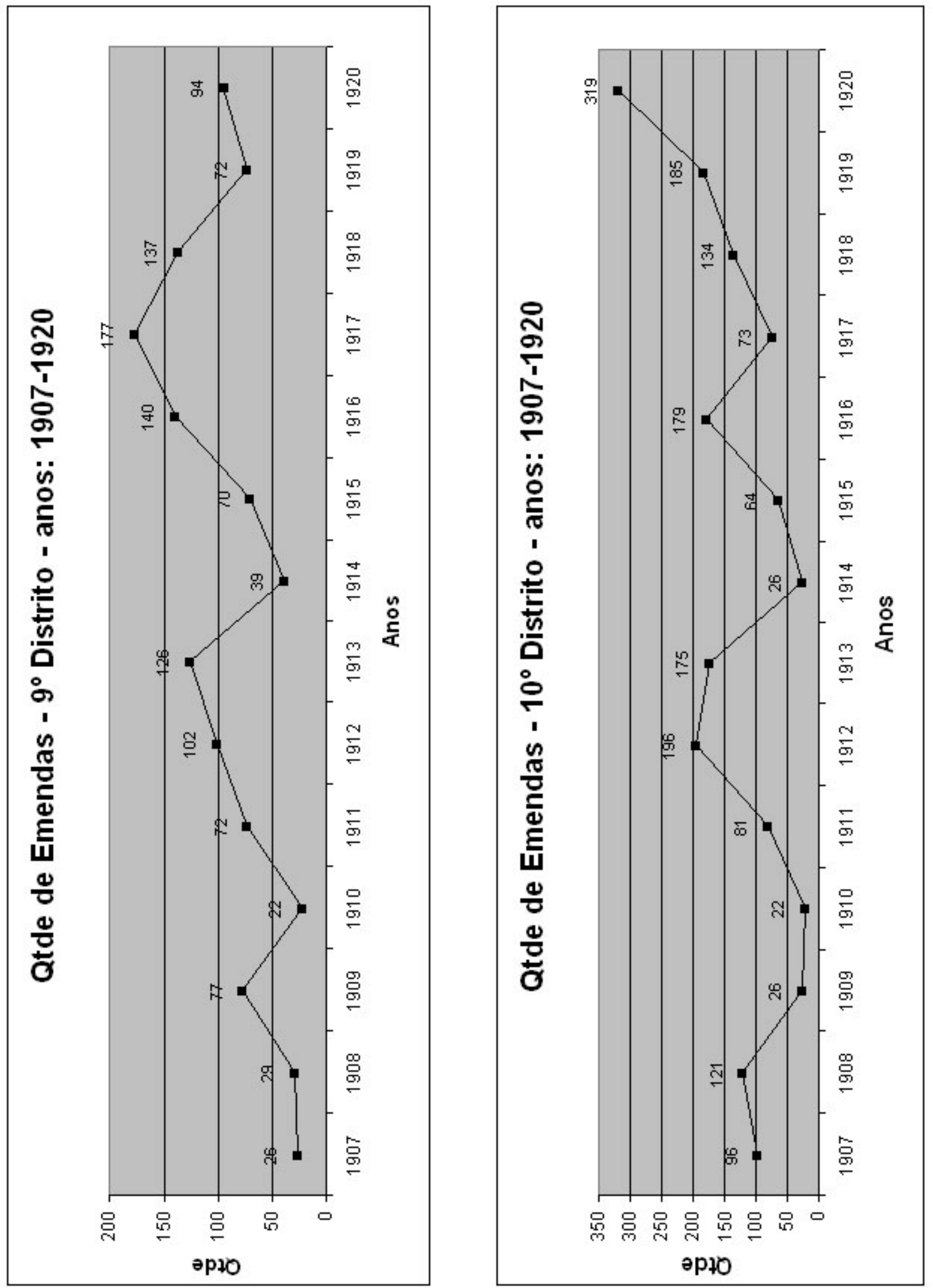


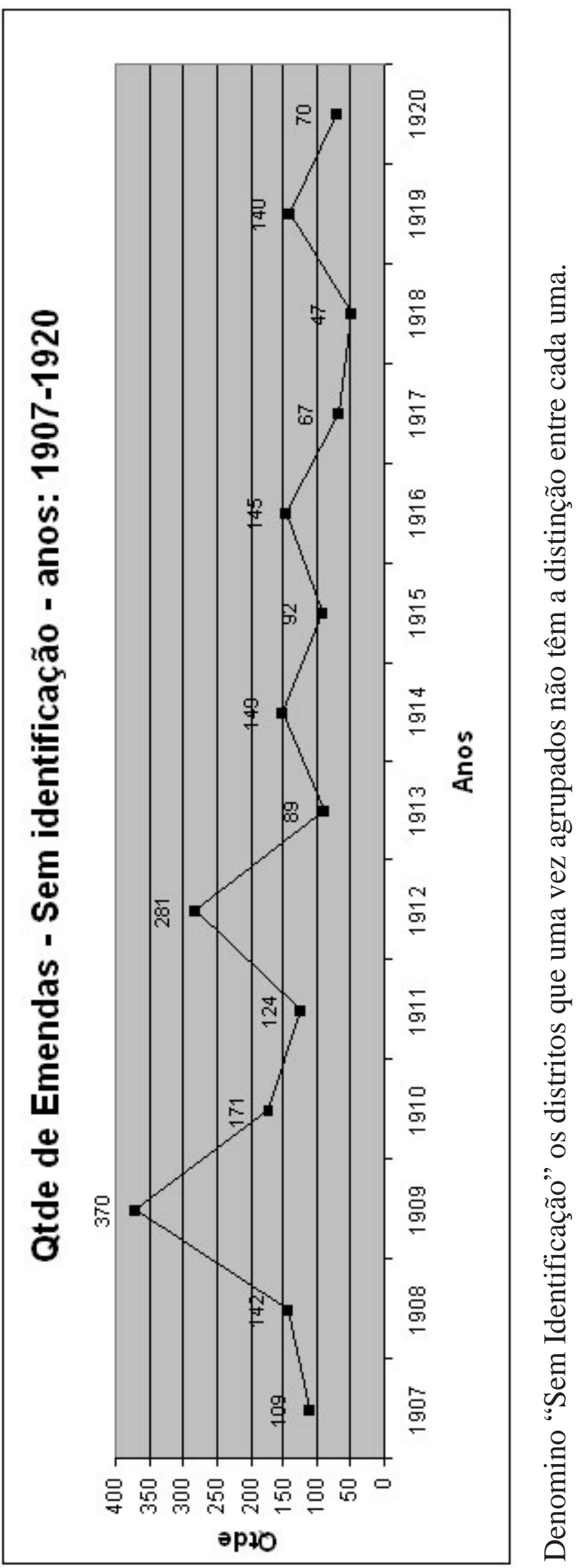


Apêndice D

Série-evolução, por Distrito Eleitoral, do Valor de Emendas Apresentadas - 1907-1920 

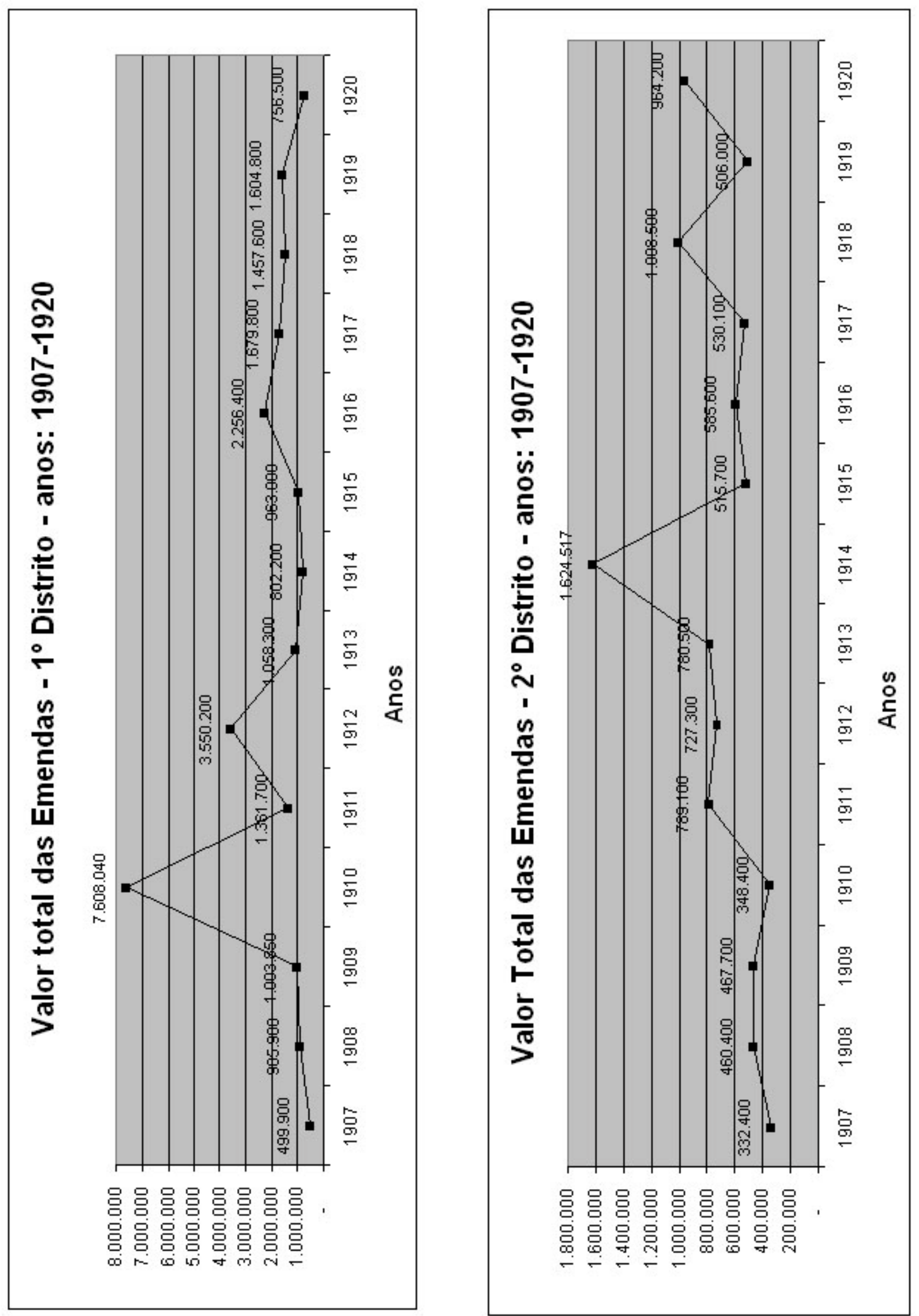

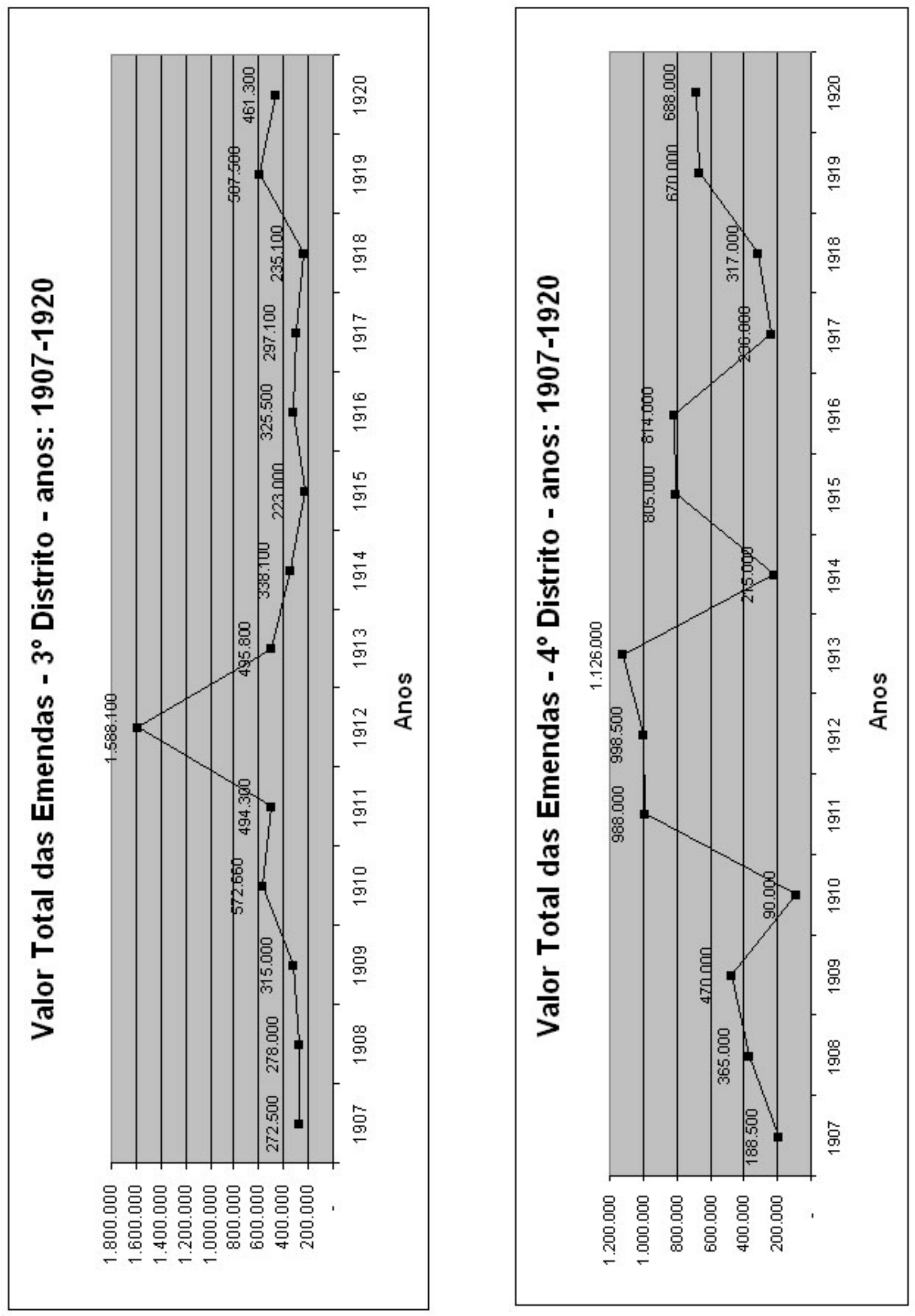

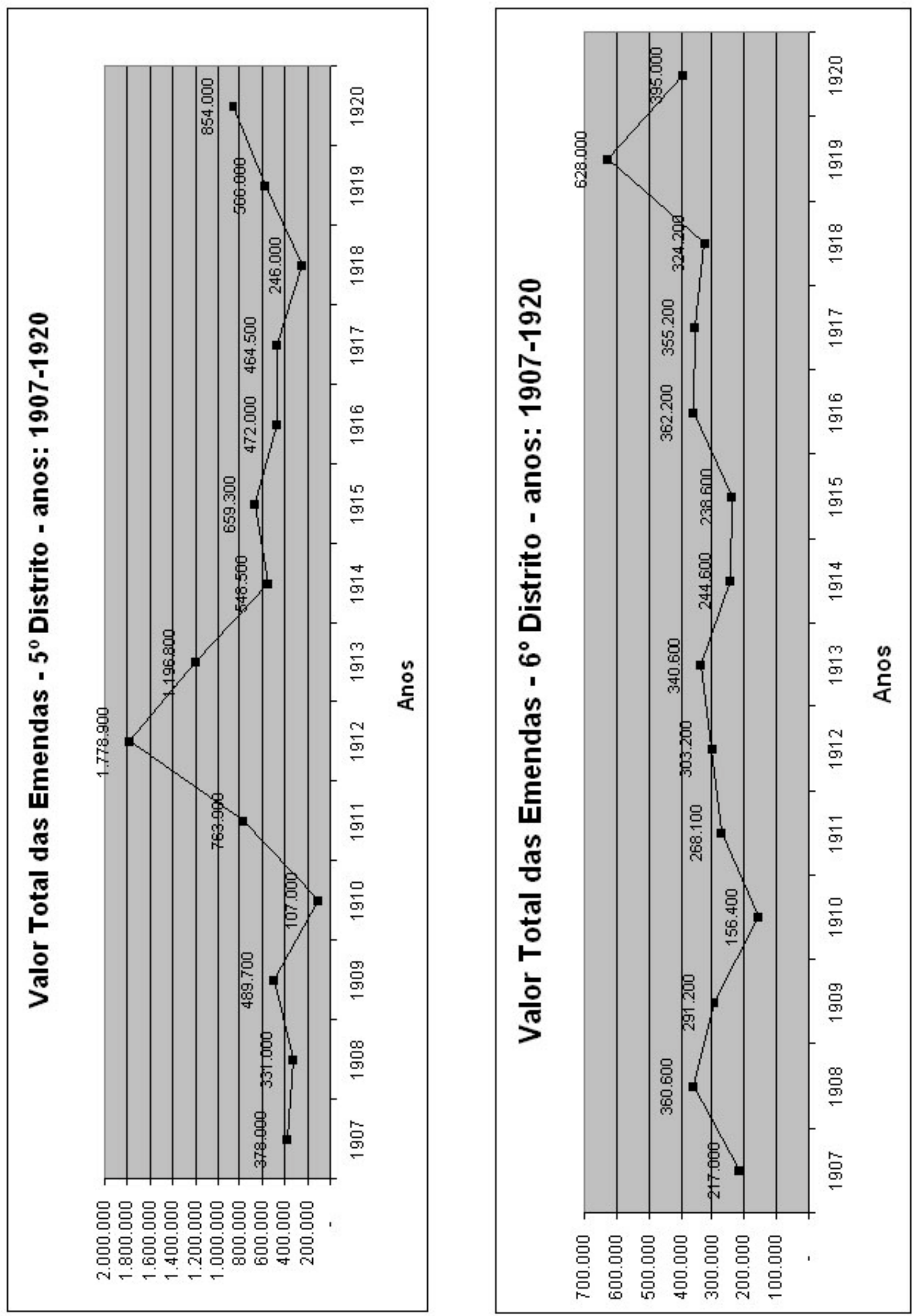

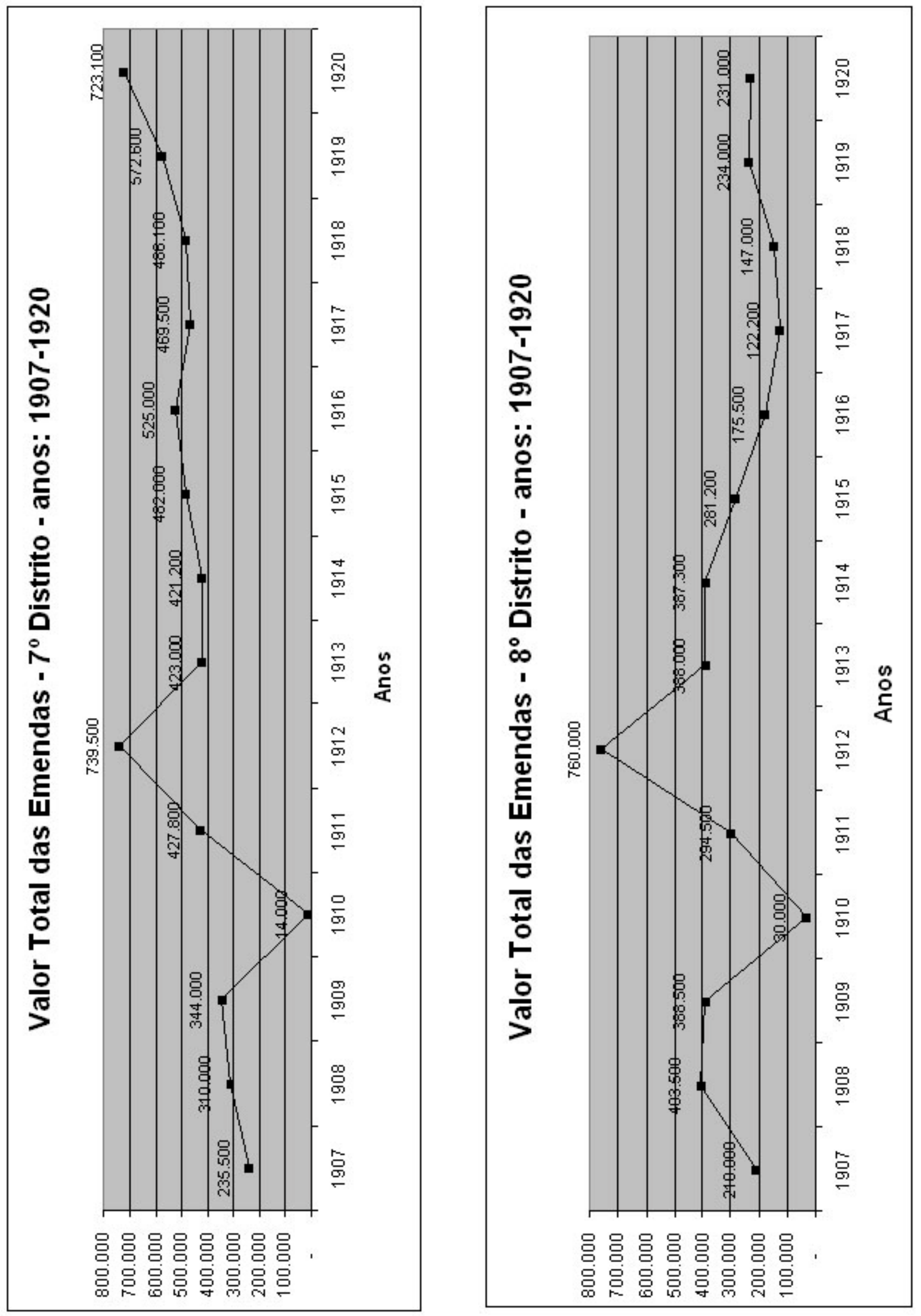

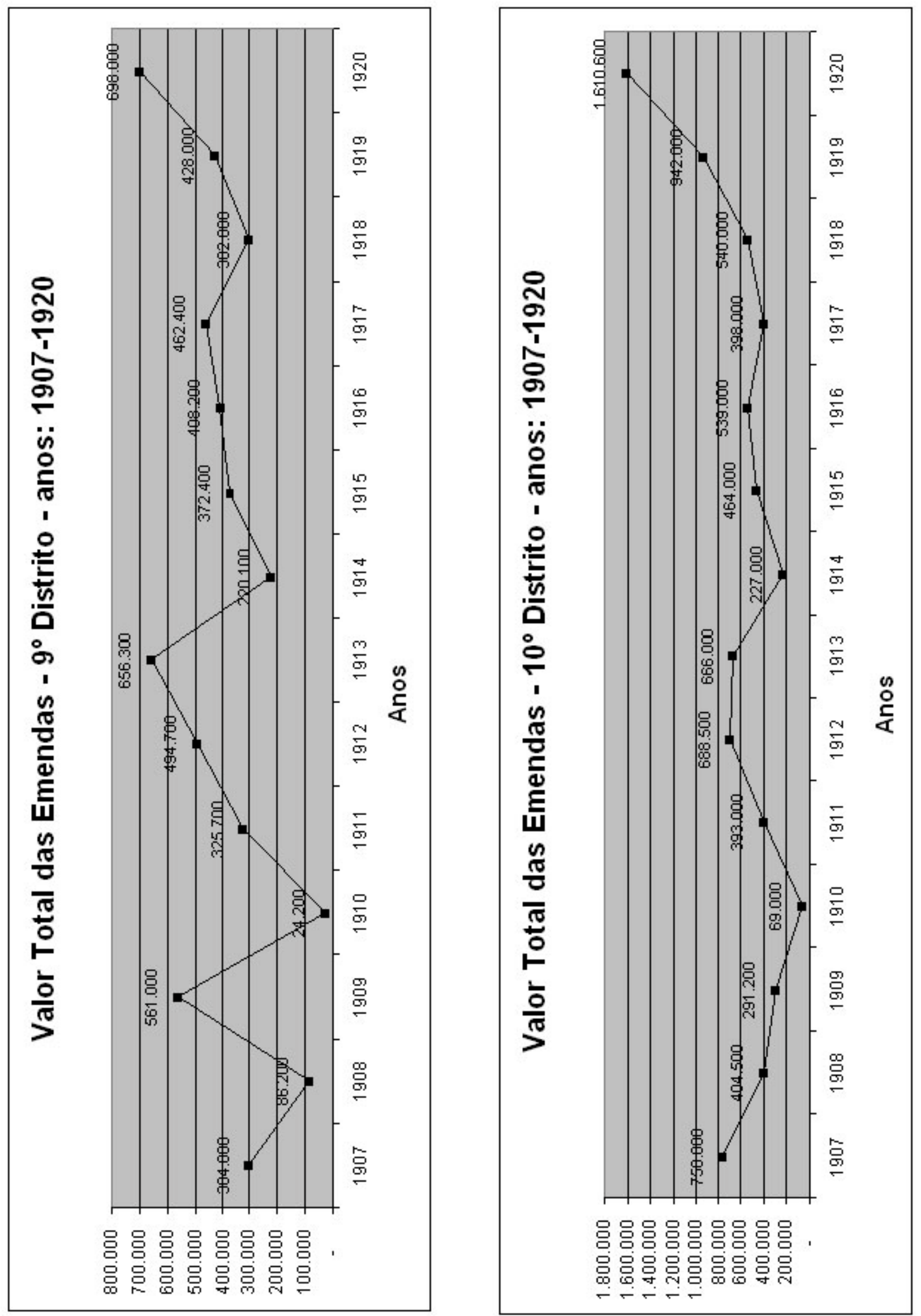


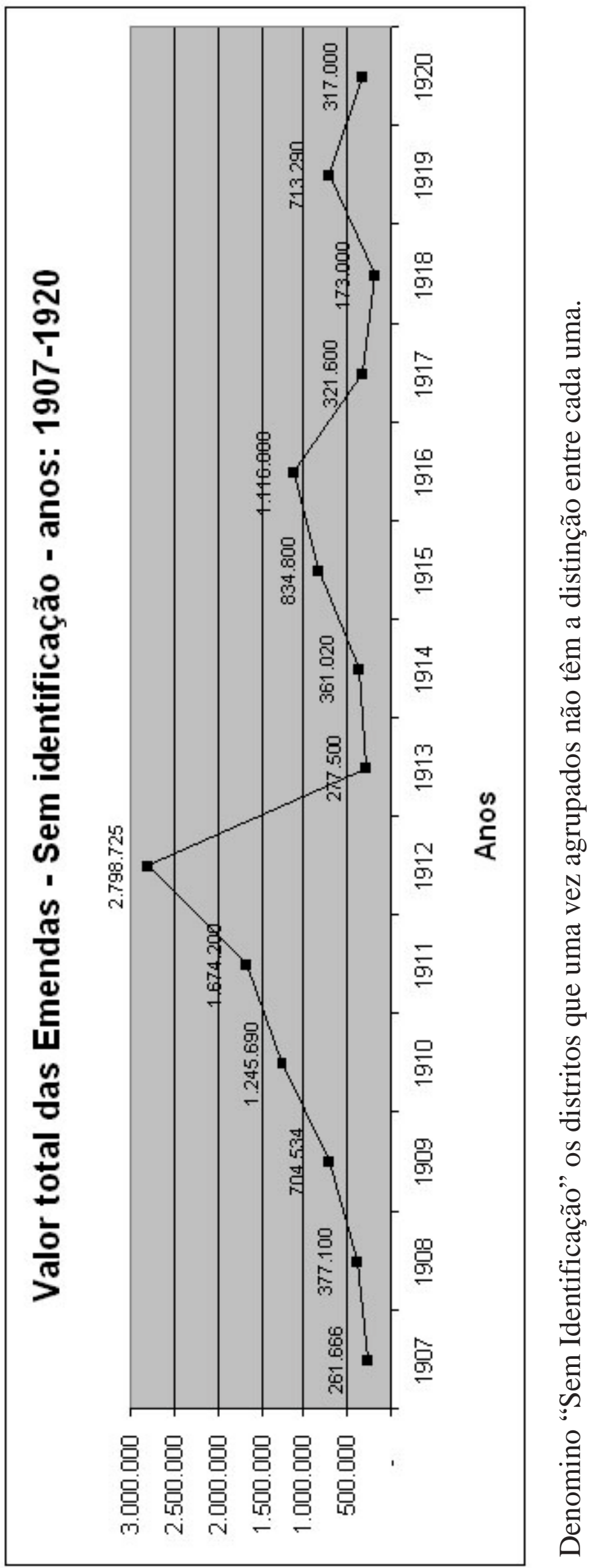


Apêndice E

Série-evolução, por Distrito Eleitoral, da Quantidade de Emendas Aprovadas - 1907-1920 

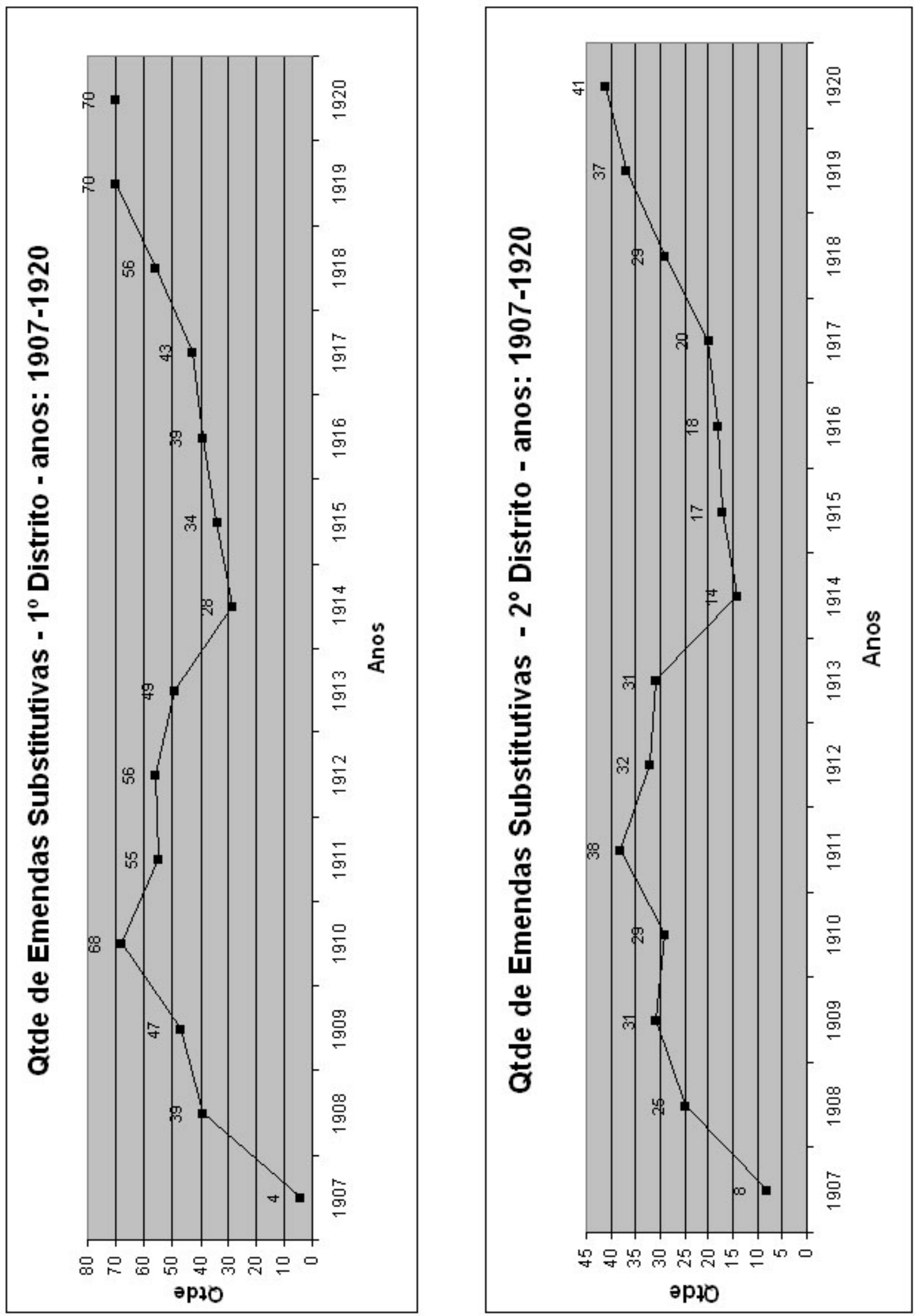

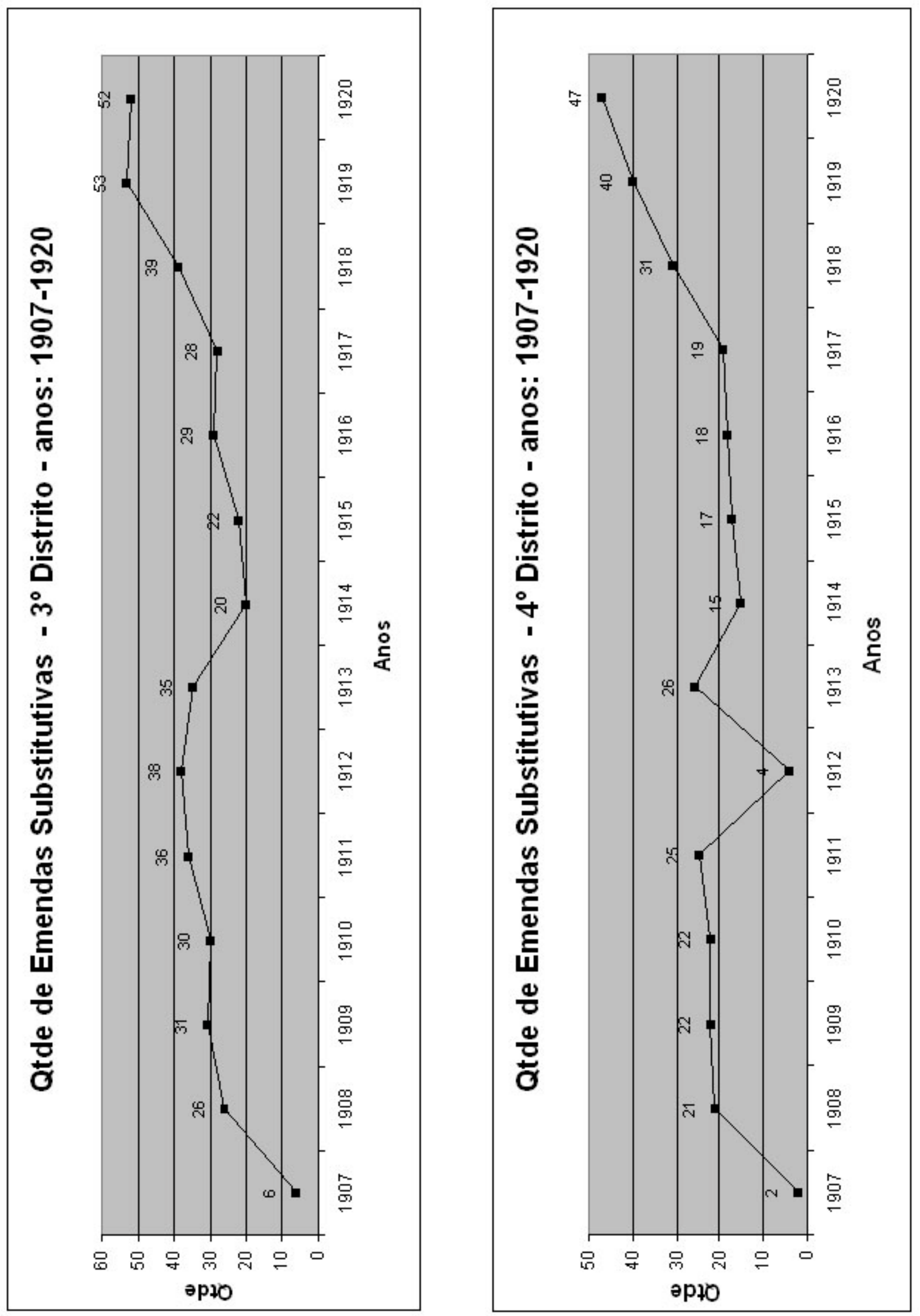

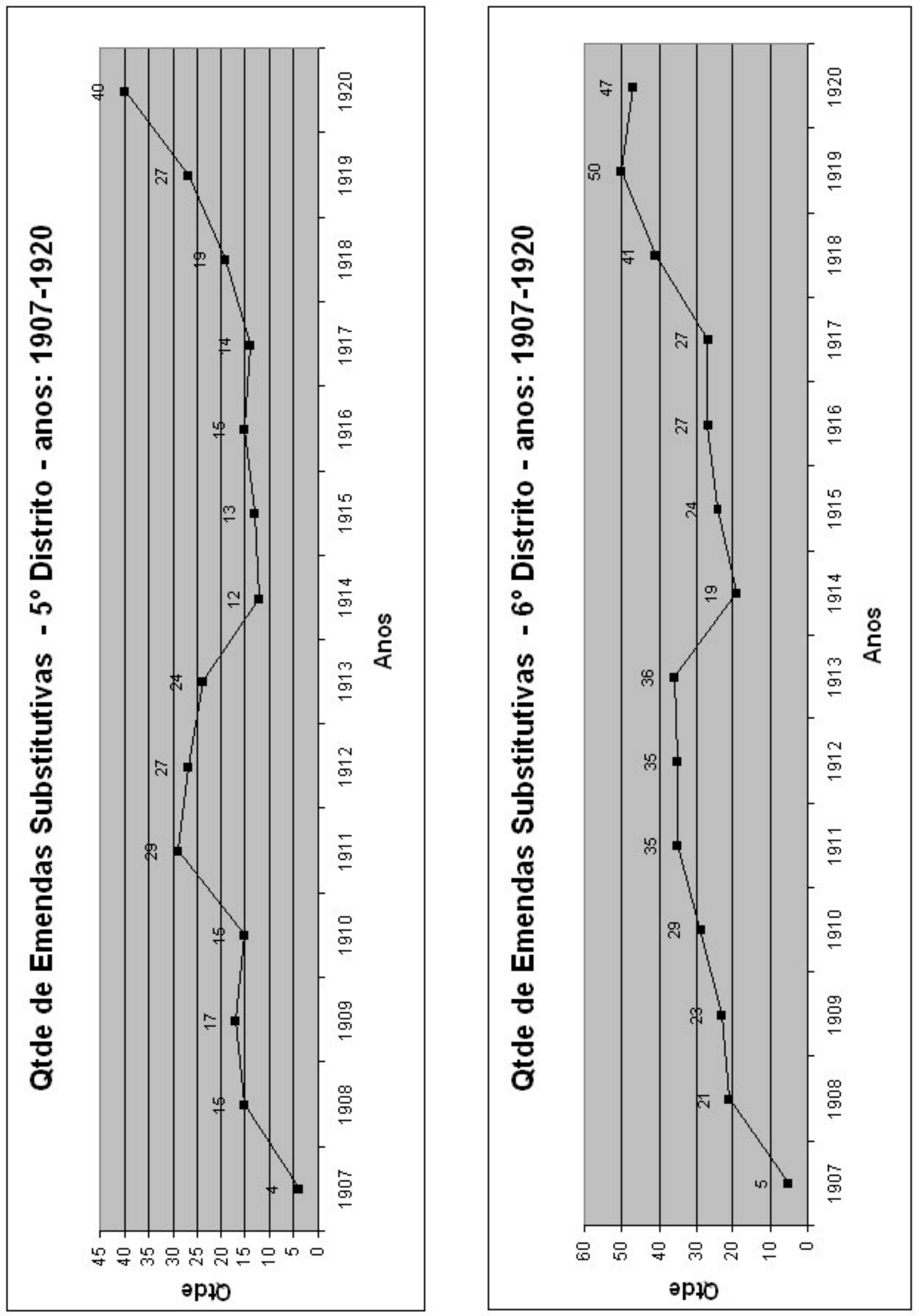

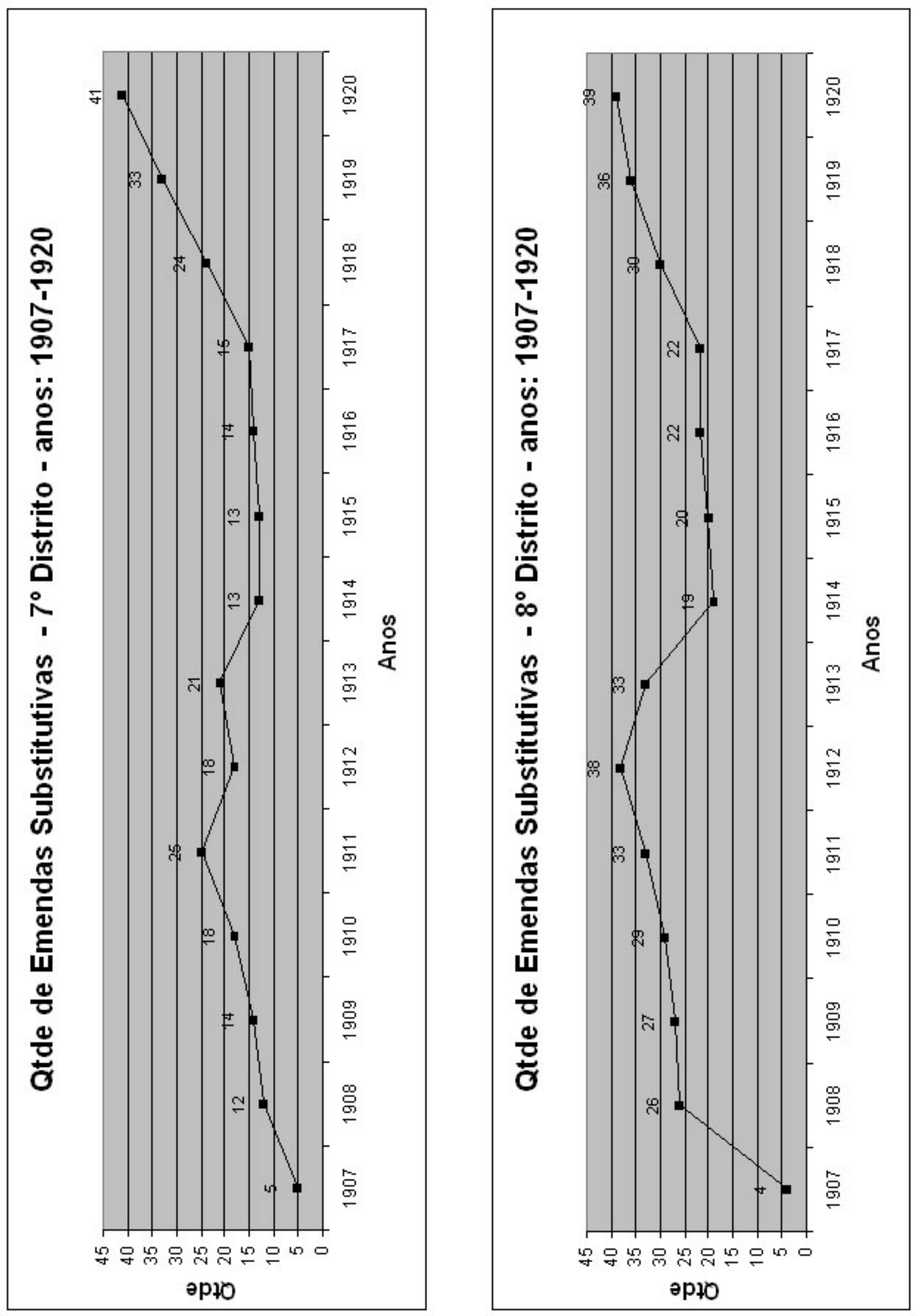

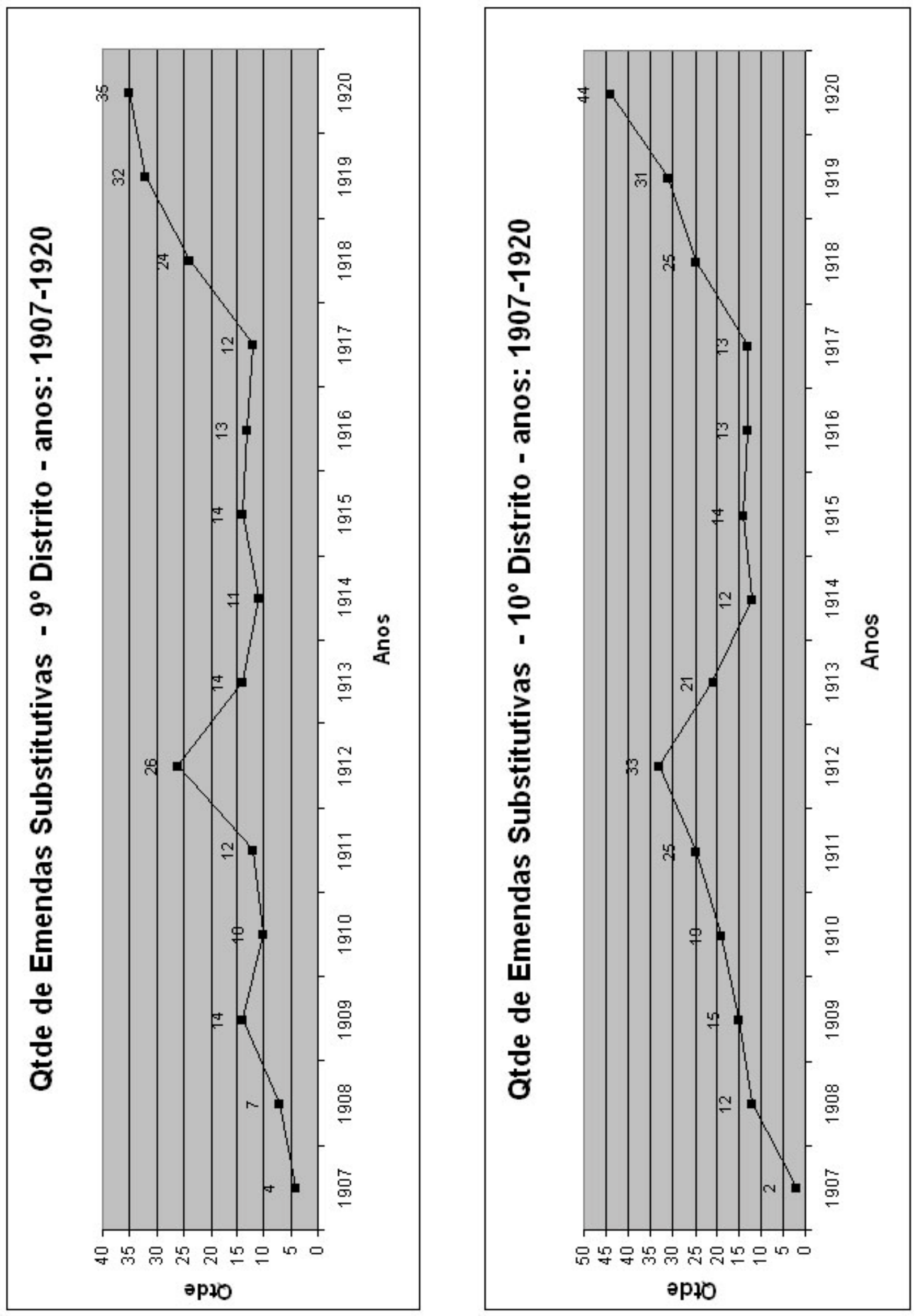


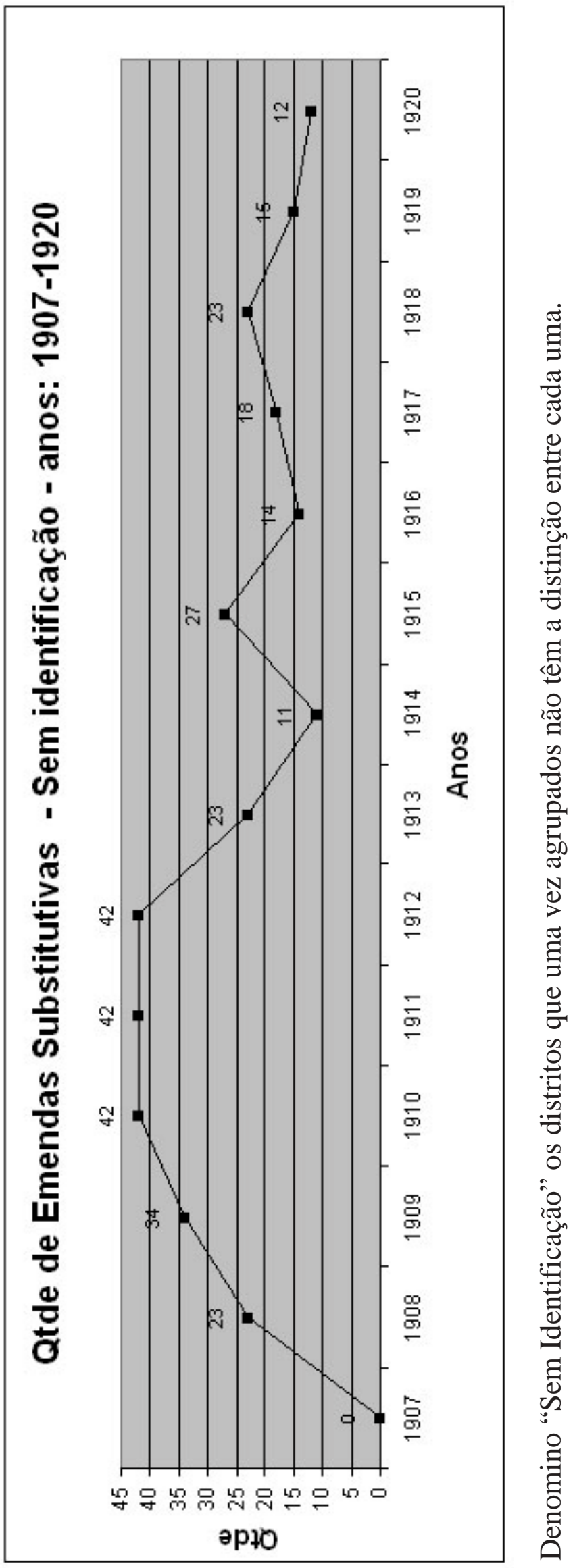


Apêndice F

Série-evolução, por Distrito Eleitoral, do Valor Total das Emendas Substutivas - 1907-1920 

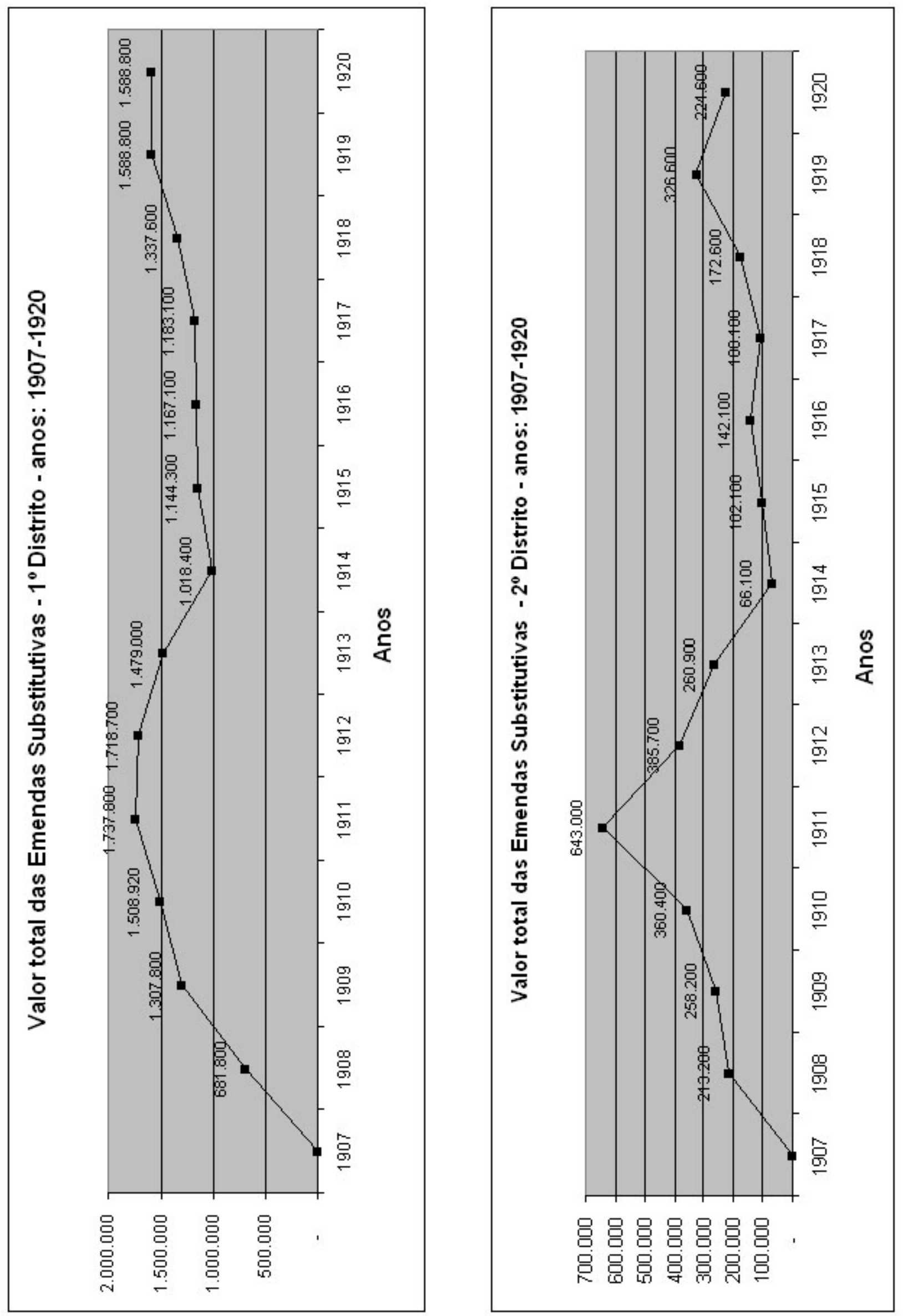

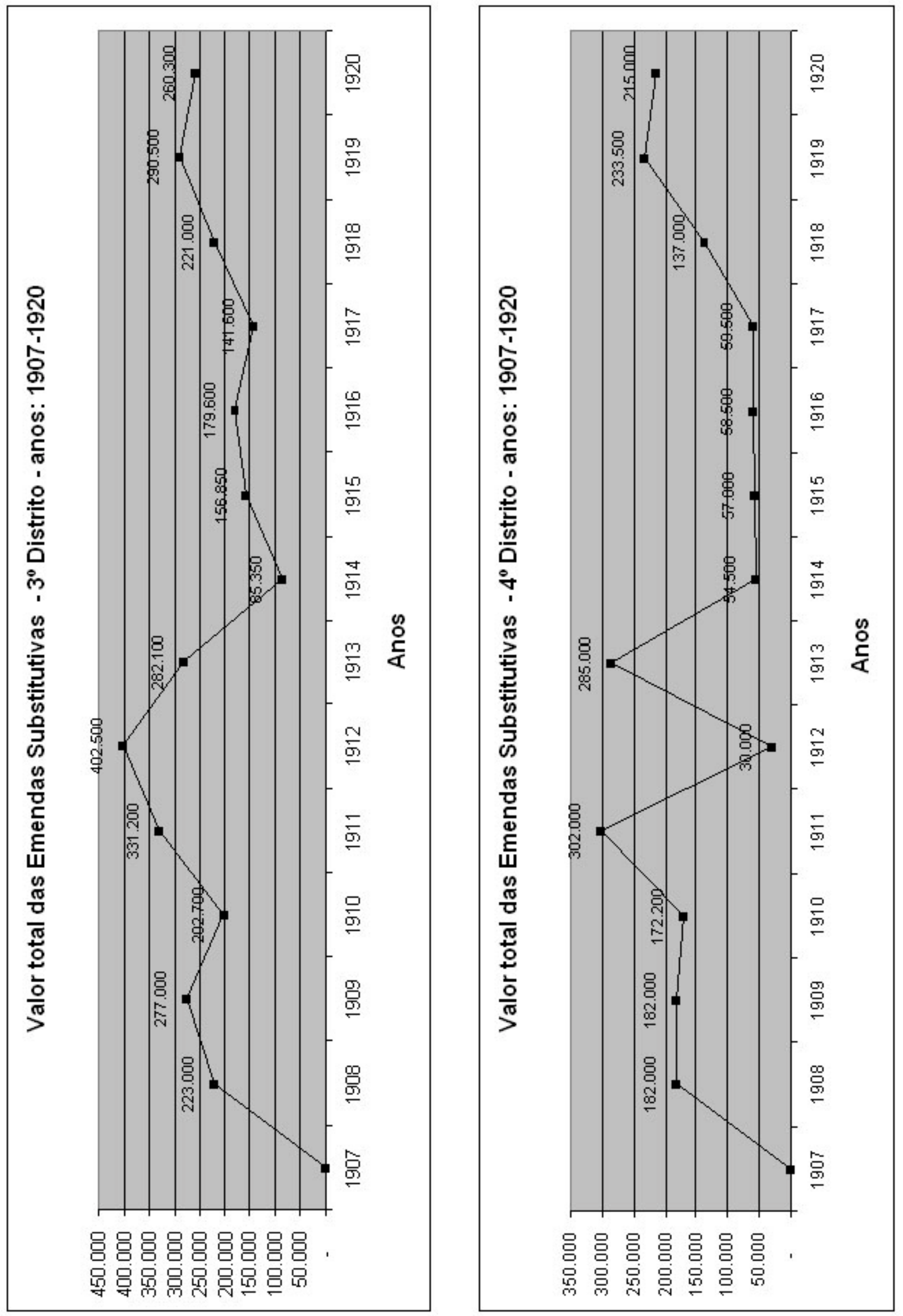

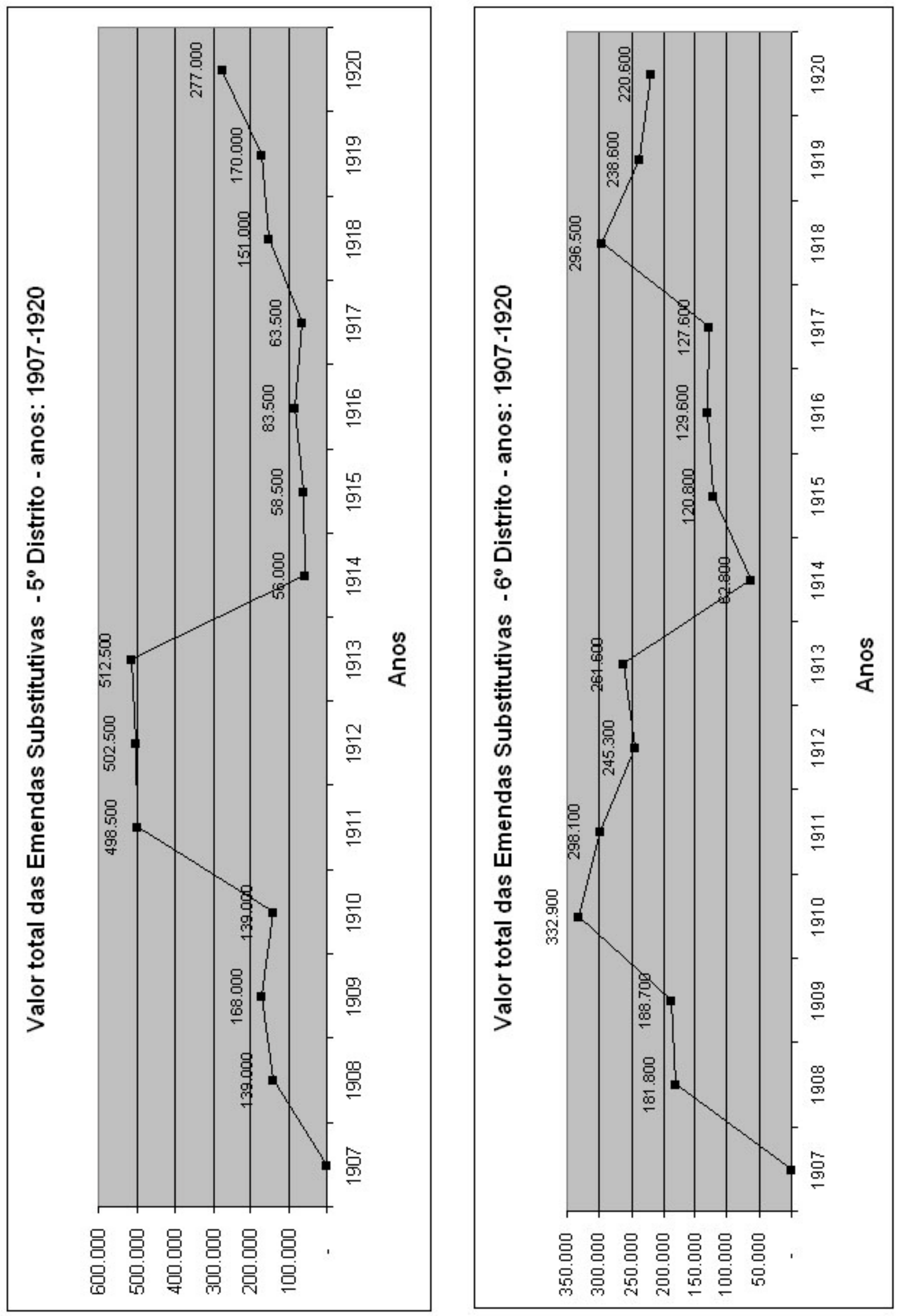

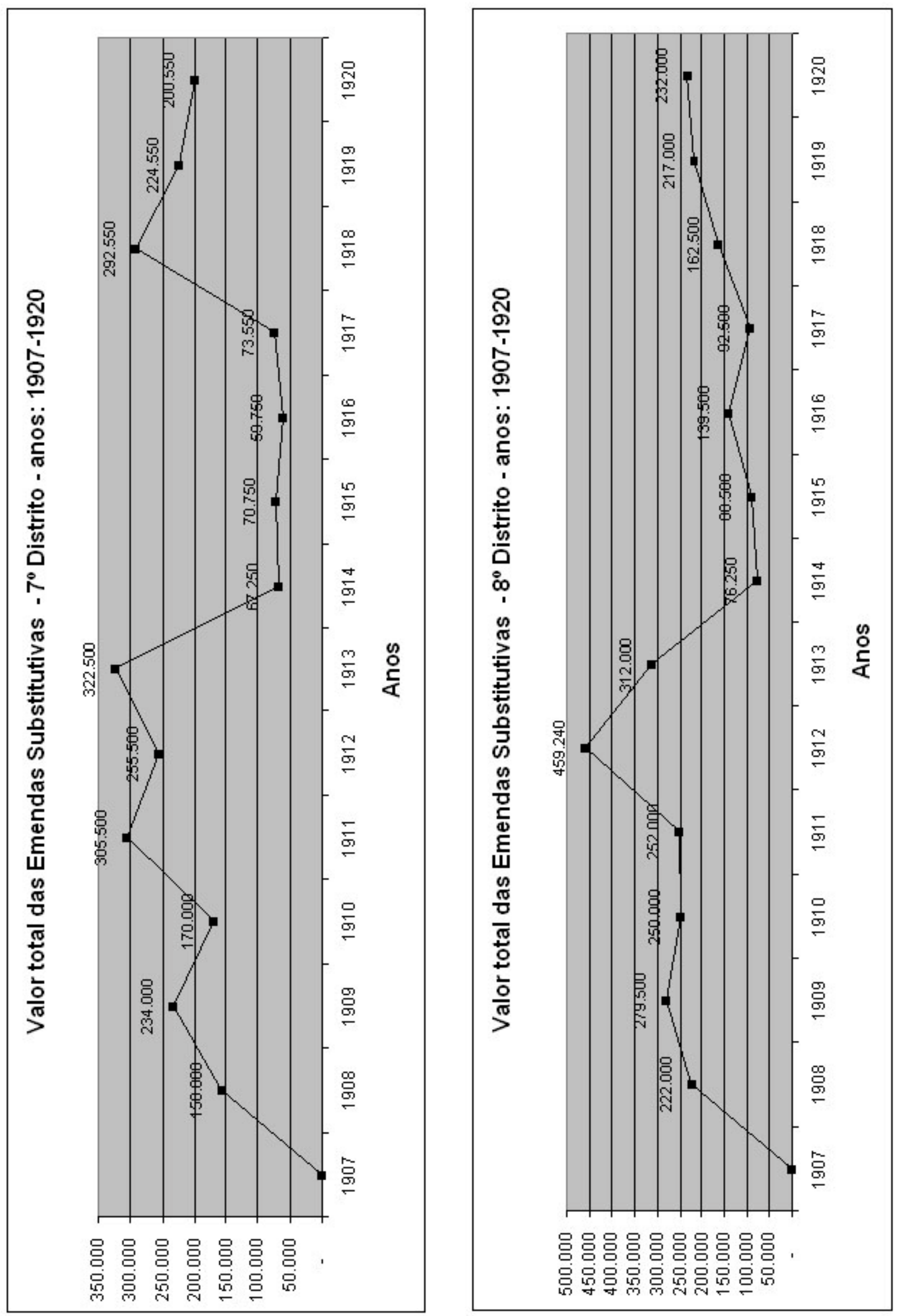

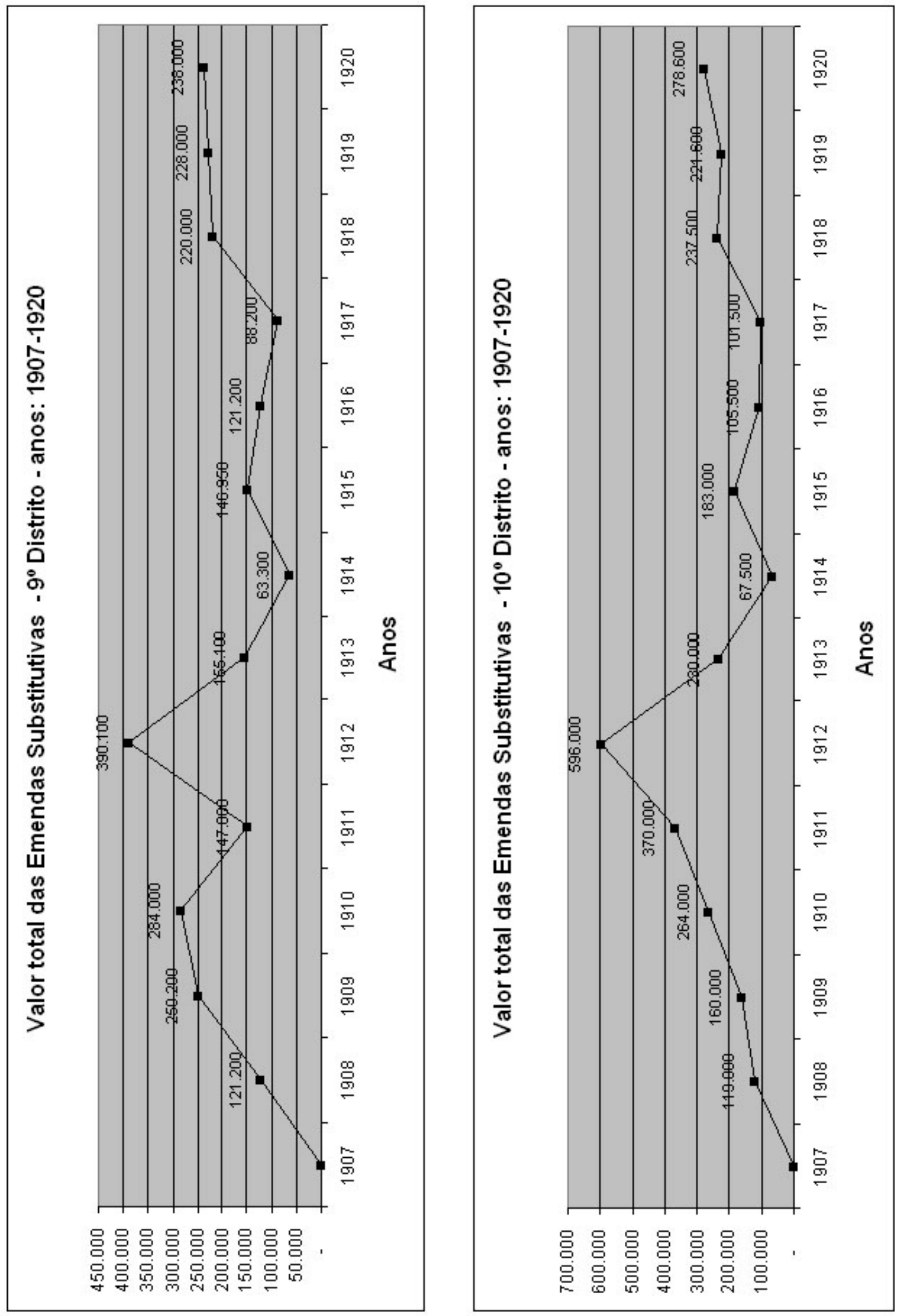


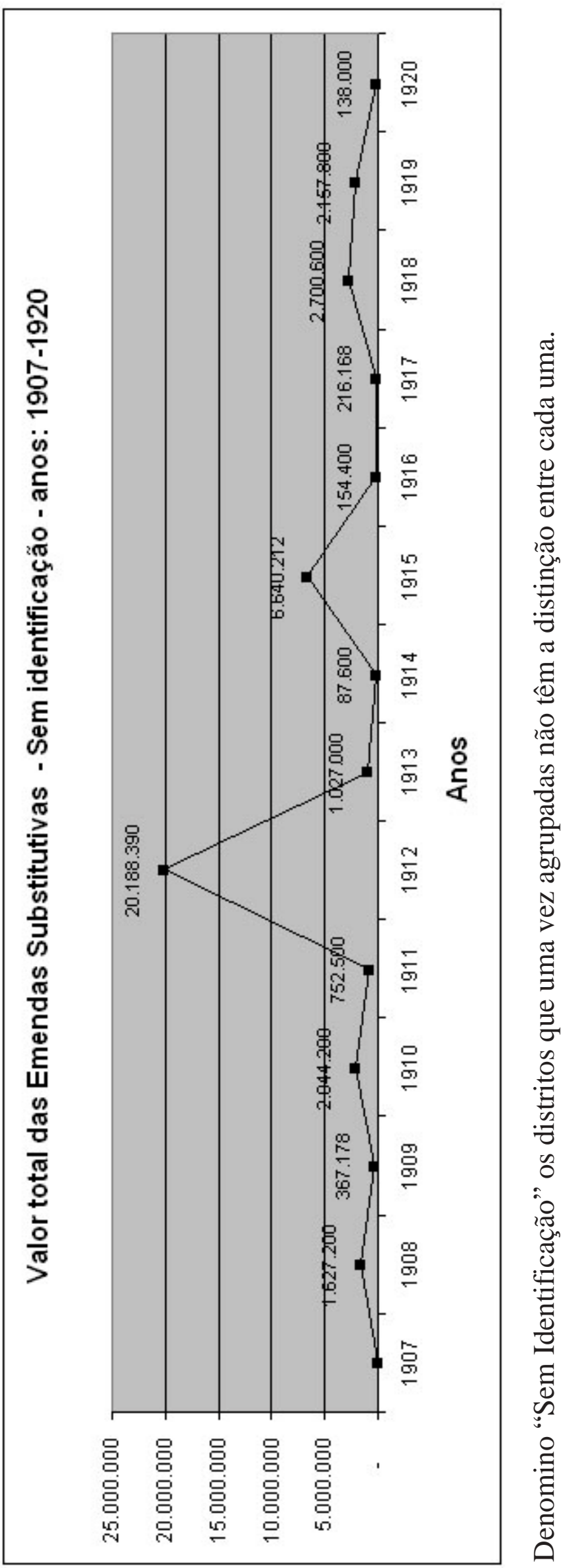


Apêndice G

Comparativo entre Emendas Apresentadas e Aprovadas, por Zonas, 1891-1906 (Quantidade e Valor) 

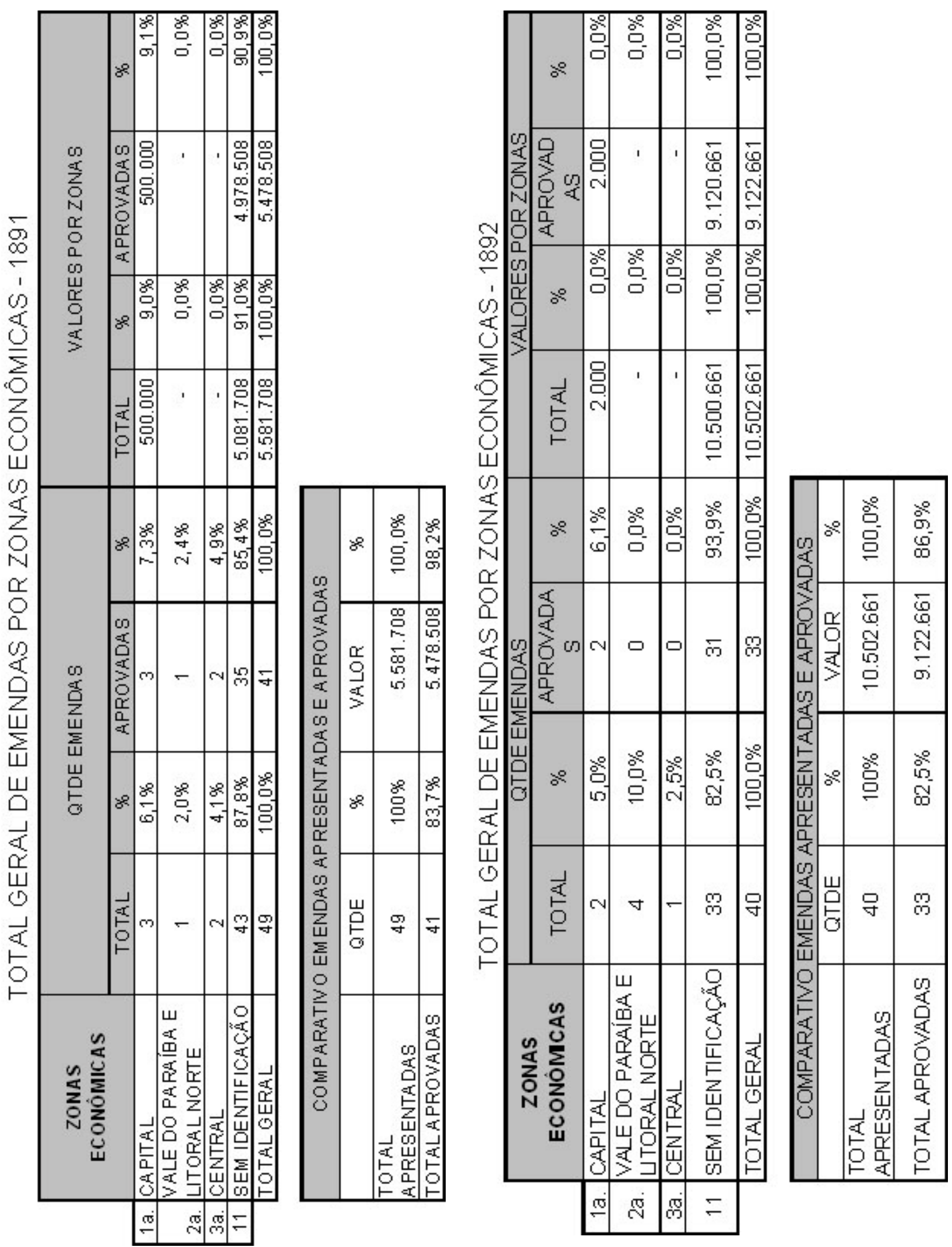

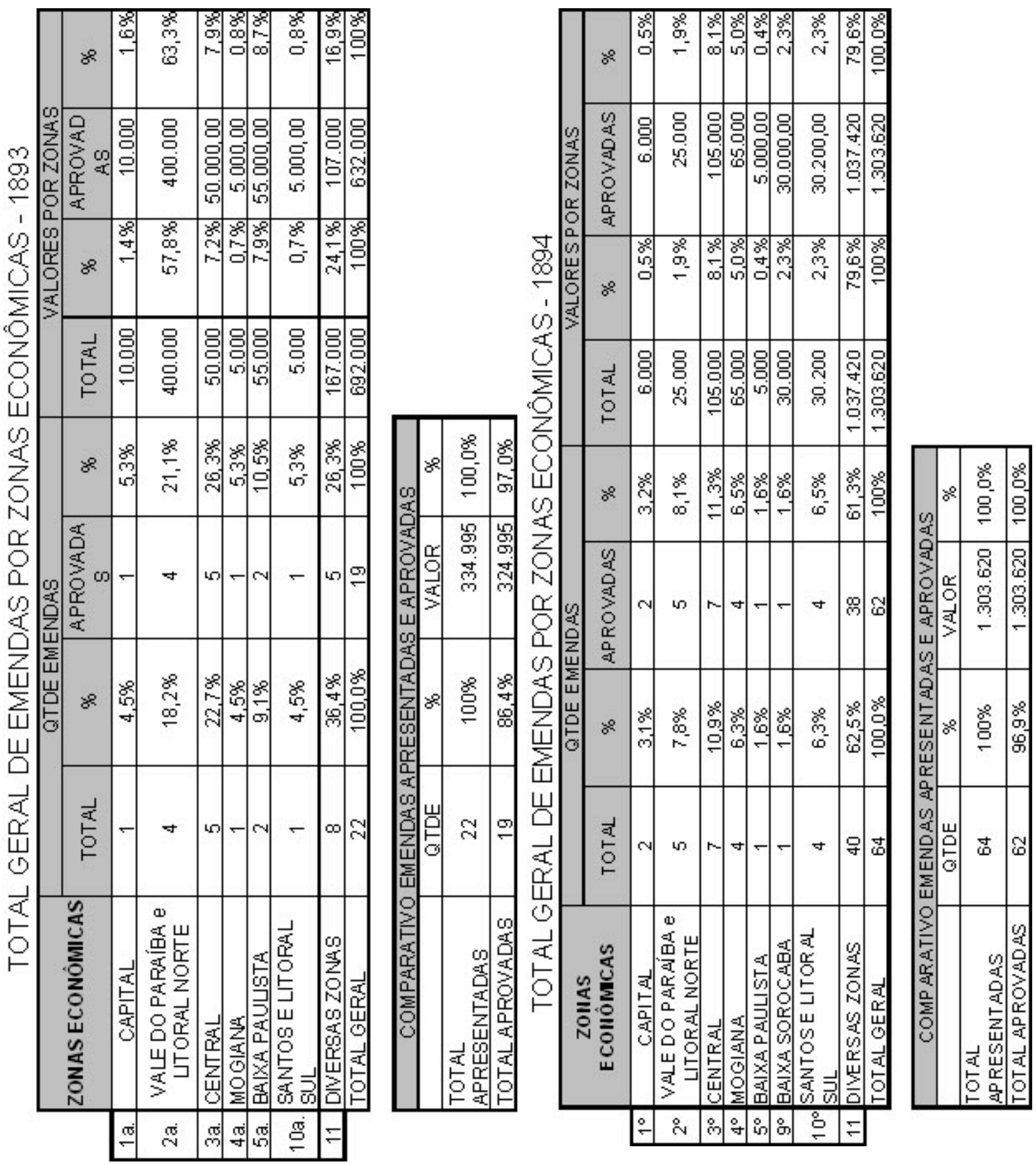

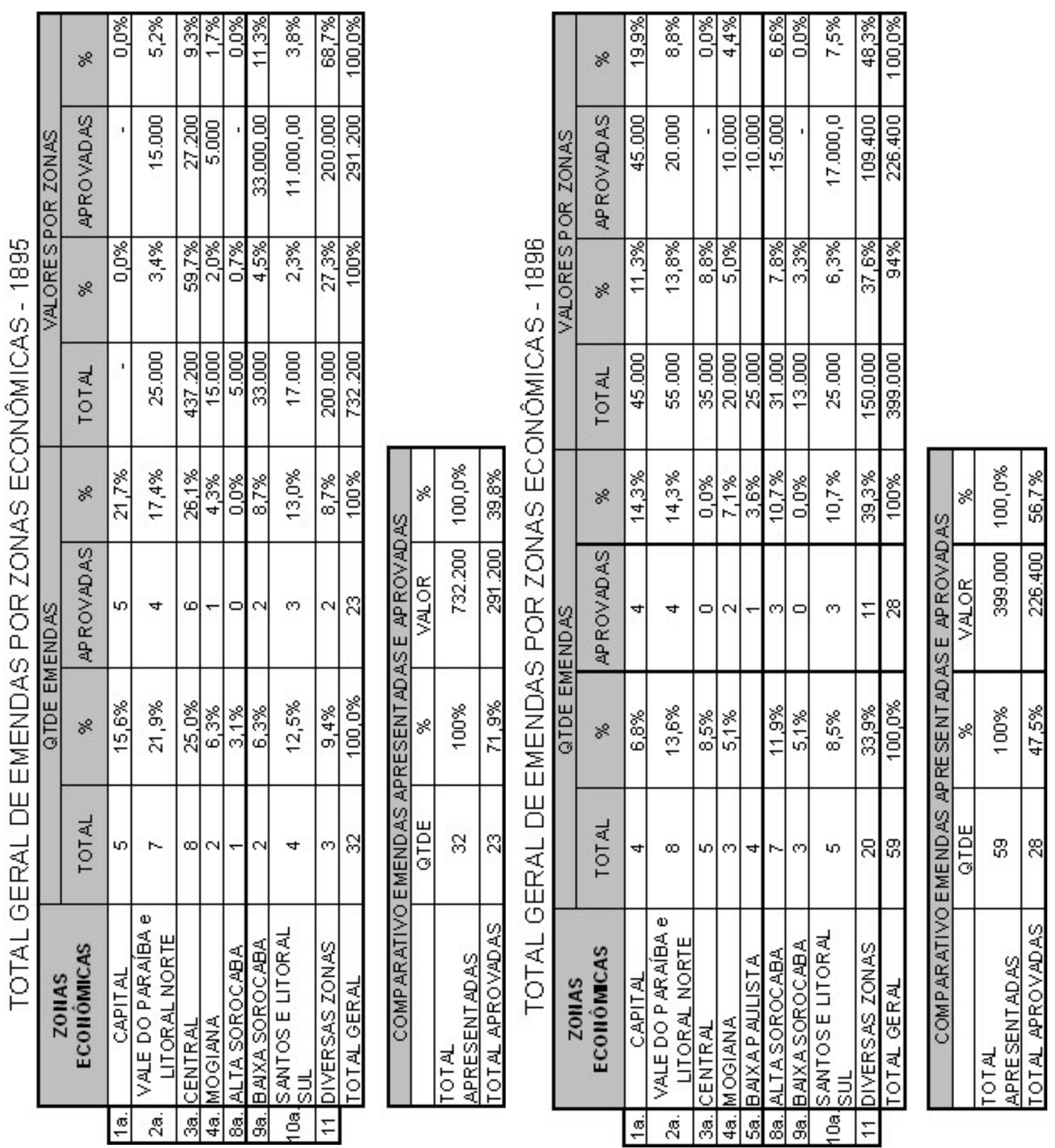

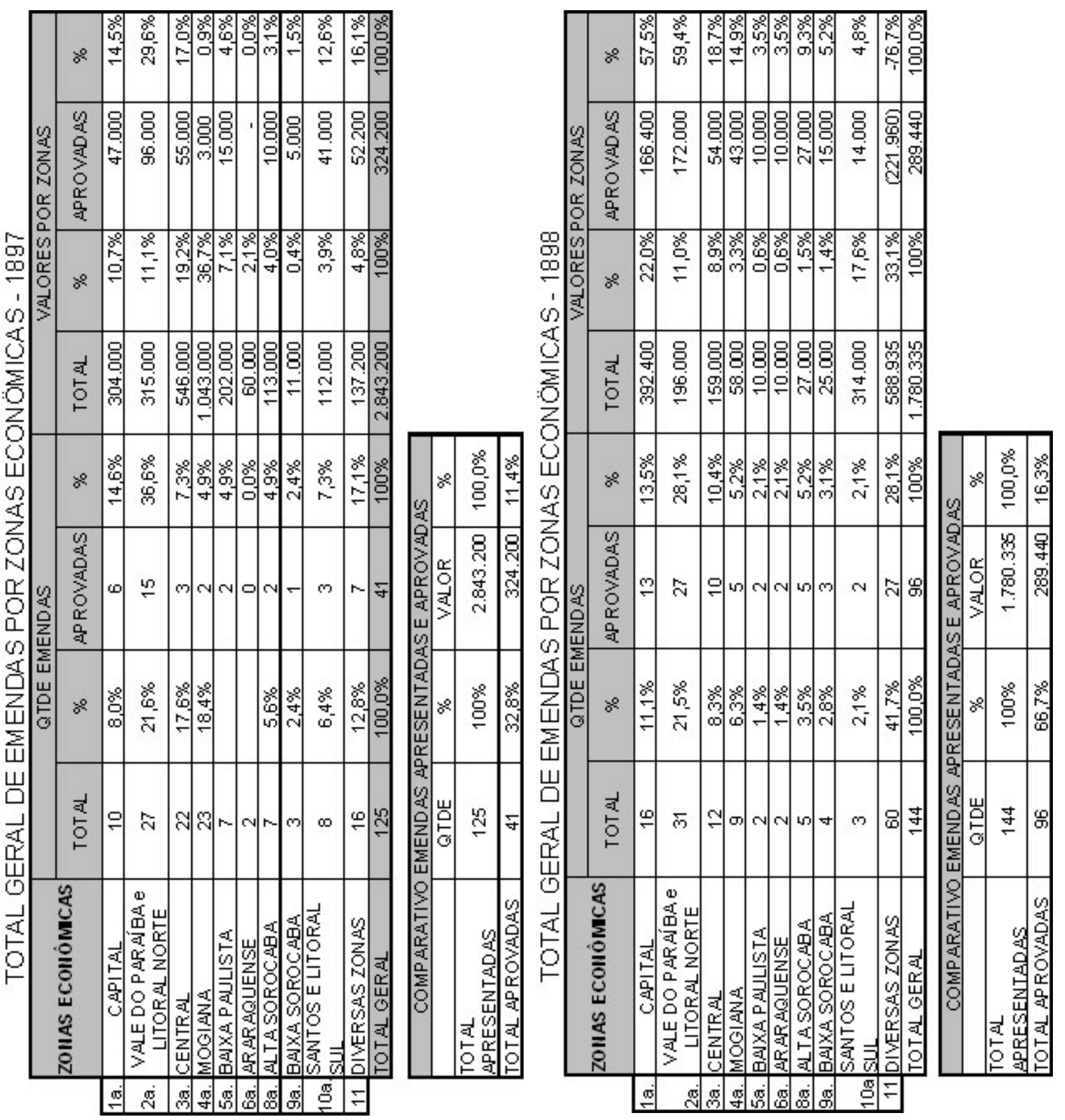

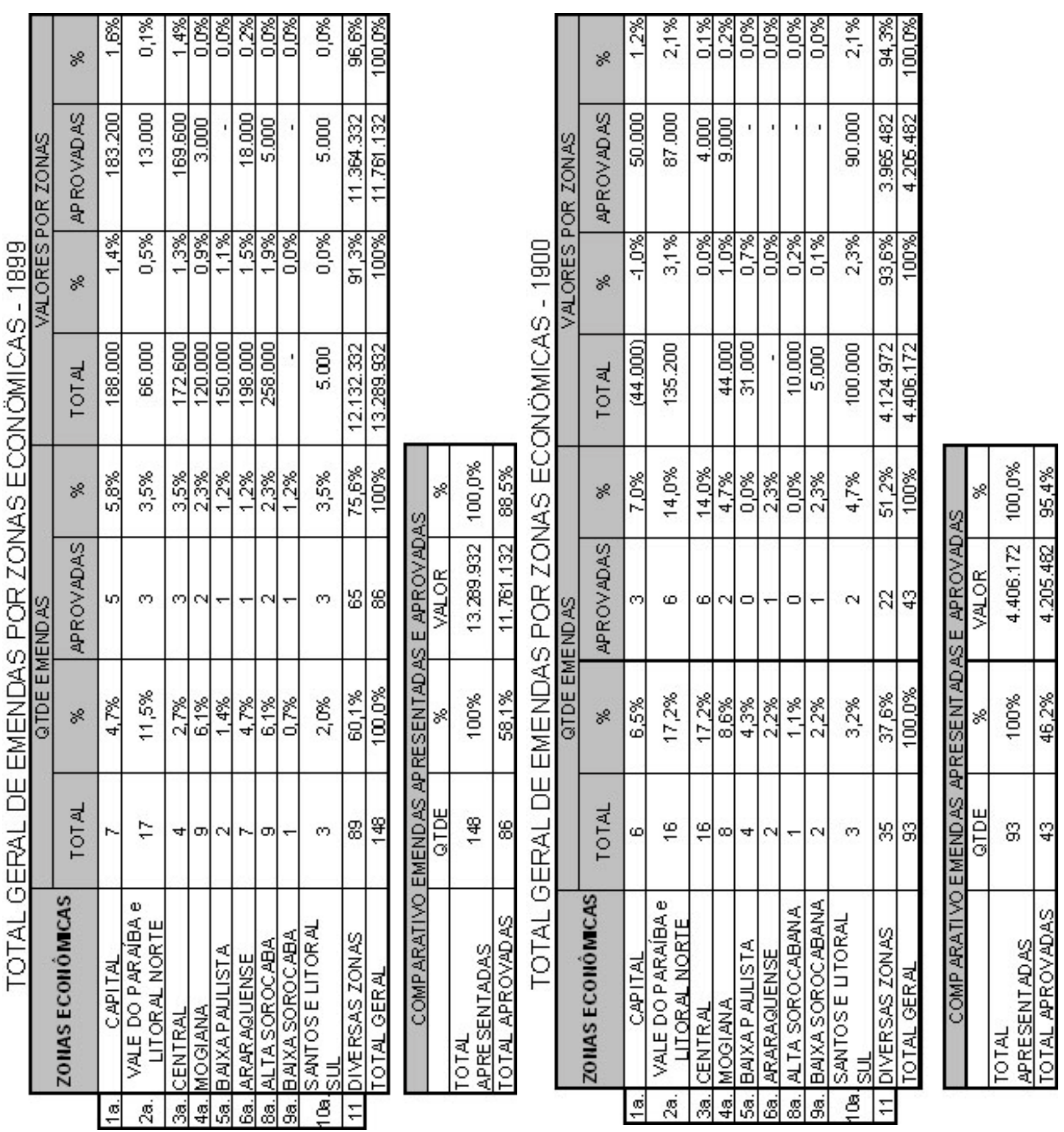

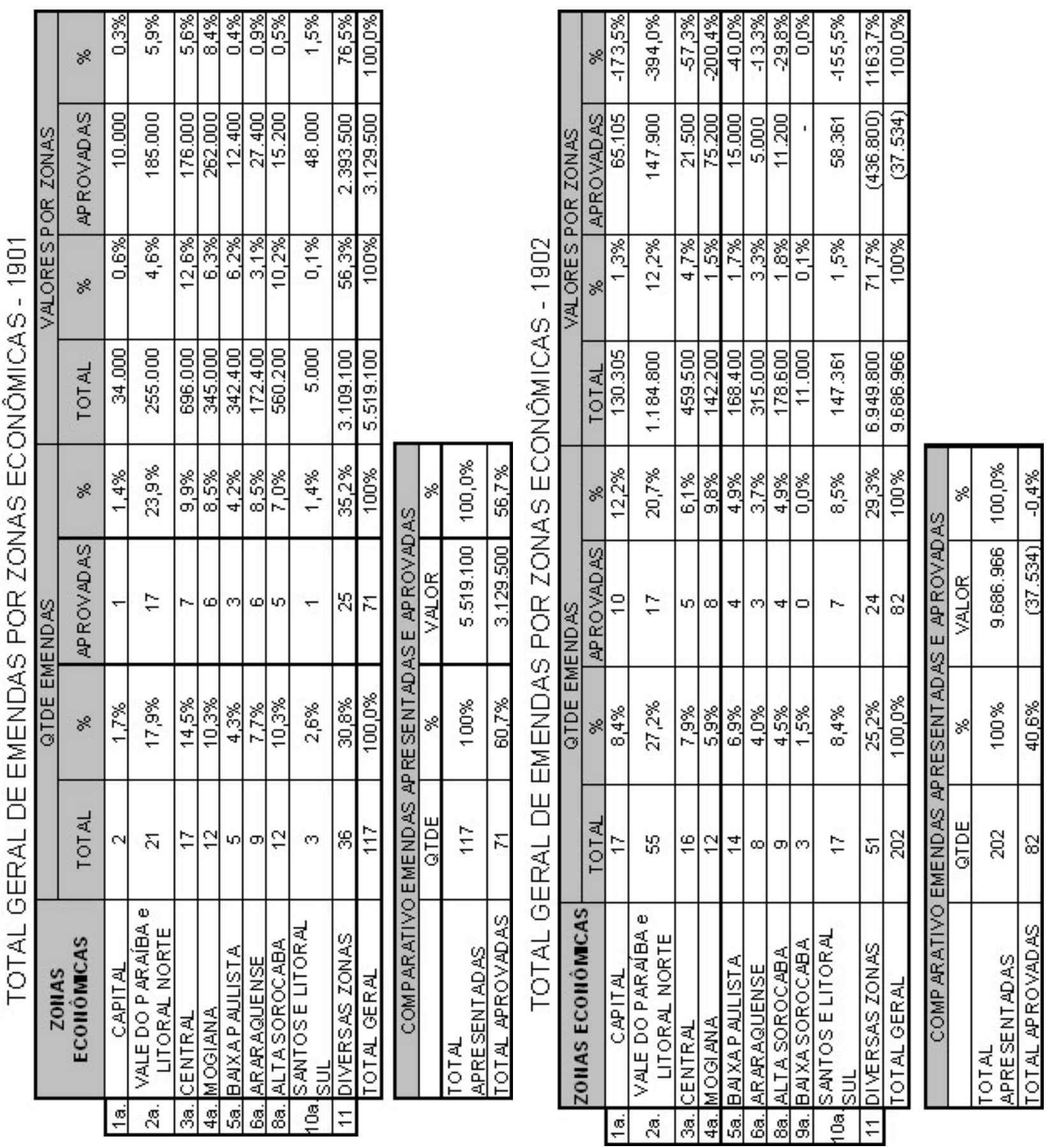

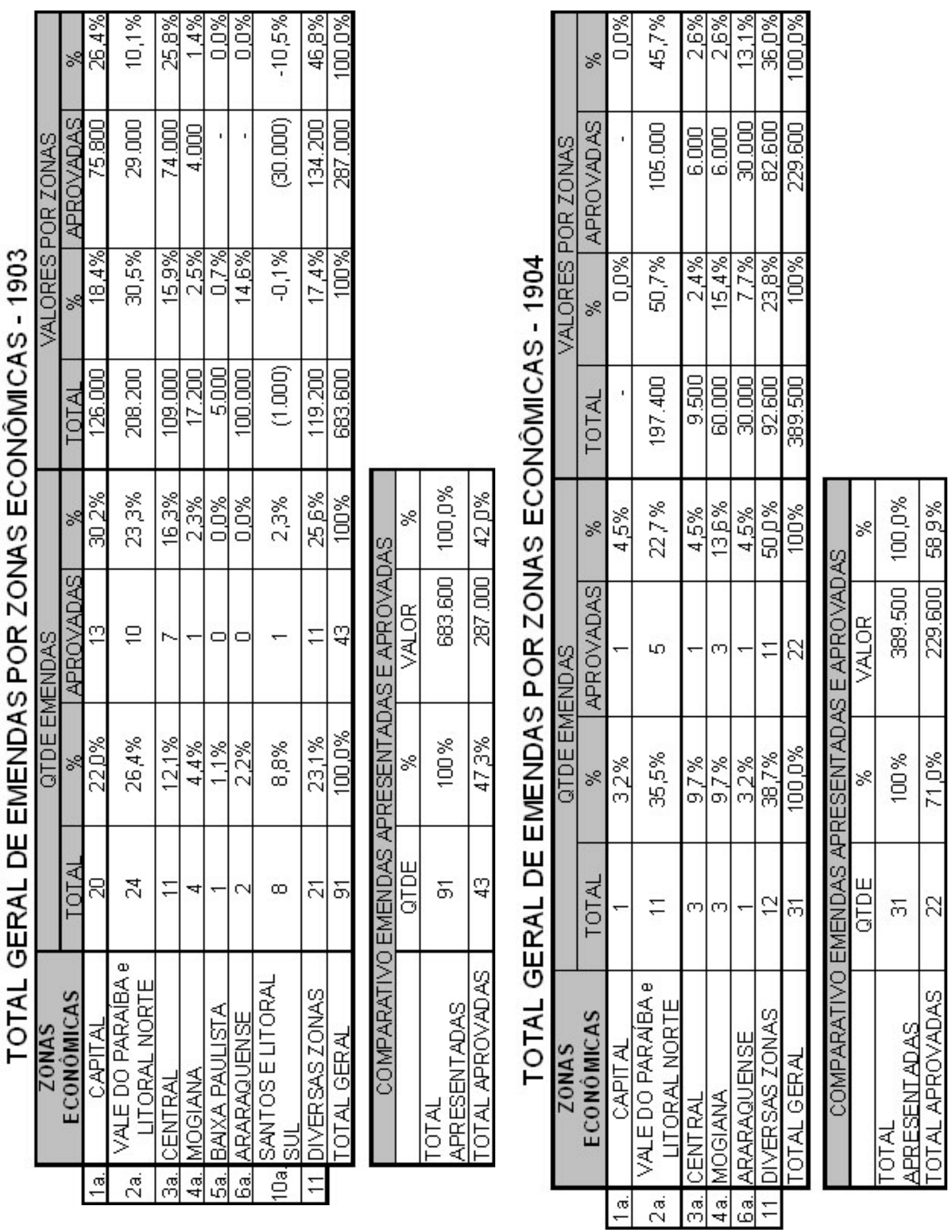

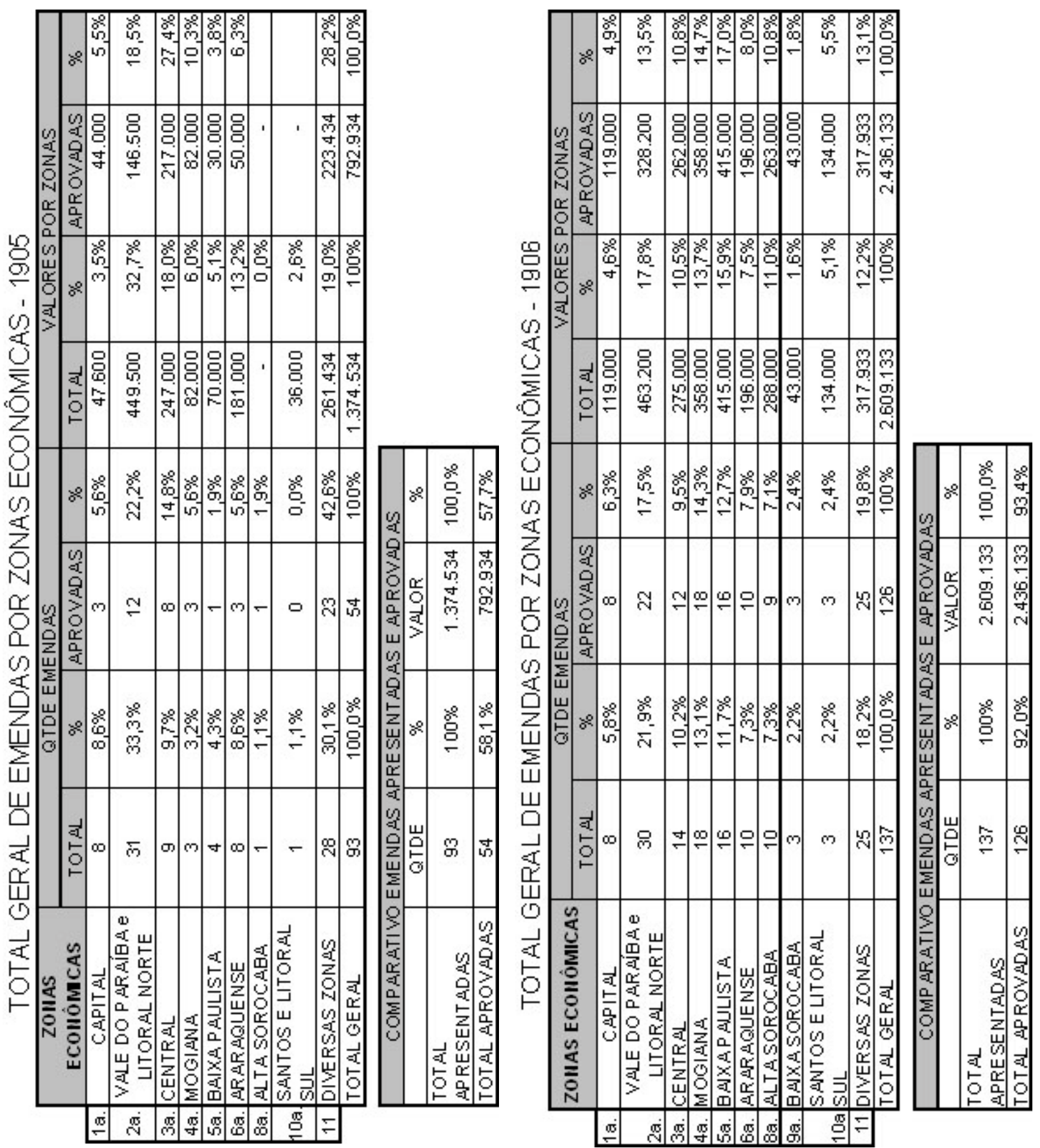
Apêndice H

Comparativo entre Emendas Apresentadas, Rejeitadas e Prejudicadas, por Distrito Eleitoral, 1907-1920

(Quantidade e Valor) 


\begin{tabular}{|c|c|c|c|c|c|c|}
\hline & & Q1 & DE DE EMEI & DAS - 1907 & & \\
\hline $\mathrm{N}^{\circ}$ & SEDE DO DISTRITO & APROVADAS & RE JEIT AD AS & PREJUDICADAS & TOTAL & $\%$ \\
\hline $1^{\circ}$ & CAPITAL & 16 & 17 & 2 & 35 & $13,5 \%$ \\
\hline $2^{\circ}$ & TAUBATÉ & 12 & 6 & 10 & 28 & $10,8 \%$ \\
\hline $3^{\circ}$ & GUARATINGUETÁ & 10 & 5 & 10 & 25 & $9,6 \%$ \\
\hline $4^{\circ}$ & ITÚ & 8 & 11 & 3 & 22 & $8,5 \%$ \\
\hline $5^{\circ}$ & BOTUCATU & 9 & 8 & 4 & 21 & $8,1 \%$ \\
\hline $6^{\circ}$ & CAMPINAS & 7 & 3 & 5 & 15 & $5.8 \%$ \\
\hline $7^{\circ}$ & MOGY-MIRIM & 6 & 2 & 4 & 12 & $4,6 \%$ \\
\hline $8^{\circ}$ & பMEIRA & 8 & 2 & 6 & 16 & $6,2 \%$ \\
\hline $9^{\circ}$ & SÄO CARLOS & 5 & 4 & 4 & 13 & $5,0 \%$ \\
\hline $10^{\circ}$ & RIBEIRÁOO PRETO & 5 & 19 & 3 & 27 & $10,4 \%$ \\
\hline $11^{\circ}$ & SEM IDENTIFICACĂOO & 31 & 11 & 4 & 46 & $17,7 \%$ \\
\hline & TOTAL & 117 & 88 & 55 & 260 & $100,0 \%$ \\
\hline & TOTAL $\%$ & $45,0 \%$ & $33,8 \%$ & $21,2 \%$ & $100,0 \%$ & \\
\hline
\end{tabular}

OBS N01: As Emendas prejudicadas foram substituídas pelas apresentadas pela Comissẫo de Fazenda, entretanto entendo que o mérito continua sendo dos parlamentares que as apresentaram.

OBS N02: As emendas substitutivas contemplam as prejudicadas, sendo que, na maioria das vezes, com valores menores, com a finalidade de ajustar o total de despesas com o total previsto de rec eitas no orçamento.

\begin{tabular}{|c|c|c|c|c|c|c|}
\hline & \multicolumn{6}{|c|}{ VALOR DAS EMENDAS - 1907} \\
\hline $\mathbf{N}^{\circ}$ & SEDE DO DISTRITO & APROVADAS & RE JEIT ADAS & PREJUDIC ADAS & TOTAL & $\%$ \\
\hline $1^{\circ}$ & CAPITAL & 117.400 & 328.500 & 54.000 & 499.900 & $13,7 \%$ \\
\hline $2^{\circ}$ & TAUBATÉ & 105.000 & 46.400 & 181.000 & 332.400 & $9,1 \%$ \\
\hline $3^{\circ}$ & GUARATINGUETÁ & 67.500 & 29.000 & 176.000 & 272.500 & $7,5 \%$ \\
\hline $4^{\circ}$ & ITÚ & 68.000 & 75.500 & 45.000 & 188.500 & $5,2 \%$ \\
\hline $5^{\circ}$ & BOTUCATU & 100.000 & 163.000 & 115.000 & 378.000 & $10,3 \%$ \\
\hline $6^{\circ}$ & CAMPINAS & 73.400 & 32.000 & 111.600 & 217.000 & $5,9 \%$ \\
\hline $7^{\circ}$ & MOGY-MIRIM & 74.500 & 55.000 & 106.000 & 235.500 & $6,4 \%$ \\
\hline $8^{\circ}$ & பMEIRA & 62.000 & 15.000 & 133.000 & 210.000 & $5,7 \%$ \\
\hline $9^{\circ}$ & SÁO CARLOS & 105.000 & 69.000 & 130.000 & 304.000 & $8,3 \%$ \\
\hline $10^{\circ}$ & RIBEIRÄO PRETO & 55.000 & 583.000 & 120.000 & 758.000 & $20,7 \%$ \\
\hline & SEM IDENTIFICACÄ́O & 218.066 & 40.400 & 3.200 & 261.666 & $7,2 \%$ \\
\hline & TOTAL & 1.045 .866 & 1.436 .800 & 1.174 .800 & 3.657 .466 & $100,0 \%$ \\
\hline & TOTAL $\%$ & $28,6 \%$ & $39,3 \%$ & $32,1 \%$ & $100,0 \%$ & \\
\hline
\end{tabular}

OBS N01: As Emendas prejudicadas foram substituídas pelas apresentadas pela Comissẫo de $\mathrm{Fazenda,}$ entretanto entendo que o mérito continua sendo dos parlamentares que as apresentaram

OBS $N^{\circ} 02$ : As emendas substitutivas contemplam as prejudicadas, sendo que, na maioria das vezes, com valores menores, com a finalidade de ajustar o total de despesas com o total previsto de rec eitas no orçamento. 


\begin{tabular}{|c|c|c|c|c|c|c|}
\hline & \multicolumn{6}{|c|}{ QTDE DE EMENDAS - 1908} \\
\hline $\mathbf{N}^{\circ}$ & SEDE DO DISTRITO & APROVADAS & RE JEIT ADAS & PRE JUDIC AD AS & TOTAL & $\%$ \\
\hline $1^{\circ}$ & CAPITAL & 4 & 0 & 45 & 49 & $13,5 \%$ \\
\hline $2^{\circ}$ & TAUBATÉ & 1 & 0 & 43 & 44 & $12,1 \%$ \\
\hline $3^{\circ}$ & GUARATINGUETÁ & 0 & 0 & 31 & 31 & $8,5 \%$ \\
\hline $4^{\circ}$ & ITÚ & 1 & 0 & 31 & 32 & $8,8 \%$ \\
\hline $5^{\circ}$ & BOTUCATU & 3 & 0 & 25 & 28 & $7,7 \%$ \\
\hline $6^{\circ}$ & CAMPINAS & 0 & 0 & 35 & 35 & $9.6 \%$ \\
\hline $7^{\circ}$ & MOGY-MIRIM & 0 & 0 & 20 & 20 & $5,5 \%$ \\
\hline $8^{\circ}$ & பMEIRA & 0 & 0 & 38 & 38 & $10,5 \%$ \\
\hline $9^{\circ}$ & SÃO CARLOS & 3 & 0 & 5 & 8 & $2,2 \%$ \\
\hline $10^{\circ}$ & RIBEIRÅO PRETO & 1 & 0 & 26 & 27 & $7,4 \%$ \\
\hline $11^{\circ}$ & SEM IDENTIFICACÄ́O & 20 & 1 & 30 & 51 & $14,0 \%$ \\
\hline & TOTAL & 33 & 1 & 329 & 363 & $100,0 \%$ \\
\hline & TOTAL $\%$ & $9,1 \%$ & $0,3 \%$ & $90,6 \%$ & $100,0 \%$ & \\
\hline
\end{tabular}

OBS N 01: As Emendas prejudicadas foram substituídas pelas apresentadas pela Comissão de $\mathrm{F}$ azenda, entretanto entendo que o mérito continua sendo dos parlamentares que as apresentaram

OBS No 02: As emendas substitutivas contemplam as prejudicadas, sendo que, na maioria das vezes, com valores menores, com a finalidade de ajustar o total de despesas com o total previsto de rec eitas no orçamento.

\begin{tabular}{|c|c|c|c|c|c|c|}
\hline & \multicolumn{6}{|c|}{ VALOR DAS EMENDAS - ANO 1908} \\
\hline $\mathbf{N}^{0}$ & SEDE DO DISTRITO & APROVADAS & RE JEIT AD AS & PREJUDIC ADAS & TOTAL & $\%$ \\
\hline $1^{\circ}$ & CAPITAL & 5.000 & - & 900.900 & 905.900 & $21,2 \%$ \\
\hline $2^{\circ}$ & TAUBATÉ & - & - & 460.400 & 460.400 & $10,8 \%$ \\
\hline $3^{\circ}$ & GUARATINGUETÁ & - & - & 278.000 & 278.000 & $6,5 \%$ \\
\hline $4^{\circ}$ & ITÚ & 5.000 & - & 360.000 & 365.000 & $8,5 \%$ \\
\hline $5^{\circ}$ & BOTUCATU & 4.000 & - & 327.000 & 331.000 & $7,7 \%$ \\
\hline $6^{\circ}$ & CAMPINAS & - & - & 360.600 & 360.600 & $8,4 \%$ \\
\hline $7^{\circ}$ & MOGY-MIRIM & - & - & 310.000 & 310.000 & $7,2 \%$ \\
\hline $8^{\circ}$ & பMEIRA & - & - & 403.500 & 403.500 & $9,4 \%$ \\
\hline $9^{\circ}$ & SÅO CARLOS & 10.000 & & 76.200 & 86.200 & $2,0 \%$ \\
\hline $10^{\circ}$ & RIBEIRÁO PRETO & 5.000 & & 399.500 & 404.500 & $9,4 \%$ \\
\hline $11^{\circ}$ & SEM IDENTIFICACÄO & 154.300 & - & 222.800 & 377.100 & $8,8 \%$ \\
\hline & TOTAL & 183.300 & - & 4.098 .900 & 4.282 .200 & $100,0 \%$ \\
\hline & TOTAL \% & $4,3 \%$ & $0,0 \%$ & $95,7 \%$ & $100,0 \%$ & \\
\hline
\end{tabular}

OBS N01: As Emendas prejudicadas foram substituídas pelas apresentadas pela Comissẫo de Fazenda, entretanto entendo que o mérito continua sendo dos parlamentares que as apresentaram

OBS N02: As emendas substitutivas contemplam as prejudicadas, sendo que, na maioria das vezes, com valores menores, com a finalidade de ajustar o total de despesas com o total previsto de rec eitas no orçamento.

\begin{tabular}{|l|l|r|r|r|c|}
\hline \multicolumn{7}{|c|}{ EMENDAS SUBSTITUTIVAS - 1908} \\
\hline $\mathbf{N}^{\circ}$ & SEDE DO DISTRITO & QTDE & $\%$ QTDE & \multicolumn{1}{c|}{ VALOR } & $\%$ VALOR \\
\hline $1^{\circ}$ & CAPITAL & 39 & $17,2 \%$ & 681.800 & $17,6 \%$ \\
\hline $2^{\circ}$ & TAUBATÉ & 25 & $11,0 \%$ & 213.200 & $5,5 \%$ \\
\hline $3^{\circ}$ & GUARATINGUETÁ & 26 & $11,5 \%$ & 223.000 & $5,8 \%$ \\
\hline $4^{\circ}$ & ITÚ & 21 & $9,3 \%$ & 182.000 & $4,7 \%$ \\
\hline $5^{\circ}$ & BOTUCATU & 15 & $6,6 \%$ & 139.000 & $3,6 \%$ \\
\hline $6^{\circ}$ & CAMPINAS & 21 & $9,3 \%$ & 181.800 & $4,7 \%$ \\
\hline $7^{\circ}$ & MOGY-MIRIM & 12 & $5,3 \%$ & 158.000 & $4,1 \%$ \\
\hline $8^{\circ}$ & LIMEIRA & 26 & $11,5 \%$ & 222.000 & $5,7 \%$ \\
\hline $9^{\circ}$ & SÄO CARLOS & 7 & $3,1 \%$ & 121.200 & $3,1 \%$ \\
\hline $10^{\circ}$ & RIBEIRAिO PRETO & 12 & $5,3 \%$ & 119.000 & $3,1 \%$ \\
\hline $11^{\circ}$ & SEM IDENTIFICACÁO & 23 & $10,1 \%$ & 1.627 .200 & $42,1 \%$ \\
\hline \multicolumn{2}{|c|}{ TOTAL } & 227 & $100 \%$ & 3.868 .200 & $100 \%$ \\
\hline
\end{tabular}




\begin{tabular}{|c|c|c|c|c|c|c|}
\hline & \multicolumn{6}{|c|}{ QTDE DE EMENDAS - 1909} \\
\hline $\mathbf{N}^{\circ}$ & SEDE DO DISTRITO & APROVADAS & RE JEIT ADAS & PRE JUDIC AD AS & TOTAL & $\%$ \\
\hline $1^{\circ}$ & CAPITAL & 6 & 0 & 67 & 73 & $16,5 \%$ \\
\hline $2^{\circ}$ & TAUBATÉ & 2 & 1 & 45 & 48 & $10,8 \%$ \\
\hline $3^{\circ}$ & GUARATINGUETÁ & 3 & 0 & 38 & 41 & $9,3 \%$ \\
\hline $4^{\circ}$ & ITÚ & 0 & 6 & 36 & 42 & $9,5 \%$ \\
\hline $5^{\circ}$ & BOTUCATU & 0 & 0 & 26 & 26 & $5,9 \%$ \\
\hline $6^{\circ}$ & CAMPINAS & 0 & 0 & 21 & 21 & $4,7 \%$ \\
\hline $7^{\circ}$ & MOGY-MIRIM & 2 & 0 & 24 & 26 & $5,9 \%$ \\
\hline $8^{\circ}$ & LMEIRA & 2 & 2 & 33 & 37 & $8,4 \%$ \\
\hline $9^{\circ}$ & SÄ́O CARLOS & 0 & 0 & 21 & 21 & $4,7 \%$ \\
\hline $10^{\circ}$ & RIBEIRÄO PRETO & 1 & 1 & 22 & 24 & $5,4 \%$ \\
\hline & SEM IDENTIFICACÁ̃O & 40 & 3 & 41 & 84 & $19,0 \%$ \\
\hline & TOTAL & 56 & 13 & 374 & 443 & $100,0 \%$ \\
\hline & TOTAL \% & $12,6 \%$ & $2,9 \%$ & $84,4 \%$ & $100,0 \%$ & \\
\hline
\end{tabular}

OBS N01: As Emendas prejudicadas foram substituídas pelas apresentadas pela Comissẫo de Fazenda, entretanto entendo que o mérito continua sendo dos parlamentares que as apresentaram

OBS N02: As emendas substitutivas contemplam as prejudicadas, sendo que, na maioria dasvezes, com valores menores, com a finalidade de ajustar o total de despesas com o total previsto de rec eitas no orçamento.

\begin{tabular}{|c|c|c|c|c|c|c|}
\hline & \multicolumn{6}{|c|}{ VALOR DAS EMENDAS - 1909} \\
\hline $\mathbf{N}^{\circ}$ & SEDE DO DISTRITO & APROVADAS & RE JEITADAS & PREJUDIC ADAS & TOTAL & $\%$ \\
\hline $1^{\circ}$ & CAPITAL & 11.000 & & 992.850 & 1.003 .850 & $18,8 \%$ \\
\hline $2^{\circ}$ & TAUBATÉ & $(7.000)$ & 1.000 & 473.700 & 467.700 & $8,8 \%$ \\
\hline $3^{\circ}$ & GUARATINGUETÁ & 3000 & & 312.000 & 315.000 & $5,9 \%$ \\
\hline $4^{\circ}$ & ITÚ & & 6.000 & 464.000 & 470.000 & $8,8 \%$ \\
\hline $5^{\circ}$ & BOTUCATU & - & - & 489.700 & 489.700 & $9,2 \%$ \\
\hline $6^{\circ}$ & CAMPINAS & - & - & 291.200 & 291.200 & $5,5 \%$ \\
\hline $7^{\circ}$ & MOGY-MIRIM & 7.000 & - & 337.000 & 344.000 & $6,5 \%$ \\
\hline $8^{\circ}$ & பMEIRA & 2.000 & 3.000 & 383.500 & 388.500 & $7,3 \%$ \\
\hline $9^{\circ}$ & SÁO CARLOS & - & - & 561.000 & 561.000 & $10,5 \%$ \\
\hline $10^{\circ}$ & RIBEIRÁO PRETO & - & 30.000 & 261.200 & 291.200 & $5,5 \%$ \\
\hline & SEM IDENTIFICACÄ́O & 232.814 & 2.000 & 469.720 & 704.534 & $13,2 \%$ \\
\hline & TOTAL & 248.814 & 42.000 & 5.035 .870 & 5.326 .684 & $100,0 \%$ \\
\hline & TOTAL $\%$ & $4,7 \%$ & $0,8 \%$ & $94,5 \%$ & $100,0 \%$ & \\
\hline
\end{tabular}

OBS N01: As Emendas prejudicadas foram substituídas pelas apresentadas pela Comissẫo de Fazenda, entretanto entendo que o mérito continua sendo dos parlamentares que as apresentaram

OBS N02: As emendas substitutivas contemplam as prejudicadas, sendo que, na maioria das vezes, com valores menores, com a finalidade de ajustar o total de despesas com o total previsto de rec eitas no orçamento.

\begin{tabular}{|l|l|r|r|r|c|}
\hline \multicolumn{7}{|c|}{ EMENDAS SUBSTITUTIVAS - 1909} \\
\hline $\mathbf{N}^{\circ}$ & SEDE DO DISTRITO & QTDE & $\%$ QTDE & VALOR & $\%$ VALOR \\
\hline $1^{\circ}$ & CAPITAL & 47 & $17,1 \%$ & 1.307 .800 & $35,6 \%$ \\
\hline $2^{\circ}$ & TAUBATE & 31 & $11,3 \%$ & 258.200 & $7,0 \%$ \\
\hline $3^{\circ}$ & GUARATINGUETÁ & 31 & $11,3 \%$ & 277.000 & $7,5 \%$ \\
\hline $4^{\circ}$ & ITÚ & 22 & $8,0 \%$ & 182.000 & $5,0 \%$ \\
\hline $5^{\circ}$ & BOTUCATU & 17 & $6,2 \%$ & 168.000 & $4,6 \%$ \\
\hline $6^{\circ}$ & CAMPINAS & 23 & $8,4 \%$ & 188.700 & $5,1 \%$ \\
\hline $7^{\circ}$ & MOGY-MIRIM & 14 & $5,1 \%$ & 234.000 & $6,4 \%$ \\
\hline $8^{\circ}$ & LIMEIRA & 27 & $9,8 \%$ & 279.500 & $7,6 \%$ \\
\hline $9^{\circ}$ & SÁO CARLOS & 14 & $5,1 \%$ & 250.200 & $6,8 \%$ \\
\hline $10^{\circ}$ & RIBEIRAिO PRETO & 15 & $5,5 \%$ & 160.000 & $4,4 \%$ \\
\hline $11^{\circ}$ & SEM IDENTIFICACÁO & 34 & $12,4 \%$ & 367.178 & $10,0 \%$ \\
\hline \multicolumn{2}{|c|}{ TOTAL } & 275 & $100,0 \%$ & 3.672 .578 & $100 \%$ \\
\hline
\end{tabular}




\begin{tabular}{|c|c|c|c|c|c|c|}
\hline & \multicolumn{6}{|c|}{ QTDE DE EMENDAS - 1910} \\
\hline $\mathbf{N}^{\circ}$ & SEDE DO DISTRITO & APROVADAS & RE JEIT ADAS & PRE JUDIC AD AS & TOTAL & $\%$ \\
\hline $1^{\circ}$ & CAPITAL & 7 & 0 & 14 & 21 & $14,3 \%$ \\
\hline $2^{\circ}$ & TAUBATÉ & 6 & 0 & 5 & 11 & $7,5 \%$ \\
\hline $3^{\circ}$ & GUARATINGUETÁ & 4 & 5 & 15 & 24 & $16,3 \%$ \\
\hline $4^{\circ}$ & ITÚ & 3 & 0 & 4 & 7 & $4,8 \%$ \\
\hline $5^{\circ}$ & BOTUCATU & 8 & 0 & 9 & 17 & $11,6 \%$ \\
\hline $6^{\circ}$ & CAMPINAS & 2 & 0 & 4 & 6 & $4,1 \%$ \\
\hline $7^{\circ}$ & MOGY-MIRIM & 3 & 0 & 3 & 6 & $4,1 \%$ \\
\hline $8^{\circ}$ & பMEIRA & 2 & 0 & 2 & 4 & $2,7 \%$ \\
\hline $9^{\circ}$ & SÄ́O CARLOS & 1 & 0 & 5 & 6 & $4,1 \%$ \\
\hline $10^{\circ}$ & RIBEIRÄO PRETO & 2 & 0 & 5 & 7 & $4,8 \%$ \\
\hline & SEM IDENTIFICACÁ̃O & 15 & 3 & 20 & 38 & $25,9 \%$ \\
\hline & TOTAL & 53 & 8 & 86 & 147 & $100,0 \%$ \\
\hline & TOTAL \% & $36,1 \%$ & $5,4 \%$ & $58,5 \%$ & $100,0 \%$ & \\
\hline
\end{tabular}

OBS N01: As Emendas prejudicadas foram substituídas pelas apresentadas pela Comissão de $\mathrm{F}$ azenda, entretanto entendo que o mérito continua sendo dos parlamentares que as apresentaram

OBS N02: As emendas substitutivas contemplam as prejudicadas, sendo que, na maioria dasvezes, com valores menores, com a finalidade de ajustar o total de despesas com o total previsto de rec eitas no orçamento.

\begin{tabular}{|c|c|c|c|c|c|c|}
\hline & \multicolumn{6}{|c|}{ VALOR DAS EMENDAS - ANO 1910} \\
\hline $\mathbf{N}^{\circ}$ & SEDE DO DISTRITO & APROVADAS & RE JEIT ADAS & PREJUDIC ADAS & TOTAL & $\%$ \\
\hline $1^{\circ}$ & CAPITAL & 1.018 .000 & - & 6.590 .040 & 7.608 .040 & $74,1 \%$ \\
\hline $2^{\circ}$ & TAUBATÉ & 178.200 & - & 170.200 & 348.400 & $3,4 \%$ \\
\hline $3^{\circ}$ & GUARATINGUETÁ & 13000 & 83000 & 476.660 & 572.660 & $5,6 \%$ \\
\hline $4^{\circ}$ & ITÚ & 26.000 & - & 64.000 & 90.000 & $0,9 \%$ \\
\hline $5^{\circ}$ & BOTUCATU & 48.000 & - & 59.000 & 107.000 & $1,0 \%$ \\
\hline $6^{\circ}$ & CAMPINAS & 3.000 & - & 153.400 & 156.400 & $1.5 \%$ \\
\hline $7^{\circ}$ & MOGY-MIRIM & $(2.000)$ & - & 16.000 & 14.000 & $0,1 \%$ \\
\hline $8^{\circ}$ & பMEIRA & 1.000 & - & 29.000 & 30.000 & $0,3 \%$ \\
\hline $9^{\circ}$ & SÁ̉O CARLOS & 10.000 & - & 14.200 & 24.200 & $0,2 \%$ \\
\hline $10^{\circ}$ & RIBEIRẢO PRETO & 4.000 & - & 65.000 & 69.000 & $0,7 \%$ \\
\hline $11^{\circ}$ & SEM IDENTIFICACÁ̉O & 20.840 & $(15.000)$ & 1.239 .850 & 1.245 .690 & $12,1 \%$ \\
\hline & TOTAL & 1.320 .040 & 68.000 & 8.877 .350 & 10.265 .390 & $100,0 \%$ \\
\hline & TOTAL $\%$ & $12,9 \%$ & $0,7 \%$ & $86,5 \%$ & $100,0 \%$ & \\
\hline
\end{tabular}

OBS N01: As Emendas prejudicadas foram substituídas pelas apresentadas pela Comissẫo de Fazenda, entretanto entendo que o mérito continua sendo dos parlamentares que as apresentaram

OBS N02: As emendas substitutivas contemplam as prejudicadas, sendo que, na maioria dasvezes, com valores menores, com a finalidade de ajustar o total de despesas com o total previsto de rec eitas no orçamento.

\begin{tabular}{|l|l|r|r|r|c|}
\hline \multicolumn{7}{|c|}{ EMENDAS SUBSTITUTIVAS - 1910 } \\
\hline $\mathbf{N}^{\circ}$ & SEDE DO DISTRITO & \multicolumn{1}{|c|}{ QTDE } & $\%$ QTDE & \multicolumn{1}{c|}{ VALOR } & $\%$ VALOR \\
\hline $1^{\circ}$ & CAPITAL & 68 & $21,9 \%$ & 1.508 .920 & $26,3 \%$ \\
\hline $2^{\circ}$ & TAUBATÉ & 29 & $9,3 \%$ & 360.400 & $6,3 \%$ \\
\hline $3^{\circ}$ & GUARATINGUETÁ & 30 & $9,6 \%$ & 202.700 & $3,5 \%$ \\
\hline $4^{\circ}$ & ITÚ & 22 & $7,1 \%$ & 172.200 & $3,0 \%$ \\
\hline $5^{\circ}$ & BOTUCATU & 15 & $4,8 \%$ & 139.000 & $2,4 \%$ \\
\hline $6^{\circ}$ & CAMPINAS & 29 & $9,3 \%$ & 332.900 & $5,8 \%$ \\
\hline $7^{\circ}$ & MOGYMIRIM & 18 & $5,8 \%$ & 170.000 & $3,0 \%$ \\
\hline $8^{\circ}$ & LIMEIRA & 29 & $9,3 \%$ & 250.000 & $4,4 \%$ \\
\hline $9^{\circ}$ & SÁO CARLOS & 10 & $3,2 \%$ & 284.000 & $5,0 \%$ \\
\hline $10^{\circ}$ & RIBEIRÁO PRETO & 19 & $6,1 \%$ & 264.000 & $4,6 \%$ \\
\hline $11^{\circ}$ & SEM IDENTIFICAÇÁO & 42 & $13,5 \%$ & 2.044 .200 & $35,7 \%$ \\
\hline \multicolumn{2}{|c|}{ TOTAL } & 311 & $100,0 \%$ & 5.728 .320 & $100 \%$ \\
\hline
\end{tabular}




\begin{tabular}{|c|c|c|c|c|c|c|}
\hline & & & DE DE EMEI & DAS - 1911 & & \\
\hline $\mathbf{N}^{\circ}$ & SEDE DO DISTRITO & APROVADAS & RE JEITADAS & PREJUDIC ADAS & TOTAL & $\%$ \\
\hline $1^{\circ}$ & CAPITAL & 4 & 0 & 64 & 68 & $13,6 \%$ \\
\hline $2^{\circ}$ & TAUBATÉ & 8 & 0 & 70 & 78 & $15,6 \%$ \\
\hline $3^{\circ}$ & GUARATINGUETÁ & 1 & 0 & 49 & 50 & $10,0 \%$ \\
\hline $4^{\circ}$ & ITÚ & 4 & 0 & 44 & 48 & $9,6 \%$ \\
\hline $5^{\circ}$ & BOTUCATU & 6 & 2 & 42 & 50 & $10,0 \%$ \\
\hline $6^{\circ}$ & CAMPINAS & 1 & $\overline{0}$ & $\overline{41}$ & $\overline{42}$ & $8,4 \%$ \\
\hline $7^{\circ}$ & MOGY-MIRIM & 0 & 0 & 27 & 27 & $5,4 \%$ \\
\hline $8^{\circ}$ & UMEIRA & 0 & 0 & 37 & 37 & $7,4 \%$ \\
\hline $9^{\circ}$ & SÁO CARLOS & 2 & 1 & 20 & 23 & $4,6 \%$ \\
\hline $10^{\circ}$ & RIBEIRÁO PRETO & 0 & 0 & 31 & 31 & $6,2 \%$ \\
\hline & SEM IDENTIFICACÄ́O & 8 & 3 & 35 & 46 & $9,2 \%$ \\
\hline & TOTAL & 34 & 6 & 460 & 500 & $100,0 \%$ \\
\hline & TOTAL $\%$ & $6,8 \%$ & $1,2 \%$ & $92,0 \%$ & $100,0 \%$ & \\
\hline
\end{tabular}

OBS N01: As Emendas prejudicadas foram substituídas pelas apresentadas pela Comissẫo de Fazenda, entretanto entendo que o mérito continua sendo dos parlamentares que as apresentaram

OBS $N^{\circ} 02$ : As emendas substitutivas contemplam as prejudicadas, sendo que, na maioria das vezes, com valores menores, com a finalidade de ajustar o total de despesas com o total previsto de rec eitas no orçamento.

\begin{tabular}{|c|c|c|c|c|c|c|}
\hline & \multicolumn{6}{|c|}{ VALOR DAS EMENDAS - 1911} \\
\hline $\mathbf{N}^{0}$ & SEDE DO DISTRITO & APROVADAS & RE JEIT ADAS & PREJUDICADAS & TOTAL & $\%$ \\
\hline $1^{\circ}$ & CAPITAL & 98.500 & - & 1.263 .200 & 1.361 .700 & $175 \%$ \\
\hline $2^{\circ}$ & TAUBATÉ & 57.800 & - & 731.300 & 789.100 & $10,1 \%$ \\
\hline $3^{\circ}$ & GUARATINGUETÁ & 10.000 & - & 484.300 & 494.300 & $6,4 \%$ \\
\hline $4^{\circ}$ & ITÚ & 78.000 & 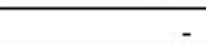 & 910.000 & 988.000 & $12,7 \%$ \\
\hline $5^{\circ}$ & BOTUCATU & 76.000 & 80.000 & 607.900 & 763.900 & $9,8 \%$ \\
\hline $6^{\circ}$ & CAMPINAS & 5.000 & - & 263.100 & 268.100 & $3,4 \%$ \\
\hline $7^{\circ}$ & MOGY-MIRIM & - & & 427.800 & 427.800 & $5,5 \%$ \\
\hline $8^{\circ}$ & UMEIRA & - & - & 294.500 & 294.500 & $3,8 \%$ \\
\hline $9^{\circ}$ & SÁO CARLOS & 13.000 & 3.000 & 309.700 & 325.700 & $4,2 \%$ \\
\hline $10^{\circ}$ & RIBEIRÁO PRETO & - & - & 393.000 & 393.000 & $5,1 \%$ \\
\hline & SEM IDENTIFICACÃO & 1.017 .000 & 230.000 & 427.200 & 1.674 .200 & $21,5 \%$ \\
\hline & TOTAL & 1.355 .300 & 313.000 & 6.112 .000 & 7.780 .300 & $100,0 \%$ \\
\hline & TOTAL \% & $17,4 \%$ & $4,0 \%$ & $78,6 \%$ & $100,0 \%$ & \\
\hline
\end{tabular}

OBS N01: As Emendas prejudicadas foram substituídas pelas apresentadas pela Comissẫo de Fazenda, entretanto entendo que o mérito continua sendo dos parlamentares que as apresentaram

OBS N02: As emendas substitutivas contemplam as prejudicadas, sendo que, na maioria das vezes, com valores menores, com a finalidade de ajustar o total de despesas com o total previsto de rec eitas no orçamento.

\begin{tabular}{|l|l|r|r|r|c|}
\hline \multicolumn{7}{|c|}{ EMENDAS SUBSTITUTIVAS - 1911} \\
\hline $\mathbf{N}^{\circ}$ & SEDE DO DISTRITO & \multicolumn{1}{c|}{ QTDE } & $\%$ QTDE & \multicolumn{1}{c|}{ VALOR } & $\%$ VALOR \\
\hline $1^{\circ}$ & CAPITAL & 55 & $15,5 \%$ & 1.737 .800 & $30,8 \%$ \\
\hline $2^{\circ}$ & TAUBATÉ & 38 & $10,7 \%$ & 643.000 & $11,4 \%$ \\
\hline $3^{\circ}$ & GUARATINGUETÁ & 36 & $10,1 \%$ & 331.200 & $5,9 \%$ \\
\hline $4^{\circ}$ & ITÚ & 25 & $7,0 \%$ & 302.000 & $5,4 \%$ \\
\hline $5^{\circ}$ & BOTUCATU & 29 & $8,2 \%$ & 498.500 & $8,8 \%$ \\
\hline $6^{\circ}$ & CAMPINAS & 35 & $9,9 \%$ & 298.100 & $5,3 \%$ \\
\hline $7^{\circ}$ & MOGY-MIRIM & 25 & $7,0 \%$ & 305.500 & $5,4 \%$ \\
\hline $8^{\circ}$ & LIMEIRA & 33 & $9,3 \%$ & 252.000 & $4,5 \%$ \\
\hline $9^{\circ}$ & SÄ́O CARLOS & 12 & $3,4 \%$ & 147.000 & $2,6 \%$ \\
\hline $10^{\circ}$ & RIBEIRARO PRETO & 25 & $7,0 \%$ & 370.000 & $6,6 \%$ \\
\hline $11^{\circ}$ & SEM IDENTIFICAÇÁO & 42 & $11,8 \%$ & 752.500 & $13,3 \%$ \\
\hline \multicolumn{2}{|c|}{ TOTAL } & 355 & $100,0 \%$ & 5.637 .600 & $100 \%$ \\
\hline
\end{tabular}




\begin{tabular}{|c|c|c|c|c|c|c|}
\hline & \multicolumn{6}{|c|}{ QTDE DE EMENDAS - 1912} \\
\hline $\mathbf{N}^{0}$ & SEDE DO DISTRITO & APROVADAS & REJEIT AD AS & PREJUDIC ADAS & TOTAL & $\%$ \\
\hline $1^{\circ}$ & CAPITAL & 10 & 74 & 1 & 85 & $12,6 \%$ \\
\hline $2^{\circ}$ & TAUBATÉ & 7 & 69 & 0 & 76 & $11,3 \%$ \\
\hline $3^{\circ}$ & GUARATINGUETÁ & 12 & 88 & 1 & 101 & $15,0 \%$ \\
\hline $4^{\circ}$ & ITÚ & 2 & 46 & 1 & 49 & $7,3 \%$ \\
\hline $5^{\circ}$ & BOTUCATU & 6 & 71 & 0 & 77 & $11,5 \%$ \\
\hline $6^{\circ}$ & CAMPINAS & 4 & 32 & 0 & 36 & $5,4 \%$ \\
\hline $7^{\circ}$ & MOGY-MIRIM & 3 & 41 & 1 & 45 & $6,7 \%$ \\
\hline $8^{\circ}$ & LIMEIRA & 4 & 46 & 0 & 50 & $7,4 \%$ \\
\hline $9^{\circ}$ & SÁO CARLOS & 4 & 31 & 0 & 35 & $5,2 \%$ \\
\hline $10^{\circ}$ & RIBEIRÁO PRETO & 3 & 45 & 1 & 49 & $7,3 \%$ \\
\hline & SEM IDENTIFICACÁOO & 27 & 42 & 0 & 69 & $10,3 \%$ \\
\hline & TOTAL & 82 & 585 & 5 & 672 & $100,0 \%$ \\
\hline & TOTAL $\%$ & $12,2 \%$ & $87,1 \%$ & $0,7 \%$ & $100,0 \%$ & \\
\hline
\end{tabular}

OBS N01: As Emendas prejudicadas foram substituídas pelas apresentadas pela Comissão de $F$ azenda, entretanto entendo que o mérito continua sendo dos parlamentares que as apresentaram

OBS No02: As emendas substitutivas contemplam as prejudicadas, sendo que, na maioria dasvezes, comvalores menores, com a finalidade de ajustar o total de despesas com o total previsto de receitas no orçamento.

\begin{tabular}{|c|c|c|c|c|c|c|}
\hline & \multicolumn{6}{|c|}{ VALOR DAS EMENDAS - 1912} \\
\hline $\mathbf{N}^{\circ}$ & SEDE DO DISTRIT 0 & APROVADAS & REJEIT ADAS & PREJUDIC ADAS & TOTAL & $\%$ \\
\hline $1^{\circ}$ & $\begin{array}{l}\text { CAPITAL } \\
\end{array}$ & 80.300 & 3.444 .900 & 25.000 & 3.550 .200 & $24,6 \%$ \\
\hline $2^{\circ}$ & TAUBATÉ & 65.000 & 662.300 & - & 727.300 & $5,0 \%$ \\
\hline $3^{\circ}$ & GUARATINGUETÁ & 43.400 & $1.542 .700,00$ & 2.000 & 1.588 .100 & $11,0 \%$ \\
\hline $4^{\circ}$ & ITÚ & 48.000 & 915.500 & 35.000 & 998.500 & $6.9 \%$ \\
\hline $5^{\circ}$ & BOTUCATU & 43.000 & 1.735 .900 & - & 1.778 .900 & $12,3 \%$ \\
\hline $6^{\circ}$ & CAMPINAS & 10.300 & 292.900 & - & 303.200 & $2,1 \%$ \\
\hline $7^{\circ}$ & MOGY-MIRIM & 5.000 & 731.500 & 3.000 & 739.500 & $5,1 \%$ \\
\hline $8^{\circ}$ & LIMEIRA & 12.000 & 748.000 & - & 760.000 & $5,3 \%$ \\
\hline $9^{\circ}$ & SǺ CARLOS & 17.600 & 477.100 & - & 494.700 & $3,4 \%$ \\
\hline $10^{\circ}$ & RIBEIRÄO PRETO & 38.000 & 620.500 & 30.000 & 688.500 & $4,8 \%$ \\
\hline & SEM IDENTIFICACÄO & 1.803 .225 & 995.500 & & 2.798 .725 & $19,4 \%$ \\
\hline & TOTAL & 2.165 .825 & 12.166 .800 & 95.000 & 14.427 .625 & $100,0 \%$ \\
\hline & TOTAL $\%$ & $15,0 \%$ & $84,3 \%$ & $0,7 \%$ & $100,0 \%$ & \\
\hline
\end{tabular}

OBS No01: As Emendas prejudicadas foram substituí das pelas apresentadas pela Comissẫo de $\mathrm{F}$ azenda, entretanto entendo que o mérito continua sendo dos parlamentares que as apresentaram

OBS No2: As emendas substitutivas contemplam as prejudicadas, sendo que, na maioria das vezes, comvalores menores, com a finalidade de ajustar o total de despesas com o total previsto de receitas no orçamento.

\begin{tabular}{|c|c|c|c|c|c|}
\hline \multicolumn{6}{|c|}{ EMENDAS SUBSTITUTIVAS - 1912} \\
\hline$\overline{\mathbf{N}^{0}}$ & SEDE DO DISTRITO & QTDE & $\%$ QTDE & VALOR & $\%$ VALOR \\
\hline $1^{\circ}$ & CAPITAL & 56 & $16,0 \%$ & 1.718 .700 & $68 \%$ \\
\hline $2^{\circ}$ & TAUBATÉ & 32 & $92 \%$ & 385.700 & $15 \%$ \\
\hline $3^{\circ}$ & GUARATINGUETÁ & 38 & $10,9 \%$ & 402.500 & $16 \%$ \\
\hline $4^{\circ}$ & ITÚ & 4 & $1,1 \%$ & 30.000 & $0,1 \%$ \\
\hline $5^{\circ}$ & BOTUCATU & 27 & $7,7 \%$ & 502.500 & $2,0 \%$ \\
\hline $6^{\circ}$ & CAMPINAS & 35 & $10,0 \%$ & 245.300 & $10 \%$ \\
\hline $7^{\circ}$ & MOGY-MIRIM & 18 & $5,2 \%$ & 255.500 & $10 \%$ \\
\hline $8^{\circ}$ & LIMEIRA & 38 & $10,9 \%$ & 459.240 & $18 \%$ \\
\hline $9^{\circ}$ & SÄO CARLOS & 26 & $7,4 \%$ & 390.100 & $15 \%$ \\
\hline $10^{\circ}$ & RIBEIRÅO PRETO & 33 & $9.5 \%$ & 596.000 & $24 \%$ \\
\hline $11^{\circ}$ & SEM IDENTIFICACÅO & $\overline{42}$ & $12,0 \%$ & 20.188 .390 & $80,2 \%$ \\
\hline & TOTAL & 349 & $100,0 \%$ & 25.173 .930 & $100 \%$ \\
\hline
\end{tabular}




\begin{tabular}{|c|c|c|c|c|c|c|}
\hline & \multicolumn{6}{|c|}{ QTDE DE EMENDAS - 1913} \\
\hline $\mathbf{N}^{\circ}$ & SEDE DO DISTRITO & APROVADAS & RE JEIT ADAS & PRE JUDIC AD AS & TOTAL & $\%$ \\
\hline $1^{\circ}$ & CAPITAL & & & 68 & 68 & $13,0 \%$ \\
\hline $2^{\circ}$ & TAUBATÉ & & & 73 & 73 & $14,0 \%$ \\
\hline $3^{\circ}$ & GUARATINGUETÁ & & & 53 & 53 & $10,1 \%$ \\
\hline $4^{\circ}$ & ITÚ & 1 & & 57 & 58 & $11,1 \%$ \\
\hline $5^{\circ}$ & BOTUCATU & & & 57 & 57 & $10,9 \%$ \\
\hline $6^{\circ}$ & CAMPINAS & & & 44 & 44 & $8,4 \%$ \\
\hline $7^{\circ}$ & MOGY-MIRIM & & & 28 & 28 & $5,4 \%$ \\
\hline $8^{\circ}$ & பMEIRA & & & 40 & 40 & $7,6 \%$ \\
\hline $9^{\circ}$ & SÄ́O CARLOS & & & 32 & 32 & $6,1 \%$ \\
\hline $10^{\circ}$ & RIBEIRÄO PRETO & & & 36 & 36 & $6,9 \%$ \\
\hline & SEM IDENTIFICACÁ̃O & 1 & & 33 & 34 & $6,5 \%$ \\
\hline & TOTAL & 2 & 0 & 521 & 523 & $100,0 \%$ \\
\hline & TOTAL \% & $0,4 \%$ & $0,0 \%$ & $99,6 \%$ & $100,0 \%$ & \\
\hline
\end{tabular}

OBS N01: As Emendas prejudicadas foram substituídas pelas apresentadas pela Comissẫo de Fazenda, entretanto entendo que o mérito continua sendo dos parlamentares que as apresentaram

OBS N02: As emendas substitutivas contemplam as prejudicadas, sendo que, na maioria dasvezes, com valores menores, com a finalidade de ajustar o total de despesas com o total previsto de rec eitas no orçamento.

\begin{tabular}{|c|c|c|c|c|c|c|}
\hline & \multicolumn{6}{|c|}{ VALOR DAS EMENDAS - 1913} \\
\hline $\mathrm{N}^{0}$ & SEDE DO DISTRITO & APROVADAS & RE JEIT ADAS & PREJUDIC ADAS & TOTAL & $\%$ \\
\hline $1^{\circ}$ & CAPITAL & & & 1.058 .300 & 1.058 .300 & $14,3 \%$ \\
\hline $2^{\circ}$ & TAUBATÉ & & & 780.500 & 780.500 & $10,5 \%$ \\
\hline $3^{\circ}$ & GUARATINGUETÁ & & & 495.800 & 495.800 & $6,7 \%$ \\
\hline $4^{\circ}$ & ITÚ & 6.000 & & 1.120 .000 & 1.126 .000 & $15,2 \%$ \\
\hline $5^{\circ}$ & BOTUCATU & & & 1.196 .800 & 1.196 .800 & $16,2 \%$ \\
\hline $6^{\circ}$ & CAMPINAS & & & 340.600 & 340.600 & $4,6 \%$ \\
\hline $7^{\circ}$ & MOGY-MIRIM & & & 423.000 & 423.000 & $5,7 \%$ \\
\hline $8^{\circ}$ & DMEIRA & & & 388.000 & 388.000 & $5,2 \%$ \\
\hline $9^{\circ}$ & SÄO CARLOS & & & 656.300 & 656.300 & $8,9 \%$ \\
\hline $10^{\circ}$ & RIBEIRÁO PRETO & & & 666.000 & 666.000 & $9,0 \%$ \\
\hline & SEM IDENTIFICACÄO & - & & 277.500 & 277.500 & $3,7 \%$ \\
\hline & TOTAL & 6.000 & - & 7.402 .800 & 7.408 .800 & $100,0 \%$ \\
\hline & TOTAL $\%$ & $0,1 \%$ & $0,0 \%$ & $99,9 \%$ & $100,0 \%$ & \\
\hline
\end{tabular}

OBS N01: As Emendas prejudicadas foram substituídas pelas apresentadas pela Comissẫo de Fazenda, entretanto entendo que o mérito continua sendo dos parlamentares que as apresentaram

OBS $\mathrm{N}^{\circ} 02$ : As emendas substitutivas contemplam as prejudicadas, sendo que, na maioria das vezes, com valores menores, com a finalidade de ajustar o total de despesas com o total previsto de rec eitas no orçamento.

\begin{tabular}{|l|l|r|r|r|c|}
\hline \multicolumn{7}{|c|}{ EMENDAS SUBSTITUTIVAS - 1913} \\
\hline $\mathbf{N}^{\circ}$ & SEDE DO DISTRITO & QTDE & $\%$ QTDE & \multicolumn{1}{c|}{ VALOR } & $\%$ VALOR \\
\hline $1^{\circ}$ & CAPITAL & 49 & $15,7 \%$ & 1.479 .000 & $28,8 \%$ \\
\hline $2^{\circ}$ & TAUBATE & 31 & $9,9 \%$ & 260.900 & $5,1 \%$ \\
\hline $3^{\circ}$ & GUARATINGUETÁ & 35 & $11,2 \%$ & 282.100 & $5,5 \%$ \\
\hline $4^{\circ}$ & ITÚ & 26 & $8,3 \%$ & 285.000 & $5,6 \%$ \\
\hline $5^{\circ}$ & BOTUCATU & 24 & $7,7 \%$ & 512.500 & $10,0 \%$ \\
\hline $6^{\circ}$ & CAMPINAS & 36 & $11,5 \%$ & 261.600 & $5,1 \%$ \\
\hline $7^{\circ}$ & MOGY-MIRIM & 21 & $6,7 \%$ & 322.500 & $6,3 \%$ \\
\hline $8^{\circ}$ & LIMEIRA & 33 & $10,5 \%$ & 312.000 & $6,1 \%$ \\
\hline $9^{\circ}$ & SÁO CARLOS & 14 & $4,5 \%$ & 155.100 & $3,0 \%$ \\
\hline $10^{\circ}$ & RIBEIRAिO PRETO & 21 & $6,7 \%$ & 230.000 & $4,5 \%$ \\
\hline $11^{\circ}$ & SEM IDENTIFICACÁO & 23 & $7,3 \%$ & 1.027 .000 & $20,0 \%$ \\
\hline \multicolumn{2}{|c|}{ TOTAL } & 313 & $100,0 \%$ & 5.127 .700 & $100 \%$ \\
\hline
\end{tabular}




\begin{tabular}{|c|c|c|c|c|c|c|}
\hline & \multicolumn{6}{|c|}{ QTDE DE EMENDAS - 1914} \\
\hline $\mathbf{N}^{0}$ & SEDE DO DISTRITO & APROVADAS & REJJEIT ADAS & PREJUDICADAS & TOTAL & $\%$ \\
\hline $1^{\circ}$ & CAPITAL & 1 & & 55 & 56 & $15,7 \%$ \\
\hline $2^{\circ}$ & TAUBATÉ & & 1 & 30 & 31 & $8.7 \%$ \\
\hline $3^{\circ}$ & GUARATINGUETÁ & & & 38 & 38 & $10,6 \%$ \\
\hline $4^{\circ}$ & ITÚ & & & 24 & 24 & $6.7 \%$ \\
\hline $5^{\circ}$ & BOTUCATU & 2 & 1 & 37 & 40 & $11,2 \%$ \\
\hline $6^{\circ}$ & CAMPINAS & & & 40 & 40 & $11,2 \%$ \\
\hline $7^{\circ}$ & MOGY-MIRIM & & & 24 & 24 & $6.7 \%$ \\
\hline $8^{\circ}$ & பMEIRA & & & 37 & 37 & $10,4 \%$ \\
\hline $9^{\circ}$ & SÄO CARLOS & & & 14 & 14 & $3,9 \%$ \\
\hline $10^{\circ}$ & RIBEIRÄO PRETO & & & 15 & 15 & $4,2 \%$ \\
\hline $11^{\circ}$ & SEM IDENTIFICACÃO & 4 & & 34 & 38 & $10,6 \%$ \\
\hline & TOTAL & 7 & 2 & 348 & 357 & $100,0 \%$ \\
\hline & TOTAL $\%$ & $2,0 \%$ & $0,6 \%$ & $97,5 \%$ & $100,0 \%$ & \\
\hline
\end{tabular}

OBS N01: As Emendas prejudicadas foram substituídas pelas apresentadas pela Comissẫo de Fazenda, entretanto entendo que o mérito continua sendo dos parlamentares que as apresentaram

OBS N02: As emendas substitutiv as contemplam as prejudicadas, sendo que, na maioria das vezes, comvalores menores, com a finalidade de ajustar o total de despesas com o total previsto de receitas no orçamento.

\begin{tabular}{|c|c|c|c|c|c|c|}
\hline & \multicolumn{6}{|c|}{ VALOR DAS EMENDAS - 1914} \\
\hline $\mathbf{N}^{\circ}$ & SEDE DO DISTRITO & APROVADAS & REJEIT ADAS & PREJUDICADAS & TOTAL & $\%$ \\
\hline $1^{\circ}$ & CAPITAL & 10.000 & & 792.200 & 802.200 & $14,9 \%$ \\
\hline $2^{\circ}$ & TAUBATÉ & & 3.000 & 1.621 .517 & 1.624 .517 & $30,1 \%$ \\
\hline $3^{\circ}$ & GUARATINGUETÁ & & & 338.100 & 338.100 & $6,3 \%$ \\
\hline $4^{\circ}$ & ITÚ & & & 215.000 & 215.000 & $4,0 \%$ \\
\hline $5^{\circ}$ & BOTUCATU & 23.000 & 2.000 & 523.500 & 548.500 & $10,2 \%$ \\
\hline $6^{\circ}$ & CAMPINAS & & & 244.600 & 244.600 & $4,5 \%$ \\
\hline $7^{\circ}$ & MOGY-MIRIM & & & 421.200 & 421.200 & $7,8 \%$ \\
\hline $8^{\circ}$ & UMEIRA & & & 387.300 & 387.300 & $7,2 \%$ \\
\hline$g^{\circ}$ & SÁO CARLOS & & & 220.100 & 220.100 & $4.1 \%$ \\
\hline $10^{\circ}$ & RIBEIRÁO PRETO & & & 227.000 & 227.000 & $4,2 \%$ \\
\hline & SEM IDENTIFICACÁO & 44.800 & & 316.220 & 361.020 & $6,7 \%$ \\
\hline & TOTAL & 77.800 & 5.000 & 5.306 .737 & 5.389 .537 & $100,0 \%$ \\
\hline & TOTAL $\%$ & $1,4 \%$ & $0,1 \%$ & $98,5 \%$ & $100,0 \%$ & \\
\hline
\end{tabular}

OBS N01: As Emendas prejudicadas foram substituídas pelas apresentadas pela Comissẫo de Fazenda, entretanto entendo que o mérito continua sendo dos parlamentares que as apresentaram

OBS N02: As emendas substitutiv as contemplam as prejudicadas, sendo que, na maioria das vezes, comvalores menores, com a finalidade de ajustar o total de despesas com o total previsto de receitas no orçamento.

\begin{tabular}{|l|l|r|r|r|c|}
\hline \multicolumn{7}{|c|}{ EMENDAS SUBSTITUTIVAS - 1914 } \\
\hline $\mathbf{N}^{\circ}$ & SEDE DO DISTRITO & QTDE & $\%$ QTDE & \multicolumn{1}{c|}{ VALOR } & $\%$ VALOR \\
\hline $1^{\circ}$ & CAPITAL & 28 & $16,1 \%$ & 1.018 .400 & $59,7 \%$ \\
\hline $2^{\circ}$ & TAUBATE & 14 & $8,0 \%$ & 66.100 & $3,9 \%$ \\
\hline $3^{\circ}$ & GUARATINGUETÁ & 20 & $11,5 \%$ & 85.350 & $5,0 \%$ \\
\hline $4^{\circ}$ & ITÚ & 15 & $8,6 \%$ & 54.500 & $3,2 \%$ \\
\hline $5^{\circ}$ & BOTUCATU & 12 & $6,9 \%$ & 56.000 & $3,3 \%$ \\
\hline $6^{\circ}$ & CAMPINAS & 19 & $10,9 \%$ & 62.800 & $3,7 \%$ \\
\hline $7^{\circ}$ & MOGY-MIRIM & 13 & $7,5 \%$ & 67.250 & $3,9 \%$ \\
\hline $8^{\circ}$ & LIMEIRA & 19 & $10,9 \%$ & 76.250 & $4,5 \%$ \\
\hline $9^{\circ}$ & SÄO CARLOS & 11 & $6,3 \%$ & 63.300 & $3,7 \%$ \\
\hline $10^{\circ}$ & RIBEIRÁO PRETO & 12 & $6,9 \%$ & 67.500 & $4,0 \%$ \\
\hline $11^{\circ}$ & SEM IDENTIFICACÅO & 11 & $6,3 \%$ & 87.600 & $5,1 \%$ \\
\hline \multicolumn{2}{|c|}{ TOTAL } & 174 & $100,0 \%$ & 1.705 .050 & $100 \%$ \\
\hline
\end{tabular}




\begin{tabular}{|c|c|c|c|c|c|c|}
\hline & \multicolumn{6}{|c|}{ QTDE DE EMENDAS - 1915} \\
\hline $\mathbf{N}^{0}$ & SEDE DO DISTRITO & APROVADAS & REJEIT ADAS & PREJUDICADAS & TOTAL & $\%$ \\
\hline $1^{\circ}$ & CAPITAL & 5 & 0 & 48 & 53 & $11,9 \%$ \\
\hline $2^{\circ}$ & TAUBATÉ & 13 & 2 & 43 & 58 & $13,0 \%$ \\
\hline $3^{\circ}$ & GUARATINGUETÁ & 6 & 0 & 37 & 43 & $9,7 \%$ \\
\hline $4^{\circ}$ & ITÚ & 7 & 0 & 43 & 50 & $11,2 \%$ \\
\hline $5^{\circ}$ & BOTUCATU & 10 & 0 & 45 & 55 & $12,4 \%$ \\
\hline $6^{\circ}$ & CAMPINAS & 6 & 0 & 30 & 36 & $8,1 \%$ \\
\hline $7^{\circ}$ & MOGY-MIRIM & 5 & 0 & 23 & 28 & $6,3 \%$ \\
\hline $8^{\circ}$ & பMEIRA & 4 & 0 & 32 & 36 & $8,1 \%$ \\
\hline $9^{\circ}$ & SÄO CARLOS & 3 & 0 & 15 & 18 & $4,0 \%$ \\
\hline $10^{\circ}$ & RIBEIRÄO PRETO & 2 & 0 & 21 & 23 & $5,2 \%$ \\
\hline $11^{\circ}$ & SEM IDENTIFICACÃO & 9 & 18 & 18 & 45 & $10,1 \%$ \\
\hline & TOTAL & 70 & 20 & 355 & 445 & $100,0 \%$ \\
\hline & TOTAL $\%$ & $15,7 \%$ & $4,5 \%$ & $79,8 \%$ & $100,0 \%$ & \\
\hline
\end{tabular}

OBS N01: As Emendas prejudicadas foram substituídas pelas apresentadas pela Comissẫo de Fazenda, entretanto entendo que o mérito continua sendo dos parlamentares que as apresentaram

OBS N02: As emendas substitutiv as contemplam as prejudicadas, sendo que, na maioria das vezes, comvalores menores, com a finalidade de ajustar o total de despesas com o total previsto de receitas no orçamento.

\begin{tabular}{|c|c|c|c|c|c|c|}
\hline & \multicolumn{6}{|c|}{ VALOR DAS EMENDAS - 1915} \\
\hline $\mathbf{N}^{\circ}$ & SEDE DO DISTRITO & APROVADAS & REJEIT ADAS & PREJUDICADAS & TOTAL & $\%$ \\
\hline $1^{\circ}$ & CAPITAL & 60.000 & & 903.000 & 963.000 & $16,5 \%$ \\
\hline $2^{\circ}$ & TAUEATÉ & 43.000 & 50.000 & 422.700 & 515.700 & $8,8 \%$ \\
\hline $3^{\circ}$ & GUARATINGUETÁ & 27.000 & - & 196.000 & 223.000 & $3.8 \%$ \\
\hline $4^{\circ}$ & ITÚ & 30.000 & - & 775.000 & 805.000 & $13,8 \%$ \\
\hline $5^{\circ}$ & BOTUCATU & 52.000 & - & 607.300 & 659.300 & $11,3 \%$ \\
\hline $6^{\circ}$ & CAMPINAS & 32.000 & - & 206.600 & 238.600 & $4,1 \%$ \\
\hline $7^{\circ}$ & MOGY-MIRIM & 30.000 & - & 452.000 & 482.000 & $8,3 \%$ \\
\hline $8^{\circ}$ & LIMEIRA & 30.000 & - & 251.200 & 281.200 & $4,8 \%$ \\
\hline $9^{\circ}$ & SÄO CARLOS & 30.000 & - & 342.400 & 372.400 & $6,4 \%$ \\
\hline $10^{\circ}$ & RIBEIRÄO PRETO & 14.000 & 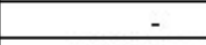 & 450.000 & 464.000 & $7,9 \%$ \\
\hline & SEM IDENTIFICACÃO & 616.200 & $(144.000)$ & 362.600 & 834.800 & $14,3 \%$ \\
\hline & TOTAL & 964.200 & $(94.000)$ & 4.968 .800 & 5.839 .000 & $100,0 \%$ \\
\hline & TOTAL $\%$ & $16,5 \%$ & $-1,6 \%$ & $85,1 \%$ & $100,0 \%$ & \\
\hline
\end{tabular}

OBS N01: As Emendas prejudicadas foram substituídas pelas apresentadas pela Comissẫo de $\mathrm{F}$ azenda, entretanto entendo que o mérito continua sendo dos parlamentares que as apresentaram

OBS N02: As emendas substitutivas contemplam as prejudicadas, sendo que, na maioria das vezes, comvalores menores, com a finalidade de ajustar o total de despesas com o total previsto de receitas no orçamento.

\begin{tabular}{|l|l|r|r|r|c|}
\hline \multicolumn{7}{|c|}{ EMENDAS SUBSTITUTIVAS - 1915} \\
\hline $\mathbf{N}^{\circ}$ & SEDE DO DISTRITO & QTDE & $\%$ QTDE & \multicolumn{1}{c|}{ VALOR } & $\%$ VALOR \\
\hline $1^{\circ}$ & CAPITAL & 34 & $15,8 \%$ & 1.144 .300 & $13,0 \%$ \\
\hline $2^{\circ}$ & TAUBATE & 17 & $7,9 \%$ & 102.100 & $1,2 \%$ \\
\hline $3^{\circ}$ & GUARATINGUETÁ & 22 & $10,2 \%$ & 156.850 & $1,8 \%$ \\
\hline $4^{\circ}$ & ITÚ & 17 & $7,9 \%$ & 57.000 & $0,7 \%$ \\
\hline $5^{\circ}$ & BOTUCATU & 13 & $6,0 \%$ & 58.500 & $0,7 \%$ \\
\hline $6^{\circ}$ & CAMPINAS & 24 & $11,2 \%$ & 120.800 & $1,4 \%$ \\
\hline $7^{\circ}$ & MOGY-MIRIM & 13 & $6,0 \%$ & 70.750 & $0,8 \%$ \\
\hline $8^{\circ}$ & LIMEIRA & 20 & $9,3 \%$ & 88.500 & $1,0 \%$ \\
\hline $9^{\circ}$ & SÁO CARLOS & 14 & $6,5 \%$ & 146.950 & $1,7 \%$ \\
\hline $10^{\circ}$ & RIBEIRAिO PRETO & 14 & $6,5 \%$ & 183.000 & $2,1 \%$ \\
\hline $11^{\circ}$ & SEM IDENTIFICACÅO & 27 & $12,6 \%$ & 6.640 .212 & $75,7 \%$ \\
\hline \multicolumn{2}{|c|}{ TOTAL } & 215 & $100,0 \%$ & 8.768 .962 & $100 \%$ \\
\hline
\end{tabular}




\begin{tabular}{|c|c|c|c|c|c|c|}
\hline & \multicolumn{6}{|c|}{ QTDE DE EMENDAS - 1916} \\
\hline $\mathbf{N}^{0}$ & SEDE DO DISTRITO & APROVADAS & REJEIT ADAS & PREJUDICADAS & TOTAL & $\%$ \\
\hline $1^{\circ}$ & CAPITAL & 6 & 1 & 56 & 63 & $13,2 \%$ \\
\hline $2^{\circ}$ & TAUBATÉ & 14 & 0 & 49 & 63 & $13,2 \%$ \\
\hline $3^{\circ}$ & GUARATINGUETÁ & 12 & 0 & 37 & 49 & $10,3 \%$ \\
\hline $4^{\circ}$ & ITÚ & 12 & 0 & 52 & 64 & $13,4 \%$ \\
\hline $5^{\circ}$ & BOTUCATU & 6 & 0 & 32 & 38 & $8.0 \%$ \\
\hline $6^{\circ}$ & CAMPINAS & 7 & 0 & 30 & 37 & $7,8 \%$ \\
\hline $7^{\circ}$ & MOGY-MIRIM & 4 & 0 & 27 & 31 & $6,5 \%$ \\
\hline $8^{\circ}$ & பMEIRA & 6 & 0 & 23 & 29 & $6,1 \%$ \\
\hline $9^{\circ}$ & SÄO CARLOS & 12 & 0 & 23 & 35 & $7,4 \%$ \\
\hline $10^{\circ}$ & RIBEIRẤO PRETO & 9 & 0 & 28 & 37 & $7,8 \%$ \\
\hline $11^{\circ}$ & SEM IDENTIFICACÁO & 2 & 1 & 27 & 30 & $6,3 \%$ \\
\hline & TOTAL & 90 & 2 & 384 & 476 & $100,0 \%$ \\
\hline & TOTAL $\%$ & $18,9 \%$ & $0,4 \%$ & $80,7 \%$ & $100,0 \%$ & \\
\hline
\end{tabular}

OBS N01: As Emendas prejudicadas foram substituídas pelas apresentadas pela Comissẫo de Fazenda, entretanto entendo que o mérito continua sendo dos parlamentares que as apresentaram

OBS N02: As emendas substitutiv as contemplam as prejudicadas, sendo que, na maioria das vezes, comvalores menores, com a finalidade de ajustar o total de despesas com o total previsto de receitas no orçamento.

\begin{tabular}{|c|c|c|c|c|c|c|}
\hline & \multicolumn{6}{|c|}{ VALOR DAS EMENDAS - 1916} \\
\hline $\mathbf{N}^{\circ}$ & SEDE DO DISTRITO & APROVADAS & REJEIT ADAS & PREJUDICADAS & TOTAL & $\%$ \\
\hline $1^{\circ}$ & CAPITAL & 96.500 & 4.000 & 2.155 .900 & 2.256 .400 & $29,8 \%$ \\
\hline $2^{\circ}$ & TAUBATÉ & 70.000 & 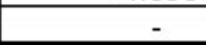 & 515.600 & 585.600 & $7,7 \%$ \\
\hline $3^{\circ}$ & GUARATINGUETÁ & 70.000 & - & 255.500 & 325.500 & $4,3 \%$ \\
\hline $4^{\circ}$ & ITUं & 80.000 & - & 734.000 & 814.000 & $10,7 \%$ \\
\hline $5^{\circ}$ & BOTUCATU & 35.000 & - & 437.000 & 472.000 & $6,2 \%$ \\
\hline $6^{\circ}$ & CAMPINAS & 70.000 & - & 292.200 & 362.200 & $4.8 \%$ \\
\hline $7^{\circ}$ & MOGY-MIRIM & 70.000 & - & 455.000 & 525.000 & $6.9 \%$ \\
\hline $8^{\circ}$ & LMEIRA & 69.000 & - & 106.500 & 175.500 & $2,3 \%$ \\
\hline $9^{\circ}$ & SÄO CARLOS & 65.000 & - & 343.200 & 408.200 & $5,4 \%$ \\
\hline $10^{\circ}$ & RIBEIRÁO PRETO & 70.000 & - & 469.000 & 539.000 & $7,1 \%$ \\
\hline $11^{\circ}$ & SEM IDENTIFICACÁOO & 19.000 & 28.000 & 1.069 .000 & 1.116 .000 & $14.7 \%$ \\
\hline & TOTAL & 714.500 & 32.000 & 6.832 .900 & 7.579 .400 & $100,0 \%$ \\
\hline & TOTAL $\%$ & $9,4 \%$ & $0,4 \%$ & $90,2 \%$ & $100,0 \%$ & \\
\hline
\end{tabular}

OBS N01: As Emendas prejudicadas foram substituídas pelas apresentadas pela Comissẫo de Fazenda, entretanto entendo que o mérito continua sendo dos parlamentares que as apresentaram

OBS N02: As emendas substitutiv as contemplam as prejudicadas, sendo que, na maioria das vezes, comvalores menores, com a finalidade de ajustar o total de despesas com o total previsto de receitas no orçamento.

\begin{tabular}{|l|l|r|r|r|c|}
\hline \multicolumn{7}{|c|}{ EMENDAS SUBSTITUTIVAS - 1916} \\
\hline $\mathbf{N}^{\circ}$ & SEDE DO DISTRITO & QTDE & $\%$ QTDE & \multicolumn{1}{c|}{ VALOR } & $\%$ VALOR \\
\hline $1^{\circ}$ & CAPITAL & 39 & $17,6 \%$ & 1.167 .100 & $49,9 \%$ \\
\hline $2^{\circ}$ & TAUBATÉ & 18 & $8,1 \%$ & 142.100 & $6,1 \%$ \\
\hline $3^{\circ}$ & GUARATINGUETÁ & 29 & $13,1 \%$ & 179.600 & $7,7 \%$ \\
\hline $4^{\circ}$ & ITÚ & 18 & $8,1 \%$ & 58.500 & $2,5 \%$ \\
\hline $5^{\circ}$ & BOTUCATU & 15 & $6,8 \%$ & 83.500 & $3,6 \%$ \\
\hline $6^{\circ}$ & CAMPINAS & 27 & $12,2 \%$ & 129.600 & $5,5 \%$ \\
\hline $7^{\circ}$ & MOGY-MIRIM & 14 & $6,3 \%$ & 59.750 & $2,6 \%$ \\
\hline $8^{\circ}$ & LIMEIRA & 22 & $9,9 \%$ & 139.500 & $6,0 \%$ \\
\hline $9^{\circ}$ & SÁO CARLOS & 13 & $5,9 \%$ & 121.200 & $5,2 \%$ \\
\hline $10^{\circ}$ & RIBEIRÁO PRETO & 13 & $5,9 \%$ & 105.500 & $4,5 \%$ \\
\hline $11^{\circ}$ & SEM IDENTIFICACÅO & 14 & $6,3 \%$ & 154.400 & $6,6 \%$ \\
\hline \multicolumn{2}{|c|}{ TOTAL } & 222 & $100,0 \%$ & 2.340 .750 & $100 \%$ \\
\hline
\end{tabular}




\begin{tabular}{|c|c|c|c|c|c|c|}
\hline & \multicolumn{6}{|c|}{ QTDE DE EMENDAS - 1917} \\
\hline $\mathbf{N}^{0}$ & SEDE DO DISTRITO & APROVADAS & REJEIT ADAS & PREJUDICADAS & TOTAL & $\%$ \\
\hline $1^{\circ}$ & CAPITAL & 0 & 0 & 62 & 62 & $16,5 \%$ \\
\hline $2^{\circ}$ & TAUBATÉ & 0 & 0 & 39 & 39 & $10,4 \%$ \\
\hline $3^{\circ}$ & GUARATINGUETÁ & 0 & 0 & 45 & 45 & $12,0 \%$ \\
\hline $4^{\circ}$ & ITÚ & 0 & 0 & 28 & 28 & $7,4 \%$ \\
\hline $5^{\circ}$ & BOTUCATU & 0 & 0 & 34 & 34 & $9,0 \%$ \\
\hline $6^{\circ}$ & CAMPINAS & 0 & 0 & 37 & 37 & $9,8 \%$ \\
\hline $7^{\circ}$ & MOGY-MIRIM & 0 & 0 & 28 & 28 & $7,4 \%$ \\
\hline $8^{\circ}$ & பMEIRA & 0 & 0 & 23 & 23 & $6,1 \%$ \\
\hline $9^{\circ}$ & SÄO CARLOS & 0 & 0 & 37 & 37 & $9,8 \%$ \\
\hline $10^{\circ}$ & RIBEIRẤO PRETO & 0 & 0 & 20 & 20 & $5,3 \%$ \\
\hline $11^{\circ}$ & SEM IDENTIFICACÁO & 1 & 0 & 22 & 23 & $6,1 \%$ \\
\hline & TOTAL & 1 & 0 & 375 & 376 & $100,0 \%$ \\
\hline & TOTAL $\%$ & $0,3 \%$ & $0,0 \%$ & $99,7 \%$ & $100,0 \%$ & \\
\hline
\end{tabular}

OBS N01: As Emendas prejudicadas foram substituídas pelas apresentadas pela Comissẫo de Fazenda, entretanto entendo que o mérito continua sendo dos parlamentares que as apresentaram

OBS N02: As emendas substitutiv as contemplam as prejudicadas, sendo que, na maioria das vezes, comvalores menores, com a finalidade de ajustar o total de despesas com o total previsto de receitas no orçamento.

\begin{tabular}{|c|c|c|c|c|c|c|}
\hline & \multicolumn{6}{|c|}{ VALOR DAS EMENDAS - 1917} \\
\hline $\mathbf{N}^{\circ}$ & SEDE DO DISTRITO & APROVADAS & REJEIT ADAS & PREJUDICADAS & TOTAL & $\%$ \\
\hline $1^{\circ}$ & CAPITAL & - & 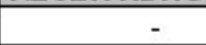 & 1.679 .800 & 1.679 .800 & $31,5 \%$ \\
\hline $2^{\circ}$ & TAUBATÉ & - & - & 530.100 & 530.100 & $9,9 \%$ \\
\hline $3^{\circ}$ & GUARATINGUETÁ & - & - & 297.100 & 297.100 & $5,6 \%$ \\
\hline $4^{\circ}$ & ITÚ & - & - & 236.000 & 236.000 & $4,4 \%$ \\
\hline $5^{\circ}$ & BOTUCATU & - & - & 464.500 & 464.500 & $8,7 \%$ \\
\hline $6^{\circ}$ & CAMPINAS & - & 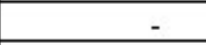 & 355.200 & 355.200 & $6,7 \%$ \\
\hline $7^{\circ}$ & MOGY-MIRIM & - & - & 469.500 & 469.500 & $8,8 \%$ \\
\hline $8^{\circ}$ & UMEIRA & - & - & 122.200 & 122.200 & $2,3 \%$ \\
\hline 9 & SÄO CARLOS & - & - & 462.400 & 462.400 & $8,7 \%$ \\
\hline $10^{\circ}$ & RIBEIRÁO PRETO & - & - & 398.000 & 398.000 & $7,5 \%$ \\
\hline & SEM IDENTIFICACÁ̃O & 10.000 & - & 311.600 & 321.600 & $6,0 \%$ \\
\hline & TOTAL & 10.000 & - & 5.326 .400 & 5.336 .400 & $100,0 \%$ \\
\hline & TOTAL $\%$ & $0,2 \%$ & $0,0 \%$ & $99,8 \%$ & $100,0 \%$ & \\
\hline
\end{tabular}

OBS N01: As Emendas prejudicadas foram substituídas pelas apresentadas pela Comissẫo de Fazenda, entretanto entendo que o mérito continua sendo dos parlamentares que as apresentaram

OBS N02: As emendas substitutivas contemplam as prejudicadas, sendo que, na maioria das vezes, comvalores menores, com a finalidade de ajustar o total de despesas com o total previsto de receitas no orçamento.

\begin{tabular}{|c|c|c|c|c|c|}
\hline \multicolumn{6}{|c|}{ EMENDAS SUBSTITUTIVAS - 1917} \\
\hline $\mathbf{N}^{\circ}$ & SEDE DO DISTRITO & QTDE & $\%$ QTDE & VALOR & $\%$ VALOR \\
\hline $1^{\circ}$ & CAPITAL & 43 & $18,6 \%$ & 1.183 .100 & $52,5 \%$ \\
\hline $2^{\circ}$ & TAUBATÉ & 20 & $8,7 \%$ & 108.100 & $4,8 \%$ \\
\hline $3^{\circ}$ & GUARATINGUETÁ & 28 & $12,1 \%$ & 141.600 & $6,3 \%$ \\
\hline $4^{\circ}$ & ITÚ & 19 & $8,2 \%$ & 59.500 & $2,6 \%$ \\
\hline $5^{\circ}$ & BOTUCATU & 14 & $6,1 \%$ & 63.500 & $2,8 \%$ \\
\hline $6^{\circ}$ & CAMPINAS & 27 & $11,7 \%$ & 127.600 & $5,7 \%$ \\
\hline $7^{\circ}$ & MOGY-MIRIM & 15 & $6,5 \%$ & 73.550 & $3,3 \%$ \\
\hline $8^{\circ}$ & LIMEIRA & 22 & $9,5 \%$ & 92.500 & $4,1 \%$ \\
\hline $9^{\circ}$ & SÄO CARLOS & 12 & $5,2 \%$ & 88.200 & $3,9 \%$ \\
\hline $10^{\circ}$ & RIBEIRÁO PRETO & 13 & $5,6 \%$ & 101.500 & $4,5 \%$ \\
\hline $11^{\circ}$ & SEM IDENTIFICACÁO & 18 & $7,8 \%$ & 216.168 & $9,6 \%$ \\
\hline & TOTAL & 231 & $100,0 \%$ & 2.255 .318 & $100 \%$ \\
\hline
\end{tabular}




\begin{tabular}{|c|c|c|c|c|c|c|}
\hline & \multicolumn{6}{|c|}{ QTDE DE EMENDAS - 1918} \\
\hline $\mathrm{N}^{0}$ & SEDE DO DISTRITO & APROVADAS & REJEIT ADAS & PREJUDICADAS & TOTAL & $\%$ \\
\hline $1^{\circ}$ & CAPITAL & & & 56 & 56 & $15,5 \%$ \\
\hline $2^{\circ}$ & TAUBATÉ & & & 43 & 43 & $11,9 \%$ \\
\hline $3^{\circ}$ & GUARATINGUETÁ & & & 39 & 39 & $10,8 \%$ \\
\hline $4^{\circ}$ & ITÚ & & & 40 & 40 & $11,0 \%$ \\
\hline $5^{\circ}$ & BOTUCATU & & & 21 & 21 & $5.8 \%$ \\
\hline $6^{\circ}$ & CAMPINAS & & & 40 & 40 & $11,0 \%$ \\
\hline $7^{\circ}$ & MOGY-MIRIM & & & 28 & 28 & $7,7 \%$ \\
\hline $8^{\circ}$ & பMEIRA & & & 27 & 27 & $7,5 \%$ \\
\hline $9^{\circ}$ & SÄO CARLOS & & & 28 & 28 & $7,7 \%$ \\
\hline $10^{\circ}$ & RIBEIRÄO PRETO & & & 26 & 26 & $7,2 \%$ \\
\hline $11^{\circ}$ & SEM IDENTIFICACÄO & & & 14 & 14 & $3,9 \%$ \\
\hline & TOTAL & 0 & 0 & 362 & 362 & $100,0 \%$ \\
\hline & TOTAL $\%$ & $0,0 \%$ & $0,0 \%$ & $100,0 \%$ & $100,0 \%$ & \\
\hline
\end{tabular}

OBS N01: As Emendas prejudicadas foram substituídas pelas apresentadas pela Comissẫo de Fazenda, entretanto entendo que o mérito continua sendo dos parlamentares que as apresentaram

OBS N02: As emendas substitutiv as contemplam as prejudicadas, sendo que, na maioria das vezes, comvalores menores, com a finalidade de ajustar o total de despesas com o total previsto de receitas no orçamento.

\begin{tabular}{|c|c|c|c|c|c|c|}
\hline & \multicolumn{6}{|c|}{ VALOR DAS EMENDAS - 1918} \\
\hline $\mathbf{N}^{\circ}$ & SEDE DO DISTRITO & APROVADAS & REJEIT ADAS & PREJUDICADAS & TOTAL & $\%$ \\
\hline $1^{\circ}$ & CAPITAL & & & 1.457 .600 & 1.457 .600 & $27,8 \%$ \\
\hline $2^{\circ}$ & TAUBATÉ & & & 1.008 .500 & 1.008 .500 & $19,3 \%$ \\
\hline $3^{\circ}$ & GUARATINGUETÁ & & & 235.100 & 235.100 & $4,5 \%$ \\
\hline $4^{\circ}$ & ITÚ & & & 317.000 & 317.000 & $6,1 \%$ \\
\hline $5^{\circ}$ & BOTUCATU & & & 246.000 & 246.000 & $4,7 \%$ \\
\hline $6^{\circ}$ & CAMPINAS & & & 324.200 & 324.200 & $6.2 \%$ \\
\hline $7^{\circ}$ & MOGY-MIRIM & & & 486.100 & 486.100 & $9,3 \%$ \\
\hline $8^{\circ}$ & UMEIRA & & & 147.000 & 147.000 & $2,8 \%$ \\
\hline $9^{\circ}$ & SÄO CARLOS & & & 302.000 & 302.000 & $5,8 \%$ \\
\hline $10^{\circ}$ & RIBEIRÁO PRETO & & & 540.000 & 540.000 & $10,3 \%$ \\
\hline & SEM IDENTIFICACÁ̈O & & & 173.000 & 173.000 & $3,3 \%$ \\
\hline & TOTAL & - & - & 5.236 .500 & 5.236 .500 & $100,0 \%$ \\
\hline & TOTAL $\%$ & $0,0 \%$ & $0,0 \%$ & $100,0 \%$ & $100,0 \%$ & \\
\hline
\end{tabular}

OBS N01: As Emendas prejudicadas foram substituídas pelas apresentadas pela Comissẫo de Fazenda, entretanto entendo que o mérito continua sendo dos parlamentares que as apresentaram

OBS $N^{\circ} 02$. As emendas substitutivas contemplam as prejudicadas, sendo que, na maioria das vezes, comvalores menores, com a finalidade de ajustar o total de despesas com o total previsto de receitas no orçamento.

\begin{tabular}{|c|c|c|c|c|c|}
\hline \multicolumn{6}{|c|}{ EMENDAS SUBSTITUTIVAS - 1918} \\
\hline $\mathbf{N}^{\circ}$ & SEDE DO DISTRITO & QTDE & $\%$ QTDE & VALOR & $\%$ VALOR \\
\hline $1^{\circ}$ & CAPITAL & 56 & $16,4 \%$ & 1.337 .600 & $22,6 \%$ \\
\hline $2^{\circ}$ & TAUBATÉ & 29 & $8,5 \%$ & 172.600 & $2,9 \%$ \\
\hline $3^{\circ}$ & GUARATINGUETÁ & 39 & $11,4 \%$ & 221.000 & $3,7 \%$ \\
\hline $4^{\circ}$ & ITÚ & 31 & $9,1 \%$ & 137.000 & $2,3 \%$ \\
\hline $5^{\circ}$ & BOTUCATU & 19 & $5,6 \%$ & 151.000 & $2,5 \%$ \\
\hline $6^{\circ}$ & CAMPINAS & 41 & $12,0 \%$ & 296.500 & $5,0 \%$ \\
\hline $7^{\circ}$ & MOGY-MIRIM & 24 & $7,0 \%$ & 292.550 & $4,9 \%$ \\
\hline $8^{\circ}$ & LIMEIRA & 30 & $8,8 \%$ & 162.500 & $2,7 \%$ \\
\hline $9^{\circ}$ & SÄO CARLOS & 24 & $7,0 \%$ & 220.000 & $3,7 \%$ \\
\hline $10^{\circ}$ & RIBEIRẢO PRETO & 25 & $7,3 \%$ & 237.500 & $4,0 \%$ \\
\hline $11^{\circ}$ & SEM IDENTIFICACẢO & 23 & $6,7 \%$ & 2.700 .600 & $45,6 \%$ \\
\hline & TOTAL & 341 & $100,0 \%$ & 5.928 .850 & $100 \%$ \\
\hline
\end{tabular}




\begin{tabular}{|c|c|c|c|c|c|c|}
\hline & \multicolumn{6}{|c|}{ QTDE DE EMENDAS - 1919} \\
\hline $\mathbf{N}^{0}$ & SEDE DO DISTRITO & APROVADAS & REJJEIT ADAS & PREJUDICADAS & TOTAL & $\%$ \\
\hline $1^{\circ}$ & CAPITAL & 0 & 0 & 60 & 60 & $12,1 \%$ \\
\hline $2^{\circ}$ & TAUBATÉ & 0 & 0 & 62 & 62 & $12,5 \%$ \\
\hline $3^{\circ}$ & GUARATINGUETÁ & 0 & 0 & 55 & 55 & $11,1 \%$ \\
\hline $4^{\circ}$ & ITÚ & 0 & 0 & 46 & 46 & $9,3 \%$ \\
\hline $5^{\circ}$ & BOTUCATU & 0 & 0 & 44 & 44 & $8.9 \%$ \\
\hline $6^{\circ}$ & CAMPINAS & 0 & 0 & 47 & 47 & $9,5 \%$ \\
\hline $7^{\circ}$ & MOGY-MIRIM & 0 & 0 & 37 & 37 & $7,5 \%$ \\
\hline $8^{\circ}$ & பMEIRA & 0 & 0 & 34 & 34 & $6,9 \%$ \\
\hline$g^{\circ}$ & SÁOO CARLOS & 0 & 0 & 37 & 37 & $7,5 \%$ \\
\hline $10^{\circ}$ & RIBEIRÁO PRETO & 0 & 0 & 47 & 47 & $9,5 \%$ \\
\hline $11^{\circ}$ & SEM IDENTIFICACÄA & 0 & 0 & 27 & 27 & $5,4 \%$ \\
\hline & TOTAL & 0 & 0 & 496 & 496 & $100,0 \%$ \\
\hline & TOTAL $\%$ & $0,0 \%$ & $0,0 \%$ & $100,0 \%$ & $100,0 \%$ & \\
\hline
\end{tabular}

OBS N01: As Emendas prejudicadas foram substituídas pelas apresentadas pela Comissấo de Fazenda, entretanto entendo que o mérito continua sendo dos parlamentares que as apresentaram

OBS N02: As emendas substitutivas contemplam as prejudicadas, sendo que, na maioria das vezes, comvalores menores, com a finalidade de ajustar o total de despesas com o total previsto de receitas no orçamento.

\begin{tabular}{|c|c|c|c|c|c|c|}
\hline & \multicolumn{6}{|c|}{ VALOR DAS EMENDAS - 1919} \\
\hline $\mathbf{N}^{0}$ & SEDE DO DISTRITO & APROVADAS & REJEIT ADAS & PREJUDICADAS & TOTAL & $\%$ \\
\hline $1^{\circ}$ & CAPITAL & - & - & 1.604 .800 & 1.604 .800 & $21,5 \%$ \\
\hline $2^{\circ}$ & TAUBATÉ & - & - & 506.000 & 506.000 & $6.8 \%$ \\
\hline $3^{\circ}$ & GUARATINGUETÁ & - & - & 587.500 & 587.500 & $7,9 \%$ \\
\hline $4^{\circ}$ & ITÚ & - & - & 670.000 & 670.000 & $9,0 \%$ \\
\hline $5^{\circ}$ & BOTUCATU & - & - & 566.000 & 566.000 & $7,6 \%$ \\
\hline $6^{\circ}$ & CAMPINAS & - & - & 628.000 & 628.000 & $8,4 \%$ \\
\hline $7^{\circ}$ & MOGY-MIRIM & - & - & 572.600 & 572.600 & $7.7 \%$ \\
\hline $8^{\circ}$ & பMEIRA & - & - & 234.000 & 234.000 & $3,1 \%$ \\
\hline $9^{\circ}$ & SÄO CARLOS & - & - & 428.000 & 428.000 & $5,7 \%$ \\
\hline $10^{\circ}$ & RIBEIRÁO PRETO & - & - & 942.000 & 942.000 & $12,6 \%$ \\
\hline $11^{\circ}$ & SEM IDENTIFICACÅOO & - & - & 713.290 & 713.290 & $9,6 \%$ \\
\hline & TOTAL & - & - & 7.452 .190 & 7.452 .190 & $100,0 \%$ \\
\hline & TOTAL $\%$ & $0,0 \%$ & $0,0 \%$ & $100,0 \%$ & $100,0 \%$ & \\
\hline
\end{tabular}

OBS N01: As Emendas prejudicadas foram substituídas pelas apresentadas pela Comissấo de $\mathrm{F}$ azenda, entretanto entendo que o mérito continua sendo dos parlamentares que as apresentaram

OBS N02: As emendas substitutivas contemplam as prejudicadas, sendo que, na maioria das vezes, comvalores menores, com a finalidade de ajustar o total de despesas com o total previsto de receitas no orçamento.

\begin{tabular}{|l|l|r|r|r|c|}
\hline \multicolumn{7}{|c|}{ EMENDAS SUBSTITUTIVAS - 1919} \\
\hline $\mathbf{N}^{\circ}$ & SEDE DO DISTRITO & \multicolumn{1}{c|}{ QTDE } & $\%$ QTDE & VALOR & $\%$ VALOR \\
\hline $1^{\circ}$ & CAPITAL & 70 & $16,5 \%$ & 1.588 .800 & $26,9 \%$ \\
\hline $2^{\circ}$ & TAUBATÉ & 37 & $8,7 \%$ & 326.600 & $5,5 \%$ \\
\hline $3^{\circ}$ & GUARATINGUETÁ & 53 & $12,5 \%$ & 290.500 & $4,9 \%$ \\
\hline $4^{\circ}$ & ITÚ & 40 & $9,4 \%$ & 233.500 & $4,0 \%$ \\
\hline $5^{\circ}$ & BOTUCATU & 27 & $6,4 \%$ & 170.000 & $2,9 \%$ \\
\hline $6^{\circ}$ & CAMPINAS & 50 & $11,8 \%$ & 238.600 & $4,0 \%$ \\
\hline $7^{\circ}$ & MOGY-MIRIM & 33 & $7,8 \%$ & 224.550 & $3,8 \%$ \\
\hline $8^{\circ}$ & LIMEIRA & 36 & $8,5 \%$ & 217.000 & $3,7 \%$ \\
\hline $9^{\circ}$ & SÁO CARLOS & 32 & $7,5 \%$ & 228.000 & $3,9 \%$ \\
\hline $10^{\circ}$ & RIBEIRÁO PRETO & 31 & $7,3 \%$ & 221.600 & $3,8 \%$ \\
\hline $11^{\circ}$ & SEM IDENTIFICACÁO & 15 & $3,5 \%$ & 2.157 .800 & $36,6 \%$ \\
\hline \multicolumn{2}{|c|}{ TOTAL } & 424 & $100,0 \%$ & 5.896 .950 & $100 \%$ \\
\hline
\end{tabular}




\begin{tabular}{|c|c|c|c|c|c|c|}
\hline & \multicolumn{6}{|c|}{ QTDE DE EMENDAS - 1920} \\
\hline $\mathrm{N}^{0}$ & SEDE DO DISTRITO & APROVADAS & REJEIT ADAS & PREJUDICADAS & TOTAL & $\%$ \\
\hline $1^{\circ}$ & CAPITAL & & & 84 & 84 & $13,3 \%$ \\
\hline $2^{\circ}$ & TAUBATÉ & & & 81 & 81 & $12,8 \%$ \\
\hline $3^{\circ}$ & GUARATINGUETÁ & & & 55 & 55 & $8,7 \%$ \\
\hline $4^{\circ}$ & ITÚ & & & 60 & 60 & $9,5 \%$ \\
\hline $5^{\circ}$ & BOTUCATU & & & 63 & 63 & $10,0 \%$ \\
\hline $6^{\circ}$ & CAMPINAS & & & 53 & 53 & $8,4 \%$ \\
\hline $7^{\circ}$ & MOGY-MIRIM & & & 52 & 52 & $8,2 \%$ \\
\hline $8^{\circ}$ & பMEIRA & & & 39 & 39 & $6,2 \%$ \\
\hline $9^{\circ}$ & SÄO CARLOS & & & 48 & 48 & $7,6 \%$ \\
\hline $10^{\circ}$ & RIBEIRÄO PRETO & & & 78 & 78 & $12,3 \%$ \\
\hline $11^{\circ}$ & SEM IDENTIFICACÄO & & & 19 & 19 & $3,0 \%$ \\
\hline & TOTAL & 0 & 0 & 632 & 632 & $100,0 \%$ \\
\hline & TOTAL $\%$ & $0,0 \%$ & $0,0 \%$ & $100,0 \%$ & $100,0 \%$ & \\
\hline
\end{tabular}

OBS N01: As Emendas prejudicadas foram substituídas pelas apresentadas pela Comissấo de Fazenda, entretanto entendo que o mérito continua sendo dos parlamentares que as apresentaram

OBS N02: As emendas substitutiv as contemplam as prejudicadas, sendo que, na maioria das vezes, comvalores menores, com a finalidade de ajustar o total de despesas com o total previsto de receitas no orçamento.

\begin{tabular}{|c|c|c|c|c|c|c|}
\hline & \multicolumn{6}{|c|}{ VALOR DAS EMENDAS - 1920} \\
\hline $\mathrm{N}^{\circ}$ & SEDE DO DISTRITO & APROVADAS & REJEIT ADAS & PREJUDICADAS & TOTAL & $\%$ \\
\hline $1^{\circ}$ & CAPITAL & & & 756.500 & 756.500 & $9,8 \%$ \\
\hline $2^{\circ}$ & TAUBATÉ & & & 964.200 & 964.200 & $12,5 \%$ \\
\hline $3^{\circ}$ & GUARATINGUETÁ & & & 461.300 & 461.300 & $6,0 \%$ \\
\hline $4^{\circ}$ & ITUं & & & 688.000 & 688.000 & $8,9 \%$ \\
\hline $5^{\circ}$ & BOTUCATU & & & 854.000 & 854.000 & $11,1 \%$ \\
\hline $6^{\circ}$ & CAMPINAS & & & 395.000 & 395.000 & $5,1 \%$ \\
\hline $7^{\circ}$ & MOGY-MIRIM & & & 723.100 & 723.100 & $9,4 \%$ \\
\hline $8^{\circ}$ & UMEIRA & & & 231.000 & 231.000 & $3,0 \%$ \\
\hline $9^{\circ}$ & SÄO CARLOS & & & 698.000 & 698.000 & $9,1 \%$ \\
\hline $10^{\circ}$ & RIBEIRÁO PRETO & & & 1.610 .600 & 1.610 .600 & $20,9 \%$ \\
\hline & SEM IDENTIFICACÁAO & & & 317.000 & 317.000 & $4,1 \%$ \\
\hline & TOTAL & - & - & 7.698 .700 & 7.698 .700 & $100,0 \%$ \\
\hline & TOTAL $\%$ & $0,0 \%$ & $0,0 \%$ & $100,0 \%$ & $100,0 \%$ & \\
\hline
\end{tabular}

OBS N01: As Emendas prejudicadas foram substituídas pelas apresentadas pela Comissấo de $\mathrm{F}$ azenda, entretanto entendo que o mérito continua sendo dos parlamentares que as apresentaram

OBS $N^{\circ} 02$ : As emendas substitutivas contemplam as prejudicadas, sendo que, na maioria das vezes, comvalores menores, com a finalidade de ajustar o total de despesas com o total previsto de receitas no orçamento.

\begin{tabular}{|l|l|r|r|r|c|}
\hline \multicolumn{7}{|c|}{ EMENDAS SUBSTITUTIVAS - 1920} \\
\hline $\mathbf{N}^{\circ}$ & SEDE DO DISTRITO & \multicolumn{1}{c|}{ QTDE } & $\%$ QTDE & \multicolumn{1}{c|}{ VALOR } & $\%$ VALOR \\
\hline $1^{\circ}$ & CAPITAL & 70 & $15,0 \%$ & 1.588 .800 & $41,0 \%$ \\
\hline $2^{\circ}$ & TAUBATÉ & 41 & $8,8 \%$ & 224.600 & $5,8 \%$ \\
\hline $3^{\circ}$ & GUARATINGUETÁ & 52 & $11,1 \%$ & 260.300 & $6,7 \%$ \\
\hline $4^{\circ}$ & ITÚ & 47 & $10,0 \%$ & 215.000 & $5,6 \%$ \\
\hline $5^{\circ}$ & BOTUCATU & 40 & $8,5 \%$ & 277.000 & $7,2 \%$ \\
\hline $6^{\circ}$ & CAMPINAS & 47 & $10,0 \%$ & 220.600 & $5,7 \%$ \\
\hline $7^{\circ}$ & MOGY-MIRIM & 41 & $8,8 \%$ & 200.550 & $5,2 \%$ \\
\hline $8^{\circ}$ & LIMEIRA & 39 & $8,3 \%$ & 232.000 & $6,0 \%$ \\
\hline $9^{\circ}$ & SÄO CARLOS & 35 & $7,5 \%$ & 238.000 & $6,1 \%$ \\
\hline $10^{\circ}$ & RIBEIRAिO PRETO & 44 & $9,4 \%$ & 278.600 & $7,2 \%$ \\
\hline $11^{\circ}$ & SEM IDENTIFICACÁO & 12 & $2,6 \%$ & 138.000 & $3,6 \%$ \\
\hline \multicolumn{2}{|c|}{ TOTAL } & 468 & $100,0 \%$ & 3.873 .450 & $100 \%$ \\
\hline
\end{tabular}


Apêndice I

Série de Planilhas indicando Destino das Emendas, de cada Deputado, da $1^{\mathrm{a}}$ à $11^{\mathrm{a}}$ Legislaturas 1891-1920

(\%) 


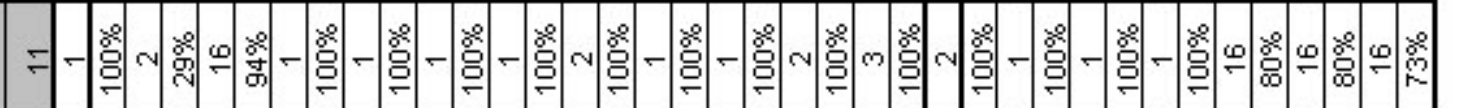

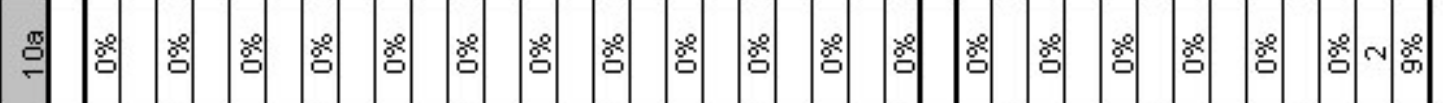

罚 皇

옹

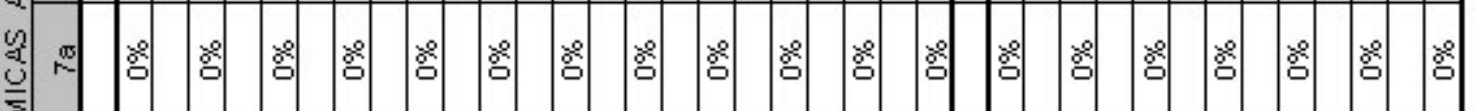

皇

乐

号

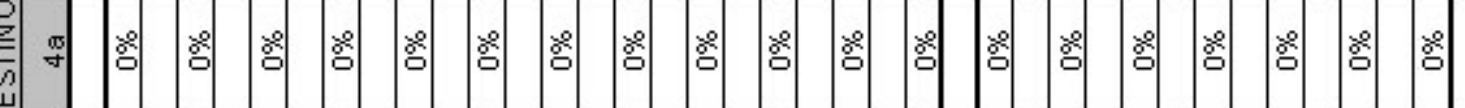

m

옹-争

융

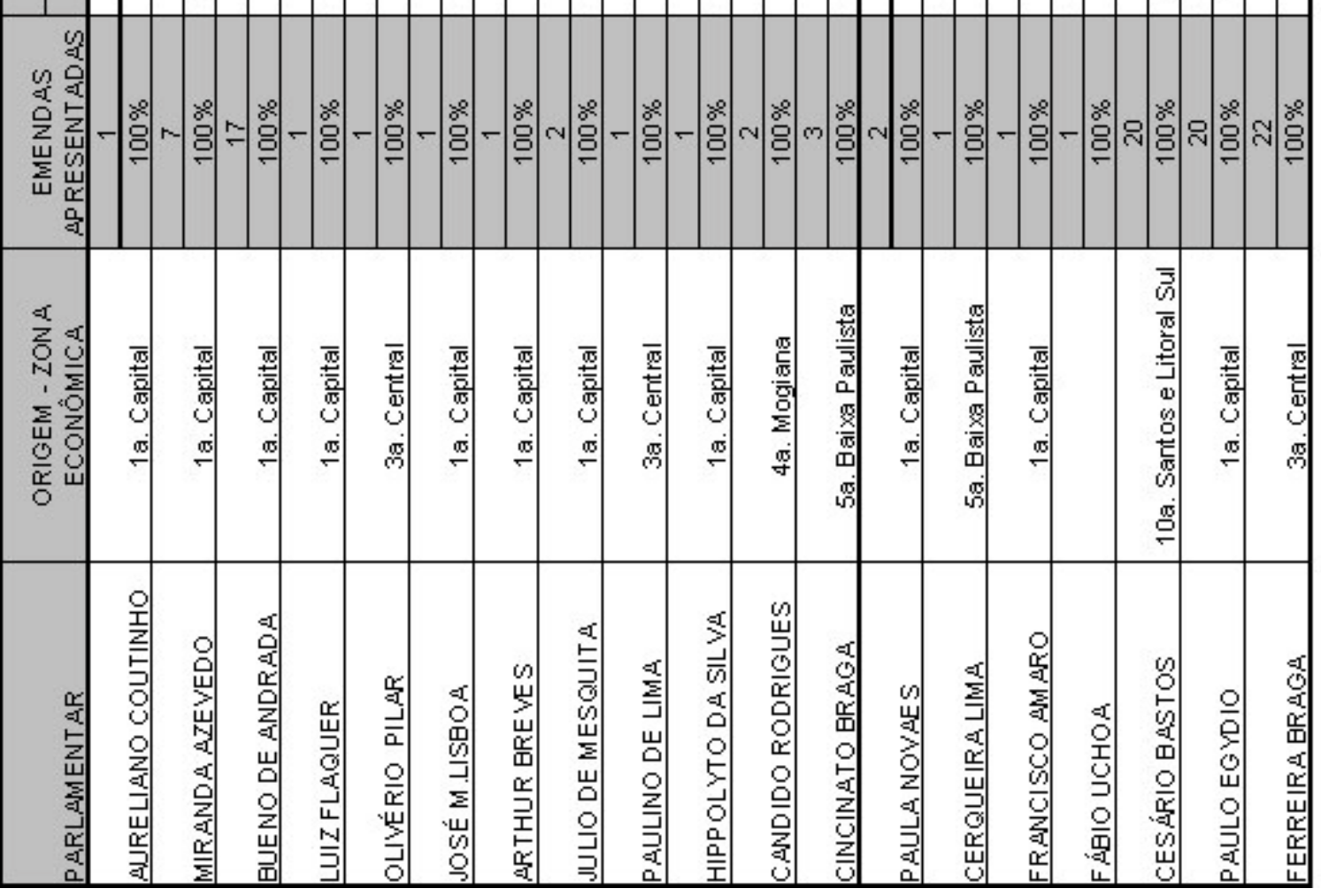

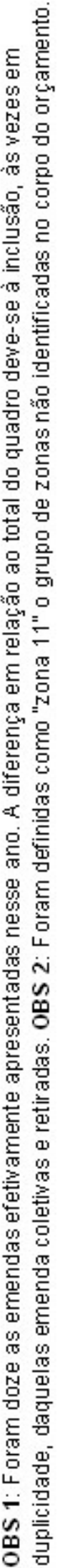




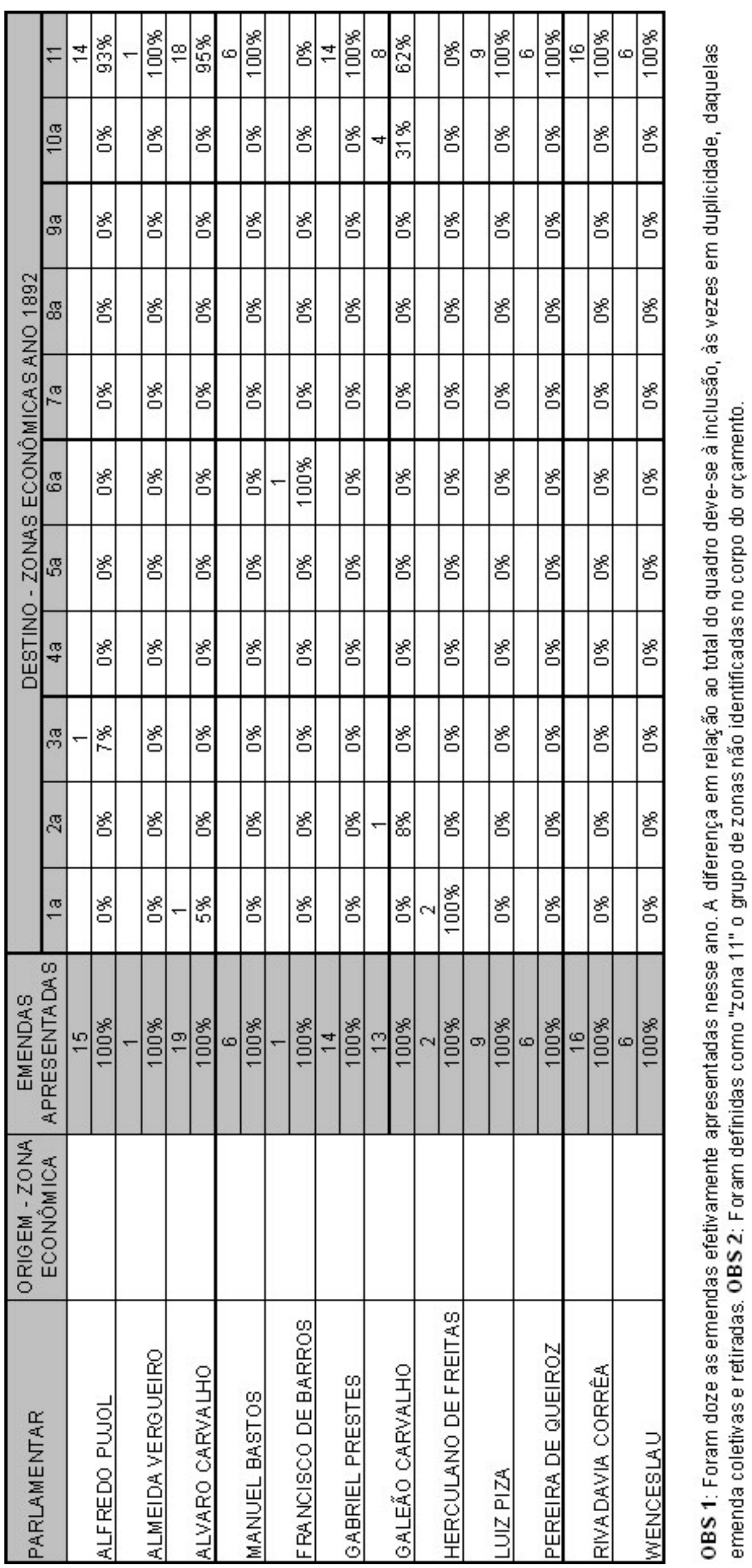




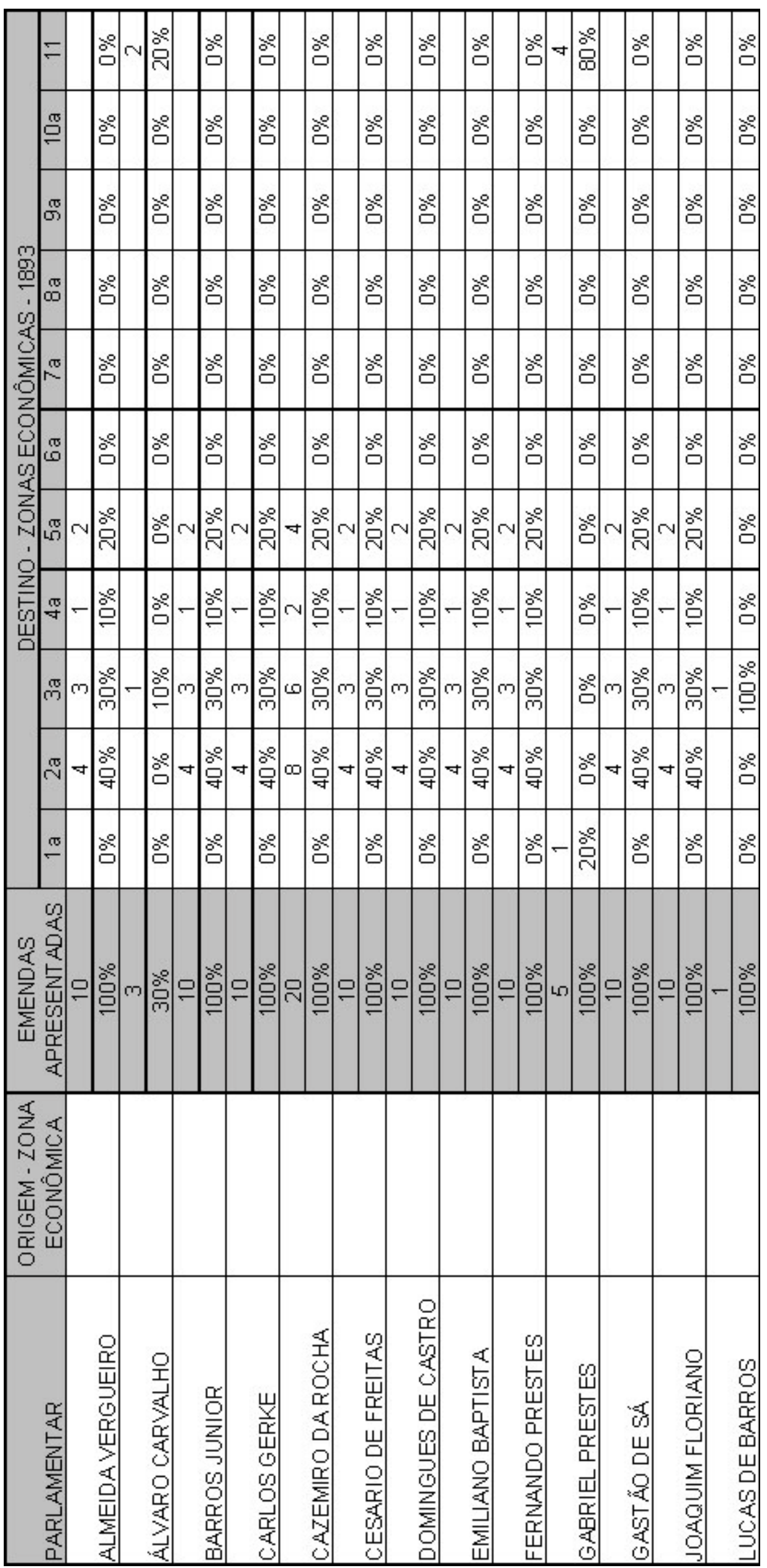




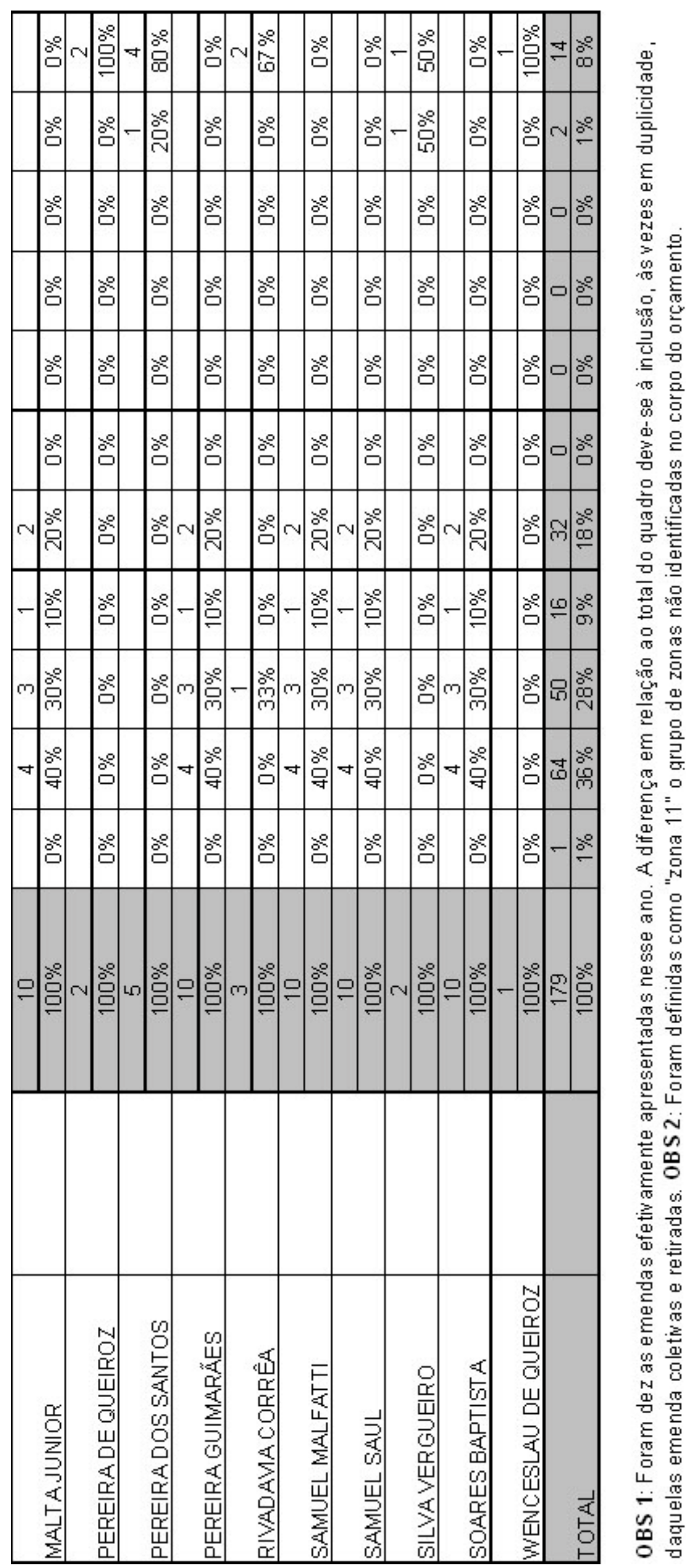




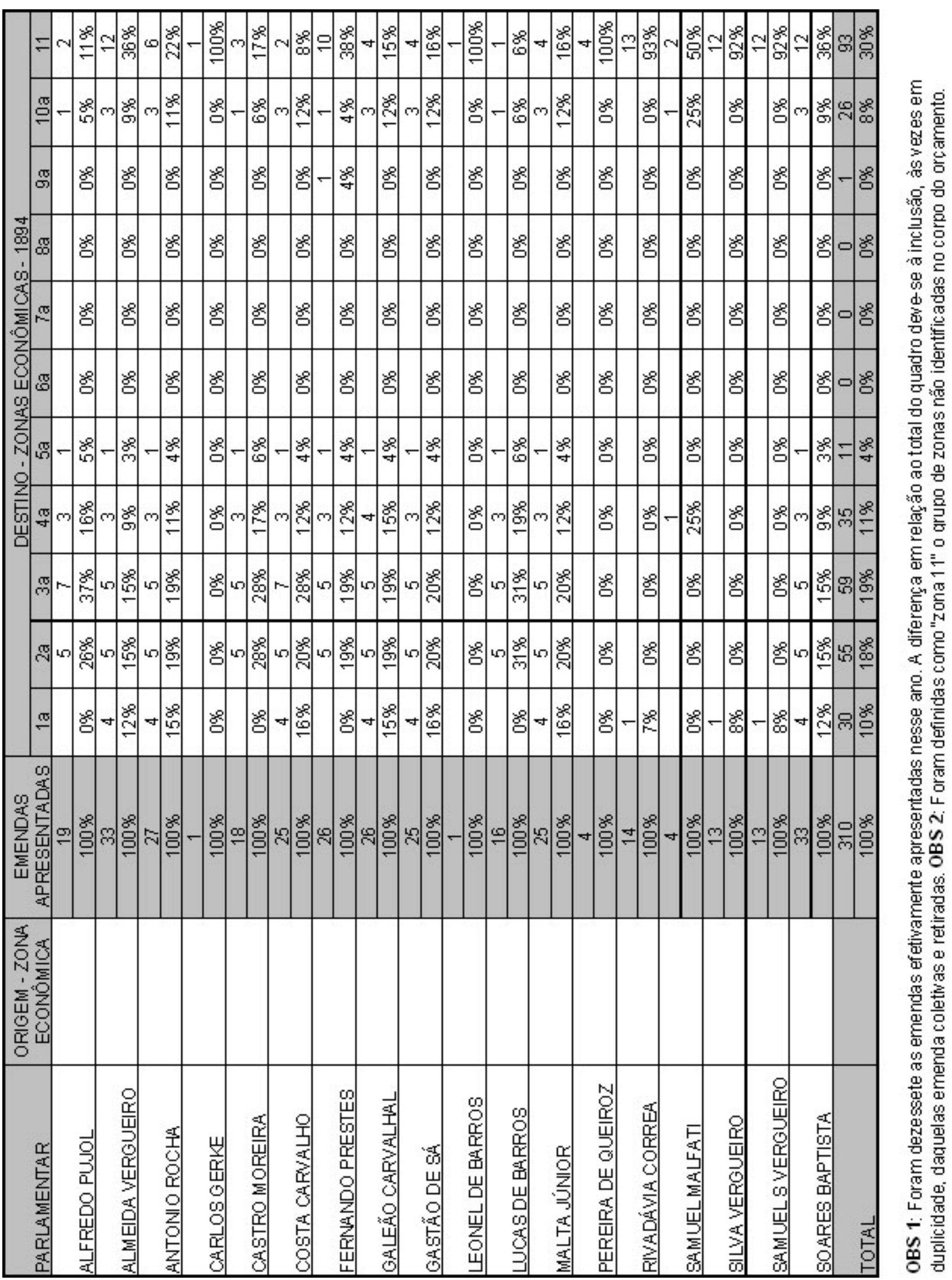




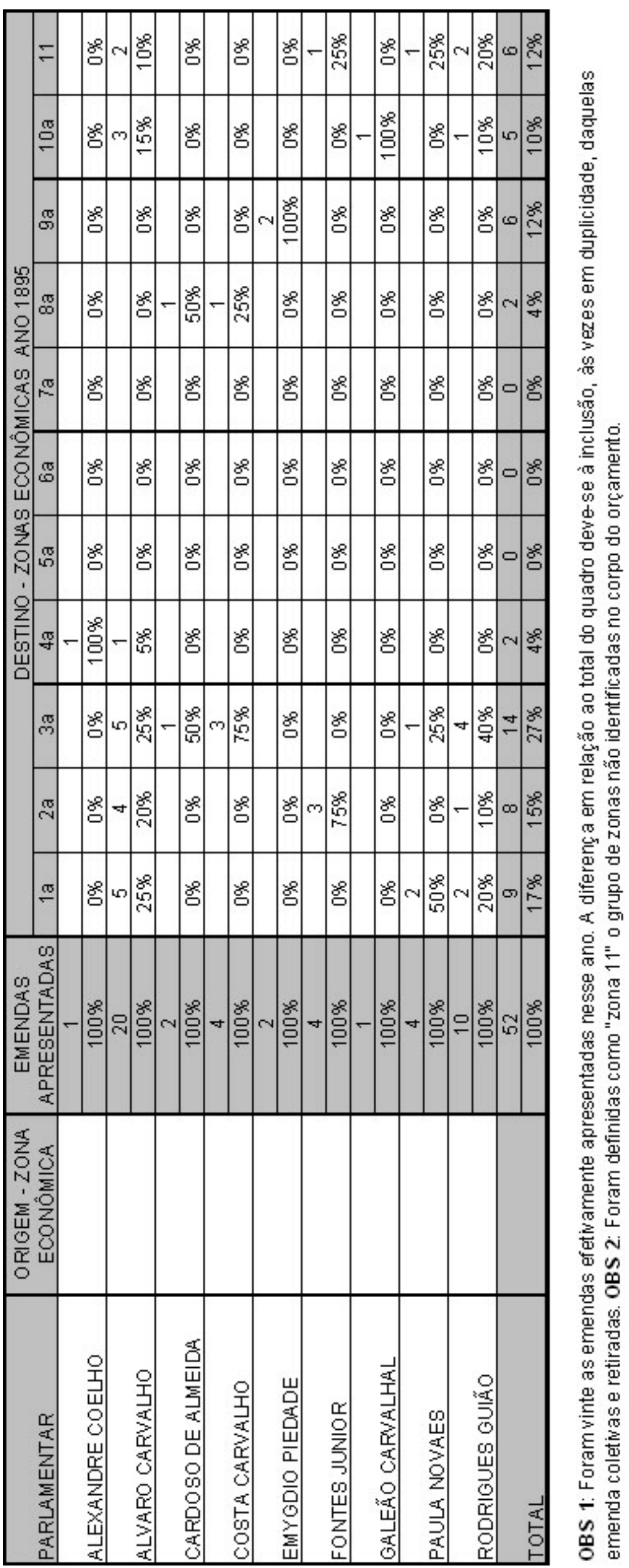




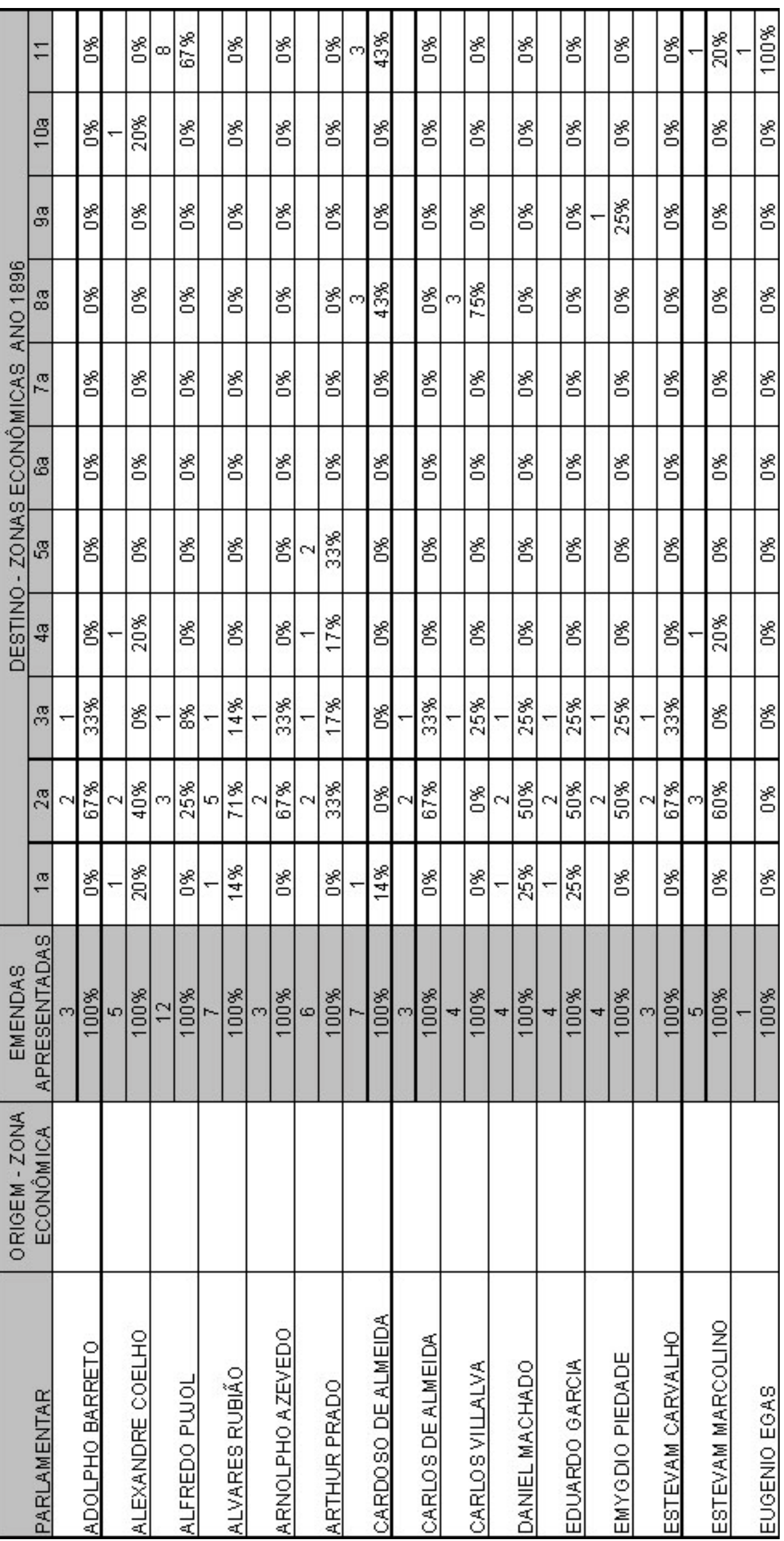




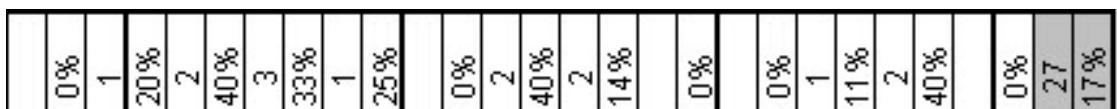

염 -

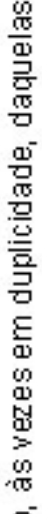

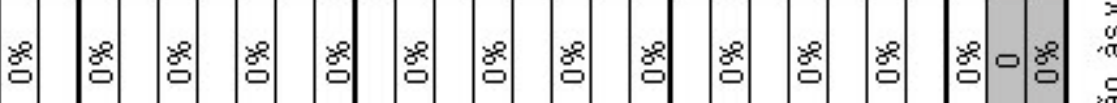

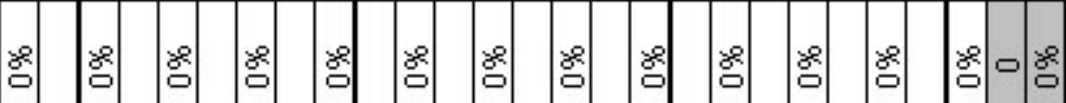

总

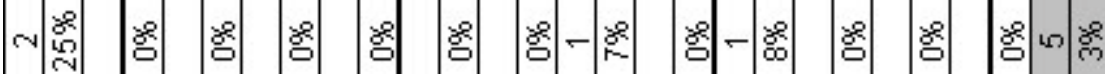

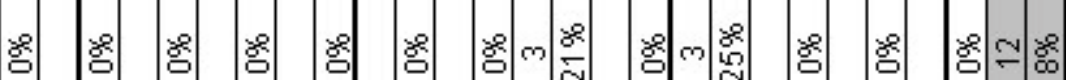

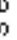

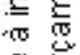

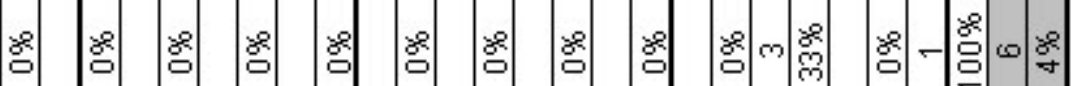

d

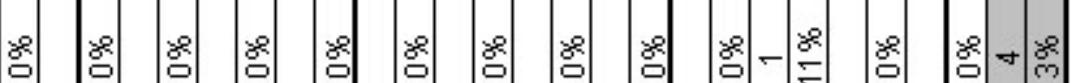

咅

음 응

要

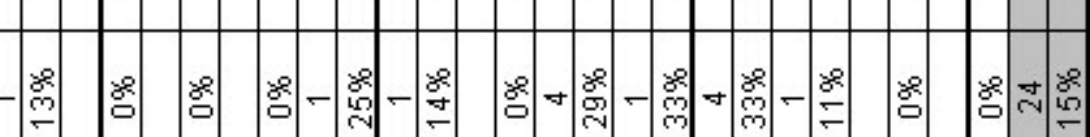

음

覃

雨

क

㲅

要

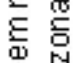

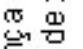

- -

善

$=10$

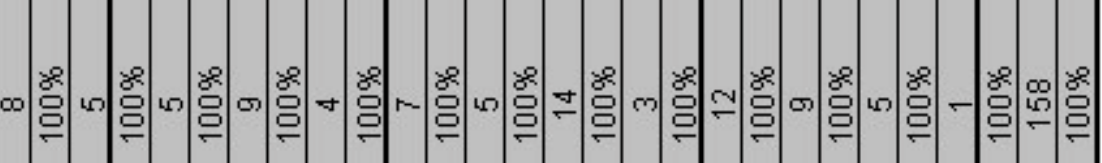

른

弯吉

믈

要

离

产害

呂

몬

壳识

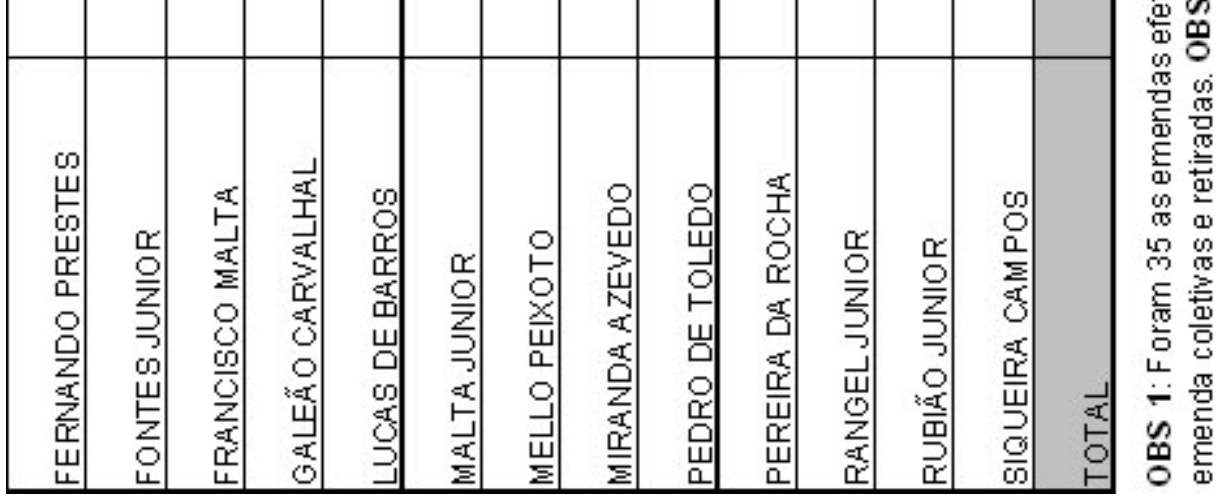




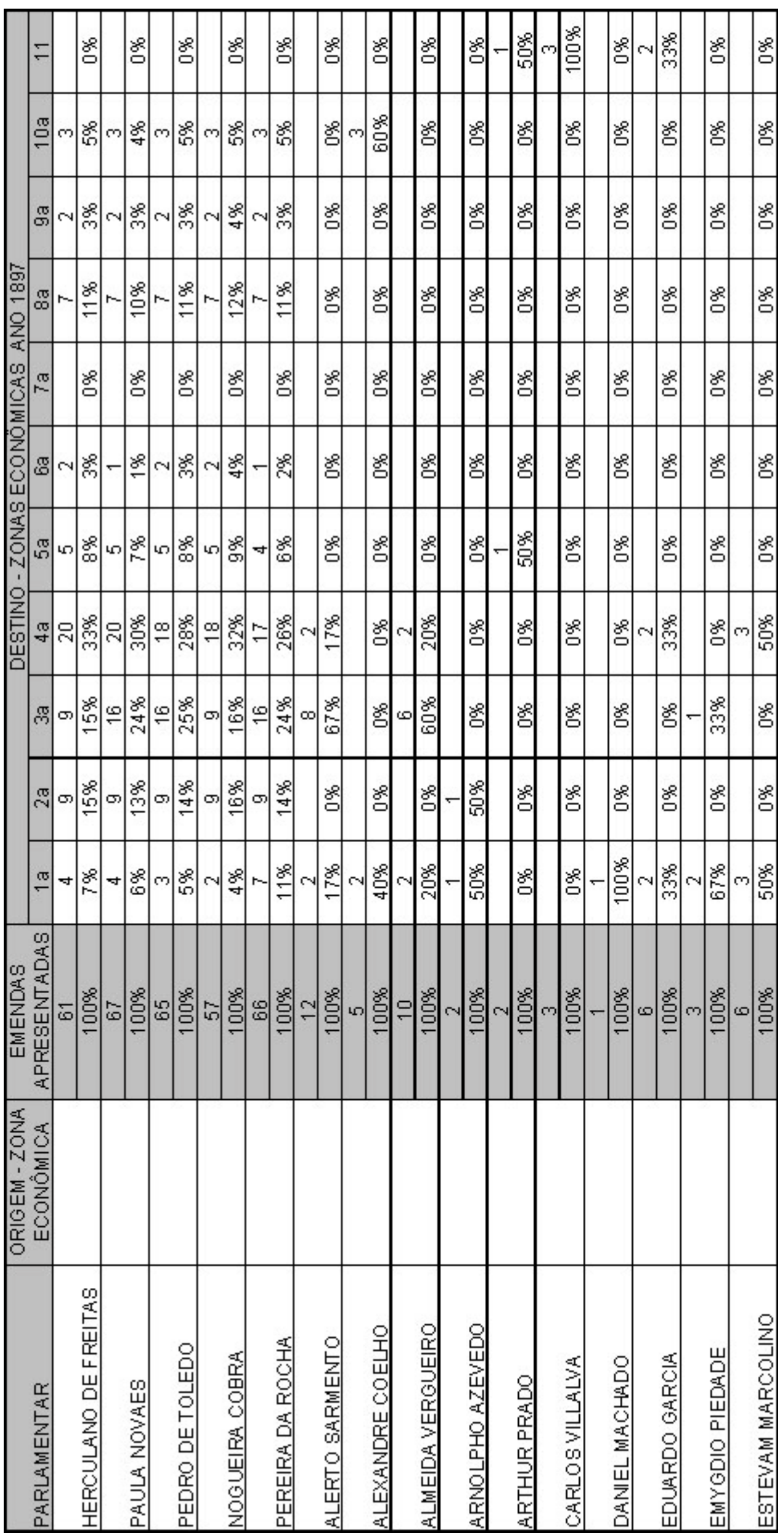




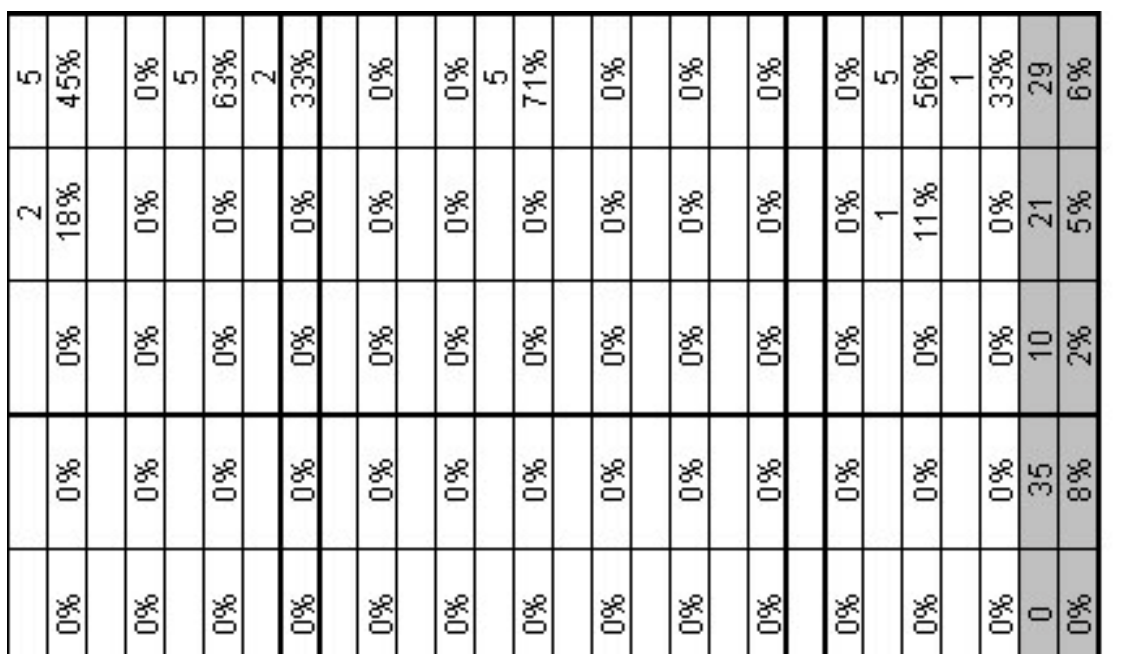

兽

क 을

总 므

要

通

음

氧器

동 을

息

㟔=-

क

喵

兽 은

염 염 염 염

要

d

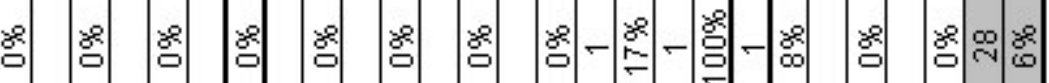

-

-

$-2+\frac{2}{\infty}-m$ m

- -

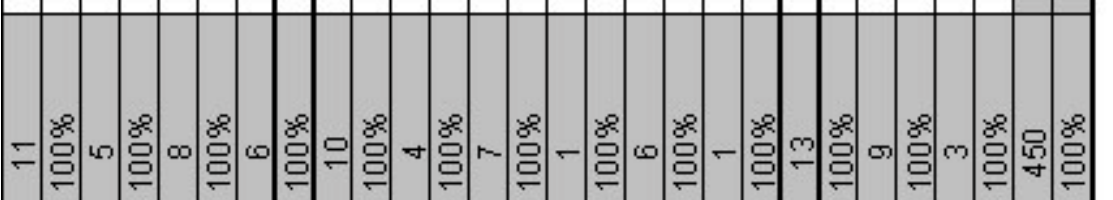

는

릉

吕瓷

홍

음

品票

产

혼

心票

氙 흔

喜 骂

次 $\frac{\text { D }}{\mathrm{T}}$

焉

要

总 뭄

잉

要吢

言

空 要

豆

究 㟔

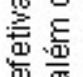

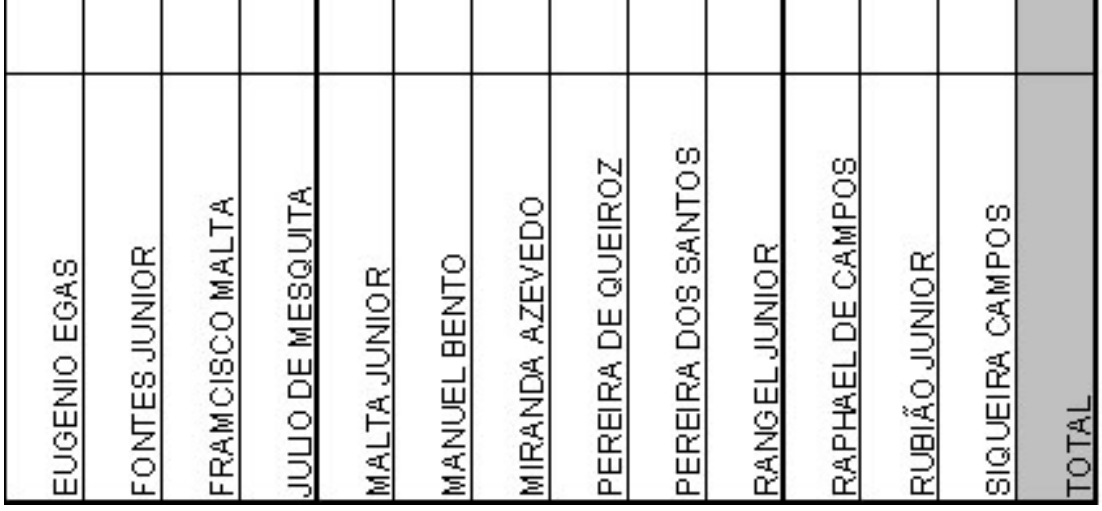

要

농

䓌言品

क व

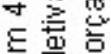

咅总号

눙

ํㅡㅁ

品 䆑吕 


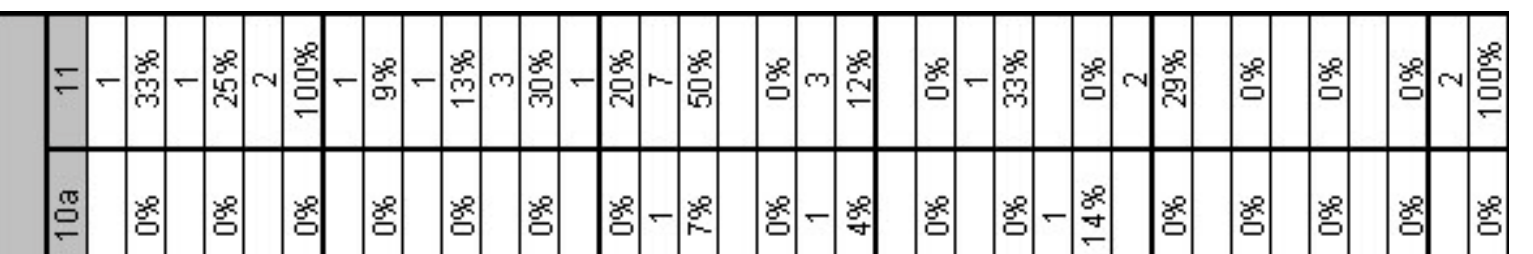

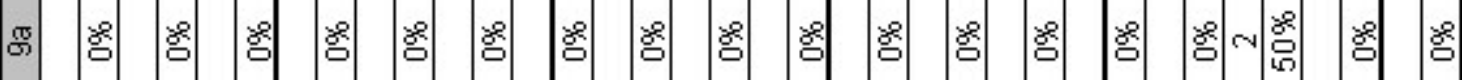
采 -

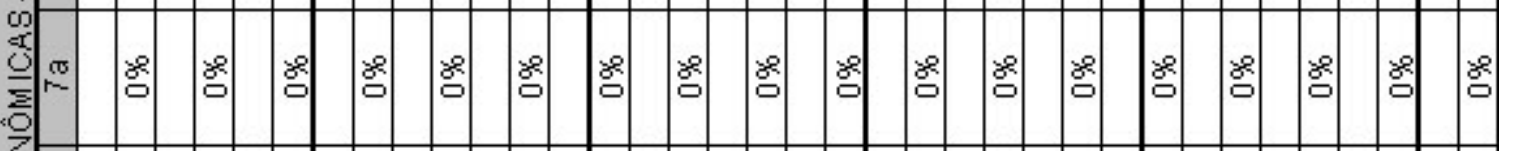

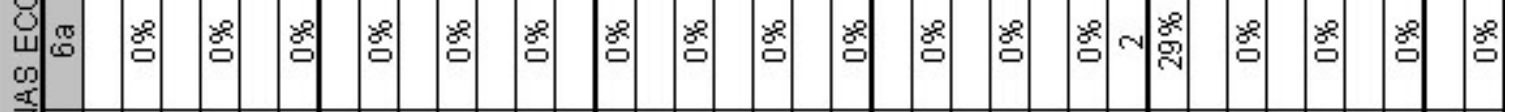
乐

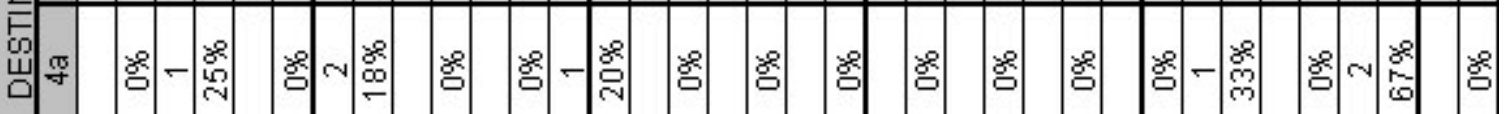
-

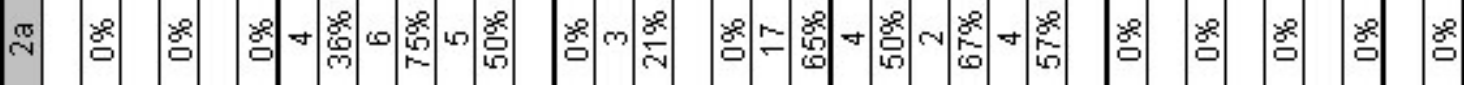
$\div$ - 8 m

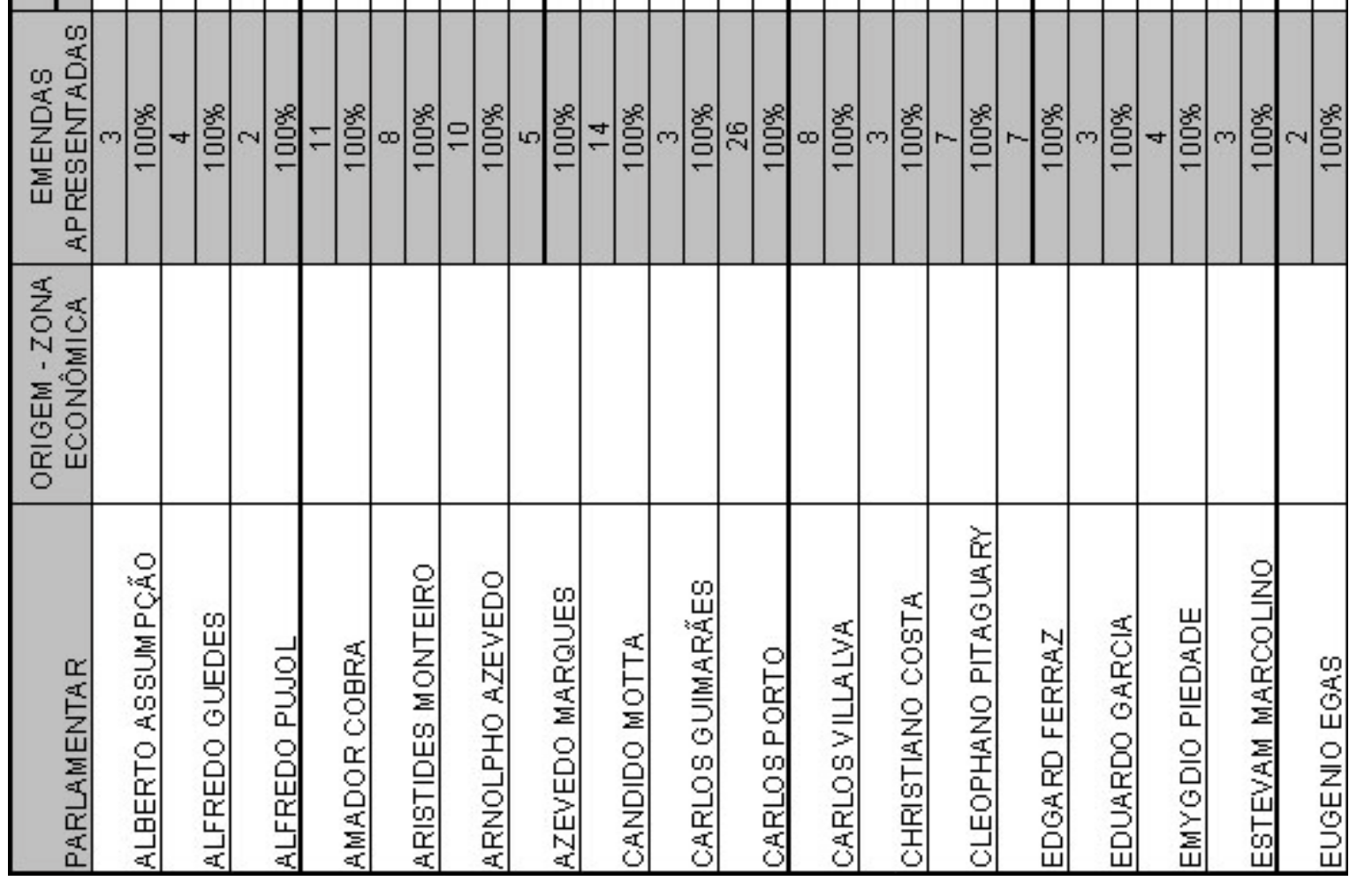


$\infty$ -

-

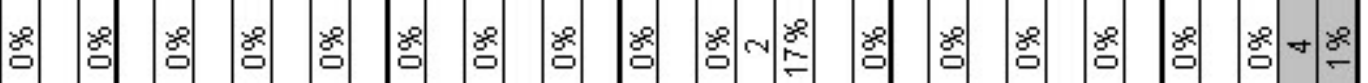

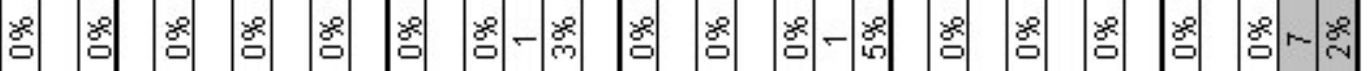

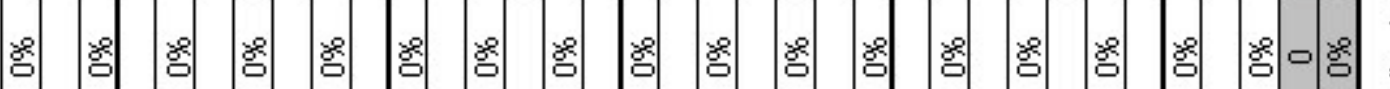

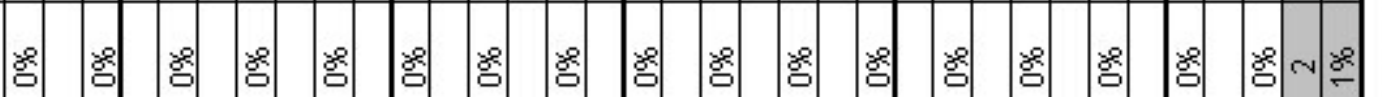

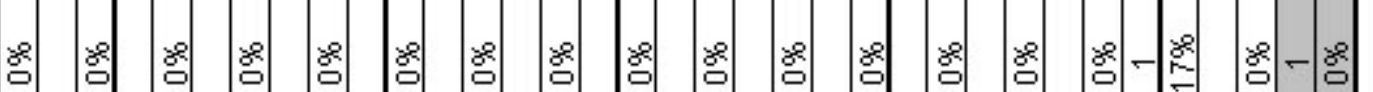

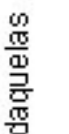

高

염

2

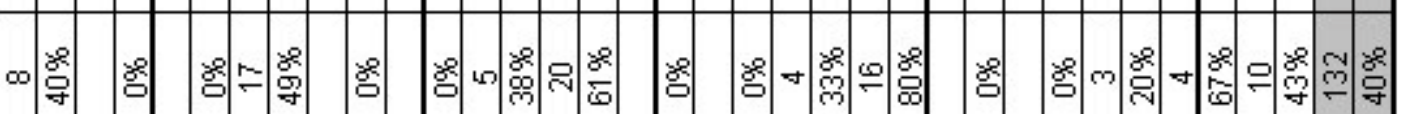

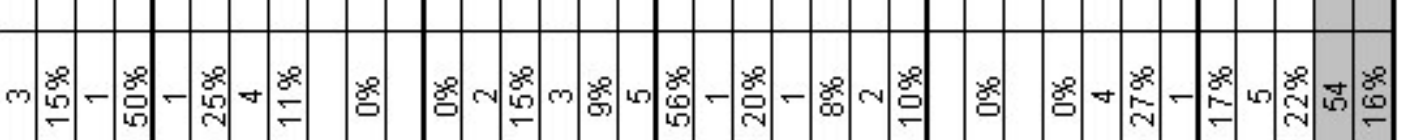

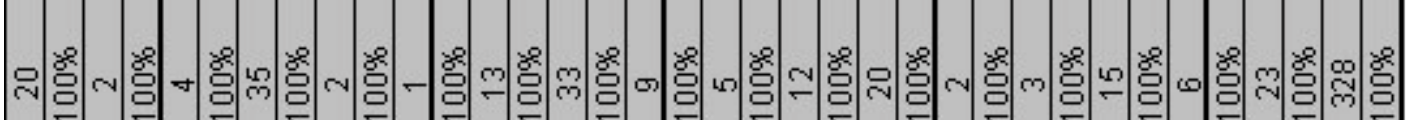

.

号 를

品

d

홈응

政

政

음

覃:

品

织高

要

동

怘 品

홍

음

$x=$

(

颚突

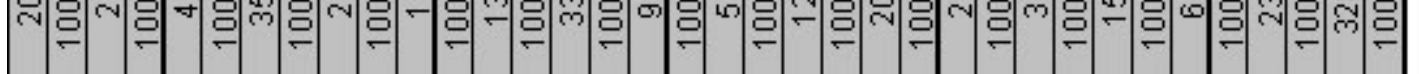

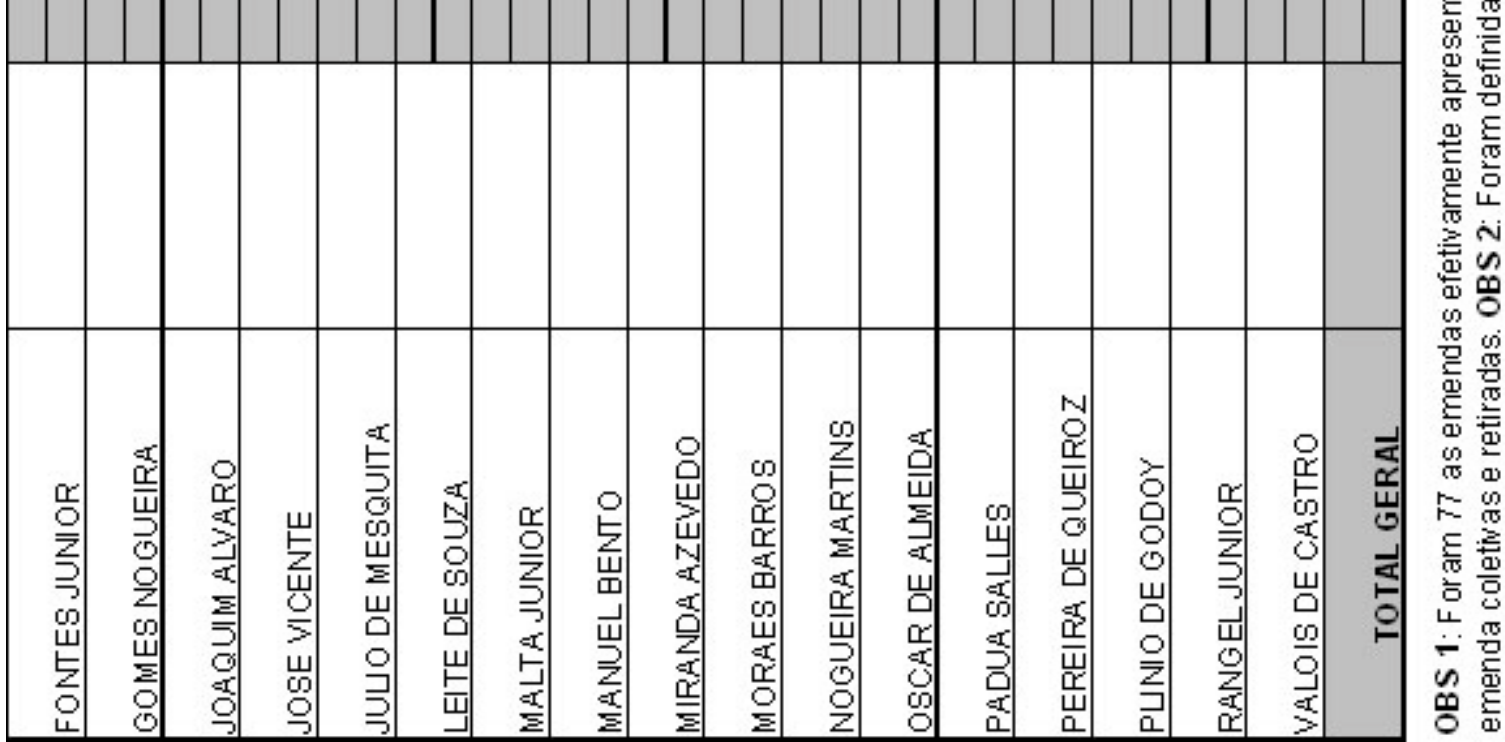




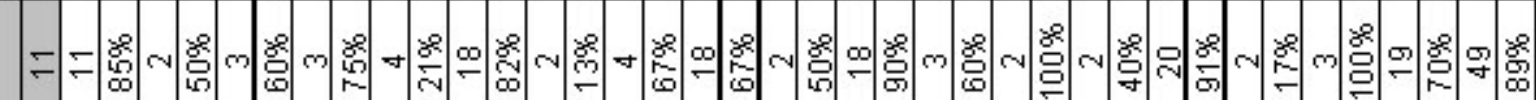

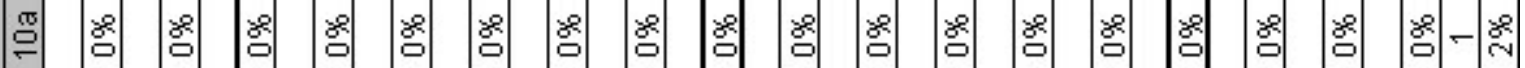

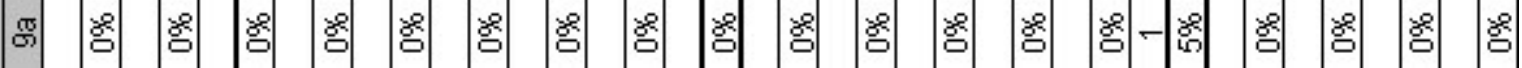

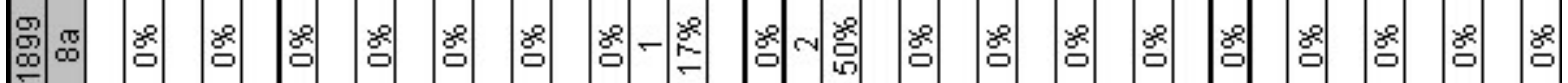
舟 으

붕

$\infty$

인

䎡

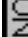

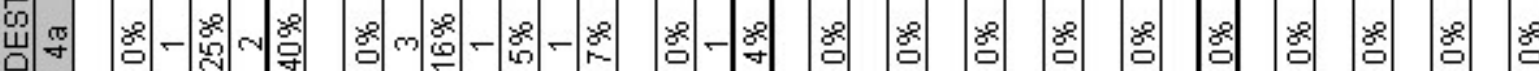

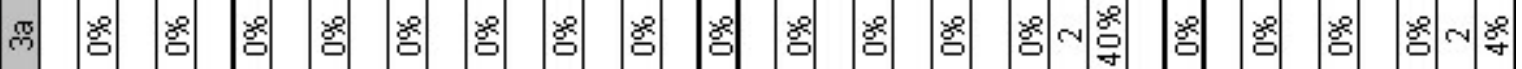
乐

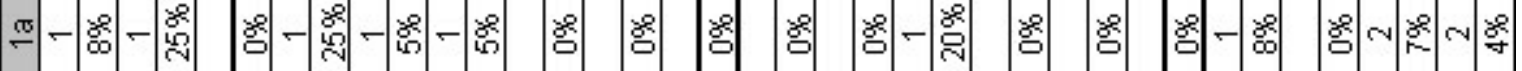

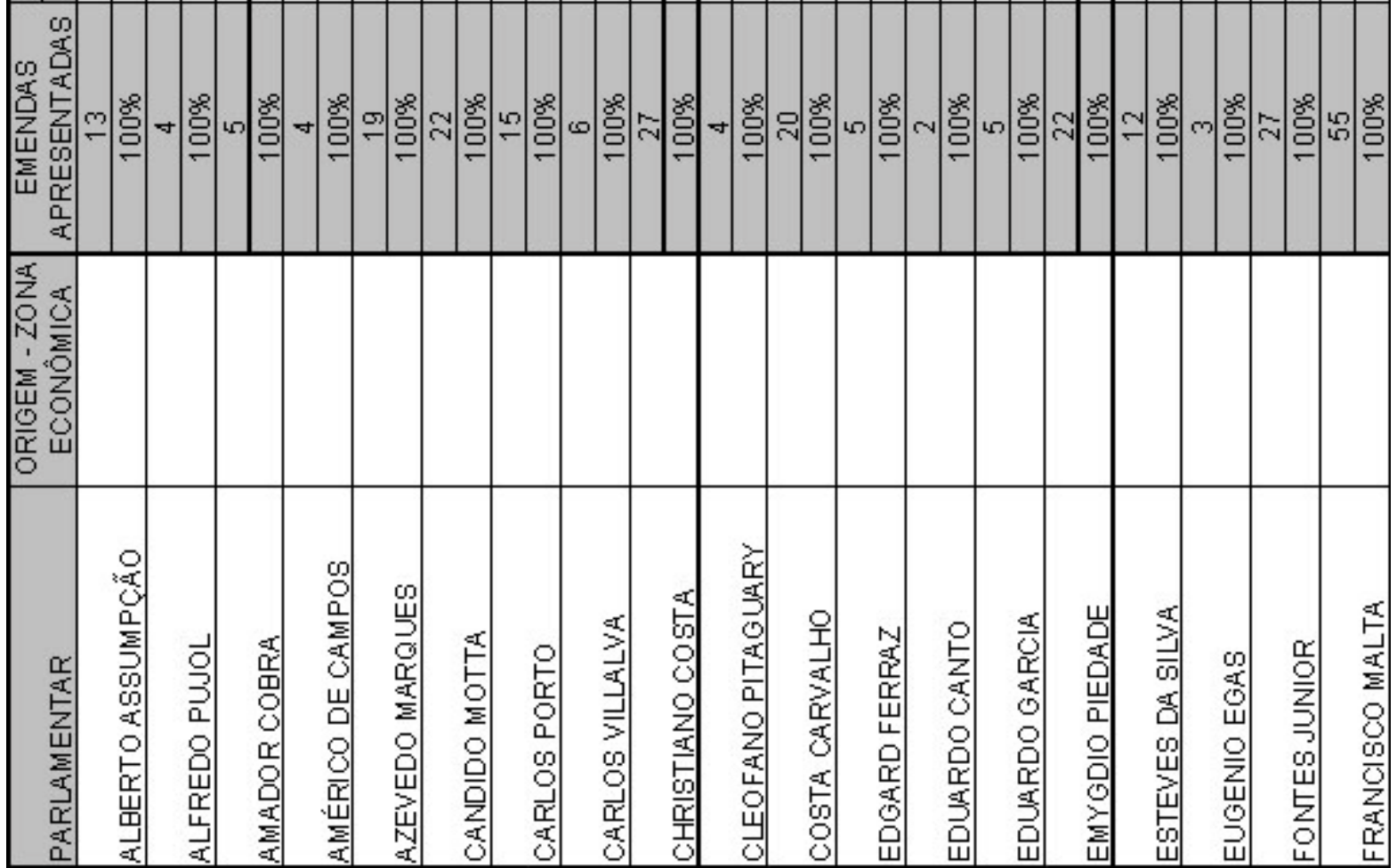




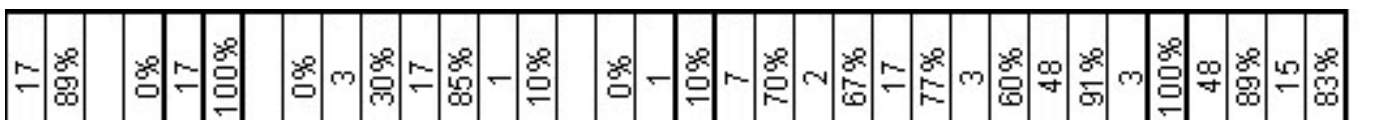

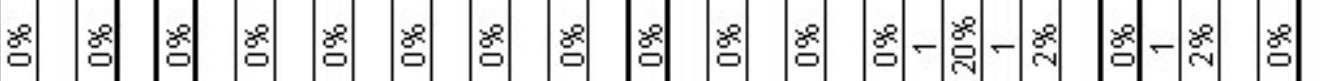

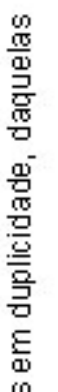

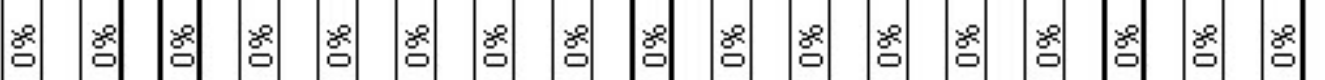

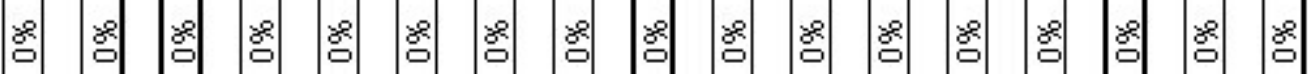

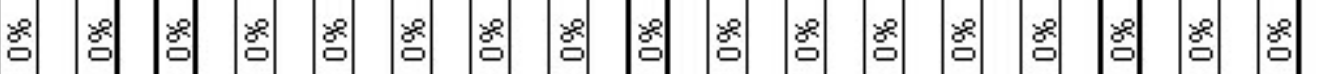

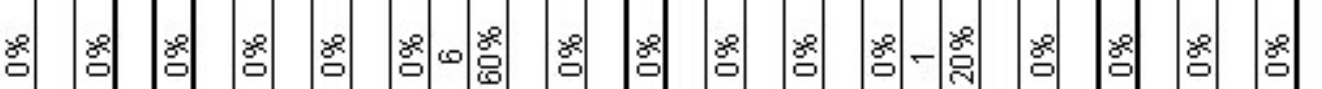

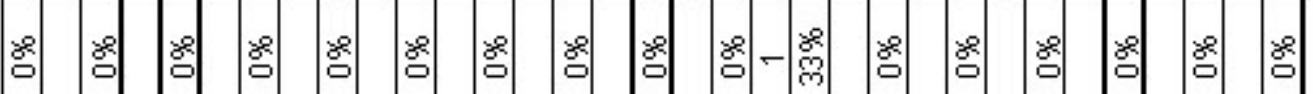

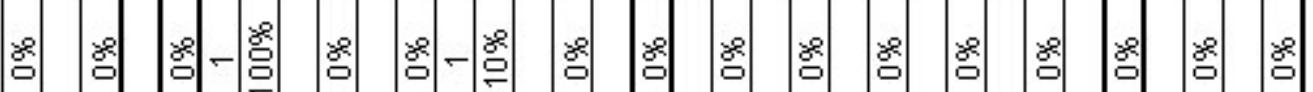

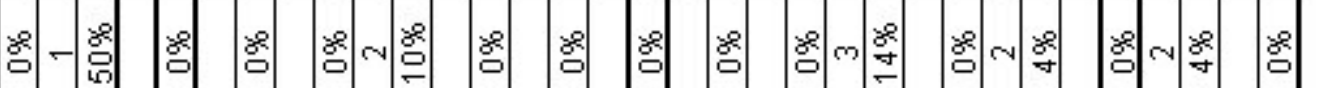

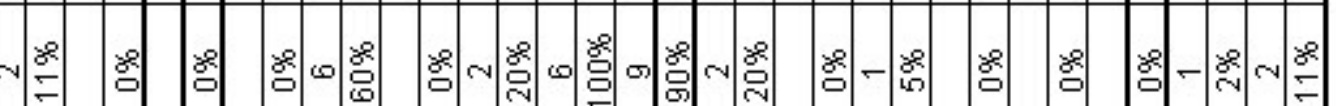

-

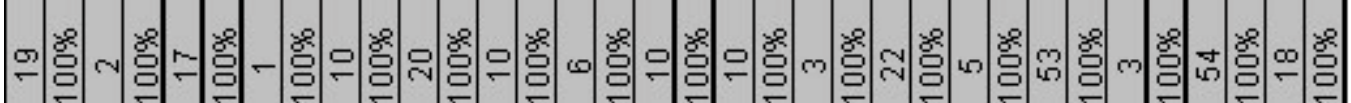

$\stackrel{\infty}{a}$

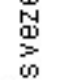

$\mathrm{s}^{-}$

当

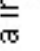

o

d

흠

은 응

금

음

要

品

离

동

需

产

器哭

$x$ 응

음

兽

总

㖞

戀

흘

g 임

홇

혼

密岕

品

용

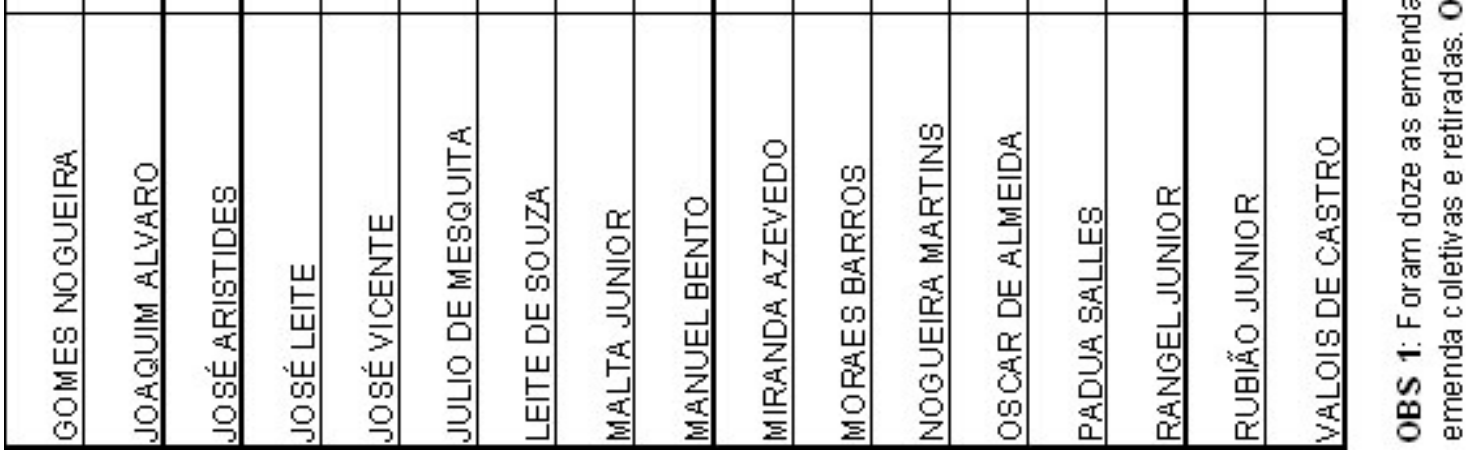




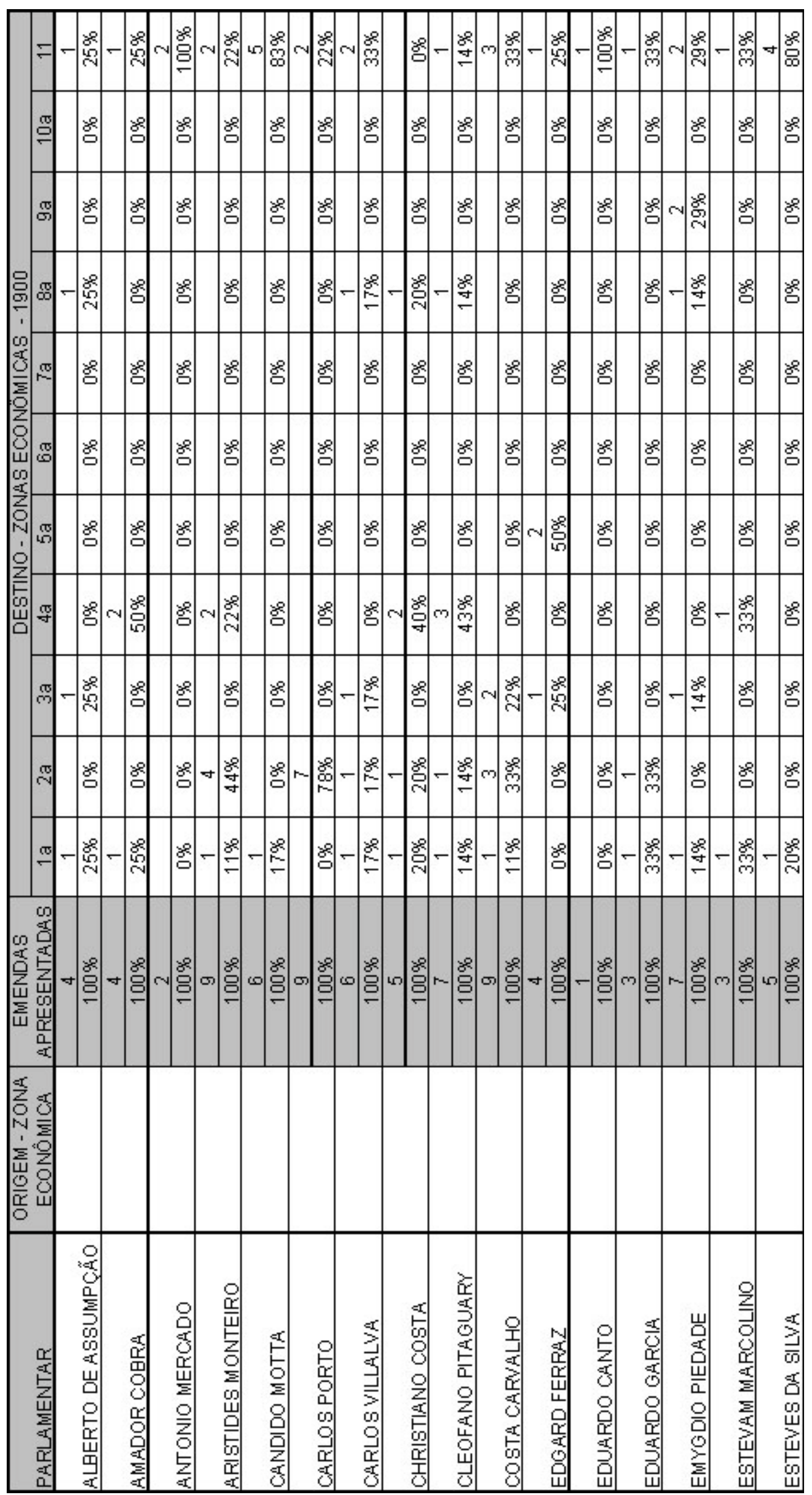


-

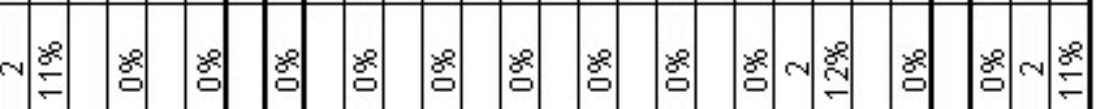

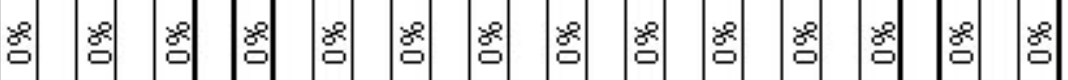

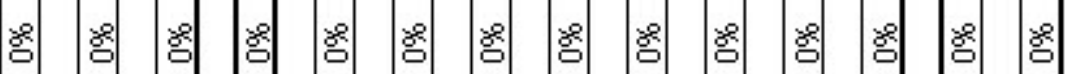

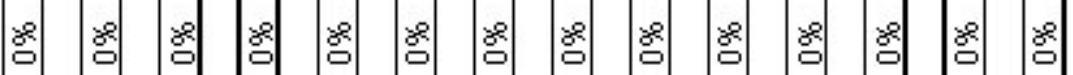

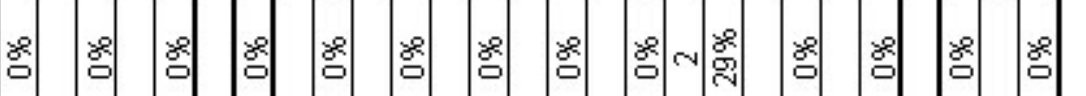

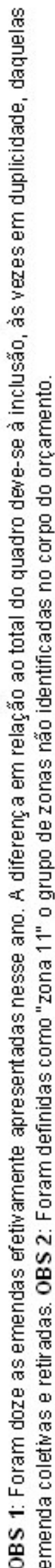

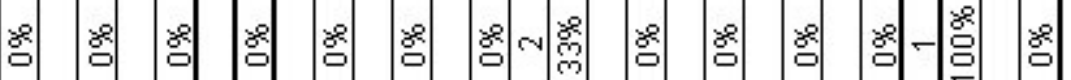

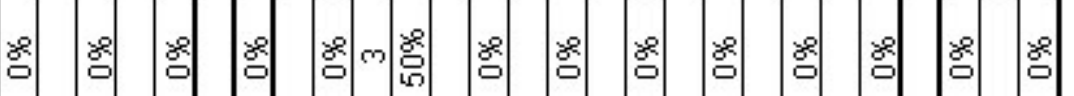

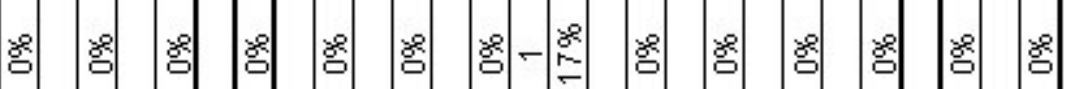

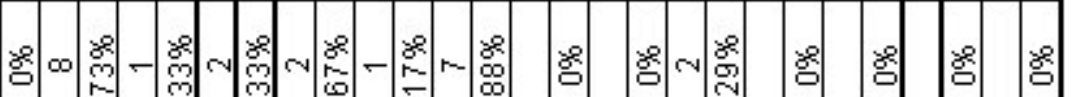

v色

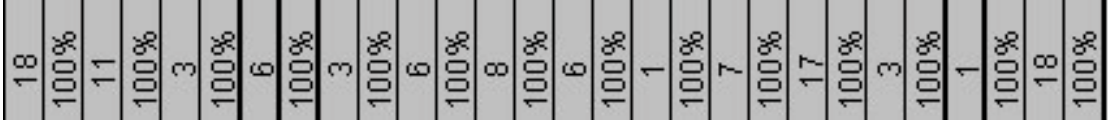

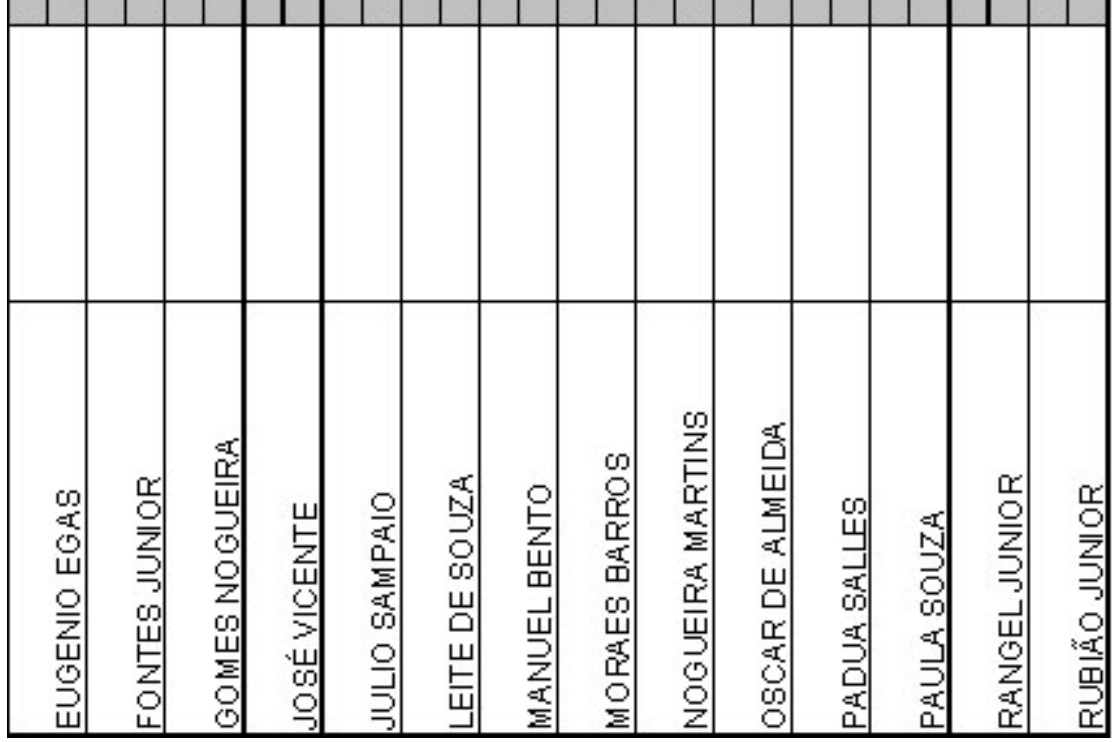




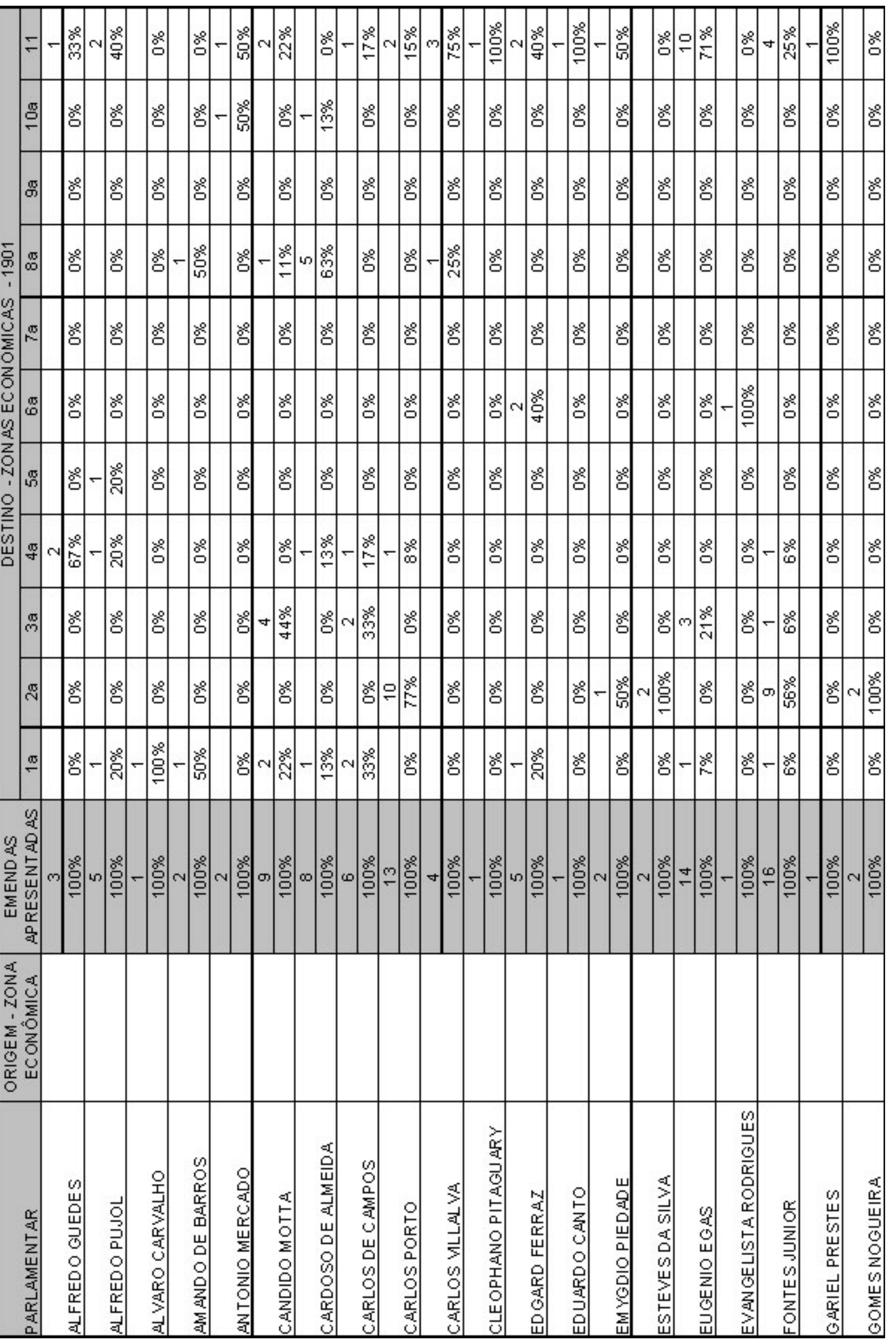


$m$ 象

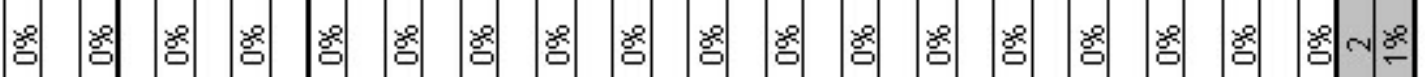

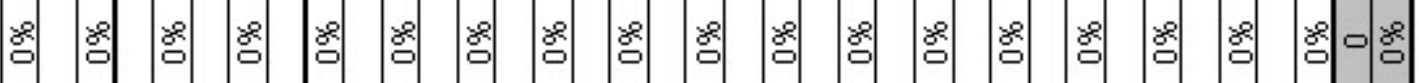

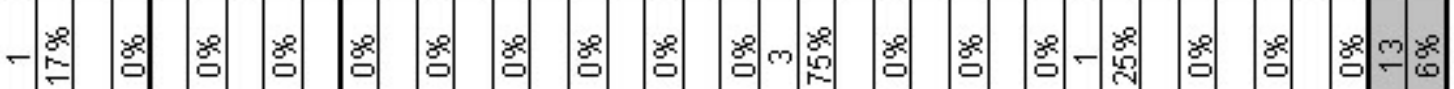

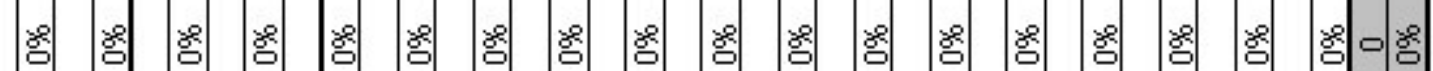

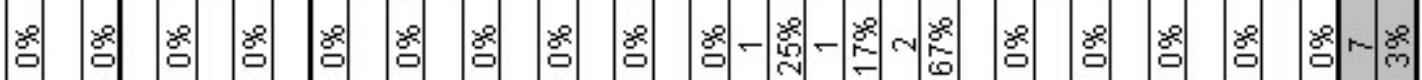

象

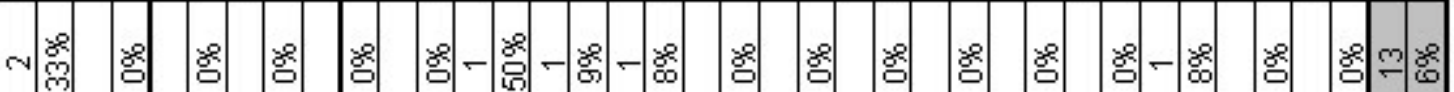

웜

염 임 웜

웜

м-

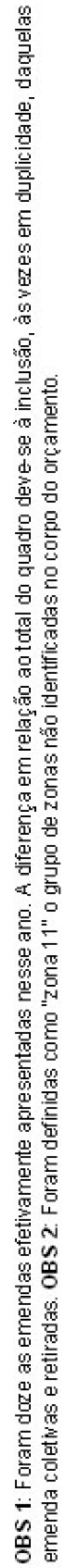




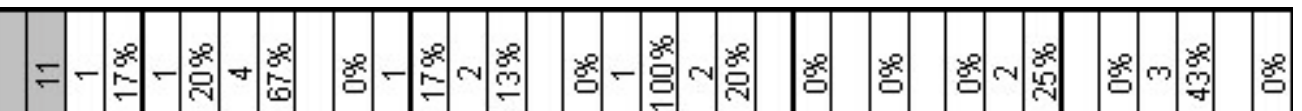

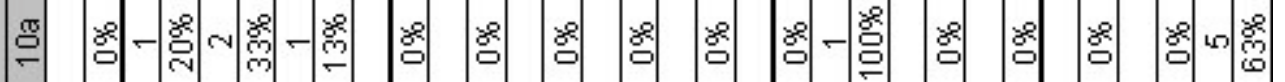

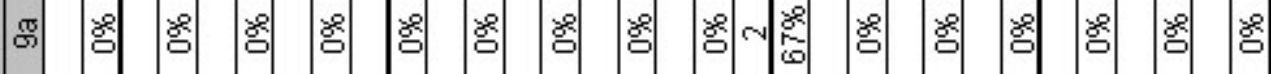
氙

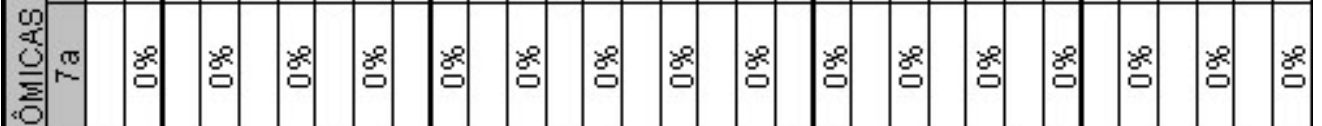

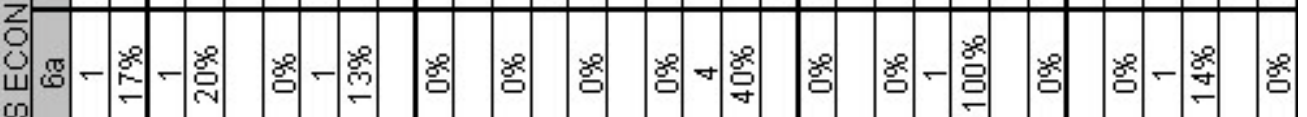
$\infty$ 엥 은

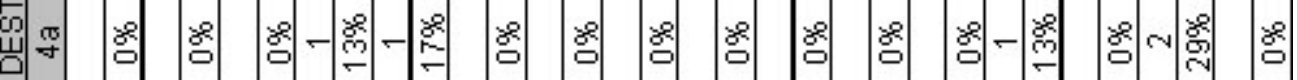

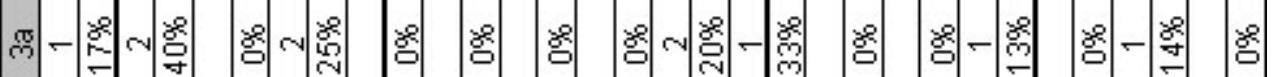
원 웡

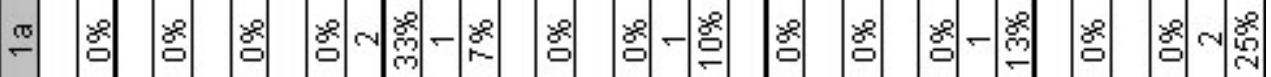

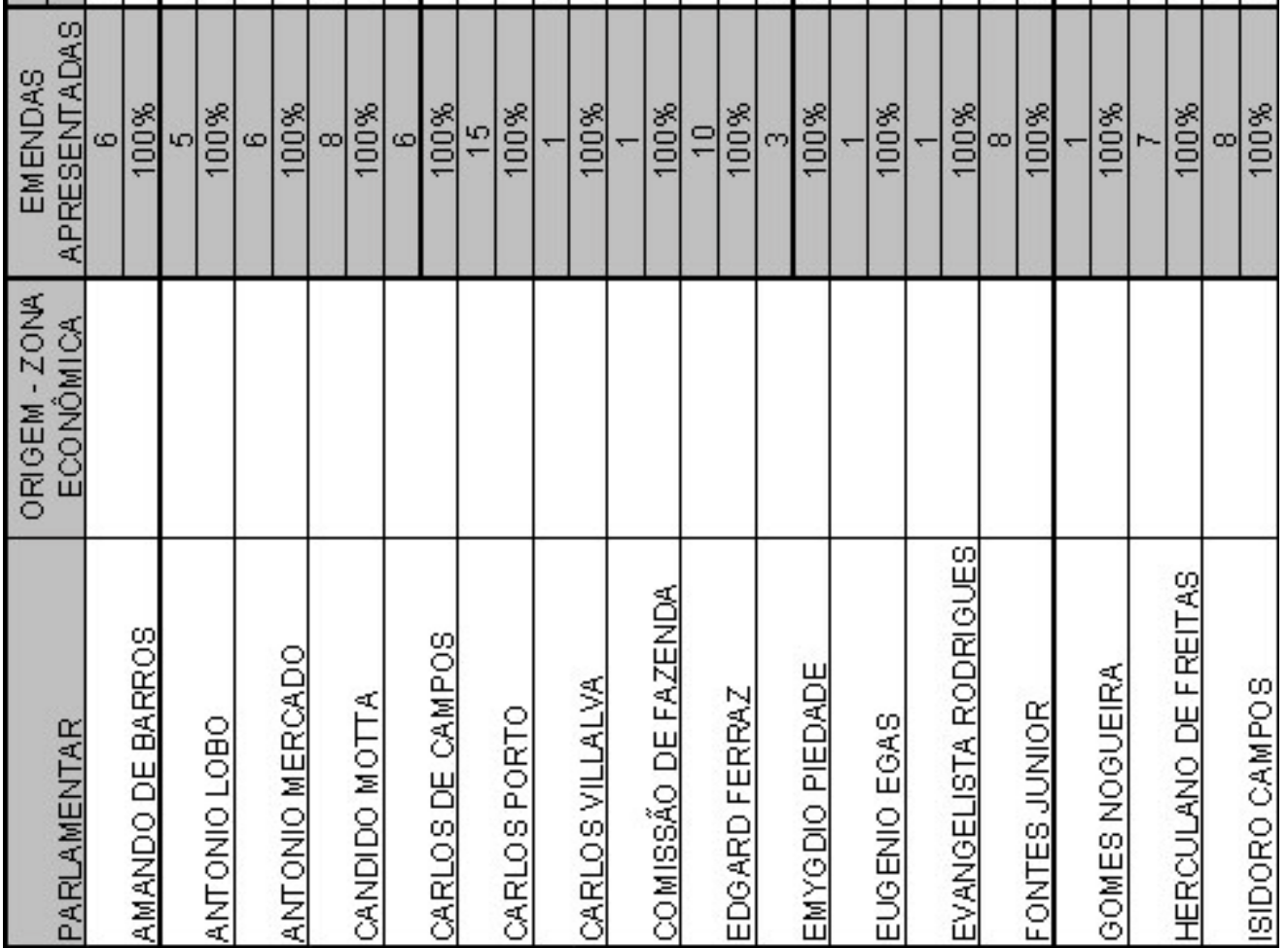


$\sim$ 我

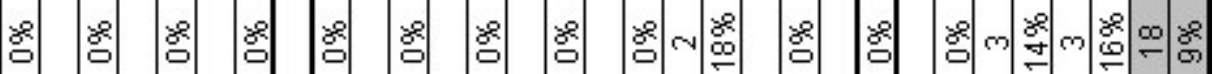

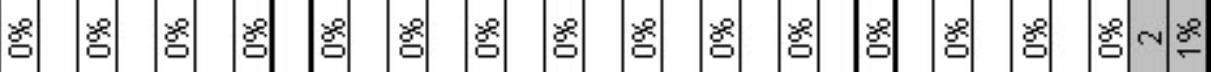

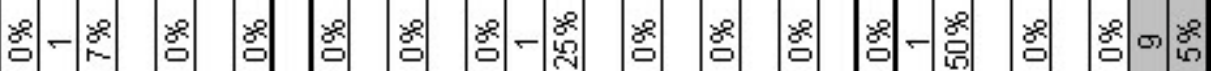

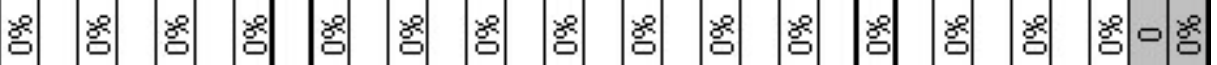

ㅇํㅁ 次

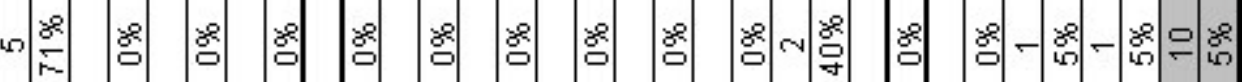

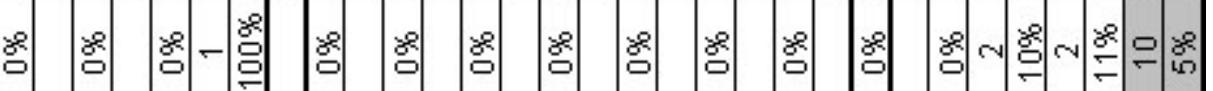

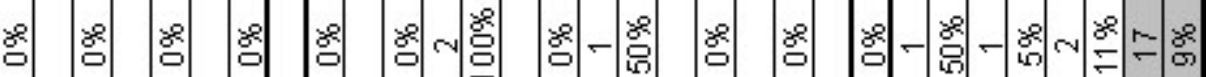

임

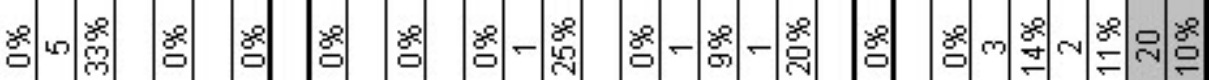

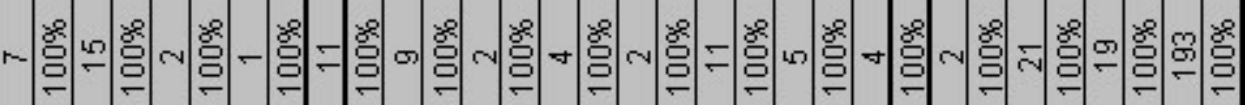

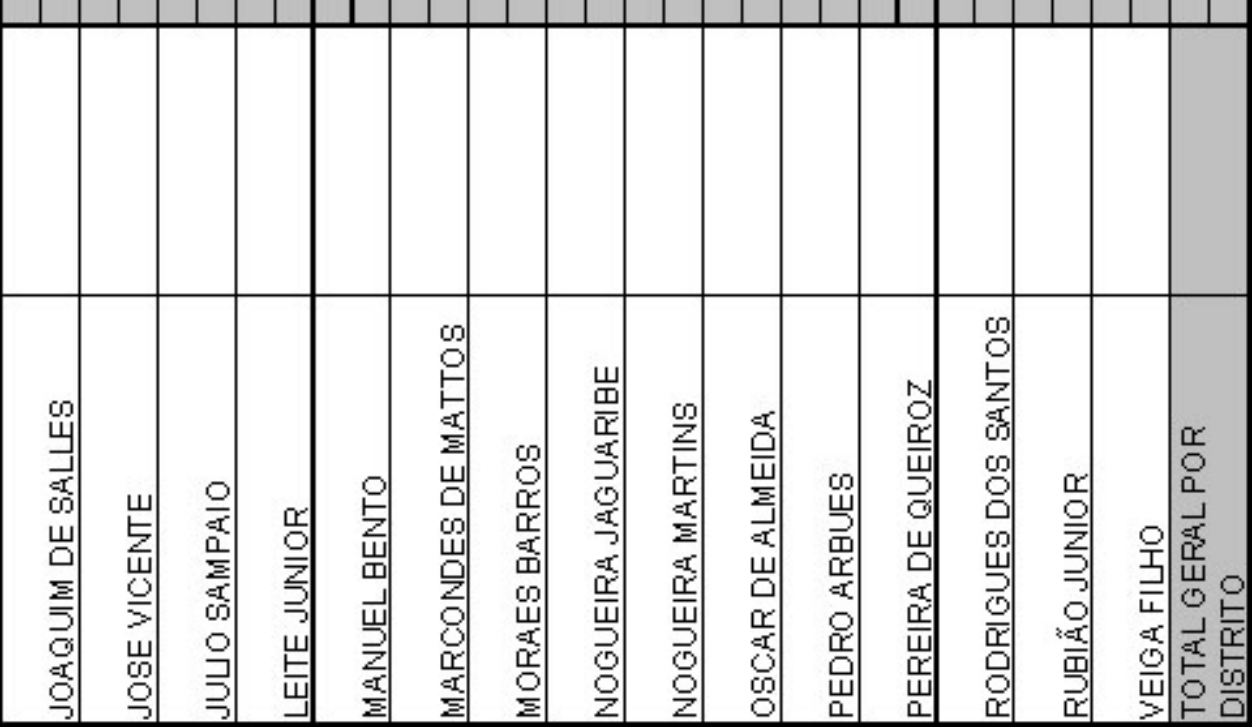




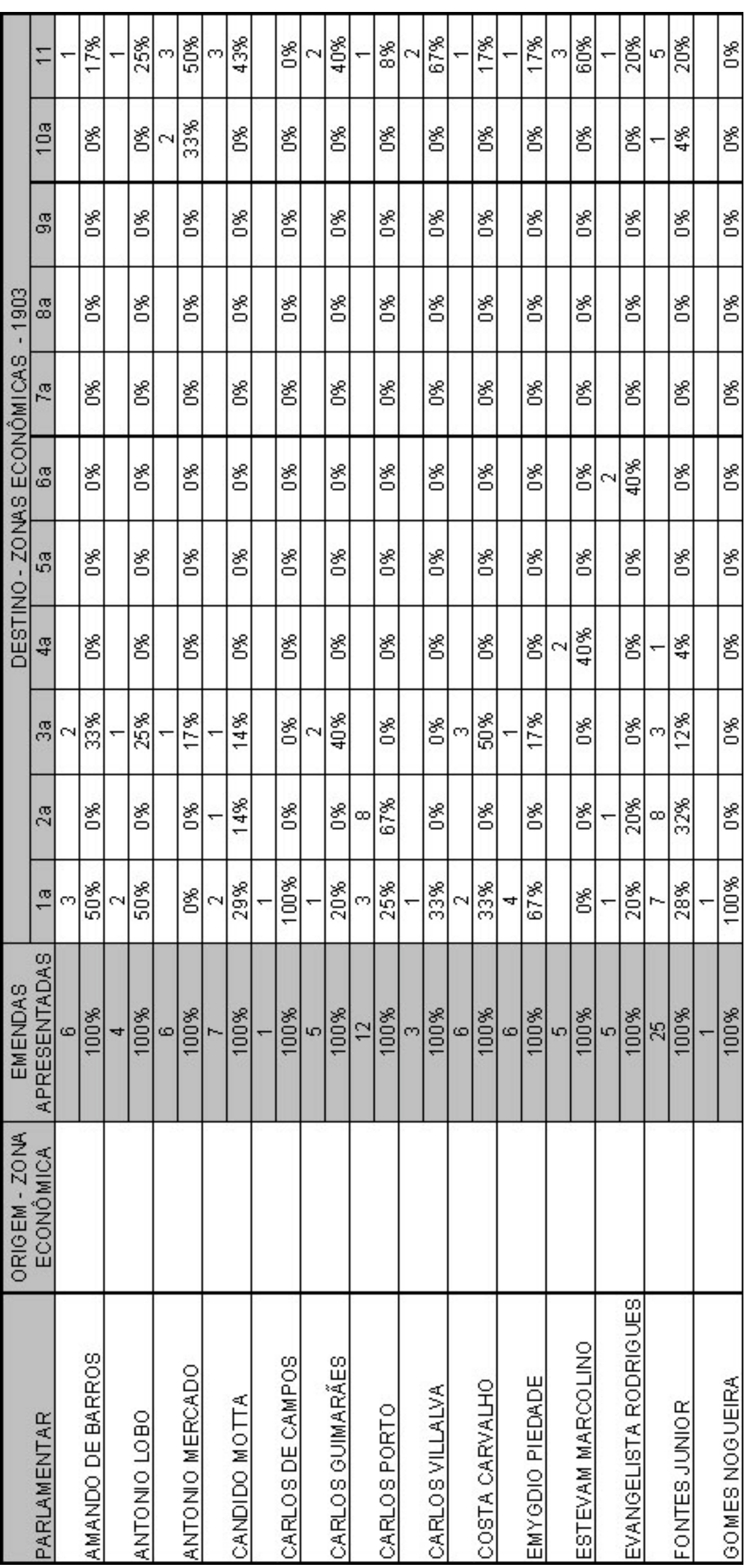




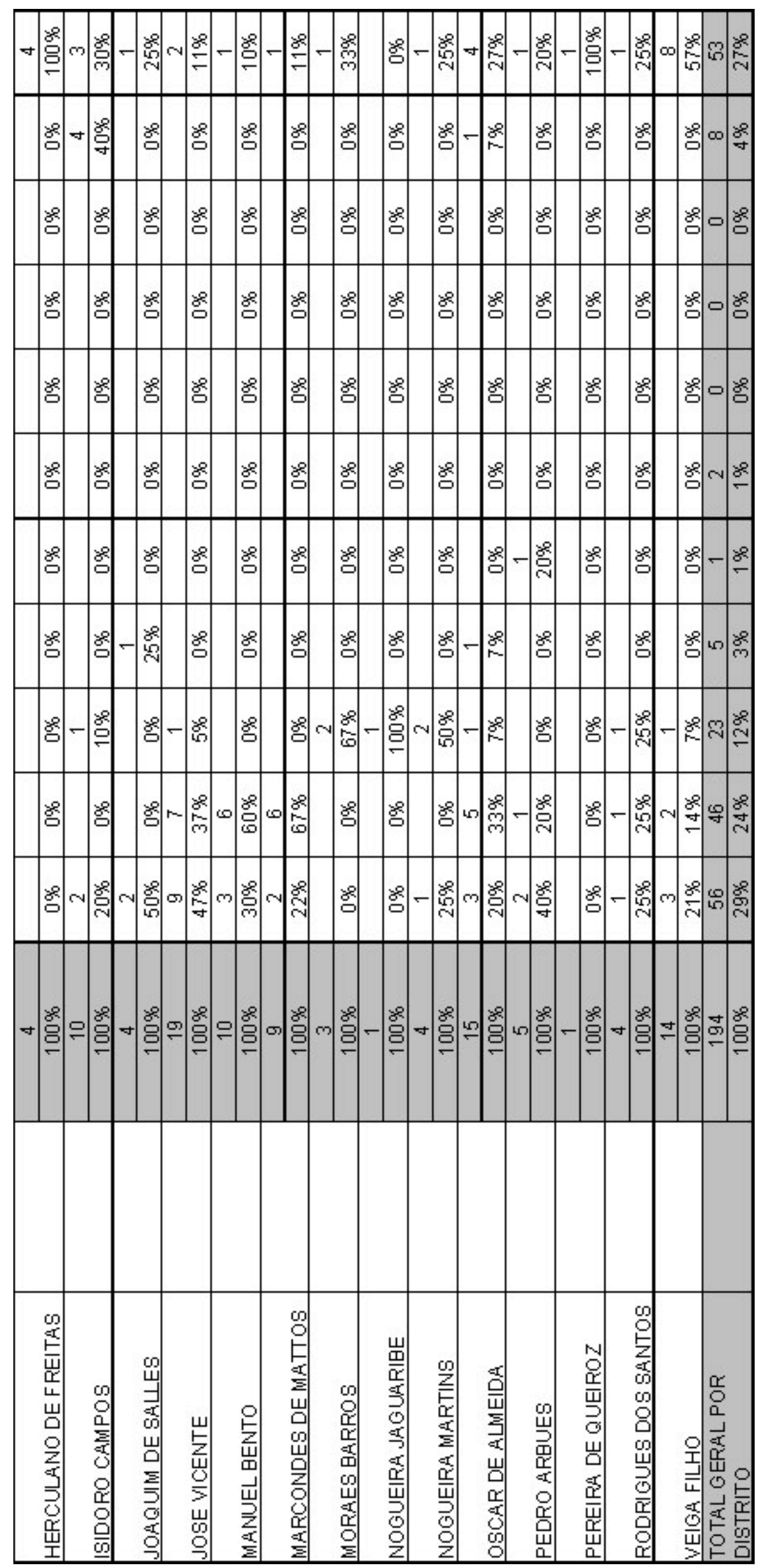




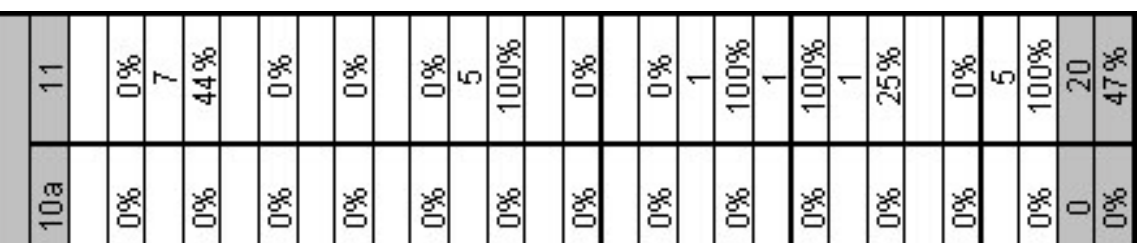

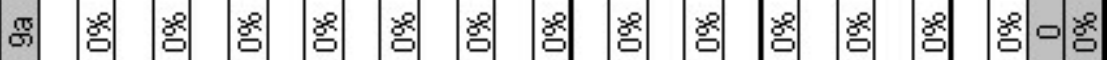

可

要

응

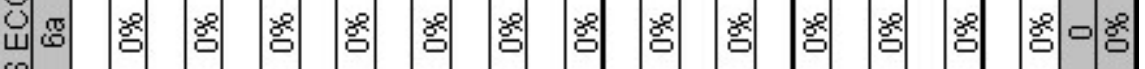
0

舟

를

㟧 기영 乐

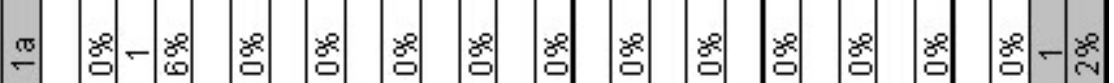

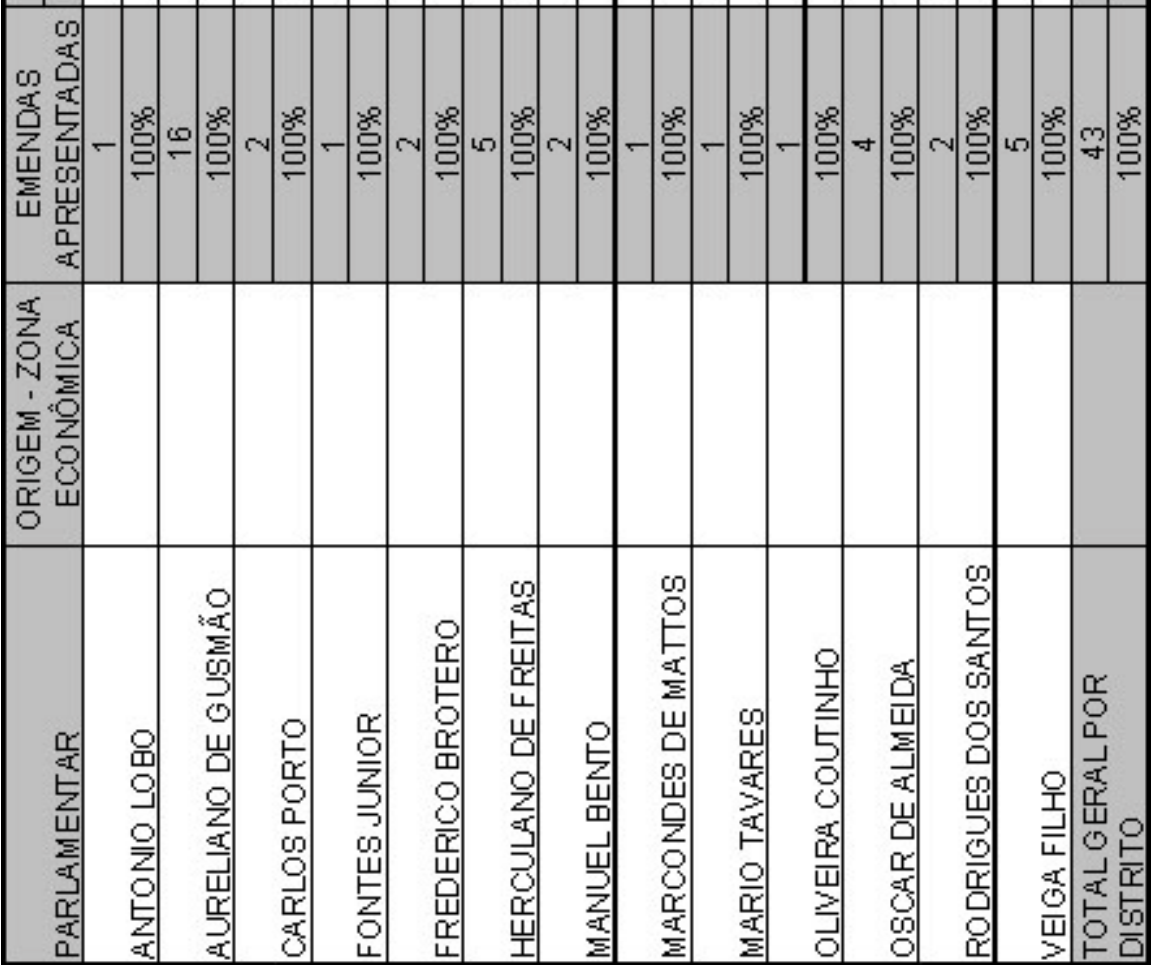




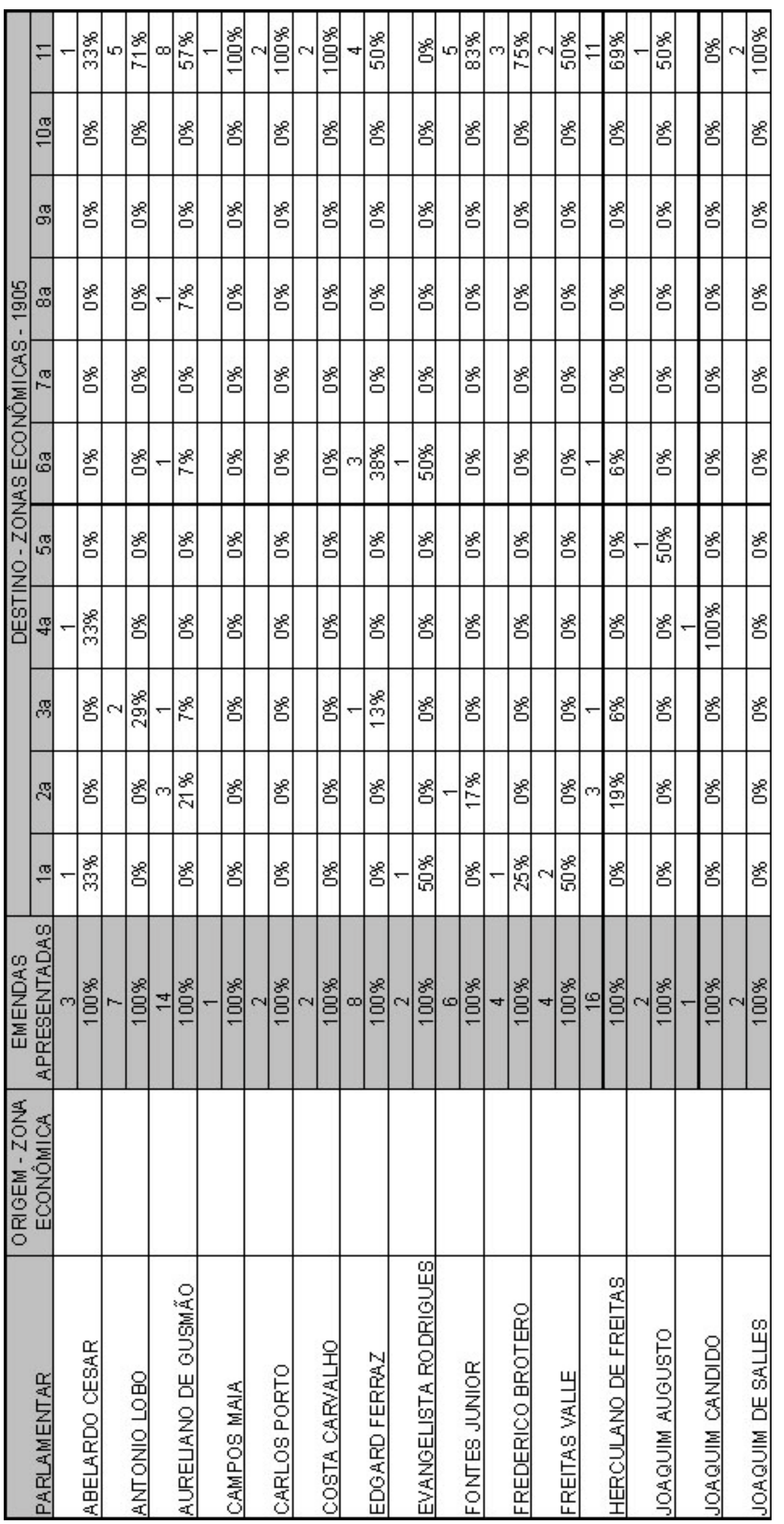




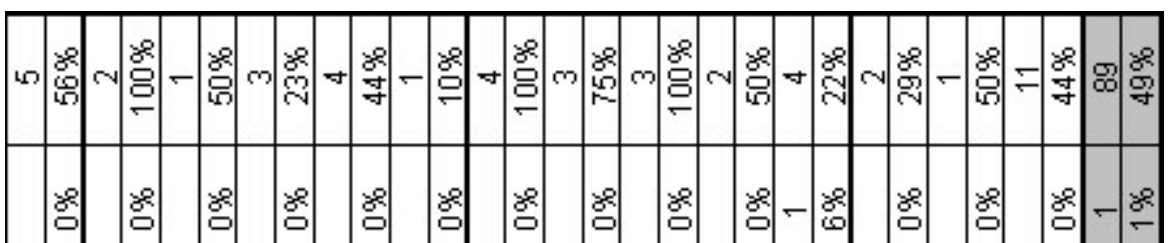

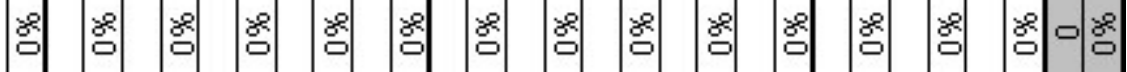

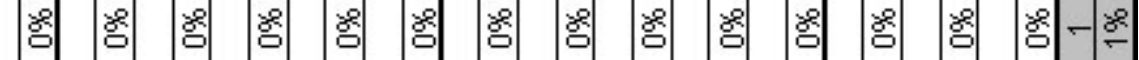

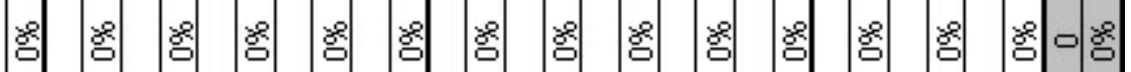

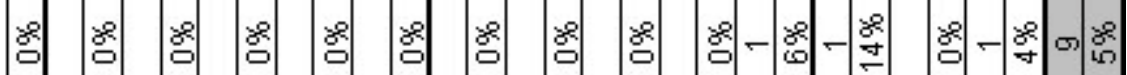

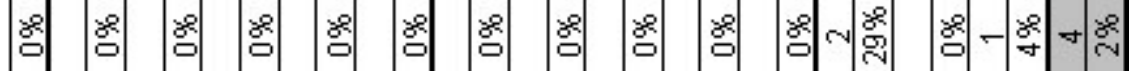

ㅇํㅁ 次

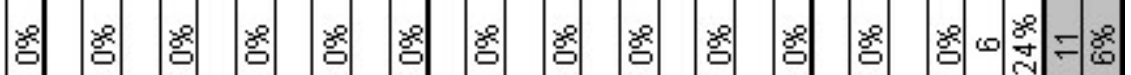

- 释

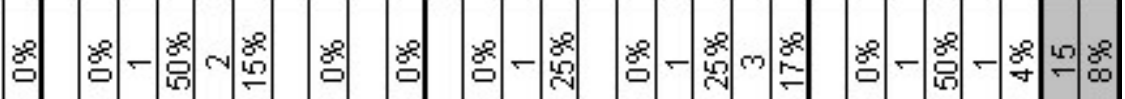

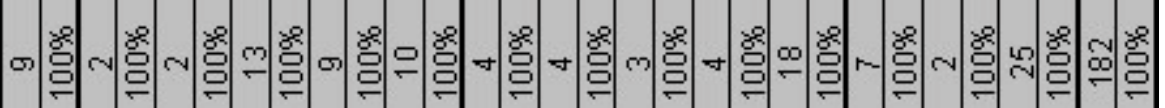

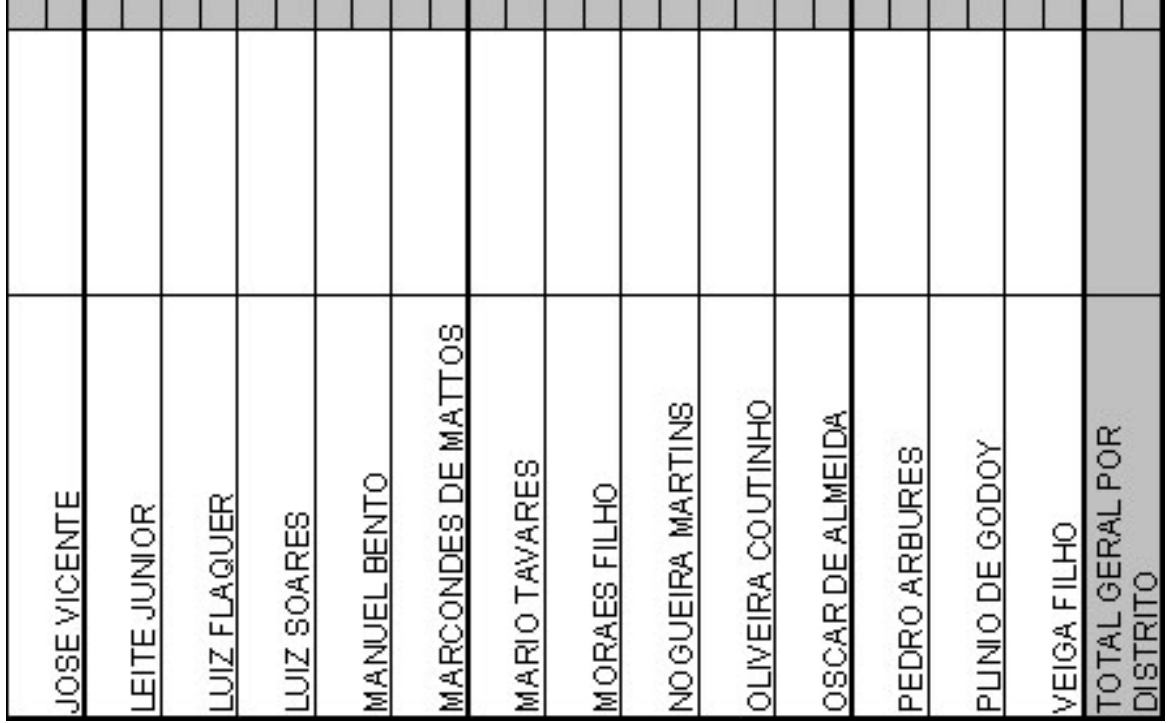




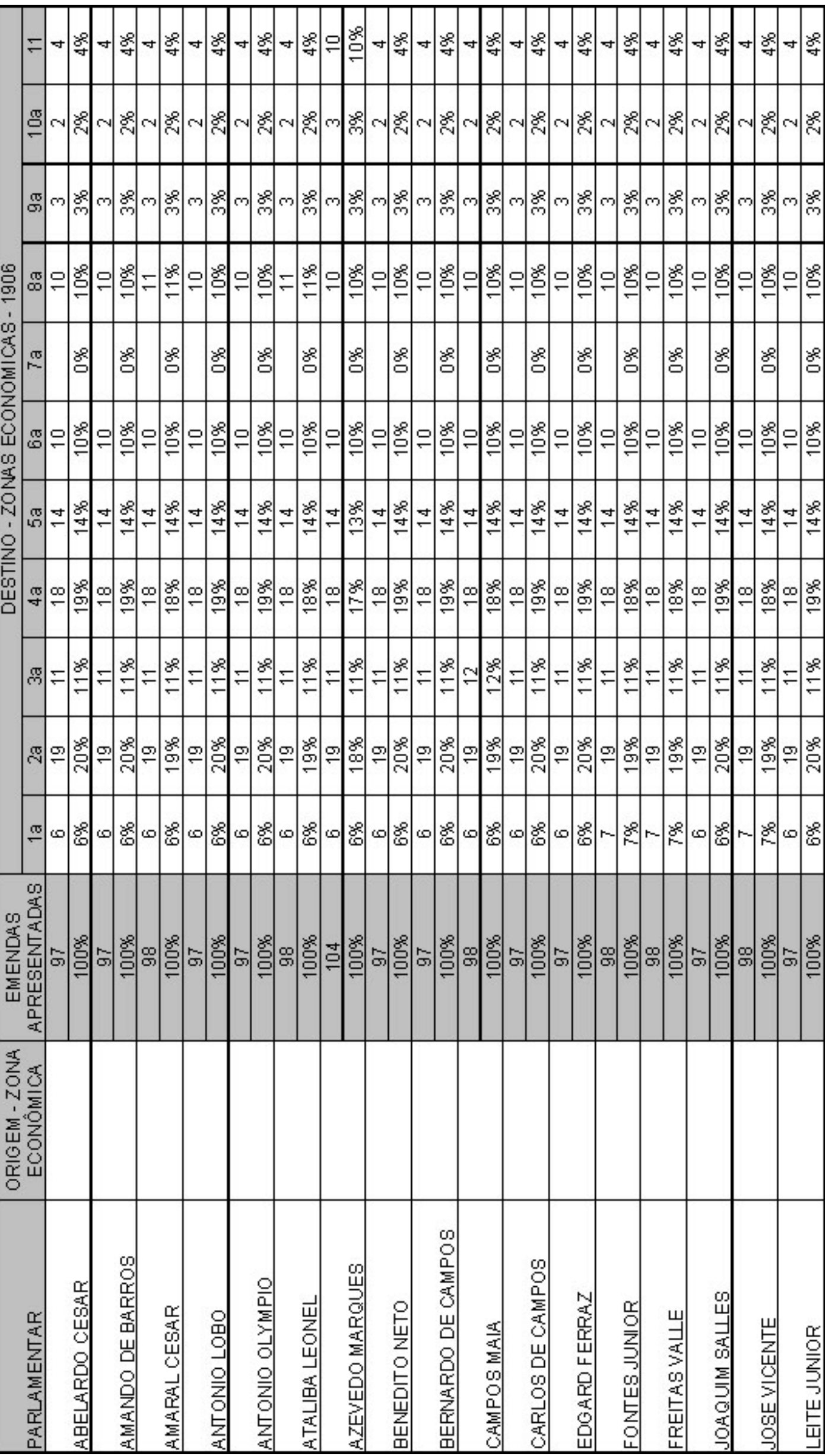




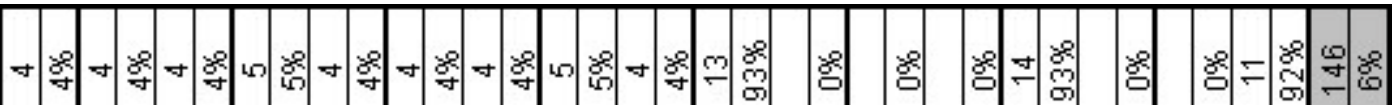

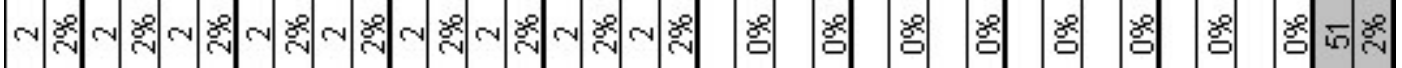

m

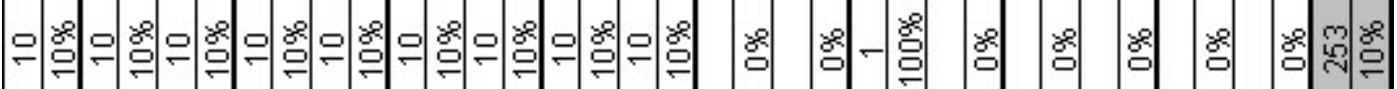

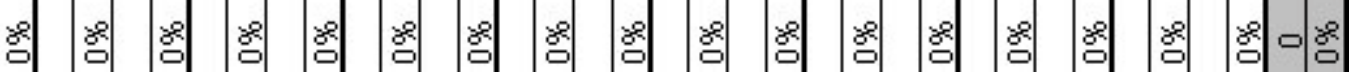

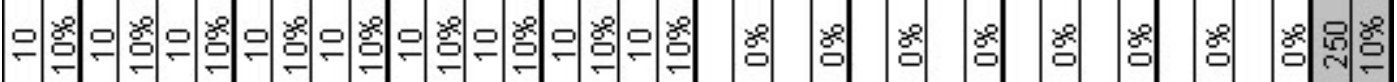

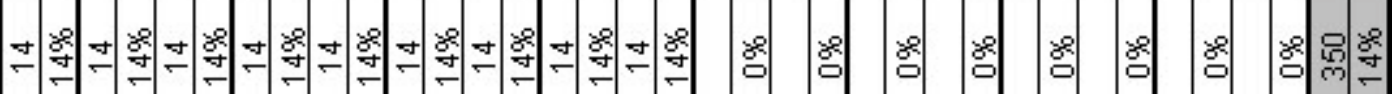

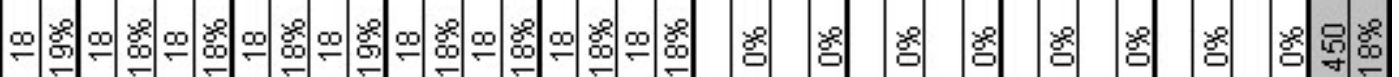

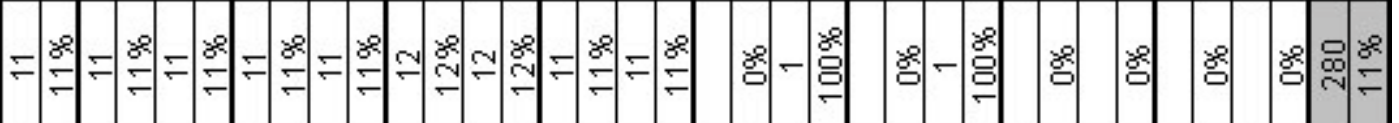

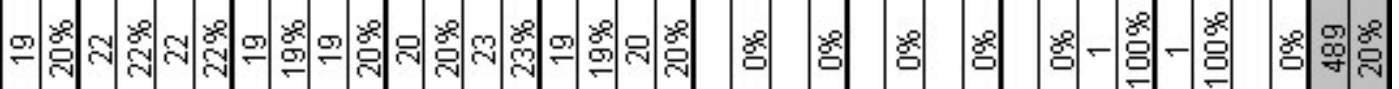

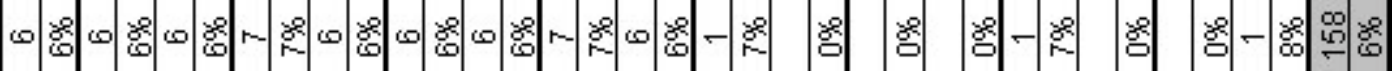

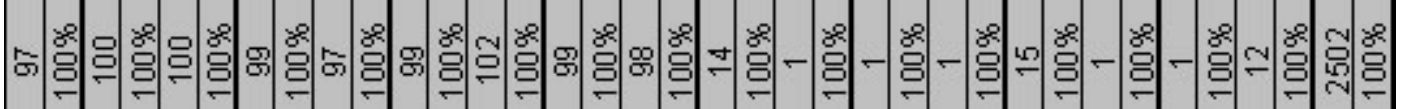

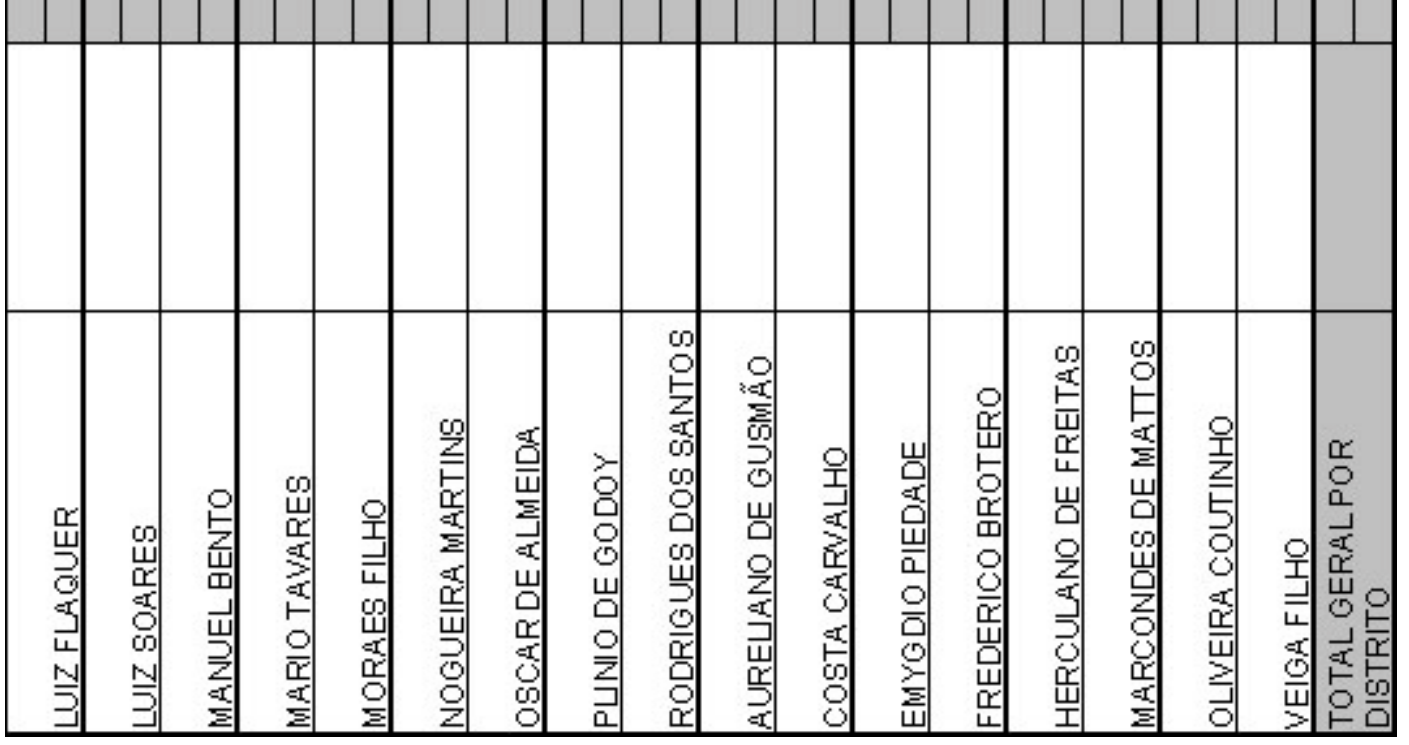




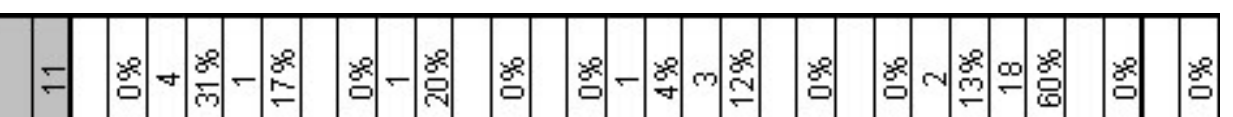

응-

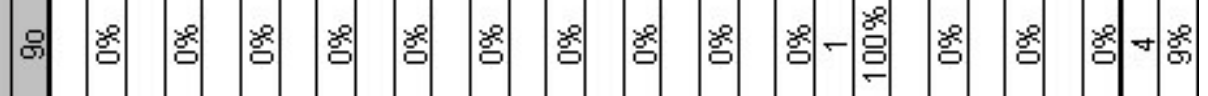

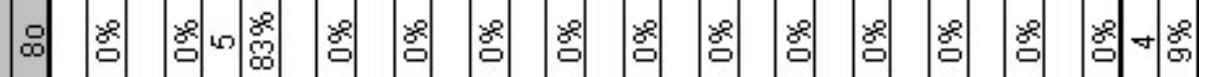

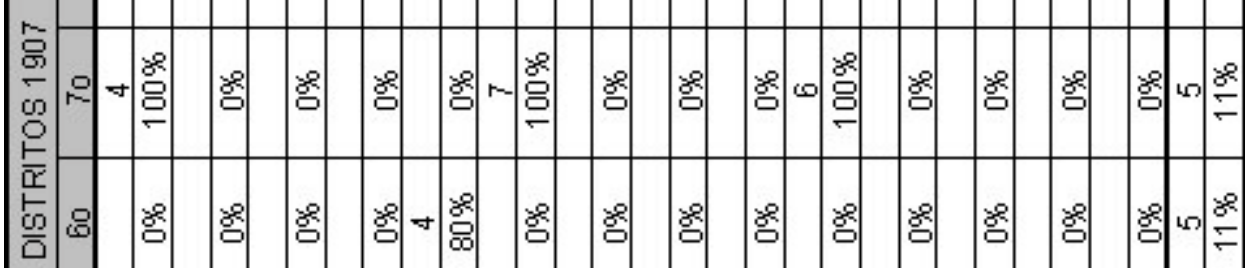

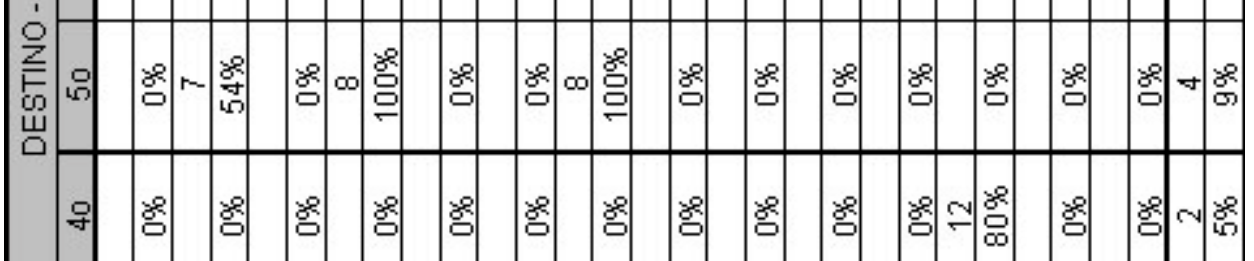

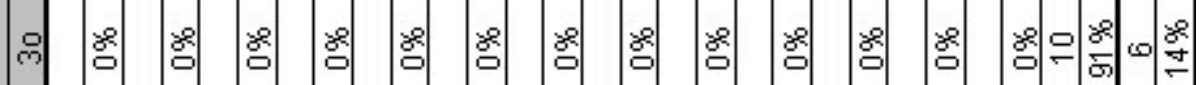

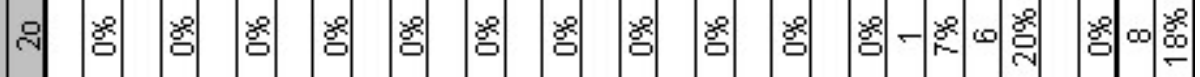

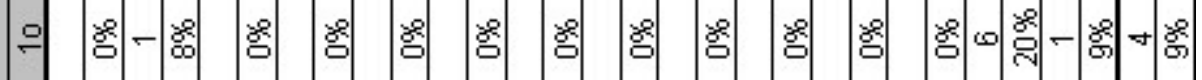

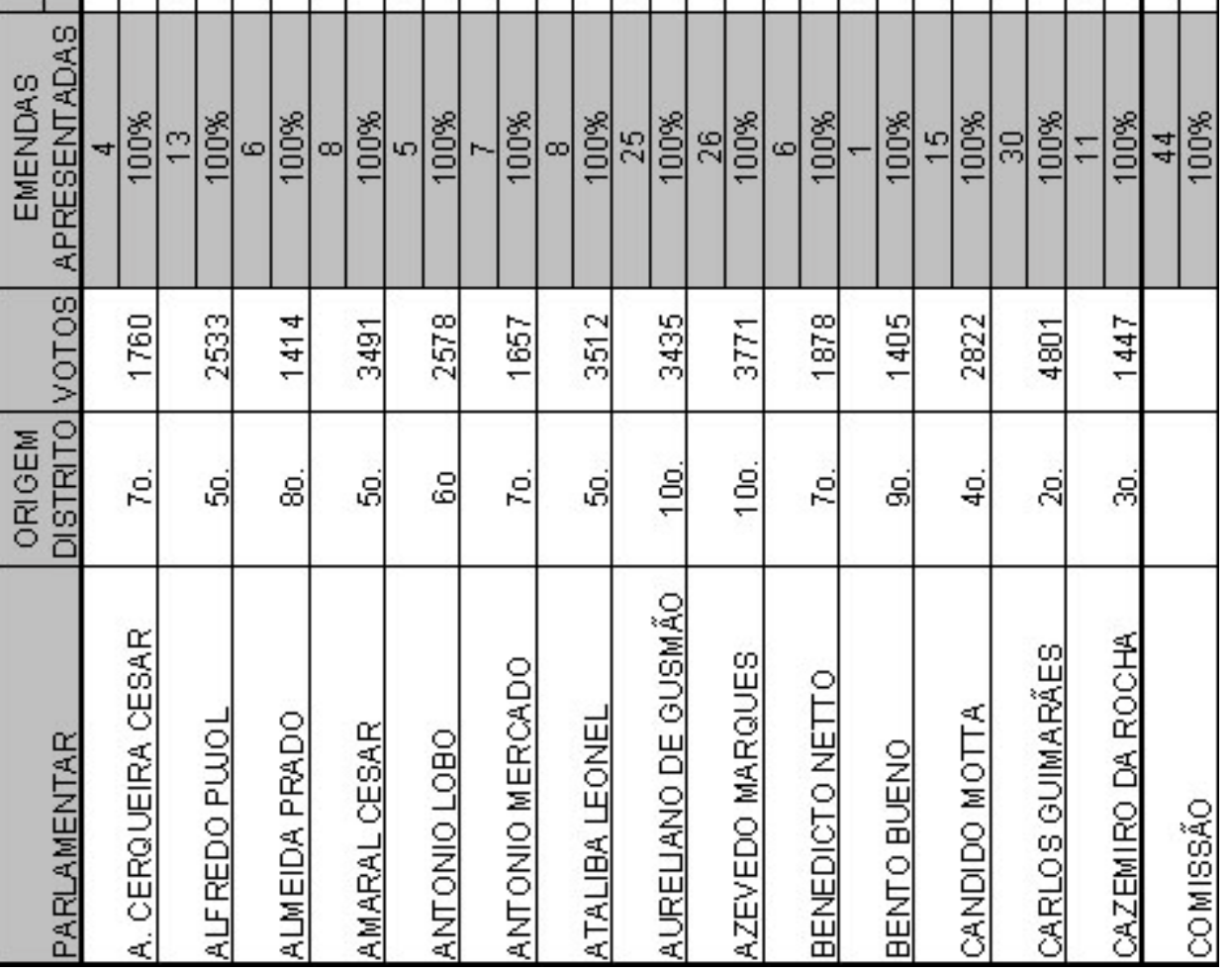


(क)

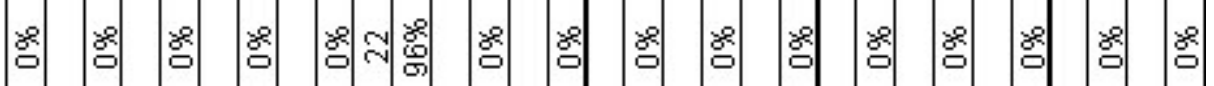

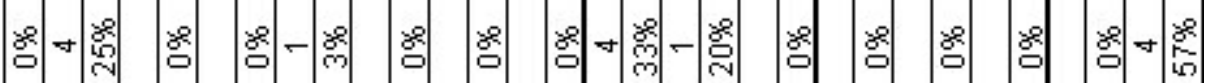

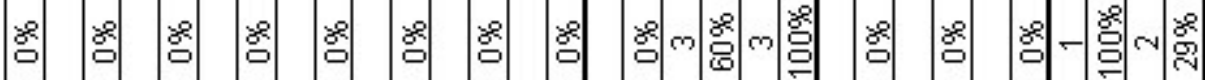

윰

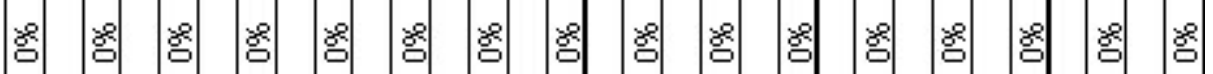

-

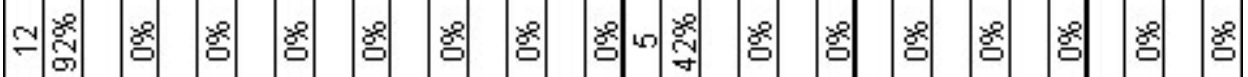

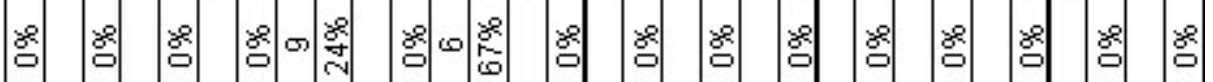

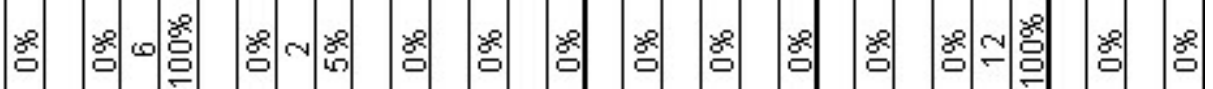

염

m

品 可

वे

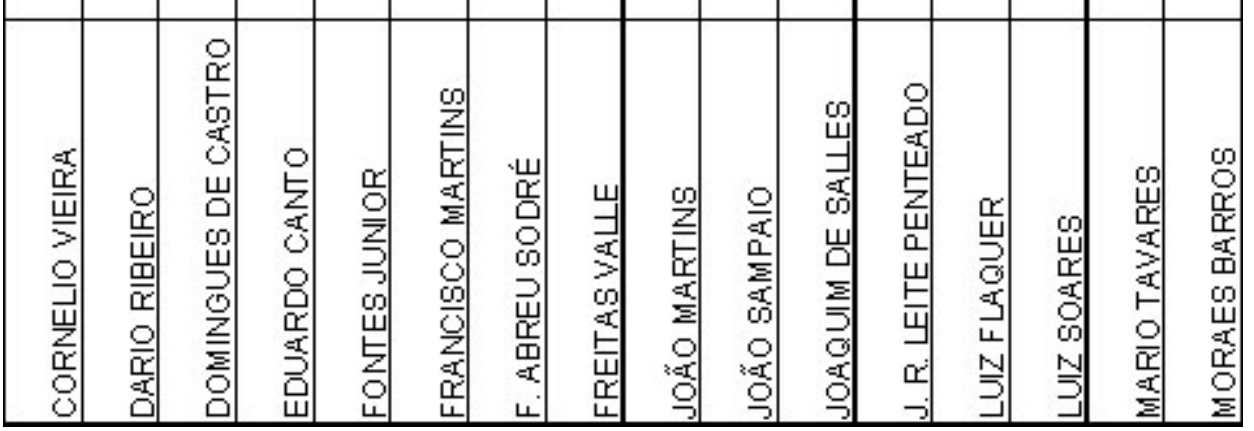


-

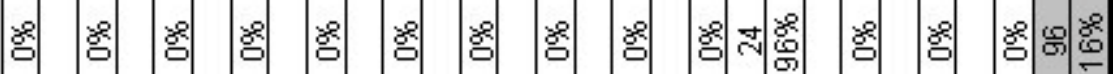

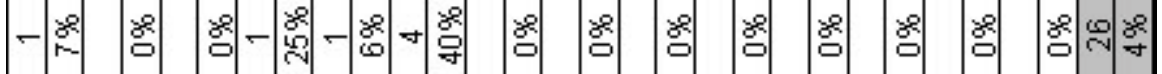

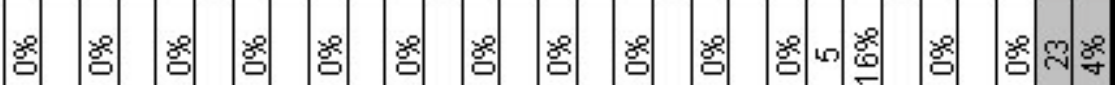

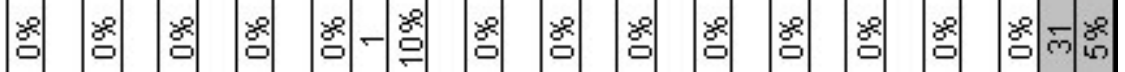

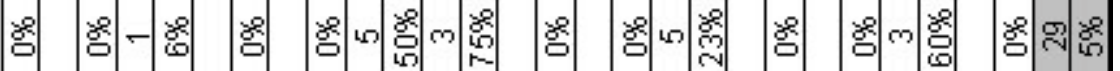

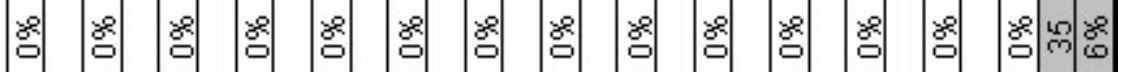

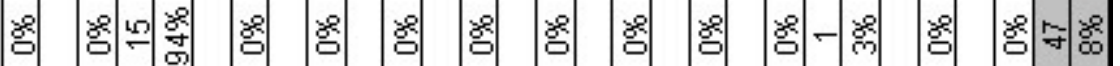

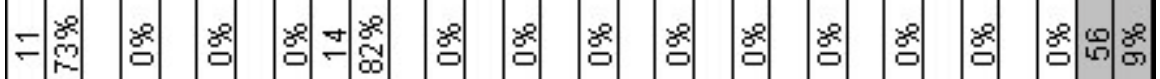

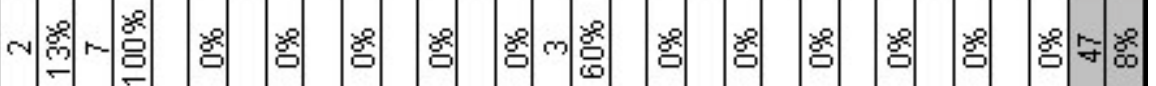

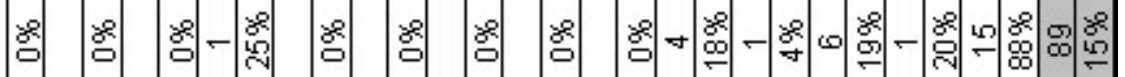

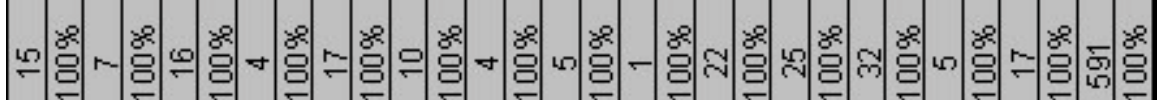

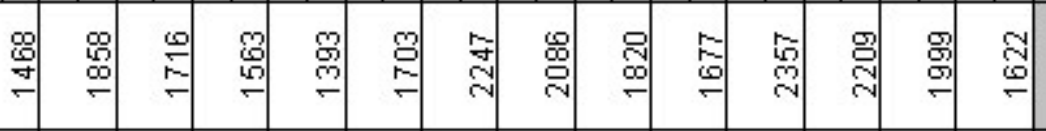

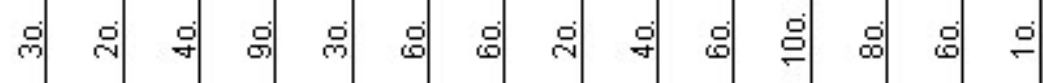

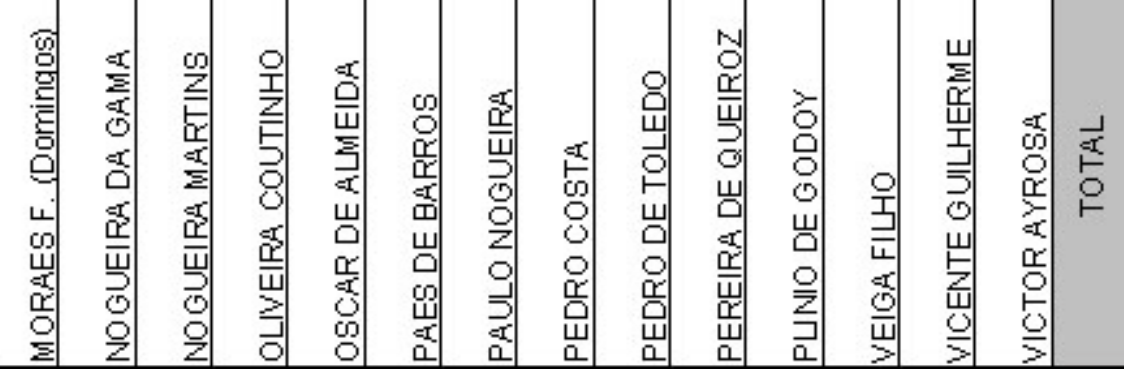




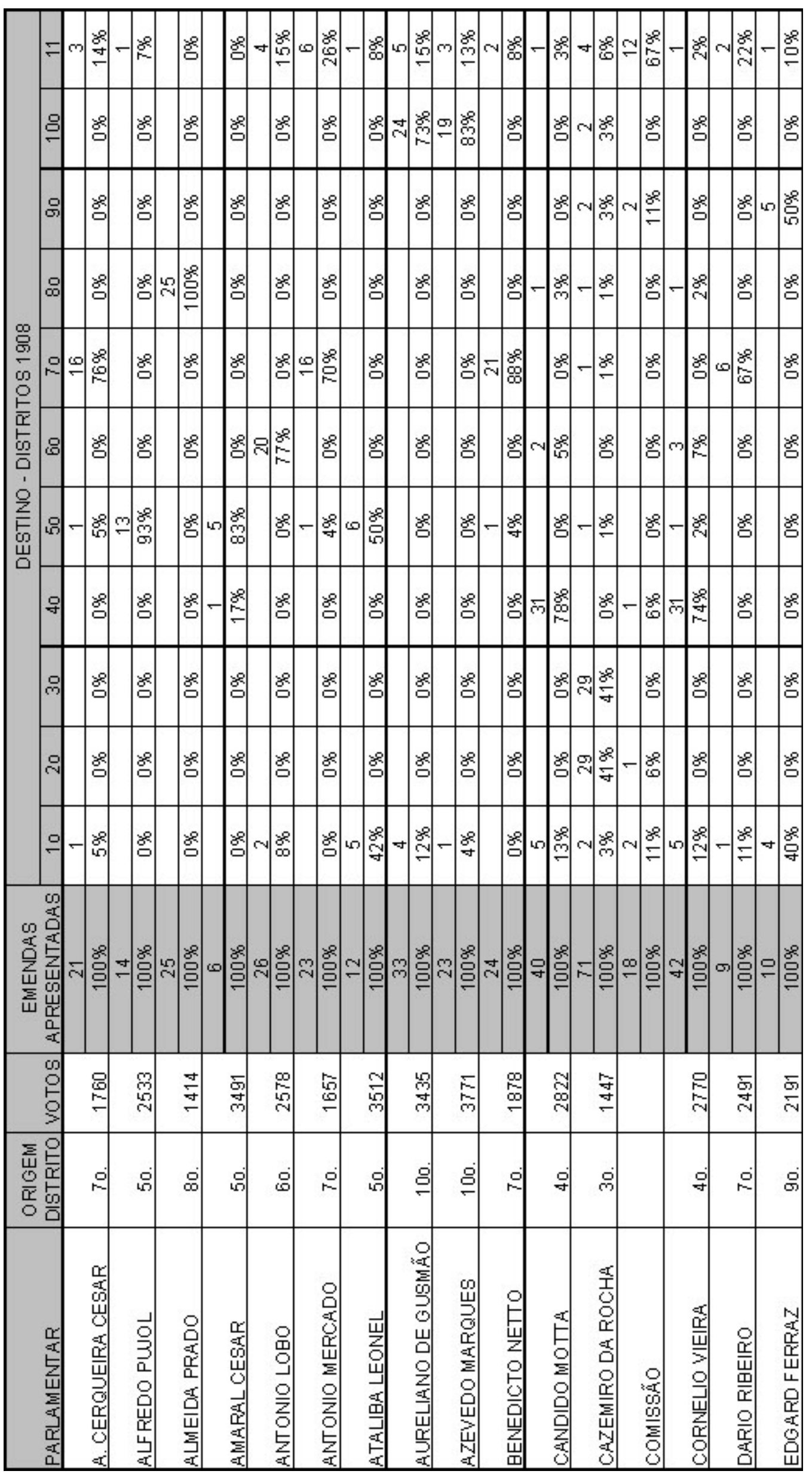




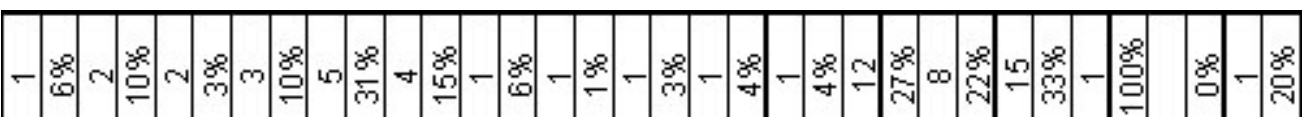

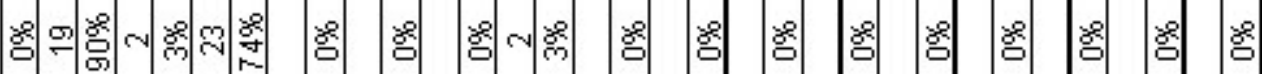
염 - 웜 염 웜 염 - 웜 영 -

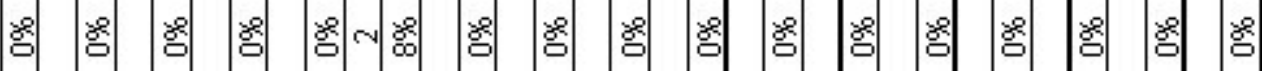
-

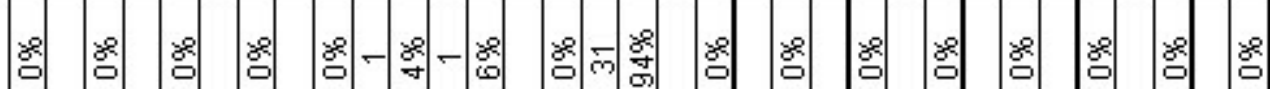
읨

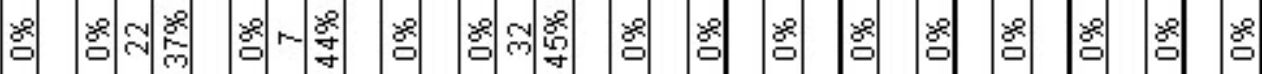
要 +

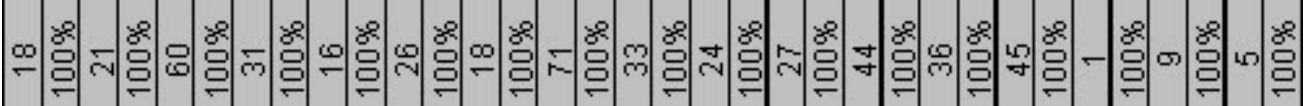

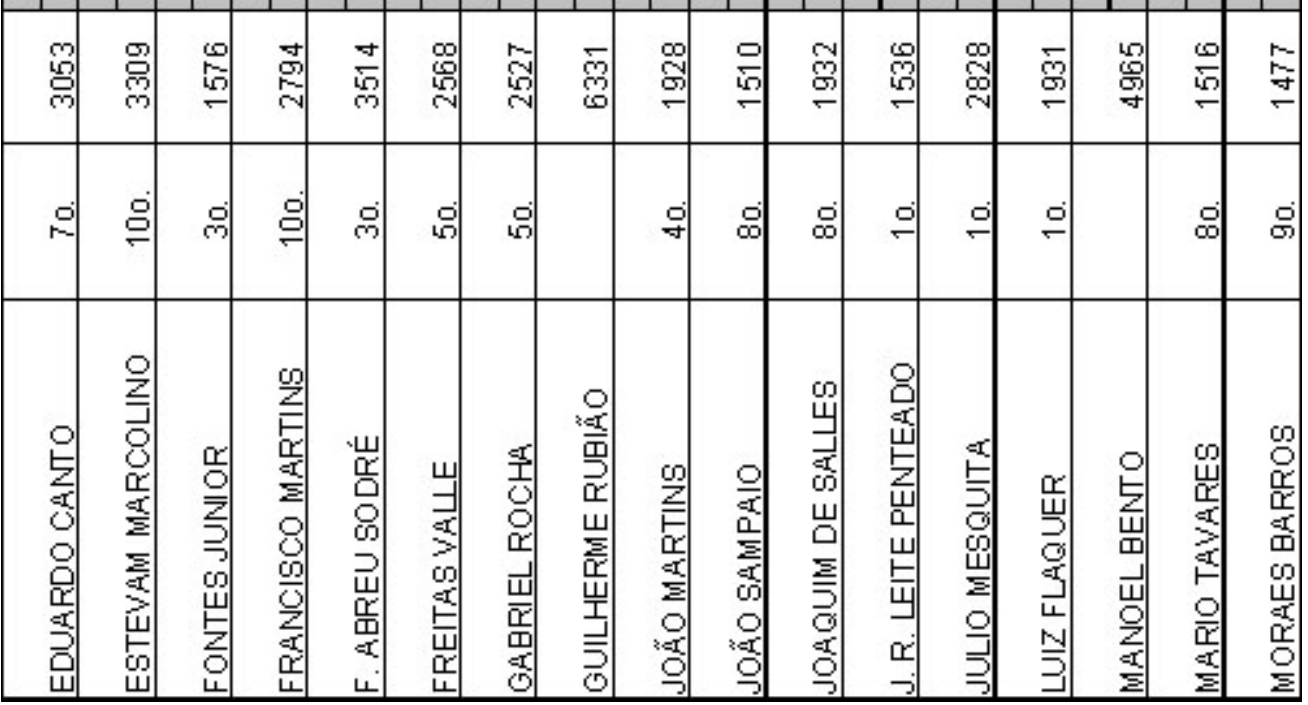




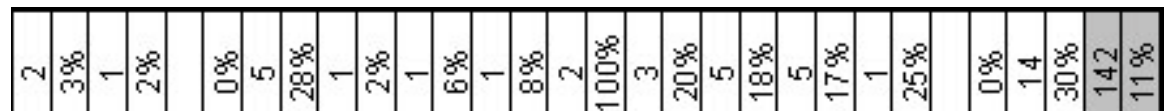

-

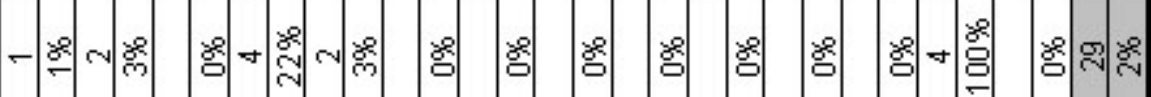

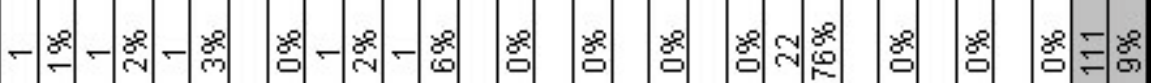

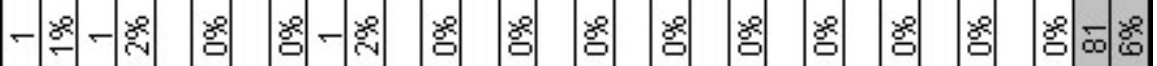

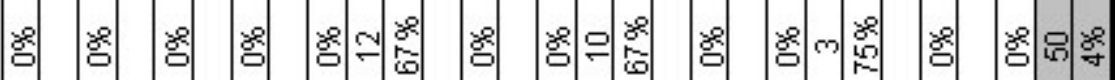

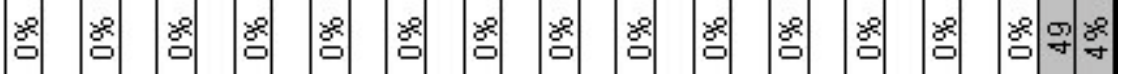

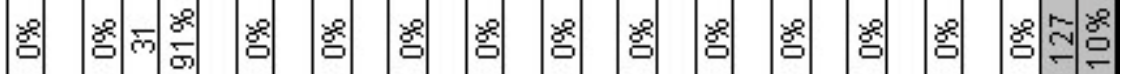

象语

诲

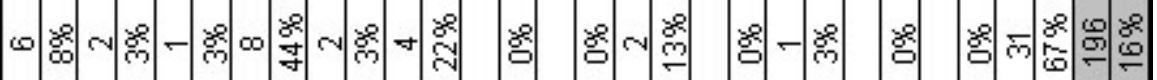

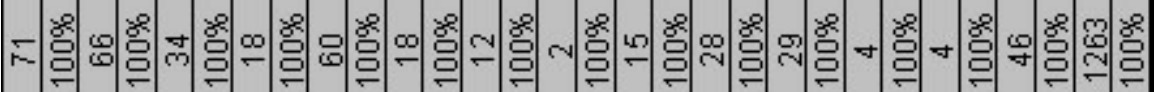

\begin{tabular}{|c|c|c|c|c|c|c|c|c|c|c|c|c|c|c|}
\hline 䍖 & $\begin{array}{l}\text { 品 } \\
\stackrel{0}{\circ}\end{array}$ & $\stackrel{\oplus}{=}$ & 罟 & $\stackrel{9}{9}$ & $\stackrel{9}{\circ}$ & $\begin{array}{l}0 \\
: 0\end{array}$ & 웡 & $\begin{array}{l}\text { - } \\
\text { a }\end{array}$ & 9 & 워ำ & 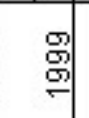 & 易 & $\mathbb{\Xi}$ & \\
\hline ले & 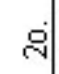 & o & : & 9 & : & 에 & 守 & 它 & 耐 & 8 & 它 & 영 & 의 & \\
\hline 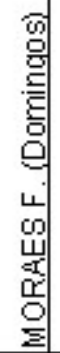 & 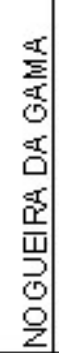 & 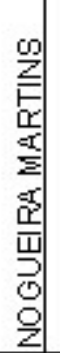 & 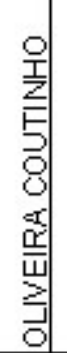 & 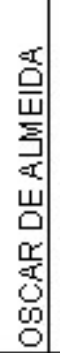 & 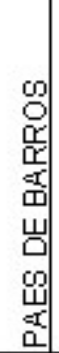 & 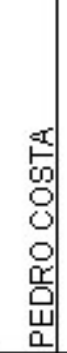 & 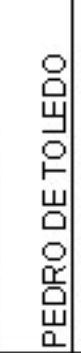 & 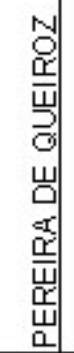 & 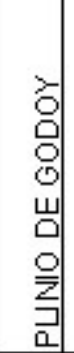 & 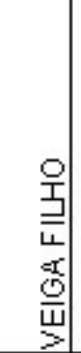 & 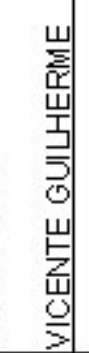 & 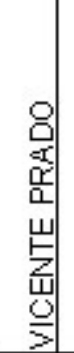 & 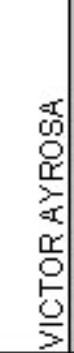 & 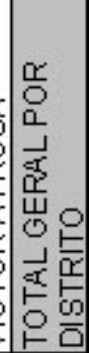 \\
\hline
\end{tabular}




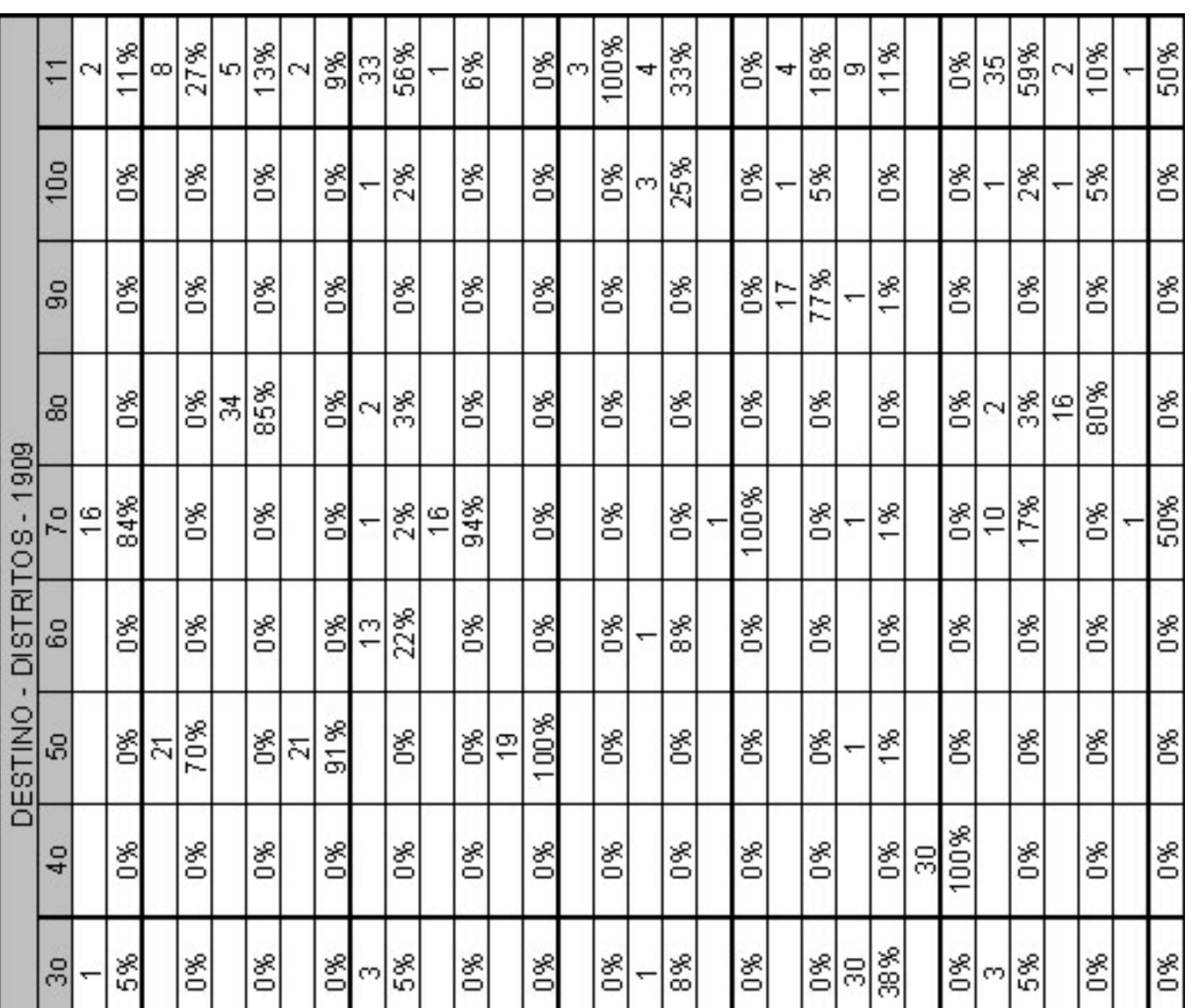

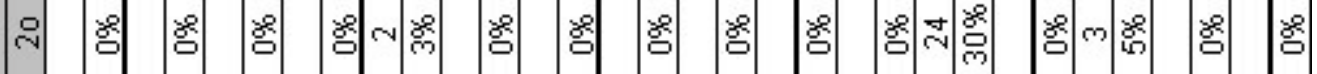
음 -

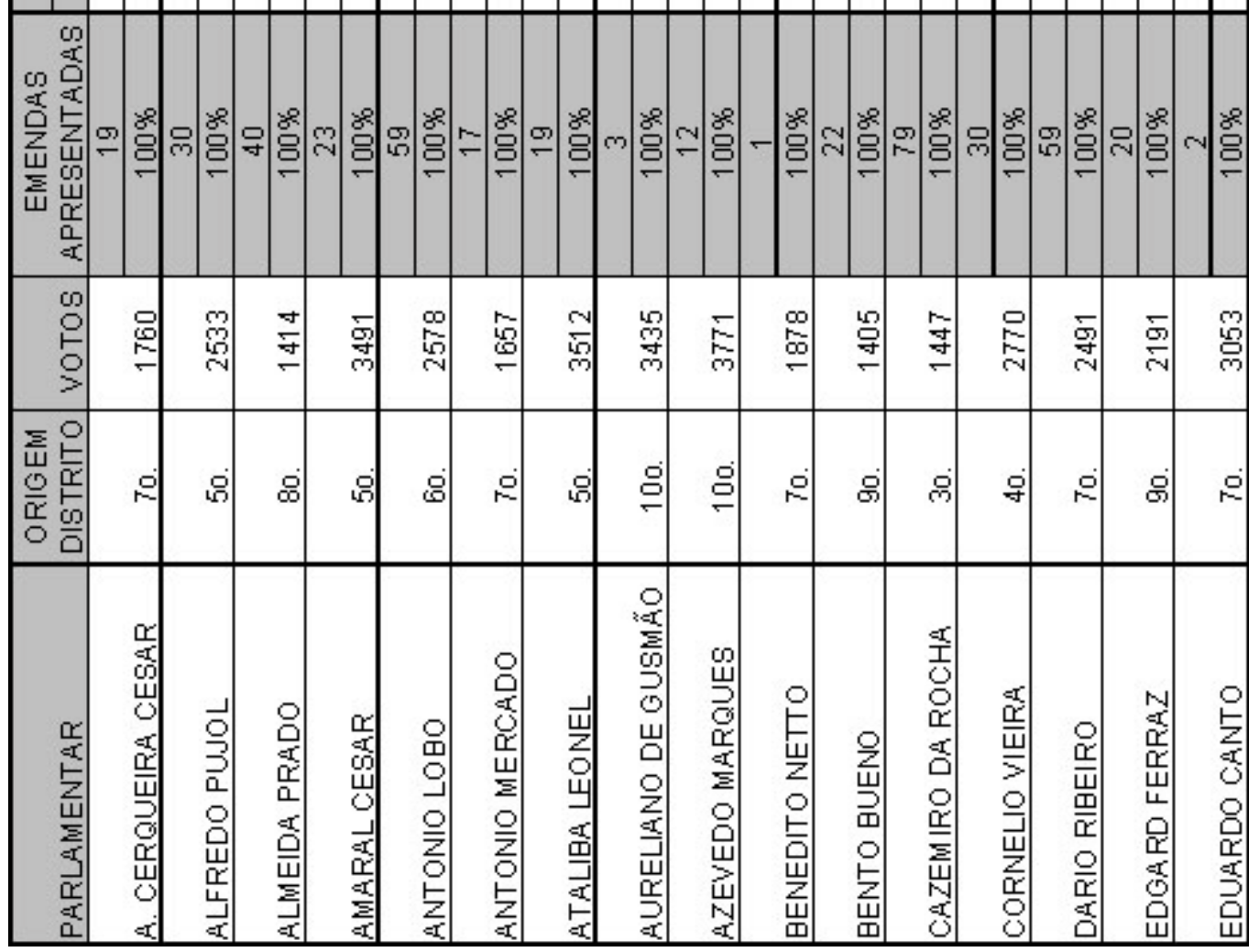


-

以-

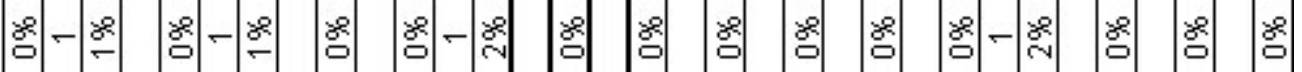

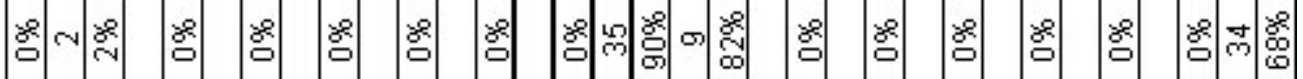

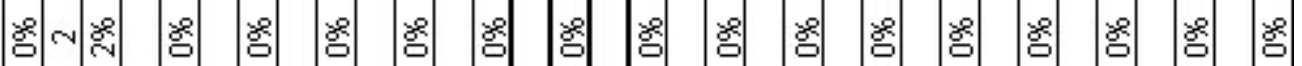

염 次

-

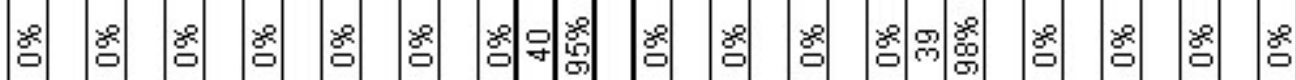

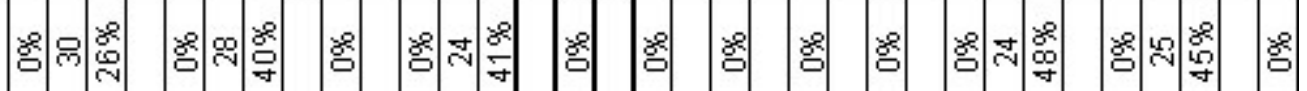

밈

뜸

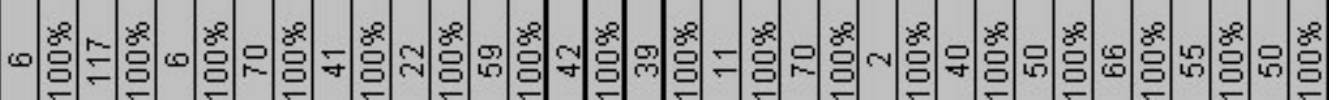

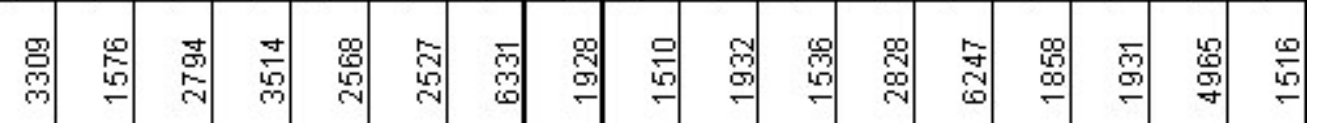

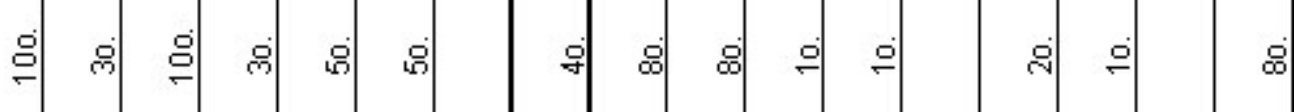

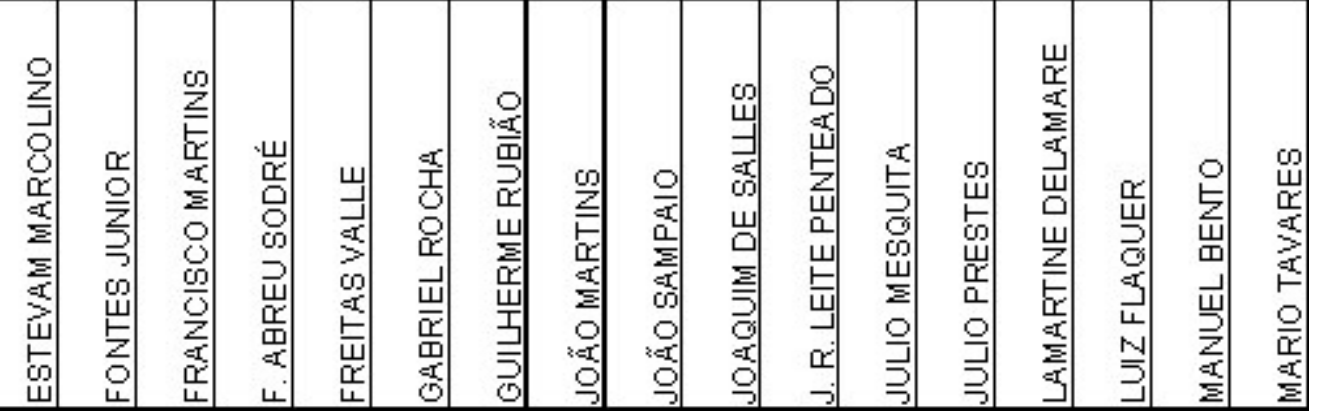




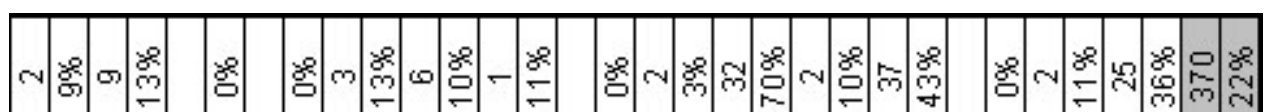

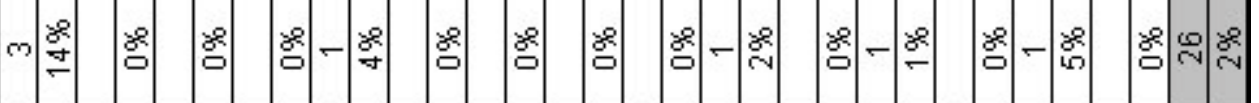

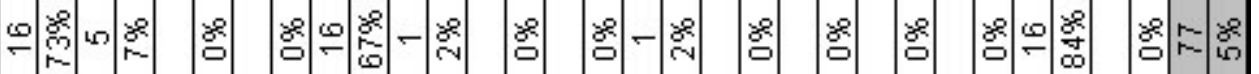

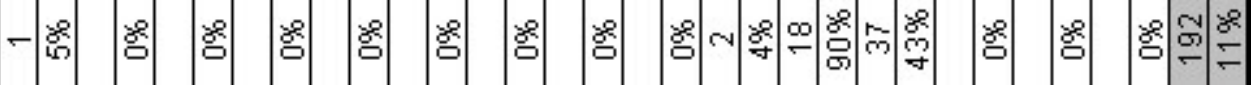

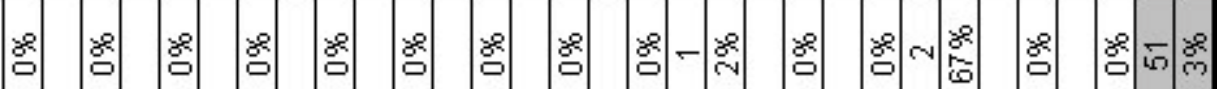

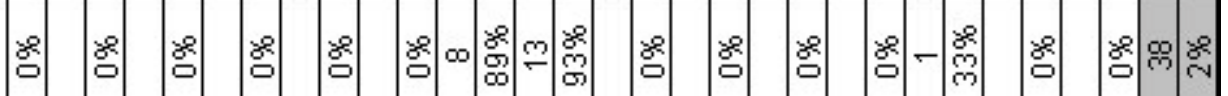

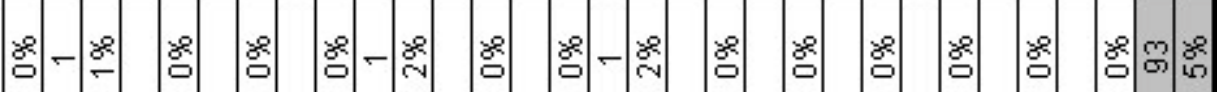

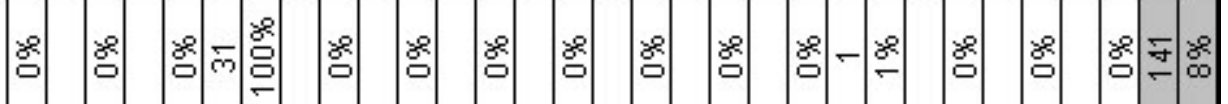

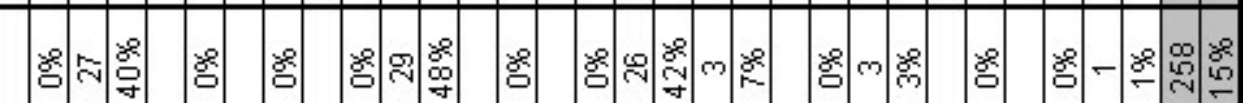

舟高

임

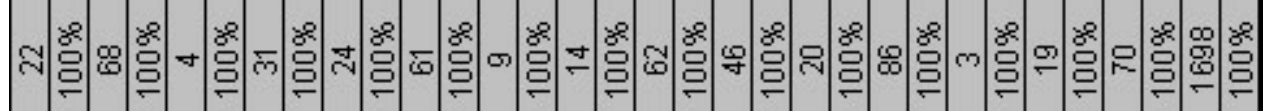

\begin{tabular}{|c|c|c|c|c|c|c|c|c|c|c|c|c|c|c|c|}
\hline$\frac{m}{8}$ & $\begin{array}{l}\text { 吅 } \\
\text { 寸 }\end{array}$ & $\begin{array}{l}\infty \\
15 \\
\infty\end{array}$ & $\begin{array}{l}9 \\
0 \\
0 \\
0\end{array}$ & $\begin{array}{l}9 \\
0 \\
5 \\
5\end{array}$ & $\begin{array}{c}m \\
\stackrel{9}{\circ}\end{array}$ & $\stackrel{9}{9}$ & 商 & $\begin{array}{l}\mathscr{9} \\
\stackrel{9}{9}\end{array}$ & $\begin{array}{l}- \\
\mathbf{0} \\
0\end{array}$ & ल) & 웜 & $\begin{array}{l}\text { g } \\
\text { 임 }\end{array}$ & $\begin{array}{l}5 \\
5 \\
0\end{array}$ & $\underset{\mathrm{d}}{\mathrm{Q}}$ & \\
\hline 9 & ले & 이 & 肙 & 踝 & ले & 9 & 9 & 이 & 8 & 9 & $\$$ & 이 & 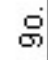 & 음 & \\
\hline 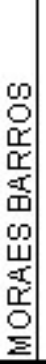 & 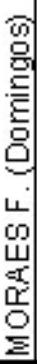 & 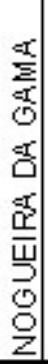 & 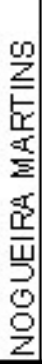 & 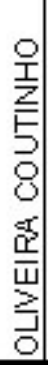 & 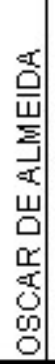 & 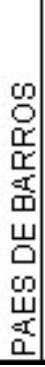 & 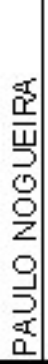 & 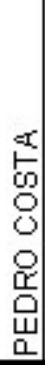 & 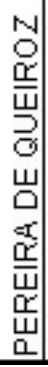 & 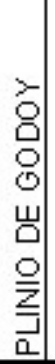 & 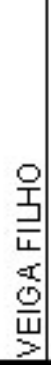 & 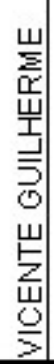 & 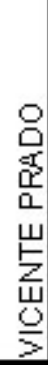 & 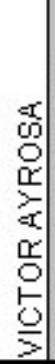 & 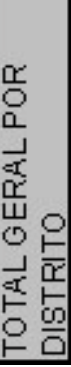 \\
\hline
\end{tabular}




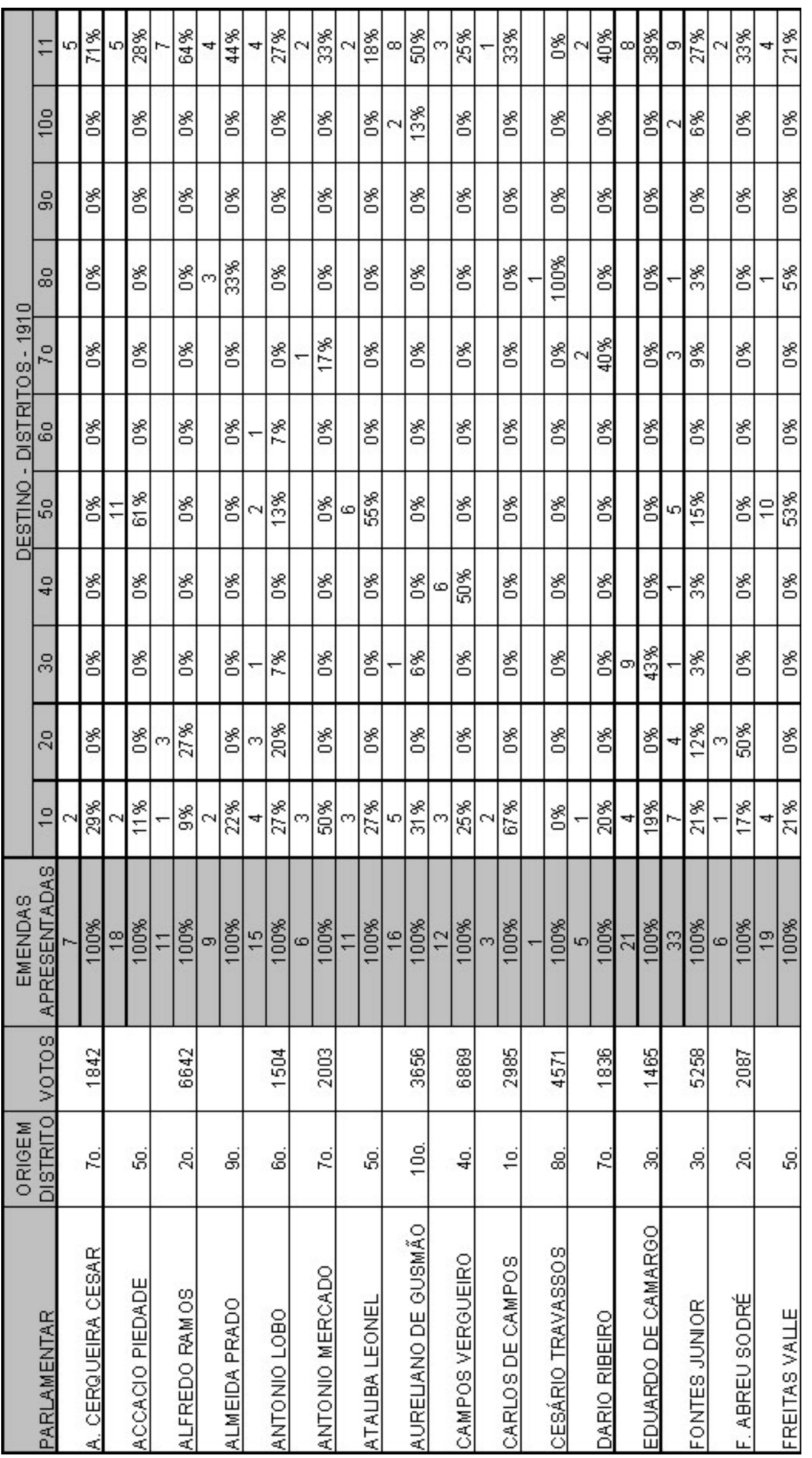




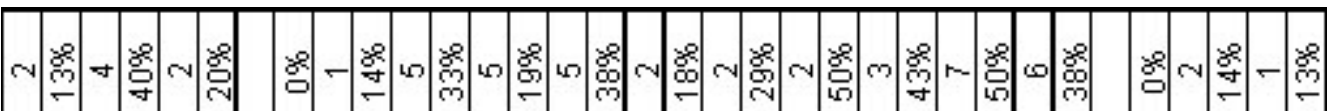

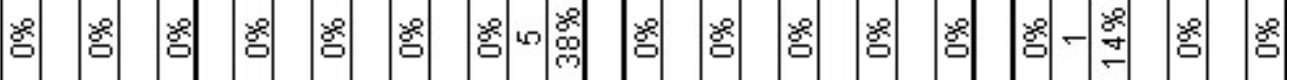

영

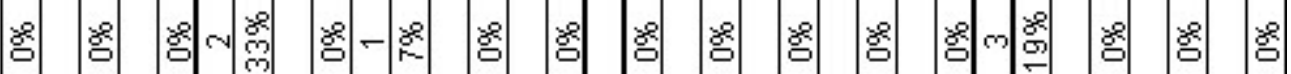

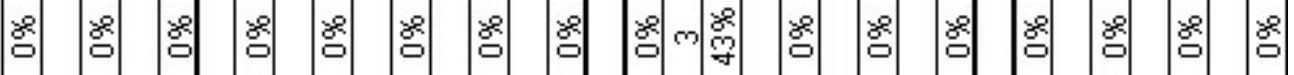

影

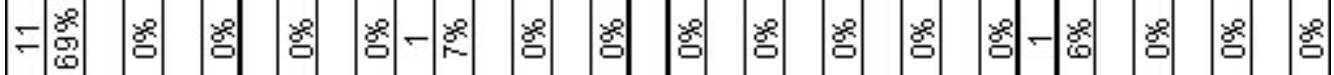

음 以

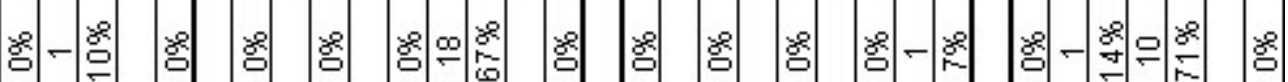

m

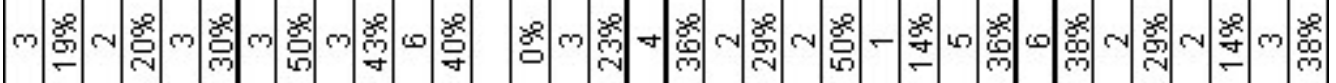

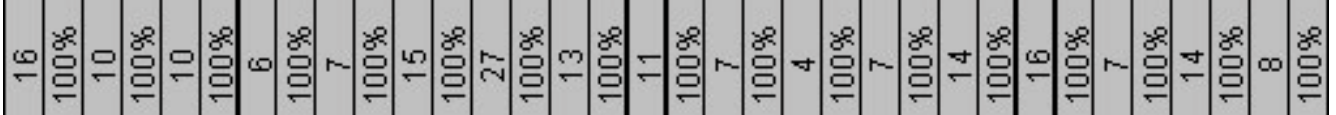

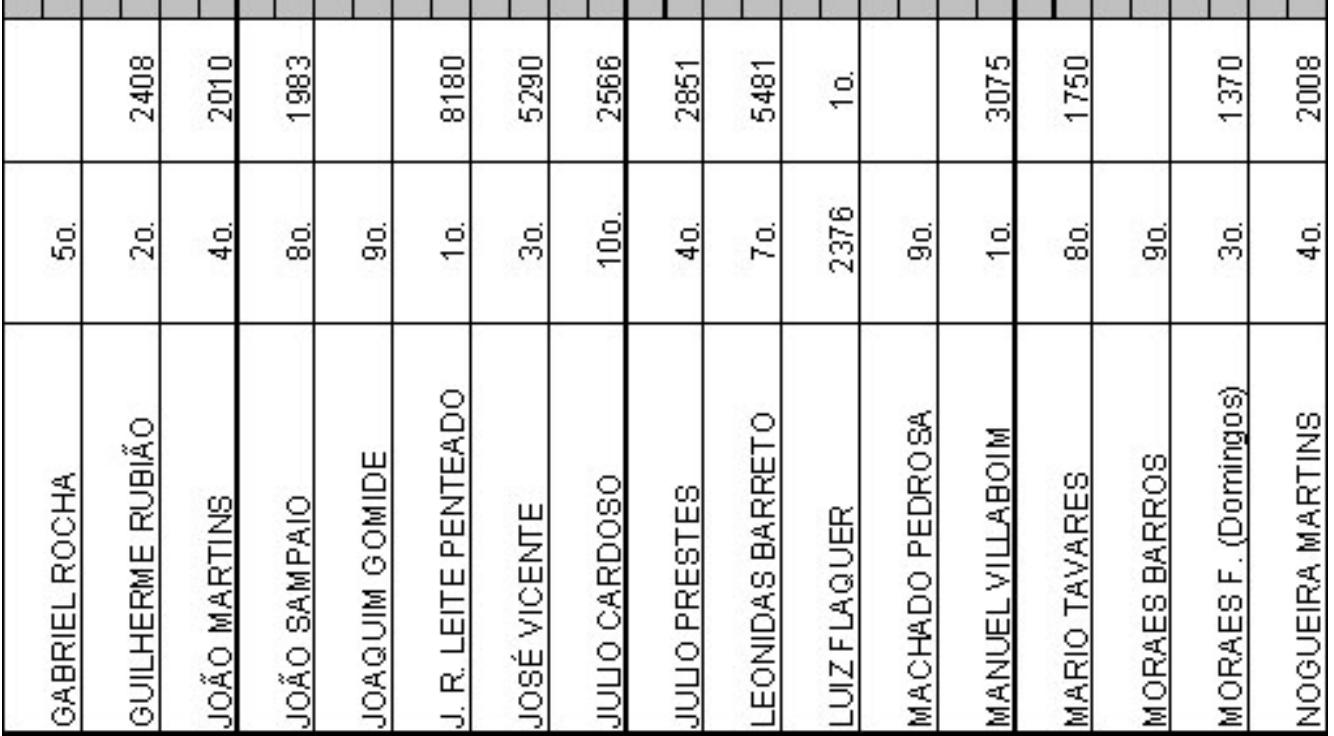




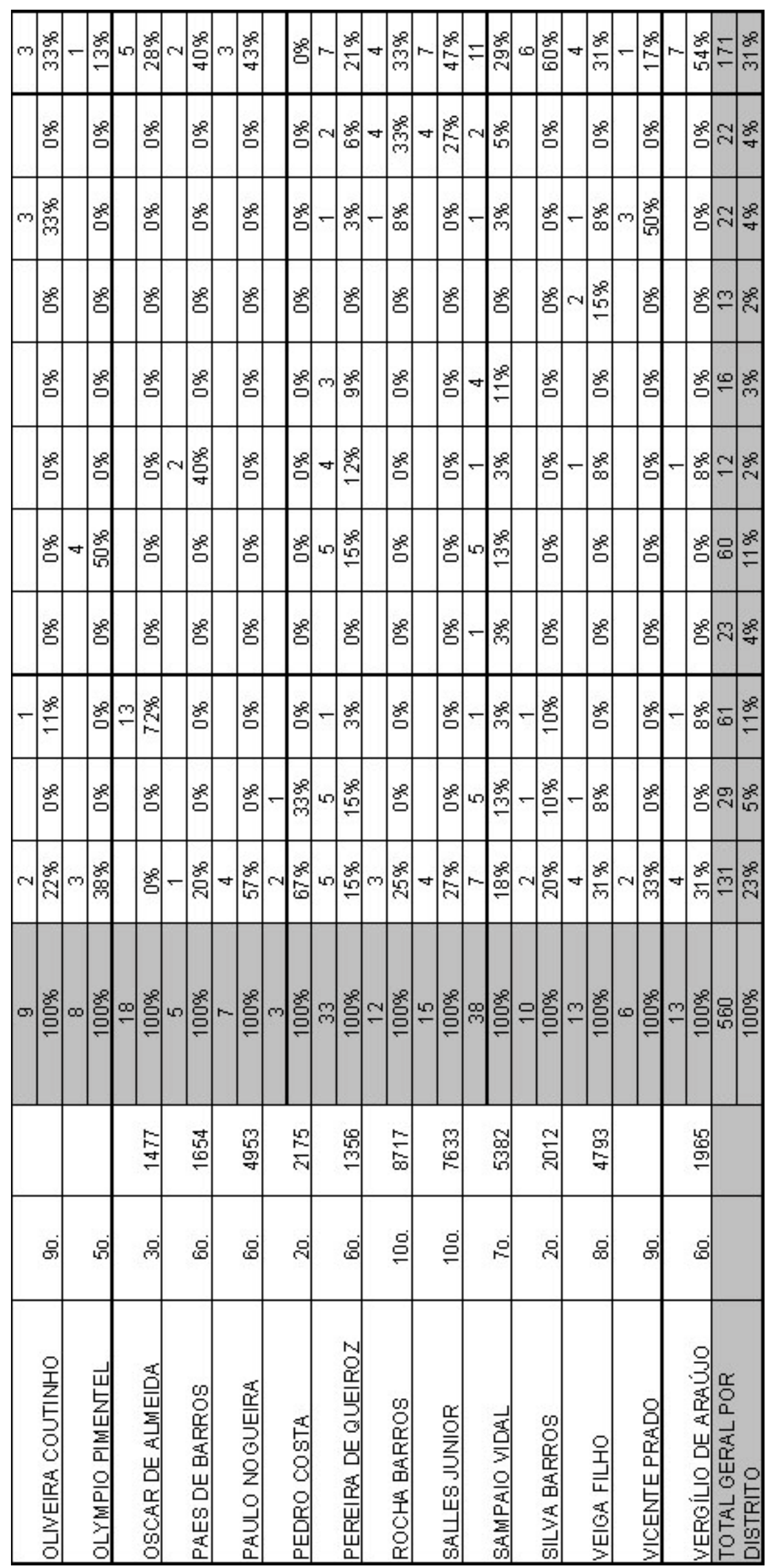




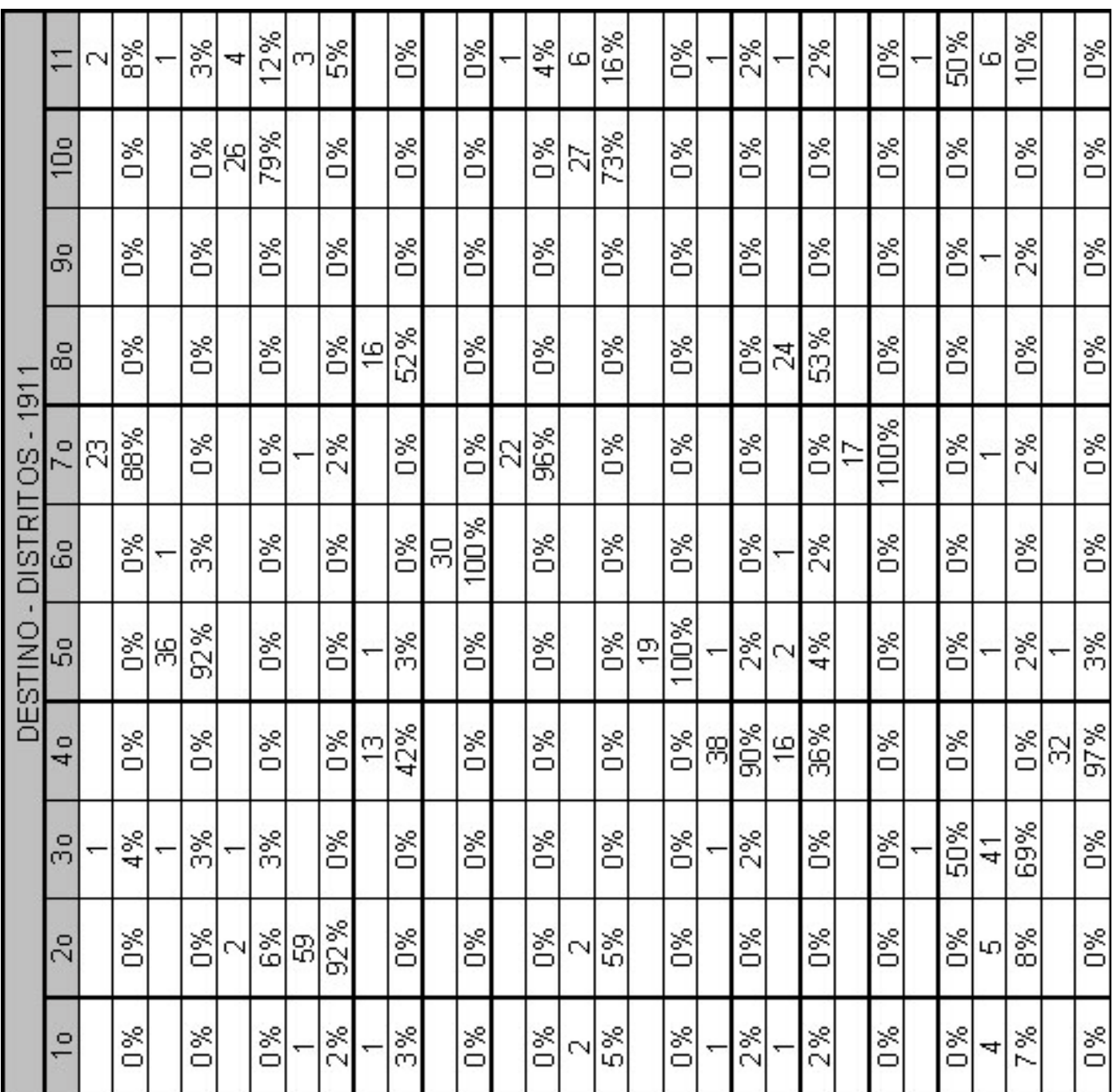

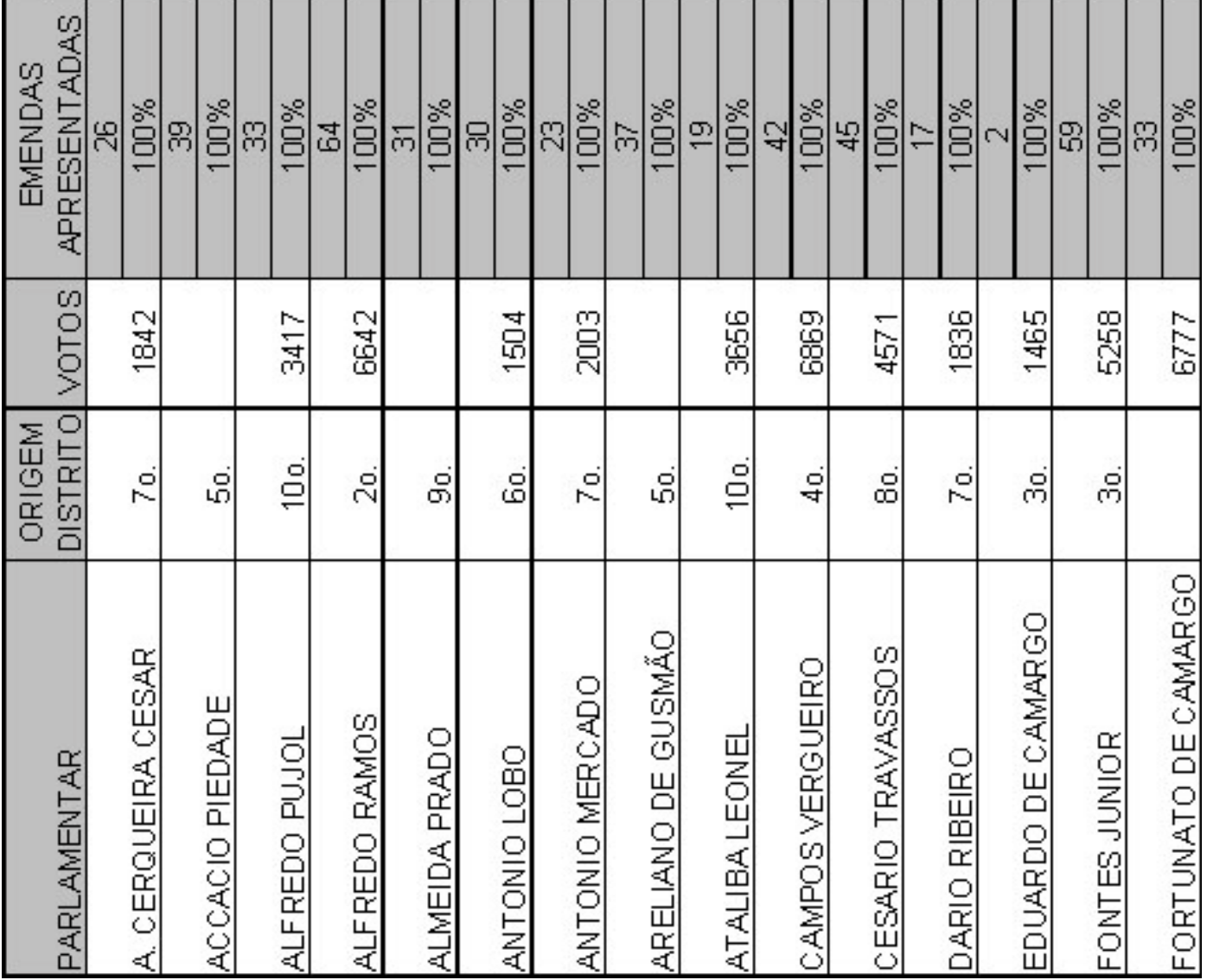




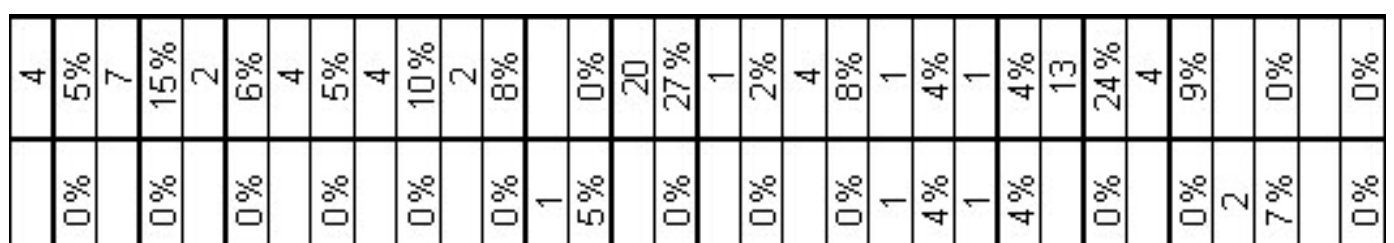

○ ஃ

ஃ

× ஃ

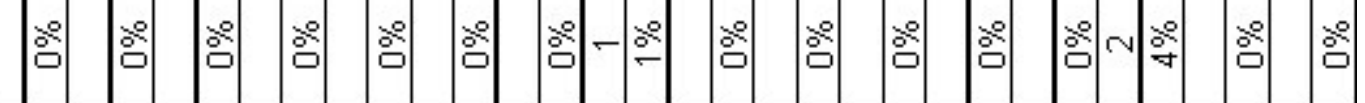

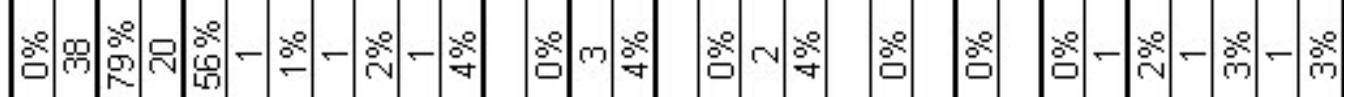

ஃ

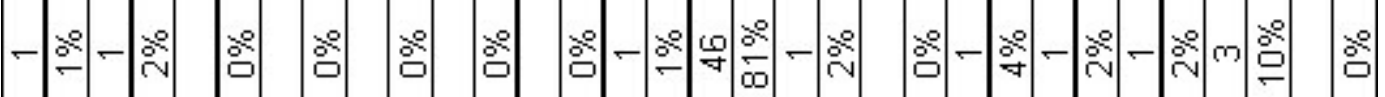
வ

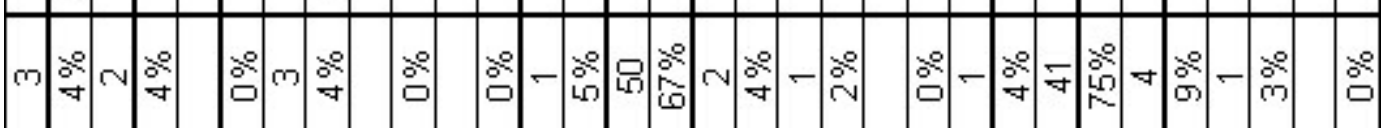

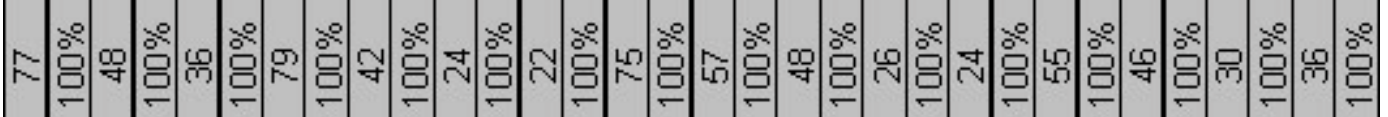

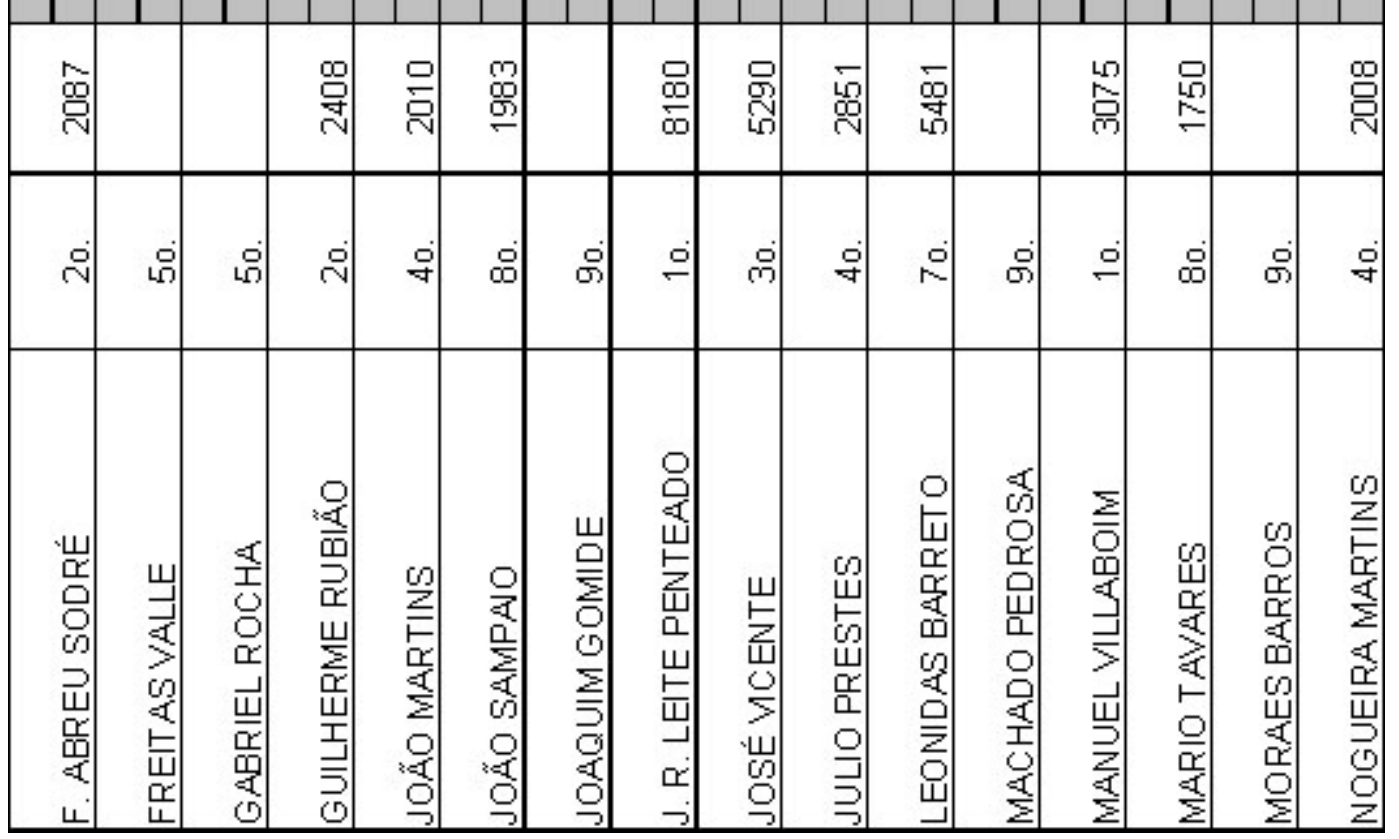




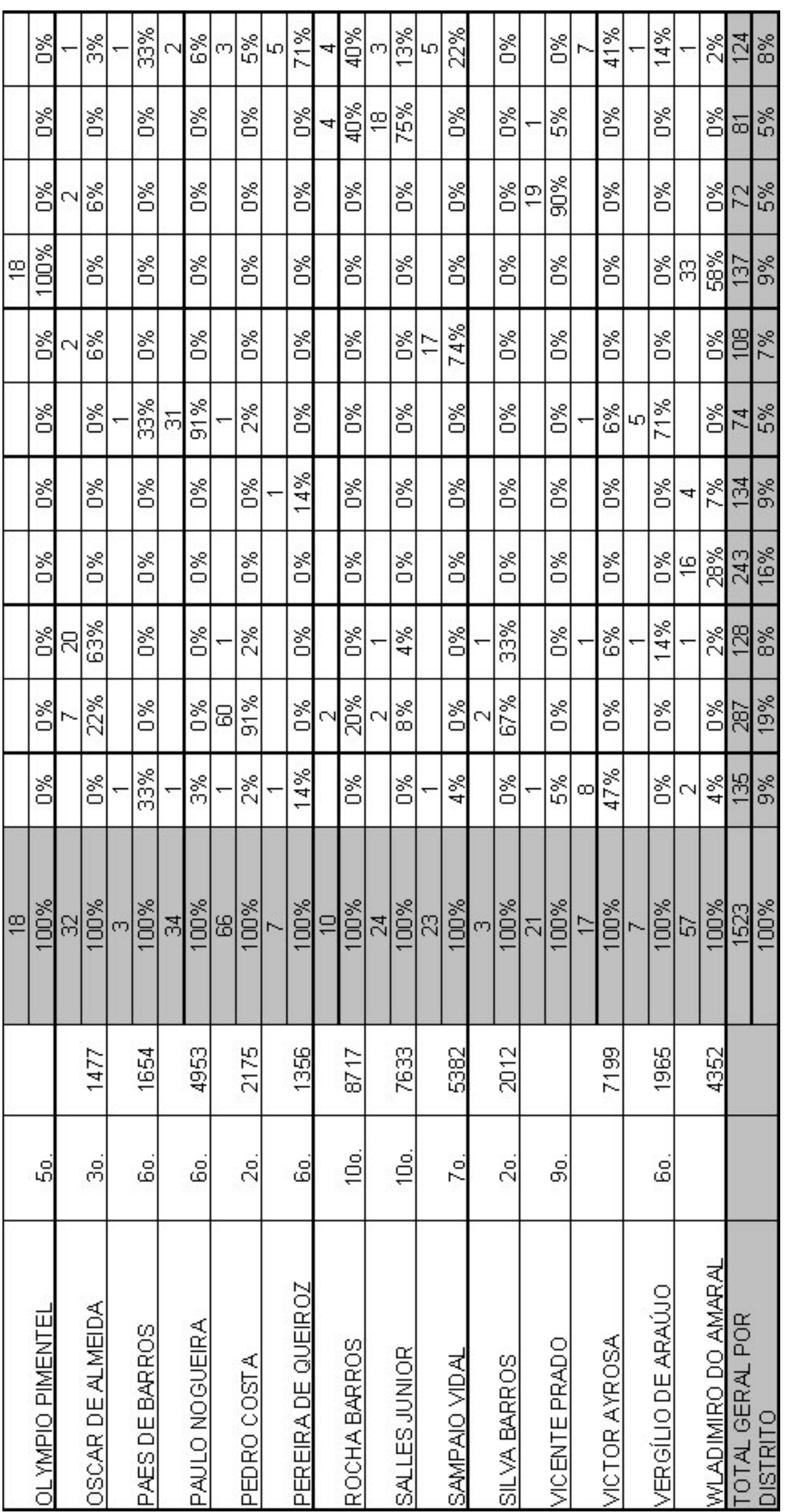




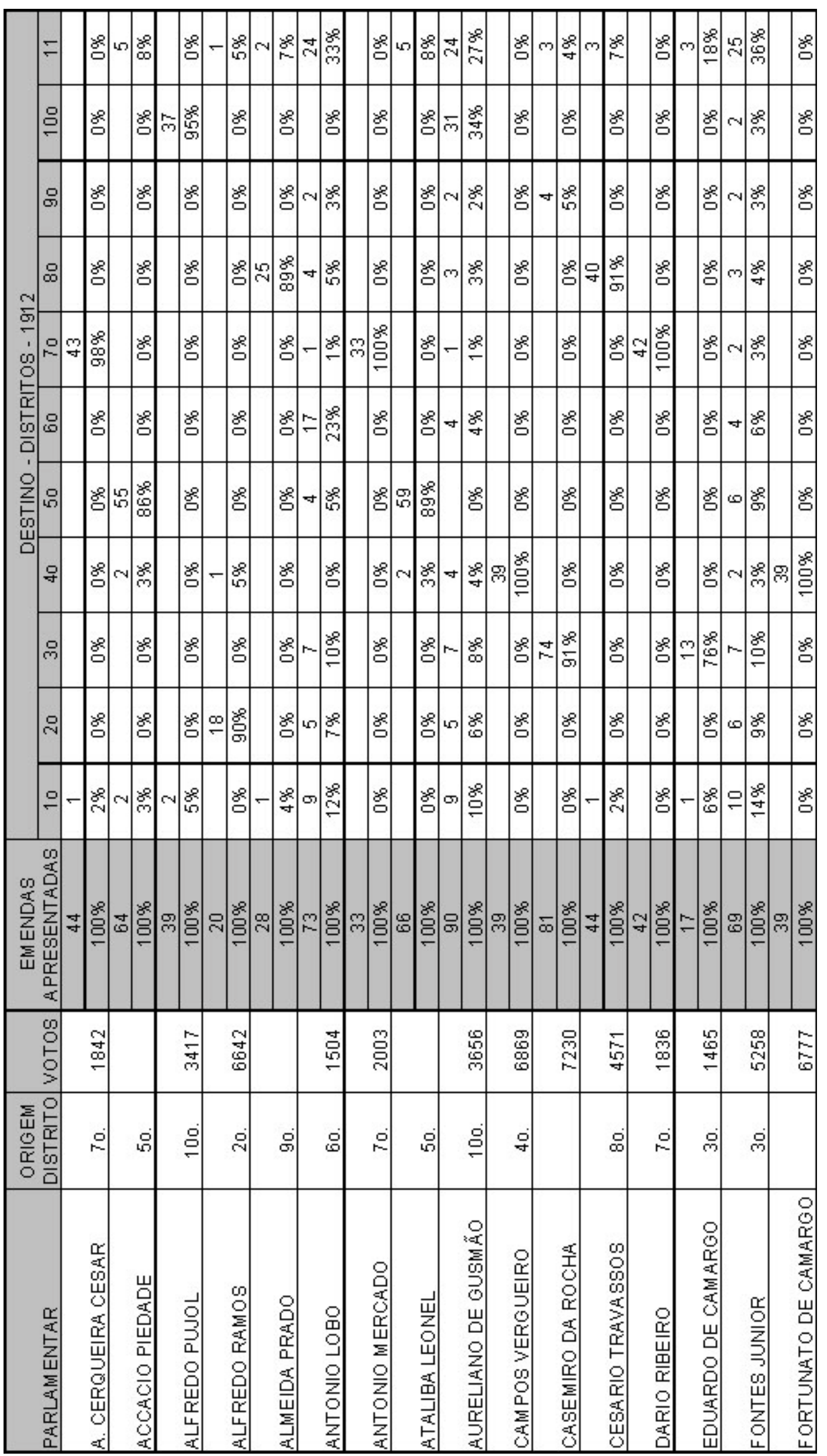




\begin{tabular}{|c|c|c|c|c|c|c|c|c|c|c|c|c|c|c|c|c|c|c|c|c|c|c|c|c|c|}
\hline$=$ & $\stackrel{8}{\rightarrow}$ & $\therefore \stackrel{20}{-\infty}$ & $\nabla$ & \% & $m \frac{8}{4}$ & $m$ & 요 & - & 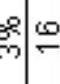 & 월. & $\nabla$ & $\begin{array}{l}8 \\
8\end{array}$ & 2 & 2 & & : & 28 & $-\infty_{\infty}^{\infty}$ & $\infty$ & $\frac{8}{\infty}$ & & 8 & & 5 & 8 \\
\hline & 。ㅇ & 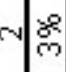 & - & s & 8 & & 웜 & & 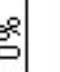 & 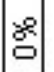 & g & . & $m$ & 。 & & 。̊ & 웜 & 89 & & 움. & $\nabla$ & ๑ & $\infty$ & & 8 \\
\hline & 8 & 80 & & . & $\checkmark \underbrace{2}_{m}$ & & 웜 & 월 & & : & $\infty$ & 8 & 8 & 8 & & 。ㅁ & 量 & 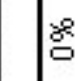 & & 8 & $\stackrel{\infty}{-}$ & 过 & & & $\stackrel{8}{\circ}$ \\
\hline & 8̊ & 82 & & 。 & 8 & & 웜 & $\stackrel{\square}{\square}$ & 解 & के & & . & $-\infty$ & 尺 & & 8잉 & 웜 & ช̊ & $-\infty$ & $\begin{array}{c}8 \\
0\end{array}$ & & $\begin{array}{c}8 \\
m \\
m\end{array}$ & & & 。̊ \\
\hline & 8 & 8 & & 8 & $\stackrel{8}{\circ}$ & & 웜 & & 8 & 8 & z & ? & 8 & 8 & v & 。 & 웜 & 8 & & 。 & & 。 & $\sim$ & & $\ddot{g}$ \\
\hline & 8 & 8 & & 。 & 8 & & 웜 & & 。 & 咹 & ğ & 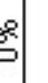 & 8 & 总 & & 。 & 89 & 8 & & 咹 & & 8 & 寸 & & 암 \\
\hline
\end{tabular}

엠

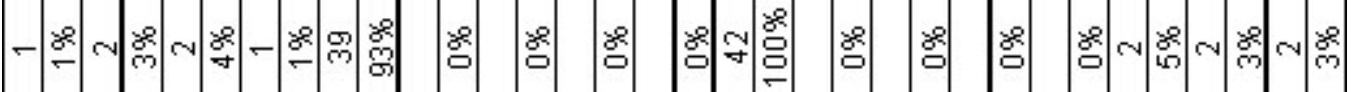

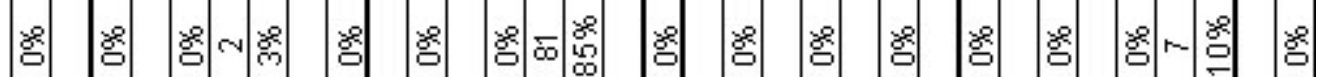

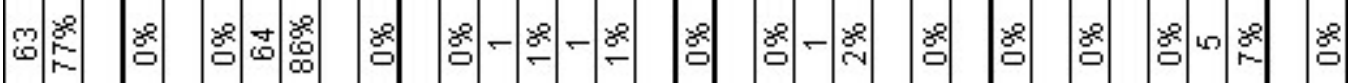
क +

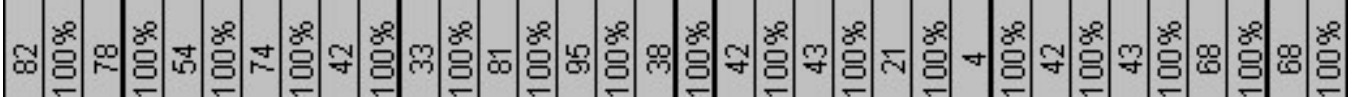

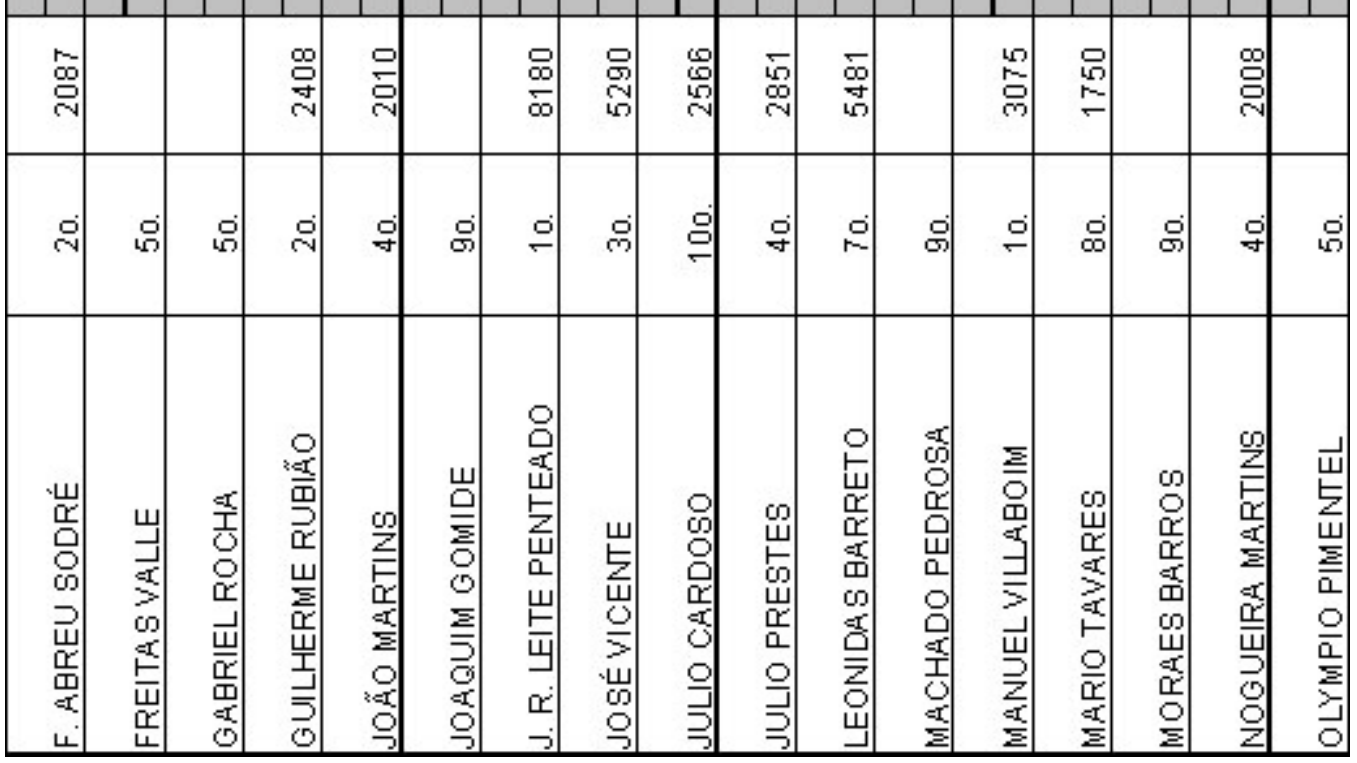


$=$ = 웅 음

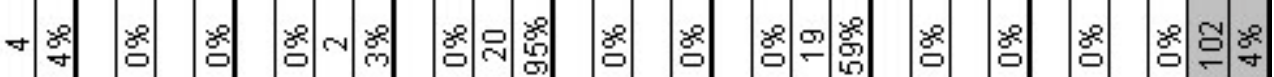
웜

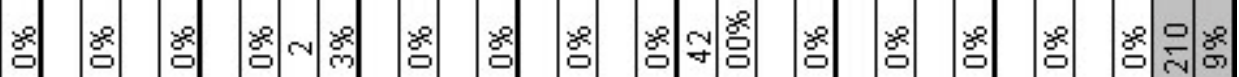
염 m

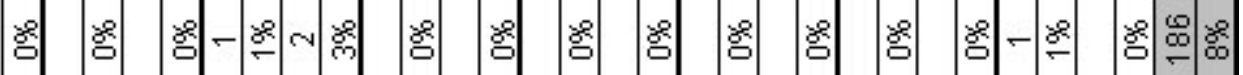

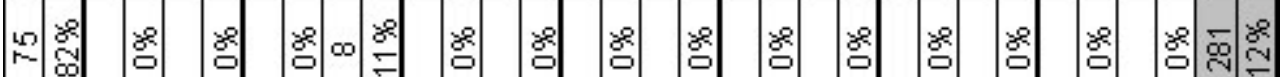

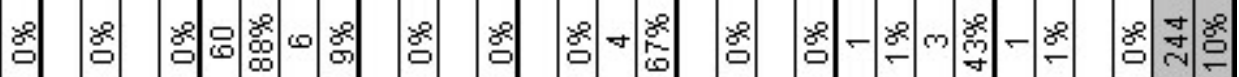
- 웅 웜

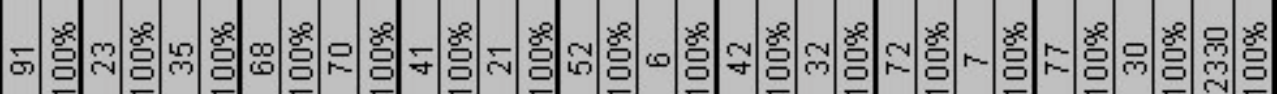

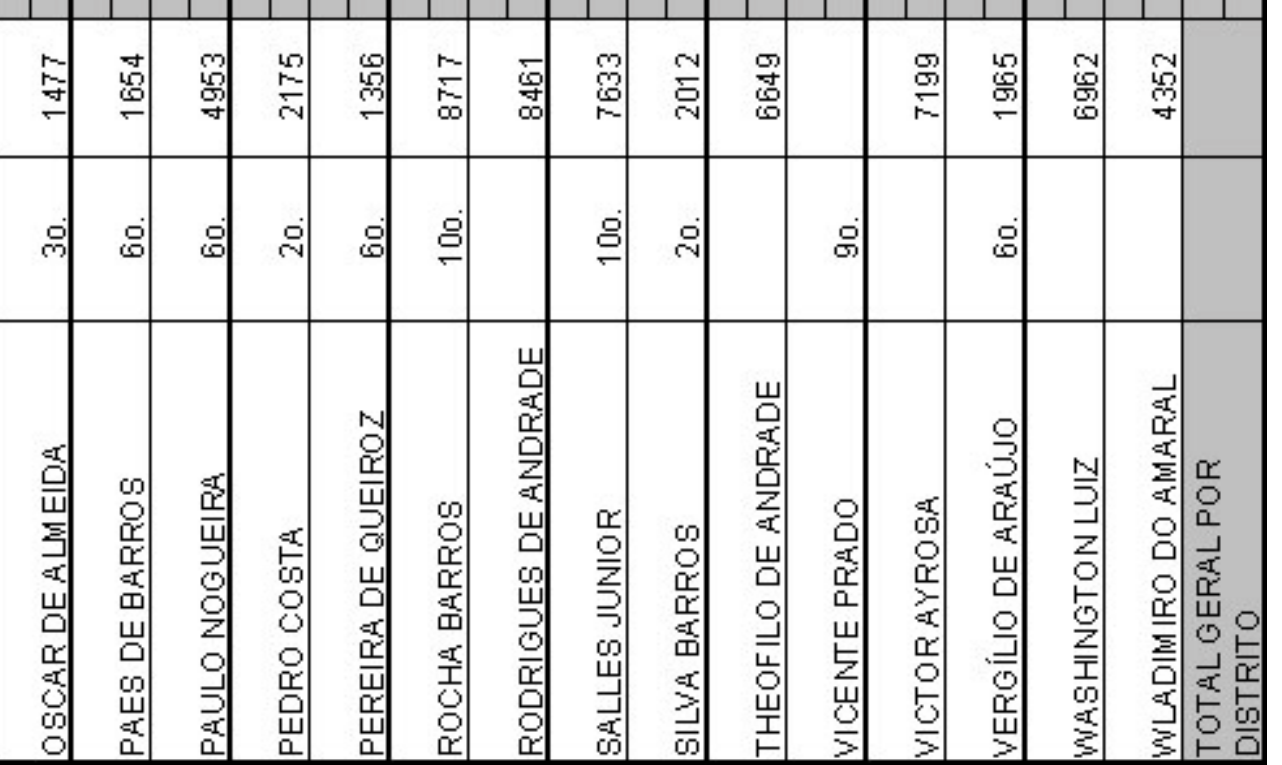




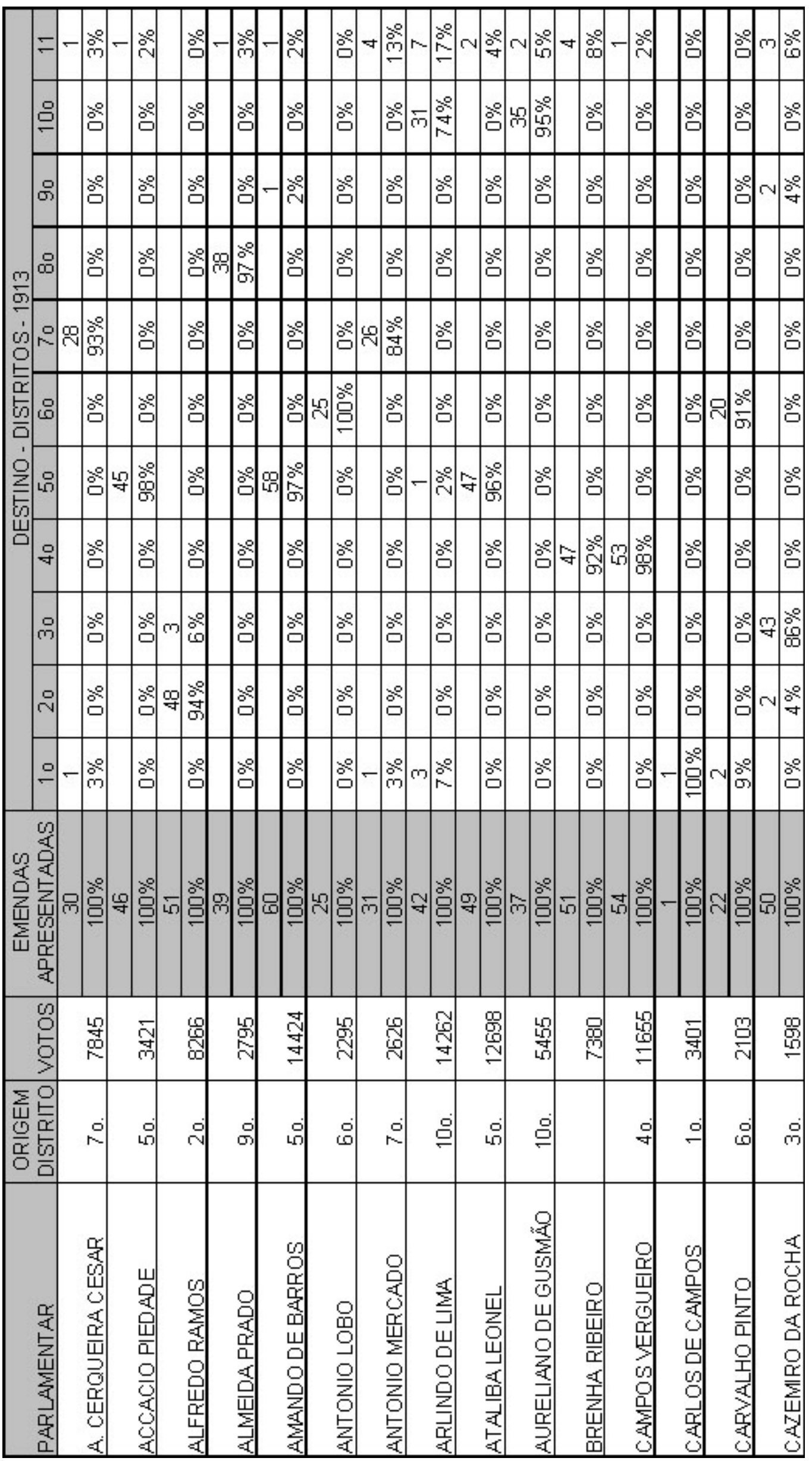




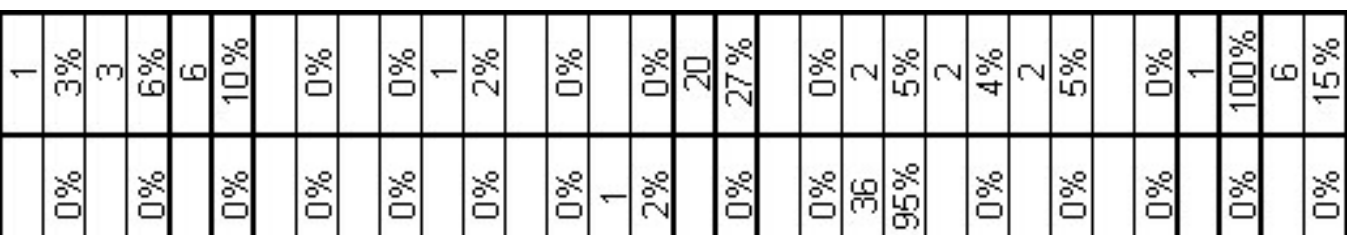

의 ஃ ஃ

ㅇㅎㅁ ஃ ஃ

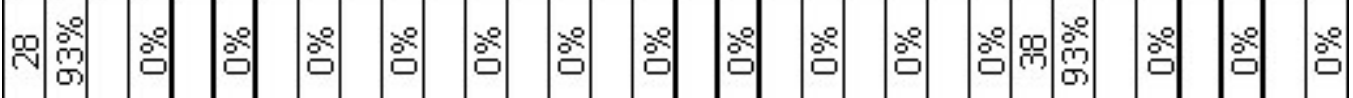

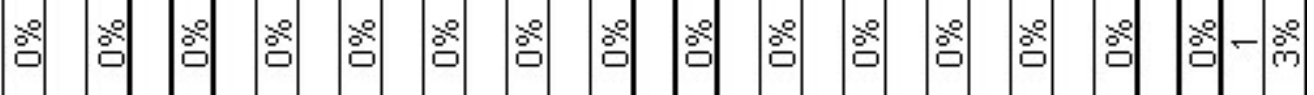

ㅇํㅁำ

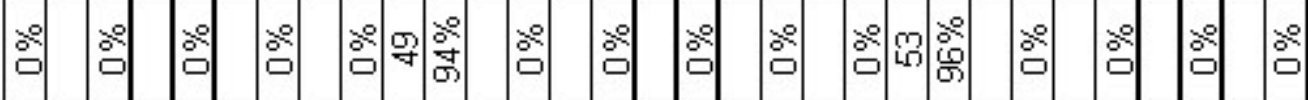

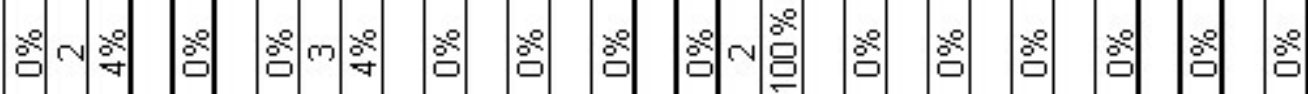

ㅇํㅁ ஃ

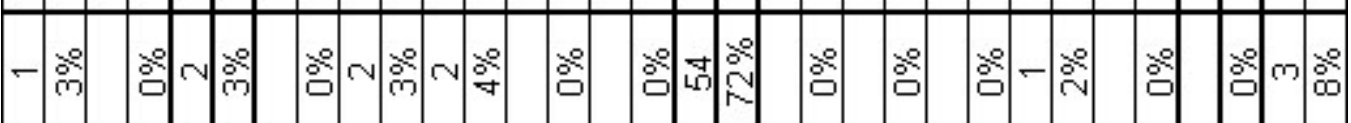

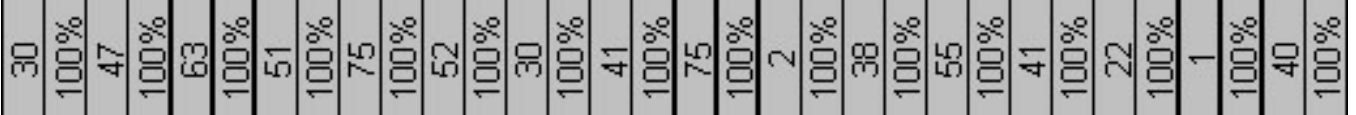

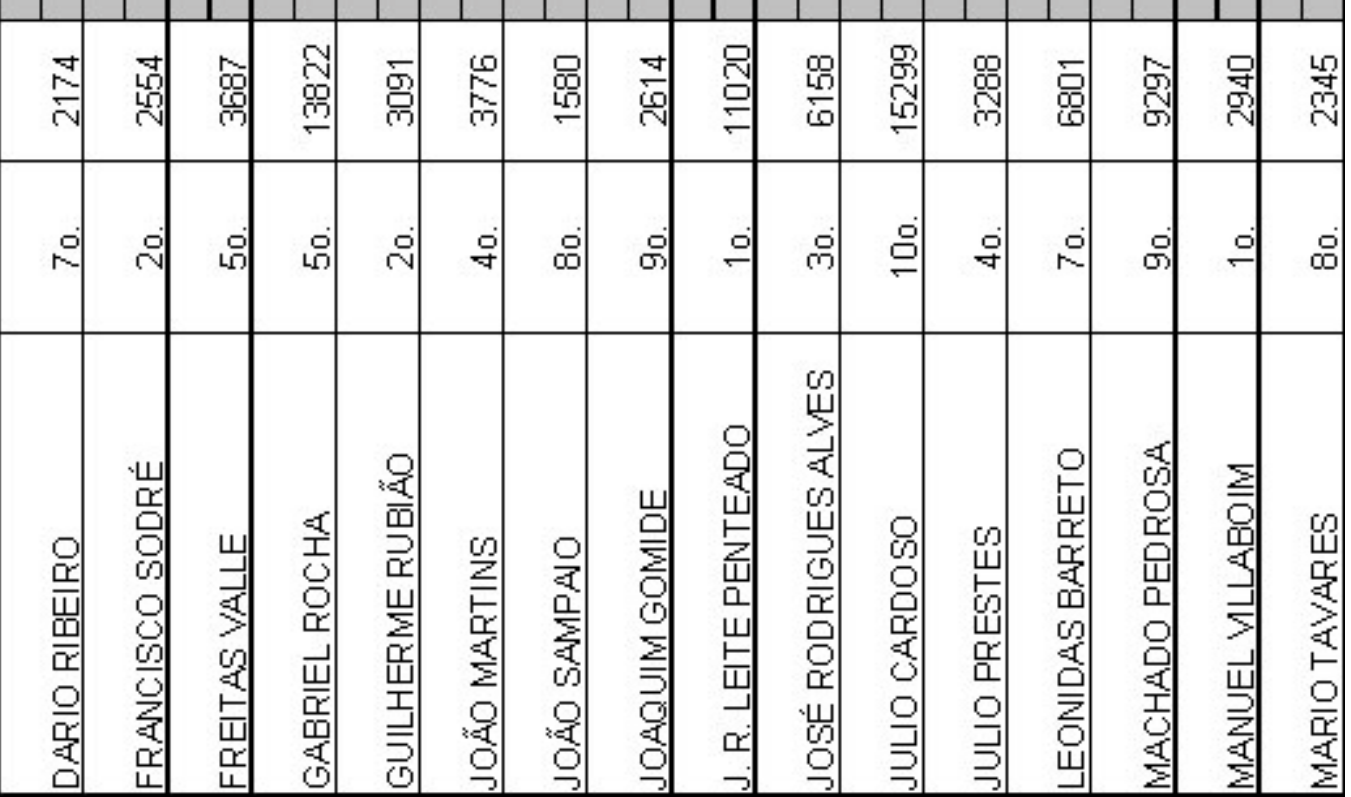




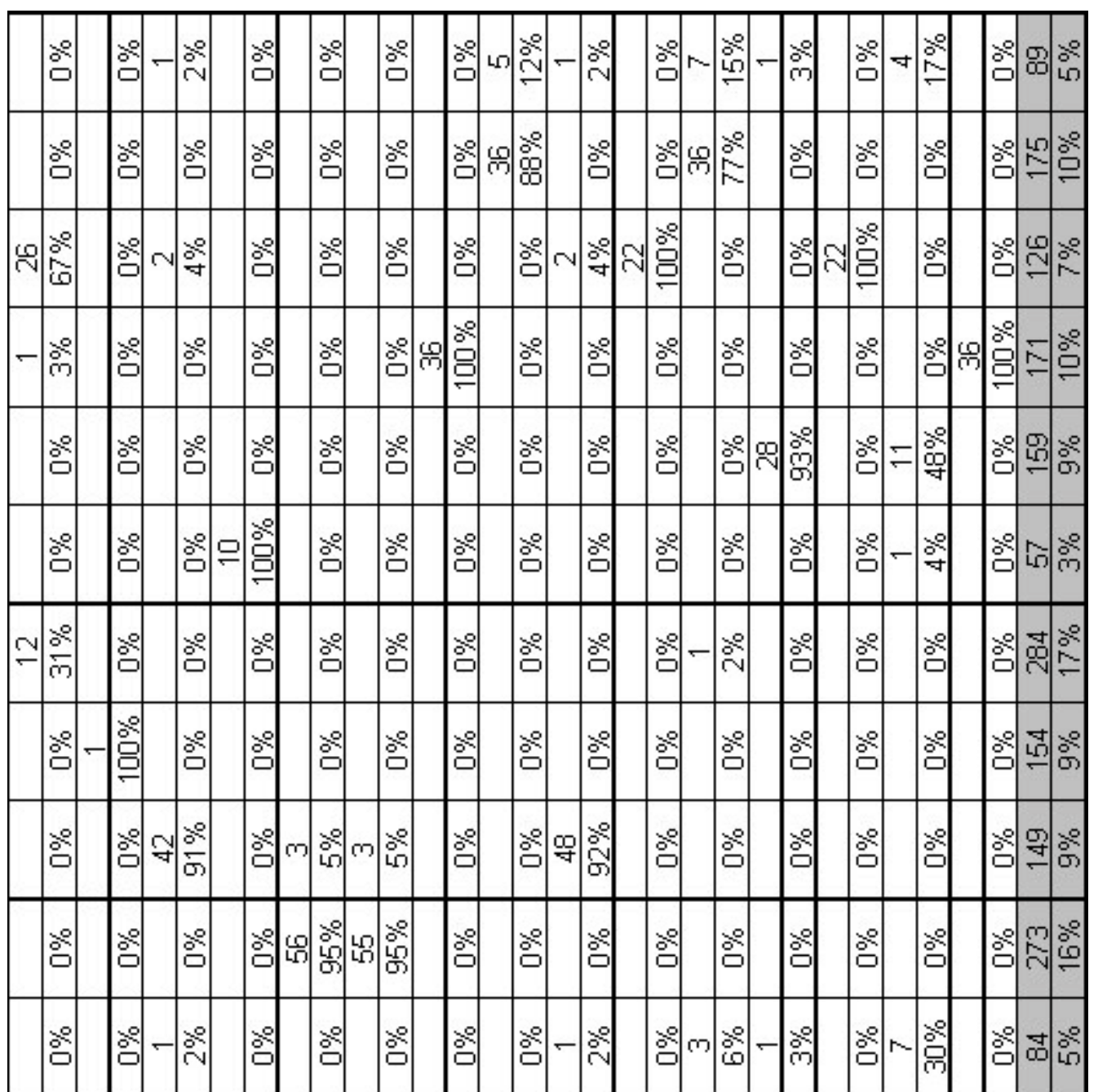

m-

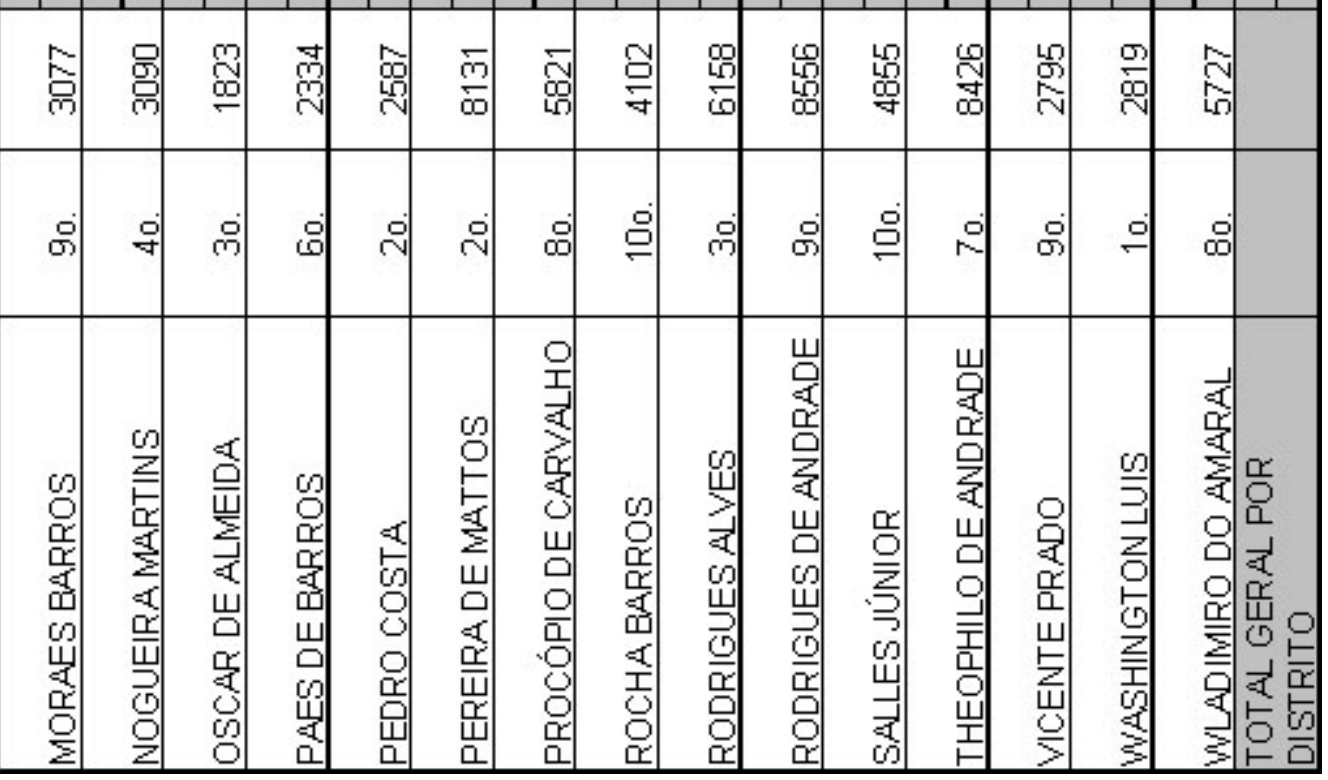




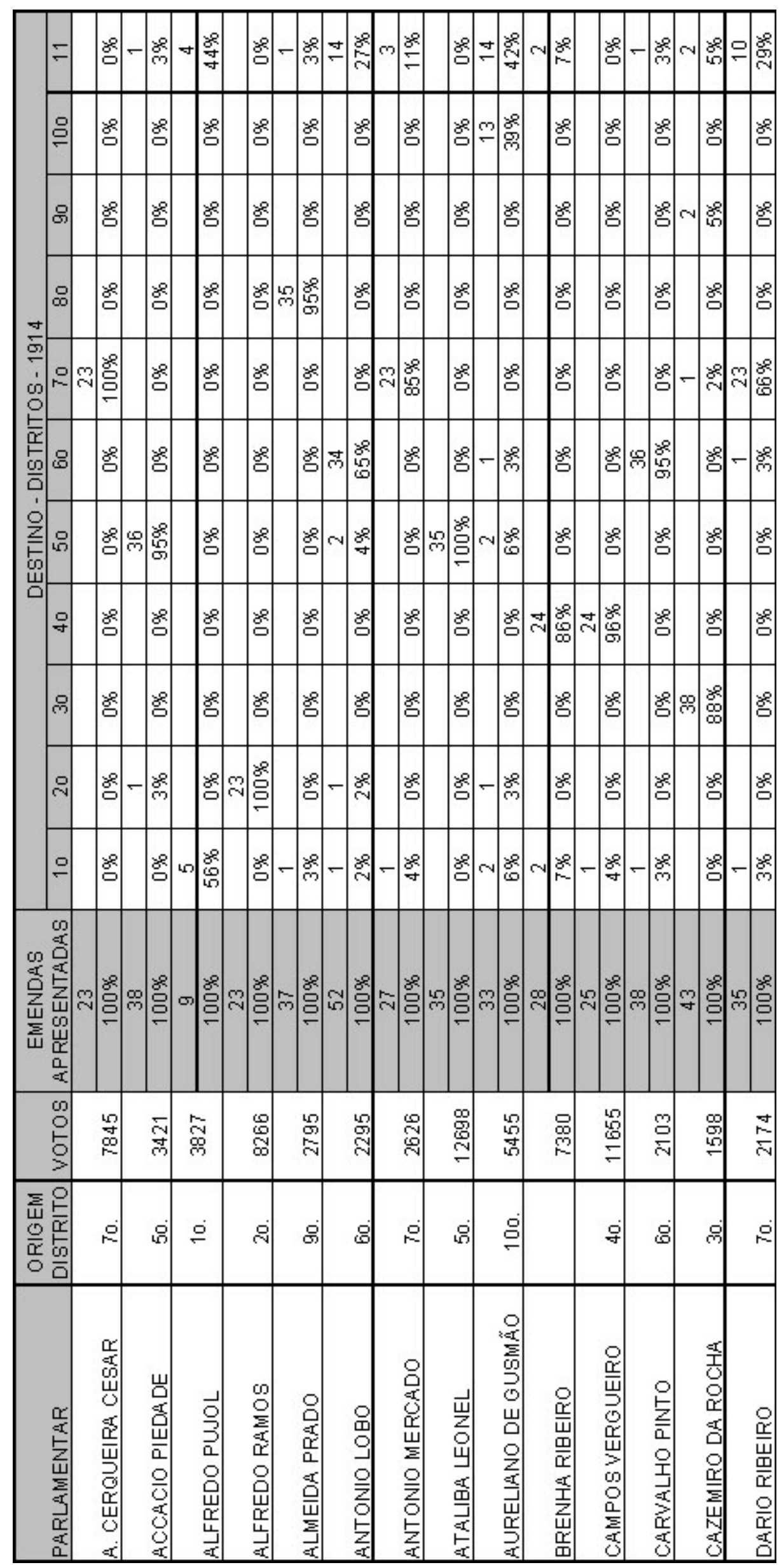




\begin{tabular}{|c|c|c|c|c|c|c|c|c|c|c|c|c|c|c|c|c|}
\hline$m$ & $m$ & \% & . & $-\infty$ & $m \frac{8}{\square}$ & $m$ & 8 & 可 & क्व & 웜 & 咛 & $m$ 舀 & $\sim$ & \% & 웜 & 움 \\
\hline 80 & & 。 & 움 & 㝵 & 움 & & 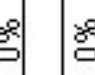 & ? & 웜 & 임 & 욤 & 8 & & 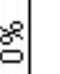 & 옴 & 。 \\
\hline 吕 & - & 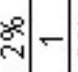 & 8 & 웜 & 。 & & $8=$ & 8 & 园 & 包 & $=8$ & 8 & & 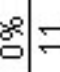 & $\frac{8}{5}$ & $\stackrel{8}{\circ}$ \\
\hline 8 & & 。 & 8 & 8 & 8 & 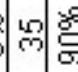 & ? & 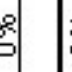 & 8 & 8 & 8 & 8 & m & \% & 웜 & $\stackrel{8}{6}$ \\
\hline 8 & & 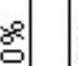 & 总 & 8 & 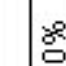 & 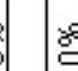 & 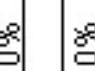 & 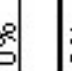 & 8 & 의 & హீ & 8 & & 8 & 8 & 皃 \\
\hline
\end{tabular}

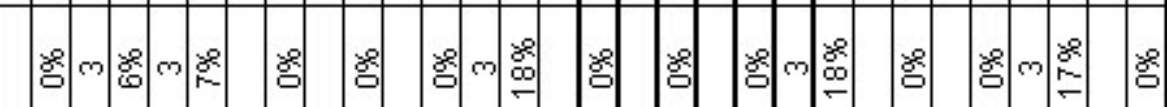

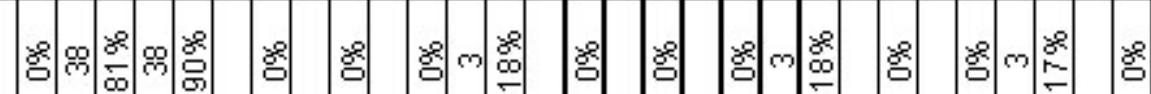

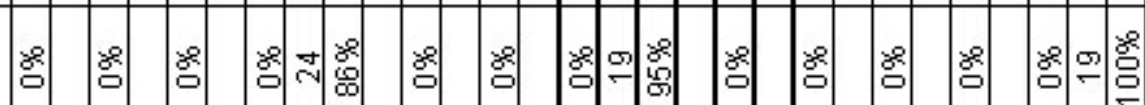

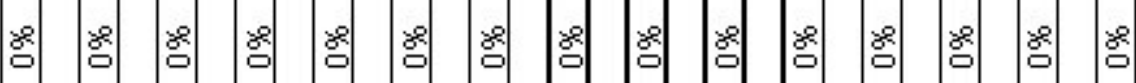

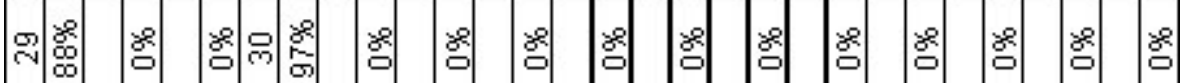

-

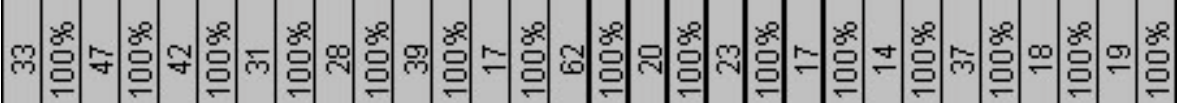

\begin{tabular}{|c|c|c|c|c|c|c|c|c|c|c|c|c|c|c|}
\hline 志 & $\stackrel{\mathrm{m}}{\mathrm{S}}$ & $\begin{array}{l}\text { बे } \\
\mathrm{m}\end{array}$ & 司 & $\begin{array}{l}0 \\
0 \\
0\end{array}$ & 品 & $\sqrt{0}$ & 웡 & $\stackrel{9}{9}$ & 氮 & $\begin{array}{l}0 \\
0\end{array}$ & 怘 & ले & $\begin{array}{l}m \\
\mathrm{~m}\end{array}$ & 号 \\
\hline
\end{tabular}

\begin{tabular}{|c|c|c|c|c|c|c|c|c|c|c|c|c|c|c|}
\hline$g$ & 9 & 9 & id & 守 & $:$ & की & 의 & 额 & $\mathrm{g}$ & : & 0 & $\dot{\infty}$ & 家 & g \\
\hline 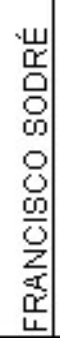 & 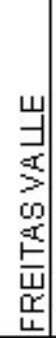 & 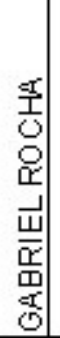 & 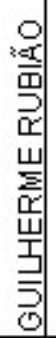 & 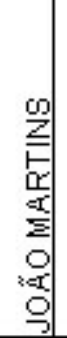 & 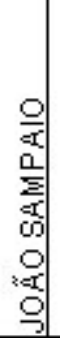 & 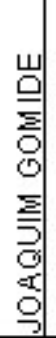 & 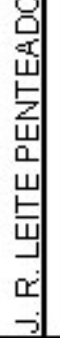 & 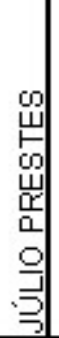 & 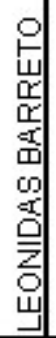 & 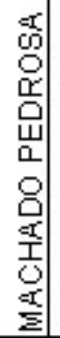 & 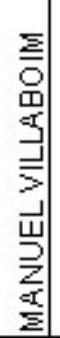 & 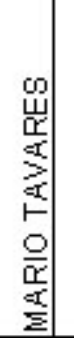 & 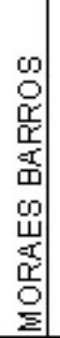 & 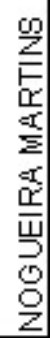 \\
\hline
\end{tabular}




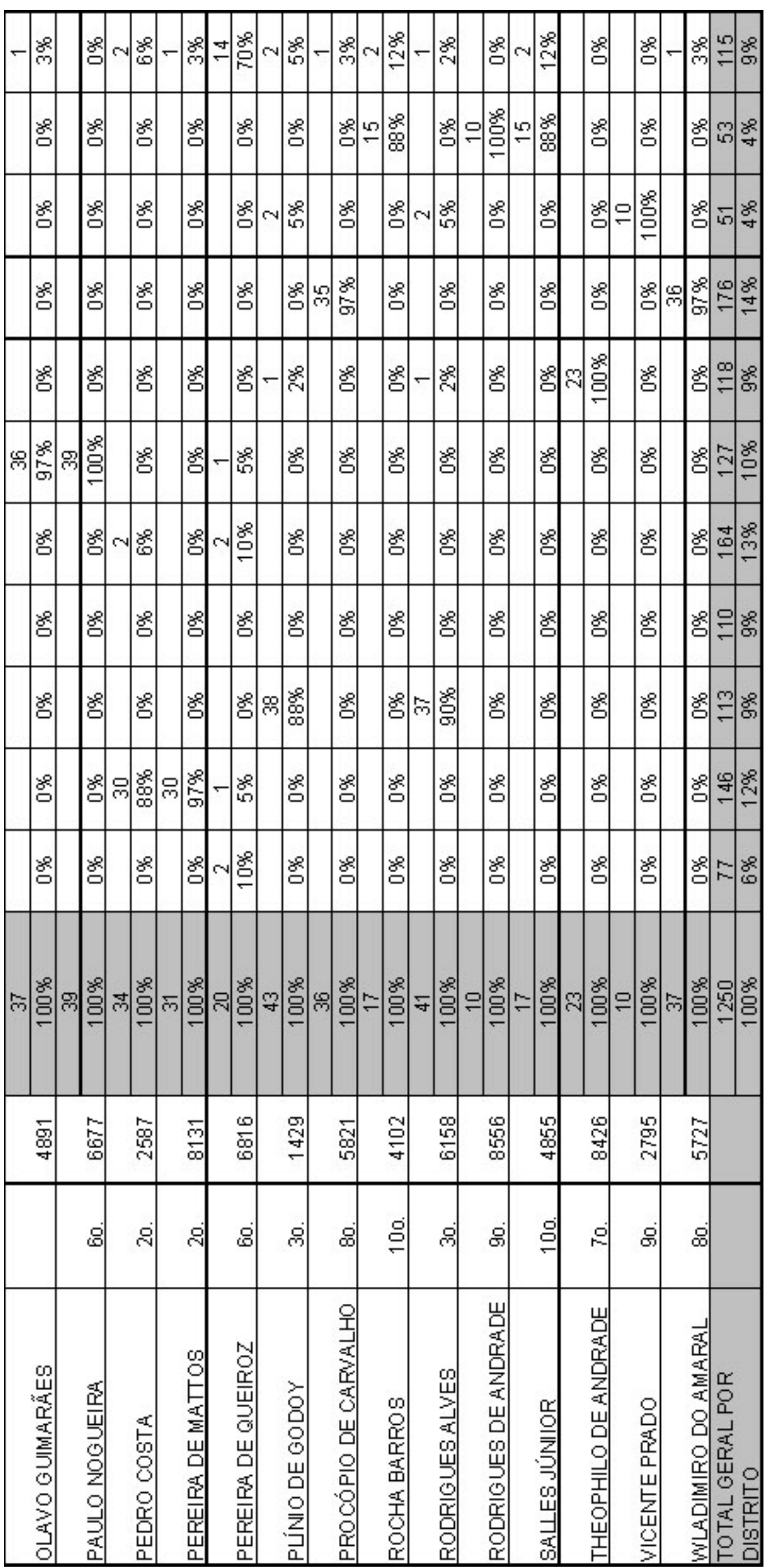




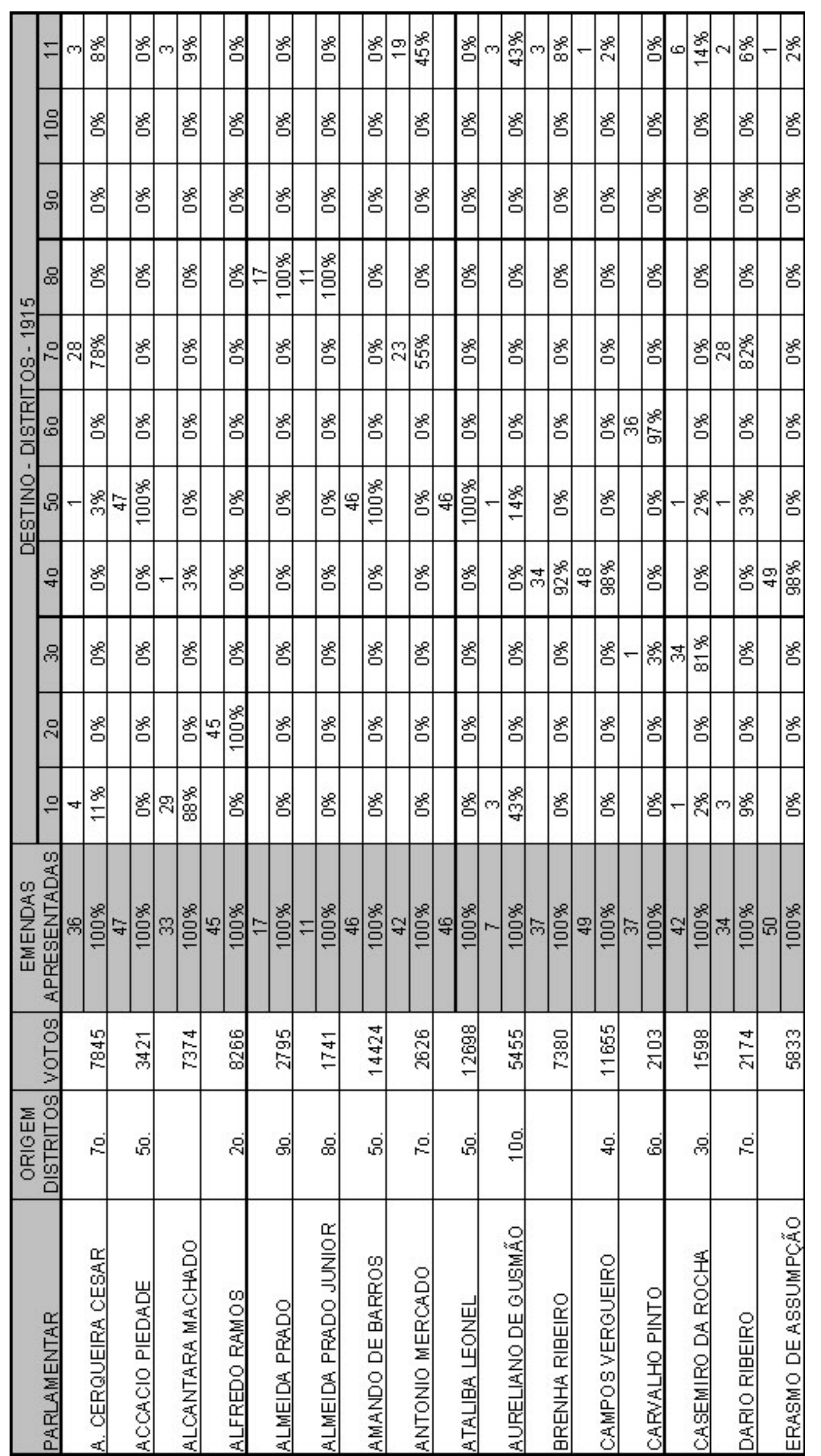


$m$ m

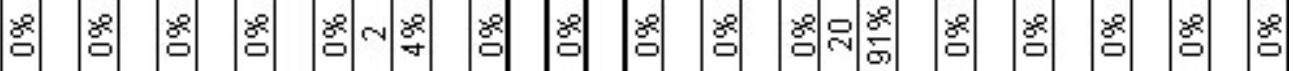

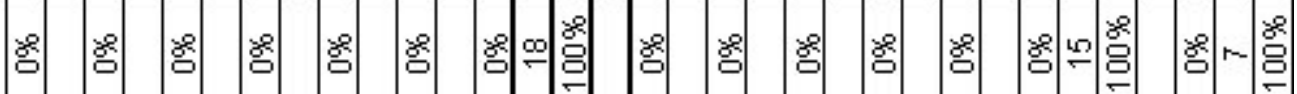

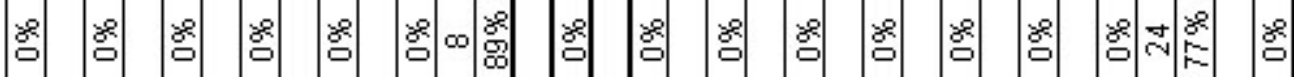

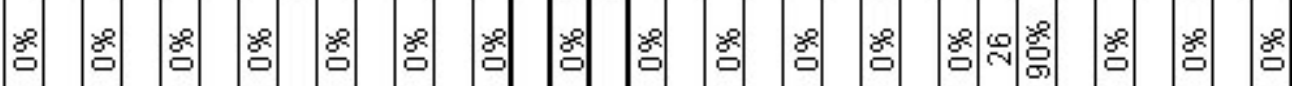

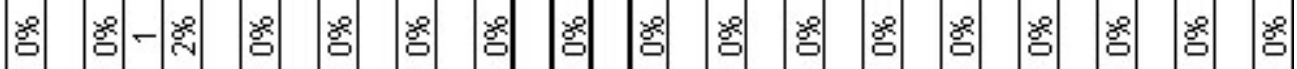

- 斿

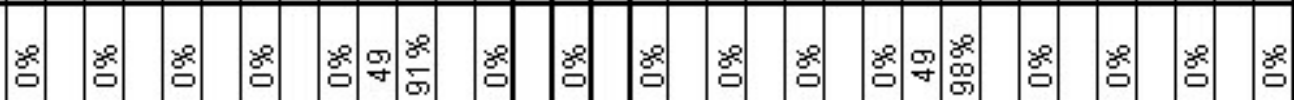

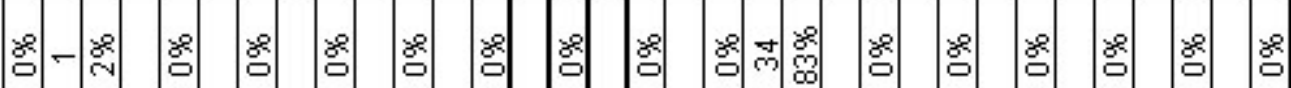

登

m-

$m$ 음

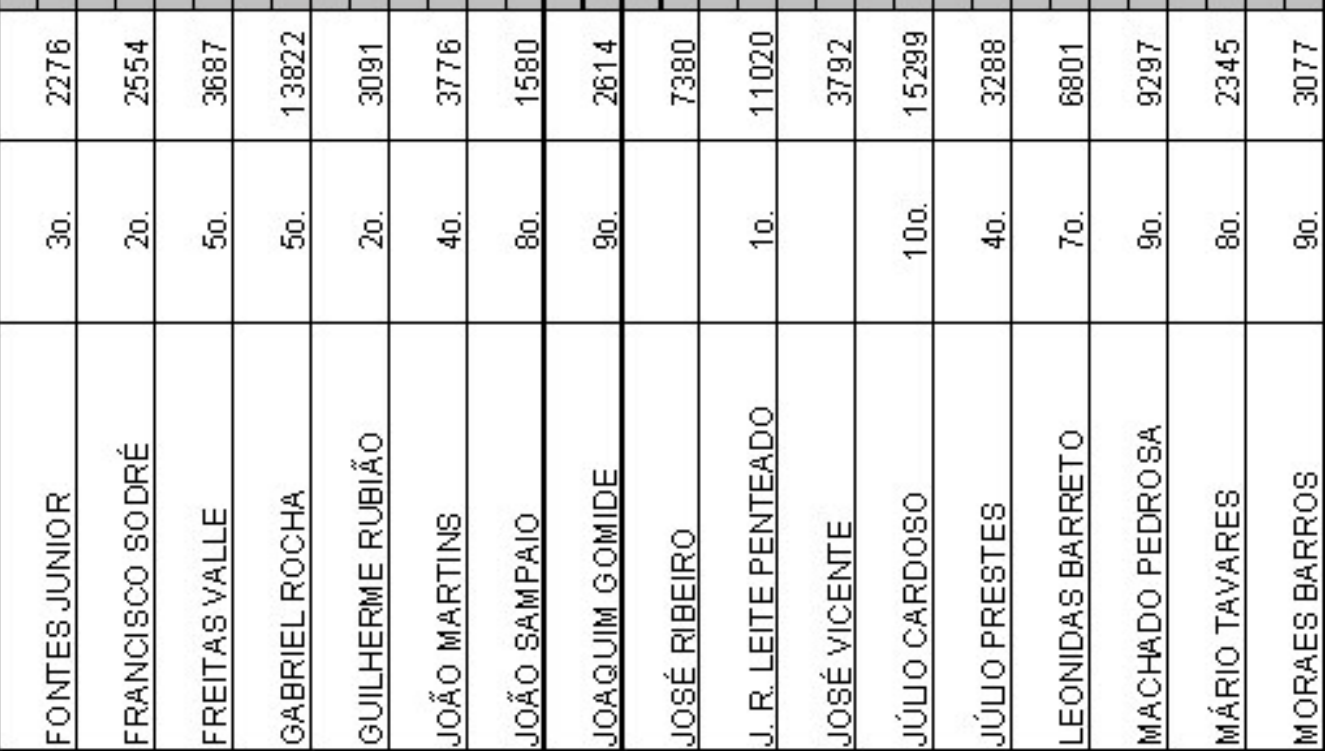


m

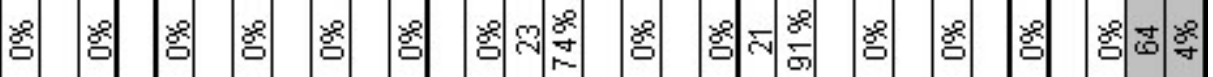

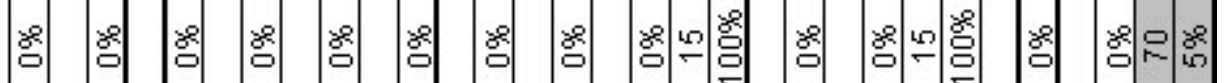

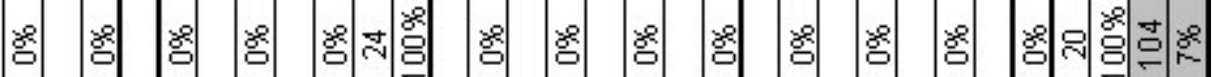

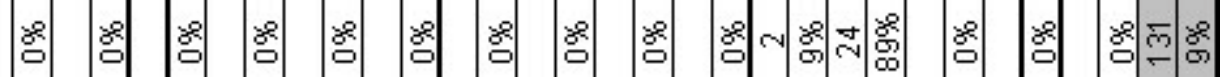

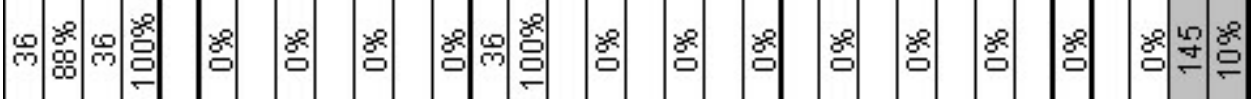

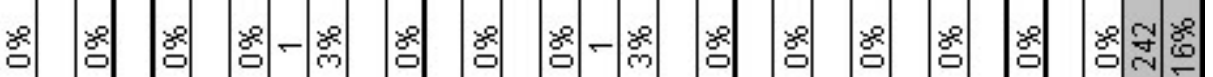

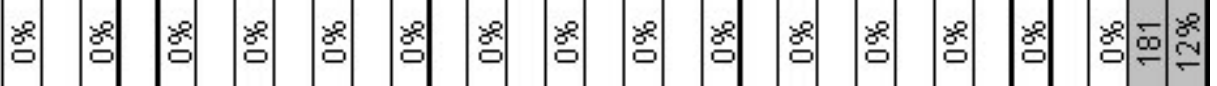

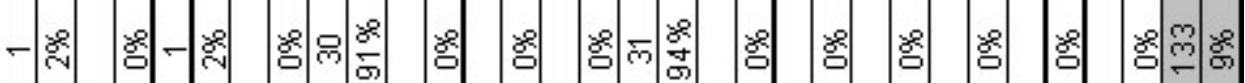

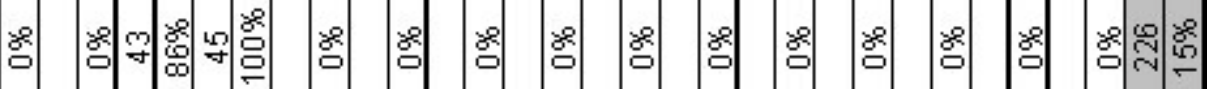

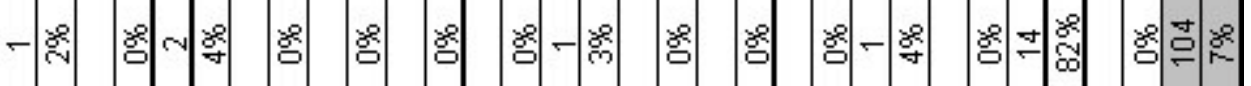

-

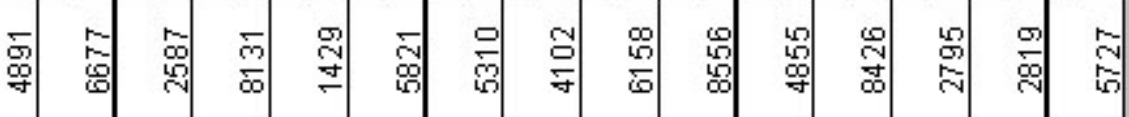

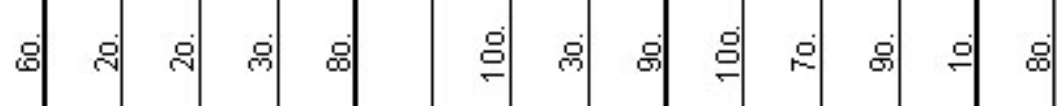

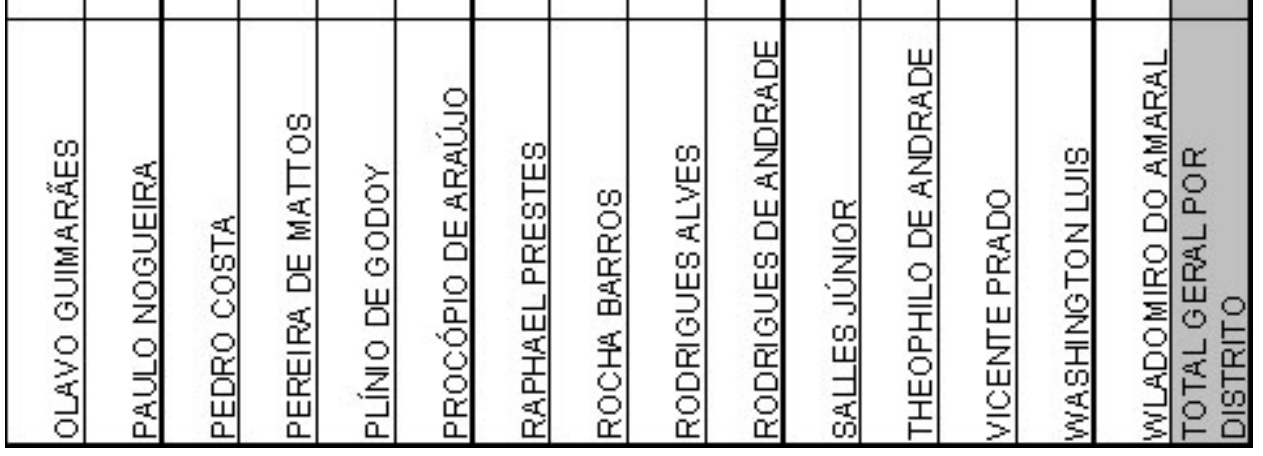




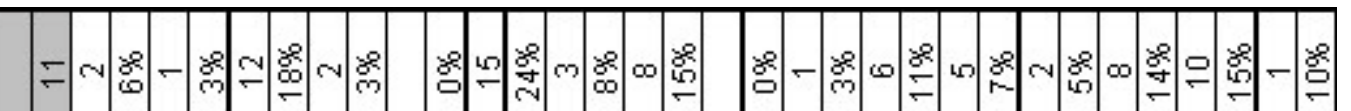

ㅇํㅇ

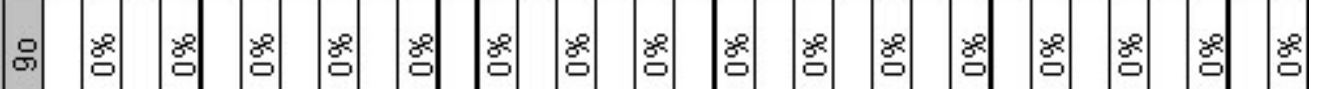

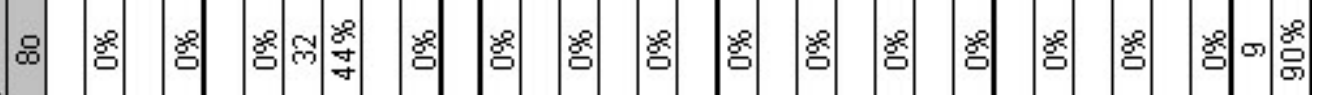

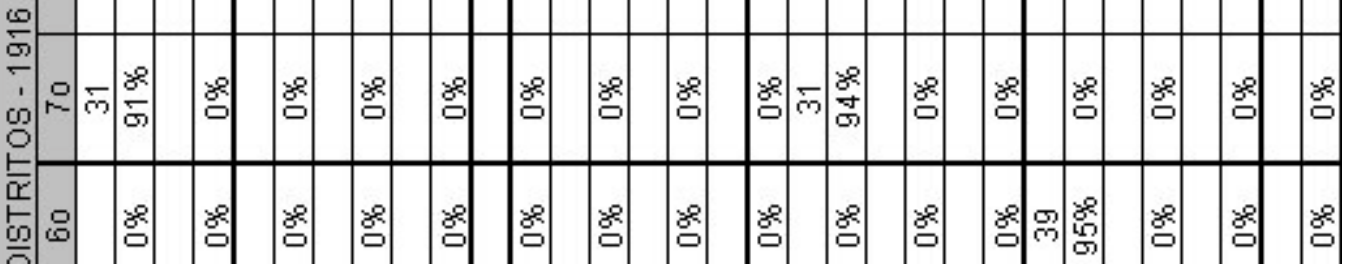
言舟 㟧

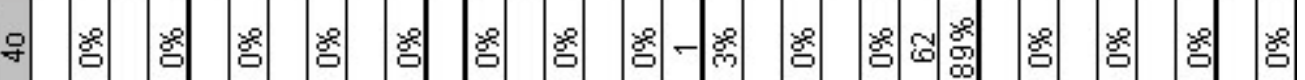

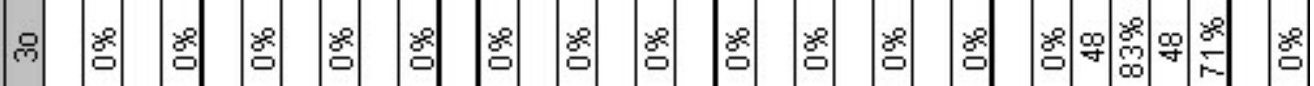

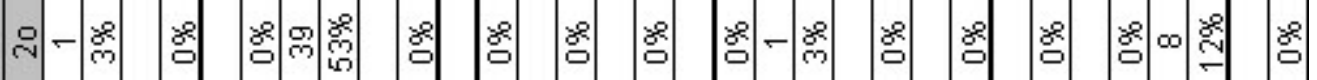

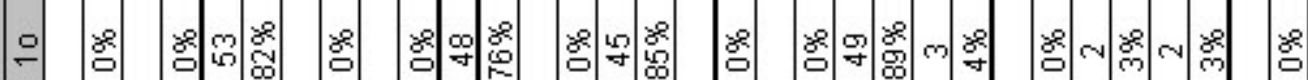

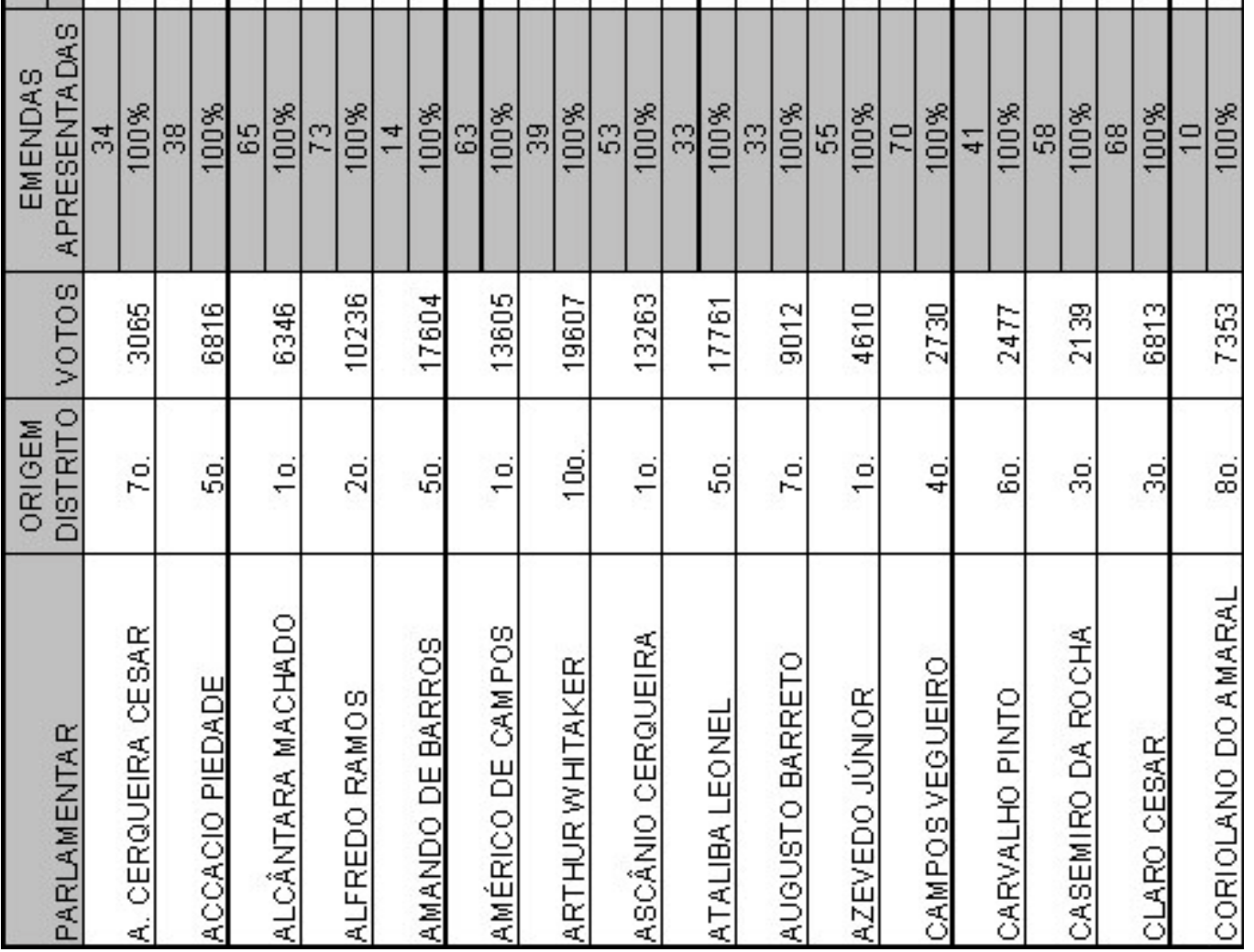




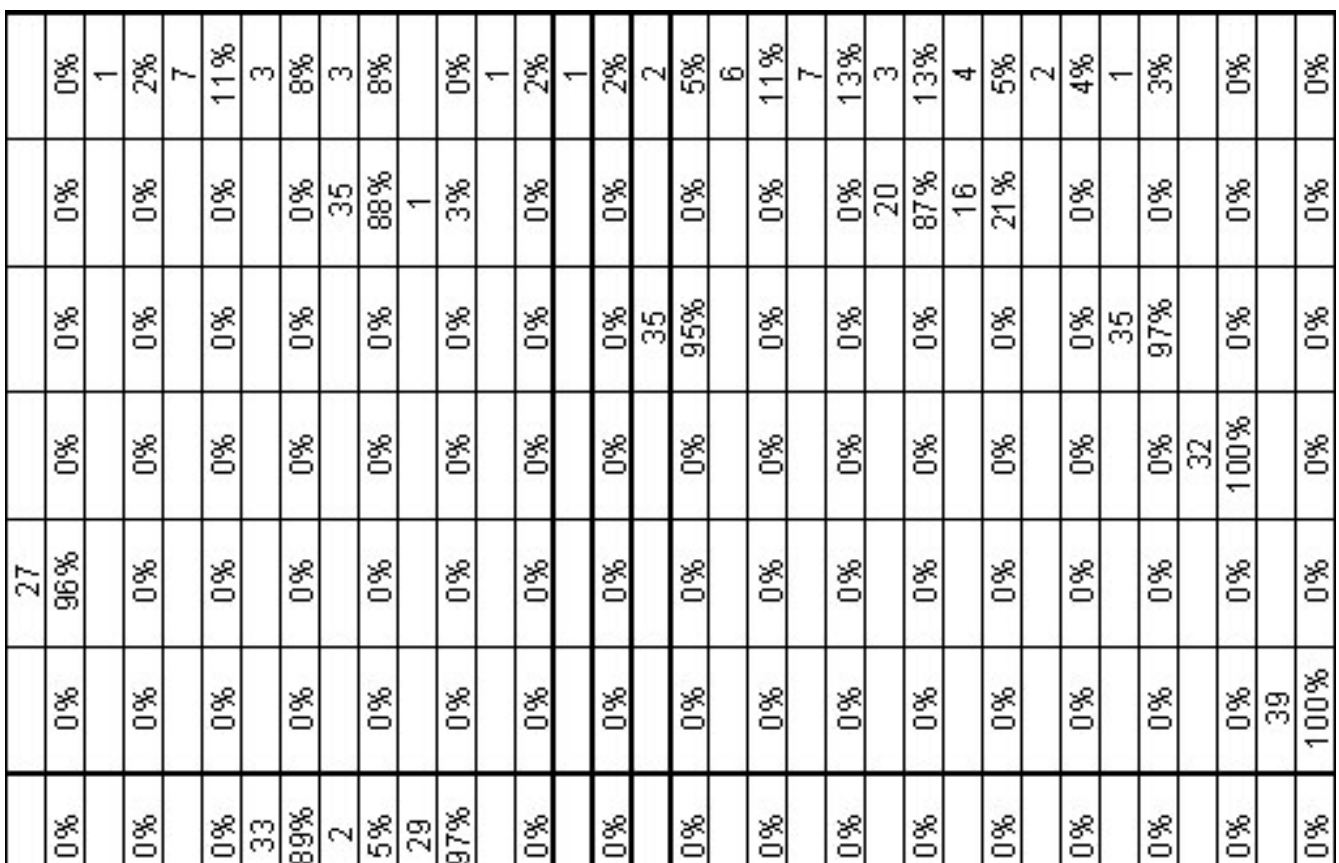

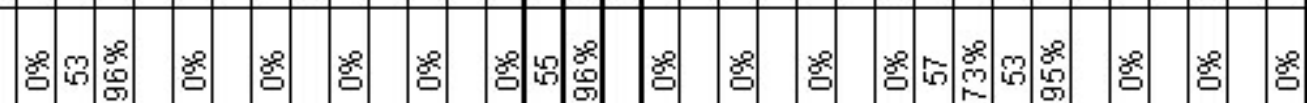

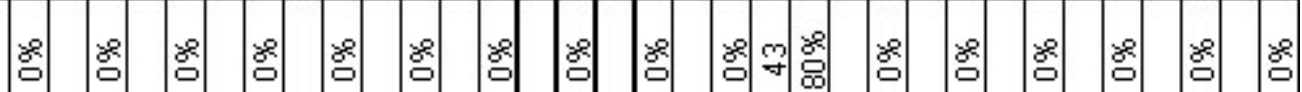

- 年

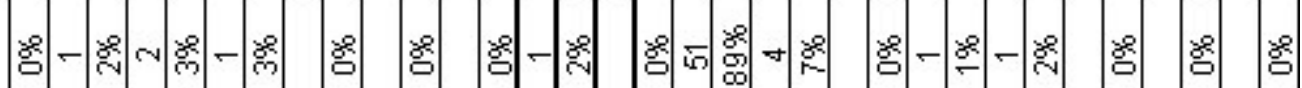
象象

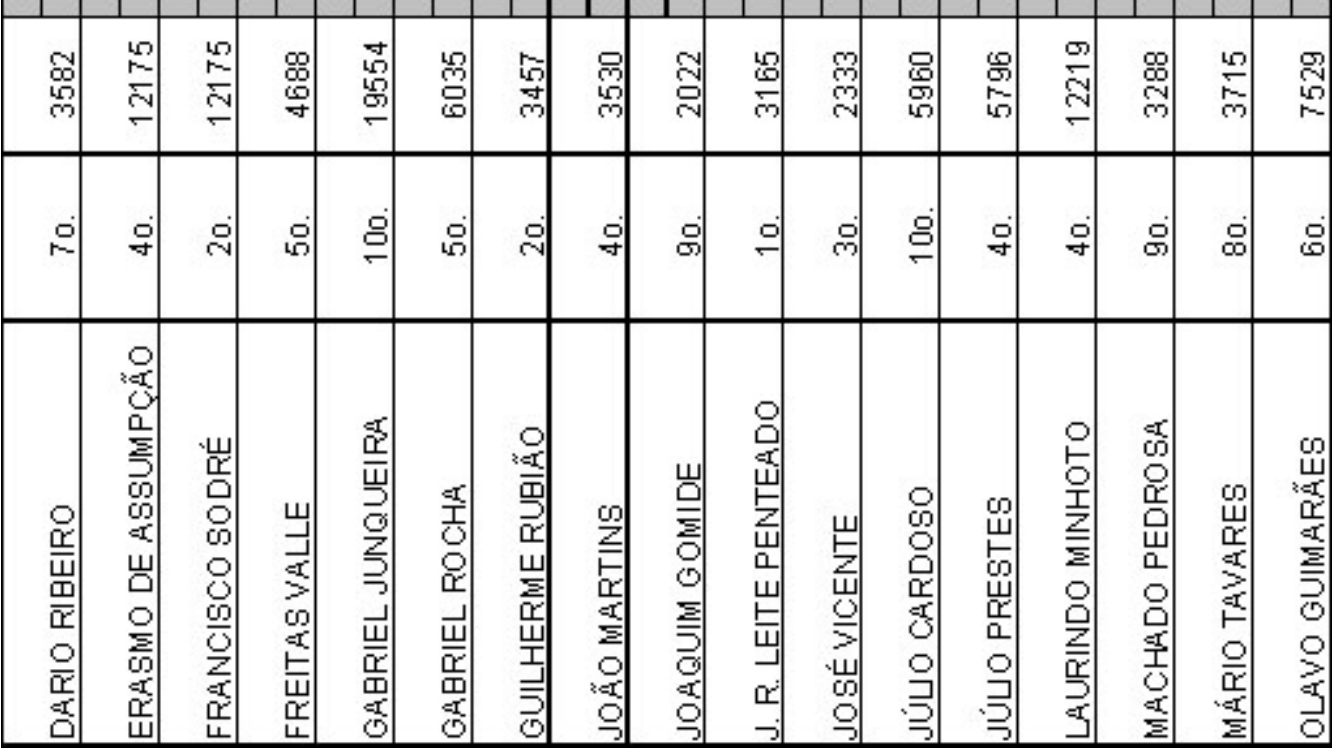




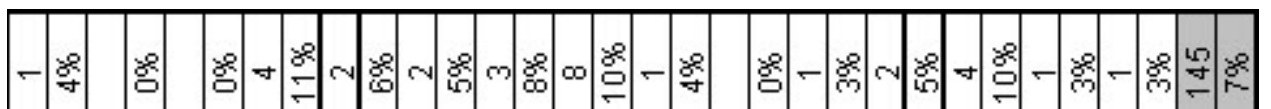

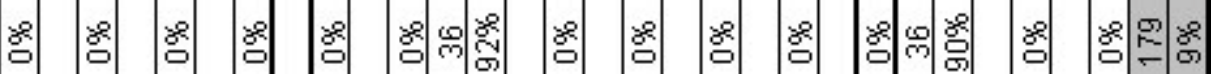

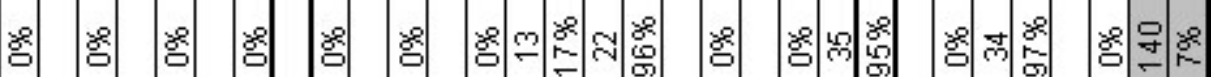

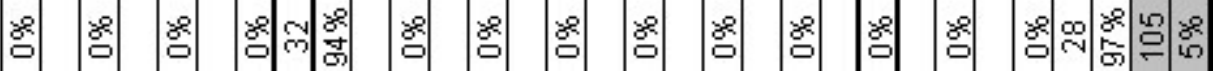

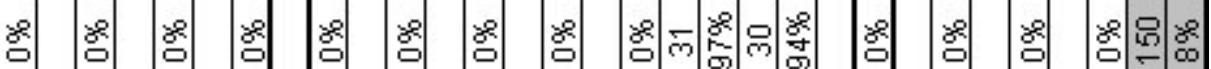

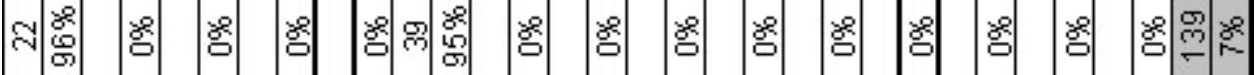

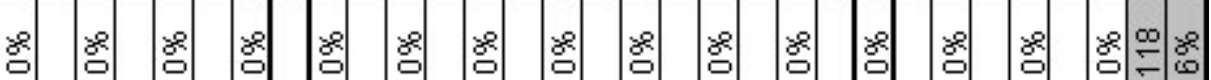

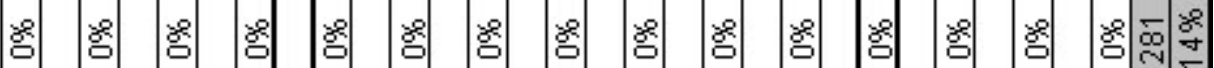

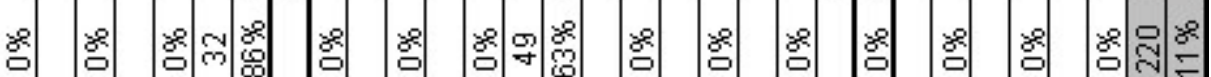

舟要

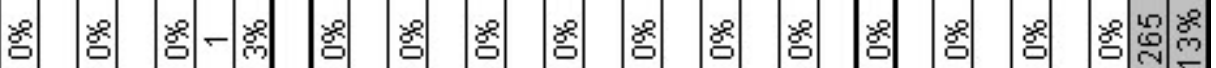

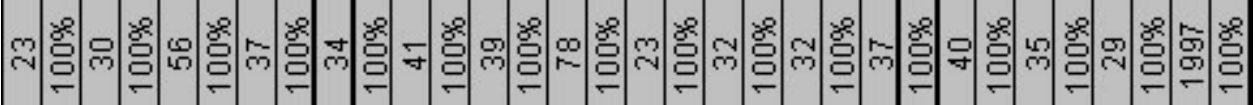

됭

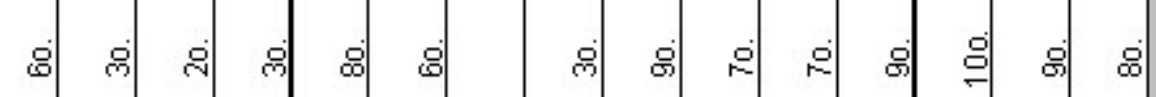

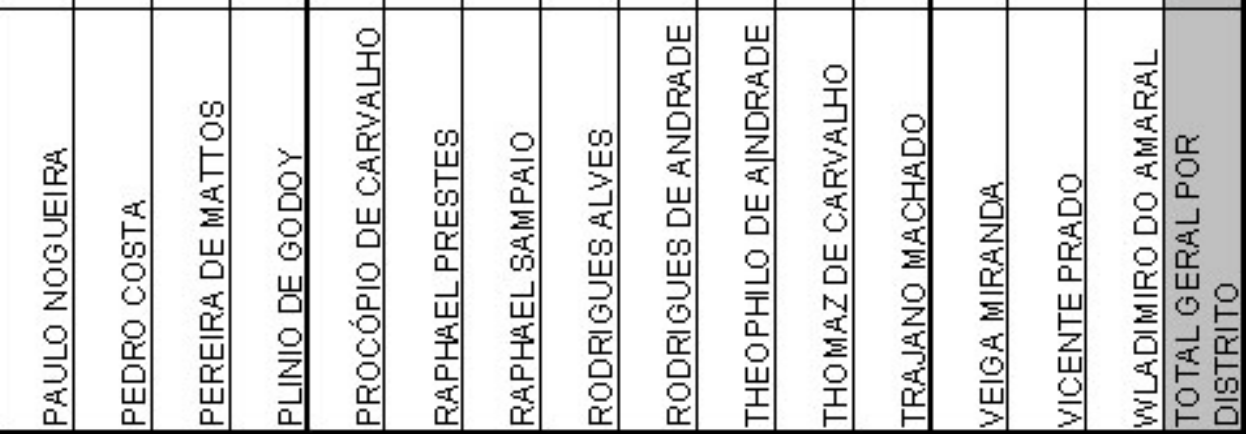




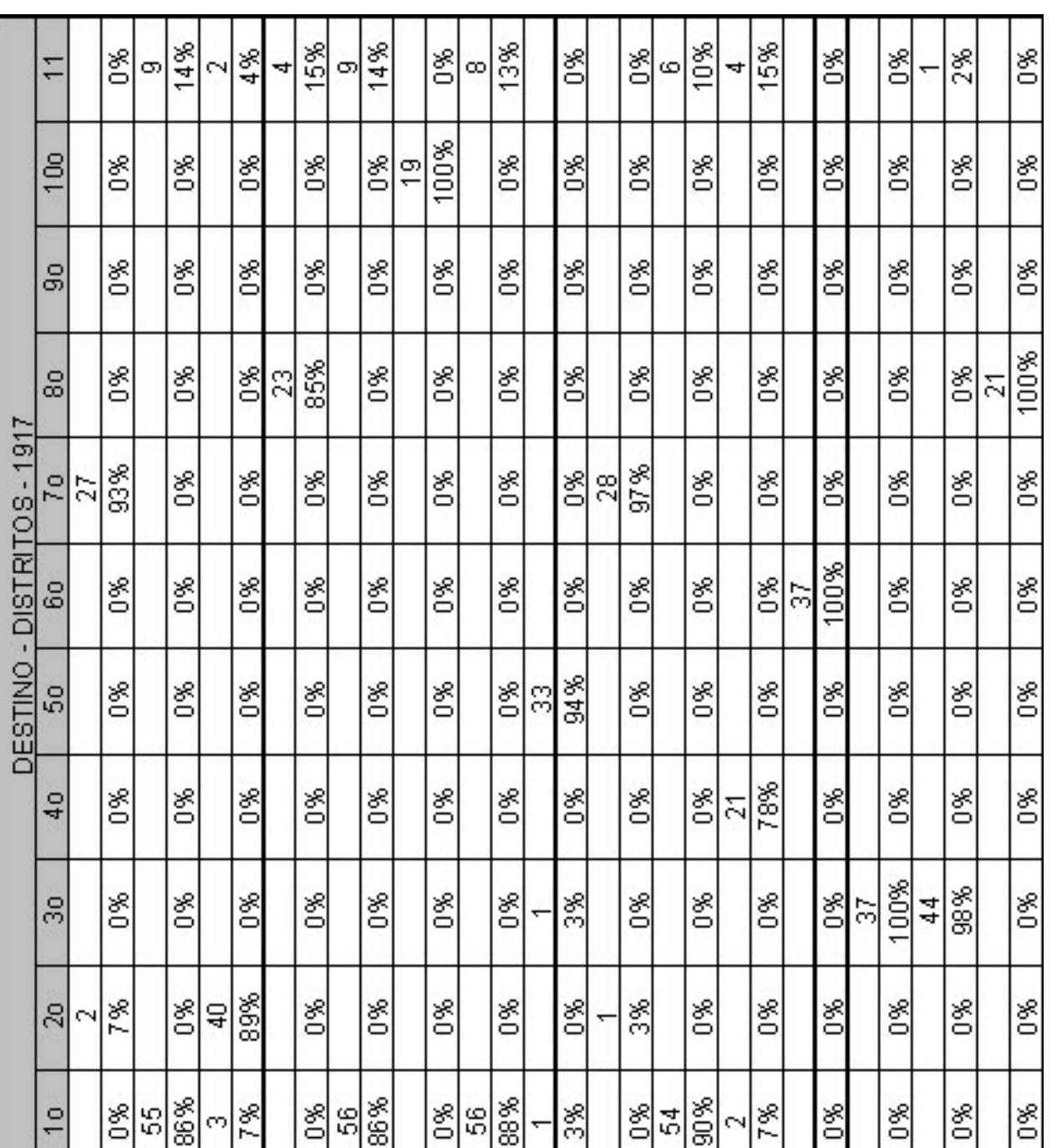

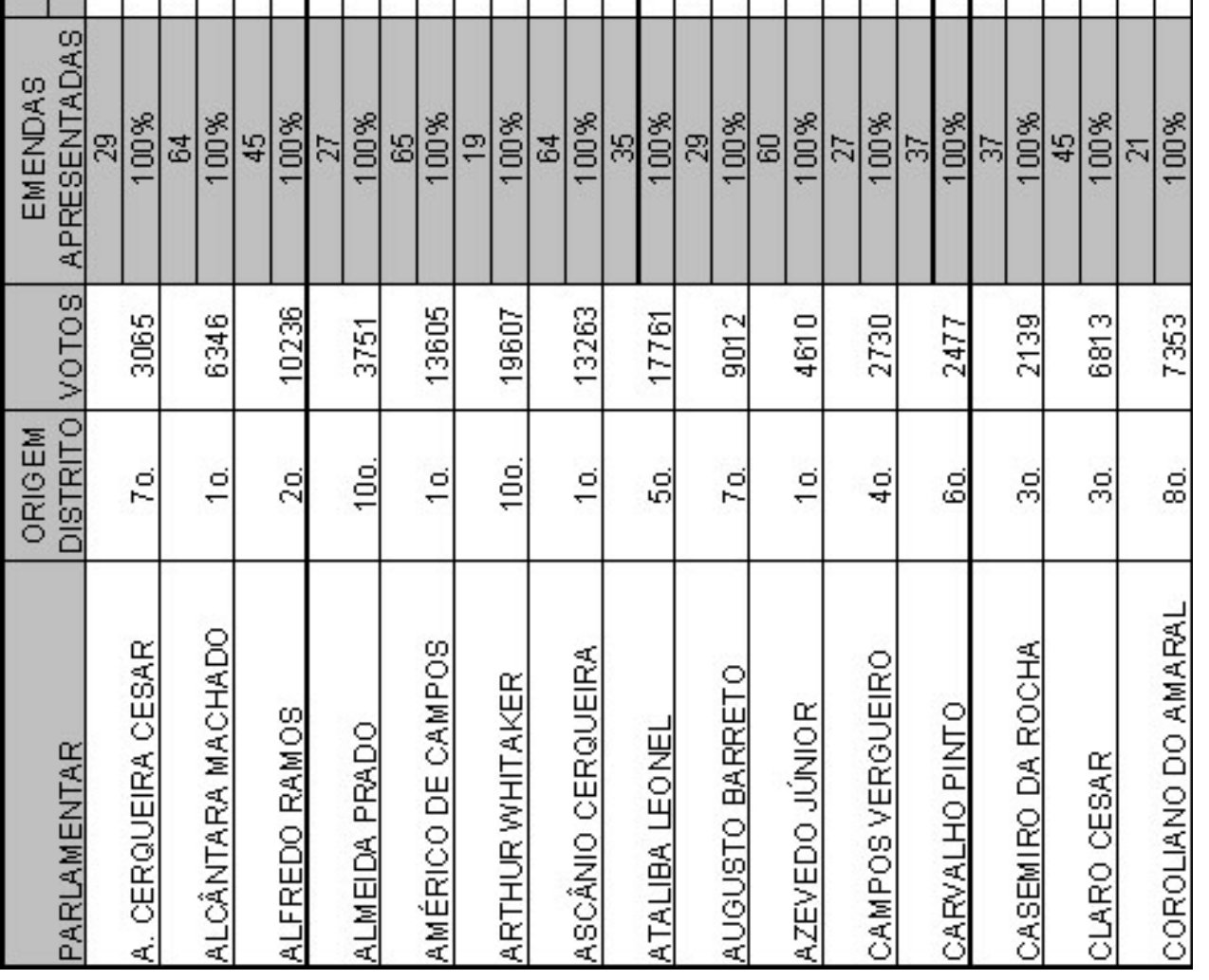




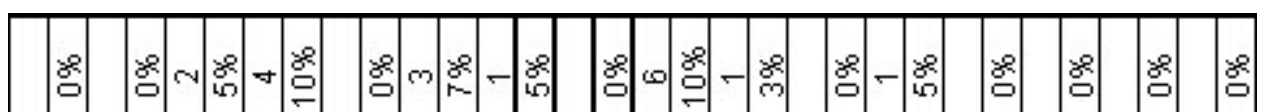

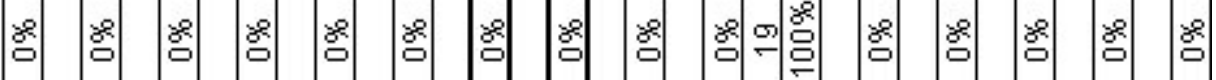

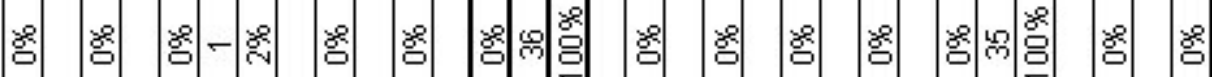

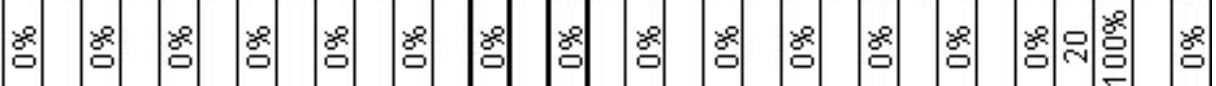

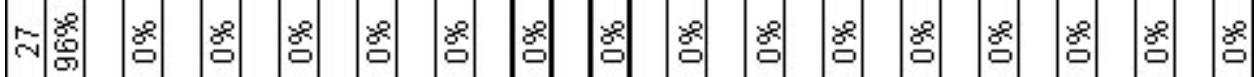

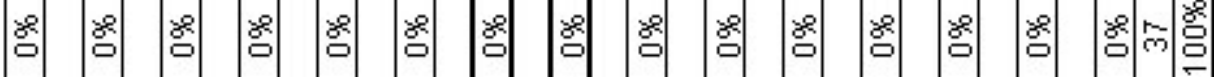

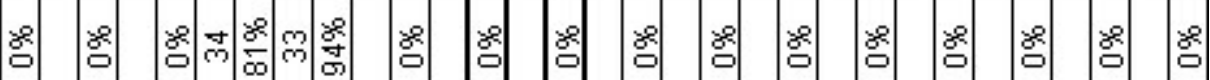

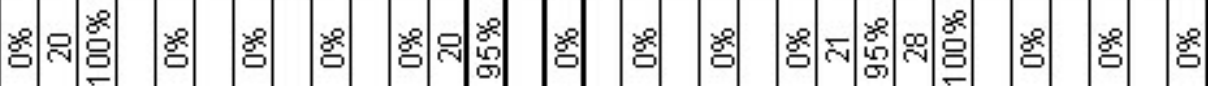
冱

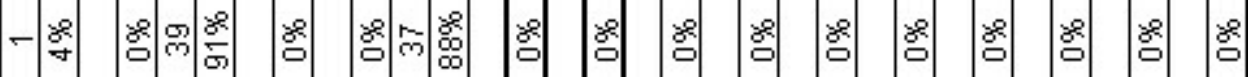

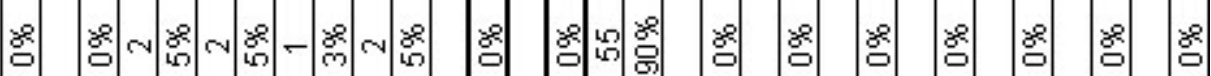

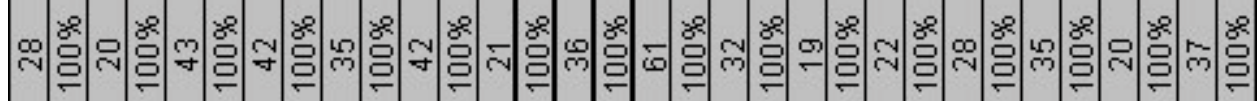

\begin{tabular}{|c|c|c|c|c|c|c|c|c|c|c|c|c|c|c|c|}
\hline $\begin{array}{l}9 \\
0 \\
1 \\
5\end{array}$ & $\stackrel{n}{-\infty}$ & $\stackrel{n}{=}$ & $\begin{array}{l}9 \\
9 \\
9 \\
\text { o }\end{array}$ & $\frac{10}{9}$ & 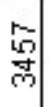 & 甪 & 쾽 & $\frac{4}{0}$ & 9 & $\begin{array}{l}\text { 怘 } \\
\text { 员 }\end{array}$ & $\begin{array}{l}9 \\
9 \\
0\end{array}$ & $\stackrel{\sigma}{\mathrm{v}}$ & $\begin{array}{l}\infty \\
\infty \\
\text { లె }\end{array}$ & $\frac{n}{m}$ & 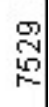 \\
\hline 9 & 号 & 品 & 㖞 & 只 & 이 & 路 & 이 & 의 & 9 & 跑 & 号 & 号 & 踝 & 9 & 이 \\
\hline 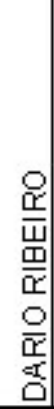 & 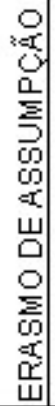 & 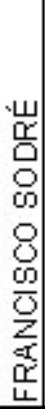 & 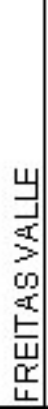 & 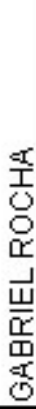 & 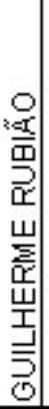 & 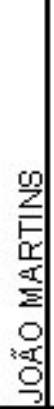 & 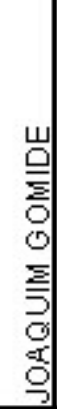 & 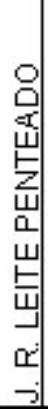 & 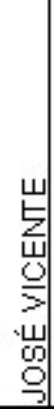 & 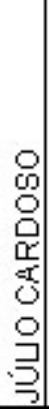 & 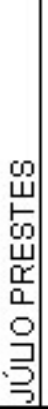 & 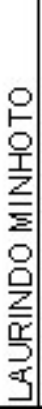 & 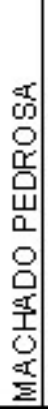 & 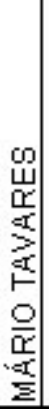 & 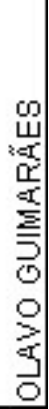 \\
\hline
\end{tabular}




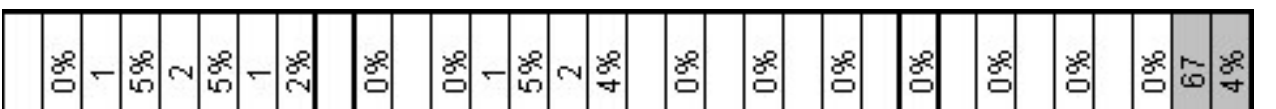

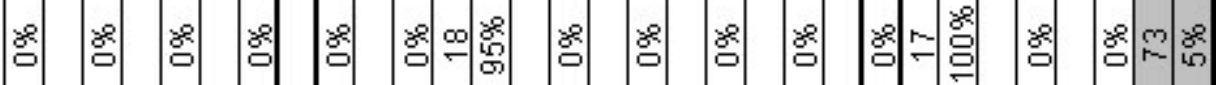

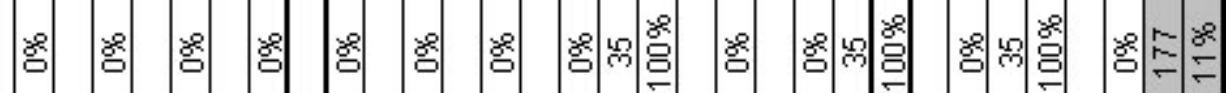

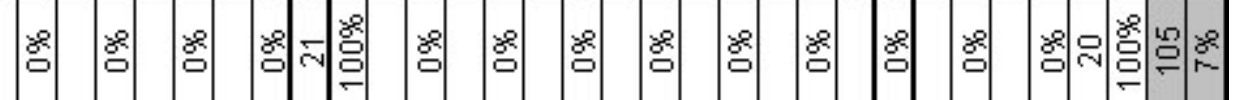

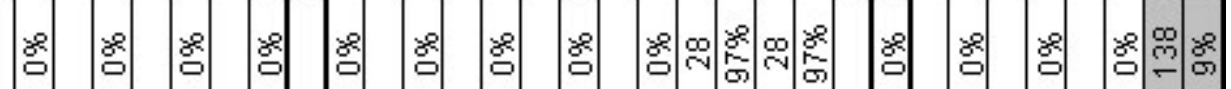

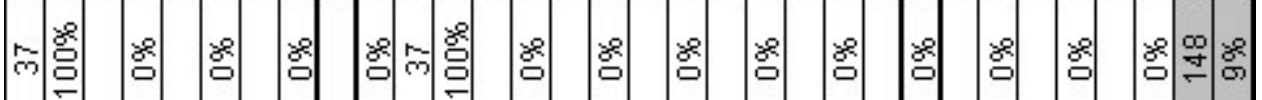

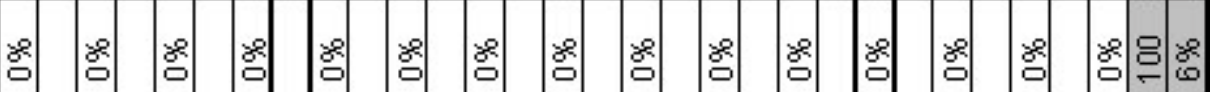

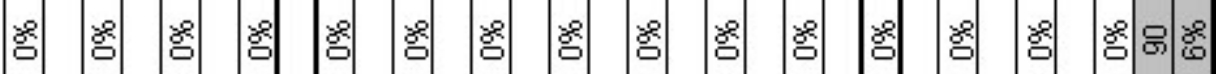

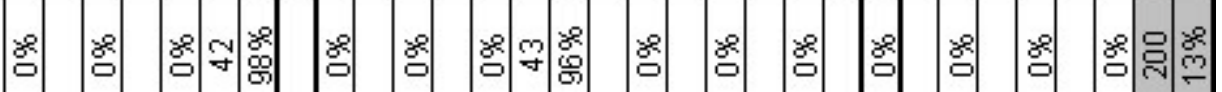

임윰

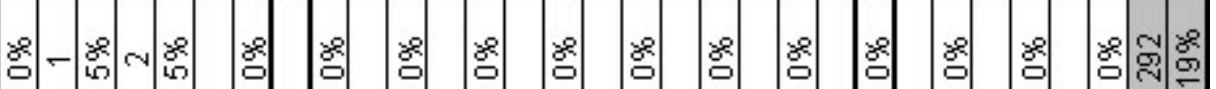

m 家家

\begin{tabular}{|c|c|c|c|c|c|c|c|c|c|c|c|c|c|c|c|}
\hline$\stackrel{ }{\frac{0}{D}}$ & $\stackrel{5}{m}$ & $\begin{array}{l}5 \\
5 \\
5\end{array}$ & $\begin{array}{l}\mathrm{N} \\
\mathrm{9}\end{array}$ & m & $\stackrel{\mathrm{g}}{\mathrm{g}}$ & $\begin{array}{l}10 \\
0 \\
0\end{array}$ & 吉 & $\stackrel{9}{6}$ & 㤐 & 寺 & $\begin{array}{l}m \\
\mathrm{~m}\end{array}$ & 象 & $\overline{\mathrm{n}}$ & 氙 & \\
\hline 잉 & 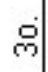 & 9 & 임 & 9 & 9 & & 이 & 路 & 9 & $r=$ & 9 & 号 & 영 & 9 & \\
\hline & 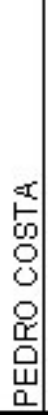 & 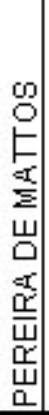 & 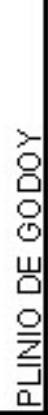 & 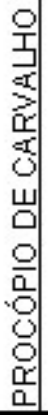 & 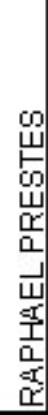 & 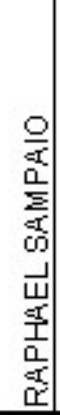 & 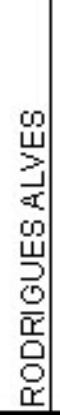 & 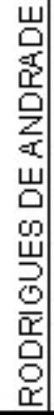 & 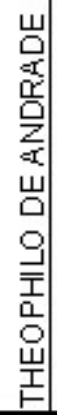 & 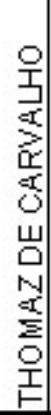 & 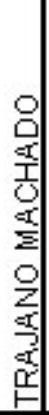 & 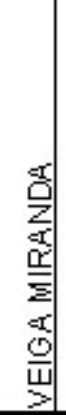 & 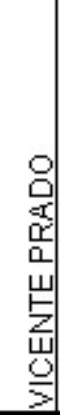 & 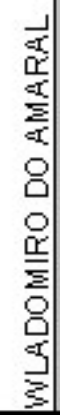 & 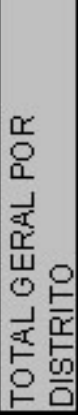 \\
\hline
\end{tabular}




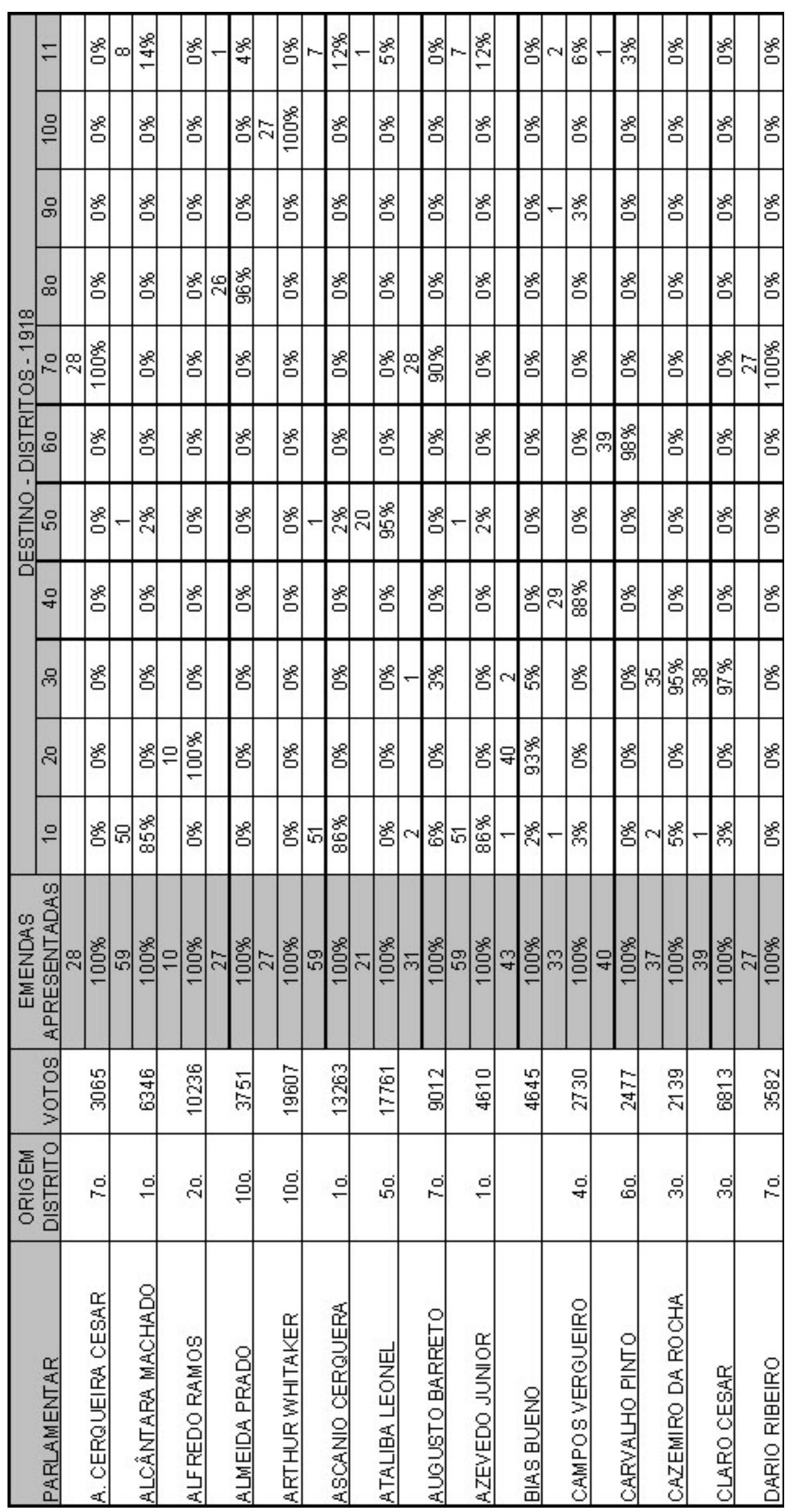




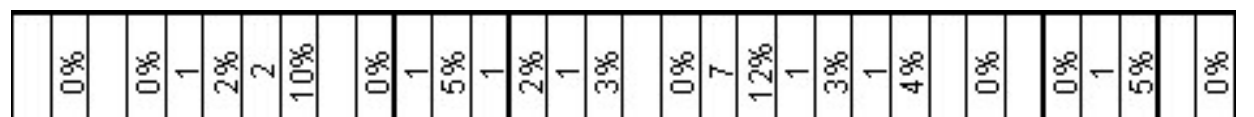

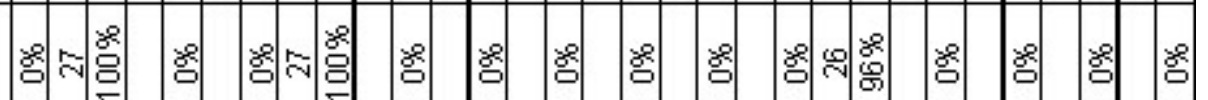

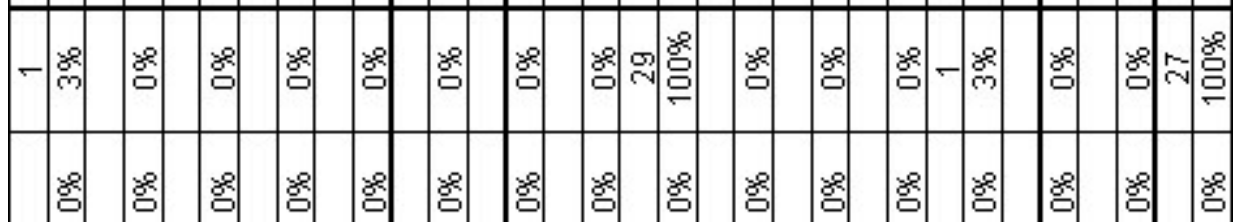

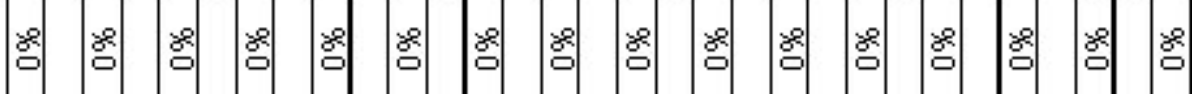

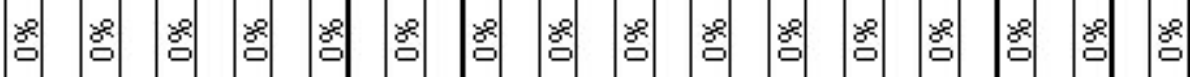

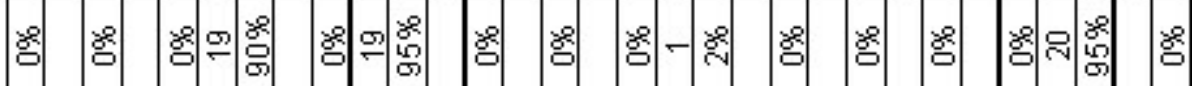
잉

象

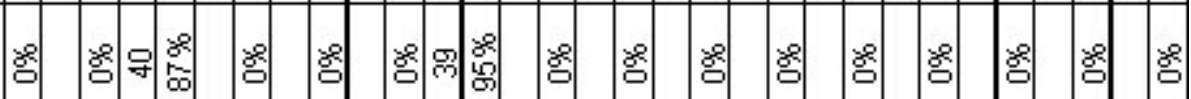

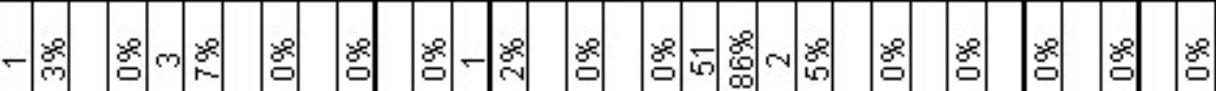

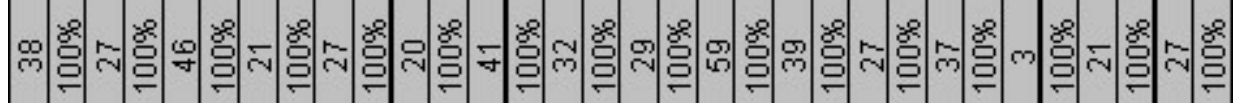

\begin{tabular}{|c|c|c|c|c|c|c|c|c|c|c|c|c|c|c|c|}
\hline 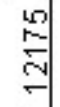 & 筞 & 照 & $\begin{array}{l}\text { 口. } \\
\text { ô } \\
\text { v }\end{array}$ & 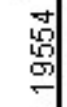 & 恕 & 氛 & 忿 & จิ & 恕 & ले & $\begin{array}{l}9 \\
\text { 号 }\end{array}$ & $\begin{array}{l}9 \\
\text { s. } \\
\text { 心 }\end{array}$ & 김 & 影 & 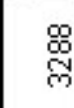 \\
\hline 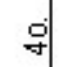 & & in & 昜 & 静 & 影 & 哓 & 影 & : & - & - & : & 肙 & 웜 & & 9 \\
\hline 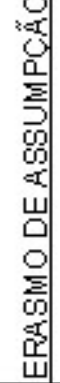 & 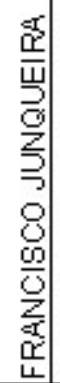 & 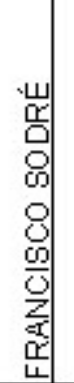 & 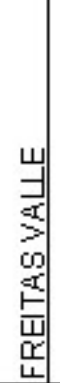 & 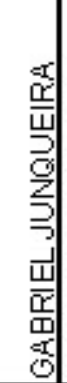 & 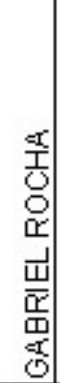 & 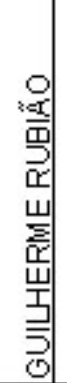 & 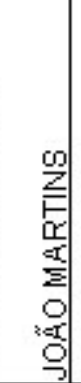 & 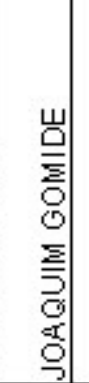 & 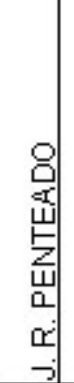 & 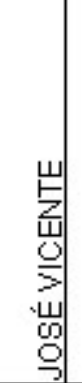 & $\begin{array}{l}9 \\
9 \\
9 \\
0 \\
0 \\
0 \\
0 \\
0 \\
3\end{array}$ & 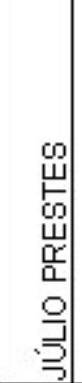 & 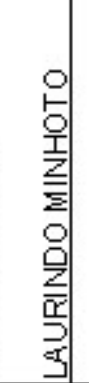 & 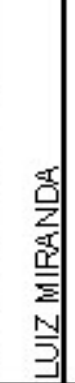 & 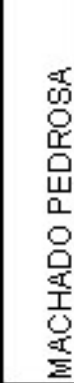 \\
\hline
\end{tabular}




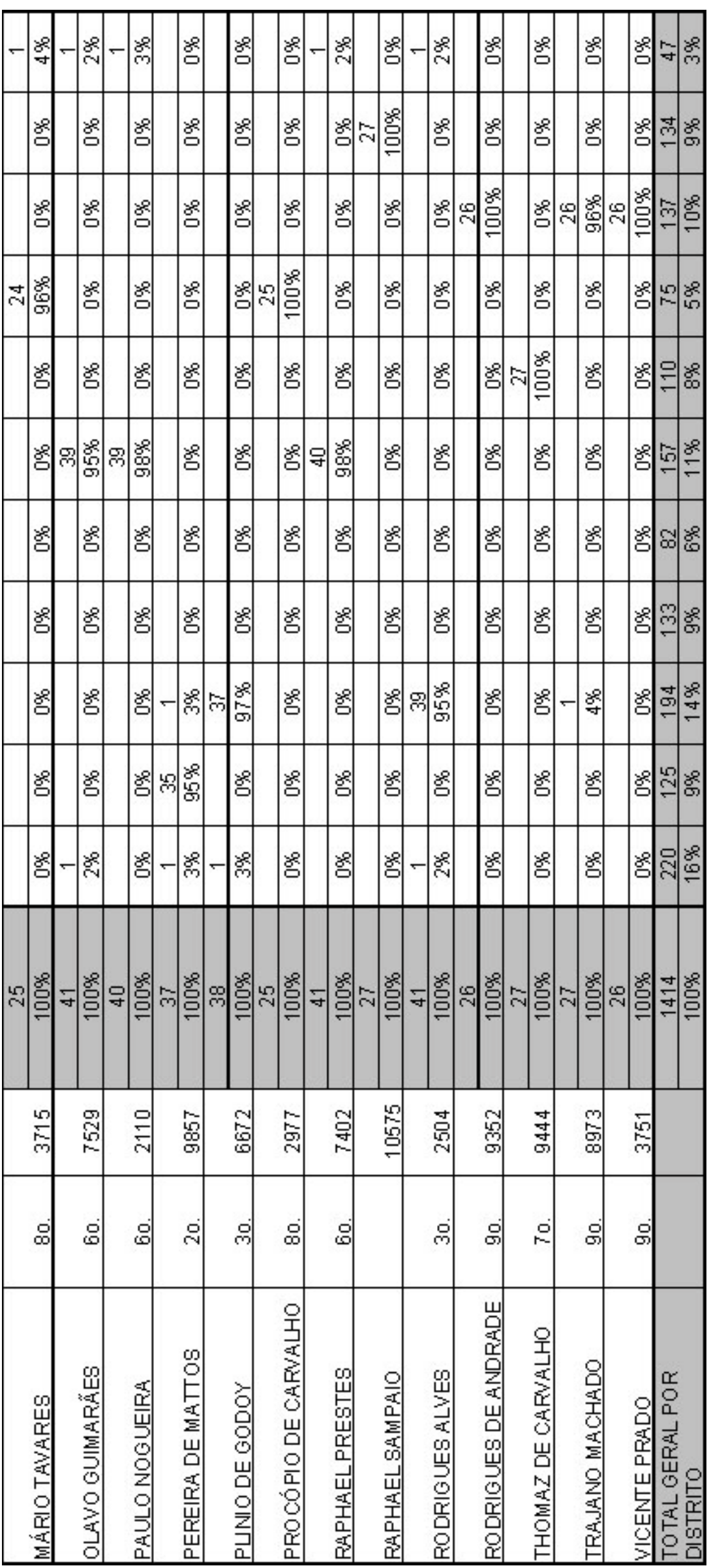




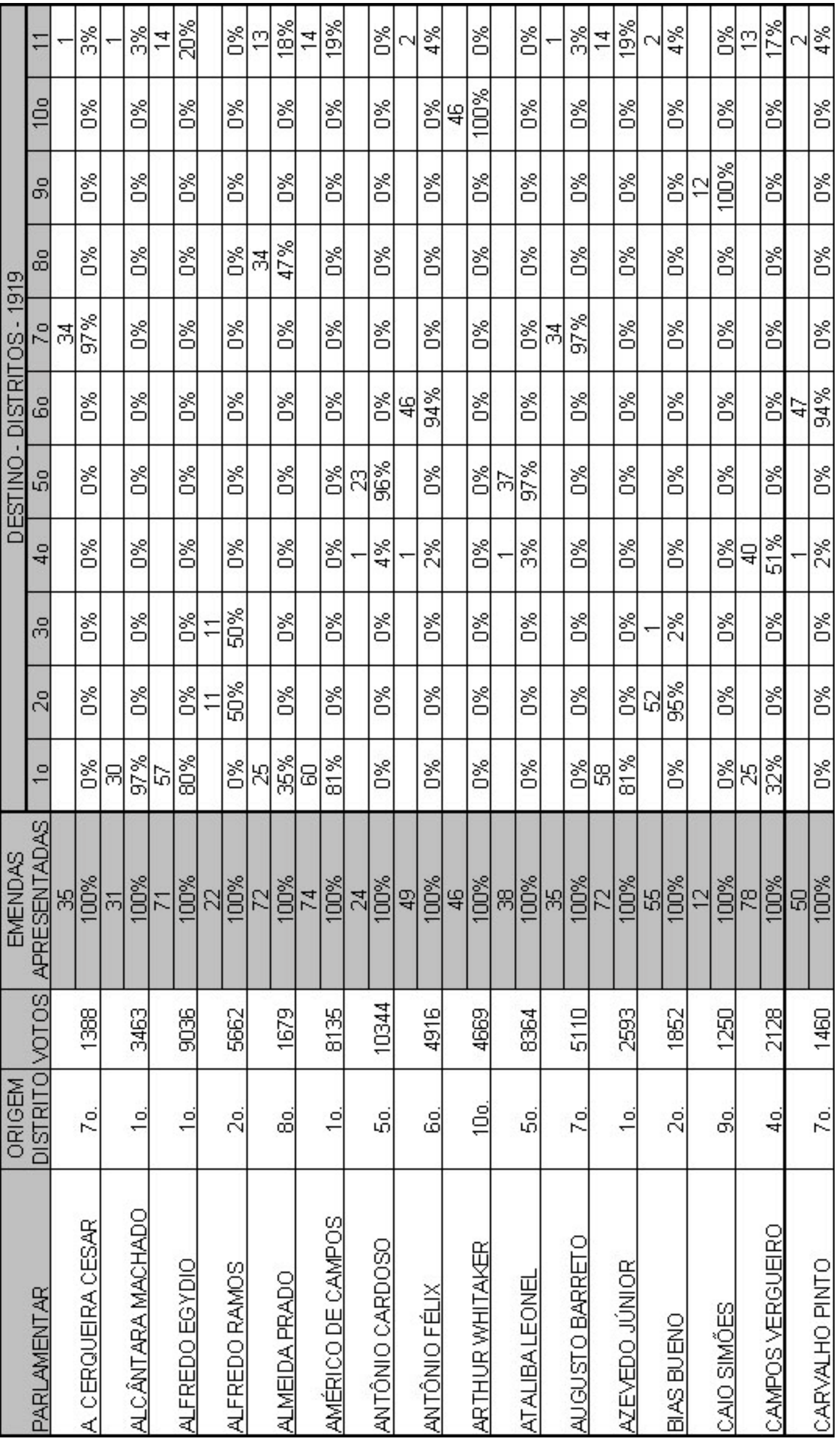




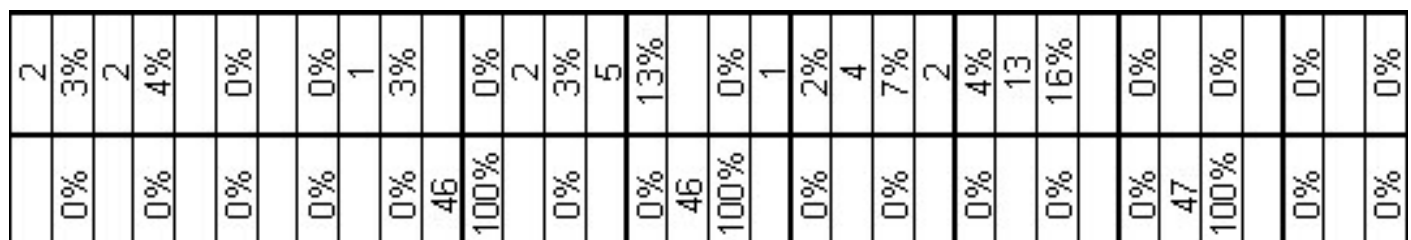

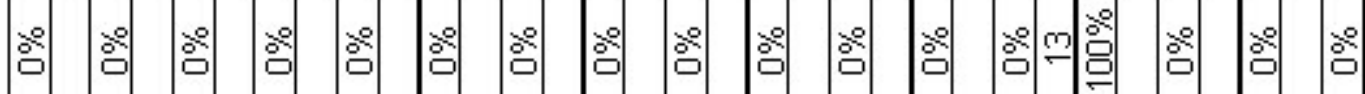

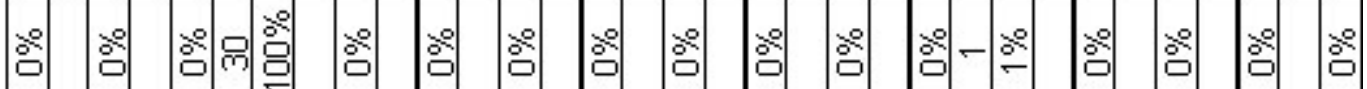
ஃ ஃ ㅇㅁㅁ ○

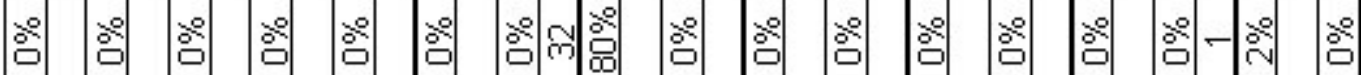

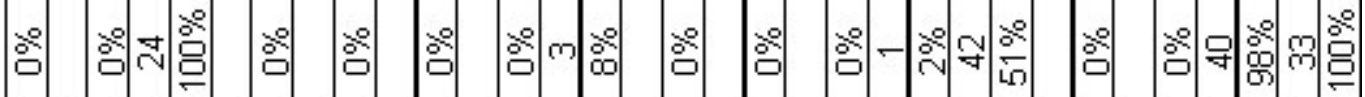

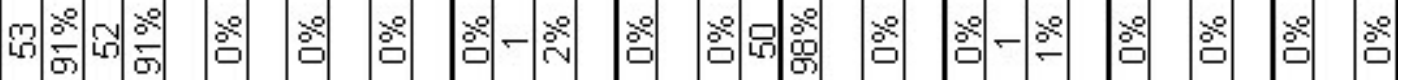

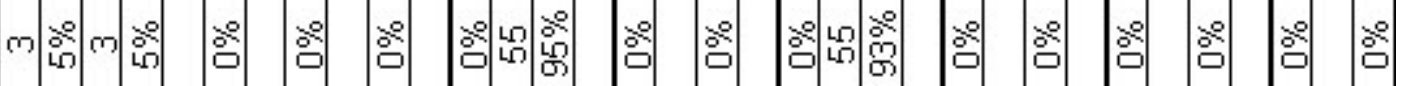

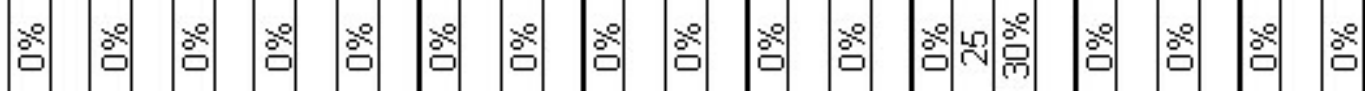

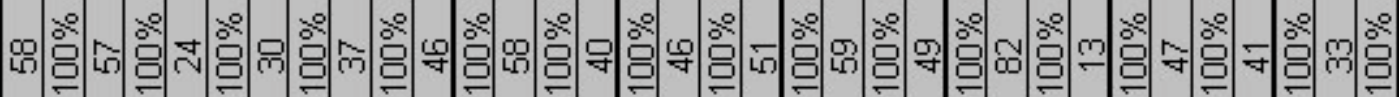

\begin{tabular}{|c|c|c|c|c|c|c|c|c|c|c|c|c|c|c|c|c|}
\hline$\frac{40}{9}$ & $\stackrel{\infty}{=}$ & $\frac{9}{\sigma}$ & 5 & $\stackrel{\frac{6}{50}}{=}$ & $\frac{5}{6}$ & $\infty$ & 号 & $\begin{array}{l}\frac{10}{5} \\
\frac{5}{\sigma}\end{array}$ & $\stackrel{\square}{\square}$ & $\frac{\mathrm{v}}{\mathrm{v}}$ & 寸 & $\begin{array}{l}\text { 号 } \\
\text { \% }\end{array}$ & 或 & $\begin{array}{l}\frac{9}{0} \\
\text { ஸे }\end{array}$ & 器 & 高 \\
\hline m & m & 肙 & 象 & $r$ & 음 & $\stackrel{\Omega}{\sim}$ & เ9 & 吕 & की & 이 & & 肙 & 号 & 吕 & 嗐 & 肙 \\
\hline 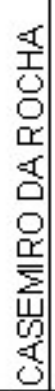 & $\begin{array}{l}0 \\
0 \\
0 \\
0 \\
0 \\
0 \\
0 \\
0 \\
0\end{array}$ & 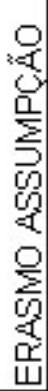 & 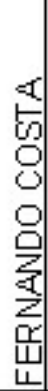 & 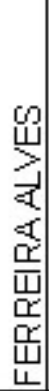 & 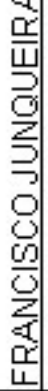 & 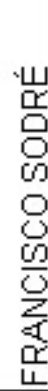 & 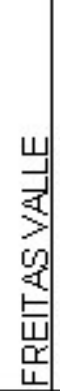 & 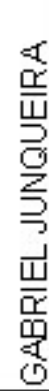 & 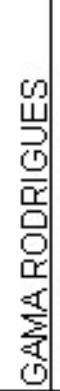 & 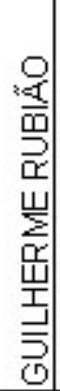 & 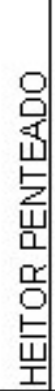 & 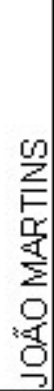 & 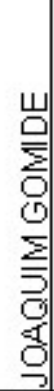 & 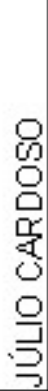 & 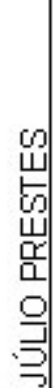 & 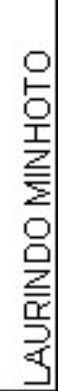 \\
\hline
\end{tabular}




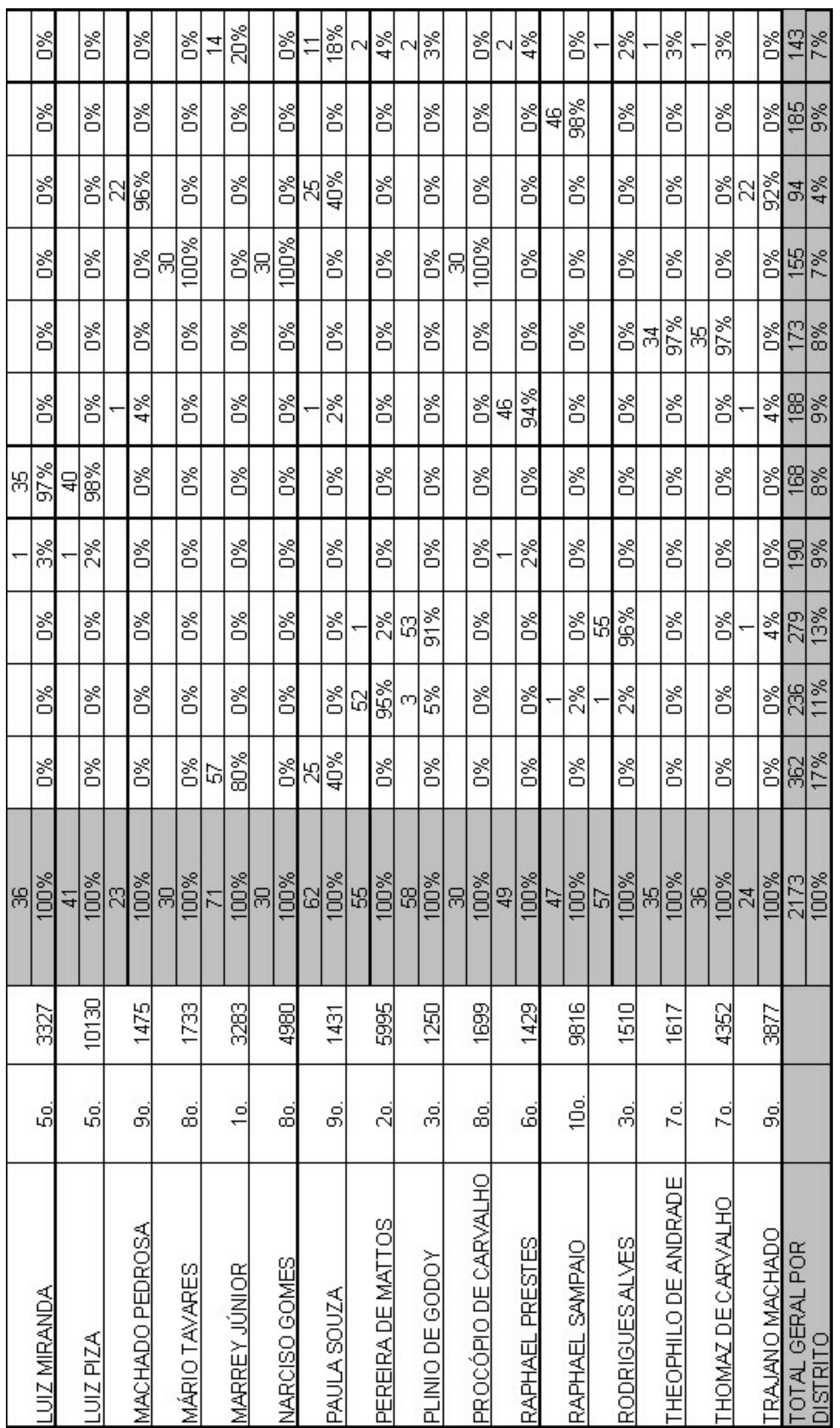




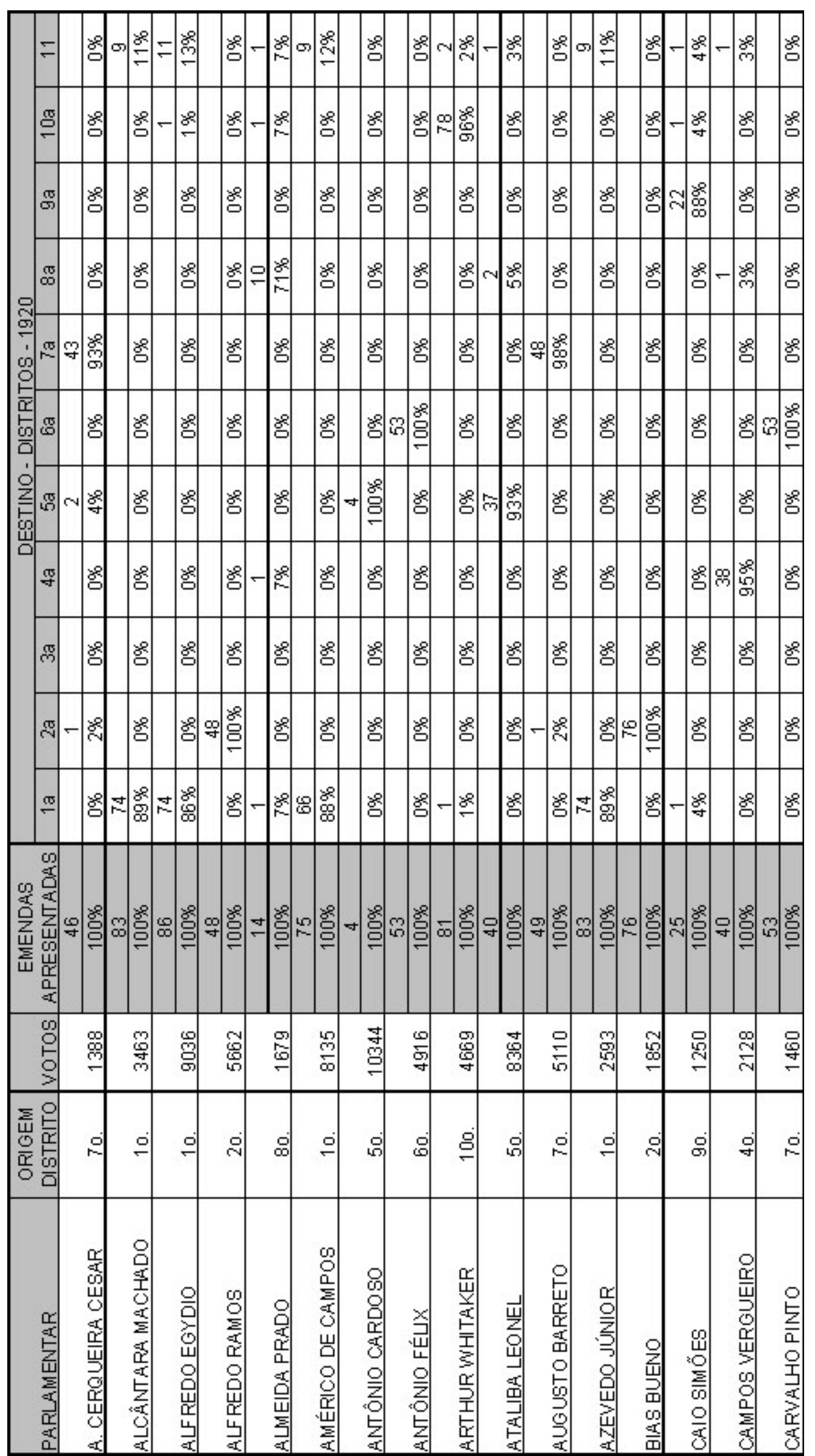




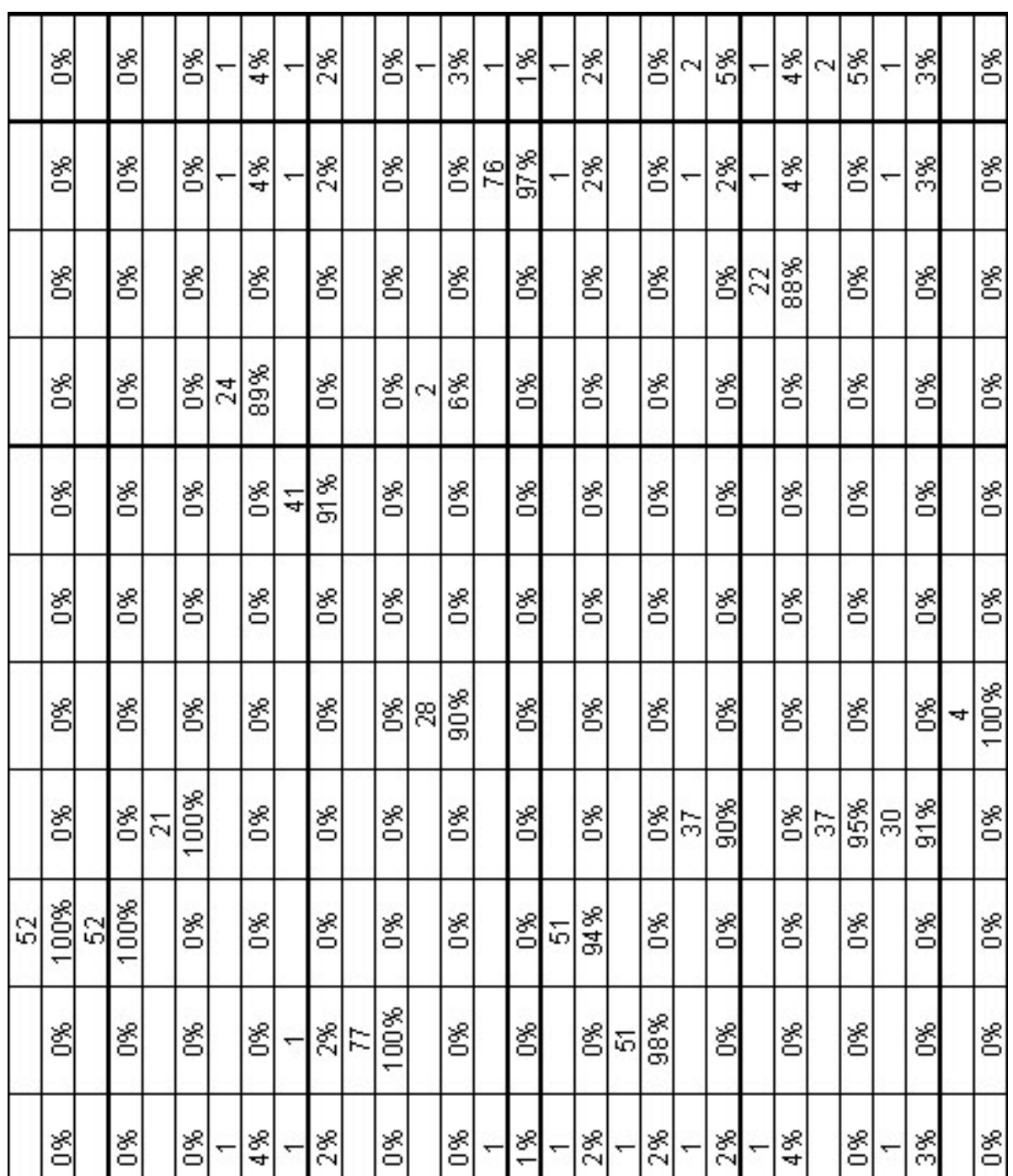

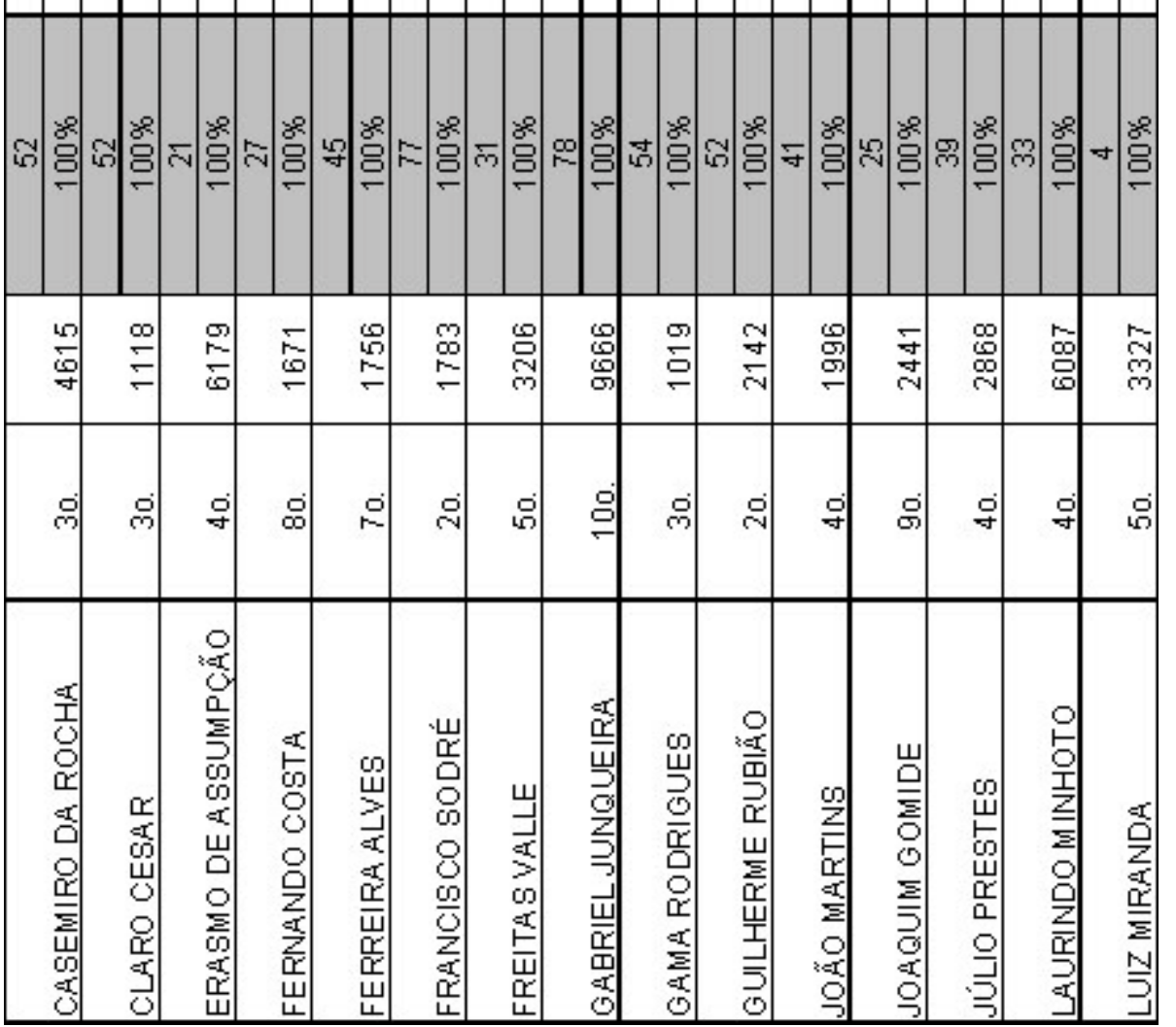




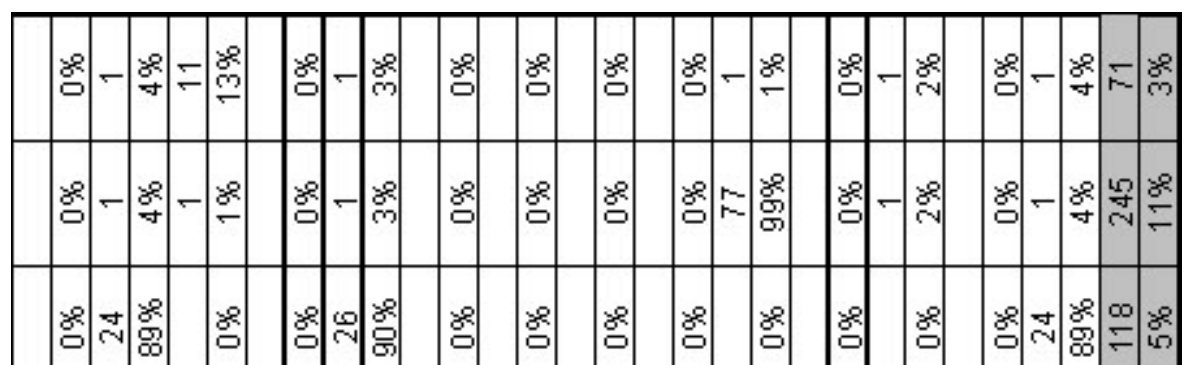

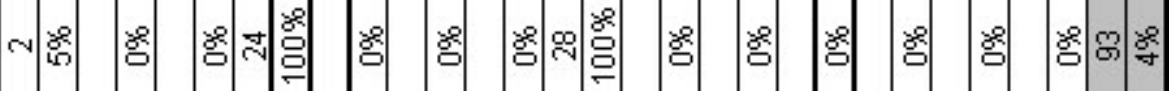

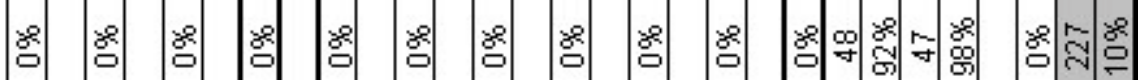

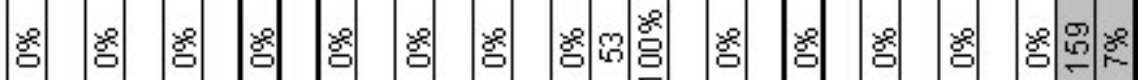

-

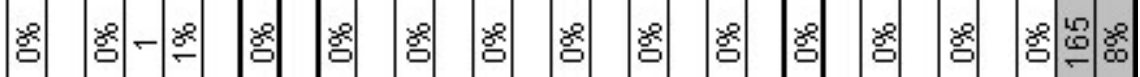

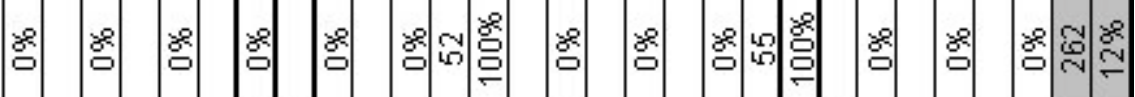

웅 윰 음

-

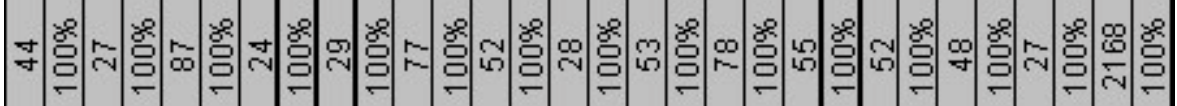

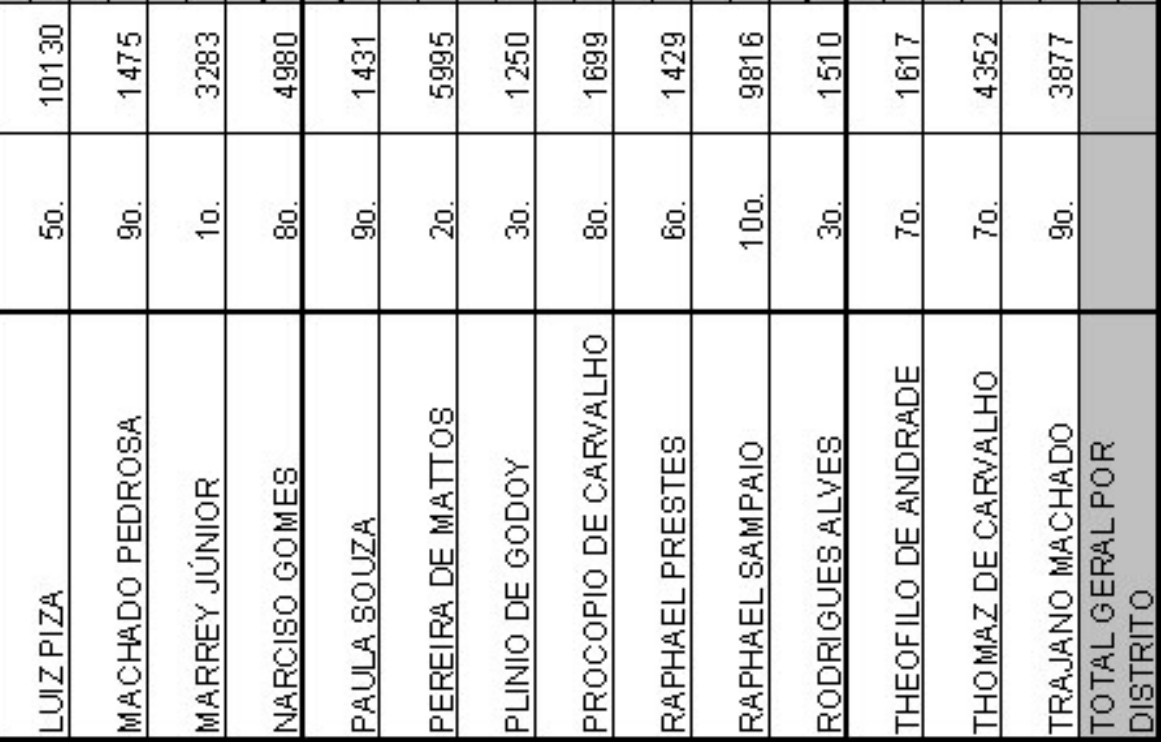




\section{FONTES E BIBLIOGRAFIA}

\section{Fontes}

ABRANCHES, Dunshee de. Governos Congressos de República dos Estados Unidos do Brasil. 1889 a 1917. Vol. II, São Paulo, 1918.

Assembléia Legislativa de São Paulo. Um exercício de democracia. São Paulo: ALESP, 1984.

Códigos Penais do Brasil. Evolução histórica. PIERANGELLI, José Henrique (Org.). São Paulo: Jalovi, 1980.

Coleção dos Anais do Congresso Paulista - Sessões Ordinárias e Extraordinárias -. 1890-1920. (30 volumes).

Constituição Estadual de 1891 (São Paulo)

Constituição Federal de 1891 - República..

Coleção de Leis Eleitorais ao Longo da História - 1890 a 1929. Tribunal Regional Eleitoral/SP

Emendas aos Orçamentos do Estado de São Paulo de 1891 a 1920.

Emendas Substitutivas aos Orçamentos do Estado de São Paulo de 1907 a 1920.

Orçamentos para os anos de 1891 a 1920.

Primeiros Atos do Governo Provisório ao ser Proclamada a República. Ariosto Cesar de Azevedo e Antonio Carlos da Fonseca, 1918.

Projetos de Lei Orçamentária de 1891 a 1920.

Regimento Interno da Câmara dos Deputados e Senado de São Paulo.

Relação das Assembléias Republicanas, desde o Congresso Constituinte e a Primeira Legislatura (1891) até 1916-1918. Ariosto Cesar de Azevedo e Antonio Carlos da Fonseca, 1918.

\section{Bibliografia}

ALVES, P. Coronelismo, mandonismo local e oligarquias: críticas e proposições aos modelos de interpretação da História Política da Primeira República. In: DE NIPOTTI, C.; JOANILHO, A. (Orgs.). Leituras em História. Curitiba: Aos Quatro Ventos, 2003.

ARINOS, Afonso de Melo Franco. Idéias Políticas do Constitucionalismo Imperial. In: O pensamento constitucional brasileiro. Brasília: Câmara dos Deputados, 1978.

BASBAUM, L. História Sincera da República - 1889 a 1930. São Paulo: Alfa-Omega, 1976.

História Sincera da República: das origens até 1889. São Paulo: Alfa-Omega, 1981. 4 v.

BELO, José Maria. História da República, 1889-1954. São Paulo: Nacional, 1976.

CAMARGO, José Francisco de. Crescimento da população no Estado de São Paulo e seus aspectos econômicos (Ensaios sobre as relações entre a demografia e a economia), 3v. Boletim, 153, no. 1, USP,1952. 
CANO, Wilson. Raízes da concentração industrial de São Paulo. São Paulo: HUCITEC, 1990 CARDOSO, Fernando Henrique. Dos governos militares a Prudente de Morais/Campos Sales. In: FAUSTO, Boris (Org.). Historia Geral da Civilização Brasileira. São Paulo: Difel, 1980, v. 8. História Geral da Civilização Brasileira, tomo III

CARONE, E. República Velha: instituições e classes sociais. São Paulo: Difel, 1972. . A Primeira República (1889-1930). São Paulo: Difel, 1973.

CARVAlHO, J.M. Pontos e Bordados. Escritos e História e Política. Belo Horizonte: UFMG, 1999.

CASALECCHI, J.E. Proclamação da República e o Partido Republicano Paulista. São Paulo: Brasiliense, 1984.

. O partido republicano paulista: política e poder, 1889-1926. São Paulo: Brasiliense, 1987.

CASTRO, M.I.M. O preço do Progresso. A construção da Estrada de Ferro Noroeste do Brasil, 1905-1914. Campinas: Unicamp. Dissertação de Mestrado, 1993.

CORRÊA, A.M.M. Poder local e representatividade político-partidária no Vale do Paranapanema - 1920-1930. Tese de Livre-Docência em História, FCL de Assis/UNESP, 1988. . História social de Araraquara, 1817-1930. Dissertação de Mestrado em História, USP, São Paulo, 1967

COSTA, Hernani Maia, O triângulo das barreiras do Vale do Paraíba Paulista (1835-1860). Tese de doutoramento, USP/FFLCH, 2001.

DEAN, W. A industrialização de São Paulo. São Paulo: Difel, 1971.

DEBES, Célio. Partido Republicano de São Paulo na propaganda, 1872-1889. São Paulo, s.c.p. 1975.

A propaganda republicana em São Paulo, 1872 - 1889. In: LAPA, José Roberto do Amaral (Org.). História Política da República. Campinas: Papirus, 1990.

DELFIM NETTO, Antônio. O problema do café no Brasil. São Paulo, USP-FEA, 1959

DEL RIOS, Jéferson. Ourinhos. Memórias de uma cidade paulista. São Paulo, Ourinhos, Prefeitura Municipal/IMESP, 1992

DIAS, Maria Odila L.S. Cotidiano e poder em São Paulo no século XIX. São Paulo: Brasiliense, 1995.

DINIZ, Eli. Voto e máquina política. Patronagem e clientelismo no Rio de Janeiro. Rio de Janeiro: Paz e Terra, 1982.

DORIA, C. A. Coronelismo e oligarquias, In: MENDES JR., A.; MARANHÃO, R. (Orgs.). Brasil História. Texto e Consulta. República Velha. São Paulo: Brasiliense, 1979, v. 3. 
. Poder local na República Velha. São Paulo: Nacional, 1977.

FAORO, R. Os donos do poder. Formação do patronato político brasileiro. Porto Alegre: Globo. vol. II, 1979.

FAUSTO, B. Pequenos ensaios de História da República: (1889-1945). São Paulo: Cebrap, 1972. p. 1.

FURTADO, C. Formação econômica do Brasil. 8. ed., São Paulo: Companhia Editora Nacional, 1968

GHIRARDELlo, N. A beira da linha. Formações urbanas da Noroeste Paulista. São Paulo: Edunesp, 2002.

GOMES, A.M.C. Burguesia e Trabalho - Política e legislação social no Brasil, 1917-1937. Rio de Janeiro: Campos, 1983.

GUILHERME, Glicério de Freitas. Glicério: República e Federação. In: LAPA, José Roberto do Amaral. Op. cit., p. 90.

HOLANDA, S. B. História Geral da Civilização Brasileira - Do Império à República

HOLLOWAY, T. Imigrantes para o café. Café e sociedade em São Paulo (1886-1934). Rio de Janeiro: Paz e Terra, 1984.

IOKOI, Zilda Márcia Gricoli. O Poder Legislativo na construção da República (1891-1894). São Paulo, dissertação de mestrado em História, USP, 1985.

JANOTTI, M.L.M. Coronelismo: uma política de compromissos. São Paulo: Brasiliense, 1981. A República: oposições e consolidação. In: LAPA, José Roberto do Amaral. Op. cit. . Sociedade e política na Primeira República. São Paulo: Atual, 1999

KERBAUY, M.T.M. A morte dos coronéis: Política interiorana e poder local. Araraquara: UNESP, 2000.

KUGELMAS, E. A Primeira República no período de 1891 a 1909. In: BEIGUELMAN, P. Pequenos Estudos de Ciência Política. São Paulo: Pioneira, 1973.

Difícil hegemonia. Um estudo sobre São Paulo na Primeira República. Tese de doutorado em ciências sociais, USP, 1988.

LANG, Alice de B. da Silva Gordo. A propaganda republicana paulista na Província de São Paulo - 1984.

LAPA, J.R.A. (Org.). História Política da República. Campinas: Papirus, 1990

LEAL, Victor Nunes. Coronelismo, enxada e voto. São Paulo: Alfa-Omega, 1978.

. O coronelismo e o coronelismo de cada um. Rio de Janeiro: DADOS/1980.

LOVE, J. A Locomotiva. São Paulo na Federação Brasileira 1889-1937. Rio de Janeiro: Paz e Terra, 1982.

LUZ, Nice Villela. A luta pela industrialização do Brasil. 2. ed., São Paulo: Alfa-Ormega, 1975. 
MARTINS, J. de S. O cativeiro da terra. São Paulo: LECH, 1978.

. Conde Matarazzo, o empresário e a empresa.. 2. ed., São Paulo: Hucitec, 1973

MATOS, O.N. Café e Ferrovias: A evolução ferroviária de São Paulo e o desenvolvimento da cultura cafeeira. São Paulo: Arquivo do Estado de São Paulo, 1981.

MILLIET, Sérgio. Roteiro do café e outros ensaios. S.c.p., São Paulo,1946.

MELLO, J. M. C. O capitalismo tardio. 4. ed., São Paulo, Brasiliense, 1986

MONBEIG, P. Pioneiros e fazendeiros em São Paulo. São Paulo: Hucitec, 1984.

NOGUEIRA, M.A. As desventuras do liberalismo: Joaquim Nabuco, a Monarquia e a República. Rio de Janeiro: Paz e Terra, 1981.

OLIVEIRA, Flávia A. M. de. Faces da dominação da terra. (Jaú, 1890 - 1910). São Paulo: Edunesp/Fapesp, 1999

PELÁEZ, C. M. História da industrialização brasileira. Rio de Janeiro: Apec, 1972.

PERISCINOTTO, R. M. Classes dominantes, Estados e os conflitos políticos na Primeira República em São Paulo. In: DELORENZO, H.C. e COSTA, W.P. da (Orgs.). A década de vinte e as origens do Brasil moderno. São Paulo: Edunesp, 1997.

Estado, capital cafeeiro e política tributária na economia paulista exportadora, 18891930. Latin American Research Review. University of Texas, v. 36, n. 1 (2001)

POSSAS, L.M.V. Mulheres, trens e trilhos. Modernidade no sertão paulista. São Paulo: Edusc, 2001.

PRADO JR., Caio. Evolução política do Brasil e outros estudos. São Paulo: Brasiliense, 1969. . História econômica do Brasil. 12. ed., São Paulo: Brasiliense, 1970

QUEIROZ, M.I.P. de. O coronelismo numa interpretação sociológica. In: FAUSTO, B. (Org.). O Brasil Republicano - Estrutura de Poder e Economia, 1889-1930. História Geral da Civilização Brasileira. v. 8, tomo III, São Paulo: Difel, 1975.

. O mandonismo local na vida política brasileira e outros ensaios. São Paulo: AlfaOmega, 1976.

QUEIROZ, Suely Robles R. de. Os radicais da República. Jacobinismo, ideologia e ação (18931897). São Paulo: Brasiliense, 1986.

SAES, F.A .As ferrovias de São Paulo - 1870-1940. São Paulo: Hucitec, INL/MEC, 1981.

SALLES, Campos. Da Propaganda à Presidência. São Paulo: s.c.p. 1908.

SEGNINI, L.P. Ferrovia e Ferroviários. São Paulo: Cortez, 1982.

SILVA, Lígia M. Osório. A apropriação territorial na Primeira República. In: SILVA, S.; SZMRECSANYI, T. (Orgs.). História Econômica da Primeira República. São Paulo: Edusp, 2002. 
Terras Devolutas e Latifúndio (efeitos da Lei de 1850). $1^{\text {a }}$. ed. Campinas: EDUNICAMP, 1996

SILVA, Hélio. República Velha: instituições e classes sociais;

SILVA, S. Expansão cafeeira e origens da industrialização no Brasil. São Paulo: Alfa-Omega, 1976 SIMONSEM, Roberto C. Aspectos da história econômica do café. Evolução industrial do Brasil e outros estudos. São Paulo: Companhia Editora Nacional/EDUSP, 1973

SODRÉ, N. W. Formação histórica do Brasil.. 4. ed., São Paulo: Brasiliense, 1967

SOUZA, Maria do Carmo Campello de. O processo político-partidário na Primeira República. In: MOTA, Carlos Guilherme (Org.). Brasil em Perspectiva. 3. ed. São Paulo: Difel, 1973.

SUZIGAN, W. Indústria brasileira: origem e desenvolvimento. Nova edição. São Paulo: HUCITEC/EDUNICAMP, 2000.

SUZIGAN, Wilson; SZMRECSÁNYI, Tomás. Os investimentos estrangeiros no início da industrialização do Brasil. In: SILVA, Sérgio S.; SZMRECSÁNYI, Tomás (Orgs.). História Econômica da Primeira República. São Paulo: Hucitec/Associação Brasileira de Pesquisadores em História Econômica/Edusp/Imprensa Oficial, 2002.

TELAROLLI, R. Eleições e fraudes eleitorais na República Velha. São Paulo: Brasiliense, 1972. O poder local na República Velha. São Paulo: Cia. Editora Nacional, 1977.

VARGAS, Claudia Regina. As várias faces da cidade. Bento de Abreu e a modernização de Araraquara (1908-1916). Dissertação de Mestrado em História, UNESP, Franca, 2000.

VERSIANI, F. R. e VERSIANI, M.T.R.O. A industrialização brasileira antes de 1930: uma contribuição. In: VERSIANI, F. R. e BARROS, J. R. M. (Orgs.). Formação econômica do Brasil. São Paulo, 1973

VILAÇA, M.V. e ALBUQUERQUE, R.C. Coronel, coronéis. Brasília: UNB, 1980.

VILLELA, A. V. e SUZ1GAN, W. Política do governo e crescimento da economia brasileira, 1889-1945. Rio de Janeiro: IPEA/INPES, 1973

VIZENTINI, P.G.F. Liberais e a crise da República Velha. São Paulo: Brasiliense, 1983.

WITTER, J.S. Partido político, federalismo e República : O PRP e a política dos governadores. São Paulo: Arquivo do Estado, 1984.

Partido Republicano Federal: 1893-1897. São Paulo: Brasiliense, 1987. República, Política e Partido: O PRF e a política dos governadores. Bauru/São Paulo: Edusc, 1999.

ZIMMERMANN, M.E.M. Da propaganda à Republica. A organização do Partido Republicano Paulista, 1870-1889. In: LAPA, José Roberto do Amaral [Org.]. Histórias Políticas da República. Campinas: Papirus, 1990. 